DE GRUYTER

MOUTON

Susan Baddeley, Anja Voeste (Eds.)

ORTHOGRAPHIES

IN EARLY

MODERN EUROPE 
Orthographies in Early Modern Europe 



\section{Orthographies in Early Modern Europe}

Edited by

Susan Baddeley

Anja Voeste

De Gruyter Mouton 


An electronic version of this book is freely available, thanks to the support of libra-
ries working with Knowledge Unlatched. KU is a collaborative initiative designed to
make high quality books Open Access. More information about the initiative can be
found at www.knowledgeunlatched.org

\section{(cc) BY-NC-ND}

This work is licensed under the Creative Commons Attribution-NonCommercial-NoDerivs 3.0 License, as of February 23, 2017. For details go to http://creativecommons.org/licenses/by-nc-nd/3.0/.

ISBN 978-3-11-028812-4

e-ISBN 978-3-11-028817-9

Library of Congress Cataloging-in-Publication Data

A CIP catalog record for this book has been applied for at the Library of Congress.

Bibliographic information published by the Deutsche Nationalbibliothek

The Deutsche Nationalbibliothek lists this publication in the Deutsche Nationalbibliografie; detailed bibliographic data are available in the Internet at http://dnb.dnb.de.

(C) 2012 Walter de Gruyter GmbH \& Co. KG, Berlin/Boston

Printing: Hubert \& Co. GmbH \& Co. KG, Göttingen

$\infty$ Printed on acid-free paper

Printed in Germany

www.degruyter.com 


\section{Contents}

Introduction

Orthographies in Early Modern Europe:

A comparative view. . . . . . . . . . . . . . . . . 1

Susan Baddeley and Anja Voeste

Spanish

Variation and standardization

in the history of Spanish spelling . . . . . . . . . . . 15

Elena Lamas Pombo

Italian

Italian orthography in Early Modern times . . . . . . . 63

Andreas Michel

French

French orthography in the 16th century

Susan Baddeley

English

Variable focusing in English spelling

between 1400 and 1600

Terttu Nevalainen

German

The emergence of suprasegmental spellings

in German. . . . . . . . . . . . . . . . . . . . . . 167

Anja Voeste

Swedish

Variable norms in 16th-century

Swedish orthography .

Alexander Zheltukhin

Polish

The standardization of Polish orthography in the 16 th century . . . . . . . . . . . . . . . . . . . . . . . 219

Daniel Bunčić 
vi Contents

Czech

Religion and diacritics:

The case of Czech orthography. . . . . . . . . . . . 255

Tilman Berger

Croatian

On the creation of Croatian:

The development of Croatian Latin orthography 269

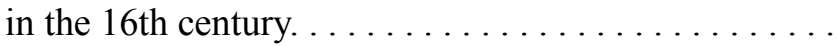

Roland Marti

Hungarian

16th-century Hungarian orthography . . . . . . . . . 321 Klára Korompay

Finnish

Standardization of Finnish orthography:

From reformists to national awakeners.

Taru Nordlund

Index Rerum. . . . . . . . . . . . . . . . . . . . . . . . . . . . . . . . . . . . . 373

Index Nominum . . . . . . . . . . . . . . . . . . . . . . . . . . . . . . . 379 


\title{
Introduction
}

\section{Orthographies in Early Modern Europe: A comparative view}

\author{
Susan Baddeley and Anja Voeste
}

This volume brings together a series of articles written by specialists in the orthography of European languages, the aim of which is to promote a better understanding of the development of national orthographies in Europe during the pivotal period constituted by Early Modern times. The comparative view of European orthographic history that we propose here naturally cuts across language boundaries and across conventional fields of scholarly thinking focused on the respective Romance, Germanic, Slavonic and Finno-Ugrian language groups. It is therefore a new approach, but one which constitutes an important supplement to existing national perspectives on individual philologies that often tend to be teleologically constructed. The approach should also be of interest to language historians, both methodologically and theoretically, since European linguistic histories are based on a number of shared traditions (for an overview cf. Auroux et al. 2000 2006) that have also influenced the development of national orthographies. Consider, for example, the establishment of universities, the invention of letterpress printing and its paths of diffusion, the Protestant Reformation and the Counter-Reformation, the Renaissance, Humanism and the Enlightenment, and the rise of modern nation-states: all of these developments are typical of this Europe; they have also left an indelible mark on its linguistic and orthographic history.

In order to provide as balanced a view as possible of the linguistic situation in Europe, we have selected three Romance, three Slavonic, three Germanic and two Finno-Ugrian languages from this cultural domain to serve as examples here. Each author has been given freedom of choice in the approach used to chart the history of the language in question, and the different approaches used reflect the different characteristics of each language. However, beyond these differences, the common ground shared by all of the languages appears clearly, occasionally with surprising parallels 
to be seen in the histories of quite distinct orthographic systems used in regions which are geographically remote.

At this point, it ought to be clear that the "Europe" we are talking about here is the geographical expanse which, in the aftermath of the Schism of 1054 under the Church of Rome, gradually developed into a unitary social and cultural sphere. The Latin Church constituted the encompassing element that bound together the individual secular dominions, and accordingly certain common features shaped developments throughout its sphere of influence.

All of the languages described in our corpus now use the Latin alphabet, and only two of them (Croatian and Czech) ever used other alphabets. In most cases, the emergence of a written language itself was linked to the adoption of Latin Christianity. It is, therefore, easy to imagine how the course of development proceeded in the Early Modern period, when Latin continued to be the written language par excellence, in spite of the progressive rise of the vernaculars. Indeed we encounter in all the languages under consideration here oscillations between, on the one hand, traditional semiographic $^{1}$ systems of spelling, often incorporating a strong Latinate element, and others indicating greater independence from Latin, i.e., phonographic systems of spelling.

However, as the break with Latin became consummated, with the increasing independence of the phonological systems of these languages with regard to Latin, the first order of business - and this applies to all European languages - was to come up with a graphic expression of each vernacular's respective linguistic peculiarities, and for "new" sounds unknown to the Latin phonological system, such as palatals and fricatives: for instance, the affricate consonants in Italian, the numerous affricates and sibilants of the Slavonic languages (such as Polish, which possessed a particularly rich phonological system, of which only a third could be adequately transcribed by the Latin alphabet), the eñe and elle in Spanish, or a differentiation of the $e$-grapheme in French that could stand for the closed and open $e$-variants as well as the schwa. This gave rise to a great deal of experimentation, with a whole range of solutions frequently being found to overcome these problems: palatalization of consonants, for example, could be indicated by juxtaposing an $<\mathrm{h}>$, a $<\mathrm{g}>$ or an $<\mathrm{i}>$. A case in point is the former French palatal $/ K /$, for which at least 10 variant spellings existed during the medieval period. ${ }^{2}$

Language contact in England and the influence of written French as a prestige language also saw the replacement of typically English letters such 
as thorn (p) and eth (ð) by Latin equivalents (although spelling reformers such as Sir Thomas Smith would, later, attempt to reintroduce them), and the adoption of a whole range of graphemes of French origin, such as $<\mathrm{ou}>$ for the long /u:/ (which later transformed into a diphthong, as in the word house).

Secondly, the so-called "silent letters" inherited from Latin (but which had become mute through phonetic erosion) were to be expunged, whereby $<$ tractado $>$ became the Spanish word $<$ tratado $>$ and $<$ nocte $>$ became $<$ notte $>$ in Italian. ${ }^{3}$ In Spanish and Italian notably, this ideal of phonographic "simplicity" was to prevail. However, throughout the Middle Ages, norms were quite diffuse in most languages, and this allowed for the presence of widespread variation, an essential part of the medieval "mental architecture" according to the French linguist Claude Buridant, but one which has not always been perfectly understood by language historians. The 16th century was to inherit this complex orthographical situation, which, in many cases, was to become yet more complex before certain norms and standard practices could even begin to prevail.

The Early Modern period in Europe is associated with a certain number of movements which affected the whole of the area: humanism and the rediscovery of the Classical tradition, the Reformation, the rise of vernaculars and the supplanting of Latin as the only language in the church and for learning, the introduction and development of letterpress printing, and the rise of modern nation-states, all of which impacted in different ways upon the development of the written vernaculars according to local circumstances.

As Sylvain Auroux (1994) has pointed out, the vast production of tools to learn and to teach the vernacular languages such as dictionaries, grammars and manuals, led to an increasing "grammatization" of the written language. Moreover, with the rediscovery of Greek (and to a lesser extent, of Hebrew), written languages other than Latin could be taken as a model for orthography, and could lend solutions to the myriad problems of writing many vernacular languages. In Italy, Trissino's Castellano of 1529 showed the influence of Greek scholarship, and he attempted to use Greek letters both to resolve the inadequacies of the Latin alphabet and to confer greater prestige upon the written vernacular. Erasmus' defence of the vernaculars and his appeal for people of all nations to be able to read the Scriptures in their own language also encountered widespread support throughout Europe, and authorities such as Quintilian and Priscian were widely drawn upon as models for describing vernacular languages and codifying their written systems. In Spain, the role of the great humanist scholar Antonio de Nebrija 
would be fundamental in this respect; in other countries, the importance of other less well-known "globetrotting humanists" would be no less important.

The other key intellectual and spiritual movement that swept through Europe was, of course, the Reformation. It is well known that religion has always been a key force promoting the production of written texts and the way in which they are received. Siegfried Morenz, a historian of religion, distinguishes between "book religions" and "cult religions"; accordingly, Christianity can be classified as a book religion, since its foundation is a book (the Bible), which is something it has in common with other religions including Islam, Judaism and Buddhism. Nevertheless - and this is a fact which has far-reaching consequences - its scripture is not considered to be literally the word of God. In contrast to the Koran, for instance, its verbatim wording is not considered to be purely a divine revelation. And, according to historian Michael Mitterauer, it was precisely this specific set of circumstances that provided sufficient latitude to work on the Holy Scriptures. For the language historian, this means: enough leeway to transpose them into other forms, to copy them, to translate them, to produce literary revisions and adaptations and, later, to use the printing press to duplicate them on a mass scale. ${ }^{4}$ This is something that would seem to be a matter of course, but most definitely is not.

Compare this, for example, to Islam, whose holy book, as the word of God, is sacred and thus unalterable. The Koran is bound not only to a single language, Arabic, but also to the handwritten text that has been handed down through the ages, and thus to a specific set of characters and signs. Under these circumstances, a tradition of vernacular translations as well as literary revisions and adaptations failed to emerge. And despite the fact that the technique had long been known, letterpress printing did not establish itself in the Islamic world until the 19th century. Instead, an elaborate calligraphy was very widespread there.

In Europe, the translation and printing of the Scriptures into the vernacular was one of the main aims and achievements of the Lutheran Reformation. In Sweden, printed editions of the Bible established a fairly fixed type of orthography from quite an early date. However, these initiatives did not always go unopposed. In France, as in many other European countries, reformed spellings at this time were largely connected with Protestantism and with the wish to make the written language more widely available to audiences with little or no command of Latin. The Protestants promoted literacy and education, and were well aware of the role of vernaculars and the importance of letterpress printing in the promulgation of 
their teachings. In France, however, the so-called Affaire des Placards in 1534 triggered ruthless persecution of Protestants. Later, the key individuals who had been involved in the dissemination of reformed orthographies such as Pierre de la Ramée (Petrus Ramus) were among the victims of the St. Bartholomew's Day massacre in 1572 or else fled the country together with many printers and intellectuals. Thereafter, approaches to spelling reform were carried on in Geneva, Lyon and, later, Antwerp.

In other European countries, however, the Reformation followed a different course. In Spain and in Poland, this religious movement had little impact, although in Poland the "Hussite" nature of some spelling reforms seems to have been the main reason for their rejection. In England, diffusion of the Scriptures in English remained controversial until the reign of Elizabeth I, and biblical editions were not uniform or widespread enough to have impacted on spelling.

To these social and intellectual upheavals, we must add the technological upheavals introduced by the spread of letterpress printing, from the middle of the 15 th century onwards.

The experience of all the languages studied here shows that in the earliest years after the introduction of printing technology, the press in fact often created more spelling variants than existed previously. Spelling standardization was not the main preoccupation of the first printers; they had no "house styles" to speak of, and indeed, in many cases, did not even speak the language of the country in which they practiced their art: in Poland, until the second half of the 16th century, for example, nearly all of the major printing houses were run by Germans or by German-speakers, and printing workers like humanist scholars were an extremely mobile profession.

From the beginning of the 16th century onwards, however, the role of great humanist printers such as Manutius in Italy, Tory and Dolet in France, Vietor in Poland (for the printing of both Polish and Hungarian texts) in spelling innovation would be decisive. While manuscript use would continue to be extremely variable, printers tended to regularize and, accordingly, certain types of variants would gradually prevail.

The printers brought with them a new approach to written texts. As in manuscripts, spelling variants could be used (and were used) to justify lines, to ensure that a certain amount of text fitted into a precise number of pages (with the technique known as "casting off"), and to achieve certain aesthetic effects. However, from the early 16th century onwards, many printers simultaneously started to abandon certain abbreviations, and began to adopt standard practices: for example, in the way in which words were separated over two lines. Andreas Michel shows how, in the 1502 Venice 
edition of Dante's Divine Comedy by Manutius and Bembo, words were separated for the first time according to grammatical criteria, and punctuation was added. In Germany, the rules for hyphenation and word-separation at line endings would be broached by Valentin Ickelsamer in the 1530s.

Reforms of printing-shop practices and greater productivity led to streamlining of printers' cases and the elimination of certain little-used characters, such as ligatures. Similarly, certain solutions found by spelling reformers (such as diacritics on letters with ascenders as in Polish, or on capitals as in French, or positional variants) turned out to be impractical when translated into printing technology. However, despite technical problems and the opposition of printers on certain points, printing brought in its wake an undoubted standardization of written texts. In many languages, this "reshuffling of the cards" induced by the new technology would also bring about a fresh way of looking at spelling, although the technology also had the effect of fixing, sometimes arbitrarily, certain forms. By the mid16th century in many countries, such as in England or in France, a certain consensus had become established on the spelling of the native lexis, and it was too late to implement the propositions of spelling reformers, and especially of those that upheld the phonemic principle.

The spelling reform debate took place in most European countries, impelled either by the humanistic philological tradition or by the preoccupations of the printers, or by both. The "phonetic ideal" was defended for various reasons: easier access to literacy for all (as in the Protestant countries), "reason", "naturalness" and the rejection of "artifice" (as in Spain), or the belief, fostered by Classical thinking, that writing should be the "mirror" of speech. Scholars such as Scaliger, Ramus and Sanctius sought to establish new philosophical bases for the study of language, and the logical outcome for Ramus, basing his arguments on the opposition between sermo and ratio, usage and reason, was the elaboration of a new, phonetic spelling system (cf. Padley 1976: 85). Similar arguments can be found among tenants of the phonemic principle all over Europe: Trissino in Italy, Meigret in France, Hart in England. On the external side, however, the phoneticists were immediately confronted with a classic problem namely, the question of which linguistic region and which dialect was to be put forward as the exemplary form of speech and thus to serve as the model for phonographic spelling. Naturally, these discussions did not take place in a political vacuum. Let us take a look at the oldest vernacular grammar, that of the Castilian language published by Antonio de Nebrija in 1492. In his dedication to Queen Isabella, Nebrija refers of course to Castile's position of cultural supremacy, but he also propagates the Castilian vernacular as 
the handmaiden of dominion and power, as "la compañera del Imperio" and the equivalent of the role of Latin in the Roman Empire. Even if this claim to preeminence was exaggerated in the light of everyday political practice, we must nevertheless concur with Nebrija on one point: in the process of pre-modern state formation, language was an important instrument of power. Particularly in states with a highly centralized government, linguistic unity assured efficient administration, and fluency in that language was a key precondition for a civil service career that was an attractive prospect for many. In England, the question of spelling was closely linked with the preoccupations of the teaching profession. A standardized written language became the medium of the new privileged elites who occupied key positions in the government bureaucracies. It became the language of social prestige, and thus what most certainly was the language of power. This is the context in which the discussions about regional linguistic prestige are to be interpreted.

Beyond these questions of which speech variety (if any) was to be recorded in writing, the solutions proposed by the reformers were multiform. Some positions went so far as to suggest taking phonographic encoding well beyond the word boundaries and propagated, in Spanish, for example, forms such as <destagua > for de este agua 'of this water' (Juan de Valdés); others advocated compromise systems, such as the two-layered graphic system featuring supralinear vernacular graphic symbols above the etymological ones - in France, for example, <liģ́ns $>$ lisons 'we read' with the etymological $<\mathrm{g}>$ from the Latin word legere (as proposed by Jacques Sylvius).

Although the efforts of the phonemic reformers raised awareness of the issues associated with the use of writing systems, their impact was, in most cases, negligible, and practices in many countries became increasingly nonphonemic throughout the century.

When we attempt to synthesize the types of changes that the different languages encountered throughout the period, we may notice that the changes involved very often cut across language boundaries and did not necessarily affect families of languages in the same way. Let us look first at the three Romance languages in our study, as exemplified by Spanish, Italian and French. Here, the transition from Latin to the vernacular was not a process of transposition, as was the case with the members of the other linguistic families: indeed, it has even been argued (notably by Wright 1982) that there was initially no real break between the emergence of the vernaculars and the development of corresponding written systems, since Latin continued to be used as the written equivalent for languages which were no longer, technically, Latin. Therefore, the question of whether or 
not to employ the Latin alphabet never even really came up for debate - it was, rather, a foregone conclusion. However, as vernacular pronunciation became increasingly removed from written Latin, the more "logographic" (in the sense of Sampson 1985) - deeper, so to speak - their systems of writing became. Accordingly, the emergence of written vernacular Romance languages is characterized in all cases by a "logographic" phase, although this phase lasted longer in some languages than in others: the break with Latin took longer to accomplish in Italian than in the other Romance languages. And French, indeed, was to revert later to the more semiographic and strongly morphographic system that it still possesses.

Conversely, we may identify a second type of written systems: those that had a phonographic starting point. These include German, English and Swedish for the Germanic languages; Czech, Polish and Croatian for the Slavonic; as well as Finnish and Hungarian. A comparison of the subsequent growth of these languages from their phonographic starting points reveals differential courses of development. Even though they belong to different language families, German, Polish and Hungarian make up a subgroup, insofar as their written languages developed semiographic (morphological, to be more precise) characteristics on a phonographic foundation. In German, for instance, the $a$-umlaut is used to indicate paradigmatic interrelationships. Thus, $<$ lender $>$ and $<$ nechte $>$ became $<$ länder/länder $>$ 'lands' and $<$ nåchte/nächte $>$ 'nights', on the model of the singular with $<\mathrm{a}>$. In Polish, forms with $<$ ó $>$ such as stót 'table' (nom. sg.) have a correlative /u/, but writing it with $<$ ó $>$ leads to consistency in the paradigm (consider gen. sg. stotu, nom. pl. stoly). The same holds true in Hungarian for the maintenance of a constant form in verb paradigms containing geminates. Thus, the third person singular present of the verb tud 'to know', tudja 'he knows it', is written with $<\mathrm{d}>$ like the other forms in the paradigm (such as tudom 'I know it', tudod 'you know it') even though it is pronounced with a geminate palatal consonant (/tuf:o/) and, accordingly, should actually be written < tuggya $>$.

All of these morphological spellings facilitate the process of decoding insofar as they operate with set visual word patterns. According to our hypothesis, they especially serve the experienced reading public whose members are accustomed to reading silently. Whereas an inexperienced reader used to reading aloud could be disconcerted by the lack of correspondence between the spelling and the pronunciation, the designation of paradigmatic affinity, the "semiographic" reference, enables the proficient reader to deal with morphemes in the same way as with graphic images. Thus, if our hy- 
pothesis is correct, then the emergence of morphological spellings in the Early Modern period would be associated with an increasing degree of literacy.

Analyses by scholars including social historian Jan van Zanden as well as Buringh, Gawthrop and Strauss have shown that Protestantism was the decisive factor in the spread of literacy - more important than median income, the degree of urbanization, the number of universities or whether a particular territorial entity was a centralized state or not. The significance of Protestantism for German and Hungarian history is obvious. In Germany, Luther's activities and the Reformation were the definitive events of the 16th century. The Reformation also quickly gained a foothold in Hungary, where the Battle of Mohács in 1526 and the conquest by the Turks of Buda, the country's political and cultural center, can be said to have delivered additional impetus to the Hungarians' turning towards Protestantism. The Protestants propagated their teachings with the help of many newly established print shops. Beginning in the 1560s, Catholicism, Lutheranism, Calvinism and Unitarianism were officially recognized religions with equal status. Thus, the 16th century was characterized not only by extensive religious debates but also by a Protestant orthography which, by the 17th century, was contending for hegemony with the Catholic system.

How, then, did Poland fit into this pattern? Here, the Reformation did not play a significant role, and Hussite diacritical marks were even prevented from being used in Polish orthography until well into the 16th century, precisely because of their connotations as belonging to "Protestant orthography". Indeed, the proportion of Protestant printers and proofreaders was high in Poland, but this had hardly any effect on spelling. Perhaps the Polish path of development was instead more closely connected to the rise there of an urban bourgeoisie whose members were not conversant in Latin and did their writing in Polish. Or with the immigration of German printers in search of a new market who promoted the publication of vernacular texts and brought their professional know-how to bear. However, it might also be the case that it was not Protestantism itself but rather the vernacular dispute surrounding religion and the translation of the Bible that was the decisive point. After all, there was certainly no shortage of these in Poland, where two Catholic and four Protestant (a Lutheran, a Calvinist and two Unitarian) Bible translations vied for readership. The Counter-Reformation was tremendously successful in Poland, once again vigorously promoting the publication of Polish texts and leading to the founding of countless Jesuit schools. In the 16 th and 17 th centuries, Poland was a culturally 
highly developed country with a high level of literacy. Thus - and in accordance with our hypothesis - it fulfilled the preconditions for the establishment of morphological spelling. ${ }^{5}$

On the surface, the development of English orthography conformed to the pattern of the German-Polish-Hungarian subtype. In England, the scripting process likewise began phonographically, and even featured the emergence of home-grown Anglo-Saxon graphic symbols such as the thorn (b), eth (ð) and ash (æ), and English also developed distinctive semiographic traits. However, in contrast to German, Polish and Hungarian, the semiography of the English written language is above all of an etymological/historical rather than a morphological type. In the early 15th century, when Englishmen increasingly wrote in English, Latin and French continued to serve as models for orthographic implementation, whereby words that had been borrowed from French were re-etymologized. Middle English spellings such as $<$ doute $>$ and $<$ aventur $>$ returned to their historical roots as $<$ doubt $>$ akin to Latin dubitare and $<$ adventure $>$ akin to the Latin advenire. This enhanced the prestige of these spellings, especially in comparison to the enormous number of orthographic variants generated by "rescripting". Furthermore, the fact that the attempt in the 16th century to establish phonographic orthography failed may well be connected not only to the prestige of these etymological (or, sometimes, pseudo-etymological) spellings, but also to the great many dialectal differences that were even further intensified by the Great Vowel Shift that was then underway.

In addition to the four languages that proceeded along a phonographicsemiographic developmental path, we now consider Czech, Croatian, Finnish and Swedish, which have more or less remained phonographic. This is perhaps not very surprising in the cases of Finnish and Swedish. The Finnish language was put into written form during the Reformation - a primer appeared in 1543 and a translation of the New Testament in 1548 - but written Finnish remained little-used for centuries. Instead, Swedish served as the language of government administration, education and culture.

Swedish, in turn, was strongly influenced by German. The trained scriveners of the 16th century were bilingual and had studied abroad, first and foremost in Lutheran Wittenberg, Rostock or Greifswald. One sign of this was borrowings in the field of orthography. Pursuant to the German pattern, the educated elite introduced the so-called silent $<\mathrm{h}>$, a lengthening form used before a sonorant (cf. $<$ swahr $>,<$ fahra $>$ ), and thus a syllabic spelling, but not a morphological one.

Background factors in Croatian were somewhat more intricate. Croatian, like Czech, was first written with a Glagolitic alphabet. In contrast to Czech, however, this tradition was maintained uninterrupted until the Early 
Modern period. Moreover, Croatian was also written and printed using both Cyrillic and Latin characters. Even 16th-century Protestants used all three alphabets to propagate their teachings. Furthermore, there was the fact that Protestantism failed to become established, and that many members of the urban elites eschewed Croatian and preferred to speak the language of whichever civilization had dominion over their respective province.

It is undoubtedly Czech, however, whose phonographic path of development proves to be the most surprising. In the Late Middle Ages, the Kingdom of Bohemia was a major European centre of education and culture. The Hussite Revolution of the 15th century was a reformation that preceded even the European Reformation of the 16th century, and the first Bible in Czech including both the Old and New Testaments was printed as early as 1488. Accordingly, one would expect to see development in the direction of semiography, and Czech does indeed show signs of morphological spelling. Thus, the ring diacritic on the $u(\stackrel{\mathrm{u}}{)})$ actually indicates an $o$ in the paradigm - for example, in <dům> 'house' (nom. sg.) as opposed to genitive singular domu and nominative plural domy - but this path of development was interrupted. Beginning in the 16th century under Habsburg dominance, Czech increasingly lost its status as the lingua franca of the elites. Its prestige diminished and it became the idiom of the underprivileged classes. This is a good reason why the Czechs look back on the three centuries following the Battle of the White Mountain in 1620 as the temno, the Dark Years.

As the approach that we have briefly outlined here shows, one can summarize the various paths of development of European orthographies at the beginning of the Early Modern period into different types. In the case of the first main type with a "logographic" starting point, the Romance languages, we can distinguish two paths of development: Italian and Spanish became mainly phonographic while French became increasingly "logographic", after going through a more phonemic phase. In the case of the second main type with a phonographic starting point, we have also traced two paths: German, Polish, Hungarian and English became "logographic" while Finnish, Swedish, Croatian and Czech remained more or less phonographic. The very fact of assigning the various languages to their respective subgroups makes it clear that orthographic developments do not conform to the boundaries of language families, and this is why we are arguing that it must necessarily have been factors external to the languages themselves that were responsible for these differences - above all, Protestantism or the degree of literacy. This is so because when disputes surrounding questions of faith are conducted in the vernacular and printed matter can reach a 
broad readership, then systems of writing develop reader-friendly characteristics. Abbreviations are phased out, heads of nominal groups are written with capital letters, punctuation marks are introduced, paradigmatic spellings are standardized and silent letters are utilized as reading aids. All of this is characteristic of what Maas has referred to as the "demoticizing" of writing.

The comparative view that we have striven to take here is a first and still quite modest step. This anthology clearly indicates the great extent to which the orthographic histories of the languages under consideration here were determined by the shared European traditions of the Western Church and Latin, and of print culture, and thus also how much scholarly research would have to gain from systematic comparison. It is our fervent wish that what has been shown here using the example of orthography could be a first step towards a more general comparative history of European languages.

We sincerely thank all the contributors for their committed involvement and for the enthusiasm with which they have participated in this undertaking and given us their support.

\section{Notes}

1. The term semiographic covers here all non-phonographic elements, which may have different origins (morphological distinction or analogy, etymological reference, historical survival of obsolete forms, litterae legibilior [for example, the letter $y$ ], all of which have in common the fact that their purpose is to transmit information of a semantic nature).

2. $<$ ill $>$ (Taillebosc), $<\mathrm{il}>$ (Tailebosc), $<\mathrm{lg}>$ (Talgebosc), $<\mathrm{illi}>$ (Batailliae), $<\mathrm{ilg}>$ (Tailgebosc), <ilgi $>$ (Tailgia), <lli $>$ (Talliebosc), <illg> (Taillgebosc), <ll $>$ (Tallebosc), $<$ llg $>$ (Tallgebosc), cf. Pope (1934: §696).

3. We will not focus here on the underlying manifestations of phonetic assimilation, but rather on the perceived gap between "logographic" spelling and phonetic recoding.

4. The earliest known printed book also plays a key role for a book religion, Mahāyāna Buddhism. It dates back to 868 and is called Diamond Sūtra (Vajracchedikā Prajñāpāramitā Sütra).

5. The question of how external factors such as literacy interact with internal factors such as homophony still has to be discussed. 


\section{References}

Auroux, Sylvain

1994 La Révolution Technologique de la Grammatisation. (Philosophie et Langage.) Liège: Mardaga.

Auroux, Sylvain, E. F. K. Koerner, H.-J. Niederehe, and Kees Versteegh (eds.)

2000-06 History of the Language Sciences. An International Handbook on the Evolution of the Study of Language from the Beginnings to the Present. (Handbücher zur Sprach- u. Kommunikationswissenschaft 18/1-3.) Berlin/New York: Walter de Gruyter.

Buridant, Claude

1996 Varietas delectat. Prolégomènes à une grammaire de l'ancien français. Vox Romanica 55: 87-125.

Buringh, Eltjo, and Jan Luiten van Zanden

2009 Charting the "Rise of the West": manuscripts and printed books in Europe. A long-term perspective from the sixth through eighteenth centuries. The Journal of Economic History 69: 409-445.

Gawthrop, Richard, and Gerald Strauss

1984 Protestantism and literacy in Early Modern Germany. Past and Present 104: 31-55.

Maas, Utz

1985 Lesen - Schreiben - Schrift. Die Demotisierung eines professionellen Arkanums in der Frühen Neuzeit. Zeitschrift für Literaturwissenschaft und Linguistik 59: 55-81.

Mitterauer, Michael

2003 Warum Europa? Mittelalterliche Grundlagen eines Sonderwegs. 2d ed. Munich: Beck.

Morenz, Siegfried

1950 Entstehung und Wesen der Buchreligionen. Theologische Literaturzeitung 75: 705-15.

Padley, G. A.

1976 Grammatical Theory in Western Europe, 1500-1700. The Latin Tradition. Cambridge: Cambridge University Press.

Pope, Mildred K.

1934 From Latin to Modern French with Especial Consideration of

Sampson, Geoffrey Anglo-Norman. Manchester: Manchester University Press.

1985 Writing Systems. A Linguistic Introduction. Stanford, California: Stanford University Press.

Wright, Roger

1982 Late Latin and Early Romance in Spain and Carolingian France. Liverpool: Francis Cairns. 



\title{
Spanish \\ Variation and standardization in the history of Spanish spelling
}

\author{
Elena Llamas Pombo
}

\section{Introduction: Spelling through the looking-glass}

If writing is a fundamental field in the ideological and symbolic production of societies, there are two ideas or, rather, ideals, that run through the entire history of written Spanish: first, its phoneticism, as an ideal of orthographical simplicity; and secondly, spelling unity as opposed to diversity of orthographical rules.

The present-day system of Spanish spelling is much simpler than that of many other languages of modern European cultures, such as English or French. The correspondence between phonemes and graphemes is greatest in present-day orthography, and this primacy of the phonemic principle is the result of a long process and of a series of reforms that began in the Middle Ages. Let us compare, for example, the following words: written Spanish shows a high degree of correspondence between spelling and pronunciation, so that, although there are exceptions, the phonemic principle of writing predominates over the etymological principle and orthographical conservatism:

Table 1. Spelling-pronunciation correspondence in French, English, Spanish

\begin{tabular}{|c|c|c|}
\hline French & English & Spanish \\
\hline orthographe & orthography & ortografia \\
\hline /oRto'graf/ & /o:r' $\theta$ agrofi/ & /ortogra'fia/ \\
\hline automne & autumn & otoño \\
\hline /o'ton/ & /'o:təm/ & /o'tojo/ \\
\hline football & football & fútbol \\
\hline /fut'bol/ & /'føtbo:l/ & /'futbol/ \\
\hline pharmacie & pharmacy & farmacia \\
\hline /farma'si/ & /'fa:rməsi/ & /far'ma $\theta j a /$ or /far' masja/ \\
\hline
\end{tabular}


In languages such as French or English, in which the phonic and the graphic elements have acquired an especially complex relationship throughout the centuries, reflection on writing has mainly focused on the functioning of this correspondence. In the case of Spanish, the better adaptation of the letters to the sound has fostered phoneticism as the most important and ideal reference point for scholars. This phoneticism has characterized both the works of our orthographic coding and the modern studies on the great milestones of our standardization (Martínez Alcalde 2001: 692-693).

For example, in the 15th century, there was a Latinizing trend that favoured etymological spellings, such as escriptor or tractado, already pronounced then as escritor and tratado, which are the present-day written forms of these words. Given the few occurrences of these cases of etymologism, they have been considered as "marginal" or "minor pitfalls" with respect to what Rosenblat (1951: XXI) calls the "firm Hispanic tradition of simplicity and respect for pronunciation".

To deal with the correspondence between the phonological units and the graphic signs representing them, theoreticians of writing have referred to three principles throughout the centuries: pronunciation, etymology and usage; combined harmoniously or used in isolation, they have given rise to many different proposals, some of which are opposing and irreconcilable (Esteve Serrano 1982: 13, 17).

These three principles that intervene in the fixing of spelling have at times acquired, implicitly or explicitly, a hierarchy. Thus, according to the phonemic theory which is so deeply rooted in Hispanic thought, the main purpose of spelling is to reflect phonemic reality, in such a way that this phonemic reason ideally tends to be opposed to usage and etymology. Hence, proposals that do not respect this particular view have been interpreted by many scholars as "regressive" (Martínez Alcalde 2001: 698). ${ }^{1}$

One of the strong arguments in defence of the phonemic principle of our spelling system has been educational: the ease with which writing is learned in languages which have the closest correspondence between the letters and their pronunciation. In recent years, certain pedagogues in the English-speaking world have initiated a debate, which has had echoes in France and Spain, about the age at which children should learn to read and write. From the Spanish Royal Academy (RAE), the academician Gregorio Salvador defended the advantages of Spanish and the possibility of starting to teach how to write it, not at the age of six, as is the case in other languages, but at the age of four, given the almost phonological nature of our system: a system quite different from English, for example, in which the 
spelling of many words, because of their archaic spelling, needs constant practice to be acquired. Phoneticism as an ideal still prevails:

The sooner children ... transfer their phonic system into writing, the sooner and the more fully they will integrate their language into their brains as a whole, both oral and written; they will think of the words without distinction as they are written or as they are pronounced: one will be the faithful reflection of the other, as in a mirror-image. To move freely, naturally, through the looking-glass, into the reflected or illusory written world, to take one's own way of thinking over to that other side, is to take the open road into such a wonderful dimension of life, which for children is beginning, and which can bring them wonders so amazing that not even Lewis Carroll could imagine them. (Salvador 2004: 59) ${ }^{2}$

However, the existence of a perfectly phonological spelling is a mirage that fades when we consider the reality of the spoken language of Spanish speakers at close range. Our spelling could never be completely phonological, simple and transparent, since the spoken language takes on quite different forms in Spain and in the countries of Latin America. If we wished to represent faithfully the phonological systems of all Spanish speakers, we would have to have two or perhaps more spelling systems; and this would very likely break up the unity of the written language, depriving us of the advantages of a standard system common to almost 500 million speakers.

The Spanish spelling system has to be common to different pronunciations: consequently, the spelling rules entail a certain amount of arbitrariness. We well know that the problems and "mistakes" in spelling are directly proportional to the degree of distance between the spelling conventions and the oral ones. Thus, some of the most serious proposals for reforming spelling towards a totally phonemic and transparent system have come from Latin America, where the struggle against illiteracy has been an urgent and primordial task. ${ }^{3}$

One of the major movements in favour of spelling reform was that which took place in Chile in the 19th century, promoted by Andrés Bello, and inspired by a social ideal: all the peoples who became independent should be able to benefit from written culture. Nevertheless, in order to make this written culture more accessible, Bello claimed, "keeping useless letters for the sake of etymology is like keeping rubble in a new building so as not to forget the old building" (quoted by Martínez de Sousa 1991: 59). His proposals were applied radically by Domingo Faustino Sarmiento, in the violent anti-Spanish wave that swept through Latin America at the beginning of the 19th century. A new norm, based on Latin American pro- 
nunciation, became the national spelling of Chile between 1844 and 1847 . However, during the 19th century, all the Latin American countries progressively adopted the spelling of the Spanish Academy, made official in 1844. This to a certain extent isolated Chile, a country where the reform was maintained until 1927 with divergences, or rather with a certain amount of chaos, which, instead of favouring the reform, harmed the efforts to simplify. Therefore, the history of radical spelling reforms during the 19th century is "the history of a series of failures" (Esteve Serrano 1982: 14).

Far from favouring diversity of spelling, all the proposals to reform and simplify the spelling agree on the need to protect the unity of Spanish. This unity is precisely the primordial mission that today's Spanish Academy has taken upon itself. Nowadays, the only spelling rules having widespread value in the Spanish-speaking world are those of the Spanish Royal Academy, associated with the Spanish language academies in each Spanishspeaking country. They all recognize that this linguistic unity is the major unifying force of the Spanish-speaking cultural community. This unity makes for strength in the face of the primacy and cultural visibility of the English-speaking world.

From this perspective, it will be understood, in short, that the phonetic argument and the powerful arguments of unity are two of the key elements around which the history of written Spanish has been established. It will also be understood that in the face of the ideal of homogeneity, spelling variation has often been perceived as "chaos" or "anarchy".

\section{Patterns of spelling variation in Iberian languages in the Middle Ages}

\subsection{Diachronic variation: The broad frontier between Latin and Romance}

If we are to study the origins of spelling variation in the Middle Ages, we must first go back to Latin. When tackling a graphematic study of the earliest documents in Romance languages, it must be taken into account, just as on any other level of the language, that there is no break between Latin and Romance. $^{4}$

To characterize the development from one of these languages to the other, Carlos Cabrera (1998: 12) has insisted on the idea of "an unlimited frontier": a linguistic continuum and therefore a spelling continuum. We can speak of a continuum, because the early documents from Spain show a 
spectrum of diachronic variation which goes in its extremes from writing in Latin to writing in the Romance language, and between which there is a whole range of different spelling traditions.

As Cabrera explains, the scribe of the early Middle Ages inherited a spelling system which, right from Late Latin, began to pose some problems: specifically, a progressive breaking of the principle of spellingpronunciation adaptation. For example, this author (1998: 13) has called attention to the corrections of the famous Appendix Probi. This documentary source has often been used to identify pronunciations criticized by a purist commentator. However, for Cabrera, these corrections of the Appendix concern rather the written level, and examples such as the following $A$ non $B$ type sequences seem to indicate less that "[in Latin] one must say $\mathrm{A}$ and not B" but rather "one must write A and not B":

vacua non vaqua

crista non crysta

garrulus non garulus

\subsubsection{Diachronic, diaphasic and diasituational variation}

These types of double spellings, one supposedly normative and the other more vulgarized, support the author's hypothesis that, within the Latin spelling tradition, a double spelling trend began quite early (Cabrera 1998: 14):

a) A puristic trend, continuing the spelling pressure from classical Latin texts, which seeks to imitate the written rules of the latter;

b) Another more vulgarized tradition of writing Latin, in which the principle of correspondence between the spoken and the written word seems to have been abandoned. This tradition is characterized by frequent cases of heterographs (one sound represented by several spellings) and heterophones (one spelling for several pronunciations). In some cases, we find that the more puristic spelling tradition is contaminated by the more vulgar one, because of the different spelling traditions the scribes knew. Thus, the particular traits of Latin in each territory and the influences or linguistic interferences of Early Romance conditioned the linguistic and hence graphic characterization of these texts, which show certain differences from one geographic area to another;

c) At the end of this scale we would have to situate the writing system of the Romance language. 
This diastratic and diachronic variation (a cultivated form and a vulgar form) is related to patterns of diasituational variance, because, according to Cabrera (1998: 14), the different spelling types were used by the scribes according to the type of document or its addressee:

a) The more puristic and more complex tradition was reserved for the most cultured tasks;

b) The vulgarized tradition was used in more routine documentary tasks, such as texts referring to buying and selling or donations, since this writing had to be more understandable, given its greater proximity to the spoken Romance language.

Additionally, Cabrera (1998: 14) has shown that there was diaphasic variation, because sometimes one same scribe had command of both Latin spelling systems, as well as the Romance system when the latter existed. Three spelling traditions could even coexist in one document, especially in the 12th and above all, in the 13th century. That is to say, this plurality of traditions exists not only as external variation (variation from one text to another), but even as internal variation (variation within a single text).

The data that Cabrera gives concerning this type of internal variation comes from 13th century Leonese Vulgar Latin texts. ${ }^{5}$ For example, a document dated 1247 begins with a typical formula written according to the classical, puristic spelling tradition: In Dei nomine, amen. Notum sit omnibus per hoc scriptum... However, further on, elements of the Vulgar Latin system (quod ego, unam meam uinam...) and of the Romance spelling system (donna, lugar, ennos...) appear simultaneously:

... quod ego Marin Yllanz de mia ueluntad vendo a uso donna Sancha Moniz, abbatissa de Carrizo et al conuento des [sic] mismo monesterio, unam meam uinam que he sobre Rebolar, lugar nomrado ennos Mayolos, que sic determinatur de.$^{\mathrm{a}}$. parte vinna que fu de don Velasco ...

Then, in a short transition, the Vulgar Latin system gives way to a more classical style of Latin: Hanc uineam sic determinatam uendimus uobis cum omni iure et integrate sua pro . $X^{a}$. morabetinos bonis quos nobis iam dedistis ... And the colophon reverts to a Vulgar Latin and properly Romance tradition (with place names, proper names, and Spanish expressions or words such as estos son testigos, fiyosdalgo, capellan, etc.)

Consequently, there seems to be an intention to distribute the different spelling traditions according to the information provided: what is of most interest for the receiver, the basic information in the document, appears in a 
vulgar tradition, even Romance, which when read aloud would be clearly understandable; on the other hand, the purely formulistic, routine information, keeps to a conservative spelling.

This type of text has allowed Cabrera to defend the idea of a linguistic and spelling continuum, in which the various Latin spelling rules and even the Romance element coexist in a state of perfect symbiosis. ${ }^{6}$

This convergence of different Latin spelling traditions in competition worked - in the words of Cabrera (1998: 16) - as a "true field of practice" for the future consolidation of the Romance spelling system. The Spanish vernacular system was to owe much to the Vulgar Latin writing variant. (However, evidently, not all scribes would have been capable of using the different written registers of Latin.)

\subsubsection{Cryptographic writing?}

The existence of this type of mixed text with a strange Latin-Romance writing has given rise to a particular theory proposed by Roger Wright (1982, 1988, 1993). To explain the relationship between Latin and Romance in the Middle Ages, Wright and other linguists have defended the argument that in Hispania and in France, there was only one language, Romance, which is the language in which texts were written, although this writing adopted the form of Latin spelling. In other words, what the spelling system of Vulgar Latin texts really represented was the pronunciation of the vernacular language, a writing system that would blur the frontiers between two quite different linguistic situations. It would thus be a logographic or cryptographic writing system.

However, this hypothesis has been widely criticized by historians of Spanish. ${ }^{7}$ Manuel Ariza (2005: 309), for example, sums up his criticism with an illustrative example: according to Wright's theory, when in a text we read GUNDISALVUS AMAUIT MULIEREM SUAM, we would be reading Gonçalo amó a su mujer. Or when we read SCILICET, what we suppose they read then was es decir.

The explanation for these mixed texts, for Ariza (2005: 318), is different: it seems obvious that the scribe was trying to write in Latin, but his knowledge of the language was minimal. Thus, what he does is to Latinize as best he can what he was thinking in Romance. Hence, the texts are full of hypercorrect forms (e.g., *apate, as if it were the Latin form of abad; * soprino as if it were the Latin form of the Spanish sobrino), and of a mixture of Latin forms (cirka, alio... etc.) and Romance forms. ${ }^{8}$ 
1.2. External variation: The first steps from sounds to letters (10th-12th centuries)

Let us now examine the situation of the oldest texts written in Hispanic vernacular languages. Since Menéndez Pidal (considered as the "father" of Spanish philology), the idea of irregularity and graphic anarchy in the earliest documents in Spain, which date from the 10th and 11th centuries, has been accepted. Menéndez Pidal (1986: 68-69) considered that the writing of those centuries "is characterized by great confusion" and by being "very indecisive, using several representations, sometimes seven or eight at the same time, for the same sound. It is thus in a perfect state of chaos".

We can confirm this state of spelling variation by examining, for example, how writers transcribed new sounds of Hispanic Romance that did not exist in Latin, and for which, obviously, the Latin alphabet did not, in principle, have special letters. As an example, we can look at the treatment given to two palatal consonants. For Menéndez Pidal (1986: 47), in the first attempts at transforming Hispanic Romance from voice to letter, we find a complete writing system and a special spelling for the notation of these palatals. We can see that the solutions found for transcribing these sounds oscillated widely or rather, they correspond to different attempts at transcribing new phonemes, which would give rise to different writing traditions according to the regions or the scriptoria (see Menéndez Pidal 1986: 48-52):

a) The palatal fricative consonant /j/ (in the Phonetic Alphabet of the Revista de Filologia Española, this phoneme is represented by /y/). For the transcription of this phoneme inherited from Vulgar Latin, the scribes of the earliest texts found several solutions:

Table 2. Variants corresponding to $/ \mathrm{j} /$

\begin{tabular}{|c|c|c|}
\hline variant & example & \\
\hline \multirow[t]{2}{*}{$<\mathrm{g}>$} & get $[$ jet] & (Sp. 'él es', Engl. 'he is') \\
\hline & segamus [sejamus] $<$ SEDEAMUS & (Sp. 'seamos', Fr. 'soyons') \\
\hline$<\mathrm{j}>$ & jet $[$ jet $]$ & (Sp. 'él es', Engl. 'he is') \\
\hline$<\mathrm{i}>$ & iet $[\mathrm{jet}]$ & (Sp. 'él es', Engl. 'he is') \\
\hline \multirow[t]{2}{*}{$<\mathrm{gi}>$} & segiant $[$ sejant $]<$ SEDEANT & (Sp. 'sean', Fr. 'soient') \\
\hline & \multicolumn{2}{|c|}{ Compare with Earliest Old French regiel < REGALEM } \\
\hline
\end{tabular}


b) The palatal nasal $/ \mathrm{n} /$ : there is a whole range of solutions for noting down this sound, which did not exist in Latin:

Table 3. Variants corresponding to $/ \mathrm{n} /$

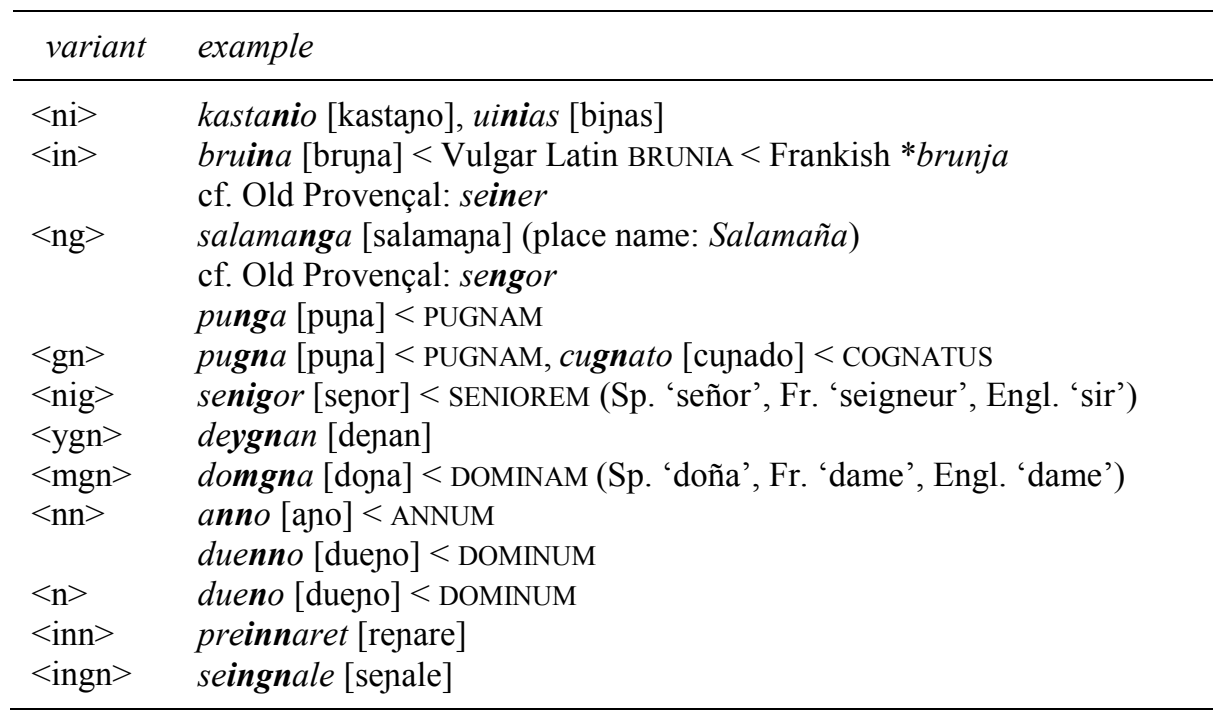

In this latter, somewhat complicated solution, we have the impression that the scribe is using the letters of the Latin alphabet not simply to transcribe a phoneme, but as an instrument of analysis of something similar to a third articulation: it could be thought that he is seeking to transcribe each individual phonetic characteristic of the consonant (nasality with the $<\mathrm{n}>$, the palatal nature with the $<\mathrm{i}>$, etc.). This spelling is much less economical than the simple letter $<\tilde{\mathrm{n}}>$ in Spanish, used to transcribe the sound $/ \mathrm{n} /$. But this "spelling complication" allows us to glimpse, at least, an attempt to reflect the 10th-century oral reality, as well as the difficulty in achieving it.

It was a complex graphic world, in which there was no lack of "hybrid uses and diverse spelling experiments" - in the words of Cabrera (1998: 17) - with "complicated transcriptions" of "enormous graphic inaccuracy" at times - according to Menéndez Pidal (1986: 54).

Nevertheless, both Menéndez Pidal (1986: 69) and Lapesa (1980: 166) admit that, within this apparent anarchy, there is an order, that is, "certain dominant norms" that spread throughout Spain or throughout large expanses of its territory. Some of the spelling solutions shown above were preferred to others in certain regions; for example $<\mathrm{nn}>$ was preferred in 
the North of the peninsula to $<$ ng $>$, used only in the East and in the South, $<$ mgn $>$ in Leon, etc.

But the most important feature of the earliest writing is that it already contained all the elements, all the solutions that would later be selected by Alphonse $X$ the Wise in the 13th century, in the first attempt to simplify and standardize Castilian spelling. It formed an integral part of what Menéndez Pidal (1986: 70) calls the "simple and so admirably phonetic Alphonsine spelling, which is the basis of the no less admirable modern one".

\subsection{Diatopic variation}

The plurality of solutions for a single sound thus corresponds to several attempts at transcription, which gave rise to different traditions in different regions or centres of culture. The examples of spelling variants cited above belong to Castile, Leon and the Navarro-Aragonese area.

Moreover, we should not overlook the basic fact that, in the Iberian Peninsula around the 10th century, Vulgar Latin gave rise not just to one language, but to many languages, some of which still survive today (see Lapesa 1980: 178 and Bustos Tovar 2005: 271-275). As José Antonio Pascual (1996: 448) points out: "The language of the 10th and 11th centuries presents itself to us in its full variation, quite remote from the uniformity to which the linguists who reconstruct the early stages of the language are accustomed". ${ }^{10}$

In the South of the Iberian Peninsula:

Mozarabic Romance: The Early Romance of Muslim Spain is the direct descendent of the linguistic changes that had taken place in Hispanic Vulgar Latin from Visigothic times. The Hispano-Visigoths, under Muslim domination, preserved cultural and linguistic autonomy from the 7th to the 10th centuries; the language spoken by these Mozarabs was the first Romance language spoken in the Iberian Peninsula. From the beginning of the 11th century, Mozarabic decreased progressively owing to the advance of the Reconquista; its dialects, isolated from the rest and restricted by the use of Arabic as the language of culture, evolved very slowly.

In the North of the Iberian Peninsula:

Galician-Portuguese Vernacular (which would give rise to the presentday Galician and Portuguese languages)

Catalan Vernacular (which became a language of culture) 


\section{Leonese Vernacular}

Castilian Vernacular: over the centuries, and with contributions from several languages, it would become the official Spanish language.

Aragonese Vernacular

There was also the Earlier Navarrese Vernacular, which would finally blend with Aragonese, and the Riojan Vernacular, a dialect of transition between Aragonese and Castilian.

During the Middle Ages, one of the varieties from the North would become the language that would later receive the name of Spanish. This language came into being in a different way from all the other Romance languages, and it would not be amiss to recall here - with E. de Bustos Tovar (1995: 13) - that languages are the products of a historical process, the result of the use of language by a given human community. The linguistic history of Spain is linked to the historical process of the Reconquista, with its stages of fighting to recover territory occupied by the Muslims and with its longer stages of co-existence with them. We must constantly refer to this important event, from the most superficial aspects (the linguistic maps of the Iberian Peninsula have to be read from North to South) to the most complex ones, such as the spreading of Castilian and its becoming the national language.

From the 11th century onwards, Castilian advanced like a wedge, spreading southwards as the Reconquista forged on, and along the sides, by virtue of the cultural and political influence of Castile (Menéndez Pidal 1986; Lapesa 1980: 192).

Among all the Neo-Latin dialects in the Iberian Peninsula, there was, then, in the first place, important linguistic and phonetic variation. For example, in the 10th century, the following words would have been written differently in the various dialects, for the simple reason that they had different phonetic realizations in each of them:

Table 4. Latin oculum in different dialects

\begin{tabular}{ll}
\hline dialect & variant \\
\hline Galician-Portuguese & ollo / olho \\
Leonese & uello $>$ ueyo \\
Aragonese & uello $>$ güello \\
Catalan & ull \\
\hline
\end{tabular}


Concerning this level of variation, some specialists today insist that it is not correct to say that Castilian "was not fixed" in the period between the 10th and 12th centuries. José Antonio Pascual (1996-97: 100-101) has shed a little more light on the nature of spelling variation at that time, attempting to explain the apparent "disorder", using a hypothetical example: if, in the 21 st century, the word caballo 'horse' were to be represented according to its different real pronunciations in the Spanish-speaking world, and according to different writing traditions, this word would perhaps show forms such as *caballo, *cavallo, ${ }^{*}$ cabayo, ${ }^{*}$ cabašo, ${ }^{*}$ kabažo. ${ }^{11}$ Something similar occurs - in J. A. Pascual's view - with the coexistence in medieval documents of the forms altariu, autariu, autairo, otero, auteiro, outeiro, oterio, autero and oteiro 'hill': according to this author, these forms do not reflect "chaos", but "latent spelling rules", the product of learning to write. This learning of the scribe's trade took place early on in the monasteries and then spread to the cathedral schools. In both - Pascual adds - each master managed to transmit, for better or for worse, his preferences to his students. Those who were learning were certainly in favour of the normative tradition of their masters; or otherwise they could adopt spelling conventions taught in other more important places. That is to say, in Pascual's view, there was no "lack of fixation", but rather a variety of "rules avant la lettre". ${ }^{12}$

\subsection{Internal variation as an aesthetic principle}

As Sánchez-Prieto (2005: 426) has rightly affirmed, medieval spelling variation should not be accused of arbitrariness. In our present-day rulebased mentality, spelling heterogeneity is discredited, whereas lexical variation is considered positively (for example, we are told not to repeat the same word in a sentence, to avoid endings that rhyme, etc.). However, in the Middle Ages, variatio was a constituent characteristic of writing style, especially in the 13th century, and it was evident at all levels of the language, and in particular on the graphic and phonetic levels, as Margherita Morreale (1978: 253) has pointed out.

The French grammarian Claude Buridant (1996: 90), in his study of Old French grammar, attributes an anthropological significance to the importance of variance in the Middle Ages. And his reflection seems to us to be totally valid for medieval Spanish as well. For this author, variance goes beyond mere linguistic competence, as it forms part of the medieval mental architecture and is revealed at different levels. The essence of this architec- 
ture would be a taste for variety, within the setting of a society in which orality prevails. Buridant attributes the Latin saying varietas delectat to medieval man, and, in particular, to the intellectual, because the latter moved naturally in a universe of variance, in which he took pleasure.

Indeed, this mental architecture impregnated the very nature of literary production. In the case of medieval French literature, Paul Zumthor spoke of its constituent mouvance, a characteristic largely common to other medieval Romance literature: "Before the age of the book, the oeuvre was almost an abstraction, since the specific texts written had variations and rewritings, within an unceasing oscillation and fundamental instability" (Zumthor 1972: 507; see also 1980: 69).

This essential variance of texts has frequently been a source of problems for philologists, in their need to establish a single, stable text. However, this fundamental trait has also been perceived positively, especially by Bernard Cerquiglini, who in 1989 intoned a Praise of the Variant, by understanding this mouvance as the "euphoric appropriation of writing" and "joyous excess" of the medieval scribes. ${ }^{13}$

In parallel, this particular mindset is also revealed on the purely linguistic level. For example, as the Hispanist Margherita Morreale pointed out some time ago (1978), variatio formed part of 13th-century adornment of prose in syntax, morphology, phonetics and of course, in spelling. Morreale reminds us that variatio, as a word figure and as a sentence figure, is a subdivision of the repetitio in Western rhetoric. That is why she pointed out that the scholarly preparation of some scribes and copyists should be investigated, since this rhetorical resource must have served as a stimulus to linguistic variation that went beyond models. ${ }^{14}$

In a study such as Morreale's on a 13th-century Bible, in which morphological, syntactic, phonetic and spelling variations are considered conjointly, the latter acquire sense within a general stylistic adornment understood as variatio. When the translator wrote without distinction:

assyrios or assirios, conplido or complido, Egipto or Egypto, espirito or spirito,

\author{
fui or fuy, \\ onrra or onra, \\ sábbado or sábados, \\ santo or sancto,
}

sesenta or sessenta, Syón or Sión, Tophet or Thophet, uessos or huessos,

he was applying to spelling the same aesthetic principle of variation that he applied in the vocabulary (offering synonyms) or in the syntax (varying the word order in symmetrical structures). Often, today's reader of medieval manuscripts feels uncomfortable with an apparent lack of spelling consis- 
tency or the apparent carelessness of the medieval scribe. However, within the particular "economy" of an aesthetics of variation, those differences become a stylistic resource. Margherita Morreale's insightful article puts us on the track of the extensive possibilities of choice that 13th-century Castilian prose offered: its great flexibility and its room for manoeuvre as regards spelling. I think we should consider her perspective when studying the spelling of many other texts, not just Castilian ones, but also those in other Romance languages, such as Old French. ${ }^{15}$

This same flexibility and tolerance allowed the margins of acceptance of morphological variation to be very broad. Bodo Müller (1996-97: 121) studied a particular case of morphological (and spelling) variation for aesthetic reasons: in 13th-century texts in verse, some authors used morphological variation to create, sometimes mechanically, rhymes and assonances. Thus, for example, Gonzalo de Berceo made use of very artificial and very rare variants in order to satisfy the demands of rhyme. Let us consider a few examples of his morphological variation (see table 5 below). Alongside frequent forms, Berceo used stranger, infrequent or artificial variants that allowed the rhyme with other verse endings.

Table 5. Morphological variation (Gonzalo de Berceo, from Müller 1996-97)

\begin{tabular}{|c|c|c|}
\hline frequent forms & $\begin{array}{l}\text { Berceo's infre- } \\
\text { quent variants }\end{array}$ & rhymes with other verse endings \\
\hline doliente & dolioso, $-a$ & gloriosa $-\operatorname{cosa}-$ dolios $a-$ sannosa \\
\hline error & erranza & fianza - erranza - venganza - malandanza \\
\hline escarnio & escarnimiento & $\begin{array}{l}\text { piment - maravillosamente }- \text { falliment }- \\
\text { escarniment }\end{array}$ \\
\hline fallimiento & $\begin{array}{l}\text { fallencia, } \\
\text { falla }\end{array}$ & $\begin{array}{l}\text { penitencia - creencia - fallencia - violencia } \\
\text { vocealla - falla - agalla - vatalla }\end{array}$ \\
\hline folganza & folgura & derechura - folgura - escriptura - mesura \\
\hline frio & fridura & tempradura - fridura - calentura - ardura \\
\hline padecer & padir & encobrir - reir - decir - padir \\
\hline pavor & pavura & pavura - ardura - mesura - criatura \\
\hline potencia & podestadía & ledanía - María - podestadía-día \\
\hline
\end{tabular}




\section{Variation and standardization (13th-16th centuries)}

Spanish has experienced four great periods of deliberate reform and regulations, aimed at its codification:

a) The 13th century, with King Alphonse $X$ the Wise, who chose Castilian as the official language of the realm and established the first bases of its orthographical system;

b) The 16th century, with the triumph of the ideals of an imperial and universal vernacular language;

c) The 18th century, with the creation of the Spanish Royal Academy;

d) And finally, the 20th century, with the renewal of the academic institutions and their interest in maintaining the unity of the language among Spanish speakers.

All these movements have been closely linked to exogenic background; the characteristic trait of the first three - 13th, 16th and 18th centuries - is their "socially open" nature, in the words of Marcos Marín (1979: 96). But they were not all of the same nature: in the 13th century, the reforms were institutional, since they originated in the royal school, the scriptorium of Alphonse X and his school of translators in Toledo. However, in the 16th century, collective concerns about the language were revealed in the individual works of the Spanish humanists. These first two stages of reform had a permanent impact on the written language (Marcos Marín 1979: 9597).

\subsection{The first "official" spelling of Castilian (13th century)}

The 13th century was when the first steps were taken to standardize Castilian. Playing a fundamental role in this transformation was the initiative of Alphonse X (King of Castile, Leon and Galicia from 1252 until his death in 1284), the most universal and brilliant monarch of the Hispanic Middle Ages as a whole. He was a king who has deservedly received the name "the Wise", because he institutionalized the use of Castilian and promoted a production of texts without comparison in his time.

The constitution of a standard language is a centuries-long process which takes place on three fronts (according to Fernández-Ordóñez 2005: 231): 
a) Selection of the linguistic variety that will be the basis of the standard language;

b) Use of that selected variety in all possible functional spheres;

c) Coding or fixing of the linguistic uses of that variety.

During the reign of Alphonse X, advances were made on all three fronts in the standardization of Castilian, although the entire process would take several more centuries (Fernández-Ordóñez 2005: 383):

a) The first phase of linguistic nationalization and the "official" choice of Castilian: In the Chancery of Alphonse X, the Castilian vernacular was deliberately adopted as opposed to Latin, thus moving ahead of the other three kingdoms of the Iberian Peninsula and also of the English and French kingdoms, which took at least half a century more to make this practice widespread. Castilian was adopted above all in legal texts, and the repopulation of the territories captured from the Muslims accelerated this process, owing to the need for understandable texts in the distribution of lands and for the new administrative organization of those territories. If Castilian was chosen, it was because the region of Castile had the greatest demographic and economic weight, as of the middle of the 12 th century.

b) Broadening of the functional sphere: Alphonse $\mathrm{X}$ fostered a vast programme of intellectual renovation in the three fields of law, historiography and science. The royal scriptorium produced the first History of Spain and numerous translations of scientific texts in Arabic; it also cultivated poetry, with both religious and profane cantigas ${ }^{16}$, produced books about parlour games, hunting techniques, and so on. The king surrounded himself with translators and collaborators who must have had a variety of linguistic usages, which is why the corpus of Alphonse $\mathrm{X}$ is not exempt from a certain degree of dialectal colouring. ${ }^{17}$

c) Coding and simplification of spelling: The 13th century saw the establishment of a spelling system that ensured its fidelity to living pronunciation and not to the writing of Latin. This spelling criterion tallies with the pre-eminence given to the spoken Castilian vernacular, since, following an ever more widespread practice under the reign of Ferdinand III, the father of Alphonse X the Wise, Castilian became the language of the administration as opposed to the Latin of the notaries. This agreement is a reflection of Alphonse's great intellectual project: a passionate follower of science, he made an attempt to renovate it and strip it of its Latin wrapping with the idea - according to Menéndez Pidal (1986: 
100) - of making all the social classes in his kingdom a party to it. In the translations made under his direct tutelage or under his inspiration, superfluous Latinisms and scholarly terms were suppressed in favour of Castilian words from the popular tradition, words directly adapted from Arabic, from the minstrel style, as well as words from Latin.

\subsubsection{The new spelling (13th century)}

This enormous production made it easier to establish a first "standardized" spelling, which was determined following a phonological criterion based on an almost complete correspondence between each graphic sign and each phoneme of medieval pronunciation, especially as regards the phonemes appearing in this Romance language and non-existent in Latin (Marcos Marín 1979: 91). ${ }^{18}$ The spelling model adopted the criterion followed in the writings of minstrels, namely, popular pronunciation.

True to the phonology of its time, this first spelling system of Spanish propagated, among other things (but always with a certain amount of variation), a set of graphic oppositions based on the simplest solutions and on the most economical combinations of letters of the alphabet, including the following:

- The graphy $<\mathrm{nn}>$ for notation of the palatal nasal $/ \mathrm{n} /$ ), sometimes abbreviated to $<\tilde{\mathrm{n}}>$, forerunner of the Spanish letter $<\tilde{\mathrm{n}}>$, as opposed to $<\mathrm{n}>$, for the phoneme /n/. E.g., sennor (today señor), annos (today años), as opposed to detener, hermanos.

- The graphy $<11>$ for the palatal lateral $/ K /$, as opposed to $<\mathrm{l}>$, for the phoneme /1/. E.g., llaman, ellos, as opposed to luego, salir, titulo.

- The opposition between $<c ̧>$ and $<\mathrm{z}>$ for the voiceless dental sibilant $/$ ts/ before $/ \mathrm{a} /, / \mathrm{o} /, / \mathrm{u} /$, and the voiced dental sibilant /dz/. E.g., cabeça, esforçado, as opposed to dize, fazer.

- The opposition between $<\mathrm{s}>$ and $<\mathrm{ss}>$, in intervocalic position, for the voiced sibilant /z/ and the voiceless sibilant/s/. E.g., cosas, guisado as opposed to esse, otrossi. 


\subsubsection{Chronology of the new spelling (13th century)}

This system, however, was not revolutionary; it was rather a coding, which selected and established the simplest spelling solutions from among all the previously recorded trends. As opposed to the spelling variation and the diversity of spellings that the sounds that appeared in Romance could have given rise to during previous centuries, the first "reform" of Castilian consisted above all of a standardization and a fixing. Alphonsine spelling did nothing more than continue a long practice and a slow selection that had been in operation between the 10th and 13th centuries (Menéndez Pidal 1986: 70).

In fact, Alphonse $\mathrm{X}$ did not invent any graphemes. The documents produced at the time of his father Ferdinand III clearly anticipate the graphic traits of the texts promoted by the son. The phoneticism of the writing attributed to the times of Alphonse $\mathrm{X}$ reached its high point and was anticipated three decades before in the documents of his father's time (SánchezPrieto 2005: 429 and 445).

The system was far from perfect, but it was much simpler than that of other contemporary languages. For example, Martínez de Sousa (1991: 40) insists that the difference between Spanish and French spelling is marked by the nature of their origins, since exactly at the same time (the 13th century), French spelling began to be fixed by following Latin closely, as the mastery of the written language at the time passed from schools for minstrels to the learned men of Parliament and the Royal Chancery. ${ }^{19}$

\subsubsection{Survival of diatopic variation (13th century)}

Despite this great moment of standardization and simplification of spelling, Alphonsine writing is not completely unified (Lapesa 1985, Sánchez-Prieto 2005: 444). There are palaeographic and linguistic differences in two quite distinct traditions:

a) In the writing of the Chancery, addressed to the administration, there is a notable unity. This is logical: the new territories conquered, the distribution of land, the charters, etc., required a unified linguistic form that would serve as a koinè, a common dialect for people of diverse origins, who came to resettle the conquered territories. 
b) However, in the major historiographical, legal and scientific codices, there was a "striking dialectal diversity" because of the disparate provenance of the collaborators and translators (Sánchez-Prieto 2005: 445).

In fact, most of the texts prior to the 15th century display, to a greater or lesser extent, traits that do not fit in with Alphonsine Castilian, and which are considered as dialectal forms (Blecua 1992: XCXCI).

\subsubsection{Palaeographic factors}

Historians of Spanish have always praised and admired the simplicity of this spelling, its relationship to the people's pronunciation, and so on. However, recently, more subtle and technical studies have demonstrated that the selection of a correspondence between writing and phonemes that arose in the 13th century also has palaeographic causes. Sánchez-Prieto (1996; 2005: 431) has analyzed how the Gothic book hand used in the Chancery of Ferdinand III and Alphonse X is characterized by a notable phoneticism. It is square, higher than it is wide, with a slight prolongation of the downstroke, which allows the lines to be written closer together, thus saving space on the parchment. The main consequence for the spelling options is the predominance of rounded letters, $<\mathrm{i}>$ and $<\mathrm{u}>$ versus the forms $<j>$ and $<v>$. The homogeneity of the line, with similar letters such as $<\mathrm{m}>,<\mathrm{n}>,<\mathrm{i}>,<\mathrm{u}>$, makes fast reading difficult, since it requires a linear type of reading in which the eye has to pass over almost all the letters. For Sánchez-Prieto, it was precisely this factor of legibility that favoured phoneticism, a trait that was never absolute, as this author insists.

In short: the first standardization of Castilian in the 13th century was related to exogenic circumstances: the growing political power of a monarch, the modernization of the administration through the use of a vernacular language, and the systematization of knowledge which necessarily brought in its wake a systematization of language and spelling. This first standardization of spelling opted for simplification, owing to what has been called its "open social nature". Hence, the first period of the history of Spanish spelling, which goes from the origins of Castilian to the middle of the 16th century, is called the phonetic period by some language historians (for example, Martinez de Sousa 1991: 42). One should, nevertheless, not forget an endogenic factor that favoured phoneticism: the material nature of writing and its conditioners of legibility and graphic layout. 


\subsection{Etymologism in the 14 th and 15 th centuries}

In the 14th century, the phoneticism that Alphonsine spelling had achieved broke down and non-etymological spellings began to appear. SánchezPrieto (2005: 431 and 445) has pointed out, in a subtle analysis, that the appearance of this type of spelling had some purely palaeographic causes. By the 14th century, administrative documents had already reached great cursiveness, by virtue of which the letters had to vary their form according to the surrounding characters. Letters no longer had identical shapes in all contexts; hence, the unit of writing was no longer the letter, but rather the nexus or union of two or more letters and, in many cases, the word. At that time, it became unnecessary literally to "see" the letters to read, because word segments and whole words "stood out" overall and writing thus acquired an almost "logographic" nature. ${ }^{20}$

Cursiveness and the development of abbreviations favoured the appearance of non-etymological spellings, which began to be used for reasons of legibility, and which served to shape the visual image of the word and mark its borders. As opposed to the linearity of reading in the 13th century, which was favoured by the correspondence between spelling and phonemes, the new script gave greater weight to the visual image of the word. Thus, in the 14th and 15th centuries, the following devices became increasingly frequent:

- A non-pronounced, non-etymological or hypercorrect $<\mathrm{h}>$, as in the words hera (< ERAT, now era, of the verb ser) or husar (now usar);

- Spellings with $<j>$ (with a different form for the vocalic value, as in djxo, and the consonantal value, as in fijo);

- Spellings with $<\mathrm{y}>$;

- The learned groups $<\mathrm{ph}>,<\mathrm{th}>,<\mathrm{gn}>$, often used against etymology;

- The doubling of consonantal graphemes in initial position ( $s s^{-}, \mathrm{ff}-$, etc.).

Alphonsine spelling had been a more or less faithful reflection of a diatopic variety of the language, but over time it became more removed from an oral reality which was multiple and constantly changing. As Rivarola (1996: 890) reminds us, standardized writing contributed to strengthening the factors of homogeneity, opposing trends towards heterogeneity. Spelling rules that do not constantly adapt to the rhythm of evolution become outdated, but there are factors of cultural permanence and unity, as opposed to the centripetal trends that occur in orality. 
Therefore, despite the distancing, traditional Alphonsine-based spelling remained in force, with some efforts at updating, in the 16th century and even until the 17th century, despite many individual attempts at reform. Its bastion was, on the one hand, in the script of the Chancery, and on the other hand, in printing, which attempted to maintain uniformity.

\subsection{6th-century spelling: Variation or chaos?}

In the 16th century, the medieval phonological system of Castilian had evolved to such an extent that Alphonsine spelling no longer reflected the pronunciation, so it would have been necessary to reform its written representation (Lapesa 1980: 367). This divergence between writing and pronunciation gave rise to a divergence of criteria which has been described as "spelling anarchy" (e.g., by Marcos Marín 1979: 100): while some users of the written language, such as Saint Teresa of Avila, adopted innovative principles and no longer respected the medieval system of writing, many authors, grammarians and printers continued to maintain the old system of writing, based on medieval pronunciation.

We can therefore consider 16th-century orthographical variation to be due, in the first place, to the absence of standardization, but in second place it is indirectly due to endogenic factors: the phonetic evolution of the language. We could say that the graphic vestments that medieval pronunciation had received no longer fitted the phonetic body of a language that had changed (see below, 2.3.3.).

As regards the degree of standardization, it must be borne in mind that "the concept of linguistic correctness was broader than it would be in later periods, so that, between vulgarism and accepted expressions there were no categorical limits" (Lapesa 1980: 367).

This spelling variation - or "anarchy", as some authors prefer to call it would last until the foundation of the Spanish Royal Academy. Hence, the period between the second half of the 16th century and the beginning of the 18th century, when the Academy was founded, has been given in the history of our language the name anarchic period (according to the chronological division of Martínez de Sousa 1991: 42). Actually, this period according to Esteve Serrano (1982: 14) - extends up to 1800 since, while it lasted, no spelling system achieved general and constant acceptance. According to this author, we can speak of "spelling variability" during these three centuries, but he insists that for certain periods the more suitable term would be "spelling chaos". And indeed, 16th-century spelling variability 
has been perceived as chaos, anarchy and confusion. Neither the grammarians of that age nor most of today's scholars have conceived of this variability as something positive. Rather, for both, the ideal of standardization and spelling unity has predominated.

Nevertheless - in the opinion of Lapesa (1980: 367) - "in the 16th and 17 th centuries there was a process of selection among sounds, forms, and coinciding expressions, which led to a considerable fixing of usage in literary language". This regulation was greatly influenced by the development of printing, capable of reproducing the same text in many copies, "without the anarchic variants of handwritten transmission" - as Lapesa says.

The invention of printing in the 15th century brought about a strong impetus for the fixing of spelling habits throughout Europe. Although the printers at first copied the spelling imposed by the scribes of manuscripts from the mid-15th century, with all their "irregularities", soon the growing importance of printed texts would make the printers concerned about regulating spelling (Martínez de Sousa 1991: 42).

Printing, with greater flexibility than it would have from the 16th century onwards, imposed spelling rules, correcting the individualism of the originals, "frequently free and whimsical. One need only compare the handwritten versions by authors such as Lope de Vega with the corresponding printed texts to understand the scope of this greater order in spelling" (Lapesa 1980: 367).

As regards 16th-century manuscripts, all authors agree in pointing out the lack of rules, although some place more emphasis on the beginning of the norm, "seeing the glass as half-full", like Lapesa (1980: 367): "Although the manuscripts only obey the spontaneity of the author or the scribe, there are still some that reveal subjection to a system", whereas other authors emphasize the persistence of variation, "seeing the glass as half-empty": "However, at the end of the 16th century, Spanish spelling still followed the judgement of each master, scribe or printer" (Martínez de Sousa 1991: 42).

This last author justifies the name "period of confusion" by the "chaos" and "anarchy" of Spanish spelling at that time, which would reach its height at the beginning of the 17th century: everybody wanted to write with his own choice of letters and with his own particular rules. While some grammarians proposed a return to Latin spelling (the etymologists), others were in favour of extreme phoneticism (the phoneticists) and neither group would yield an inch in the defence of their positions. Spelling, until the first half of the 18th century, was a matter of personal opinion, and there were no generally accepted rules (Martínez de Sousa 1991: 42). 
Therefore, from the 15th century onwards Spanish men of letters showed great interest in orthography, to which they were to devote major reform and simplification proposals. Two figures stood out in the 16th century, Antonio de Nebrija and Juan de Valdés, both of whose thoughts on linguistics represent a true "modernizing reform" of the Spanish language, according to Abad (1986: 482).

\subsubsection{The ideal of phoneticism in the 16th century}

The ideas on Castilian and the trends towards spelling reforms in the 16th century were profoundly marked as cultural manifestations by humanism. The humanist defence of the prestige of vernacular languages was first expressed on the political level. Language became the national instrument par excellence for the expansion of the Spanish empire. The Emperor Charles V granted Spanish the status of an international language, and demonstrated this, for example, on an occasion that has become famous: in April 1536, at a meeting with Pope Paul II, the pontifical court and the ambassadors of France and Venice, Charles used Spanish in his speech rather than Latin or French. The French ambassador protested, and the Emperor replied: "Don't expect from me, sir, any other words than those of my Spanish language, for it is so noble that it deserves to be understood by all Christian people". ${ }^{21}$

Humanism also permeated linguistic thought. But the theory about the standardization of spelling in Spain did not come from the same circles as in Romance Europe - as Marcos Marín (1979: 97) and Martínez de Sousa (1991: 40) have pointed out. In France and in Italy, the printers Tory, Estienne, Aldus Manutius, etc. were those who produced the most important theoretical reflections on the need for the unification of spelling. However, in Spain, collective concern for the language was manifested rather in the individual works of the Spanish humanists.

Outstanding among them was the grammarian Elio Antonio de Nebrija, who wrote the first grammar of Spanish in 1492, as well as the first spelling text, published as a separate work in $1517 .^{22}$

When Nebrija proposed an immediate reform of the spelling system in his Ortografia in 1517, he wanted to demonstrate that the vernacular language could be supplied with rules like those of the classical languages. Above all, he proposed to fix the usage of Castilian, stabilize the vernacular language of Spain and provide it with rules, with a view to avoiding later changes and making the writing legible for the future. 
a) "We should write as we pronounce"

As a good humanist, Nebrija based his spelling on an ancient authority, that of Quintilian, who had stated the suitability of adapting the number of letters to the sounds in Latin. As an heir to the principles of the Hispano-Roman rhetorician, Nebrija affirmed in 1492 that "We should write as we pronounce and pronounce as we write, because if not, the letters were invented in vain" (Nebrija 1492: 18).

These ideas on writing correspond to a general ideal of simplicity, to a whole aesthetics of language that was developed in the 16th century, inspired by Italian humanism. Attention has been called, for example, to a passage of Baldassare de Castiglione's Il Cortegiano, translated into Spanish in 1534 by Juan Boscán, in which he describes how a courtier should express himself. ${ }^{23}$ This aesthetic ideal, relating to the relationship between spoken language and written language, can be summarised in these words: "Write as you speak, but speak well, avoiding affectation". This ideal of simplicity was to mark the style in prose and poetry of many essential figures in the history of Spanish literature and philosophy.

The innovative trend in the 16th century was prolonged in the Baroque movements in the 17 th, and spelling reform thus had among its defenders second-generation figures such as Gonzalo de Correas, who in 1630 published a treatise entitled Ortografia Kastellana in which he proposed a "new and perfect" system for transcribing Spanish, which would never be applied except in his own work. All these individual attempts at reform and simplification of the spelling system, including that of Nebrija, never caught on, and were never officially adopted.

b) "We should pronounce as we write"

In the first part of this famous passage from Nebrija, the grammarian defends the phonemic principle of writing ("we should write as we pronounce"). However, we should not overlook the second part of his principle: "We should pronounce as we write", because it is closely linked to his plan to fix the language through its orthography. Nebrija, who was aware of the fact that languages with no written system are more subject to change than written languages, defended the idea of spelling which would reflect polite speech rather than popular speech, which was in a state of continual change. A fixed spelling would help to stop the vernacular from changing, and this is the way in which his praise of pronunciation based on writing should be understood. ${ }^{24}$ 


\subsubsection{Humanism and linguistic thought in the 16th century: Juan de Valdés}

Juan de Valdés was trained at the University of Alcalá de Henares, a centre of Spanish "Erasmiansm", and began a correspondence with Erasmus of Rotterdam in 1528. He later lived in Italy, and, while in Naples, dealt with diplomatic affairs in favour of the Imperial cause. From 1536 onwards, he seems to have been devoted to setting out and expounding his religious doctrines, which he communicated to a small circle of inquisitive souls. $\mathrm{He}$ was the main introducer of the reform to Italy, although he did not publicize this fact among the masses.

In Spain, the Reformation acquired few converts, but Erasmianism and the trend of the Illuminati had a moment of effervescence in the first third of the century. Spain thus pioneered the diffusion of the work of Erasmus in the Romance languages. ${ }^{25}$ The fact that large numbers of readers could not read Latin led some individuals to translate Erasmus' works, thus following the scholar's wish that his work be disseminated among lay people in the vernacular, and that the Holy Scriptures be brought closer to the public at large, in opposition to the ultraconservative attitude of scholastic theology. The diffusion of Erasmus' works in Castilian gathered momentum, until in 1559 it began to swell the long list of prohibited books, and its divulgation was then brutally stopped. Despite this, the number of printed Romance editions of Erasmus was twice the number of Latin editions in Spain: a clear indication of the popular interest aroused by the thinker from Rotterdam (Sanz Hermida 2002: 138). Clearly, Erasmus's spiritual influence declined after his books were banned. Nevertheless, his linguistic and literary theories left behind a rich and varied inheritance in Spain. For instance, his rhetorical theories lived on until well into the 17th century (López Grigera 1986: 500). And it has been pointed out that followers of Erasmus often cultivated Spanish grammar, a classic case being Juan de Valdés (Abad 1986: 487). Let us now take a look at Valdés's ideas on language with respect to humanist thought.

a) In his essay Diálogo de la Lengua (1535), written in the literary genre of fictional dialogues, Valdés gives advice with respect to language usage, and recommends books for learning Castilian. But the contents of the Diálogo exceed its circumstantial motivation of solving questions of language and teaching Spanish to Italian people, because it also deals with ideas closely related to Renaissance ideology. The first of these is that of respecting and using the vernacular. 
For Lapesa (1940: 14), his recognition of the dignity of the mother tongue is strictly related to the exaltation of everything natural at the height of the Renaissance. It was considered that Nature, as an emanation of God, was perfect in its creations. And one of these was the mother tongue, which was rehabilitated through well-known apologetic works such as those of Pietro Bembo ${ }^{26}$ in Italy (Prose della volgar lingua, 1525), Joachim Du Bellay in France (La Deffence et illustration de la langue françoyse, 1549) or of Valdés, with his Diálogo.

b) These bold defenders of Romance agreed on one essential issue: if the native language could not compete with the classical languages, it was not because it was incapable of doing so, but rather because there was a lack of cultivation and language policy. For Valdés (Lapesa 1980: 309), the Castilian language was just as dignified and cultured as Tuscan, but "more vulgar", less elaborated and lacking in classics. As a consequence, the mother tongue should be "illustrated" and enriched, and used in serious matters, which had until then been reserved for Latin. In this context, the special effort made by Valdés was aimed at fixing doctrinal prose in Castilian.

c) Valdés received from humanism a taste for naturalness and an appreciation of reason: "I will never be able to take such a liking to something that makes me forgo the use of reason". The stylistic doctrine of the time is illustrated in a well-known sentence of his, which summarizes the ideal of natural distinction, simplicity and the rejection of artifice that is formulated in Castiglione's Il Cortegiano:

The style I have is natural to me, and without affectation. I write as I speak; I am only careful to use words that convey well what I want to say, and I say it as simply as possible, because, in my opinion, affectation is not good in any language. ${ }^{27}$

Among the Spanish humanists, these two linguistic ideals were disseminated widely: "We should write as we speak", but "we should speak without affectation", ideals which López Grigera (1986: 493) has attributed to the Erasmian heritage in Spain. In De conscribendis epistolis, Erasmus states a similar preference for the use of Latin: he explains that he writes the same Latin as he speaks, fleeing from the affectation of the Ciceronian school of thought. This preference would have been applied to the Spanish language in Spain. 
d) However, Valdés's ideals of "naturalness", "simplicity" and "rejection of affectation" were not opposed to linguistic selection. Thus, in his Diálogo, certain passages are devoted to a selection of spelling rules, following three general principles deriving from the humanistic ideal of "simplicity" (Lapesa 1940: 20, Klein 1983):

- The fundamental criterion is to make writing conform to pronunciation: exact parallelism between letters and phonemes;

- Autonomy for the writing of Romance;

- Aversion to the forced use of learned words.

In the following section, we will show some of the solutions proposed by Juan de Valdés, inspired by these principles, in view of the variants available for Spanish speakers in the 16th century.

\subsubsection{Language change and spelling variation in the 16th century. Some options for standardization}

In the 16th century, Spanish was at a very active stage of evolution, in which a selection among sounds and forms occurred, and specifically an elimination of phonetic "archaisms" (Lapesa 1980: 367, Braselmann 1988). The problem with spelling was that different pronunciations coexisted for some words (i.e., diachronic variants used at the same point in time), ${ }^{28}$ and thus writing offered different spelling possibilities for that same word. In other cases, a single pronunciation of a word could be transcribed according to two sets of spelling rules: one more archaic and one more innovative.

Below, we shall look at some examples of phonetic hesitations that gave rise to spelling variants that were the subject of reflection on standardization in the 16th century. As we shall see, if Juan de Valdés in his Diálogo de la lengua displays his preference for a specific form, it is because at that time several different spellings coexisted.

a) Hesitations in unaccented vowels

During the 16th century, hesitations in the timbre of unaccented vowels, such as vanidad/vanedad, decreased. Juan de Valdés preferred, in theory, the more modern forms, vanidad, invernar, aliviar, abundar, cubrir, ruido, as opposed to the older forms vanedad, envernar, aleviar, abondar, cobrir, roido. His preference was to be endorsed, sooner or later, by usage, since the first series contains the present-day forms of 
Spanish (vanidad, invernar, etc.). Nevertheless, in his own writings, we find the old form intelegible instead of the modern form inteligible. Equally, in literature, the author of El Lazarillo de Tormes uses the older form of recebir, instead of the more modern recibir. Saint Teresa of Ávila presents the forms mormorar and sepoltura, older than the more cultured forms murmurar and sepultura (Lapesa 1980: 368).

b) Consonant groups

The conservation of some groups of consonants, already falling out of use, also lasted through the first half of the 16th century, although in plain speech they had been simplified (Lapesa 1980: 369). In this case, Juan de Valdés recommends the archaic use of cobdiçiar, cobdo and $d u \boldsymbol{b d} a$, as opposed to the forms codiciar, codo and $d u \boldsymbol{d} a$, according to the linguistic trend that was to become widespread later on. In this case, he prefers them because, written in this way, words are "fuller and better", i.e., so as not to eliminate sounds from them (Lapesa 1940: 18). In actual fact, Valdés's internal set of rules responds to an orthodox Castilianism: he defends the old forms cobdo and $d u b d a$ simply because they are the forms he had used since he was a child in the city of Toledo (Menéndez Pidal 1958: 69; Abad 1986: 484).

c) Phonetic archaisms

In the first half of the 16th century, the archaic /f/ was still tolerated in words like fijo, fincar or fecho (today hijo, hincar, hecho); there is evidence that it was used among notaries and lawyers throughout the 17th century.

Valdés proposed to get rid of archaisms. In his view, if people pronounced hazer and hijo (with a non-aspirate $<\mathrm{h}>$, i.e., one which had been silent in Castile for a long time before), "fossils" such as fazer or fijo should not be maintained in the spelling. This initial /f/ was already silent in Valdés's time, which is why he censures it, considering that those who write it do so "to appear Latinate without being so" (Lapesa 1940: 60).

d) Phono-syntactic problems

The phonetic principle gives rise to certain problems of phonetic syntax. When two identical vowels come into contact at the boundaries of two words, they are reduced to a single vowel: thus, the phrases de esta agua 'of this water', nuestra ama 'our mistress', está acá '[he] is here' are pronounced as one single phonetic group. In Valdés's view, they should therefore be written as a single graphic segment: destagua, nuestrama, estácá. Of the two possible variants (the analytical one and the agglutinated one), the latter was frequent in the times of Valdés: he selected the variant in which writing corresponds most faithfully to pronunciation. 
The modern rules of Spanish obviously do not follow this option, but rather adopt an analytical type of writing (de esta agua = three words: preposition + demonstrative + noun).

e) Pronunciation and the spelling of learned words (cultismos)

In the words inherited from Latin through uninterrupted oral transmission, many Latin consonant groups had been simplified: for example, the Latin group $/ \mathrm{pt}$ of septem or aptare had given way to $/ \mathrm{t} /$ : siete, atar. The group /gn/ of lignum or segna had changed to a /n/: leño, seña. But after the time had passed when these changes had taken place, other learned words had been introduced into Spanish from written Latin, in which the consonant groups remained intact. When these groups entered Spanish, they were perceived as "odd", as "foreign" to the natural phonetic system of Spanish. Thus, in the 16th century, there were two opposing tendencies: out of respect for the Latin forms, some people pronounced the full Latin sound: efecto, doctrina, digno, significar, colum$n a$, examinar, excelencia, experiencia, whereas others pronounced the more popular form, which was best adapted to the spontaneous habits of pronunciation: efeto, dotrina, dino, sinificar, coluna, esaminar, escelencia, esperiencia. In these cases, Valdés was inclined in favour of the latter, claiming independence for Spanish from Latin and the correspondence between spelling and pronunciation: "I take out the written $g$ in sinificar, manifico, dino, because I do not pronounce it".

Note that later on in the writing of the 18th century, the academic norm opted for the forms closest to Latin; thus nowadays in Spanish we write efecto, doctrina, digno, significar, columna, examinar, excelen$c i a$, with the Latin consonant groups. These are pronounced in cultured contexts, but both the most educated speakers and the less educated very often suppress many of these groups in pronunciation. For example, in some regions, efecto and doctrina are pronounced *efeto, *dotrina, with a simplification of the consonant group. In other regions, particularly in Castile, efecto and doctrina are often pronounced transforming the group $/ \mathrm{kt} /$ to $/ \theta \mathrm{t} / \mathrm{:} / \mathrm{efe} \theta \mathrm{to} /$, /do $\theta$ trina/. This confirms that the tendency to simplify or vary the Latin consonant groups still prevails in Spain, in such a way that an educated speaker may use both pronunciations, depending on the context: efecto in formal contexts and /efe $\theta$ to/ in an informal setting. The same thing occurs with the /ks/group: we write examinar, excelencia, experiencia, although we often pronounce *esaminar, *escelencia, *esperiencia. Regarding this problem, Valdés's option is more innovative than that which the Spanish Academy maintained. 
Valdés condemns the Latin $<\mathrm{ph}>$ in words such as philosophia, esphera, phariseo. This was the solution also preferred by the Academy in 1741 (filosofia, esfera, fariseo) and which is currently upheld. However, he admitted the etymological $<\mathrm{q}>$ in quatro and qual, because he considered that its sound was different from that of the $\langle\mathrm{c}\rangle$ in the word cuello (the Academy norm later aligned these spellings: cuatro, cual, cuello).

f) The problem of the sibilants. Diatopic variants and spelling variants A radical change in consonantism, which had begun as early as the Middle Ages, but became more widespread between the second half of the 16th and the first half of the 17th centuries, determined the move from the medieval phonological system to the modern one (Lapesa 1980: 370). One of the most important phenomena was the simplification of medieval sibilants. Their reduction did not follow the same pattern in all the territories: in the South of Spain, in Andalusia, and also in the Canary Islands and Latin America, four original phonemes were reduced to only one (which in some places was articulated as the dental $/ \mathrm{s} /$ and in others as the interdental $/ \theta /$ ). Thus, some notaries and scribes in Seville (in Andalusia) wrote resebi, parese, pes, espesificadamente, ofrese, instead of recebi, parece, pez, especificadamente, ofrece (which is the spelling to be expected and the one which is preserved in today's spelling). In fact, someone who wrote resebi instead of recebi was only transcribing the $/ \mathrm{s} /$ that he pronounced, whereas a Castilian would pronounce a $/ \theta /$. The Andalusian phonetic innovation arrived early on in the Canary Islands and Latin America, because as early as 1539 we have evidence in Cuba of çurto instead of surto, or of hasiendas and haser, instead of haciendas and hacer in Mexico in 1523 (Lapesa 1980: 377).

This divergence in pronunciation norms still prevails in present-day Spanish; thus words such as bicicleta, cielo, Zapata, are pronounced with $/ \theta$ / by a part of the inhabitants of the Iberian peninsula, whereas they are pronounced with /s/ by the Spanish speakers in the South of Spain, the Canary Islands and Latin America. Nowadays, however, the correct spelling is bicicleta and cielo for everybody: that is, in the written representation, the Castilian norm has prevailed (today, the minority norm among Spanish speakers); for example, only Castilians distinguish two different words in the pronunciation of casar/s/ 'to marry' and $c a$ zar $/ \theta$ / 'to hunt', whereas the majority of Spanish speakers pronounce both words with the phoneme $/ \mathrm{s} /$. 
In the 16th century, however, the absence of a normative institution allowed the evolution of phonetics to give rise to these types of spelling divergences.

We know, thanks to a number of studies, that handwritten spelling usage was more heterogeneous and subject to variation than printed texts. Texts written by hand often reveal dialectal traits. Printing, on the contrary, developed a regulating force, and was rather reluctant to incorporate innovations (Rivarola 1996: 890), to such an extent that it tried to keep to received norms and in general - although not always ${ }^{29}$ hid the oral particularities of the scribe.

Rivarola (1996) has illustrated this phenomenon with the example of the Crónica del Perú, written by Pedro Cieza de León, born in the region of Extremadura (Spain), and who emigrated to Latin America when he was a young man. Cieza published the manuscript of the first part of his chronicle in Seville, in 1553 (although the second and third parts were not printed). If we compare the preserved manuscript with the printed text, we see that when Cieza writes in his own handwriting, he moves away from traditional spelling and reflects his local particularities, his dialect features, since he uses "anomalous spellings" - as they are called by Rivarola: çilençio, çeso, çoçegar, çaçerdotes, çentencia, etc. instead of silencio, seso, sosegar, sacerdotes, sentencia. These are spellings that indicate the existence of seseo (or "assibilation"), the pronouncing of $/ \mathrm{s} /$ instead of $/ \theta /$, a characteristic of the chronicler's region. In the printed version, however, these spellings disappear, having been corrected by the printer.

However, the dialectal spelling uses of Cieza are not the result of a personal wish to move away from spelling tradition, or of an ideal of stylistic simplicity. We know that he supported this ideal, since he mentions it explicitly in his chronicle, where he says "good writing should be as it is spoken and nothing more". However, he also gives evidence of a strong awareness of the value of the traditional norm and of the deviations of his own spelling. The contract he made for the printing of the first part of his Crónica has been preserved, and in one of its clauses the Sevillian printer promises to "place the letters according to the spelling, even though it is badly written in the original document" (Rivarola 1996: 894). 


\subsubsection{The status of spelling variation in the 16th century}

Not all Spanish linguists have described the survival of spelling variation in the 16th century as "chaos" or "disorder": those with a good knowledge of the stylistic or dialectal values of the spellings (the philologists), have been able to perceive that the desire for variation in the 16th century was not then perceived as a defect. We must highlight - as we did for the medieval period - the judgement on variation made by the linguist and member of the Spanish Academy, José Antonio Pascual:

The spelling habits of the 16 th and 17 th century writers were not uniform ... Those writers did not make a point of always writing a certain word with $h$, or to use $b$ in another word instead of $v$, or always to reproduce the sound [kwá] using the spelling $q u$ or $c u$... They were aware that this standardizing was a task to be carried out by the printers - albeit partially - whom they only rarely asked to respect their personal uses (with some exceptions) ... The manuscripts which preserve the works of the Marqués de Villena do not respect his ideas on spelling, just as the printers did not respect those of $\mathrm{Ne}$ brija. (Pascual 1993: 46)

Pascual insists on a positive assessment of spelling variation and on its parallel in lexical variation, found also in other authors: $:^{30}$

The spelling instability in the written documents of the past usually surprises those of us who have been brought up in the observance of a certain orthographical norm; however, we find perfectly natural the lack of uniformity that we practise every time we resort to a synonym to avoid repetition ... Sometimes we choose siglo or siglos de oro, at others siglo áureo or siglos áureos, sometimes we say aquellos siglos and even ese periodo, etc. We are perplexed when we see the lack of spelling uniformity in 16th century writers, but they did not perceive it as a defect. (Pascual 1993: 47)

A very illustrative and well-studied example of this status of spelling variation can be found in the writings of Saint Teresa of Ávila (1515-1582), which we propose to turn to now, as we shall see how "the editors themselves formerly did not feel the need, nor the obligation, to maintain the spelling they found in the manuscripts" (Pascual 1993: 54).

The last forty years of the 16th century, permeated by the spirit of the Counter-Reformation, were characterized by the splendour of religious literature written in Spanish. In the first place, the mystic fervour of the time stands out. Mystical writers speak of the journey of the soul which, 
stripped of all attachment to the worldly and the concrete, withdraws into itself in search of God (Lapesa 1980: 317).

Saint Teresa of Ávila, one of the mystic writers, gives us an example of innovative tendencies in spelling unconnected to learned words (cultismos). However, her choice of the ideal of simplicity seems to correspond - according to the language historian Rafael Lapesa (1980: 317) - to a moral principle of humility. In Lapesa's view, Saint Teresa felt that being scrupulous about form was a temptation towards vanity, and thus she endeavoured to stay away from the courtly taste for finery and pomp in writing, and sought a less elevated and coarser means of expression, which she dubbed the "style of hermits and recluses". To attain this, Saint Teresa stays away from the standardization of the language through literature, and preserves antiquated forms such as enclinar (instead of inclinar), mormurar (instead of murmurar) or deformations of Latin words such as iproquesía (instead of hipocresía) or primitir (instead of permitir).

To study the different uses and linguistic norms of the 16th century, García Macho and Pascual (1990) have compared an autograph text by Saint Teresa (El Camino de Perfección) with the printed edition of this work edited by Fray Luis de León in $1588 .{ }^{31}$ In the first place, it can be seen that "both writers have, as was to be expected, a great lack of spelling uniformity in the forms they use, to wit: ahora, ora (Saint Teresa), agora, ahora (F. Luis); asi, ansi (Teresa), ansi, assi (F. Luis), etc." (García Macho and Pascual 1990: 130, note 8).

Fray Luis de León's idea was to reproduce Saint Teresa's texts just as she wrote them; nevertheless, there are many discrepancies between the author's usage and that of her editor. Fray Luis had no scruples in taking to the printer spelling uses which were different from those of the saint. The forms she used often show cases of spelling variants which correspond to differences in pronunciation in the 16th century; some of them are corrected in Fray Luis's edition.

We can see that the forms employed by Saint Teresa in the 16th century have not always been selected by the subsequent norm, but, as J. A. Pascual explains, these variants found in Saint Teresa were very common, and extended throughout all of Old Castile. They are forms marked with the label of "traditional", "conservative" or "castizo" "pristine', but these traits are not comparable to vulgarisms.

Rather, some theoreticians of the age, such as Herrera, considered that the old words brought "majesty to the sentence"; their age conferred "authority" and "dignity", so that words fallen into disuse had a "grace" similar to that of neologisms. 
Table 6.1. Variations: From manuscript to printed work: ${ }^{32}$

The present-day Spanish norm is concordant with Fray Luis's form

Spelling in Saint Teresa's Spelling in printed ver- Spelling in present-day autograph sion edited by Fray Luis (1588)

Spanish (note that the norm has selected the forms that Fray Luis took to the printer)

\begin{tabular}{lll}
\hline escuro & oscuro & oscuro \\
asconder & esconder & esconder \\
acender & encender & encender \\
piadad & piedad & piedad \\
enjenplo & exemplo & ejemplo \\
añidir & añadir & añadir \\
milaglo & milagro & milagro \\
\hline
\end{tabular}

Table 6.2. Variations: From manuscript to printed work: ${ }^{33}$

The present-day Spanish norm is concordant with Saint Teresa's form

Spelling in Saint Teresa's Spelling in printed ver- Spelling in present-day autograph sion edited by Fray Luis (1588)
Spanish (note that that in these cases today's norm has preserved the Castilian form Saint Teresa preferred)

\begin{tabular}{lll}
\hline perfeçionado & perficionando & perfeccionado \\
sentiria & sintiria & sentiría \\
virjenes & virgines & vírgenes \\
confesion & confission & confesión \\
escrivir & escrevir & escribir \\
puniendonos & poniendo nos & poniéndonos \\
\hline
\end{tabular}

For García Macho and Pascual (1990: 136), the fact that Saint Teresa sought out these forms in order not to appear educated is a possibility that cannot be ruled out, but it is not necessary to resort to this "principle of humility" to explain the choice of certain spelling-phonetic solutions which, although less "learned", were certainly not vulgar or dialectal. For these authors, Saint Teresa is the writer who best achieved the goal of "writing as one speaks", choosing the traditional and the spoken as the traits of her style. 
For Menéndez Pidal (1958: 17), other 16th-century authors adapted better to the common pattern that was fashionable then: this standard of written language was, commonly, the writing of Toledo, which frequently differed from that used in Old Castile and specifically, in Ávila, the home of Saint Teresa: "The saint's prose is the perfect type of familiar language in 16th-century Castile, the same as conversation, since the author, when writing ..., does not compose, she simply speaks".

\subsubsection{Reflections on spelling variation in the 16th century}

In the 16th century there was intense grammatical reflection in Spain concerning the vernacular, but present-day authors all allude to one and the same problem and complain about it: the lack of structured principles of usage, fluctuation in the norms, and the need for a principle of authority which could bring some order and reason into such disorder (Pozuelo Yvancos 1984). The discrepancies among grammarians, for example, those between Nebrija and Valdés, came precisely from their disagreement as to who would be the repository of authority as far as linguistic matters were concerned.

Curiously enough, much of the testimony about these complaints appears in spelling books and orthographical manuals, these being the subjects that were most often the source of a conflict of norms. Spelling (which went together with pronunciation in 16th-century grammar books) was the most problematic item in grammatical theory, since it was the part of grammar most subject to change and was devoid of a general paradigm. In spelling, copying the Latin paradigms was not an option, and furthermore, pronunciation was constantly changing.

Thus, the spelling books posed as their main problem the question of the best norm to be followed, and to what extent usage creates the norm.

Spanish grammarians were divided among three different positions (according to the analysis made by Pozuelo Yvancos 1984: 79):

a) Normative traditionalism. Some grammarians defended a "normative" position, according to which the authority should be the cultured norm agreed on by scholars.

b) Anti-normative reaction. Others felt that the source of linguistic authority was to be found in the common usage of the majority: usage was understood as "common speech" or "habits extended throughout the community". Some authors complained about those Spaniards who, being 
accustomed to using Latin, easily mixed it up with Spanish, giving it the spelling used in Latin.

c) Rationalism. The third position is the one held by the rationalists, according to whom language rules should be based on reason, since they considered it superior both to usage and to tradition.

From the 16th century onwards, the orthographical question was a subject of debate in Spain, and one which provoked a large number of varying opinions: much more so than strictly grammatical questions. For this reason, not only grammarians, but also writers, printers, pedagogues and schoolmasters expressed their ideas on orthography: with more or less erudition, but always with passion (Martínez Alcalde 1999: 1). ${ }^{34}$

The absence of a standard norm even caused petitions to be made to political authorities to impose a certain order on the written language. Thus, in 1587, a group of teachers presented a Memorial to King Philip II. ${ }^{35}$ In it, they complain that Castilian writing is losing its way, and therefore they ask that elementary school teachers should be inspected. The king then ordered an inspection of teaching activities and texts used in schools, which thereafter required a special licence.

Spanish spelling, however, would not become officially fixed until 1713 , at a moment of confusion of rules and proposals of reform which never earned the favour of the users of the language.

\section{Under one spell}

The ideal of spelling uniformity could not be realized until the great reform of Spanish, begun in the 18th century by the Spanish Royal Academy, founded in 1713, following the model of the Italian Accademia della Crusca (1582) and the Académie Française (made official by Louis XIII in 1635). As in the 13th century, the great reform of the 18th century was linked to extraneous factors, and specifically to its institutional character. French influence was favoured by the Bourbon dynasty, which renewed intellectual life in a Spain that was receptive to the new encyclopaedists and to the rationalist currents coming in from France. The king was the first to support the Academy, which also had notable politicians among its members.

From 1726 onwards, the Academy progressively renewed and modernized spelling, always following the criterion of simplification, although it did maintain a small number of etymological criteria: 
- The silent $<\mathrm{h}>$ (hacer, La Habana)

- The digraph <qu> (que, quiso)

- Some consonant groups that are not always pronounced: $<$ bs $>$ (substancia $),<\mathrm{ct}>($ docto, recto $),<\mathrm{cc}>$ (producción), etc.

- The distinction between $<\mathrm{b}>$ and $<\mathrm{v}>$ in writing although they correspond to a single phoneme, $/ \mathrm{b} /$, in speech, etc.

Thus, as regards the criterion of phoneticism, certain disparities between spelling and pronunciation remain in the written language. On the other hand, the spelling still reflects some phonemes only pronounced in the Spanish spoken in Spain, whereas other Spanish speakers do not distinguish them. The present Academy, however, is satisfied with the state of things inherited from the 19th century: "Nowadays, any variation in usage would be much more arduous to accomplish, since it would affect many more people and would require the prior agreement of the twenty-two associated bodies" (RAE 1999: xvii).

The penultimate Spelling Book published by the Spanish Royal Academy (RAE 1999) became a best-seller. Seven months after its publication, 500,000 copies had been sold in Spain alone. At the same time, the Mexican government had bought a million copies to be sent to all the schools in the country. This reflects the fact that Spanish speakers all over consider the Spanish Royal Academy - and the Association of Spanish Language Academies of Spanish speaking countries (ASALE) - as the most authoritative instance in matters of language.

This institution has made maintaining the unity of Spanish its main objective. This unity does not imply homogeneity at all linguistic levels, but it has a secure bastion: a single spelling, a single looking-glass in which the speech of almost 500 million people can be reflected more or less faithfully. ${ }^{36}$

\section{Notes}

1. For example, as Martínez Alcalde (2001: 698) observed, the specialist Esteve Serrano (1982: 91) called Felipe Monlau, a 19th-century member of the Spanish Royal Academy, a "retrograde" and "outmoded" for defending a spelling adjusted solely to use and etymology. Monlau considered that words were something more than sounds, something more than the result of a mere division into syllables. For him, the word acceded to the category of symbol in writing 
and this allowed it to be transmitted to those absent and to posterity without the fleeting echo of pronunciation. But Serrano called the theory defended by Monlau "a totally erroneous conception" and "unsustainable".

2. In all cases, unless specifically stated, the English translations of all quotations are our own.

3. The need to reform and simplify spelling has been understood to be a social problem: see, for example, Mosterín (1981), Ávila (1986), Lara and Garrido (1986), Martínez de Sousa (1991), Contreras (1994).

4. The graphematic study of the origins of written Spanish based on Latin texts has gathered new momentum with the theories of Roger Wright, adopted by other scholars (Wright 1982, Blake 1991, 1992, 1993).

5. Corpus from the Monastery of Carrizo (Cabrera 1998: 14-15). The example is taken from document $\mathrm{n}^{\circ} 241$, dated 1247 .

6. As Cabrera himself reminds us (1998: 15), Menéndez Pidal had already pointed this out in his seminal and still valid work on the origins of Spanish (Orígenes del español, 1986: 457).

7. Wright's theory has been contested by Cabrera (1998: 16), Ariza (2005: 309) and J. J. de Bustos Tovar (2005: 276, 281-283), among others. These authors include, in a recent Historia de la lengua española, other references criticizing Wright's theory.

8. For other examples of mixed texts, see Ariza (2005: 318-320).

9. Lapesa (1980: 163-164) expresses the same idea.

10. J. A. Pascual (1996) gives a critical review of the methodological principles used by Menéndez Pidal (1986) to describe those early stages of Spanish.

11. A. Pascual's examples are transcribed partially using the Phonetic Alphabet of the Revista de Filología Española (RFE). The RFE symbols /̌̌s and /ž/ correspond, respectively, to /ts/ and /dz/ in the IPA.

12. The statement that "early Spanish lacks fixation" comes from Lapesa (1980: 165), although this language historian also subscribes to the view put forward by Pascual since he refers further on in his book to a "coexistence of rules" (Lapesa 1980: 166).

13. See Cerquiglini 1989 and 1989-90. On the positive consideration of variation in medieval Spanish texts, see Cahiers de Linguistique Hispanique Médiévale 21 (1996-97) and 22 (1998-99).

14. With this suggestion, Morreale refers to the author of a 13th-century romanceamiento biblico, that is, to the translation into Castilian of a Bible in Latin. However, her hypothesis has been validated by several authors, who have pointed out instances of conscious variation in medieval texts. J. A. Pascual (1996-97: 100, note 40), for example, admits that, in a series of words, spelling variation will be consciously sought, and considers that this is of philological interest; Cabrera (1998: 19) points out earlier cases than those attested by Morreale of spelling variations from the 12th century, with a clear stylistic value, which should not be considered as oscillations, doubts or anarchical forms. Sánchez-Prieto (1998; 2005: 426) also legitimizes Morreale's theory. 
15. For German, mention should be made of the studies by Anja Voeste, who has broadly reflected on spelling variation as an aesthetic principle in the 16th century, and has explained clearly and precisely what the application of the spelling principle summarized in the Latin phrase variatio delectat consisted of (Voeste 2008).

16. These cantigas were not written in Castilian but in Galician, the Iberian language that was chosen for poetry rather than Provençal, the great poetic language of the Mediterranean world in those times.

17. See, for example, the synthesis of Fernández-Ordóñez (2005: 404-409).

18. It is generally claimed that this spelling was established by the Wise king himself, so that he would have corrected with his own hand a good number of the manuscripts written in his scriptorium. This is the opinion of Marcos Marín (1979: 91), for example, although recently (Sánchez-Prieto 2005: 423) it has been emphasized that this is more probably a romantic myth, since if the king had intervened in all the texts, they would not show the degree of dialectal variation observed.

19. On this point, see Beaulieux (1927: 87).

20. This theory developed by Sánchez-Prieto, which related legibility to the graphemes chosen, seems well-founded to us. However, it is not a new one, as language historians (Citton and Wyss 1989: 72, Baddeley 1993: 247, Cerquiglini 1996: 70) have pointed out, at least in the French sphere. For example, Théodore de Bèze (1555) observed that "we do not read with our mouths but with our eyes and brain; hence spelling should not be subject so much to pronunciation as to understanding, because what we extract from writing is the understanding of the meaning". In the 17th century, Bossuet expressed the same theory of reading as visual apprehension of a form: "We do not read letter by letter, but rather the whole form of the word is impressed in a single block on the eye and on the mind" (quoted by Biedermann-Pasques 1992: 252 and by Cerquiglini 1996: 70). Evidently, this theory made it possible to defend for French in the 16th and 17th century the persistence of conservative spellings such as fust, asne, beste, in which the $<\mathrm{s}>$ had not been pronounced since the Middle Ages (both references are from Cerquiglini 1996; the English translation is ours). Moreover, the complication of the spelling for palaeographic reasons, as Sánchez-Prieto postulates for Spanish, is also a theory which has been accepted in the history of French spelling. For example, following Fournier (1940), Cerquiglini (1995: 42) points out with respect to spelling towards the end of the Middle Ages, in the 14th century, that "cursive writing is not very legible and sometimes ambiguous; the etymological letters with an upstroke ( $b$, $f, p, l, s)$, form visual landmarks; they function as diacritical marks".

21. On this subject, see Morel-Fatio (1913), Menéndez Pidal (1958: 66), Lapesa (1980: 297), Alvar (1996: 91-93).

22. The academic literature about Nebrija's ideas is very impressive; some authors offer us a complete bibliography of the Spanish grammarian: Braselmann (1991), Esparza and Niederehe (1999: 265-296), Esparza (2008). For a com- 
plete bibliography of linguistic historiography and spelling theory concerning the 16th century, see Maquieira (1989, 2006), Koerner and Niederehe (2001), Esparza (2008: 91-111 and 156-292), Gómez Asencio (2006), Battaner Moro (2009).

23. See Lapesa (1980: 303), Terracini (1979), Mazzocco (2001).

24. On this subject, see the informative article by García Santos (2006: 339-340). See also further on, section 2.3.5.

25. On the penetration of Erasmianism in Spain, see Bataillon (1991), Revuelta and Morón (1986), Rallo (2003) and the catalogue of the exhibition Erasmo en España (2002).

26. See Mazzocco (2001) for a discussion of Italian influence on Juan de Valdés's Diálogo (1535) and his espousal of Bembo's premises on linguistic normalization.

27. Valdés (1535), ed. Lapesa (1940: 108).

28. By diachronic variant we understand what Lapesa (1980: 165) defines as forms that coincide in speech but which "represent different states of evolution". On spelling variation in legal texts, see Sanchez-Prieto (1991, 1995), Martínez Ortega (1999) and Puche Lorenzo (2003).

29. For example, Pascual (1993: 41) reminds us that some 16th-century spellings can allow scholars to situate a text regionally or dialectally. He gives as an example an incunabulum with Aragonese traits.

30. Morreale (1978), Sánchez-Prieto (2005: 426), Voeste (2008).

31. Los Libros de la Madre Teresa de Jesús..., ed. by Fray Luis de León, Salamanca: Guillelmo Foquel, 1588 (quoted by García Macho and Pascual 1990: 129).

32. See García Macho and Pascual (1990).

33. See García Macho and Pascual (1990).

34. See Martínez Alcalde (1999), a digitized collection of 65 treatises on Spanish orthography and writing from the 16th and 17 th centuries.

35. Memorial presentado al Rey Felipe II sobre algunos vicios introducidos en la lengua y la escritura castellana (1597) (see Martínez de Sousa 1991: 39).

36. The latest Spanish Orthography, published in 2010, is an extensive treatise, much more exhaustive and scientific than the popular manual of 1999. Its fundamental principle is linguistic unity, as "spelling is the cornerstone of language unity, while other linguistic levels ... are subject to the parameters of geographic, social, cultural and situational variation". The new Ortografia de la Lengua Española "has been designed and implemented on the basis and with the aim of unity", jointly by the Spanish Royal Academy (RAE) and the Association of Spanish Language Academies (RAE 2010: XL-XLI). The only important changes to have been introduced by the new Ortografia are the removal of optionality in former non-compulsory rules (for instance, words that could be written in two different ways) and the removal of some inconsistencies. On the academic ideal of unity, see Süselbeck (2011). 


\section{References}

\section{Primary sources}

Correas, Gonzalo

1630 Ortografia Kastellana Nueva i Perfeta. Salamanca: Xazinto Tabernier.

Memorial Presentado al Rey Felipe II Sobre Algunos Vicios Introducidos en la Lengua y Escritura Castellana

1792 Ms. Real Academia Española, copy of the original (Biblioteca Monasterio del Escorial, 1597), La Viñaza, núm. 549, cols. 1166-1180.

Nebrija, Antonio de

1492 Grammatica de la Lengua Castellana. Salamanca.

Nebrija, Antonio de

1517 Reglas de Orthographía en la Lengua Castellana. Alcalá de Henares: Arnao Guillen de Brocar.

Ruiz, Juan, known as Arcipreste de Hita

1992 Libro de Buen Amor. Alberto Blecua (ed.). (Colección Letras His-

Valdés, Juan de pánicas.) Madrid: Cátedra.

1940 Diálogo de la Lengua. Rafael Lapesa (ed.). Zaragoza/Madrid: Ebro. Original edition 1535.

\section{Secondary sources}

Abad Nebot, Francisco

1986 Juan de Valdés y la conciencia lingüística de los Erasmistas españoles. In El Erasmismo en España. Ponencias del Coloquio Celebrado en la Biblioteca de Menéndez Pelayo del 10 al 14 de Junio de 1985, Manuel Revuelta Sañudo, and Ciriaco Morón Arroyo

Alvar, Manuel (eds.), 479-489. Santander: Sociedad Menéndez Pelayo.

1996 Por los Caminos de Nuestra Lengua. 2d ed. Alcalá de Henares: Universidad de Alcalá de Henares. Original edition, 1995.

Ariza, Manuel

2005 El castellano primitivo: los documentos. In Historia de la Lengua Española, Rafael Cano (coord.), 309-324. 2d ed. Barcelona: Ariel.

Ávila, Raúl Original edition, 2004.

1986 Sólo para tus oídos. In Escritura y Alfabetización, Luis Fernando Lara, and Felipe Garrido (eds.), 11-38. México: Ediciones del Ermitaño. 
Baddeley, Susan

1993 L'Orthographe Française au Temps de la Réforme. Genève: Droz. Bataillon, Marcel

1991 Erasme et l'Espagne. 3 vols. Genève: Droz. Original edition, Paris: Droz, 1937.

Battaner Moro, Elena

2009 La investigación sobre ortografía, fonética y fonología en la tradición lingüística española. In Estudios de Historiografía Lingüística, Teresa Bastardí Candón, and Manuel Rivas Zancarrón (eds.), 27-43.

Beaulieux, Charles

Cádiz: Servicio de Publicaciones de la Universidad de Cádiz.

1927 Histoire de l'Orthographe Française. Tome I. Formation de l'Orthographe des Origines au Milieu du XVI Siècle. Paris: Champion.

Biedermann-Pasques, Liselotte

1992 Les Grands Courants Orthographiques au XVII Siècle et la Formation de l'Orthographe Moderne. Tübingen: Max Niemeyer.

Blake, Robert

1991 Aspectos sintácticos del español antiguo: La prosa latinizada del "Cartulario de S. Millán de la Cogolla". In Actas del II Congreso Internacional de Historia de la Lengua Española, Manuel Ariza Blake, Robert Viguera (coord.), vol. 1, 291-305. Madrid: Arco Libros.

1992 Syntactic aspects of Latinate texts of the Early Middle Ages. In Latin and Romance Languages in the Early Middle Ages, Roger Wright (ed.), 219-232. London/New York: Roudledge.

Blake, Robert

1993 Tracing the development of Old Spanish. In Linguistic Perspectives on the Romance Languages, William J. Ashby, Marianne Mithun, Blecua, Alberto and Giorgio Perissinotto (eds.), 363-375. Amsterdam: Benjamins.

1992 see Ruiz, Juan, known as Arcipreste de Hita.

Braselmann, Petra

1988 Architektur der Sprache bei Juan de Valdés. In Energeia und Ergon. Sprachliche Variation - Sprachgeschichte - Sprachtypologie. Studia in honorem Eugenio Coseriu, Jörn Albrecht, Jens Lüdtke, and Harald Thun (eds.), vol. 2, 301-315. Tübingen: Narr.

Braselmann, Petra

1991 Humanistische Grammatik und Volkssprache. Zur "Gramática de la Lengua Castellana” von Antonio de Nebrija. (Studia Humaniora 21.) Düsseldorf: Droste.

Buridant, Claude

1996 Varietas Delectat. Prolégomènes à une grammaire de l'ancien français. Vox Romanica 55: 87-125. 
Bustos Tovar, Eugenio de

1995 El español y los romances. In La Lengua Española, Hoy, Manuel Seco, and Gregorio Salvador (coords.), 11-22. Madrid: Fundación Juan March.

Bustos Tovar, José Jesús de

2005 La escisión latín-romance. El nacimiento de las lenguas romances: el castellano. In Historia de la Lengua Española, Cano, Rafael (coord.), 2d ed., 259-290. Barcelona: Ariel.

Cabrera, Carlos

1998 Reflexiones sobre el sistema gráfico avulgarado de los textos primitivos leoneses. In Estudios de Grafemática en el Dominio Hispano, José Manuel Blecua, Juan Gutiérrez, and Lidia Sala (eds.), 9-23. Salamanca: Instituto Caro y Cuervo/Ediciones Universidad de Salamanca.

Cahiers de Linguistique Hispanique Médiévale 21

1996-97 De la Variation Linguistique et Textuelle. En l'Honneur de Jean Roudil 1. Linguistique médiévale.

Cahiers de Linguistique Hispanique Médiévale 22

1998-99 De la Variation Linguistique et Textuelle. En l'Honneur de Jean Roudil 2.

Cerquiglini, Bernard

1989 Éloge de la Variante. Histoire Critique de la Philologie. Paris: Seuil [English translation: In Praise of the Variant. A Critical History of Philology, Betsy Wing (transl.). Baltimore: Johns Hopkins University Press, 1999].

Cerquiglini, Bernard

1989-90 La paraphrase essentielle de la culture scribale. Cahiers de Linguistique Hispanique Médiévale 14-15: 9-16.

Cerquiglini, Bernard

1995 L'Accent du Souvenir. Paris: Minuit.

Cerquiglini, Bernard

1996 L'accent circonflexe: archéologie d'une passion. In La Linguistique Française: Grammaire, Histoire, Epistémologie, Emilia Alonso, Manuel Bruña, and María Muñoz (eds.), vol. 1, 65-72. Sevilla: Grupo Andaluz de Pragmática.

Citton, Yves, and André Wyss

1989 Les Doctrines Orthographiques du XVI Siècle en France. Genève: Droz.

Contreras, Lidia

1994 Ortografia y Grafémica. Madrid: Visor.

Erasmo en España.

2002 La Recepción del Humanismo en el Primer Renacimiento Español. Madrid: Sociedad Estatal para la Acción Cultural Exterior. 
Esparza Torres, Miguel Ángel

2008 Bibliografía Temática de Historiografía Lingüística Española. Fuentes Secundarias, vol. 1. Hamburg: Buske.

Esparza Torres, Miguel Ángel, and Hans-Josef Niederehe

1999 Bibliografía Nebrisense. Las Obras Completas del Humanista Antonio de Nebrija desde 1481 hasta Nuestros Días. Amsterdam: Benjamins.

Esteve Serrano, Abraham

1982 Estudios de Teoría Ortográfica del Español. Murcia: Publicaciones del Departamento de Lingüística General y Crítica Literaria de la Universidad de Murcia.

Fernández-Ordóñez, Inés

2005 Alfonso X el Sabio en la historia del español. In Historia de La Lengua Española, Cano, Rafael (coord.), 2d ed., 381-422. Barcelona: Ariel.

Fournier, P. F.

1940 Sur l'origine des complications de l'orthographe française. Le Français Moderne 8: 257-266.

García Macho, Maria Lourdes, and José Antonio Pascual

1990 Sobre la lengua de Santa Teresa y el valor de sus elecciones gráficas evitadas por Fray Luis. Mélanges de la Casa de Velázquez 26 (2): 129-140.

García Santos, Juan Felipe

2006 La ortografía nebrisense. In El Castellano y su Codificación Gramatical. Vol. 1: De 1492 (A. de Nebrija) a 1611 (John Sanford), José J. Gómez Asencio (dir.), 335-364. Salamanca: Instituto Castellano y Leonés de la Lengua.

Gómez Asencio, José Jesús (dir.)

2006 El Castellano y su Codificación Gramatical. Vol. 1: De 1492 (A. de Nebrija) a 1611 (John Sanford). Vol. 2: De 1614 (B. Jiménez Patón) a 1697 (F. Sobrino). Salamanca: Instituto Castellano y Leonés de la Lengua.

Klein, Franz-Josef

1983 "Escribo como pronuncio". Zur Orthographiekonzeption des Juan de Valdés. Romanische Forschungen 95: 294-305.

Koerner, E.F.K., and Hans Josef Niederehe (eds.)

2001 History of Linguistics in Spain. Historia de la Lingüística en España. Vol. 2. Amsterdam: Benjamins.

Lapesa, Rafael

1940 See Valdés, Juan de.

Lapesa, Rafael

1980 Historia de la Lengua Española. 8th ed. Madrid: Gredos. 
Lapesa, Rafael

1985 Contienda de normas lingüísticas en el castellano alfonsí. In Estudios de Historia Lingüística Española, Lapesa, Rafael, 209-225. Madrid: Paraninfo.

Lara, Luis Fernando, and Felipe Garrido (eds.)

1986 Escritura y Alfabetización. México: Ediciones del Ermitaño.

López Grigera, Luisa

1986 Estela del erasmismo en las teorías de la lengua y del estilo en la España del siglo XVI. In El Erasmismo en España. Ponencias del Coloquio Celebrado en la Biblioteca de Menéndez Pelayo del 10 al 14 de Junio de 1985, Manuel Revuelta Sañudo, and Ciriaco Morón Arroyo (eds.), 491-500. Santander: Sociedad Menéndez Pelayo.

Maquieira Rodríguez, Marina

1989 Las Ideas Lingüisticas en España en el Siglo XVI: Fonética y Gramática. Diss., Universidad de León,

$<$ http://www.revistacontextos.es/e-contextos.html $>$

Maquieira Rodríguez, Marina

2006 Teoría y práctica ortográficas en las gramáticas del español del siglo

XVI. In El Castellano y su Codificación Gramatical. Vol. 1: De 1492 (A. de Nebrija) a 1611 (John Sanford), José J. Gómez Asencio (dir.), 365-395. Salamanca: Instituto Castellano y Leonés de la Lengua.

Marcos Marín, Francisco

1979 Reforma y Modernización del Español. Ensayo de Sociolingüística Histórica. Madrid: Cátedra.

Martínez Alcalde, María José (comp.)

1999 Textos Clásicos sobre la Historia de la Ortografía Castellana. (Colección Clásicos Tavera VIII, 10.) Madrid: Digibis [CD-ROM].

Martínez Alcalde, María José

2001 Teoría de la escritura y tópicos historiográficos sobre la ortografía española. In Actas del II Congreso Internacional de la Sociedad Española de Historiografía Lingüística (León, 2-5/3/1999), Marina Maquieira Rodríguez, Maria Dolores Martínez Gavilán, and Milka Villayandre Llamazares (eds.), 691-703. Madrid: Arco Libros.

Martínez Ortega, Maria Ángeles

1999 La Lengua de los Siglos XVI y XVII a través de los Textos Jurídicos. Los Pleitos Civiles de la Escribanía de Alonso Rodríguez. Valladolid: Universidad de Valladolid.

Martínez de Sousa, José

1991 Reforma de la Ortografía Española. Estudio y Pautas. Madrid: Visor.

Mazzocco, Angelo

2001 The Italian connection in Juan de Valdés' Diálogo de la lengua (1535). In History of Linguistics in Spain. Historia de la Lingüistica 
en España, E.F.K. Koerner, and Hans Josef Niederehe (eds.), vol. 2, 79-94. Amsterdam: Benjamins.

Menéndez Pidal, Ramón

1958 El lenguaje del siglo XVI. In La Lengua de Cristobal Colón. El Estilo de Santa Teresa y Otros Estudios sobre el Siglo 16, Ramón Menéndez Pidal, 4th ed., d7-g4. Madrid: Espasa-Calpe.

Menéndez Pidal, Ramón

1986 Orígenes del español. Obras completas, vol. 8, 10th ed. Madrid: Espasa Calpe.

Morel-Fatio, Alfred

1913 L'espagnol langue universelle. Bulletin Hispanique 15: 207-225.

Morreale, Margherita

1978 Trascendencia de la variatio para el estudio de la grafía, fonética, morfología y sintaxis de un texto medieval, ejemplificada en el Ms. Esc. I-1-6. Annali della Facoltà di Lettere e Filosofia dell'Università di Padova 2: 249-261.

Mosterín, Jesús

1981 La Ortografía Fonémica del Español. Madrid: Alianza Editorial. Müller, Bodo

1996-97 La variation morphologique dans le lexique espagnol du Moyen Âge. Cahiers de Linguistique Hispanique Médiévale 21: 119-126.

Pascual, José Antonio

1993 La edición crítica de los textos del Siglo de Oro: de nuevo sobre su modernización gráfica. In Estado Actual de los Estudios sobre el Siglo de Oro. Actas del II Congreso Internacional de Hispanistas del Siglo de Oro, Manuel García Martín (ed.), vol. 1, 37-57. Salamanca: Ediciones Universidad de Salamanca.

Pascual, José Antonio

1996 Del latín a las lenguas romances: la complicada gestación - sobre el papel - del castellano. In De Roma al Siglo XX, Ana María Aldama (ed.), vol. 1, 447-471. Madrid: UNED.

Pascual, José Antonio

1996-97 Variación fonética o norma gráfica en el español medieval. A propósito de los dialectos hispánicos centrales. Cahiers de Linguistique Hispanique Médiévale 21: 89-104.

Pozuelo Yvancos, José Maria

1984 Norma, uso y autoridad en la teoría lingüística del siglo XVI. Historiographia Linguistica 11 (1-2), 77-94.

Puche Lorenzo, Miguel Ángel

2003 El Español del Siglo XVI en Textos Notariales. Murcia: Universidad de Murcia.

RAE (Real Academia Española)

1999 Ortografía de la Lengua Española. Madrid: Espasa. 
RAE (Real Academia Española, Asociación de Academias de la lengua española) 2010 Ortografía de la Lengua Española. Madrid: Espasa.

Rallo Gruss, Asunción 2003 Erasmo y la Prosa Renacentista Española. Madrid: Laberinto.

Revuelta Sañudo, Manuel, and Ciriaco Morón Arroyo (eds.)

1986 El Erasmismo en España. Ponencias del Coloquio Celebrado en la Biblioteca de Menéndez Pelayo del 10 al 14 de junio de 1985. Santander: Sociedad Menéndez Pelayo.

Rivarola, José Luis

1996 Ortografía, imprenta y dialectalismo en el siglo XVI. El caso de Pedro Cieza de León. In Actas del III Congreso Internacional de Historia de la Lengua Española (Salamanca, 22-27 de Noviembre de 1993), A. Alonso González, L. Castro Ramos, B. Gutiérrez Rodilla, and J. A. Pascual Rodríguez (eds.), vol. 1, 887-897. Madrid: Arco Libros.

Rosenblat, Ángel

1951 Las ideas ortográficas de Bello. In Obras Completas, V. Estudios Gramaticales, Andrés Bello, IX-CXXXVIII. Caracas: Ministerio de Educación.

Salvador, Gregorio

2004 De leer, escribir y algo más. Diario $A B C, 05 / 06 / 2004$ : 58-59. [First published in: Diario $A B C, 19 / 08 / 2003]$.

Sánchez-Prieto Borja, Pedro (coord.)

1991 Textos para la Historia del Español, I. Alcalá de Henares: Universidad de Alcalá de Henares.

Sánchez-Prieto Borja, Pedro (coord.)

1995 Textos para la Historia del Español, II, Archivo Municipal de Guadalajara. Alcalá de Henares: Universidad de Alcalá de Henares.

Sánchez-Prieto Borja, Pedro

1996 Sobre la configuración de la llamada 'ortografía alfonsí'. In Actas del III Congreso Internacional de Historia de la Lengua Española (Salamanca, 22-27 de Noviembre de 1993), A. Alonso González, L. Castro Ramos, B. Gutiérrez Rodilla, and J. A. Pascual Rodríguez (eds.), vol. 2, 913-922. Madrid: Arco Libros.

Sánchez-Prieto Borja, Pedro

1998 Cómo Editar los Textos Medievales. Criterios para su Presentación Gráfica. Madrid: Arco Libros.

Sánchez-Prieto Borja, Pedro

2005 La normalización del castellano escrito en el siglo XIII. Los caracteres de la lengua: fonemas y grafías. In Historia de la Lengua Española, Rafael Cano (coord.), 2d ed., 423-448. Barcelona: Ariel.

Sanz Hermida, Jacobo

2002 La imprenta y la difusión de la espiritualidad erasmista. In Erasmo en España. La Recepción del Humanismo en el Primer Renacimiento 
Español. Madrid: Sociedad Estatal para la Acción Cultural Exterior, 128-139.

Süselbeck, Kirsten

2011 “Una Estirpe, una Lengua y un Destino”. Das Sprachideal der Academias de la Lengua Española (1950-1998). Frankfurt: Vervuert.

Terracini, Lore

1979 Lingua come Problema nella Letteratura Spagnola del Cinquecento. Turin: Stampatori.

Voeste, Anja

2008 Orthographie und Innovation. Die Segmentierung des Wortes im 16. Jahrhundert. Hildesheim/Zurich/New York: Olms.

Wright, Roger

1982 Late Latin and Early Romance in Spain and Carolingian France. Liverpool: Francis Cairns. [Spanish transl.: Latín Tardio y Romance Temprano en España y la Francia Carolingia. Madrid: Gredos, 1988].

Wright, Roger

1988 Latín tardío y romance temprano (1982-1988). Revista de Filología Española 68: 257-269.

Wright, Roger

1993 La escritura: ¿foto o disfraz? In Actas del I Congreso Anglo-Hispano, Ralph Penny (ed.), vol. 1, 225-233. Madrid: Castalia.

Zumthor, Paul

1972 Essai de Poétique Médiévale. (Collection Poétique) Paris: Seuil.

Zumthor, Paul

1980 Parler du Moyen Age. Paris: Minuit. 


\title{
Italian
}

\section{Italian orthography in Early Modern times}

\author{
Andreas Michel
}

\section{The ideal of phonological spelling and the writing tradition}

The 16th century had a profound effect on the development of many European languages. The letterpress created in the mid-15th century played a significant part in this development, which led to a certain long-term orthographical unity, as well as to the establishment of punctuation rules. However, the 16th century was not just a time of linguistic regulation: it was also one of phonographemic experiments by individual philologists and grammarians.

The French grammarian Louis Meigret (c. 1510- c.1560) published Le tretté de la grammére françoéze in 1550, and in this work he used a kind of spelling which was based on phonological criteria (cf. Baddeley, this volume). The same thing was done by Jacques Peletier du Mans (1517-1583) in his Dialogue de l'ortografe e Prononciation Françoęse (1550). They both met with rejection to the greatest possible extent. A quarter of a century earlier, the Italian grammarian Giangiorgio Trissino (1478-1550) had encountered a similar experience in his attempt to mark open and closed vowels as well as voiced and unvoiced $s$ with special characters. The conflict emerged because, before the establishment of real orthographical norms between the Middle Ages and Early Modern times, many Romance languages had already developed writing traditions, whose reform encountered resistance from traditionalists. These traditions grew stronger over the centuries, and often hindered the progress of rational writing systems based on phonological criteria.

In the case of spelling in European alphabetic writing, two different systems can be distinguished: the phonemic and the morphophonemic. Phonemic spelling aims to achieve, as far as possible, an exact relation between phonetic structure and characters, in which ideally a graph conforms to a single phoneme. Examples of morphophonemic spelling systems with strongly etymological components include that of English, as well as 
that of French, while Italian and Spanish come quite close to the ideal of phonemic spelling (cf. also Dürscheid 2006: 23-34).

\section{The historico-cultural context}

The politically-split Italy had no uniform spoken standard language until the 20th century, since the majority of the population only used their local dialects. A global Italian written language had become established already, as indicated above, in the course of the 16th century, and had replaced the different written dialects (scriptae) that had emerged in the Middle Ages. It is also the basis for the present standard spoken language. The codification of the Italian written language was carried out to a great extent by grammarians and lexicographers. The linguistic model was the Florentine literary language of the 14th century, which was broadly accepted by scholars throughout the whole of Italy. The assertion of the Tuscan variety as the general Italian written language at first marked a break with the dominance of the Latin tradition, which took longer in Italy than in the other Romance countries, and at the same time established the supremacy of the phonemic principle over the etymological, which, for instance, prevailed in France.

\subsection{The Latin written tradition and the volgare}

The difficulty in putting the Italian dialects into writing in the Middle Ages was due to the fact that a large number of sounds could not be adequately expressed by means of traditional Latin orthography. This applied above all to the Gallo-Italic dialects in Northern Italy, whereas the Tuscan variety remained closer to its Latin origin. However, even here there were some sounds including phenomena which were unknown to Latin: for instance, the affricates $/ \mathrm{dz} /, / \mathrm{dz} /, / \mathrm{ts} /$ and $/ \mathrm{t} /$, or the fricative $/ \mathrm{g} /$.

As far as the development of the Italo-Romance written dialects was concerned, there were two basic types. The first was characterized by relatively weak diatopic marking, as well as by strong Latinization; the second, conversely, by a strong regional or local characterization as well as by slight Latinization. For instance, to the first group belong the Ligurian scriptae, in which the form [' $\mathrm{f} y \mathrm{y}$ ] ( $<$ Lat. PLUS) is in general expressed by $<$ plu $>$. In Neapolitan and Sicilian texts, however, we find $<$ pluj $>$ for spoken ['kju] (< Lat. PLUS). 
The Tuscan dialect represents generally, as we have already mentioned, a relatively low rate of discrepancy between phonetics and written representation. Thus, the sound connections [pj] ( $<$ Lat. PL-), [fj] ( $<$ Lat. FL-) are, in most cases, expressed by $<$ pi $>$ (Lat. PLUS $>$ Tusc./It. ['pju] $<$ più $>$ ) and $<\mathrm{fi}>$ (Lat. FLOREM $>$ Tusc./It. ['fjore] $<$ fiore $>$ ), while Latinized spelling tends to be more the exception.

\subsection{The Tuscan spelling of the Middle Ages}

In the development of the Tuscan writing tradition in the 13th century, it was not literature that played the main role, but rather the correspondence of merchants. It was the business people in particular who disentangled themselves relatively early from the monopoly of the Latin written language (cf. Castellani 1982). The documents of this time, however, were characterized by a degree of heterogeneity. Alternations between $<\mathrm{k}>$ and $<\mathrm{ch}>$ emerged for the expression of /k/ (e.g., ke; chuore, chose, chome); $<\mathrm{k}>$ and $<\mathrm{q}>$ were sporadically used for the expression of $/ \mathrm{g} /$ : Kerardi (Gherardi); quadannio (guadagno). The group $<$ th $>$ served sometimes for the expression of /ts/: vethosa (vezzosa); in Pisa and Lucca $<\mathrm{z}>$ often represented a voiced intervocalic $s(/ \mathrm{z} /)$ (e.g., bizogno, uzare). Characteristic of the Florentine merchants of the Duecento is for instance the following document from 1256 (cf. Casapullo 1999: 328):

Arighetto f. Tolomei d'Agliana: aven konperato da lui un peço di tera posta a rio grande, ke fue del padre, k'è dal primo lato Giaffero f. Triki per la tera ke konperò da' fratelli Ispinelli, e ii sì è i • rio e iii Righetto medesimo e iiii via; avenne karta per mano di ser Andrea da Enpoli vekio, ke s'inbrevò dies otto intrante febraio nel cinquantasei, ke ne de avere ib. Xxv questo die.

A Righetto demo lb. Xiij e s. iiij dies otto intrante febraio: ponemo a sua ragione ove dovea dare, ke saldamo.

Demoli s. xxvii questo die: ponemo $<$ a sua $>$ a ragione ove dovea dare Tolomeio suo padre, ke saldamo.

Demo a Righetto ib. x e s. xi dies quatro intrante marzo in sua mano, ke ne paghò la konpagna da Enpoli lb. Otto. ...

Conspicuous here is the massive usage of $<\mathrm{k}>$ (e.g., ke, konperato, karta, konpagna, vekio). The group $/ \mathrm{mp} /$ is represented by $<\mathrm{np}>$ (e.g., konperato). The voiced plosive $/ \mathrm{g} /$ is expressed before palatal as well as before velar vowels by <gh> (e.g., Arighetto, pagho). The unvoiced affricate /tis/ is represented in intervocal positions by $<c ̧>$, the postconsonantal affricate 
/ts/, conversely, by $<\mathrm{z}>$ (e.g., peço vs marzo). Geminate consonants are often expressed by a simple character (e.g., demo instead of demmo, saldamo instead of saldammo, tera instead of terra).

Table 1. Possible phoneme-grapheme relations (selection) in the medieval scriptae of the Tuscan speech area

\begin{tabular}{ll} 
Phoneme & Grapheme \\
\hline$/ \mathrm{k} /$ & $<\mathrm{ch}>+<\mathrm{e}>,<\mathrm{i}>,<\mathrm{a}>,<\mathrm{0}>,<\mathrm{u}>;<\mathrm{k}>$ \\
$/ \mathrm{g} /$ & $<\mathrm{g}>+<\mathrm{a}>,<\mathrm{0}>,<\mathrm{u}>;<\mathrm{gh}>+<\mathrm{e}>,<\mathrm{i}>;<\mathrm{k}>;<\mathrm{qu}>$ \\
$/ \mathrm{g} /$ & $<\mathrm{sci}>$ \\
$/ \mathrm{d} 3 /$ & $<\mathrm{g}>+<\mathrm{e}>,<\mathrm{i}>$ \\
$/ \mathrm{t} /$ & $<\mathrm{c}>+<\mathrm{e}>,<\mathrm{i}>$ \\
$/ \mathrm{ts} /$ & $<\mathrm{c}>;<\mathrm{z}>;<\mathrm{th}>$ \\
$/ \mathrm{dz} / ; / \mathrm{z} /$ & $<\mathrm{z}>$ \\
$/ \lambda /$ & $<\mathrm{gli}>$ \\
$/ \lambda \mathrm{i} /$ & $<\mathrm{gli}>$ \\
$/ \mathrm{n} /$ & $<\mathrm{gn}>;<\mathrm{nn}>;<$ ngni $>$ \\
\hline
\end{tabular}

\subsection{Phonographemic experiments in Alberti's Grammatichetta} and in the fragment Ordine délle loettére pélla ling ${ }^{h} u a \operatorname{tosc}^{h}$ ana

Leon Battista Alberti (1404-1472), the author of the first synchronouslydesigned grammar of the Italian language (c. 1435) - which however is only available in a manuscript from the early 16th century - uses in the chapter Ordine delle lettere diacritical signs for the distinction of open and closed vowels, as well as of voiced and unvoiced consonants. The conjunction $e$ (usually pronounced [e]!) is expressed by $<_{\mathrm{a}} \mathrm{e}>$, which represents [ $\varepsilon$ ]; the third person of essere, $\dot{e}[\varepsilon]$ by $<\mathrm{e}>$, the masculine article in the plural at that time, by $\left\langle\mathrm{e}^{\prime}>\right.$. The phonemes $/ \varepsilon /$ and $/ \mathrm{o} /$ are expressed respectively by $<_{\mathrm{a}} \mathrm{e}>$ and $<\breve{\mathrm{o}}>$; conversely, /e/ and /o/ are reprensented by $<$ é $>$ and $<\dot{\mathrm{o}}>$ respectively, or simply by $<_{0}>$ (e.g., lcettére ['let:ere] and pŏrci a' porci ['portfi a 'portfi]). To mark the phoneme /ts/ the sign $<c ̧>$ was used (e.g., $<$ çio> ['tsio]): 
Ordine délle lettere

i $r \quad t$

$\mathrm{n} \mathrm{u} \mathrm{m}$

c e o

$1 \mathrm{~s} \mathrm{f}$

d b v

p q $g$

a $\mathrm{x} \mathrm{Z}$

ç ch gh

Vochali

a ${ }_{\text {a }}$ e é ó ŏ u

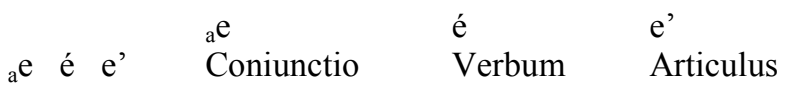

El g $\mathrm{g}^{\mathrm{h}}$ iro giró al çio el zembo

Et volse pŏrci a' porci quéllo che' è pèlla pelle.

Similar approaches to the phonological marking of characters also exist in the short document Ordine délle loettére pélla ling ${ }^{h} u a \operatorname{tosc}^{h}$ ana (cf. figure 1). As a whole, Alberti's spelling system shows a certain inconsistency.
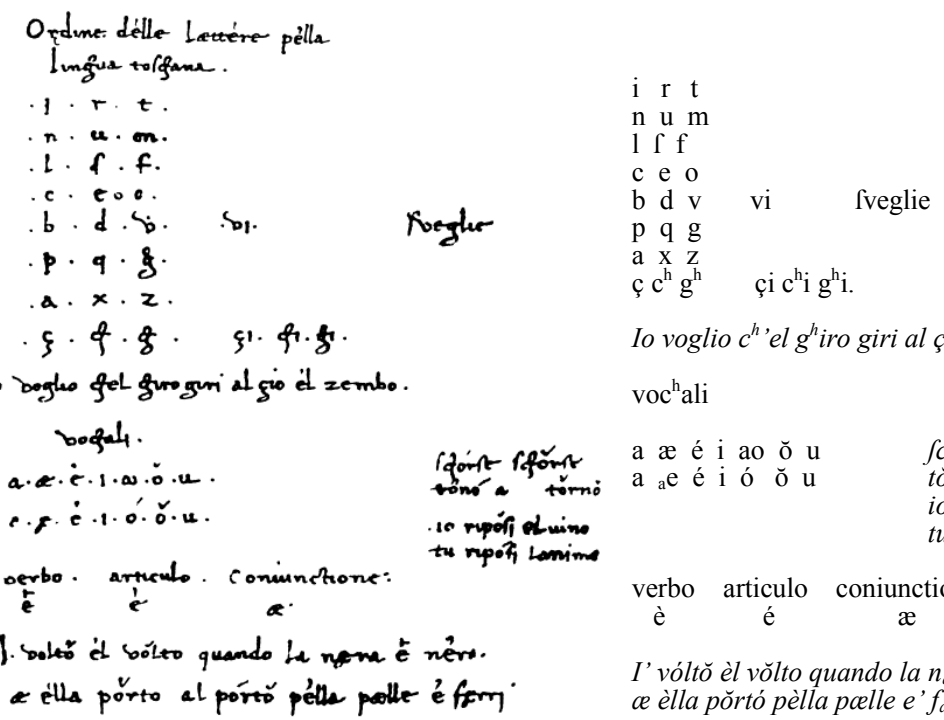

Io voglio $c^{h}$ 'el $g^{h}$ iro giri al çio él zembo

$\operatorname{voc}^{\text {hali }}$

a æé i ao ŏ u $\quad c^{h}$ órse, $\int c^{h}$ orse

a ${ }_{\text {a }}$ e é i ó ŏ u tŏnó a tórnŏ io ripófi el uino tu ripófi l'animo

$\underset{\text { è }}{\text { verbo }} \underset{\text { é }}{\text { articulo }} \underset{æ}{\text { coniunctione }}$

I' vóltǒ èl vŏlto quando la $n_{a}$ era é nèra. a èlla porrtó pèlla pcelle e' $f_{a}$ erri

Figure 1. Ordine délle lættére pélla ling ${ }^{\mathrm{h}} u a \operatorname{tosc}^{\mathrm{h}}$ ana ${ }^{1}$ 


\section{The development of the Italian written language after the introduction of the letterpress}

Between 1450 and 1455, Johannes Gutenberg (1400-1468) invented the letterpress with movable type. In the 1460 s, this new art came to Italy. The letterpress was the basis for the development of a uniform Italian written language (cf. Trovato 1998: 131-141). To this purpose, there arose not only a partly uniform spelling (cf. Maraschio 1993: 140-227), but also a systematic usage of punctuation marks. The standardization process, however, had to develop slowly.

Upon invitation from the Spanish cardinal Juan de Torquemada, the German typographers Conrad Sweynheym and Arnold Pannartz came to Subiaco (near Rome) in 1463 or 1464. They printed works by Cicero, De Oratore (1465) and Epistolae ad familiares (1467). From 1468 to 1473, Sweynheym and Pannartz published no fewer than 48 Latin classics. Between 1470 and 1472, printing presses had already been set up in sixteen towns, and by 1479 a further thirty printers' workshops had followed.

Venice, which introduced the letterpress in 1469, quickly became the Italian centre for this new art. By 1500, Venice had no fewer than 151 printers' workshops. From 1540 onwards, book production strongly increased once again in Italy, and in the second half of the century more Italian than Latin books were being published. ${ }^{2}$ The presses in Venice, Rome, Naples, Florence, etc. not only published texts which had been produced in particular regions, but, when these texts came to be printed, there were often interferences from local dialects. For instance, Luigi Pulci's (14321484) Venetian edition of the Morgante (1482) contains various phonographemic Venetian influences (e.g., zente instead of gente, zorno instead of giorno, zentile instead of gentile).

\subsection{The early printed editions of the classics of the Trecento}

The majority of books printed were, at first, in Latin; however the Tuscan classics of the Trecento were also among the works produced in Italian printing houses practically from the beginning. In 1472, Johannes $\mathrm{Nu}$ meister, a student of Gutenberg, and Evangelista Angelini published the Divina Commedia in Foligno. In Naples, an edition of Dante's main work appeared in 1477, as well as an edition of Boccaccio's Filocolo (1478). Already in 1470 in Venice, there had appeared an edition of Petrarch's Sonetti e canzoni. All printed editions of the Quattrocento, however, show 
clear traces of the humanistic writing tradition, such as the Venetian edition of Petrarch's Canzoniere (Sonetti e canzoni 1470) or the Neapolitan edition of Dante's Divina Commedia (1477).

L oblusion gliafpecti oblcuri \& adri pluche mal bei tor nando lafceranno a morte impetuofa igiorni ladri

Nel eta piu fiorita et uerde aranno chon immortal bellezza eterna fama ma innanzl a tutticha rifar fi uanno

E tquellache piangendo il mondo chiama chon la mia lingua et chon la ftanca penna malciel pur diuederla interra brama

$A$ rriua un fiume che nafce in gebenna amor mi die per lui fi lunga guerra che la memoria ancora el core accenna

F elice faxo chel bel uifo ferra che porchaura riprefo il fuo bel uelo Se tu beito chila uide in terra

Or che ha dunque a riuederla incielo?
INCOMINCIA IL TRACTATO DI PVRGATORIO DIDANTE ALDE GIERI DIFIRENZE.CANTICA.I.

Ercorrer meglior acque alza le uele o mai la nauicella delmio ingnegno che lafcia dietro affemar ficrudele

E t cantero diquel fecondo regno doue lhumano fpirto fipurga \& difalite alciel diuenta degno

$\mathrm{M}$ a qui lamorta poefi rifurga ofante mufe poi che uoftrofono \& qui caliope alquanto furga

$S$ eguitandol mio canto conquel fono dicui lepiche mifere fentiro locolpo tal che difperar perdono

$D$ olce color doriental 3 affiro che faccholglieua nel fereno afpecto dalmezo puro infino alprimo giro

Figures 2 and 3. Extracts from the Venetian edition of the Canzoniere (1470) and from the Neapolitan edition of the Divina Commedia $(1477)^{3}$

Both texts almost manage without punctuation marks. Elided forms are not expressed graphemically (che poi chaura; chel bel uifo; lhumano; facchoglieua). The phonemes $/ \mathrm{u} /$ and $/ \mathrm{v} /$ are both expressed by $<\mathrm{u}>(/ \mathrm{v} /$ : uanno, uerde, uelo; /u/: fiume, lunga, fuo). In the Venetian edition of the Canzoniere the etymological $<\mathrm{h}>$ is left out in individual cases (aranno, but ha), Latin characters (faxo ['sas:o]) and letter combinations (afpecti obfcuri [a'spet:i o'skuri]) which had no sound counterpart in the Tuscan dialects are, however, consistently used. Similarly, $<\mathrm{c}>$ was combined before velar vowels with a redundant $<\mathrm{h}>$ (chon). Also in the Neapolitan edition of the Divina Commedia, many words show an etymologizing spelling, e.g., by the use of $\langle\mathrm{h}>$ (humano), the maintaining of Latin letters and letter combinations which had no phonological representation value in the volgare, such as $\langle\mathrm{x}\rangle$ (dextra ['destra]) and $<\mathrm{ct}\rangle$ (tractato [trat':ato]), as well as by the use of short Latin grammatical morphemes $(e t, a d)$. The phonetic wordstress at the end of a word is not expressed in writing (cantero, sentiro instead of modern canterò, sentirò). 
Similarly, in the edition of Dante's Convivio published in 1490 in Florence, a Latinizing way of spelling dominates, which alternates with influences of the contemporary language of the Quattrocento.

\section{CONVIVIO DIDANTE ALIGHIERI FIORENTINO}

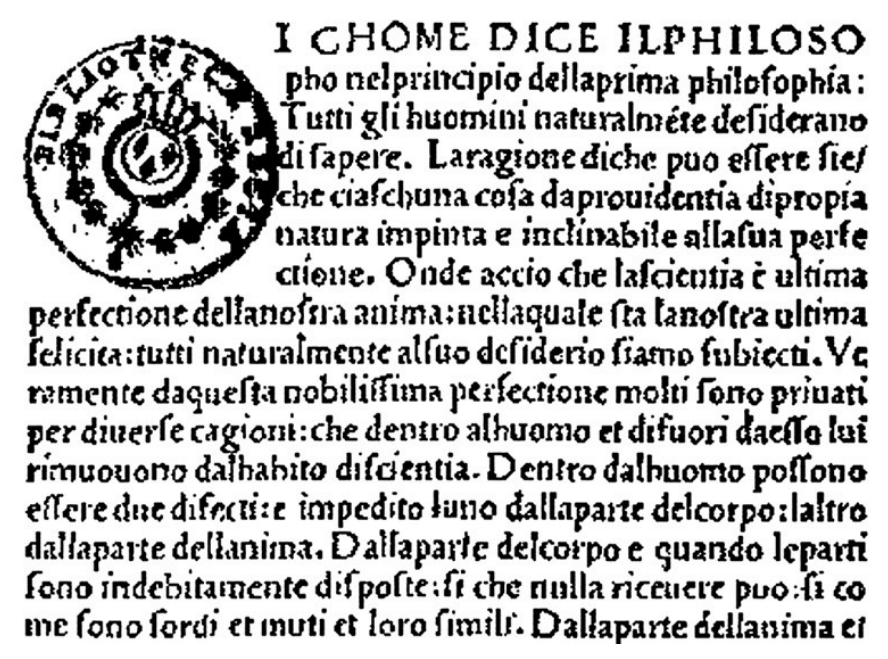

Figure 4. Extract from the Florentine edition of the Convivio (1490) ${ }^{4}$

The characteristics of the text are the redundant usage of $<\mathrm{h}>$ after $<\mathrm{c}>$ and $<\mathrm{g}>$ before velar vowels (e.g., chome, ciafchuna, alchuno, boccha, purgha, luogho). The retention of $<\mathrm{h}>$ (huomini), $<\mathrm{ph}>$ (philofophia), $<\mathrm{rh}>$ (rhetorici) and $<\mathrm{ct}>$ (fubiecti) as well as the ending -tione (perfectione) are also Latinate forms. Apart from these forms, phonological spellings also appear ( crittura). The phoneme /ts/ is expressed partly by $<\mathrm{c}>$ (giudicio), partly by $<\mathrm{z}>($ Janza $)$.

\subsection{The influence of Aldus Manutius and Pietro Bembo}

on the standardization of the written language in the Cinquecento

The printing location of Venice had a great influence on the creation of a standardized Italian spelling at the beginning of the Cinquecento. This is especially due to two scholars who worked here: the publisher and typogra- 
pher Aldus Manutius (1449-1515) and the humanistically-inclined cardinal Pietro Bembo (1470-1547).

Aldus Manutius settled in Venice in around 1490 and opened a printing workshop in 1494. At first, Manutius restricted himself to the publication of Greek authors; however, he also published works by contemporary Italian writers. Worth mentioning in this connection is the work Hypnerotomachia Poliphili, attributed to Francesco Colonna (1433-1527), which was printed in 1499. The book comprises 234 unnumbered pages and is illustrated with 171 woodcut illustrations by an unknown artist.

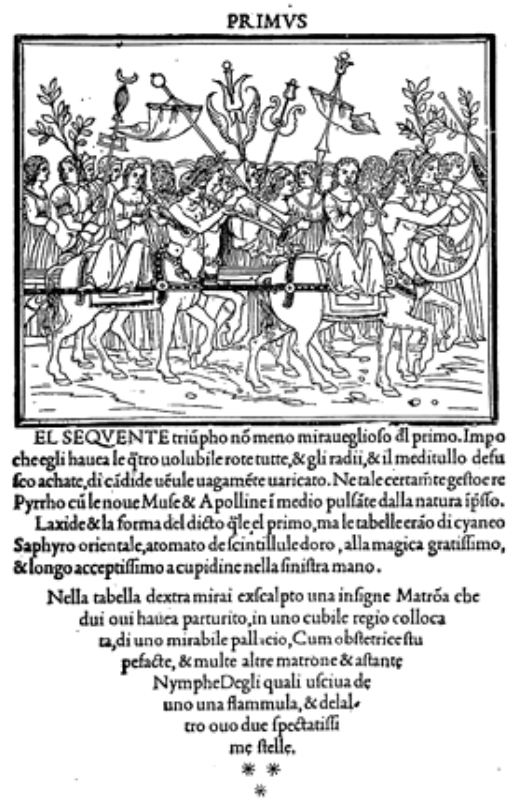

Figure 5. Extract from Francesco Colonna's Hypnerotomachia Poliphili (1499)

The text presents all the characteristics of the humanistic volgare of the 15th century. Apart from a vast number of abbreviations ( $n \tilde{o}, \mathrm{dl}$, cãdide, erão etc.) in particular, etymologized spelling forms based on Latin attract attention (triüpho, Pyrrho, dicto, cyaneo, Saphyro, dextra, exfcalpto, hauea etc.). The phonemes $/ \mathrm{u} /$ and $/ \mathrm{v} /$ are not distinguished graphically and are both transcribed by $<\mathrm{u}>$ (miraueglioso, uolubile, uēule, uagamète, ufciua etc.). Conversely, in cases of capitalization, both sounds are represented by $<$ V $>$ (SEQVENTE). 
From 1501 onwards, Manutius turned more and more towards Latin and Italian classics. Thus, together with Pietro Bembo, he published Petrarch's Canzoniere. In 1502 an edition of Dante's Divina Commedia followed, in which for the first time italics were used, based on the cursive handwriting that was used at the time in the Chancery.

Up until that time, the most important edition of Dante's chief work had come from Cristoforo Landino (which, however, had a strong influence on the contemporary volgare). Bembo avoided the corruption of the Dante editions of the Quattrocento by using for his edition of the Divina Commedia a manuscript (Vat. Lat. 3199) from the 14th century, which had been a present to Petrarch from Boccaccio, and which somehow came to be in the library of Bernardo Bembo, Pietro's father. Pietro Bembo copied the manuscript which Aldus Manutius used for his edition.

The text edition of Manutius and Bembo is characterised by a high degree of philological meticulousness, which for a vernacular work was unusual at that time. For the first time, abbreviations were expanded, and words were separated according to grammatical criteria.

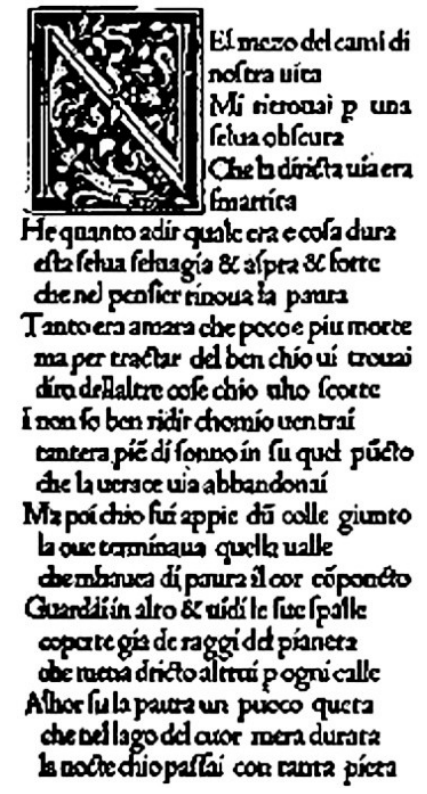

INFE RNO.

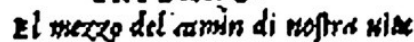

* Mi sitrowai por uns folmo ofarra;

Che Is diritue wis tots fromie:

E $t$ quanto os dir qual $a s, c$ of Effe felwa felwagg $\mathrm{g}+$ it afpra it forte; che nol penfir rimeosa la passa.

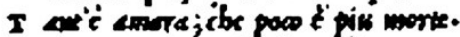

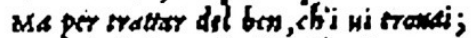
Dire rie laltere offe, chti uho forte.

1 nox fo ben ridir, omm's s'erryai;

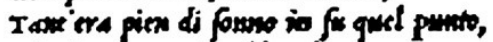
che la weraer vias abbandosect.

As a po chi firi al pie dism colle gisto Id ove armonisus quells walli,

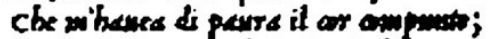

C wardsitis alto; et widi le fre pratic vefire ga d'e rags del pianet:. che mons dritticitrui per ognd aitle.

a Whor fis la pants an poro grets; che net laged del or miers duraice Ia rotse, shi paffai an axnas pliex.

Figures 6 and 7. Extracts from Landino's (1497) and from Bembo's (1502) editions of the Divina Commedia ${ }^{6}$ 
The qualitative and linguistic programmatic difference is visible if one compares Landino's and Bembo's editions of the Divina Commedia:

Table 2. A comparison of Landino's (1497) and Bembo's (1502) extracts from the Divina Commedia

Landino (1497)

Bembo (1502)

\begin{abstract}
Nel mezo del cami di nostra uita Mi ritrouai $\mathrm{p}$ una felua obfcura Che la diricta uia era fmarrita Ahi quanto adir qual era e cosa dura esta felua feluaggia \& afpra \& forte che nel penfier rinoua la paura

Tanto era amara che poco e piu morte ma per tractar del ben chío uí trouai díro dellaltre cofe chío uho fcorte í non so ben rídír comío uentraí, tantera piě dí fonno a quel pũcto che la uerace uía abbandonaí Ma poi chio fui appíe dũ colle giunto la oue termínaua quella ualle che mauea di paura il cor cŏponcto guardai in alto \& uidi le fue fpalle coperte gía de raggí del pianeta che mena drícto altruí p ogní calle

Alhor fu la paura un puoco queta che nel lago del cuor mera durata la nocte chio paffaí con tanta píeta
\end{abstract}

\author{
nEl mezzo del camin di noftra uita \\ Mi ritrouai per una felua ofcura; \\ Che la diritta uia era fmarrita: \\ Et quanto a dir qual era, è cofa dura \\ esta felua felvaggia et afpra et forte; \\ che nel penfier rinuoua la paura. \\ Tant'è amara; che poco è piu morte. \\ Ma per trattar del ben ch'i ui trouai; \\ Diro de l'altre cofe, ch'i u'ho fcorte. \\ I non so ben ridir, com'i u'entrai; \\ Tant'era pien di fonno in su quel punto, \\ che la uerace uia abbandonai. \\ Ma poi ch'i fui al pie d'un colle giunto, \\ La, oue terminaua quella ualle, \\ Che m'hauea di paura il cor compunto; \\ Guarda'in alto; e uidi le fue fpalle \\ vestite gia d'e raggi del pianeta, \\ che mena dritt' altrui per ogne calle. \\ Allhor fu la paura un poco queta; \\ Che nel lago del cor m'era durata \\ La notte, ch'i paffai con tanta pieta.
}

Apart from some lexical variants (Ahi quanto vs. Et quanto; Tanto era amara/Tant'è amara), Bembo's edition is especially characterized by comprehensive punctuation. Bembo's word-limits are more or less consistently marked by an apostrophe (ch'i u'ho vs. chio uho; m'hauea vs. mauea). While the edition by Landino is full of abbreviations, the words in the Bembo edition appear in their full form (dũ colle vs. d'un colle; $\underline{p}$ ogni calle/per ogne calle). Whereas Landino uses an etymologized spelling, Bembo generally prefers a phonological spelling system (obfcura vs. ofcura; dirictaldiritta; tractar/trattar; cöponcto/compunto; nocte/notte). Despite a phonological orientation, the edition of Bembo also has Latinizing elements, in particular with regard to the letter $<\mathrm{h}>$ (Allhor, $m$ 'hauea), but also in the form of Latin short words $(e t)$. Neither Landino nor Bembo make a graphemic distinction of $/ \mathrm{u} /$ and $/ \mathrm{v} /$ : in both editions, $<\mathrm{u}>$ serves for a representation of the vowel as well as for the consonant phoneme. In Bembo's edition, $<\mathrm{v}>$ only appears at the beginning of the verse (vestite gia). 
The edition of the Tuscan classics of the Trecento formed the starting point for the Venetian influence on the establishment of the old Tuscan linguistic model as a pan-Italian written language. Bembo was not content with editing old texts, but deliberately imitated their language. With regard to this, special consideration deserves to be given to the prosimetrum Asolani, a philosophical dialogue about Platonic love in the style of Boccaccio, written between 1497 and 1502, which was published for the first time by Aldus Manutius in 1505.

\section{A MADONNA LVCRETIA ESTEN. SE BORCIA DVCHESSA ILLV. STRISSIMA DI FERRARA.}

\section{PIETRO BEMBO.}

\section{E io non ho a V.S. piu tofto quegli ragiona =} 5 menti mandati, che effendo l'anno pajfato in Ferrara le promifi giunto che lo fuffi qui di mandare; if cufimi appo lei la morte de lmio caro fratel lo Carlo; che io oltre ogni mia credéza ritrouai di que fat uita paffato: la gual morte fi mi fordi; che a gufa di coloro, che dal fuoco delle faette tocchi rimangono lungo tempo fanza fentimento, non ho peranchora ad altro potuto rivolger lanimo, che alla fur in fauabile et penetreuoliffima ferita; Percio che io non folamente ho un fratello perduro; ilche fuole tuttauia effer graue et

Figure 8. Extract from Bembo's Asolani $(1505)^{7}$

The extract shows the dedication to Lucrezia Borgia, which contains the following graphemic characteristics. The letter $<\mathrm{u}>$ stands for both $/ \mathrm{u} /(g i-$ unto, fuoco, perduto) and for $/ \mathrm{v} /$ (uita, riuolger, tuttauia), while in the case of capitalization, $\langle\mathrm{V}\rangle$ is generally used (LVCRETIA, DVCHESSA ILLVSTRISSIMA). Sporadically after $<\mathrm{c}>$ an $<\mathrm{h}>$ appears before velar vowels (peranchora). Apart from etymological $<\mathrm{h}>$, the spelling of the conjunction et (pronounced e) also shows Latinizing influences. The digraph $<\mathbb{\Omega}>$ alternates with $<\beta>$ (e.g., neßuna, effermi).

Bembo's efforts in the area of textual criticism and textual edition, as well as in the field of poetry and literary prose, paved the way for the lin- 
guistic model of the Trecento. The linguistic and literary reform project culminated in the programmatic Le prose della volgar lingua (1525), in which Petrarch and Boccaccio were proposed as linguistic models for the Italian literary language, in the same way that Virgil and Cicero had served as models for the humanistic usage of the Latin language.

While Pietro Bembo raised the literary canon of the Tuscan Trecento to a pan-Italian level, Aldus Manutius introduced a series of innovations into both Italian and international printing practices, which have partly been maintained up to the present day. The most important contribution he made to the modern written language was the systematization of punctuation: he imposed the full stop, comma, semicolon, apostrophe and graphic accents as a general standard.

As a whole, the written language of the 16th century is characterized by fluctuations in the usage of certain notations.

In Francesco Sansovino's (1521-1583) anthology Le osservationi della lingua volgare di diversi huomini illustri: cioe del Bembo, del Gabrielo, del Fortunio, del Corso, dell'Acarisio, et di altri scrittori..., for instance, published in Venice in 1562, we find a redundant $<\mathrm{h}>$ in Thoscana as well as an etymologizing $p h$ in Ortographia. The written $<\mathrm{u}>$ and $<\mathrm{v}>$ stand respectively for the phonemes $/ \mathrm{u} /($ vfaffero) and $/ \mathrm{v} /($ uoci):

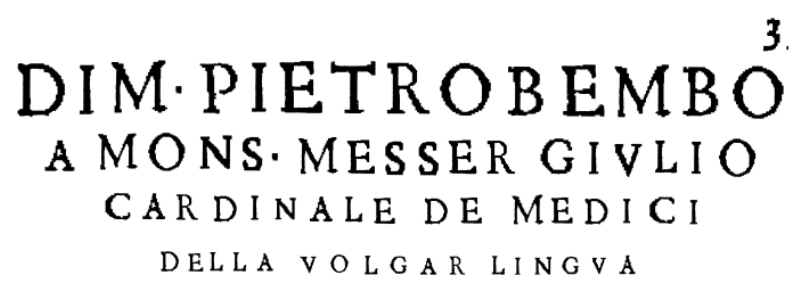

LIBRO PRIMO.

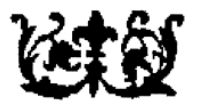

Si ragiona in quetto primo libro l'origine della lingua volgare, \& s'ella fi dee chiamar Thof cana o nò , \& qual $f$ dee abbracciare delle molte lingue che fono in Italia; Et come gli a ntichi vfaffero molte uoci di uere da quelle che s'adoperano ne tempi prefenti dagli 5crittori.

Figure 9. Extract from Sansovino, Le osservationi... (1562) ${ }^{8}$ 
The character $\beta$ which arose from the ligature of long $\int$ and round $s\left(\rightarrow \int s\right.$ $\rightarrow \beta)$ was not unknown in the Italian language. The usage of $<\uparrow>$ and $<\beta>$ did not follow firm rules: the position of either character was more dependent on the space available. The written sign $<\beta>$ which today only appears in the German language was used in handwritten as well as in printed texts at that time.

In some texts $\langle\beta>$ even appears as the last character before abbreviations, as, for instance, in Giambattista Gelli's (1498-1563) Il Gello. Sopra un sonetto di M. Franc. Petrarca (1549), which was printed in Florence (honorati $\beta$. conteffa $=$ onoratissima contessa) (cf. figure 10).

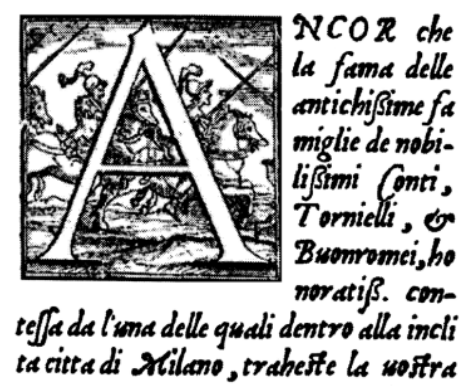

Figure 10. Extract from the Gello (1549) ${ }^{9}$

We find the forms effe, haueffe, paffar, effere alongside neceßità and eßi (cf. figure 11). This practice would not be abandoned until the 18th century.

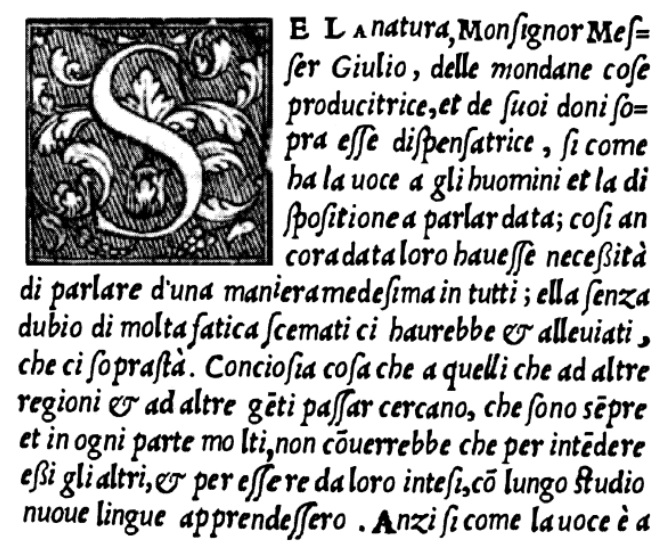

Figure 11. Extract from Sansovino's Le osservationi... $(1562)^{10}$ 
A further characteristic of the Cinquecento written language is the fluctuating usage of separation signs in cases of word-separation at the end of a line. Separation was marked in printed texts by a single hyphen, a double hyphen, a superscripted dot, or not at all.

In many printed works of the Quattrocento separation signs were completely unused, as is the case for instance in an edition of Dante's treatise Convivio which dates from 1490 (see the form Ve ramente in lines 2-3).

\section{perfecrione delianotsa animaincliaquale fta lanoftra ultima felicien:tutti naturalmente alfio defiderio fiamo fubiecti. Ve rumente daguefta nobilifima perfectione molti fono privati}

Figure 12. Extract from Dante's Convivio (1490) $)^{11}$

In Aldus Manutius' edition of Colonna's Hypnerotomachia Poliphili (1499), however, separated words are marked by horizontal or transversal dashes.

\section{de fono,curiofo excogitato \& penficu, latamente ritrouato, Et forfa oltrael fo-}

Figure 13. Extract from Colonna's Hypnerotomachia Poliphili (1499) ${ }^{12}$

In the Florentine edition of the Gello (1549), however, word-separation is used very inconsistently. Thus, in the cited part for instance in the case of famiglie (fa miglie), honoratiß (ho norati $\beta$.) and inclita (incli ta), no separation sign is used, but it is used in the case of nobilißimi (nobi-lißimi) and

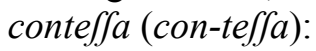

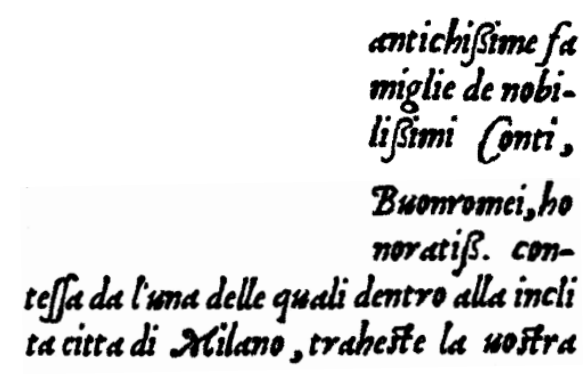

Figure 14. Extract from the Gello (1549) ${ }^{13}$ 
In turn, in the edition of Sansovino (1562), word-separations are basically marked by a double hyphen:

\section{E I a natura, Monfignor Mef= fer Giulio, delle mondane cofe producitrice, et de fuoi doni $\int 0=$ pra effe difpenfatrice, $\int i$ come}

Figure 15. Extract from Sansovino's Le osservationi... (1562) ${ }^{14}$

Here one can clearly see the influence of Manutius and Bembo, who had already used this method at the beginning of the 16th century, as we can see in the following extract from Bembo's Asolani (1505):

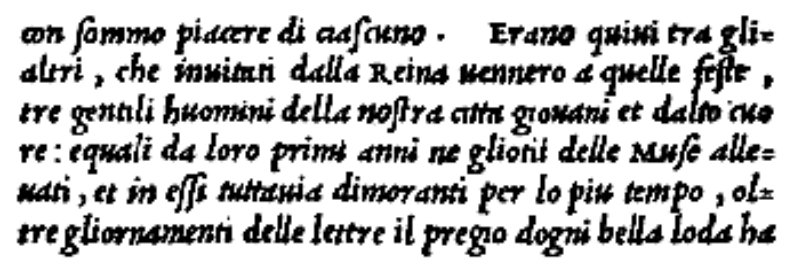

con fommo piacere di ciafcuno. Erano quiui tra gli= altri, che inuitati dalla Reina uennero a quelle fefte, tre gentili huomini della noftra citta giouani et dalto cuo re : equali da loro primi anni ne gliotii delle Mufe alle= uati, et in effi tuttauia dimoranti per lo piu tempo, ol= tre gliornamenti delle lettre il pregio dogni bella loda ha

Figure 16. Extract from Bembo's Asolani $(1505)^{15}$

In the case of Manutius, however, one can sometimes see certain inconsistencies. Thus, gli altri (glialtri) is clearly comprehended as a single graphemic unit, and thus is separated at the end of a line (gli=altri), while the noun cuore is separated without any marking (cuo re) ${ }^{16}{ }^{16}$ Striking is also the writing in one word of dalto ${ }^{17}$ (dalto cuo re), of gliornamenti (ol=tre gliornamenti $)^{18}$ as well as of dogni (dogni bella loda $)^{19}$. 


\subsection{Giangiorgio Trissino's orthographical reform}

While Pietro Bembo adopted the puristic linguistic model of the Trecento, the scholar and poet Giangiorgio Trissino, who came from Vicenza, was a follower of an eclectic language. He learnt Greek in Milan with the scholar Demetrios Chalcocondylis (1423-1511), who came from Athens. On the model of the Greek language as an Attic koinè, Trissino developed his own conception of a future Italian language in the Castellano (1529). On the basis of different diatopic varieties, a global informal Italian language should be created by the elimination of striking local and regional characteristics. The influence of Greek scholarship on the linguistic theories of Trissino is also visible in the Epistola de le lettere nuovamente aggiunte ne la lingua italiana (1524), in which the Italian phonemes /e/, / $/ \varepsilon /, / 0 /$ and /o/ are differentiated on a graphemic basis by means of Greek characters $(<\varepsilon>$ for $/ \mathrm{e} /,<\omega>$ for $/ \mathrm{o} /)$ :

Le lettere, adunque, che io primamente aggiunsi a l'alphabsto, furono $\varepsilon$ aperto $\varepsilon t \omega$ apert $\omega$. $\varepsilon$ questo feci, perció che, $\varepsilon s s \varepsilon n d o$ in $e$ et $o$ lettere vocali due pronuntie, l'una più piccola $\varepsilon$ più chiusa $\omega$ vero più corta $\varepsilon$ più obtusetta che l'altra... ${ }^{20}$

[And so the letters that I first added to the alphabet were open $\varepsilon$ and open $\omega$. And I did this because the vowel letters $e$ and $o$ have two pronunciations, one smaller and more closed (or rather, shorter and blunter)...]

Trissino also considers it necessary to express the phonemes /ts/ and /dz/ by special written signs.

... quando la pronuntia del $z$ sarà simile al $c$, la scriveremo per lo $z$ con-

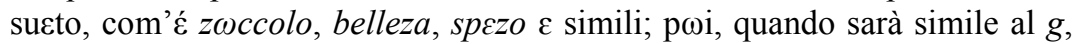
si scriverà per questo altro charactere $c ̧$, come $\dot{\varepsilon}$ çephyro, $m \varepsilon c ̧ o$, reço, $\varepsilon$ simili. $^{21}$

[When the pronunciation of $z$ is like that of $c$, we will write it with $z$ in the usual way, as in zwccolo, belleza, spezo and others of this kind; however, when it is like a $g$, it will be written with this other character, $c$, as in çєphyro, mєço, reço, and others of the same kind.]

From one text to another, there are certain fluctuations in the use of the characters. In the Castellano we find $<\mathrm{c}>$ (giudici $\omega$ ) as well as $<\mathrm{c}>$ (Sannaçar $\omega$ ). Interestingly, Trissino forgoes double z (belleza, spezo).

The new orthographical model also appeared in the tragedy Sofonisba (LA SWPHWNISBA DEL TRISSIN $\omega$ ), and was explained and advocated in a letter to Pope Clement VII (CLEMENTE SETTIM $\omega$ ). 
Lodovico Martelli (1503-1531) and Agnolo Firenzuola (1493-1543) rejected Trissino's spelling reform. Firenzuola criticized the usage of Greek characters in his polemic Discacciamento de le lettere inutilmente agguinte ne la lingua toscana published in $1524 .{ }^{22}$ Martelli refused the linguistic model in the Risposta alla Epistola del Trissino delle lettere nuovamente aggionte alla lingua volgar fiorentina. In turn, Trissino reaffirmed his conception in the treatise Dubbi grammaticali. In 1529, Trissino published the Epistola again in Vicenza. In the same year, Tolomeo Gianicolo printed a booklet in Trissino's reformed Italian alphabet. As well as an index with all of the alphabetic characters, the printed work also contains an edition of Our Father as well as the Ave Maria. Trissino remained faithful to his reformed spelling all his life and even used it in his will. ${ }^{23}$

\section{IA $S \omega P H \omega N$ IS B A}

\section{DEL TRISSIN $\omega$.}

\section{Cbel'avenir nela virtu divina}

É porta; i cuinan cognito cosfume

Fa'lnostro antiveder privo difume .
Che l'avenir, ne la virtù divina

E' post, , il cui nळn cognitø costume

$\mathrm{Fa}$ ' l noftrø antiveder privø di lume

Figure 17. Extracts from the cover and the colophon of Trissino's tragedy Sofonisba $(1529)^{24}$

In Trissino's spelling system (cf. table 3), not only open and closed $e$ and $o$ are differentiated, but also the phonemes $/ \mathrm{u} /$ and $/ \mathrm{v} /$ (lume, costume vs. divina, privœ). Words with final stress are marked by an accent (virtù). Also, the apostrophe is used after elided articles (l'avenir). Despite the phonological basis, some Greek-Latin elements are used as terms of humanistic scholarship in Trissino's written system, for instance the diagraph $<\mathrm{ph}>($ SWPHWNISBA, Philipp $\omega)$, the digraph $<\mathrm{ch}>($ cholera $)$ and $<\mathrm{ct}>($ charactcre), $<\mathrm{y}>$ (çєphyro) as well as mute $<\mathrm{h}>$ (prøhibiziøne, hønळrevøli).

In a later printed edition of Trissino's works (see figure 18) the reformed orthography was forgone. In the Italian printing milieu of the Cinquecento, Aldus Manutius generally prevailed as the model with regard to spelling and punctuation. A major part of the books printed from now on appeared in the in-octavo format and in italics. 
Table 3. Phonographemic markings of Trissino's experimental spelling system

\begin{tabular}{cc}
\hline graphemes & phonemes \\
\hline$<\varepsilon>$ & $/ \mathrm{e} /$ in some texts also $/ \varepsilon /$ \\
$<\mathrm{e}>$ & $/ \varepsilon /$ in some texts also $/ \mathrm{e} /$ \\
$<\omega>$ & $/ \mathrm{o} /$ in some texts also $/ \mathrm{o} /$ \\
$<\mathrm{O}>$ & $/ \mathrm{J} /$ in some texts also $/ \mathrm{o} /$ \\
$<\mathrm{u}>$ & $/ \mathrm{u} /$ \\
$<\mathrm{v}>$ & $/ \mathrm{v} /$ \\
$<\mathrm{z}>$ & $/ \mathrm{ts} /$ \\
$<\mathrm{c}>$ & $/ \mathrm{dz} /$ \\
\hline
\end{tabular}

In the 1562 edition of Sofonisba, the reformed spelling of the author no longer appeared. Some etymological elements of the first edition were also removed. Thus, $<\mathrm{ph}>$ was replaced by $<\mathrm{f}>$. Mute $<\mathrm{h}>$, however, was maintained in the Latin style (HAVENDO, huomini). The useful distinction between $/ \mathrm{u} /$ and $/ \mathrm{v} /$ was abandoned in favour of the $<\mathrm{u}>$ which was common at that time (deueßi), with the exception of the words capitalized whenever $<\mathrm{V}>$ was used (HAVENDO, Vostra). Double $s$ was expressed by $\langle\beta\rangle$ as well as by $<\Gamma>($ deueßi, grädiffima). The 1562 edition was also characterized by a consistent use of punctuation.

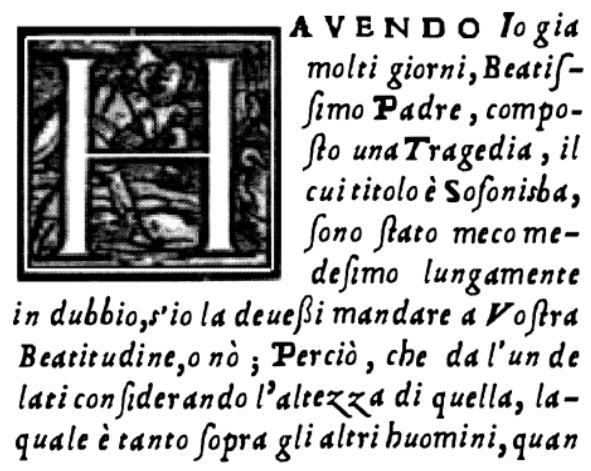

Figure 18. Extract from the edition of Sofonisba from $1562^{25}$ 


\subsection{Theoretical discussion about orthographical problems}

After Aldus Manutius had set standards with his edition of Tuscan classics as well as contemporary authors such as Pietro Bembo, leading to a certain standardization of the Italian language, theoretical discussion was to gain importance in the course of the Cinquecento. In 1547, Claudio Tolomei (1492-1555) argued about questions of spelling in his work De le lettere ... Con vna breue dichiarazione in fine di tutto l'ordin de l'ortografia di questa opera. Also, in the case of the editions of the chief works of the Trecento, major importance was attached to orthographical correctness: this was the case, for instance, in Il Petrarca nuouamente con la perfetta ortografia della lingua volgare, corretto da Girolamo Ruscelli (1554). For Francesco Sansovino, who published a work with the title Ortografia delle voci della lingua nostra o vero Dittionario volgare et latino nel quale s'impara a scriuer correttamente ogni parola così in prosa come in uerso, per fuggir le rime false \& gli errori in 1568, the dominance of correct orthography played a key role in connection with poetry, as it is emphasized in the preface:

Non però dico che l'ortografia fia come il legame rifpetto alle uefti, percioche ella importa molto. Et fra l'altre cofe ella è affai neceffaria a Verfificatori, attento che douendosi legare i uerfi con le rime, come potrà guardarfi dalle rime falle colui che non harà cognitione dell' Ortografia? come potrà concordar bello con fello, folo con duolo, fanno con fanno, chi non ha cognitione dell' Ortografia? ${ }^{26}$

[But I am not saying that orthography is like a tie in relation to pieces of clothing, because it is very important. And, among other things, it is very necessary for poets, since they must link together verses and rhymes. And how can anyone who has no knowledge of Orthography beware of making false rhymes? How could they match together bello and fello, solo and duolo, fanno and sanno if they had no knowledge of Orthography?]

Sansovino shows an interest in controversial points of Italian grammar:

Habbiamo adunque dato fuori quefta Ortografia fotto ordine di Dittionario per uoftro comun benefitio. Et perche in materia dell'Ortografia l'opinioni fono infinite, attento che alcuni non uogliono che la $\mathrm{H}$ fi accetti, altri fono ftati nemici della $Z$ et della $X$ \& altri hanno trouate altre lettere nuoue, come o chiufi o aperti fecondo ch'è caduto nella mente a ciafcuno, onde fi ueggono i libri imprefli ne tempi noftri tanto uariati nell'Ortografia, quanti fono ftati i correttori di detti libri... ${ }^{27}$ 
[We have therefore given out this Orthography in dictionary (i.e., alphabetical) order, for the convenience of all of you. And because, as far as (the matter of) orthography is concerned, there is an infinity of different opinions, given that some do not want the $\mathrm{H}$ to be accepted, and others have been enemies of the $\mathrm{Z}$ and of the $\mathrm{X}$, and yet others have invented new letters (such as closed and open $o$ ), according to whatever fancy takes them: this has meant that we can see as many variations in the Orthography of the books printed in our times as there are correctors of the said books.]

and advocates a rather conservative orthographical practice, which is to be based on the classics:

...ho uoluto attenermi all'ufo comune non de gli innouatori uaghi di gloria per quefto uerfo, ma de buoni fcrittori i quali riuolgendo le carte de gli antichi fcientiati, hanno con fermo \& faldo giuditio regolato di modo la Ortografia, che effendone fommamente lodati, fono anco ftati feguiti da i fucceffori come perfone d'autorità nelle lettere, $\&$ come intendenti molto piu che non fono gli innouatori, iquali infieme con le loro inuentioni fi fono rimafti foli nelle loro opinioni. Et accioche coloro che leggono non fieno punto ingannati o dubbiofi del modo nelquale efli hanno a fcriuere alcuna parola perauentura trouata da loro \& nel Petr. \& nel Boccaccio diuerfamente pofta nell'Ortografia... ${ }^{28}$

[... I have wished to conform to common usage: not to the use of certain innovators who are trying to find glory in this way, but to that of good writers who, turning the pages of the old scholars, have with firm and sound judgement regulated the way of spelling, who are to be most highly praised for that, and who moreover, have been followed by their successors as men of authority in the field of letters, and as experts, unlike the innovators, whose opinions have not be shared any more than their innovations. And so that those who read should not be led astray or have any doubts as to the way in which they should write any word that they might perchance find in their works, and any word they might find in the works of Petrarch and of Boccaccio, differently set down in the Orthography ...]

The question of correct writing also gained in importance in Chancery. In 1608 Benedetto Pucci published a work with the title L'idea di varie lettere vsate nella secretaria d'ogni principe, e signore con diuersi principii concetti, e fini di lettere missiue pronti da seruirsene à luogo, e tempo. Aggiontoui una breue, e facile regola dell'ortografia nella lingua volgare, with sample letters, which contain an appendix concerned with problems of spelling. 
In 1670 Daniello Bartoli (1608-1685) published the very successful treatise Dell'ortografia italiana, which was republished in 1684 and again in 1690 .

\subsection{The orthographical model of the Accademia della Crusca}

The Florentine poet Leonardo Salviati (1540-1589), a follower of the linguistic model of Pietro Bembo, played a significant role in the transformation of the Accademia della Crusca (founded in 1582) from a literary salon into an instance for linguistic standardization throughout the whole of Italy. He was not only the driving force, until his death, in the creation of the Vocabolario degli Accademici della Crusca, the first edition of which was printed in Venice in 1612, but also one of the most important linguistic theorists of his time. In the year of the foundation of the Crusca, he published a revised edition of Boccaccio's Decamerone and set out his linguistic approach in the Avvertimenti della lingua sopra 'l Decameron. Already in 1564 the treatise Orazione in lode della fiorentina lingua had appeared, the aim of which was to demonstrate the dominance of the Florentine dialect over all other Italian vernacular varieties. Salviati tried to bring into line the differences between spoken and written language.

The preface of the first edition of the Vocabolario (1612) refers to the orthographical model of Salviati: "Nell'ortografia abbiam feguitato quafi del tutto quella del fopraddetto Salviati, parendoci di prefente non ci avere, chi n'abbia più fondatamente difcorfo." In total, there are only a few theoretical annotations on the spelling system used in the vocabulary. On the one hand, the major conformity with the Latin language is referred to; on the other hand, the broad conformity between sounds and characters is also stressed:

Delle lettere, o vero elementi di questa lingua, non s'è fatto discorso particolare, se non per quanto si può così rozzamente darne un poco di regola nel pronunziargli all'usanza nostra, stimando noi, che dove eglino sono gli stessi, che que' de' latini, sarebbe stata cosa superflua. E perchè i suoni della nostra pronunzia sono di maggior numero, che i caratteri, pareva che fosse più lungo trattato a ciò necessario, che non comporta l'ordine del nostro libro. $^{29}$

[Of the letters, or elements of this language, no particular explanation has been given: only, as far as possible, some rough and short guidelines as to how we usually pronounce them, considering that when they are the same as in Latin, it would have been superfluous. And because the sounds in our 
pronunciation are more numerous than the characters, it seemed that dealing with them would have taken longer than necessary, and would not have been compatible with the order observed in our book.]

For a general presentation, the reader is referred to Salviati's Avvertimenti (1584-1586). The spelling of the first edition of the Vocabolario presents a compromise between phonological and etymological notations. Thus, the Latinate $<\mathrm{h}>$ is only used when phonetic misunderstandings are to be avoided:

\section{$\mathrm{H}$}

Non. Ha, appo i Tofcani, fuono veruno particolare, ma fe ne fervono, per difetto di caratteri, ponendola dopo 'l C, e G, quando, accoppiati, con l'E, ed I, voglion pronunziarle, con lo steflo suono, ch' elle fi pronunzierebbono aggiunte all' A, O, U, come CHETO, CHINO, GHERONE, e GHIRO. Ha fervito quefto carattere, per tor via qualche equivoco, come, per diftinguere HANNO verbo da ANNO nome, ed HA, HAI, ed HO verbi, da AI, articolo, affiffo al fegno del terzo cafo, ed A prepolizione. Potrebbefi acconciamente porre avanti al dittongo UO in principio di parola, per moftrare, che quello $\mathrm{U}$ fia vocale, e non confonante, mentrechè di quefti due $\mathrm{U}$ non abbiam diftinti caratteri, come nelle voci HUOMO HUOPO, HUOVA, acciò non fi pronunzi con l'u confonante, UOMO, UOPO. Potrebbe aver qualche luogo, per fegno d'afpirazione, come. deh dimmi: quafi pregando, a differenza di, de spedifcila, quafi bravando, ma perchè i Tofcani afpirano tutti i monofillabi, poco ci fa utile in cotal cafo. ${ }^{30}$

$[\mathrm{H}$. Among the Tuscans, it does not have any particular sound, but they use it, for a lack of characters, after $\mathrm{C}$ and $\mathrm{G}$, when they want to pronounce these letters before $\mathrm{E}$ and I with the same sound as if they were placed before A, O and $\mathrm{U}$ : as in CHETO, CHINO, GHERONE and GHIRO. And this character has been used to avoid misunderstandings, for example, in order to distinguish the verb HANNO from the noun ANNO, and the verbs HA, HAI and HO from the article AI, affixed as the indicator of the third case (i.e., the dative) and the preposition A. It can also be used properly at the beginning of a word, in front of the diphthong UO, to show that the U here is a vowel and not a consonant, since we do not have different characters for these two different sorts of U. For example, in the words HUOMO, HUOPO, HUOVA, so that they are not pronounced with the consonant U (i.e., $\mathrm{V})$, as UOMO, UOPO. It might have some use as a mark of aspiration, as in deh dimmi, almost sighing, which is different from de pronounced more brusquely and almost boldly: but since the Tuscans give an aspiration to all monosyllables, it would surely be of little use in such cases.] 
Of interest is the usage of $<\mathrm{h}>$ for the phonological distinction of $/ \mathrm{u} /$ and $/ \mathrm{v} /$, which are both represented by $<\mathrm{u}>$ (" $U$ Lettera vocale, e tal'or lettera confonante"). Thus, under the entry uomo $(<$ Lat. HOMO) there is a reference to an etymologically reasonable huomo, while in the case of the etymologically unjustified forms huovo ( $<$ Lat. OVUM) and huopo $(<$ Lat. OPUS) there is a reference to the entries uovo and uopo.

The Greek-Latin digraphs $<\mathrm{ph}>$ and $<$ th $>$ are phonologically expressed respectively by $<\mathrm{f}>$ and by $<\mathrm{t}>$ (filofofia, teatro):

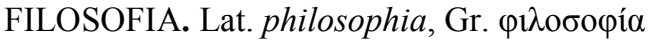

Tes. Br. 1. 2. Filofofia è verace cognofcimento delle cofe naturali, e delle divine, e delle umane, tanto quanto l'huomo è poffente d' intendere.

TEATRO. Edificio rotondo, dove fi rappresentano gli fpettacoli. Lat. theatrum, gr. $\theta \varepsilon \alpha \dot{\tau} \tau \rho{ }^{31}$

Nouns ending in -io present, in the plural form, the ending $-j(i l$ vizio $\rightarrow i$ vizj):

VIZIO. Abito elettivo, che confifte nel troppo, o nel poco, contrario di virtù. Lat. vitium. Paffav. 259. le virtù fono medicine de'vizj, i quali fono infermità dell'anima. Albert. capit. 46. I vizj confinan con le virtudi. E appreffo. Vuo' tu fchifare i vizj, fta da lunga dagli efempli de' vizj. ${ }^{32}$

Words whose Latin etyma end in -IO, -IONIS (ACTIO, -IONIS; ORATIO, -IONIS; NATIO, -IONIS), appear first with the phonological spelling -zione (azione, orazione, nazione), and not with the Latinate variant -tione, which also was common at this time.

AZIONE fatto, operazione. Lat. actio. Com. Inf. 12. Iflione viene interpretato operazione, o vero uficio di degnitade, o degnitade d'uficio, o d'azione. ${ }^{33}$

In the second edition of 1623 , the use of $<\mathrm{h}>$ is limited to fewer dictionary entries, among others the interjections hui and hoi as well as the nouns homiciatto, homiciuolo and huomo. In the case of uopo (VOPO), uosa (VOSA), uovo (VOVO), uovolo (VOVOLO), there is also a cross-reference to the entry under the variant without $<\mathrm{h}>$. The written signs $\langle\mathrm{v}>$ and $<\mathrm{u}>$ are, however, both used, but not for the representation of different phonemes. Their use is more dependent on the position within a word. Thus, $<_{\mathrm{v}}>$ only appears at the beginning of words, as well as in the case of capitalization, although it can represent $/ \mathrm{v} /$ as well as /u/ (TVTTO, virtuofamente, vniuerfal, 
Vocabolario, voce). The sign $<\mathrm{u}>$ only appears in medial and final position of a word (fauore, nouero, ageuolezza).

In the year of publication of the second edition of the Vocabolario, the Academy member Benedetto Buommattei (1581-1647) published the first edition of his grammar Delle cagioni della lingua toscana, in which orthographical problems are also discussed. In the fifth chapter (Che differenza sia tra la scrittura, e la voce), Buommattei is lost in thought about the difference of spoken and written language. He declares himself to be explicitly in favour of an independent Italian orthography as far as the problem of the group $<$ th $>$ and the letter $<\mathrm{h}>$ are concerned, which is neither based on the Latin model nor on inconsistent texts supplied by the Trecento:

Non rifpondo già niente a quelli, che adducono i puri capricci degli Stampatori; i quali, o per effer di quefta Lingua ignoranti, o pure perchè ne' principj delle ftampe erano più della Latina ftudiofi, cominciarono a ftampare non coll'Ortografia Tofcana per ancora non ferma nè ftabilita, ma con la Latina, della quale più certe regole e in particular dell'Ortografia fi trovava.

Gli altri, o feguitando gli antichi a chius'occhi hanno attefo a fcriver come loro, credendo che fare altrimente folfe male; o conofcendo la verità non hanno ardito innovar cofa alcuna, afpettando forfe che altri fi pigliafle tal briga: Benchè d'ogni tempo fieno ftati uomini e Tofcani, e non Tofcani, che nella Tofcana Lingua fcrivendo hanno fcritto fenz'H e fe ne può vedere più d'un Decamerone ftampati non modernamente in Venezia. ${ }^{34}$

Non farà dunque male chi fcriverà : AVERE, ABITO, EREDE, EROE, IERI, ISTORIA, OMICIDIO, ORA, ORTO, ONORE, OSTIA, UMANO, UMILE, e altri fî fatti. Errerebbe bene chi fcriveffe CHARTA, CHORO, GHOVERNO, SEPOLCHRO e fimili.

Non mi fi dica: ella fi dee mettere in alcune voci; perchè ve l'hanno mefla i Latini; perchè i Latini avevano diverfa pronunzia, come pure s'è moftrato, e la noftra fi regge con le regole proprie, e non con quelle della Latina.

Nè meno s'ammetta a chi voleffe addurre in contrario l'autorità del Boccaccio, del Petrarca e dello fteflo Dante; perchè a noi non fon pervenute fcritture in quefto cafo di tanta pruova; che poffano fare a coftoro molto giuoco... ${ }^{35}$

[I will reply nothing to those that were introduced by the simple caprices of the Printers, who, either because they knew nothing of this language, or because, when printing began, they were better versed in the Latin language and began to print not in the Tuscan orthography (which was not yet fixed or stable) but in the Latin orthography, in which more certain rules could be found, especially concerning spelling. 
The others - either because they followed the Ancients blindly and managed to write as they (i.e., the Ancients) did, believing that it was wrong to write any differently - or, although they knew the truth, they did not have the courage to innovate in any way, and waited for someone else to come and do the job. However, at all times there have been Tuscans as well as non-Tuscans who have written in Tuscan without using the $\mathrm{H}$, and one can see more than one Decamerone printed in Venice, and not in the modern way.

Therefore anyone who writes AVERE, ABITO, EREDE, EROE, IERI, ISTORIA, OMICIDIO, ORA, ORTO, ONORE, OSTIA, UMANO, UMILE and others formed in the same way, is not making any mistake. And it would be quite wrong to write CHARTA, CHORO, GHOVERNO, SEPOLCHRO and so on.

And do not tell me that it should be put in some words because the Latins did, because the Latins had a different pronunciation, as indeed has been shown, and our (pronunciation) is governed by its own rules, and not by those of Latin.

Nor will I accept it from anyone who, as a counter-argument, wants to evoke the authority of Boccaccio, Petrarch or of Dante himself, because no writings have come down to us which could serve as proof in this case: so people can play around with them...]

Buommattei campaigned to the same extent for the Italian spelling -zione instead of the Latinate variant -tione:

RIdono molti, e dopo il rifo fi fdegnano; qualora trovano fcritto ORAZIONE, FAZIONE, e altre fimili parole con $Z$, e lo gridano per grand'errore, per enorme peccato, per preflo ch'io non difli, e vogliono foftenere con grand'impeto, ch'elle s'abbiano a fcriver con T. Veggiamo s'egli aveffero a forte ragione alcuna.

Le ragioni, che da loro s'adducono, fon quefte: Che elle furono fcritte da' Latini col T.; Che vna fola Z fuona rimefla, e non gagliarda; e che gli antichi Tofcani tutti hanno fcritto col $\mathrm{T}$; però non doverfi feguitar l'opinioni nuove di perfone particolari di Tofcana: allargandofi poi bene fpeflo; e profferendo parole affai più rifolute, che la modeftia loro non gli doverebbe concedere, e che affai di loro non direbbono, fe la'nvidia, od altro fimile affetto non gli facefle prevaricare; effendo per altro molti di quefti uomini accoltumati, e difcreti.

Condonandofi adunque loro quel, che contro alla noftra Nazione in materia di Lingua fa dir loro il proprio intereffe, voglio provare, s'io poffo rilevare da tanta accufa coloro, che fcrivon ORAZIONE con $Z$, e non con T., che per confeguenza verrò anche a difendere con tutti gli altri me fteflo, fcrivendo anch'io ORAZIONE con la $\mathrm{Z}^{36}$ 
[Many laugh, and after laughing, show their contempt, when they see orazione, fazione and other such words written with $Z$, and they cry out that it is a huge mistake, an enormous sin and vehemently claim that they should be written with $T$. Let us see whether they are right in any way:

The reasons that are given by them are the following: that they were written with a $T$ by the Latins; that a single $Z$ sounds weakly and not vigorously; and that all the ancient Tuscans wrote with a $T$; that the modern opinions of isolated individuals from Tuscany, which are spreading in quite a number of cases, should not be followed. And they utter words which are considerably bolder than their modesty should allow them to utter, and which quite many of them would not utter were it not that envy or other similar emotions made them overstep the limits, since many of these men are otherwise orderly and reserved people.

Thus, excusing those who, in going against our Nation in the matter of Language, let their own interest speak, I would like to show that, if I can release them from such a great accusation that they write ORAZIONE with $\mathrm{Z}$ and not with T, I consequently will, together with all the others, defend myself, as I also write ORAZIONE with the Z.]

The irreversible break between the Latin tradition and phonological writing came more than 120 years after Bembo and Aldus's editions of Dante and Petrarch. The remains of etymological spelling emerge in occurrences of Huomini (as, for instance, in the Vocabolario degli Accademici della Crusca). On the other hand, Buommattei progresses beyond the dictionary in some cases of the Italianization of spelling (anno scritto instead of hanno scritto).

\section{Conclusion}

The standard Italian language dates back to the codified Florentine literary language of the Trecento. On the one hand, the prestige of these vernacular works penned by the great poets Dante, Petrarch and Boccaccio contributed to this; on the other hand, the economic and cultural expansion of the metropolis on the Arno did so as well. In the medieval scripts of Tuscany, a widely autonomous spelling system prevailed, which was more consistent than those in many other regions of Italy. The assimilations of the Latin consonant groups which occurred in the Italo-Romance sound system were generally expressed in the spelling system of the Tuscan dialects (MN $>$ $<\mathrm{nn}>$, CS $><\mathrm{SS}>$, CT $><\mathrm{tt}>$, PT $><\mathrm{tt}>$ ). This also applies to the same extent to the change of $\mathrm{PL}><\mathrm{pi}>$ and $\mathrm{FL}><\mathrm{fi}>$. The character $<\mathrm{k}>$, still widely 
used during the Duecento, had been abandoned before $<\mathrm{e}>$ and $<\mathrm{i}>$ in favour of $<$ ch $>$ since the 14 th century. The written sign $<c$ c $>$ used in medieval texts was dismissed in favour of $<\mathrm{z}>$. Greek-Latin consonant digraphs such as $\langle$ th $>,\langle$ ph $>$, and $\langle$ rh $>$ were simplified to $\langle\mathrm{t}\rangle,\langle\mathrm{f}\rangle$, and $\langle\mathrm{r}\rangle$. Especially strong graphemic and lexical Latinizing tendencies existed in the Quattrocento during the movement of so-called "Latin humanism" (umanesimo latino) up to the Cinquecento when again a continuous and consistent abolition of the Latin orthography was carried out. The principle of a phonological orthography finally prevailed against the etymological principle. Accents, apostrophes, and punctuation became established with the increasing importance of the letterpress as a general standard. Certain sound developments of the Tuscan dialects, however, were not included in the orthographical system of the Italian language. Thus, the gorgia toscana $([\mathrm{k}]>[\mathrm{h}])$ is covered by the etymological notation by $<\mathrm{c}>$ (Lat. ILLAM CASAM $>$ Tusc. [la'hasa] $<$ la casa $>$ vs. It. [la'kasa]. The same applies to the change $[\mathrm{t}]]>\left[\int\right]$, whereas the fricative modelled after the Latin etymology was expressed by a traditional $<\mathrm{c}>$ and not by the group $<$ sc $>$ (Lat. CENAM $>$ Tusc. ['fena] $<$ cena $>$ vs. It. ['tfena]). The efforts of Trissino to differentiate the open and closed vowels of the Italian language by means of Greek characters could not be established. The far less provocative suggestion to express the phonemes $/ \mathrm{u} /$ and $/ \mathrm{v} /$ by the corresponding characters only prevailed at the end of the 17 th century.

Decisive influence on the development of modern Italian spelling was made by Aldus Manutius and Pietro Bembo at the beginning of the Cinquecento, as well as by the Accademia della Crusca after the beginning of the Seicento, which paved the way for an institutional framework on a panItalian level.

\section{Notes}

1. Source: Alberti (1996: XXXIII).

2. Cf. also Marazzini (1993: 33-36) and Richardson (1999).

3. Source: Enciclopedia Italiana di scienze, lettere ed arti., vol. XXXIII, Rome 1937: following p. 896.

4. Source: http://catalogue.bnf.fr/ark:/12148/bpt6k72589v, p. 1.

5. Source: http://www.psymon.com/incunabula/masterpieces/manutius.html.

6. Source: http://www.italnet.nd.edu/Dante/images/tp1497/1497.inf1.txt.150dpi.jpeg and http://www.italnet.nd.edu/Dante/images/tp1502/1502.inf1. 150dpi.jpeg.

7. Source: http://gallica.bnf.fr/ark:/12148/bpt6k58952n, p. 1. 
8. Source: http://gallica.bnf.fr/ark:/12148/bpt6k59244b, p. 3.

9. Source: http://gallica.bnf.fr/ark:/12148/bpt6k85887x, p. 3.

10. Source: facsimile http://books.google.com, p. xx.

11. Source: http://catalogue.bnf.fr/ark:/12148/bpt6k72589v, p. 1.

12. Source: http://aleph.library.uu.nl/F?func=direct\&doc_number $=000977068$, p. 211.

13. Source: http://gallica.bnf.fr/ark:/12148/bpt6k85887x, p. 3.

14. Source: facsimile http://books.google.com, p. xx.

15. Source: http://gallica.bnf.fr/ark:/12148/bpt6k58952n, p. 8.

16. In this text we find also glihaue $\int e$, Ilquale, glialtri etc.

17. dalto $=$ d'alto $(<$ di alto $)$.

18. oltre gli ornamenti.

19. dogni $=$ d'ogni $(<$ di ogni $)$.

20. Pozzi (1988: 106-107).

21. Pozzi (1988: 108-109).

22. Firenzuola's treatise is also a spelling history which contains many references to Greek and Latin (cf. Firenzuola 1977: 53-72).

23. Cf. Gazzola (2006), http://www.bibliotecabertoliana.it/biblionauta/2006/06_12_2006.pdf

24. Source: facsimile http://books.google.com.

25. Source: bncf.firenze.sbn.it:21:FI0098:Magliabechi:TO0E013707.

26. Sansovino, Francesco (1568): Orthographia delle voci della lingua nostra. Venice, 4r-4v. Source: http://www.cinquecentine-crusca.org/scheda2.asp? radice $=000029576 \_1 \&$ seq $=5 \&$ file_seq $=18$ and 19 .

27. Sansovino, Francesco (1568): Orthographia delle voci della lingua nostra. Venice, 4v. Source: http://www.cinquecentine-crusca.org/scheda2.asp?radice $=000029576 \_1 \&$ seq $=5 \&$ file_seq $=19$.

28. Sansovino, Francesco (1568): Orthographia delle voci della lingua nostra. Venice, 4v. Source: http://www.cinquecentine-crusca.org/scheda2.asp?radice= $000029576 \_1 \&$ seq $=5 \&$ file_seq $=19$.

29. Vocabolario dell' Accademia della Crusca (1612), Venice, Introducione. Source: vocabolario.signum.sns.it/_s_index 2.html.

30. Cf. http://vocabolario.signum.sns.it

31. Cf. http://vocabolario.signum.sns.it.

32. Cf. http://vocabolario.signum.sns.it.

33. Cf. http://vocabolario.signum.sns.it.

34. Text following the edition of Della lingua Toscana (1760: 23-24).

35. Text following the edition of Della lingua Toscana (1760: 23).

36. Text following the edition of Della lingua Toscana (1760: 38-39). 


\section{References}

\section{Primary sources}

Only a limited number of Italian 15th-century incunables are consultable in digital form, e.g., from the Gallica website of the Bibliothèque Nationale de France (www.gallica.bnf.fr) or from the Bavarian State Library (http://www.bsbmuenchen.de). Many 16th-century and 17th-century editions, however, can be consulted from the Biblioteca digitale of the Accademia della Crusca (http://www.accademiadellacrusca.it/Biblioteca_Digitale.shtml), from the website Le Cinquecentine della Crusca (http://www.cinquecentine-crusca.org), from the Bavarian State Library - just mentioned above - and also from Google Books (http://books.google.de/advanced_book_search?hl=de.

Accademia della Crusca

1612 Vocabolario degli Accademici della Crusca ... In Venezia apresso Giouanni Alberti. http://vocabolario.signum.sns.it/

Accademia della Crusca

1623 Vocabolario degli Accademici della Crusca, in questa Seconda Impressione da' medesimi Riveduto, e Ampliato, con Aggiunta di Molte Veci Autor del Buon Secolo, e Buona Quantità di quelle dell'Vso. Venice: J. Sarzina.

Alberti, Leon Battista

1996 Grammatichetta e Altri Scritti sul Volgare, a cura di Giuseppe Patota. Rome.

Alighieri, Dante

1472 La Commedia. Foligno: Johannes Numeister \& Evangelista Angelini.

Alighieri, Dante

1477 La Commedia. Impresso ne la magnifica cipta di Napoli: cū ogni diligentia \& fede. Sotto lo inuictissimo Re Ferdinando inclito Re de Sicilia. \&ct. Adi XII. dil mese di Aprile, M.CCCC.LXXVII.

Alighieri, Dante

1490 Convivio di Dante. Florence: F. Bonaccorsi. (Bibliothèque nationale de France: http://catalogue.bnf.fr/ark:/12148/bpt6k72589v)

Alighieri, Dante

1497 Dante Alighieri Fiorentino: Comento di Christoforo Landino Fiorentino sopra la Commedia di Dante Alighieri Poeta Fiorentinol emendata diligentemente per ... Piero da Figino, ... Venice: per Piero de Zuanne di Quarengii da palazzo bergamasco. (Selected pages of the copy of the Newberry Library:

http://www.italnet.nd.edu/Dante/text/ 1472.foligno.html) 
Alighieri, Dante

1502 Le Terze Rime di Dante. Lo 'nferno, e 'l Purgatorio e 'l Paradiso di Dante Alighieri. Venetiis in aedib. Aldi. accuratissime. men. avg. M.D.II.

Bartoli, Daniello

1670 Dell'Ortografia Italiana Trattato del P. D. B. In Roma: a spese d'Ignatio de Lazari.

Bartoli, Daniello

1684 Dell'Ortografia Italiana Trattato del P. D. B. Venice: presso Paolo Baglioni.

Bartoli, Daniello

1690 Dell'ortografia Italiana trattato del P. D. B. In Venetia: per Sebastiano Menegati.

Bembo, Pietro

1505 Gli Asolani di Messer Pietro Bembo. Venice: Aldo Romano.

Bembo, Pietro

1525 Prose di. M. Pietro Bembo nelle quali si Ragiona della Volgar Lingua Scritte al Cardinale de Medici che poi e Stato Creato a Sommo Pontefice et Detto Papa Clemente Settimo Diuise in Tre Libri, nel Mese di Settembre del 1525. Vinegia: Giouan Tacuino.

Boccaccio, Giovanni

1478 Il Filocolo. Add: Hieronymus Squarzaficus: Vita di Boccaccio. Imprint: Naples: Sixtus Riessinger, for Francesco del Tuppo, 8 Mar. 1478 .

Boccaccio, Giovanni

1582 Il Decameron di Messer Giouanni Boccacci Cittadin Fiorentino, di Nuouo Ristampato, e Riscontrato in Firenze con Testi Antichi, \& alla sua Vera Lezione Ridotto dal Caualier Lionardo Salviati. Seconda editione. In Firenze: nella stamperia de' Giunti, del mese d'ottobre 1582, del mese di nouembre 1582 .

Buommattei, Benedetto

1623 Delle Cagioni della Lingua Toscana di Benedetto Buommattei Libro Primo. In Venezia: appresso Alessandro Polo.

Buommattei, Benedetto

1760 Della Lingua Toscana. Impressione quinta; rivista e corretta dagli Accademici della Crusca. Firenze: Nella Stamperia imperiale. (Open

Cicero, M. Tullius library: OL13510614M)

1465 De Oratore. Subiaco: Conrad Sweynheim \& Arnold Pannartz.

Cicero, M. Tullius

1467 Epistolae ad Familiares. Subiaco: C. Sweynheim \& A. Pannartz.

Colonna, Francesco

1499 Hypnerotomachia Poliphili. Venice: Aldus Manutius. (http://mitpress.mit.edu/e-books/HP/hyp000.htm) 
Firenzuola, Agnolo

1524 Discacciamento de le Nuove Lettere Inutilmente Aggiunte ne la Lingua Toscana. Stampata in Roma: per Lodouico Vincentino et Lautitio Perugino, 1524 di decembre.

Gelli, Giambattista

1549 Il Gello. Sopra un Sonetto di M. Franc. Petrarca. Florence.

Martelli, Ludovico

1524 Risposta alla Epistola del Trissino delle Lettere Nuovamente Meigret, Louis Aggionte alla Lingua Volgar Fiorentina. Florence.

1550 Le Tretté de la Grammére Françoéze. Paris: Chr. Wechel.

Peletier, Jacques

1550 Dialogue de l'Ortografe e Prononciation Françoęse, Departi an Deus Livres / par Jacques Peletier du Mans. Poitiers: J. and E. de Marnef.

Petrarca, Francesco

1470 Sonetti e canzoni. Venice: Vindelino da Spira.

Petrarca, Francesco

1501 Le Cose Volgari di Messer Francesco Petrarcha. Venice: Aldus Manutius.

Petrarca, Francesco

1554 cf. Ruscelli, Girolamo

Pucci, Benedetto

1608 L'Idea di Varie Lettere Vsate nella Secretaria d'Ogni Principe, e Signore con Diuersi Principii Concetti, e Fini di Lettere Missiue Pronti da Seruirsene à Luogo, e Tempo. Aggiontoui una Breue, e Facile Regola dell'Ortografia nella Lingua Volgare. ... Di don Benedetto Pucci monaco camaldolese, in Venetia: appresso Bernardo

Pulci, Luigi Giunti, \& Gio. Battista Ciotti, \& compagni.

1481/82 Il Morgante. Venice: Lucas Dominici F., 26 Feb. 1481/82.

Ruscelli, Girolamo

1554 Il Petrarca Nuouamente con la Perfetta Ortografia della Lingua Volgare, corretto da Girolamo Ruscelli. Con alcune annotazioni, \& un pieno vocabolario del medesimo ... con vno vtilissimo rimario di m. Lanfranco Parmegiano, \& un raccolto di tutti gli epiteti usati dall'autore, in Venetia: per Plinio Pietrasanta.

Salviati, Lionardo

1564 Orazione di Lionardo Saluiati nella quale si Dimostra la Fiorentina Fauella, \& $i$ Fiorentini Autori Essere a Tutte l'Altre Lingue, cosi Antiche, come Moderne, e a Tutti gli Altri Scrittori di Qualsivoglia Lingua di Gran Lunga Superiori. In Firenze: apresso i Giunti.

Salviati, Lionardo

1584-86 Avvertimenti della lingua sopra 'l Decameron 1584-86 Venice. urn:nbn:de:bvb:12-bsb10164155-1 
Sansovino, Francesco

1562 Le Osservationi della Lingua Volgare di Diversi Huomini Illustri: cioe del Bembo, del Gabrielo, del Fortunio, del Corso, dell'Acarisio, et di Altri Scrittori... / in Venetia: appresso Francesco Sansouino.

Sansovino, Francesco

1568 Ortografia delle Voci della Lingua nostra o vero Dittionario Volgare et Latino nel quale s'Impara a Scriuer Correttamente Ogni Parola cosi in Prosa come in Verso, per Fuggir le Rime False \& gli Errori 1 In Venetia: appresso F. Sansouino.

Tolomei, Claudio

1547 De le Lettere di M. Claudio Tolomei Lib. Sette. Con vna Breue Dichiarazione in Fine di tutto l'Ordin de l'Ortografia di questa Opera, in Vinegia: appresso Gabriel Giolito de Ferrari.

Trissino, Giangiorgio

1524 Epistola de le Lettere Nuwvamente Aggiunte ne la Lingua Italiana. Rome: Ludovico degli Arrighi \& Lautizio Perugino.

Trissino, Giangiorgio

1529? Alfabeto Italiano di Gian Giorgio Trissino Seguito dal Padre Nostro, dall'Ave Maria e da Quattro Righe di Versi, Tutti in Italiano. Marca (V547) di Tolomeo Gianicolo, Vicenza, tra le due preghiere stampate a colonne. Data probabile di stampa, 1529, basata su elementi storico-tipografici. Altro tit.: Alfabeto Italiano col Padre Nostro e Ave Maria Tradotti in Versi. (Biblioteca Civica Bertoliana, Vicenza).

(http://opac.zetesisnet.it/Zetesis/document.aspx?TRG=MD\&SRT=Y

$\mathrm{AT} \& \mathrm{SID}=137649 \& \mathrm{FWD}=1 \& \mathrm{ORD}=7 \& \mathrm{PGO}=0$ )

Trissino, Giangiorgio

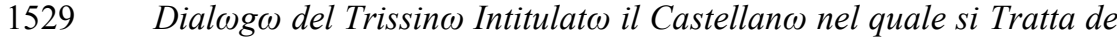
la Lingua Italiana. Vicenza: Tolomeo Ianicolo. (Reprint in Pozzi 1988: 119-176).

Trissino, Giangiorgio

1529 Dubbi Grammaticali. Vicenza: Tolomeo Janicolo.

Trissino, Giangiorgio

1529 spistola de le Lettere Nuwvamente Aggiunte. Vicenza: T. Ianiculo. (Reprint in Pozzi 1988: 105-116.)

Trissino, Giangiorgio

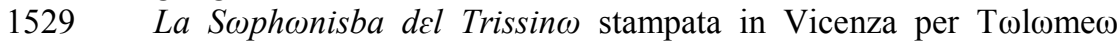

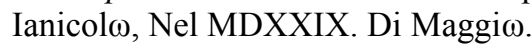

Trissino, Giangiorgio

1562 La Sofonisba Tragedia di M. Giouan Giorgio Trissino di Nuouo con Somma Diligenza Corretta e Ristampata in Venetia: appresso Francesco Rampazetto. 


\section{Secondary sources}

Casapullo, Rosa

1999 Storia della Lingua Italiana. Il Medioevo. Bologna.

Castellani, Arrigo

1982 La Prosa Italiana delle Origini. Bologna.

Dürscheid, Christa

2006 Einführung in die Schriftlinguistik. 3. Auflage. Göttingen.

Enciclopedia Italiana di Scienze, Lettere ed Arti

1937 vol. XXXIII, Rome.

Firenzuola, Agnolo

1977 Opere di Agnolo Firenzuola, a cura di Delmo Maestri. Turin.

Gazzola, Mattea

2006 L'8 dicembre moriva Giangiorgio Trissino. Il testamento autografo e gli 'scandali' linguistici. In Il Biblionauta. Esplorazioni con la Biblioteca Bertoliana. (http://www.bibliotecabertoliana.it/biblionauta/ 2006/06_12_2006.pdf)

Maraschio, Nicoletta

1993 Grafia e ortografia: evoluzione e codificazione. In: Storia della Lingua Italiana, a cura di Luca Serianni e Pietro Trifone. Volume primo. I Luoghi della Codificazione. Turin, 139-227.

Marazzini, Claudio

1993 Storia della Lingua Italiana. Il Secondo Cinquecento e Il Seicento. Bologna.

Pozzi, Mario

1988 Discussioni Linguistiche del Cinquecento. Turin.

Richardson, Brian

1999 Printing, Writers and Readers in Renaissance Italy. Cambrige:

Cambridge University Press.

Trovato, Paolo

1998 L'Ordine dei Tipografi. Lettori, Stampatori, Correttori tra Quattro e Cinquecento. Rome. 


\title{
French \\ French orthography in the 16th century
}

\author{
Susan Baddeley
}

\section{Introduction}

In France, as in many other European countries, the 16th century was a crucial period in the development of the written language. It was during this period that a number of features that still characterize modern French orthography were set in place: the distinction between $\langle\mathrm{u}>$ and $\langle\mathrm{v}\rangle,<\mathrm{i}>$ and $<\mathrm{j}>$ according to their pronunciation (rather than according to their position in the word), as well as most of the accents and diacritic signs that are still with us today. Moreover, this century witnessed, for the first time, a fullscale debate among intellectuals as to the role of the written language in society, together with the first known attempts at establishing a truly phonetic orthography.

Before we go any further, it should be pointed out that, strictly speaking, there is no such thing as "16th century French orthography", if we are to take the term "orthography" in the sense of the word that is generally the most widely accepted today, at least in France: "Way of spelling a word that is considered to be the only correct form". As we shall see, orthography, during the whole period, was extremely variable (this variability depending on factors that will be described further on) and changeable: the types of spellings that we see towards the end of the period are quite different from those that we find right at the beginning. If we are, however, to consider the spellings of different words (the term "spelling" being much more neutral, and not implying any idea of a norm), we will see that various systems coexisted, and that variability and changeability were not necessarily synonymous with a complete lack of coherence or of rules, as has sometimes been suggested. 


\section{French orthography before the 16 th century}

The history of written French as we know it begins in 842, with the "Strasbourg Oaths". This text was produced in particular circumstances, which account for its nature. Two of the sons of Charlemagne, Louis the German and Charles the Bald, decided to form an alliance against their brother Lothair. However, the two brothers concluding the pact did not speak the same language: Louis was a German speaker, and Charles spoke the French vernacular known as Romance, which had already become sufficiently detached from Latin to form a spoken language in its own right. The text of the Oaths was therefore written in three languages: Latin, Old High German and Romance, and, according to Roger Wright (1982: 122-126), the Romance version was written in a way which would enable a German speaker with no knowledge of the French vernacular but who was familiar with written Latin, to pronounce the Oath in such a way that it would be intelligible to Charles and his followers. For pragmatic reasons, what counted in this situation was not that the text should survive in a written form, but that it should be pronounced orally before witnesses, who could understand it in this form.

The first French literary text that has come down to us is the Sequence of Saint Eulalia, which dates from around the year 880. In this text, Latin letters are used to represent the phonemes of vernacular speech; however, the system of correspondence used is not always consistent, and there is also some interference from Germanic habits (the scribe who wrote the manuscript of Eulalia also wrote the text in German which follows it). For example, the phoneme $/ \mathrm{k} /$ is transcribed variously as $<\mathrm{k}>$ (efkoltet, krift, $k o f e),<\mathrm{ch}>$ (chi, chief), $<\mathrm{qu}>$ (quelle, qued) and $<\mathrm{c}>$ before $<\mathrm{a}>,<_{\mathrm{o}}>$ and $<\mathrm{u}>$ (cofe, colpef). We may add to this list the conventional Latin abbreviation $x p$ f for Christ(us). These variants were not, however, used indifferently: <qu $>$ tended to be used in grammatical morphemes that descended directly from Latin and had retained a similar form in the vernacular, and the ecclesiastical abbreviation $x p \int$ could stand equally for the Latin word and for its vernacular equivalent. ${ }^{1}$ The grapheme $<\mathrm{ch}>$ (as in chief) allowed the scribe to note simultaneously the pronunciation of $/ \mathrm{k} /$ before $<\mathrm{i}>$, and to give a visual reminder of the etymology (Latin caput). These simple examples demonstrate that written French, from the very beginning, was a mixed system, in which the phonogrammic, etymological, morphogrammic and ideographical principles coexisted. ${ }^{2}$

Medieval French orthography would deserve a chapter of its own, which cannot be provided here. ${ }^{3}$ However, we would like once and for all to dispel 
the myth of a "phonetic" orthography of French that supposedly existed during the Middle Ages. ${ }^{4}$ French orthography has always been a mixed system, although the "mix" of its various components and principles (proportions of the phonological, morphological, historical and etymological principles) has varied from period to period and from place to place.

\section{Sources of 16th-century French orthography}

The type of orthography that we find in the earliest printed texts is a direct descendent from manuscript orthography. Just as the printed book, in its earliest years, borrowed numerous features that were already present in manuscript books, so also did the orthography used in these books borrow a great number of features from the orthography of manuscripts.

To present a rather simplified view, we can say that the manuscript writing of the late 15 th century had to conform to two imperatives, which might seem at first sight to be contradictory and irreconcilable: on the one hand, that of speed, and on the other hand, that of legibility. In order to cope with an ever-increasing demand for books and documents, professional scribes had to write as quickly as possible, without raising pen from paper. However, this led to the development of a particular type of cursive writing, l'écriture gothique, in which numerous letters $(<\mathrm{i}>,<\mathrm{m}>,<\mathrm{n}\rangle,\langle\mathrm{u}>)$ could be confused. We should also remember that, at this time, $<\mathrm{u}>$ and $<\mathrm{v}>$ were not distinguished according to their phonetic value, and nor were $<\mathrm{i}>$ and $<j>.^{5}$ This problem was remedied by inserting a number of mute letters, mostly consonants, which had several functions. First of all, these consonants were generally etymological (Latin), and they gave individual words a particular "physiognomy" which immediately reminded readers of the corresponding Latin words. ${ }^{6}$ A further point that should be mentioned is the fact that the system of abbreviations used in Latin and French was practically the same (the tilde used to replace a nasal consonant, $<^{9}>$ for $-u s,<\mathrm{q} ;>$ for que, the ampersand $<\&>$ for et - the form of the conjunction being identical in Latin and in French -, as well as the abbreviations for per, pro and so on). ${ }^{7}$ This was especially useful for members of the scholarly community, who had learned to read and write first of all in Latin, and for whom Latin was the main language for reading and writing. This allowed them to gain rapid access to the meaning of a text without necessarily having to oralize it, and even allowed non-French speakers to "read" texts in French without necessarily knowing how to speak the language. Finally, at this time, the spoken language was extremely variable, despite the more or 
less well-established existence of a "standard": the form of the language that was spoken at court and in Parisian administrative spheres. Having a written language that was not based on anyone's particular speech but was anchored in a prestigious language which could no longer change made everyone equal and removed any potential obstacles to understanding. Added to these mute etymological letters, pseudo-etymological letters such as $<\mathrm{y}>$, initial $<\mathrm{h}->$, and $<\mathrm{x}>$ also had a calligraphic and distinctive role. For example, a mute $<\mathrm{h}>$ before $<\mathrm{u}>$ informed the reader that the $<\mathrm{u}>$ in question was a vowel and not a consonant: the reader was thus able to distinguish between huitre 'an oyster' and vitre 'a pane of glass'.

Although the extent of this variation has often been greatly exaggerated, the use of many notations, such as $<\mathrm{i}>$ and $<\mathrm{y}>$, was left to the appreciation of the writer. In the latter case, $<y>$ tended to be used in word-final position (amy 'friend', plural amis), as it was more legible: this convention has been carried on into English orthography (cf. lady/ladies). $<\mathrm{Th}>,<\mathrm{ch}>,<\mathrm{ph}>$ and $<$ rh $>$ were widely used in words from Greek and Latin, although imperfect knowledge of etymology often led to the use of pseudo-learned spellings. ${ }^{9}$ The letter $<\mathrm{e}>$ stood for a variety of vowel phonemes, ${ }^{10}$ and vowel length was often noted by adding a mute $<\mathrm{s}>$ : this, however, caused potential problems of mis-reading, as there were also many words in which the $<$ s $>$ was pronounced in a pre-consonantal position. ${ }^{11}$ Finally, ${ }^{12}$ the palatal consonants $/ K /$ and $/ \tilde{\mathrm{n}} /$, unknown in Latin, both had a wide range of variant spellings. ${ }^{13}$

To sum up, we can say that, at this time, the French language had an extremely rich phonological system, ${ }^{14}$ and only the 23 letters of the traditional Roman alphabet ${ }^{15}$ to write it with. This led, inevitably, to a large number of ad hoc adaptations, consisting mainly of added letters (digraphs, mute letters), with all the ambiguity and sometimes obscurity that resulted.

\section{The impact of printing ${ }^{16}$}

This type of orthography was, naturally, carried over from the manuscript to the printing press. However, various factors led to the orthography of vernacular works becoming increasingly variable. First of all, there was at the time no accepted written standard, and indeed no way of imposing a written standard that could be approved and followed by all. ${ }^{17}$ Secondly, the various agents who intervened during the process of setting a text in print were unequally literate: unlike professional scribes and administrative clerks, the workers in printing houses very often had received little or no 
formal training, and did not intervene to regularise the spelling forms of the works they reproduced. Thirdly, unlike scribal manuscripts, the production of a printed text was the work of many hands. We shall outline here the typical process which led to the production of a printed book.

\subsection{The process of printing a book}

First of all, in the case of an original work, the author would establish his manuscript, and then, in most cases, would have a copy made for the printer by a professional scribe. The author's own orthography could therefore be modified even at this early stage. Once the manuscript arrived in the printing-house, it would be annotated and divided up, different parts being given to different compositors. Generally speaking, several compositors would be working at the same time, but they did not work through the text in a linear fashion: each one would compose the parts of the text which would make up a form, and no compositor would have access to the text as a whole. Compositors did not have to have any particular linguistic competence; indeed, they did not even have to know the language of the text they were composing: they simply set into movable print what they had in front of them, using the characters that they had at their disposal. Skilful compositors no doubt understood the text they were transcribing and did so with relatively few errors; this was not, however, the case all the time. In this second process, therefore, variants due to errors or due to the compositor's own orthographical practices and preferences (supposing that he had any) could then be introduced.

Next, the whole text, once composed and a first draft printed off, would be read by a corrector, who would introduce a number of corrections. Correctors were generally more literate than compositors, and some of them, such as Raphelengius or Lipsius who worked for Christopher Plantin, were indeed very eminent humanist scholars. ${ }^{18}$ However, it would be false to suppose that all correctors, or even most of them, were excellent scholars. Some correctors would have had their own ideas or have been given guidelines concerning the orthography of texts in French; others would not. Finally, we must take into account the views and practices of the master printer or bookseller. The major printing houses evidently had some kind of "house style", and in certain cases it is possible to say, with reasonable certainty, which printing house a particular text came from by studying its orthography; ${ }^{19}$ however, this is far from being a general rule. 
Most printed texts of the first part of this century present, therefore, a large number of variants, both internal (i.e., within the same text) and external (i.e., between one text and another), and it is often impossible to say whose orthography is actually represented in them.

\subsection{Printing and standardization}

Although the shift from script to print brought about, initially, a huge mix of orthographical practices, as the century advances, we also see the opposite effect, due to the same technological changes. That variants were gradually reduced over time has been amply demonstrated by corpus-based analyses. $^{20}$

Several factors can explain this trend towards standardization. First of all, compositors, when faced with a text, could only use the characters that they had in their case: unlike scribes, they couldn't improvise, and they couldn't introduce new or personal variants. Secondly, printing workers were an extremely mobile profession, moving between cities and printing houses. As they did so, they no doubt brought with them the practices and innovations that they had acquired elsewhere. As a result, we see regional variants gradually disappearing, and it is very often impossible to tell where a text was printed, using only its orthography as an indication. Next, as texts gradually gained in readability and the price of books decreased, a whole new reading public emerged, and spellings that might be a hindrance to certain readers, who had little or no experience in reading Latin (such as abbreviations and etymological spellings) tended to disappear. Finally, for numerous reasons, ${ }^{21}$ a number of printers took it upon themselves at various periods to write treatises aimed mainly at their fellow printers, calling for a certain number of standards and innovations. We shall look at some of these innovations in the next section.

\section{Accents and auxiliary signs}

The first innovations to appear in 16th-century orthography were a number of accents and auxiliary signs, and these were mostly the work of printers belonging to what Nina Catach (1968: 31-41) called the "orthotypographical" movement. The aim of these printers was not to attempt a full-scale reform of the written language, but rather to remedy some of the main problems and deficiencies of the existing system. 
It is no coincidence that the first appeal to codify the written French language came from a man who was not only a King's printer, but also a scholar, a letter-designer, translator and philologist: Geofroy Tory. In his Champ Fleury (1529), a curious mixture of medieval scholasticism and the new humanist learning, Tory not only appeals to some "noble spirit" to "set the French language down according to firm rules", ${ }^{22}$ but also pinpoints a number of areas in which he feels the written language to be particularly lacking: the different values of $e$, (unwritten) elision of mute $e$, the use of $<\mathrm{c}>$ with a "soft" value before $<\mathrm{a}>,<_{\mathrm{o}}>$ and $<\mathrm{u}>$, diacritic $<\mathrm{u}>$ after $<\mathrm{g}>$ before a vowel, and so on. His aim is not only to codify and renovate the written language, but thereby to make French as illustrious as Latin, and to encourage his countrymen to write in their native language rather than in Latin.

The first innovation inspired by Tory's declarations was introduced in works printed in 1530 by his fellow humanist and King's printer, Robert Estienne, and consisted in introducing an acute accent on word-final $<\mathrm{e}>$ when the letter represented the " $e$-masculine" phoneme /e/, in order to differentiate it from the "mute" $e$, pronounced / $/$. This enabled readers to distinguish, for example, present-tense verb forms such as (il) aime from past-tense ones such as (il a) aimé. ${ }^{23}$ Estienne also printed the following year $^{24}$ the Isagoge of Jacques Dubois (Sylvius), which presented a very particular orthographical system (which we will examine more closely in section 5.1. below), but which also proposed certain innovations which were adopted by other printers: namely, the apostrophe (which Tory had recommended to note elision), the trema (") on vowels in hiatus, and a means of distinguishing three separate values of $e$ : not according to syllabic value, as Estienne had done the previous year, but according to aperture: $<$ é> "sonum habens plenum" corresponding no doubt more or less to a closed $/ \mathrm{e} /,<\overline{\mathrm{e}}>$ "sonum habens medium" corresponding no doubt to a more or less open $e(/ \varepsilon /)$, and $<\mathrm{e}>$ "sonum habens exilem", corresponding to the mute or feminine $e(/ / /)$.

\subsection{The Briefue Doctrine (1533)}

A lot has been written ${ }^{25}$ about this small treatise, which was the first complete theoretical work on auxiliary signs to be written in French. Although the treatise is anonymous, since Catach (1968: 51-70), building on previous work by Beaulieux (1927) and by the printing historian Jeanne VeyrinForrer (1956), it has been widely accepted among historians that it was the 
product of three pairs of hands: those of the philologist and printer Geofroy Tory; of Antoine Augereau, a printer and letter-engraver; and of Clément Marot, poet and courtier. The collaboration of the three men was, in this case, essential: Tory provided the theoretical and grammatical basis for the innovations described in the treatise, Augereau created the new characters, ${ }^{26}$ and Marot put the recommendations into practice with examples from his own verse. The treatise went through several editions. The first edition, which was published during the autumn of 1533 (Tory died in October 1533), only comprises three and a half pages, and was printed together with some anonymous Epistres Familieres, which illustrate the use of the new signs. The signs in question are: the apostrophe, the apocope (which uses the same sign as the apostrophe) and the synalephe. All these signs were useful especially in verse, in order to indicate whether a final $<\mathrm{e}>$ was elided or not, and whether or not it should be counted as a syllable. There are also one or two isolated uses of the trema. In December 1533, another improved and augmented edition was published: this time, in addition to the signs presented in the first edition, we also find the cedilla, the acute accent on final $<\mathrm{e}>$ to note /e/, the circumflex accent noting the syncope, and a tonic accent used before enclitic particles. The synalephe (which was described in the first edition, but not noted by any particular sign) is indicated here by an $\langle\phi\rangle$ with an oblique stroke through it. The Epistres Familieres once again are used to illustrate the new signs, but added to these is a work by the sister of the reigning king Francis I, Marguerite de Navarre, entitled Miroir de l'ame pecheresse ("The Mirror of the Sinful Soul"). Marguerite and Marot were very close, and both shared similar Evangelical religious convictions. Because of certain rather un-Catholic passages, the Miroir had been banned by the Paris Faculty of Theology, the Sorbonne, in the summer of 1533.

We find here, for the first time, evidence of a link which will prove to have been quite strong, between reformers of the written language and religious reformers. However, the beginnings of religious unrest were to put a stop to these orthographical innovations, at least in Paris. Following the socalled "Affaire des Placards" in 1534, ${ }^{27}$ King Francis I carried out a major clampdown against "heretics". Marot was exiled, and Augereau was burned at the stake. With Tory already dead, the main proponents of the new auxiliary signs were all out of the way, and Parisian editions reverted to their usual, traditional orthography.

However, the new signs "went underground" and were adopted in other printing centres in France and abroad, in intellectual climates which were more favourable to the "new religion": in Geneva (from 1533 onwards), in 
Lyon (1538) and in Antwerp (1540). The Lyonnese printer Etienne Dolet produced a new, revised version ${ }^{28}$ of the Parisian treatise, which went through several editions, and became a reference work for printers.

While Parisian editions tended to stagnate, between 1533 and $1550{ }^{29}$ printing centres outside of the zone of influence of the Sorbonne were quick to adopt the new signs, and Paris eventually had to follow. With the Briefue Doctrine and its reeditions, practically all of the auxiliary signs used in modern French were already put in place. With the circumflex accent (used to denote long vowels) which came into use around $1550,{ }^{30}$ and the grave accent ${ }^{31}$ in the following century, the whole set of accents and auxiliary signs necessary to written French would be complete. The new signs came into use remarkably quickly, thanks to the printers: by 1550 , nearly all printers were using the apostrophe and the acute accent on final $<\mathrm{e}>$; by the end of the century, practically all of the 16th century innovations were in general use (Baddeley 1996).

To give an idea of the extent to which the introduction of accents and auxiliary signs at this time changed the face of printed texts, here is an extract from Marguerite's Miroir: from the first edition of 1531, in traditional orthography, and from the edition of 1533, including the innovations of the Briefue Doctrine. Changes between the two versions appear in italics.

Table 1. Comparison of two editions of Marguerite's Miroir

1531

Il neft iuge qui puiffe condemner

$\mathrm{Nul} /$ puis que dieu ne le veult point damner.

Ie nay doubte dauoir faulte de biens /

Puis que mon dieu pour mon pere ie tiens.

Mon ennemy nul mal ne me fera /

Car mon pere fa force deffera.

$\mathrm{Si}$ ie doib riens / il payra tout pour moy :

Si iay gaigne la mort / luy comme roy

Me donnera grace \& mifericorde /

Me diliurant de prifon $\&$ de corde.
1533

Il $n$ 'eft Inge, qui puiffe condemner

Nul / puis que DIEV ne le veult point dāner.

Ie $n$ 'ay doubte d'auoir faulte de biens /

Puis que mon DIEV pour mon Pere ie tiēs.

Mon ennemy nul mal ne me fera :

Quar mon Pere fa force defera.

$\mathrm{Si}$ ie doy riens / il pai^ra tout pour moy :

Si i'ay gaigné la mort / luy comme Roy

Me donnera grace \& mifericorde /

Me deliurant de prifon, \& de corde 


\section{Theoretical approaches and phonetic scripts}

During the 16th century, for the first time, a full-scale debate took place nationally, concerning the need to reform the orthographical system. It was during this period that the first phonetic scripts for French emerged. However, the debate involved more than just a discussion of letter-sound correspondences: the role of writing in society, literacy, teaching and the status of religious texts all came under scrutiny at one time or another. ${ }^{32}$

\subsection{Jacques Dubois or Sylvius}

The first would-be reformer was a professor of medicine from Amiens, Jacques Dubois, who Latinized his name as Sylvius. After publishing several scholarly works on medicine in Latin, Sylvius then turned his attention to the spelling of his native language, in order to "rest and renew his mind" after such a lengthy and tiring enterprise. ${ }^{33}$ The work is in fact a grammar of the French language, written in Latin and modelled on the Latin grammars that were in use at the time. After a short chapter on the alphabet and the pronunciation of the letters in French, Sylvius then goes on to present a kind of historical and etymological study, explaining how French words had evolved from their Latin equivalents, and the changes in sound (and subsequently in spelling) that were involved. Although there are inevitably a few errors, Sylvius' etymological intuition was in fact remarkably accurate.

In order to renew the links that had been lost, over time, between Latin and French, Sylvius proposed a curious new orthography, which aimed both at indicating the present pronunciation of French in a more satisfactory way, while at the same time indicating the Latin form from which the French word derived. Sylvius achieved this by inventing a kind of "twotiered" set of printed characters, in which the upper part indicated the pronunciation, and the lower part the Latin form. For example, the form ligons, with an $<\mathrm{s}>$ above the $<\mathrm{g}>$, allows the reader to find both the French pronunciation, lisons, and the Latin, legamus. Sylvius was extremely fortunate in being able to persuade his printer, Robert Estienne, to have a whole set of new characters engraved just for this work: Estienne was never to use these particular characters again.

Although Sylvius does not indicate explicitly who the work was intended for, he says in his introduction that he hopes that it will encourage French people to gain a better understanding of their own language, instead 
of just learning it "parrot-fashion", for it is shameful for a person not to know his or her own native language. ${ }^{34}$ As the work is dedicated to the new queen of Francis I, Eleanor of Austria, we may suppose that the author also had in mind the needs of foreigners who had to learn French.

As we indicated earlier, Sylvius' system did include a number of notations (especially accents and auxiliary signs) that were eventually adopted by other authors and printers. However, generally speaking, his orthographical system was felt to be too complicated, and needed costly investment in completely new characters before it could be adopted by anyone else.

\subsection{Louis Meigret}

Although the first real "phonetic" reformer of French orthography, Louis Meigret, was also a humanist and a man of learning, his admiration for Latin and other ancient languages led him not to be a slave to them, like Sylvius, but to attempt to produce a whole new orthography for French in which, just as in Latin, ${ }^{35}$ the graphemes of the written language were the exact reflection of the phonemes of the spoken language.

Although Meigret's first publication, the Traité touchant le commun vsage de l'escriture francoise was not published until 1542, it seems likely that his work on French orthography began much earlier, in Paris, during the early 1530s. Meigret was a member of an illustrious family, several members of which were strongly linked to the Reformation, ${ }^{36}$ and Meigret's own religious views, as they are expressed occasionally in his work, leave no doubt as to his Protestant convictions. This probably explains why Meigret "laid low" during the 1530s, and did not return to Paris and publish his work until the 1540s.

In his Traité touchant le commun vsage, Meigret asks the fundamental questions: what is a writing system, and how does one go about constructing an ideal one? Like the good humanist that he is, he "goes back to the sources", and reminds us that, according to Priscian, ${ }^{37}$ the letters or "notes" of the alphabet (notae) were invented originally in order to represent articulated speech according to a principle of bi-univocity: one letter, one sound. Meigret then compares the orthography of the French language of his time against this yardstick, and is compelled to admit that French orthography is very far from this ideal. He therefore proposes a new orthography, in which words are spelt as they are sounded, and sounded as they are spelt: a system that is ideal for coding and decoding. Meigret anticipates the many objec- 
tions that will be raised by the opponents of such a project, and in particular the usual arguments of tradition, usage, distinction of homophones, morphological alignment, etymology, history and so on, but rejects all of these in turn, opposing to them all the iron law of "reason". It is interesting to see, at this point, the arguments and especially the terminology that Meigret uses to combat the old orthography: he speaks of "abuse", "superstition", "ignorance and false doctrine", "an abyss of errors and confusion", and opposes the "light of truth" to this mass of "shadows". Meigret's religious convictions undoubtedly appear in this quasi-theological vocabulary: sometimes, the reader has the impression of reading a work by Calvin.

When, in 1550, Meigret finally found a printer who would accept to print his works in this particular orthography (the Reformist printer Chrestien Wechel), there was a general outcry, and one author in particular, the poet Guillaume Des Autels, took a strong stand against Meigret and his "maigre ortographe". ${ }^{38}$ The main objection raised by Des Autels, who was a Burgundian, was that Meigret's system reflected his own pronunciation (Meigret was a native of Lyon), and his pronunciation alone. A whole exchange of pamphlets ${ }^{39}$ ensued between the two men, and the initial rational arguments on both sides soon gave way to invective and insults. Jacques Peletier du Mans, another author and poet, also joined the debate, but although his arguments were much more subtle and measured, he received in exchange the same barrage of insults that Meigret had given Des Autels.

It seems likely that Meigret, with his extreme and uncompromising positions, discredited the cause of a more simplified orthography: his works were not reprinted, and the printer Chrestien Wechel, like Robert Estienne, never again used the phonetic characters introduced by Meigret. ${ }^{40}$ Indeed, in 1554, a rather resigned and disillusioned Meigret says, in the preface to his Discours de Louis Meigret touchant la creation du Monde (printed in the ordinary orthography of the time) that his printer, Wechel, was to blame for not continuing to use Meigret's orthography, as he "preferred financial gain to reason". 41

\subsection{Jacques Peletier du Mans}

Jacques Peletier was an important figure of the mid-16th century: a poet and courtier, friend of Ronsard and the Pléiade group of poets, he was also a distinguished mathematician, author of an influential treatise on algebra, as well as another on poetics. His contribution to the reform of French orthography influenced, to some extent, Ronsard and his disciples, many of 
whom adopted his spellings in their works: for a certain time, at least. ${ }^{42}$ However, for language historians, Peletier is mostly to be remembered for his Dialogue de l'ortografe of 1550, an extremely lucid and lively account of the spelling debate that was flourishing in France at the time.

Peletier entitled his work "Dialogue", but in fact there are four protagonists: Peletier himself (who hardly speaks), Jean d'Auron, who is Peletier's spokesman, Théodore de Bèze, poet and Protestant reformer (who had not yet emigrated to Geneva to become Calvin's right-hand man) and Denis Sauvage, who plays something of the part of Candide. The "dialogue" is presented as the transcription of a genuine discussion that took place between the four men. The subject is the reform of French orthography, and two main viewpoints are presented: the pro-reform viewpoint of Peletier/ d'Auron, and the conservative, anti-reform view of Bèze.

D'Auron develops a lot of the arguments that had already been put forward by Meigret (the arguments of reason against arbitrary usage, of simplicity, and the Classical ideal of writing as the mirror of speech), but in a less dogmatic fashion. He underlines especially the need for French to be written and read outside of France, and to gain the status of a "noble" language like Latin or Greek. He also has a thought for the future generations, so that they will be able to "see, as in a mirror, the portrait of the French that was spoken in our time" (Peletier 1550: 2). Bèze, who is something of the "villain" of the piece, ${ }^{43}$ then responds, with a number of extremely cogent and compelling arguments. First of all, he refutes the well-established idea that the Romans wrote as they spoke (and offers examples to back up his argument), and points out that writing should not necessarily be a true reflection of speech. Even if such a thing were possible (which he doubts), it would not be desirable, as each person would write as he spoke and, since there are so many differences in spoken language, people would not be able to understand each other. He also puts forward another reason: writing, he says, does not have the same function as speech. When a person reads a text, he does not oralize the written forms that he has in front of him, but "extracts" the meaning directly. Moreover, if a person reads a text written with an orthographical system that resembles one that he is already familiar with (Bèze is referring here to Latin), the "resemblance of letters and syllables will appeal to his memory, and remind him that [words having] the same composition and proportion must have the same, or a similar, meaning" (Peletier 1550: 47). This is, of course, an apology for the "ideographic" type of traditional orthography that we described earlier in section 2 of this article. Finally, Bèze refutes the idea of a "spelling for the masses": writing, he says, is not something that everyone needs to use. 
Women and artisans, for example, have no education and therefore no need of it. Should they have to write documents, there is always someone who will be able to do it for them. Unlike speech, writing is and should remain the preserve of the elite.

It is interesting to see here that Bèze, a passionate Reformer, was also (unlike Meigret) a fierce opponent of the democratization of writing. While spelling reform was largely the work of Protestants (as we shall see in the next section), Bèze and Calvin are major exceptions to this rule. It should be pointed out however that Bèze was of aristocratic origin, and, like Calvin, an excellent Latin scholar. He published, indeed, a treatise on French pronunciation in Latin, ${ }^{44}$ so that the educated elite of Europe would be able to read it. Whatever Bèze's reserves concerning phonetic scripts, he was an extremely acute observer of the French language, and his descriptions of the articulation of French phonemes are quite remarkable.

\subsection{Pierre de la Ramée (Ramus)}

Pierre de La Ramée, better known in the Latinized version of his name, Ramus, was one of the greatest spelling reformers of all time, as well as a major figure of the Protestant Reformation: he died, in appalling circumstances, during the Saint Bartholemew's Day massacre of Protestants in August 1572. Like Sylvius, he was of humble origins, and, like his countryman (Ramus, like Sylvius, was from Picardy), eventually became a professor at the University of Paris through hard work and brilliant studies.

Ramus was of a strong, uncompromising temperament, and at several points in his career clashed with the tenants of tradition. He contested the omnipresence of Aristotle in University studies, introduced the new Italian humanist pronunciation of Latin (against the Sorbonne), and was the first professor to lecture in French at the Collège Royal (now the Collège de France).

In 1562, not long after Ramus definitively embraced the Protestant faith, he published his Gramere, a grammar of the French language, printed in a particular phonetic script that he had developed himself. Although Ramus gives no explanations concerning this particular orthography, it was evidently closely based on Meigret's phonetic system. Like Meigret, Ramus uses the $<\mathrm{j}>$, and the $<\mathrm{z}>$ to replace intervocalic $s$; he introduces special signs to note palatal $l$ and $n(/ K /$ and $/ \tilde{n} /)$ and distinguishes the different values of $e$ on the same lines as Meigret. However, on many points, Ramus goes further than Meigret: he cuts out all double letters, he also eliminates 
the variants that subsisted in Meigret's system $(<\mathrm{i} / \mathrm{y}>,<\mathrm{q} / \mathrm{c}>,<\mathrm{c} / \mathrm{s}>)$ and truly applies the principle of "one sound, one letter". It is significant to note that this first edition of Ramus' Grammar was printed by André Wechel, who was the son of Chrestien Wechel, Meigret's printer. ${ }^{45}$

In 1572, a new edition of the Grammar was printed again by André Wechel: ${ }^{46}$ this time, however, Ramus introduced some new features into his orthographical system, such as the use of the letter $<\mathrm{k}>^{47}$ to note $/ \mathrm{k} /$ in all positions, special signs for the vowel digraphs $<$ au $>$, $<$ eu $>$ and $<$ ou $>$ (borrowed from the poet Jean-Antoine de Baïf), and a more satisfactory description and notation of the values of $e$. In this new version of his Grammar, Ramus uses several times the term "Gaulloys" (instead of "François") to mean "French", and by doing so he showed his belief in a new, Protestant-inspired idea that the French language (and French orthography) descended not from Latin but from the Gauls. ${ }^{48}$ However, due no doubt to an unfavourable reception of his first Gramere, printed entirely in his reformed orthography, Ramus makes a concession to potential readers by printing it, this time, on two opposite pages: one page in reformed orthography, and the other in the traditional one. Ramus explains the reasons for this semi-retreat, in rather disenchanted tones:

It would have been better for us if we had to create new characters and set in place a new orthography, because there had never been one in use. However, the great usefulness of such a thing is not sufficient to dispel wellestablished habits, based on legitimate rights and on possession in good faith [of a spelling system]. ${ }^{49}$

The outcry that followed the publication of Ramus' works was similar to that provoked by Meigret's works: the jurist Estienne Pasquier rejected Ramus' works as "illegible", ${ }^{50}$ and Bossuet, in the following century, talked of "Ramus' impertinent orthography". ${ }^{51}$ However, it is no doubt an indication of the lasting influence of Ramus' work that, following his example, the letters $\left\langle\mathrm{j}>\right.$ and $<_{\mathrm{v}}>$ came to be distinguished by printers, and were often referred to as "letters Ramistes".

\section{Protestants and orthography}

From what has been said in the earlier sections of this article, it will have become clear to the reader that Protestants had an important part to play both in the debate concerning orthography and in the changes in the written 
language that took place throughout the century. As we shall see in the following section, most pedagogical works for teaching spelling were also the work of Protestants.

Even before the Reformation became "officially" established in France, ${ }^{52}$ scholars such as Lefèvre d'Etaples had been promoting the use of French in theological texts and in scripture, so that "common people" could have access directly to the word of God without necessarily knowing Latin. The need to make printed texts more accessible to a less well-educated audience resulted, in 1523, in the publication of a French-language version of the New Testament translated by Lefèvre and printed by the humanist and Reformist printer Simon de Colines. Lefèvre and Colines did all that could be done, at the time, to make their edition as accessible as possible: it was printed in in-octavo format, in two separate volumes (so that people could buy them separately), ${ }^{53}$ the orthography, without yet being modernised or (even less) made "phonetic", was kept as simple and un-etymological as possible $^{54}$ and the use of abbreviations was kept to a minimum. Moreover, unlike most French texts of the time, the text of the New Testament was punctuated quite densely, in order to help the inexperienced reader. ${ }^{55}$ The publication was condemned as heretical by the Paris parliament in August 1525.

Lefèvre was close to the circle of Parisian humanist printers that included Geofroy Tory, Robert Estienne (who was Colines' stepson) and Antoine Augereau, the latter two especially being involved in the publication of Reformed literature. Tory's convictions were never clearly expressed, and he died in 1533, before the major clampdown against the Evangelical movement. Augereau was to die at the stake because of his illicit printing activities and his active involvement in the Affaire des Placards, and Estienne fled to Geneva.

As we saw earlier, the publication of the Briefue Doctrine in 1533 involved a group of men (Tory, Marot and Augereau) who were linked by their religious convictions, and who benefited from the protection of the king's sister, Marguerite of Navarre. Indeed, the whole "microcosmos" of Parisian printers, authors, scholars and a large number of courtiers constituted a very favourable breeding-ground for what was then termed "les idées nouvelles", and was not then out-and-out protestantism. ${ }^{56}$ When, after the Affaire des Placards of 1534 and the persecutions that followed it, a large number of intellectuals and members of the printing profession fled from Paris, the "new" orthography that was just being put in place came to an abrupt halt. However, the innovations were taken up in other printing centres, more favourable to the Reformation: mainly Lyon and Geneva. 
In 1533 (which was, as we have seen, a crucial year for orthography in France), the translator of the French Bible from Greek and Hebrew, PierreRobert Olivétan, wrote a small treatise for the Vaudois children of the valleys of Piedmont, where he was a teacher. The little book, entitled Instruction des enfans, explained the use of the "new" accents and auxiliary signs that had been presented in the Briefue Doctrine. ${ }^{57}$ The aim of the book (and of Olivétan's teaching) was to allow the Vaudois ${ }^{58}$ people who inhabited the Piedmont valleys to learn to read French and therefore be able to read the French translation of the Bible that Olivétan was then working on, and whose publication indeed the Vaudois people had largely financed. In 1536, in the separate edition of the New Testament given by the Genevan printer Jean Gerard, the accents and signs taught by Olivétan are all used, and continue to be used in all Genevan editions of the Bible and the Psalms, as well as in Gerard's other publications, from then onwards.

In Lyon, pro-Reformation printers ${ }^{59}$ such as Dolet also adopted the new orthography: Dolet, indeed, wrote a treatise for other printers, explaining its use. With the arrival of the "phonetic" ideas of Meigret and Peletier, "avant-garde" Lyonnese printers such as Jean de Tournes (who was Peletier's friend and printer) began to use a new, very simplified orthography in their printed works: a system that Nina Catach (1968: xxiv) termed "orthographe modernisée". This system was widely favoured by poets (Lyon was an important literary centre) since, with this system, the relations between writing and sound were more straightforward, and their verses could be read aloud more easily.

This simplified, modernized orthography was propagated through numerous Biblical editions and literary works. Its use in such works naturally gave it a certain prestige, and it was tending to become the norm towards the end of the century. However, Nina Catach notes, in the corpus of editions she studied, a reversion to a more traditional type of orthography in the latter part of the century, linked to a decline in the standards of the printing houses: "Le recul de l'orthographe nouvelle, sauf exception, semble donc bien correspondre en fait à un recul de l'imprimerie" (Catach 1968: 253). After the Saint Bartholomew Massacre of 1572 and the beginnings of the Counter-Reformation, many of the best printers and their workers left France for more favourable parts. Printers were closely watched, and a system of monopolies and privileges was created and put in the hands of a few "reliable" printers and booksellers.

The "new" orthography did not, however, completely disappear. As in the 1530s in Paris, it "went underground": in this case, to Antwerp, where it was carried on in the prestigious printing establishments of Plantin and his 
successors, the Waesberghes and Elseviers. When France regained prosperity, in the 17th century, and orthography once more became a subject of debate, these "Dutch editions" were seen as a model upon which the spelling of French should be based.

\section{The legacy of 16th-century orthography}

In her 1990 doctoral thesis published in 1992 with the title Les grands courants orthographiques au XVII siècle et la formation de l'orthographe moderne, Liselotte Biedermann-Pasques identified, throughout the whole of the 17th century, the existence of three main types of orthography: traditional (etymological), modernized, and phonetic. These three orthographical types have their origins in the 16th century, and although the situation is not quite the same from one century to another, ${ }^{60}$ the 17 th-century situation reproduces to a great extent that of the 16th. The same heated debates were held between partisans and opponents of modernised and phonetic orthographies, and the arguments and suggested reforms were often the same. The argument of "usage" had, however, become a more compelling one by the 17th century, with the expansion of printing and of literacy. French had gained increasing international prestige and was recognised as the language of science, and the reign of Louis XIV is generally held to be the "golden age" of French literature.

Much of the debate concerning orthography took place between members of the newly-created Académie Française, founded by Richelieu in 1635. The main task entrusted to the Académie was to produce an "official" dictionary of the French language, as well as standard reference works on grammar, poetics and rhetoric. The latter three were never produced; after an extremely long and difficult gestation period, the Dictionary was finally published in 1694. After a huge amount of debate, ${ }^{61}$ the members of the Académie, following the opinion of Bossuet and Régnier-Desmarais, finally decided to adopt "l'ancienne Orthographe receuë parmi tous les gens de letters, parce qu'elle ayde à faire connoistre l'Origine des mots". ${ }^{62} \mathrm{Al}$ though the Académie modernized the spelling of its dictionary quite substantially in the second edition of 1718, and even more so in the third edition of 1740, the Académie dictionary, which was to become the main model for written French, has rarely been an example of avant-garde progress, especially in the field of orthography. 


\section{Conclusion}

16th-century French spelling is a mine of information which interests scholars from many disciplines: linguists (of course), but also social historians, historians of culture and of ideas, educational historians, printing specialists, bibliographers, specialists of translation and even of biblical exegesis, and literary scholars. Although a great deal has already been written on the subject, ${ }^{63}$ much still remains to be explored.

However, the main lessons that can be learned from this episode in the construction of the national language would appear to be the following. Although French is a Romance language, just like Spanish and Italian, its written form like its phonological form has always tended to be more complex. With phonetic erosion (and especially the effacement of a large number of final consonants, from the 16th century onwards), the presence of morphological spellings has traditionally been a means of distinguishing homophones, indicating morphemes to note differences of number, gender and person, and of showing links between members of word-families.

Although in France, as elsewhere in Europe, phoneticians dabbled with new "ideal" systems of orthography, the main obstacles to the adoption of these reforms were both technological and social. Whereas the printing press was a main factor in introducing and disseminating certain innovations (and here, we must point to the crucial role of networks and of collaborations between authors and printers), the cost involved in creating new characters and the risk of texts printed in a radically different orthography being unacceptable to the increasing reading public constituted a major argument against the adoption of such reforms. Technological advance can be seen in this case as a two-edged sword: while it made wide-scale radical spelling reforms possible, it also curbed this tendency by diffusing evermore standardized texts. Théodore de Bèze, speaking in Peletier's Dialogue in 1550, says that a radical reform should have been proposed "twenty or thirty years ago", but that by the time at which he was speaking, it was too late.

Furthermore, in France, as in other countries, orthographical reform was related to Protestantism, and many innovations were disseminated through editions of the Scriptures. However, Protestantism in France never became a state religion, and with the repeal of the Edict of Nantes (which had instituted a certain religious tolerance), the "new" orthography continued to be associated with Protestantism and with major Protestant figures such as Ramus, and consequently rejected. Throughout the 17th century, reformed or phonetic scripts continued to be produced; however, these scripts would 
have little or no impact on general usage, and the Académie dictionary at the end of the century would fix the "old" traditional orthography for several decades.

\section{Notes}

1. It is not surprising that, throughout the Middle Ages, ecclesiastical terms such as Christus, Deus, Iesus tended to be written in their conventional Latin abbreviated forms. A large number of abbreviations functioned as "logograms" or "word-pictures", allowing for different phonemic realizations.

2. For a fuller description of the orthographical system used in Eulalia, see Biedermann-Pasques (2001).

3. There is no comprehensive study to date of medieval French orthography. Beaulieux (1927) provides a rather biased view of the subject, based on carefully selected literary texts copied by selected scribes, rather than on a wider usage. A balanced (but rather succinct) overview is provided by Cerquiglini (2004).

4. An excellent and much-needed "debunking" of this persistent and pernicious myth has been carried out by Cerquiglini (2004: 14-24).

5. The problems of $\langle\mathrm{u}>$ and $\langle\mathrm{v}\rangle,<\mathrm{i}>$ and $<\mathrm{j}>$ are not entirely symmetrical. Whereas $\langle\mathrm{v}>$ was used in word-initial position and $<\mathrm{u}>$ internally and in wordfinal position, $<\mathrm{j}>$ was little-used, and is found occasionally as the final element of Roman numerals such as vij, viij. In Gothic characters, the capital $<\mathrm{I}>$ tends to resemble a present-day $<\mathrm{J}>$, but should nevertheless be transcribed as $<\mathrm{I}<$ in titles of books and so on.

6. Etymological letters gave a kind of "consonantal skeleton" to written words. For example, when the French word moult (in which the $<\mathrm{l}>$ had ceased to be pronounced for decades, even centuries) was written with this particular spelling, experienced Latinate readers would immediately be put in mind of the Latin word multum, thanks to the consonant "core", mlt.

7. These abbreviations often formed veritable "logograms", or "word-signs" which, like numbers, could be used to correspond to either language.

8. Other examples of this non-etymological initial $<\mathrm{h}>$ that are still to be found in present-day French are huit (Lat. octo), huile (Lat. oleum) and huis (Lat. ostium).

9. For example, rhyme, from the Frankish word * rim, in which the $<$ rh- $>$ and $<y>$ are analogical spellings, establishing a (spurious) connection with the Greek rhuthmos "rhythm". It is significant that, in this example again, English is seen as having retained the traditional (albeit erroneous) spelling. 
10. The exact number of values of $e$ is somewhat difficult to determine, but varies, according to speakers, between three and four. There is the additional complication of long and short vowels: vowel-length was less well described than vowel-timbre, but certain authors, such as Claude de Sainliens (1580), attest three different values for vowel-length, which could push the total number up to seven for certain speakers.

11. Compare, for example, feste (modern French fête, 'festival') and peste 'plague'. For the uninitiated, there was no way of knowing whether the written $<_{\mathrm{s}}>$ was mute or not. For grammarians and teachers of French as a foreign language such as Palsgrave (1530) and even as late as Bellot $(1578,1588)$, the only way of getting around the problem was to draw up long lists of words in which the $<\mathrm{s}>$ was pronounced.

12. This is by no means an exhaustive list of potential spelling variants. For a more complete list, see the introduction to Catach et al. (1995).

13. For $/ K /$, for example, Pope (1934: 277) identifies ten different variants in the Domesday Book for the place name Taillebosc, and nine different ways of noting $/ \tilde{n} /$. Although some of these graphic variants had become very rare by the 16 th century, most of them are still attested during this period.

14. Estimates of the exact number of phonemes differ. In what must no doubt be considered a "maximalist" view, Morin (2008) lists a possible 38 vowel phonemes and 26 consonant phonemes.

15. I.e., our present-day alphabet, minus $<\mathrm{j}>$ and $<\mathrm{w}>$, and with $<\mathrm{u}>$ and $<\mathrm{v}>$ being considered as positional variants of a single letter.

16. The best account of the impact of printing, the distribution of tasks in printing houses and an analysis of printed production is to be found in Catach (1968).

17. The first French dictionary that could have been used as a reference was Robert Estienne's Dictionnaire Francoislatin of 1539.

18. During the earlier period of Humanist printing (pre-1550), scholars and teachers such as Lefèvre d'Etaples, Geofroy Tory or Pierre Danès also worked as correctors for the main printing houses. Later on, the work of corrector became a full-time job. On correctors, see the Dictionnaire Encyclopédique du Livre (2002), article "Correcteur".

19. This has been demonstrated notably by Catach (1968), who studied a corpus of texts by author and by printer, and was able to identify the orthographical characteristics of the work of a certain number of printers.

20. Mainly those of Catach (1968) and Baddeley (1993), based respectively on over 900 and 500 editions.

21. Obviously, it made economic sense to have more or less fixed orthographical practices, not only in the same printing house, but from one printing house to another. However, the humanistic and philological background of several printers led them to become interested in the written form of their mother tongue, and to make French a "noble" language, on an equal footing with Latin.

22. "Pleuft a Dieu que quelque Noble cueur femployast a mettre \& ordōner par Reigle nofstre Lāgage Francois" (1529: fol. A8). 
23. This device had already been used in pedagogical works used in England for the teaching of French as a foreign language, and most notably by Palsgrave (1530). Palsgrave, however, used the accent on all tonic vowels: not only on $<\mathrm{e}>$, and not only in word-final position. However, Palsgrave includes a long list of words distinguished only by the value of the final $<\mathrm{e}>$, such as peche/peché, coste/costé, etc. Whether Estienne owed anything to Palsgrave is not certain; however, both men worked in Court circles (Palsgrave as teacher to the English royal family, and Estienne as King's printer), so it is not implausible that Estienne had either come into contact with Palsgrave's work, or else had heard of it.

24. The title page bears the date " 1531 ", but in fact the book was printed early in 1532 (new style): with the "old style" of dating, the new year began at Easter.

25. See: Beaulieux (1927: II, 103 et sq.), Catach (1968: 51-70), Baddeley (1993: 140-161).

26. Tory no doubt designed the characters, but it was Augereau who engraved them and who printed the whole treatise.

27. Tracts against the Roman Catholic mass, of a very virulent nature, had been stuck up all over Paris, some even in the king's personal quarters.

28. Dolet added the distinctive grave accent (on words like $\grave{a}$, là, où), borrowed from Genevan editions.

29. In 1535, King Francis I issued an edict banning printing. Needless to say, the edict had no effect at all outside of Paris, and indeed very little effect inside Paris. However, the action speaks volumes about the relations that existed at the time between the monarchy and the printing world.

30. Although the accent had been recommended by phoneticians as early as 1549 (Thomas Sebillet, Iphigene), it was popularized essentially thanks to the editions of the Antwerp printer, Christopher Plantin. On the circumflex accent, see Cerquiglini (1995) who has devoted a whole book to the history of this accent.

31. The grave accent was used for various purposes, but not to note an "open" $e$ until it was adopted by Pierre Corneille in the mid-seventeenth century.

32. The best account of these theoretical discussions can be found in Citton and Wyss (1989).

33. "Vigiliis, curis, labore fractus, materiā difquifiui, in qua ingenii vires longiore Itudio \& grauiore feflas recrearem, atque reficerem" (Sylvius 1531: fol. aiiii).

34. “... fui fermonis rationem cōdifcant, ne picarum aut fturnorum more à parentibus audit, fed nunquam animaduerfa, nunquam perpēfa, nunquā intellecta, femper effundant: quū fit foedum, hominem in ea lingua videri hofpitē, in qua natus est" (Sylvius 1531: fol. A5-A5v ${ }^{\circ}$ ).

35. Obviously Meigret, like most of his contemporaries, had a rather idealised view of classical Latin orthography and of the sound-sign correspondences of this language.

36. His half-brother Aimé Meigret was one of the first Reformed preachers in France. Another half-brother, Lambert, was a King's chamberlain and had the reputation of being a Lutheran; he was exiled to Switzerland in 1530. Finally, 
his brother Laurent was also King's chamberlain, and was a close acquaintance of Marot and Guillaume Du Bellay. He was condemned in Paris in March 1532, together with his brother Louis and Clément Marot, for eating meat during Lent, and he also left Paris for Geneva. It may be supposed that Louis went the same way as his brothers, and only returned to Paris once the political climate had become more favourable (Baddeley 1993: 114).

37. Priscianus Caesariensis (5th-6th century AD), Latin grammarian and author of the Institutiones Grammaticae, which formed the basis for the teaching of Latin during the Middle Ages and well into the 16th century.

38. There is, of course, a pun here on the surname of Meigret and the adjectif maigre, which means "poor", "thin", "underfed".

39. For this exchange, see Citton and Wyss (1996).

40. Meigret proposed the distinction between $<\mathrm{i}>$ and $<\mathrm{j}>$ according to pronunciation (but, curiously, not the distinction between $<\mathrm{u}>$ and $<\mathrm{v}>$ ). He also proposed special notations for the palatal consonants $/ K /$ and $/ \tilde{\mathrm{n}} /$, and ways of distinguishing the different values of $e$. However, his system is not strictly phonetic or even bi-univocal: in many cases, several letters represent the same sound: $<$ ç $>$ or $<_{\mathrm{s}}>$ for $/ \mathrm{s} /,<\mathrm{q}>$ or $<\mathrm{c}>$ for $/ \mathrm{k} /$, and so on.

41. The argument that texts in phonetic script "don't sell" is still used by printers and booksellers in the 17th century: see Biedermann-Pasques (1992).

42. Ronsard is a case in point, illustrating the contradictions of spelling reform. As a young poet, eager to shake off convention and make himself known by causing a bit of a stir, he readily adopted many of the innovative standpoints of Meigret and Peletier, and persuaded his printers to do the same. In later life, however, having become a court poet and an "establishment figure" (especially after the Amboise Conspiracy, a Protestant plot against the monarchy, in 1560), he reverted to a more traditional way of spelling in his works.

43. Bèze had left for Geneva by the time the Dialogue was published. In spite of his Protestant sympathies, Peletier chose to stay in France, to conform and to compromise. For this reason, Peletier was subsequently labelled as a "Nicodemite" (i.e., a religious hypocrite) by Bèze.

44. De francicae linguae recta pronuntiatione Tractatus (1584). Geneva: Eustache Vignon.

45. André Wechel, who also had Protestant convictions, was lucky to escape Paris after the Saint Bartholomew's Day massacre, and fled to Frankfurt.

46. On the two editions of the Grammar, see Swiggers (1989).

47. $<\mathrm{k}>$ was very little used in French orthography in the 16th century, except in certain proper names and loan-words from Greek (such as kalendes). It had been used more widely during the Middle Ages, especially in texts from the Picardy area, but never really "caught on" in Central French. It would therefore be perceived as a "foreign" element when used by Ramus.

48. This ideology was quite widespread among Protestant writers at the time. It seems to have been initiated by Tory (1529) and developed by various authors 
including Hotman (1574) and Bonivard (1563). For more information on this episode of "Celtomania", see Droixhe (2002).

49. "Tout cela seroit a soubhaicter, si nous auions a forger comme vng nouueau chiffre, \& a cōmencer vne orthographe, ou il ny en eust jamais este aucune en vsage: mais ceste vtilite, combien quelle soit grande, nest pas suffisante pour abolir vne si longue praescription fondee sur vng droict legitime, \& sur vne possession de bonne foy" (1572: 13-14).

50. "Plus vous fourvoyez de nostre ancienne orthographe, et moins je vous puis lire" [the further you diverge from our old orthography, the less I am able to read you] (Pasquier 1974: book III, letter 4).

51. See Beaulieux (1927: 199).

52. The Reformation in Europe "officially" dates from 1517 and the posting up of Luther's 95 theses on the door of the chapel in Wittenberg. In France, after a long period of ambiguous relations between the Reformed movement and the monarchy, made up of repression mixed with occasional bouts of tolerance, the first Reformed church was set up in Meaux in 1540.

53. The whole Bible was to have been available in 8 volumes.

54. Concessions, of course, had to be made to other readers of the time, and to printing-house habits.

55. On this edition, see Baddeley (1995: 89-91).

56. The French words Protestant (in this particular religious sense) and Huguenot date from 1542 and 1552 respectively.

57. Plus the use of the grave accent on $a$ preposition.

58. The Vaudois (Waldensians) were a dissident sect, similar to the Lollards, and who shared the Lollards' belief that the Scriptures should be read by all, in one's native language.

59. In Lyon at the time, practically all the printers were pro-Reformation!

60 . Obviously, some uses that were considered "new" or "modern" in the 16th century, such as accents, had become part of everyday printed use in the 17th.

61. The debates among the Academicians were painstakingly transcribed by the secretary of the time, Mézeray. They were published by Beaulieux in 1951. The members of the Académie who were present at the dictionary sessions were, generally speaking, not the great literary figures of the time. Moreover, they often had radically opposite viewpoints; thus, according to who was present, a decision would be voted at one session, and a completely contradictory decision voted at the following session. The Academicians occasionally had quite harsh exchanges of viewpoints among themselves, such as the following, quoted by Cerquiglini (2004: 149) concerning the adjective délié:

Perrault: Pour deslié qui signifie subtil et menu, j'y mettrois un $s$.

Tallemant le jeune: Bon.

Mézeray: O le grand docteur! Qui ne scait pas que délié vient de delicatus.

62. "The old orthography, which is commonly used among all men of learning, because it allows them to know the origins of words" (Preface to the edition of 1694). 
63. A critical bibliography of literature on the subject carried out in 1999 (Baddeley 1999) revealed almost one hundred books and articles dealing in one way or another with the question of French 16th-century orthography. Several other publications have been added to this list since then.

\section{References}

\section{Primary sources}

Many 16th-century editions can be consulted and downloaded from the Gallica website of the Bibliothèque Nationale de France: www.gallica.bnf.fr. The collection of digital texts in the Bibliothèques Virtuelles Humanistes, created by the Centre d'Etudes Supérieures de la Renaissance in Tours offers a more limited number of texts, but the images of the texts are of better quality and they are easier to browse through, being accompanied by an indication of contents (www.cesr. univ-tours.fr). The CESR team are currently preparing a number of 16th-century editions in text form.

The collection of "Textes sur la Langue Française" (Paris: Champion) includes facsimiles and translations of a number of 16th-century works on language, including several dealing with orthography. The Slatkine Reprints series in the 1970s provided good-quality facsimile copies of most of the works on orthography quoted here, but unfortunately without any critical apparatus.

Académie française

1694 Le Dictionnaire de l'Académie Françoise. Dedié au Roy. Paris: JeanBaptiste Coignard. 2 vols.

Académie française

1718 Nouveau Dictionnaire de l'Académie Françoise. Paris: Jean-Baptiste Coignard. 2 vols.

Académie française

1740 Dictionnaire de l'Académie Françoise. Paris: Jean-Baptiste Coignard. 2 vols.

Bellot, Jacques

1578 The French Grammer. London: Thomas Marshe. Bellot, Jacques

1588 The French Methode. London: Robert Robinson. (Translation and critical edition with a facsimile of the original, by Susan Baddeley. Paris: Classiques Garnier, 2010.)

Bèze, Théodore de

1584 De Francicae Linguae Recta Pronuntiatione Tractatus. Geneva: Eustache Vignon. 
Bible: New Testament

1523 Les Choses Contenues en ce Present Liure. Vne Epistre Exhortatoire. La S. Euangile selon S. Matthieu. La S. Euangile selon S. Marc. La S. Euangile selon S. Luc. La S. Euangile selon S. Iehan. Aucunes Annotations. Paris: Simon de Colines.

Bible: New Testament

1536 Le Nouneau Testament, de Nostre Seigneur et Seul Sauueur Iesus Christ. Translaté de Grec en Francois. Geneva: Jean Gerard.

Bonivard, François

1563 Advis et Devis des Lengues Suivis de la Martigenee c'est a dire de la Source de Peche par Francois Bonivard, Ancien Prieur de Saint Victor. (Reedition Geneva: J. G. Frick, 1865).

Briefue Doctrine

[1533] Briefue Doctrine pour Deuement Escripre selon la Propriete $d u$ Langaige Francoys. [Paris: A. Augereau].

Dolet, Etienne

1972 La Maniere de Bien Traduire d'une Langue en Aultre. D'Aduantage. De la Punctuation de la Langue Francoyse. Plus. Des Accents d'Ycelle. Geneva: Slatkine. Original edition, Lyon: E. Dolet, 1540.

Dubois, Jacques (Jacobus Sylvius)

1971 In Linguam Gallicam Isagøge. Geneva: Slatkine. Original edition, Paris: Robert Estienne, 1531.

Epistre Familiere de Prier Dieu

1533 Epistre Familiere de Prier Dieu. Aultre Epistre Familiere d'Aymer Chrestiennement. Item, Briefue Doctrine pour Deuement Escripre

Estienne, Robert selon la Propriete du Langaige Francoys [Paris: Antoine Augereau].

1539 Dictionnaire Francoislatin. Paris: Robert Estienne.

Hotman, François

1574 La Gaule Francoise de François Hotoman Iurisconsulte. Cologne: J. Bertulphe.

La Ramée, Pierre de (Petrus Ramus)

1562 Gramerę Paris: André Wechel.

La Ramée, Pierre de (Petrus Ramus)

1572 Grammaire. Paris: André Wechel.

Meigret, Louis

1972 Traité Touchant le Commun Vsage de l'Escriture Francoise, Faict par Loys Meigret Lyonnais ... Original edition, Paris: Denis Janot for Jean Longis and Vincent Sertenas.

Meigret, Louis

1554 Discours de Louis Meigret Touchant la Creation du Monde, et d'un Seul Createur, par Raisons Naturelles. Paris: André Wechel.

Marguerite de Navarre

1531 Le Miroir de Lame Pecherresse, ouquel Elle Recongnoist ses Faultes 
et Pechez, aussi les Graces et Benefices a Elle Faictz par Iesuchrist son Espoux. Alençon: Simon Du Bois.

Marguerite de Navarre

1533 Le Miroir de Lame Pecherresse ... [Paris: Antoine Augereau].

Olivétan, Pierre Robert

1533 Linstruction des Enfans, Contenant la Manière de Prononcer et Escrire en Francoys. Geneva: Pierre de Wingle.

Palsgrave, John

$1530 \quad$ Lesclarcissement de la Langue Francoyse. London: J. Haukyns. Critical edition and French translation with a facsimile by Susan

Pasquier, Estienne Baddeley. Paris: Honoré Champion.

1974 Choix de Lettres, Dorothy Thickett (ed.). Geneva: Droz.

Peletier du Mans, Jacques

1550 Dialogue de l'Ortografe e Prononciation Françoęse, Departi en Deus Liures par Iacques Peletier du Mans. Poitiers: J. and E. de Marnef.

Ramus, Petrus

see La Ramée, Pierre de

Sainliens, Claude de

1580 Claudii a Sancto Vinculo de Pronuntiatione Linguae Gallicae Libri Duo. London: Thomas Vautrollier.

Sebillet, Thomas

1549 L'Iphigene d'Euripide Poete Tragiq: Tourne de Grec en Francois Sylvius, Jacobus par l'Auteur de l'Art Poëtique ... Paris: Gilles Corrozet.

Tory, Geofroy see Dubois, Jacques

1973 Champ Fleury. Au quel est Contenu Lart et Science de la Deue et Vraye Proportion des Lettres Attiques ... Original edition, Paris, Gilles de Gourmont, 1529.

\section{Secondary sources}

Baddeley, Susan

1993 L'Orthographe Française au Temps de la Réforme. (Travaux d'Humanisme et Renaissance series 276.) Geneva: Droz.

Baddeley, Susan

1995 Le choix des langues: Lefèvre d'Etaples et les questions linguistiques au début du $\mathrm{XVI}^{\mathrm{e}}$ siècle. In Jacques Lefèvre d'Etaples (1450?-1536). Actes du Colloque d'Etaples les 7 et 8 Novembre 1992, 81-95. Paris: Champion. 
Baddeley, Susan

1996 Tentatives de standardisation orthographique chez les imprimeurs français au $\mathrm{XVI}^{\mathrm{e}}$ siècle. In Italia ed Europa nella Linguistica del Rinascimento, Mirko Tavoni (ed.), vol. I, 287-300. Ferrara: Panini.

Baddeley, Susan

1999 L'Orthographe française du XVI siècle: bibliographie raisonnée. In Nouvelle Revue du Seizième Siècle 17 (1): 161-176.

Beaulieux, Charles

1927 Histoire de l'Orthographe Française. Paris: Champion.

Beaulieux, Charles

1951 Observations sur l'Orthographe de la Langue Francoise. Transcriptions, Commentaire et Fac-similé du Manuscrit de Mézeray, 1673, et des Critiques des Commissaires de l'Académie, Précédés d'une Histoire de la Gestation de la lre Edition du Dictionnaire de l'Académie Françoise (1639-1694). Paris: Champion.

Biedermann-Pasques, Liselotte

1992 Les Grands Courants Orthographiques au XVII Siècle et la Formation de l'Orthographe Moderne. Tübingen: Niemeyer.

Biedermann-Pasques, Liselotte

2001 Approche du système graphique de la Séquence de sainte Eulalie (deuxième moitié du IX ${ }^{\mathrm{e}}$ siècle). In Presencia y Renovación de la

Catach, Nina Lingüistica Francesa, 25-39. Salamanca: Universidad Salamanca.

1968 L'Orthographe Française à l'Epoque de la Renaissance. Geneva: Droz.

Catach, Nina, Jeannette Golfand, Odette Mettas, Liselotte Biedermann-Pasques, Carmen Dobrovie-Sorin, and Susan Baddeley

1995 Dictionnaire Historique de l'Orthographe Française. Paris: Larousse.

Cerquiglini, Bernard

1995 L'Accent du Souvenir. Paris: Minuit.

Cerquiglini, Bernard

2004 La Genèse de l'Orthographe Française (XII ${ }^{e}-X V I I^{e}$ siècles). (Unichamp-Essentiel.) Paris: Champion.

Citton, Yves, and André Wyss

1989 Les Doctrines Orthographiques du XVI Siècle en France. Geneva: Droz.

Dictionnaire Encyclopédique du Livre

2002 Pascal Fouché, Daniel Péchoin, and Philippe Schuwer (eds.). Paris: Editions du Cercle de la Librairie.

Droixhe, Daniel

2002 L'Etymon des Dieux. Geneva: Droz.

Morin, Yves-Charles

2008 Histoire interne du français: des systèmes phonologique et graphique. In Romanische Sprachgeschichte: Ein Internationales Hand- 
Pope, Mildred K.

buch zur Geschichte der Romanischen Sprachen, Gerhard Ernst, Martin-Dietrich Gleßgen, Christian Schmitt, and Wolfgang Schweickard (eds.), 2907-2926. Berlin/New York: de Gruyter.

1934 From Latin to Modern French with Especial Consideration of AngloNorman. Manchester: University Press.

Swiggers, Pierre, and Willy van Hoecke

1989 La Langue Française au XVI Siècle: Usage, Enseignement et Approches Descriptives. Leuven-Paris: Peeters.

Veyrin-Forrer, Jeanne

1956 Antoine Augereau, graveur de lettres et imprimeur parisien (vers 1485-1534). In Paris et Ile de France. Mémoires Publiés par la Fédération des Sociétés Historiques et Archéologiques de Paris et de l'Ile de France, vol. 8: 103-156. Paris: Klincksieck. (Reprint 1987. In La Lettre et le Texte, J. Veyrin-Forrer, 3-50. Paris: Ecole Normale Supérieure de Jeunes Filles.)

Wright, Roger

1982 Late Latin and Early Romance in Spain and Carolingian France. Liverpool: Cairns. 



\title{
English \\ Variable focusing in English spelling between 1400 and 1600
}

\author{
Terttu Nevalainen
}

\section{Overview}

Processes of linguistic standardization can be described in terms of degrees of focusing, and the standardization of spelling is no exception. Focusing here refers to a high level of agreement in a language community as to what does, and what does not, constitute "the language" at a given time (Trudgill 1986: 86). Language communities differ with respect to how much variation is tolerated in a given domain of language use and, conversely, how fixed the norms are to which speakers or writers are expected to adhere. In late medieval England the norms concerning the vernacular were quite diffuse. In this paper I will discuss the marked increase in focusing that took place in the formative years of the standardization of English spelling between 1400 and $1600{ }^{1}$

In order to provide a basis for comparing the processes of spelling standardization over time and across language communities, I will relate them to some general models of standardization applicable across European languages. One such model is proposed by Peter Auer (2005: 8), who for this purpose defines a standard variety as one used supralocally, looked upon as a high-prestige variety, and used in writing; it is also to some extent codified or shows some measure of conscious development, Ausbau. Auer suggests that prior to the rise of a vernacular endoglossic standard, there is usually an exoglossic one, such as Latin in medieval Europe.

Exoglossic norms were also adopted in medieval England. After the Norman Conquest in 1066, England was in fact triglossic as three languages assumed different functions in the language community. Latin and French served as the high-prestige varieties in which the country was ruled, while English, used locally and at home, had the status of a low-prestige language. Predictably, the three languages occupied different positions on 
the scale of fixity, with English, when committed to writing at all, showing the highest degree of spelling variation.

However, English spelling, too, began to show a degree of focusing from the mid-14th century on, as the vernacular started to replace French, in particular, in various written-language functions. In his classic paper, Michael Samuels (1963) identifies four incipient standards of English, all except one originating in London. The latest, referred to as Chancery Standard, consists of documents produced by the central administration in the 15 th century. Although their spelling is far from fixed, these texts may be regarded as a major development towards a written supralocal standard before the era of movable type (Fisher 1996).

William Caxton set up the first English printing press in London in 1476. However, during its early years the innovation in fact created more spelling variation than could be found in the best manuscripts of the time, although they had the same reference variety. To use the terms proposed by Einar Haugen (1997 [1966]), the incipient standards, notably the King's writing offices, had selected the variety, southern rather than northern, that was to undergo standardization and, despite the diffuseness of their norms, the first printers had, for their part, accepted it. $^{2}$

Even in the 16th century, spelling standardization was not solely the business of the printers, but lively debates arose about a need of spelling reform. Both reformers and conservatives highlighted the practical concerns of the teaching profession. One of the arguments in favour of a reform was that spelling conventions no longer corresponded to the pronunciation of the language at the time. By contrast, the proponents of the emerging standard were intent on codifying it; many of them also saw the need of elaborating it by etymologizing the orthography of words with classical origins.

Incipient standards and early printed books illustrate another aspect associated with linguistic focusing, i.e., its domain-specificity. I will apply the term broadly both to norms that arise from regional focusing and to those that evolve in and are mediated by certain registers, such as those produced by the central administration.

The early history of English spelling norms is discussed in section 2 in the light of Auer's (2005) model of standardization. Section 3 looks at the rise and entrenchment in the community of the first, incipient endoglossic spelling standards in England in the late 14th and 15th centuries. Section 4 traces the continuity of the transmission of English spelling norms in the first half of the 16th century, and compares spelling variation in public and private registers using the methodology developed for the study of Late 
Middle English regional variation in McIntosh, Samuels and Benskin (1986). This study, based on the Helsinki Corpus of English Texts, illustrates the focusing of the selected reference variety, and its dialectal origins. The growing part played by the printing press in the standardization process is the topic of section 5. Finally, the 16th-century orthoepic debates and their outcome are detailed in section 6 .

\section{Modelling spelling standardization}

Various relations may hold between standard and vernacular varieties in a language community over time. Analyzing these changing relations on the linguistic map of Europe, Auer (2005) proposes a typology of five basic sociolinguistic repertoires to account for the various relations between dialects and standards. In multilingual communities both exoglossic and various endoglossic standards can emerge, and the typology only takes note of exoglossic varieties used as standards. Auer observes that in medieval Europe the rise of an endoglossic indigenous standard is typically preceded by an exoglossic one, such as Latin, Old Church Slavonic or Arabic. The shift from an exoglossic standard to an endoglossic one could be a prolonged process with coexisting exoglossic and endoglossic norms; the beginning and end points of this process are presented in figure 1 (Auer 2005: 12). The outcome makes a distinction between a mainly written endoglossic standard and spoken local dialects.

exoglossic standard

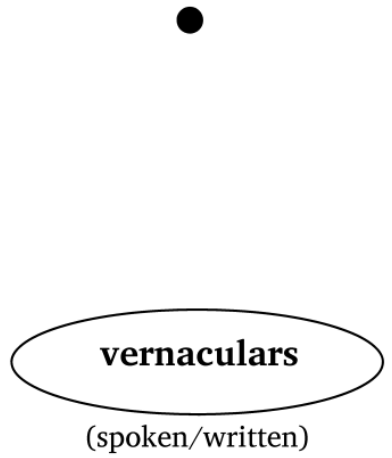

endoglossic standard

(mainly written)

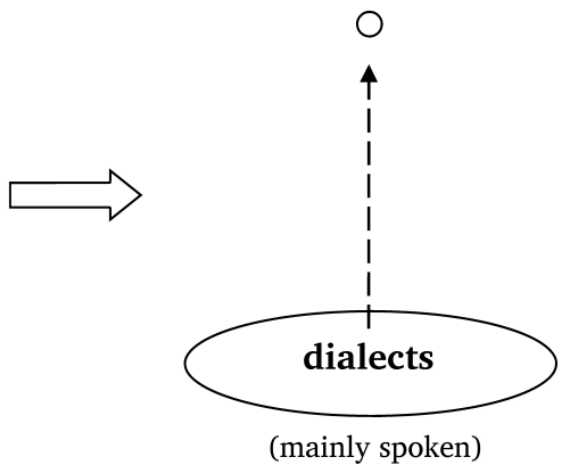

Figure 1. From exoglossic to endoglossic standards (based on Auer 2005: 12) 
Exoglossic norms also applied in medieval England. However, the history of English spelling is not one of direct continuity but several endoglossic norms emerged at different times. Although Latin, the medieval lingua franca, was used in administration and as the language of the Catholic Church and higher education throughout the Middle Ages, focused endoglossic norms arose in the Old English period (prior to 1100). By 800, a distinct Mercian literary language was taking shape and, from the late 9th to the 10th century, late West Saxon provided a dominant model in many areas of writing, including legal and religious texts. In many respects, including spelling, it was quite focused and has therefore often been referred to as "standard Old English" (Toon 1992: 426-428).

For various reasons, the late West Saxon dialect did not, however, constitute a national standard. First and foremost, England did not form a single nation with shared linguistic norms in the Old English period. Even if this had been the case, the changes that the language underwent during and after that time especially due to Scandinavian and Norman influence had altered it almost beyond recognition by the 15th century. Moreover, late West Saxon and modern Standard English are based on different reference varieties, as West Saxon was spoken in what is now the South and SouthWest of England, whereas the rise of the modern standard is associated with the East Midland area and the capital region. ${ }^{3}$

The continuity of the West Saxon tradition was interrupted by the Norman Conquest in 1066, which replaced English with Anglo-Norman French as the medium of administrative, literary and religious writings. England became in fact trilingual as the administration, church and higher education continued to use Latin throughout the Middle Ages. But the use of French, and to some extent of Latin, gradually declined towards the end of the period, and the vernacular began to gain ground supralocally as a written medium. In the latter half of the 14th century, major literary works appeared in English, including the Canterbury Tales by Geoffrey Chaucer, and in the first half of the 15th century, the vernacular gained a foothold in the written communication of the central administration.

The English that spread to the rest of the country on a nationwide scale was the written language of the government documents issued by the King's writing offices, the largest of which was the Chancery. However, as detailed in section 3, other focused varieties also emerged around the same time. The rise of the national standard from relatively focused endoglossic norms is pictured in figure 2. It suggests that, in England, domain-specific diaglossic focusing preceded the emergence of the fixed spelling standard 
as we know it today. Auer's five-stage model does not include this alternative but, as discussed below, views the emergence of regional standards as later developments, intermediate between an existing endoglossic standard and (base) dialects. In the case of English, shown in figure 2, we can speak of virtual diglossia as far as the resulting spelling standard is concerned: there is no phonemic correspondence between pronunciation and spelling, which rather follows the logographic principle of distinguishing lexical units.

focused endoglossic norms

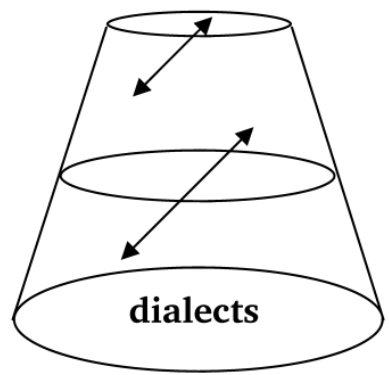

\section{endoglossic standard}
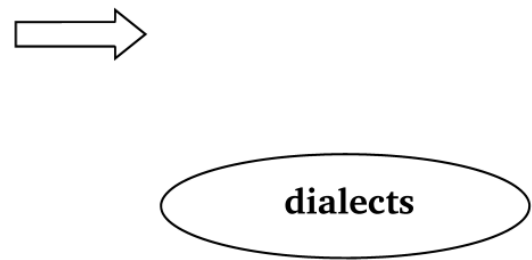

Figure 2. From focused diaglossic norms to a diglossic standard

The history of spelling norms does not always stop at the codification of an endoglossic standard. The standard can break up yielding new regional norms, as happened with British and American English in the 19th century. Auer (2005: 22) discusses these processes in the context of new-dialect formation in present-day speech communities. His model, shown in figure 3, would also appear to apply, for instance, to Romance languages in late medieval Europe, where the vernaculars developed diaglossic norms of their own. Standard English, by contrast, continues to be polycentric in that British and American orthographic norms largely coincide, but nonetheless constitute alternatives codified and upheld by educators and international publishers alike. 
standard

(spoken/written)

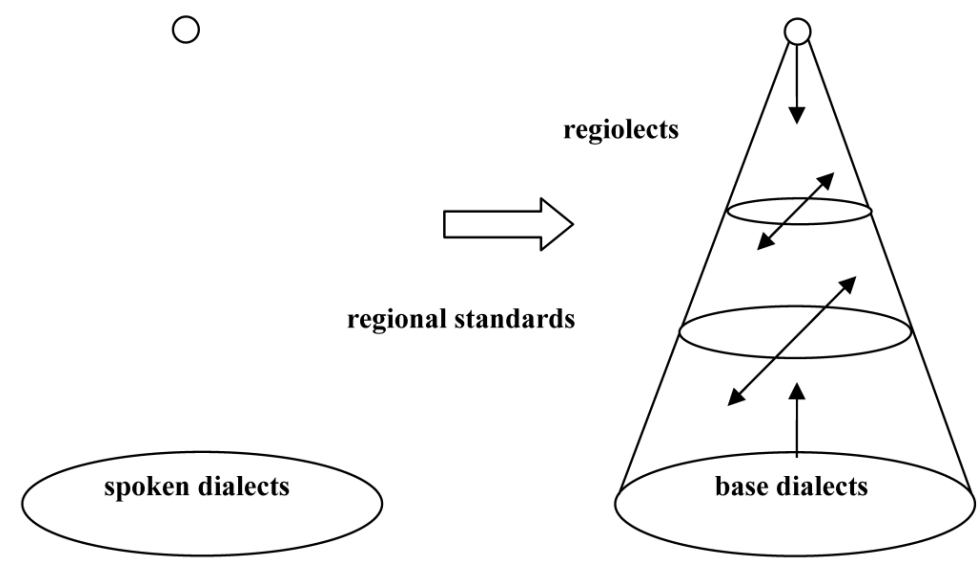

Figure 3. From diglossic to diaglossic standards (based on Auer 2005: 22)

\section{Late Middle English incipient standards}

\subsection{Contact influence}

The transition from exoglossic to endoglossic norms in Late Middle English (c. 1350-1500) did not take place without considerable contact influence. Through wide-ranging trilingualism of the literate social ranks and extensive lexical borrowing, Latin and French spelling conventions left their marks on the emerging standard of English. In systemic terms, the basic phonemic fit between English spelling and pronunciation was weakened by the adoption of new digraphs and grapheme/phoneme correspondences.

In the course of the Middle English period, the non-Latin letters thorn $<\mathrm{p}>$, eth $<\mathrm{\partial}>$, ash $<\mathfrak{x}>$ and yogh $<3>$, used in Old and Early Middle English, were gradually replaced by Latin equivalents. Thorn and eth were replaced with the digraph $<$ th $>$ (this, with), ash by $<\mathrm{a}>$ (that), and yogh typically with $<\mathrm{gh}>$ and $<\mathrm{y}>$ (thought, you). New spelling conventions were introduced as $<\mathrm{j}>$ and $<\mathrm{v}>$ were used as allographs of $<\mathrm{i}>$ and $<\mathrm{u}>$, respectively, and $<\mathrm{y}>$ and $<\mathrm{i}>$ became interchangeable.

Following French orthography, the digraph $<$ ou $>$ came to be used for the Middle English long /u:/ (house), and $<0>$ for the short /u/ (come, love). 
Other long vowels were often marked by doubling the vowel symbol, as in $<$ ee $>$ for $/$ e: $/$ and $<$ oo $>$ for /o:/. In the consonant system, besides the regular $<\mathrm{s}>$ (see), $<\mathrm{c}>$ came to be used for /s/ before front vowels not only in loan words (cellar) but in native words such as mice (cf. mouse). The digraph $<\mathrm{qu}>$ replaced $<\mathrm{cw}>$ in words such as queen (OE cwen). As shown in detail by Scragg (1974), these multiple conventions arising from language contact complicated the emergent English spelling norms.

However, it should be borne in mind that the late medieval spelling system of English - to the extent that we can talk about one system - was characterized by a high degree of regional variation and general instability. Additional fluctuation was caused by the erosion of the inflectional system in Late Old and Early Middle English, which reduced word-final endings to an unstressed vowel, typically represented by $<e>$ in later texts.

Although the focus of this volume is on the 16th century, the major steps towards the standardization of English spelling, the reduction in localizable spelling conventions, that had already been taken in the previous century deserve to be discussed in some detail. They include - in Haugen's terms (1997 [1966]) - the selection of the variety to undergo standardization and its acceptance first by institutions contributing to the process and later by the language community at large.

\subsection{Focusing of spelling in Late Middle English}

Middle English scholarship distinguishes several writing norms that tended towards regularization of spelling and morphology in the 14th and 15th centuries. Information about them, and the regional variation of English in that period, has been accumulated by the LALME project, and the research tool produced by it, A Linguistic Atlas of Late Mediaeval English (McIntosh, Samuels and Benskin 1986). On the basis of dialect comparisons Samuels (1963) established four incipient written standards, which he calls Types I to IV. All four display a fair amount of spelling variation, but Types I and IV are more focused than II and especially III.

Type I, used from the mid-14th century onwards, has come to be known as Central Midland Standard because it was based on dialects of the Central Midland counties, especially Northamptonshire, Huntingdonshire, and Bedfordshire. Typical Type I spellings include mych 'much', ony 'any', sich 'such' and silf 'self'. Features of this incipient standard are found in a large number of texts, in particular, in the religious writings of John Wycliffe (d. 1384) and his followers - tracts, sermons, and all copies of the later and 
many of the earlier versions of the Lollard Bible. Type I written language was widely copied and survived until the late 15th century (Samuels 1963: 84-85). Later research has shown that it was common in vernacular medical writings of the period (Taavitsainen 2000, 2004).

The other three incipient standards were directly connected with the London area, and it is suggested that their differences reflect the changing patterns of immigration to the capital from different parts of the country at different times (Samuels 1963: 91, McIntosh, Samuels and Benskin 1986: 27). The earliest, Type II, consists of a group of 14th-century texts. The Auchinleck manuscript, dated to the $1330 \mathrm{~s}$, is taken to be representative of this group. It contains saints' lives and legends, religious verse and romances. Type II features include the present-participle ending -ande '-ing', eld(e) 'old', noper/noiper 'neither', werld 'world'.

Type III represents a later type of London writing and appears in texts copied in the late 14th century. These are mostly literary and include the best Chaucerian manuscripts of the Canterbury Tales, a copy of Piers Plowman, writings of the poet and clerk Thomas Hoccleve (c. 1367-1426), as well as a number of London documents. Type III texts are characterized by features such as bot 'but', nat 'not', swich(e) 'such', thise 'these', and yaf 'gave', but also by neither, they, though, and world, which form part of the modern standard (Samuels 1963: 88-89).

Type IV, "Chancery Standard", is the latest of the incipient standards associated with the capital. It is found in government documents issued by the Chancery, the Exchequer, the Privy Seal Office and the Signet Office from c. 1430 onwards. Evidently it was the Signet Office, the King's small personal writing office, that provided the model - albeit a variable one that the others accommodated to. Forms identified as typical of Type IV include but, not, thes(e) 'these', theyre 'their' and such(e), but also gaf 'gave', shulde 'should' and thorough/porowe 'through'.

These usages spread as English administrative and legal documents were issued, copied and disseminated within and by the government offices. The Inns of Chancery and Inns of Court were active in training their staff, other clerks, and common lawyers to master the form and content of these documents in Latin and French, and, it is assumed, also in English. Besides Samuels (1963: 88-93), Chancery Standard is discussed and illustrated, e.g., by Richardson (1980), Fisher, Richardson and Fisher (1984), McIntosh, Samuels and Benskin (1986: 47-49), Fisher (1996: 36-64) and Smith (1996: 68-73). Benskin $(1992,2004)$ criticizes some received views, notably those by Fisher and his associates, on Chancery Standard as inaccu- 
rate, and calls for more empirical research especially on the regional diffusion of standards.

The LALME project shows that, apart from the incipient standards first identified by Samuels (1963), Late Middle English was characterized by extensive use of "colourless" mixtures of regional dialects in non-literary texts. They were unstable and showed local register variation, but as they displayed the more widespread features of their respective varieties to the exclusion of those that were more distinctly local, these usages are often referred to as "colourless regional standard" (McIntosh, Samuels and Benskin 1986: 47, Smith 1996: 73-77, Benskin 1992: 82-85).

Dialectal levelling of this kind can also be found in other medieval European vernaculars before standardization set in (Auer 2005: 10). I would assume that levelled usages suppressed stereotypical and sociostylistically marked features of regional dialects, i.e., those features that had risen above the level of social awareness in the discourse community. These "regional standards in the making", as Benskin (1992: 84) calls them, may have served as a regionally neutralized backdrop for the assimilation of more focused, nationwide norms. ${ }^{4}$

\subsection{A Lancastrian language policy?}

Before the 1430s, the use of English by the royal writing offices was the exception rather than the rule. It was during his second campaign to France in 1417-1422 that King Henry V (1387-1422) began to dispatch most of his official correspondence home in English instead of French, as had been the custom before. It is commonly held that probably his reasons for doing so were not only strategic, prompted by enemy intelligence, but also financial: by using the vernacular the King hoped to enlist support from the citizens of London (Richardson 1980: 740-741, Fisher 1996: 20-23).

John H. Fisher (1996: 20-30) goes on to argue that the decision must have been part of King Henry's deliberate language policy to justify the Lancastrian claim to the throne by promoting English nationalism among the wealthy citizens of London and other English cities against the Frenchspeaking nobility. Another indication of this policy was, according to Fisher (1996: 28), the upsurge in the production of copies of literary works in English, Chaucer manuscripts in particular, during the Lancastrian era.

Not all writers espouse Fisher's views of Lancastrian nation-building by means of a deliberate language policy. Blake (1997b), for one, expresses his reservations concerning deliberate planning and management, and also 
remarks that many Chaucerian manuscripts were produced in the early part of the 15th century and some possibly in the late 14th century, as were manuscripts of the poems of Chaucer's contemporary John Gower (d. 1408). Blake's conclusion (1997b: 512-513) is that Henry V is likely to have taken some interest in the language of his letters, but it does not follow from this that Lancastrian kings had a deliberate language policy.

Whatever the ultimate motivation for Henry V's adoption of English in his missives may have been, the clerks of his Signet Office came to select the basic reference variety to be utilized for the purpose. There had been two local norms in the London area in the 14th century, Types II and III, but no direct continuity can be traced between this first supralocal written norm and its predecessors although Chancery Standard was also Londonbased (see 3.4.). However, had the King decided to retain the city of York as the seat of government, as it had been some hundred years earlier, the choice would probably have been in favour of a northern reference variety rather than a southern one (cf. Heikkonen 1996: 116).

Institutional support may partly account for the success of Chancery Standard in comparison with the other incipient standards. Administrative and literary texts typically enjoy a rather different institutional status. Once Chancery Standard was adopted by the various government offices in their English communication around 1430, it was "backed by the full weight of the administrative machine" (Samuels 1963: 89), while the main audience of the Chaucerian manuscripts, texts of Samuels's Type III, consisted of a "rather tight circle of civil servants and lesser gentry" (Blake 1997b: 512). Samuels (1963: 88) maintains that neither Type II nor Type III could be looked upon as influential literary standards of their time.

Although London-based, these two incipient standards not only lacked sufficient institutional support but they were presumably also not focused enough to survive the diffusing Chancery Standard. By contrast, the more uniform Type I was widespread in the 14th century and continued well into the 15th century; it was also used in contemporary medical texts (Taavitsainen 2000). It was, however, associated with the sectarian religious movement of Lollardy, which met with strong persecution in the 15th century, especially under King Henry V (Corrie 2006: 111). The Lollard movement persisted throughout the 15th century, but it did not have a direct connection with the English Reformation in the next century (Hudson and Kenny 2004). Chancery Standard was thus left as the major contender for a focused variety at the national level in the 15 th century. 


\subsection{Features of "Chancery Standard"}

Auer (2005: 20-22) makes the generalization that, combined with political centralization, capital cities had a leading role to play in providing models for emerging national standard varieties in Europe. This holds true for English as well. Chancery Standard is East Midland-based, and southern rather than northern in outlook. It represents the variety associated with the capital, which was the administrative, financial, and cultural centre of late medieval England. Having the highest potential in England for interaction with other towns in terms of population, transport advantages and migration fields (Keene 2000: 101-108), London was the hub from which innovations of all kinds diffused - a position it only strengthened in the following centuries.

Grammatically, Chancery Standard typically displays London and Central Midland features such as the southern third-person verbal ending -th (hath, sayeth) as opposed to the northern $-s$ (has, says), and the plural be/ben (v. northern are). Some Midland features of northern origin also appear, probably reinforced by the number of Chancery clerks who came from the northern counties in the Lancastrian era. They include the plural personal pronouns in th- (they, them and their) as opposed to southern forms in $h$-; adverbs ending in -ly (v. southern -lich); suffixless plural forms of verbs (v. southern forms in -(e)n); and past participles without the prefix $y$-, as in called (v. southern ycalled) (Fisher 1996: 50-51, 76). ${ }^{5}$

Although it is the northern forms with $<\mathrm{g}>$ that are to become part of the national standard, Chancery Standard uses $<\mathrm{y}>$ for $/ \mathrm{j} /$ in words like ayen ('again') and yeue ('give'). It provides a conservative norm in that it does not reflect ongoing phonetic developments. The digraph $<\mathrm{gh}>$ is used as a reflection of the velar fricative in words like high and knight, although its vocalization was well under way in speech. Similarly, although $<\mathrm{h}>$ was almost certainly not pronounced, it is retained in French loans such as heir and honour in texts representing Chancery Standard. Not unlike other texts from this period, they also treat the final $<\mathrm{e}>$ unsystematically in unstressed positions (Fisher 1996: 50-51, Fisher, Richardson and Fisher 1984: 28-33).

However, few practices of the government offices were absolutely fixed in the 15th century, as can be seen from the number of variant forms and spellings of ordinary words that appear in official documents. A couple of examples may suffice to illustrate this stage of focusing. Although the spelling such, with or without a final $<\mathrm{e}>$, is the preferred form in these documents, several alternative forms are found in different proportions, including sich, sych, seche, swich and sweche. Similarly, not is the pre- 
ferred spelling of the negative particle with nat as a minority form, but there are also clerks who prefer to spell the word with $<\mathrm{gh}>$ or $<3>$ after the vowel (Fisher, Richardson and Fisher 1984: 27, 30).

Some of these practices are illustrated by two versions of a summons to arms recorded in the name of King Henry VI by the Privy Seal in 1436 (Fisher, Richardson and Fisher 1984: 161-162, 164, Smith 1996: 72). They are reproduced in part in (1) and (2). These passages display alternation, for instance, between thorn $<\mathrm{p}>$ and $<$ th $>$. Together with certain other medieval spelling conventions, notably abbreviations, this variation continued well into the next century. Other conventions shown here, such as the use of the letter $\langle\mathrm{v}\rangle$ word-initially for $\langle\mathrm{u}\rangle$ as well as for $\langle\mathrm{v}\rangle$, and the letter $<\mathrm{u}>$ word-internally, were regarded as the norm even in print until the beginning of the 17 th century.

(1) 1436E28/57A, Privy Seal: Summons to Arms (part)

By pe kynge Trusty and welbelouyd ffor asmoche as he pat calleth him Duc of Bourgoigne oure rebell with his puissaunce of fflemmenges Picardes Bourgoignons and oper is come ouer pe water of Grauelyng and hath pighte his tentes with Inne oure Pale of pe marches pere willyng and disposyng him to gete oure Toune of Caleys and alle oure strengthes in pe marches pere be whiche if so were pat god defende shulde be vn to vs you oure Reamme and subgittz to grete an hurte and a perpetuelle shame we perfore willyng to resiste pe malice of (be) saide callyng him Duc dispose vs in persone for to go to oure Citee of Caunterbury for pe rescous to oure said Toune and marches ...

(2) 1436E28/57C, Privy Seal: Summons to Arms (part)

By the kyng Trusty and welbeloued for asmoche as he pat calleth hym Duc of Bourgoine oure rebell wyth his puissance of fflemynges picardes Bourgoignons and oper is come ouer the water of Gravelyng and hath pight his tentes with Inne oure pale of the marches there willyng and disposyng hym to gete oure tovne of Caleys and all oure Strengthes in pe marches pere. the which if so were pat god defende shuld be vnto vs yowe oure roialme and subgettes to grete an hurte and perpetuell shame: we perfore willyng to resiste the malice of the said callyng hym Duc. dispose vs in persone for to goo vnto oure Citee of Caunterbury for the rescous to owre seid tovne and marches ... 
Although Chancery Standard obviously falls short of the requirement of fixity set for modern spelling standards, it represents a move towards it. The next section will look at its diffusion in the language community.

\subsection{Manuscript tradition before 1500}

Chancery Standard constituted a nationwide endoglossic written norm in 15th-century England. In the course of the 15th and early 16th centuries, legal and administrative language increasingly converged upon this norm (McIntosh, Samuels and Benskin 1986: 47-49). McIntosh, Samuels and Benskin (1986: 22) note that, during the period 1420-1550, it provides the only norm into which writers would code-switch, and replace their own original regional spellings with those of this emerging standard. This process of focusing was not, however, straightforward.

Institutionally, the central government had a leading role in setting linguistic models for others to follow. But the existence of such norm-setters did not mean a wholesale adoption of these norms by other institutions, let alone by the language community as a whole. There are several reasons for this. As we have seen, the norm itself was probabilistic, focused, rather than fixed: while there are preferred Chancery Standard spellings such as any and but, there are others that are much more variable (e.g., much(e), moch(e), mych(e) 'much'), and, interestingly, still others whose preferred Chancery form is not part of written Standard English today (e.g., wold(e) 'would'; cf. Blake 1997a). The emerging norm represented domain-specific usage and was associated with a variety of legal and administrative genres. Even if their practices had been uniform, mechanisms such as universal schooling in the vernacular through which these norms could have been enforced outside their respective institutions and communities of practice were lacking in the 15th century, as were systematic teaching materials that could have been used to that effect. In this period, the ideology of standardization, to use the term of Milroy and Milroy (1999: 30), did not extend to the vernacular to the same extent that it was observed for the classical languages.

Considering the process of spelling standardization in the 15th and early 16th centuries, Samuels (1981: 44) presents four alternative strategies that individual writers could follow: (A) localizable dialect, (B) Chancery Standard, (C) writing with a regional basis which includes forms of Chancery Standard, and (D) "colourless" regional writing. In practice he finds that the 
alternatives combine and that texts can be graded on a scale, for instance, between (A) and (C) and (C) and (D).

It is therefore hardly surprising that even the preferred Chancery forms were not systematically followed, for instance, by the scribes copying the manuscripts of Chaucer's Canterbury Tales in the 15th century. In his study of eight common lexical items (but, given, not, should, such, their, these, and through) in 50 medieval copies of the Pardoner's Tale, Smith (1996: 73) found that there had been "a slight general movement towards Chancery Standard forms" but also that "the process is neither complete nor decisive". The manuscripts continue to display colourless written language, a dialectal mixture of non-Chancery forms, the use of which was widespread in the 15th century (see 3.1.). Even by the last quarter of the 15 th century, these scribes had not adopted the preferred Chancery forms for such common items as given, these, their, and through (Smith 1996: 74-75).

Blake (1997a) made a similar study of the extent to which Chancery practices were adopted in copies of the Wife of Bath's Prologue produced in the course of the 15th century. These texts consist of 54 manuscripts and four printed books, and they cover the entire century. Blake analyzed lexical items many of which have preferred spellings in Chancery Standard: any, but, many, much, not, such and which, as well as some modals, in the later copies of the Wife of Bath's Prologue. His findings (1997a: 22) mirror those of Smith: "certain forms show a movement towards the standard associated with Chancery English but this is not true of all forms". His most striking example of standardization is the reduction of swich(e) forms in favour of $\operatorname{such}(e)$. The colourless regional forms found, however, rarely represent truly non-metropolitan spellings. Blake (1997a: 23) concludes that the tolerance for broad dialectal spellings significantly decreased in the course of the century, and variation came to be restricted to certain alternative spellings.

There are also a number of studies on individual spelling practices suggesting the relevance of dialect contact, both regional and social, in the diffusion of spelling norms at the close of the Middle Ages when formal education was focused on Latin rather than on English (Davis 1983, CondeSilvestre and Hernández-Campoy 2004, Hernández-Campoy and CondeSilvestre 2005). These studies indicate how, in the late 15th century, especially individuals connected with the legal profession modified their spelling towards the Chancery usage of the time. The divergence of the two Paston brothers with identical upbringing but different careers, is a case in 
point (Davis 1983). Overall, individual accommodation was, however, idiosyncratic and incomplete, as the norms of public documents themselves were not yet fixed either.

These studies bear witness to the displacement of regional spellings at the close of the Middle English period. One of the mechanisms that have been suggested to have contributed to this levelling is institutional in nature: the growth of centres of education, notably of grammar schools. Samuels (1981: 48) speculates that they employed teachers brought up in other areas, who would not have shared local norms. Coming into contact with outsiders was clearly the motive force behind colourless regional writing in the first place: it started to replace more strictly local forms as English was gaining ground as a language of business and administration (Benskin 1992: 84). This is of course basically the same mechanism that spread Chancery Standard not only in government missives but in personal interaction with professionals with sufficient training in or exposure to it.

\section{Official and private spelling between 1500 and 1550}

\subsection{Individual accommodation}

Not surprisingly, public writings were linguistically more focused than private ones even in the 16th century. Gómez-Soliño (1981) analyzed the relative standardness of 31 spellings in letters written in the 1520 s by two eminent public figures, Sir Thomas More (1478-1535), a classical humanist, who studied at Oxford and the Inns of Court in London and served as Lord Chancellor under Henry VIII, and Thomas Wolsey (1470/71-1530), a royal minister, archbishop, and cardinal. The comparative material GómezSoliño used consisted of the Statutes of the Realm enrolled in the Chancery in 1523 and 1529. He concludes (1981: 74) that in most cases the public documents were leading the way towards modern forms, while More and Wolsey both showed individual accommodation to this increasingly focused norm. That the emerging norm itself was not yet fixed can be seen in such preferred spellings as moch(e) 'much' and wold(e) 'would'.

A comparison of Sir Thomas More's printed work and his autograph letters shows that printers preserved some authorial spellings but replaced others by their own (Samuels 1981: 44). This suggests that these printers' implicit norms may have differed from those of More (cf. 5.2.). 


\subsection{Comparing public and private writings}

The decades leading up to heightened awareness of English spelling norms offer an opportune period for studying the consolidation of public spelling with more varied data than has customarily been included in empirical work on 16th-century English spelling variation. In Raumolin-Brunberg and Nevalainen (1990), my colleague and I investigated spelling variation using the Helsinki Corpus of English Texts. The study is based on data taken from the first Early Modern English section (1500-1570) of the corpus, which is divided into fifteen genres (Nevalainen and RaumolinBrunberg 1993). We started from the assumption that different genres are likely to display differing degrees of spelling variation, reflecting both the formality of the genre and the professional, educational and regional backgrounds of the writers. The data selected for detailed scrutiny consists of two contrasting registers, official and private texts written between 1500 and the mid-1550s.

The official registers studied consisted of the Statutes of the Realm enrolled in the Chancery (ten acts, totalling 11,640 words) and of official correspondence produced by the King and his officials (6,250 words). The private kinds of writing included correspondence (12,700 words), samples of two diaries (10,570 words) and of one autobiography (5,740 words). These private materials came from male and, in the case of letters, also female writers from different regions, North and South. For bibliographical references of the data sources, all originally hand-written, see Kytö (1996).

Samples of the two kinds of writing are shown in (3) and (4), below, with items commonly included in standardization studies (such as GómezSoliño's) marked in bold. Both texts are cited from good scholarly editions, which, however, follow the long-standing editorial practice of modernizing the regular use of $\langle\mathrm{v}>$ word-initially and $<\mathrm{u}>$ medially for both the vowel and the consonant (see above, 3.1.), and adding modern punctuation. Apart from these editorial conventions, original spelling is preserved throughout. A royal missive addressed to the citizens of London under the sign manual of Henry VIII (1491-1547) at the head of the letter is shown in (3).

(3) Henry R.

Trusty and welbiloved we grete you wele. Signifieng unto you it is shewed unto us that albeit our welbiloved servant Edward Vaux, oon of the purveyors of our wynes, hath been with you sundry tymes in our name to cause provision to be made for cariage of our wynes from that our Citie of Lon- 
don, for th'expenses of our Household, into these parties: yet neverthelesse ye have litle regarded the said provision, as it is sayed, whereby we be destitute of suche wynes as we wold have here: of the which your demeanur herin we cannot a litle mervaile: wherfor we advertise you of the same, willing and commaunding you that whansoever any our Surveyors either for Wynes or other stuf, from hensforth, shall reasorte unto you in our name for provision of cariage of the same hither or elliswhere where it shall fortune us to be, ye will effectually endevoir yourself for the qwyk expedicion therof, without any failing as ye entende to please us. Yeven under our Signet at our Monasterie of Abendon the xjth. day of Aprill.

The passage in (4) reproduces parts of Lady Katherine Skrope's letter to her father, the Earl of Cumberland, from 1536. The writer is a noblewoman from the North of England, and the letter is judged to be a holograph. Holograph letters by women are not common in the early part of the 16th century, when women's ability to write generally lagged behind men's even among the highest social ranks (Nevalainen 2002a, Nevalainen and Raumolin-Brunberg 2003: 40-43).

\section{(4) Lady Katherine Skrope}

My dewty promysed unto your Lordship in my most humbliest maner; advertysyng the same that yesterday the commons off Richmontshir did meat at Richmond, wher undoubtedly they dewydet them in thre partyes ... My Lord my bedfelow is this nyght at Helbek Hall \& wulbe with your Lordshipe at Skypton in as convenyent spead as he can maik, to tak suche parte as your Lordshipe dothe. And I wull come this mornyng towardes Katelwell $\&$ tary there off my bedfelowe, and wold come with hym to Skipton, iff ye thynk it good. And this nyght I have sent my litell boy with his nursse unto one poore mans housse, to be kept privy there to we knowe forther. And what your Lordshipes mynd is in the premysses I wull hertly besuche you to send it to Catelwell with this berere. Thus tholy Gost preserve youre good Lordship with my Lady my mother \& all youres in comfort. At Bolton, this Setterday before day,

Your humbliest doughter,

Kateryn Scrope.

The methods developed in the compilation of A Linguistic Atlas of Late Medieval English (McIntosh, Samuels and Benskin 1986) were applied to the two sets of data. Following earlier research informed by $L A L M E$, we based our analysis on sixteen common English lexemes with variable spelling. Twenty-eight forms were originally included in the list of items to be 
analyzed, but twelve were discarded, either because their frequency was too low for quantitative comparisons or because they were already invariant, having reached their Present-day level of fixity. ${ }^{6}$ If these invariant lexemes had been included, $82 \%$ of the most frequent items would have been the same in both registers.

We compared the remaining sixteen forms with alternative spellings in two ways: first, by considering all spelling variants of each lexeme, and secondly, by focusing on diagnostic orthographic signs, which might have been indicative of the writer's regional provenance. In the second analysis we followed the LALME guidelines and previous studies such as GómezSoliño (1981), and arrived at the diagnostic forms by discarding the presence or absence of word-final $<\mathrm{e}>$, and the alternation between $<\mathrm{i}>$ and $<y>$, which was so frequent and random that it cannot be taken as indicative of dialectal variation either in speech or in writing; it does not stabilize in print until the 17 th century.

\subsection{Register variation}

The items investigated are listed below in Table 1. In Group 1, each item has more than ten occurrences in both registers, and in Group 2 fewer. In broad terms, our findings show what might be expected: fewer spelling variants are found in official writings than in private ones. This is particularly the case if we consider all orthographic variation, including the final $\langle\mathrm{e}\rangle$ and the $\langle\mathrm{i}\rangle \mid\langle\mathrm{y}\rangle$ alternation. But there are some exceptions even among the diagnostic variants: LAND, THEM and AGAINST have fewer variants in the private texts than in the official ones.

Table 1 shows the distribution of what proved to be the diagnostic variants in the data. The main variants, occurring in $80-100 \%$ of the cases, are written in capitals, the lesser variants $(21-79 \%$ of the occurrences) are shown in lower case, and the rare variants (20\% or less) are put in brackets. The unstable final $<\mathrm{e}\rangle$ and $\langle\mathrm{i}\rangle|<\mathrm{y}\rangle$ are underlined.

The following generalizations emerge from these results. First of all, the two registers to a large extent share the same sets of variant forms. There is no lexeme that would be represented by one register-specific variant only. Five variant sets are identical (MUCH, ANY, THESE, WHEN, MOTHER) in both registers. What is more, the most frequent variant (the one to the left) is the same in 13 lexemes, that is in $72 \%$ of the cases ( $82 \%$ if the invariant forms are also considered). 
Table 1. Diagnostic spelling variants in two registers (Raumolin-Brunberg and Nevalainen 1990: 126)

\begin{tabular}{|c|c|c|}
\hline & Official writing & Private writing \\
\hline \multicolumn{3}{|l|}{ Group 1} \\
\hline SUCH & SUCHE, (soche $)$ & SUCHE, (soche), (syche $)$ \\
\hline LAND & LANDE्E, (londe $)$ & LANDE $\underline{E}$ \\
\hline MANY & MANYE, (meny) & monye, manye \\
\hline THEIR & THEIRE, (there) & there, theire, (thear) \\
\hline OTHER & OTHERE, (odyr) & othere, odur, (oder) \\
\hline MUCH & muche, miche, moche & muche $\underline{e}$ moche, (miche $)$ \\
\hline ANY & anye, eny & ANYE, (eny) \\
\hline THEM & them, theim & THEM \\
\hline AGAINST & againste, (ayenst), (agenst) & AGAINSTE, (aganst) \\
\hline \multicolumn{3}{|l|}{ Group 2} \\
\hline HER & HERE & HERE, (hir) \\
\hline CHURCH & CHURCHE & chyrche, churche, (cherche) \\
\hline BROTHER* & BRO/ETHERE & BRO/ETHERE, (brodere) \\
\hline OWN & owne, awne & OWNE, (owen) \\
\hline THESE & these, (thies), (thise $)$ & these, (thise), (thies) \\
\hline WHEN & when, whan & when, whan \\
\hline MOTHER & mother, moder & MOTHER, (moder) \\
\hline
\end{tabular}

* Note: BRO/ETHER marks the two stems of BROTHER, which can have either $<\mathrm{o}>$ or $<\mathrm{e}>$ medially.

At the same time, both registers display some variants of their own: the official register as many as seven, including three common 15th-century Chancery forms $(<$ londe $>$, $<$ theim $>$, and $<$ ayenst $>$ ), and two that correspond to rarer Chancery variants $(<$ meny $>$, < agenst $>)$. However, there are also some Chancery forms among the eleven register-specific variants in private writings (including $<$ hir $>$, < odur $>$, <oder $>$, and $<$ brodere $>$ ).

Both registers return forms with particular regional origins: <cherche $>$ and $<$ owen $>$ are originally Kentish, $<$ awne $>$ of northern origin and $<$ monye $>$ a West Midland form; <chyrche $>$ is a popular London variant. As might be expected, these forms are more frequent in the private writings than in the official ones.

These findings do not make the private texts regionally localizable, however. Six of these spellings did not appear in 15th-century London according to LALME (<soche>, <monye >, <meny >, <thear>, <thies $>$ and 
$<$ awne $>$ ). In our 16th-century data, five of them occur in the writings of Londoners, including Sir Thomas More and Henry Machyn. ${ }^{7}$ More was from London, but Machyn had probably moved there from Yorkshire (Britton 2000). The capital region attracted large numbers of migrants, and dialect contact promoted dialect mixing and levelling, not only in speech but also in writing. The spellings attested in London were therefore partly a reflection of the variety of regional backgrounds of the metropolitan population - as it had also been in the previous centuries. As a consequence, these forms had been absorbed into the pool of colourless written language of the time.

\subsection{Conclusions}

As pointed out above, our research was based on lexemes with alternative spellings. The texts studied also contained a number of lexemes we labelled as invariant: NOT, HAND, MAN, AND, FARTHER, FURTHER, HITHER, TOGETHER, MIGHT, YET and WHICH. In the light of these findings and previous studies (Benskin 1992: 80, Blake 1997a, Taavitsainen 2000: 144), it is obvious that lexical diffusion had a role to play in the standardization of English spelling at this stage. Partly because of this relative consensus on the spelling of native lexis, it was too late to introduce the phonemic principle as the backbone of the English spelling system, as proposed by mid-16th-century spelling reformers (see section 6 ).

These findings should not, of course, be overgeneralized. The high degree of uniformity found in the data only suggests a general tendency in the set of diagnostic variants in the first half of the 16th century. More variation can obviously be found if we go beyond these features, as shown by the private letter in (4), for instance. A look at some more varied, socially stratified corpora with private writings shows that there were few absolutely invariant spellings at the time, or even later, especially when it comes to the new borrowed strata of the English lexicon (Nevalainen 1999: 358371). As spelling is something that must be taught, variation is bound to occur as long as educational opportunities are unequally distributed.

Moreover, private registers appear to have some regularities of their own, ruled out in the public domain. Features of what Osselton (1984) calls a private, epistolary spelling system continued well after the fixing of the public. Until the 18th century and beyond, it is characterized by the use of contractions, phonetic spellings and the retention of old forms. 


\section{The role of the printing press}

\subsection{Variability in early print}

The advent of movable type provided the means of disseminating written texts in multiple identical copies, spreading certain forms and conventions, and suppressing others. While the production of medieval manuscripts was the province of scribes, who were responsible for their actual written form as well as making copies of them, more parties were involved in the process of producing printed texts: master-printers, who ran the business, compositors, correctors and press-men (see Baddeley, this volume). In practice not all of them were equally qualified, but the various tasks were divided between the master-printer and his apprentices and servants (Bennett 1989, I: 178-180).

William Caxton (1415/24-1492) set up the first English press in 1476 in Westminster, the seat of the Royal Court and the central government of the country. Born in Kent, Caxton was apprenticed to a cloth merchant in London, and spent twenty years in the Low Countries and Germany as a mercer and merchant adventurer exporting English cloth and importing luxury goods. In the early 1470 s, he went to Cologne, one of the German centres of the book-trade, where he acquired his printing press and learnt how books were produced. He also began to translate texts from French into English to provide material for his press. In 1474, he published his Recuyell of the Historyes of Troye, Raoul Le Fèvre's stories of the Trojan Wars, in Bruges. It was the first book to be printed in English (Blake 2004).

Although there were incipient standards of English, and it had been in administrative use for some fifty years before the introduction of the print medium, English was not fixed enough to meet the needs of the first English printer-translator. After fifteen years in business, Caxton is still complaining about the variability of English in a much quoted passage of the preface to Eneydos, his translation of Virgil's Aeneid (1490), presented here in (5). He observes that English has changed beyond recognition in the course of time - the early texts he had read were "more lyke to dutche [= German] than englysshe". It had changed even during his lifetime, and spoken language continued to vary regionally. 
(5) Caxton

and fayn wolde I satysfye euery man / and so to doo toke an olde boke and redde therin / and certaynly the englysshe was so rude and brood that I coude not wele vnderstande it. And also my lorde abbot of westmynster ded do shewe to me late certayn euydences wryton in olde englysshe for to reduce it in to our englysshe now vsid / And certaynly it was wreton in suche wyse that it was more lyke to dutche than englysshe I coude not reduce ne brynge it to be vnderstonden / And certaynly our langage now vsed varyeth ferre from that. whiche was vsed and spoken whan I was borne / For we englysshe men / ben borne vnder the domynacyon of the mone. whiche is neuer stedfaste / but euer wauerynge / wexynge one season / and waneth \& dyscreaseth another season / And that comyn englysshe that is spoken in one shyre varyeth from a nother.

Spelling standardization was not the major linguistic concern of the first English printers. There were no house-styles and a compositor could select a spelling variant depending on the amount of space needed to justify a line. As it happens, many early English printers and compositors were immigrants, and not necessarily familiar with the emerging standard. It is hence often observed that the first books printed in English displayed more spelling variation than is found in the best manuscripts of the time or, for that matter, in the printed books produced on the continent (Scragg 1974: 64-67). However, studies of English incunabula suggest that printers could also adopt varying attitudes to the spelling of their copy texts depending on the authority they perceived them to carry.

One of Caxton's major projects became the printing and publication of Geoffrey Chaucer's Canterbury Tales. Although he did not become a lawprinter, under Henry VII Caxton was also commissioned to print the parliamentary statutes, to be printed for the first time in English (Bennett 1989, I: 76). The first English printer was thus exposed to and active in the transmission of these two different textual traditions, each associated with spelling practices of its own.

Studying text samples totalling 264 lexemes, Fisher (1996: 128-129) found that Caxton used a large majority of Chancery forms throughout his printing career. By doing so, Fisher argues, he perpetuated the variations and archaisms found in this variety. Analyzing a set of 10 diagnostic lexemes in Caxton's Wife of Bath's Prologue, Horobin (2001: 256-257) partly agrees, but reports that Caxton preserved more original spellings than did Richard Pynson, one of his successors, who followed more closely Chancery Standard. As Caxton's other literary publications show variation ac- 
cording to author, Horobin (2001: 258) concludes that printers could adopt an individualistic response to the perceived authority of the texts to be printed.

While there seems to be clear continuity of Chancery Standard in the native, dialectally diagnostic lexemes in print, this is not true of new loan words. Brengelman (1980: 337) cites figures given by Hans Faltenbacher (1907), who found a total of 1,384 words of Romance origin that appeared for the first time in English in Caxton's publications. Only about $12 \%$ of them have survived, and only one third of these (57) are now spelled as Caxton did. However, much of the variability of the surviving items arises from the presence or absence of the final $<\mathrm{e}>$, consonant doubling, and the variable use of graphemes such as $<\mathrm{i}>$ and $<\mathrm{y}>$, all features which were not regulated before the 17 th century.

The printed word did not reach a stage of fixity even by the end of the 16th century. Salmon (1999: 19) notes that printers were less occupied by theorizing about the codification of spelling, and expressed their views indirectly in practice by adopting certain printing practices. Only a couple of printers are recorded to have used specific spelling guidelines. Wynkyn de Worde, Caxton's Alsatian assistant and successor, had a stylesheet, the rules of which for some inflectional suffixes have been preserved (Aronoff 1987: 95). Similarly, the printer and lawyer John Rastell is recorded to have issued some spelling recommendations in 1530, but only a fragment of them has survived (Salmon 1999: 19-20). In the introduction to his French textbook, Lesclarcissement de la langue françoyse (1530), John Palsgrave mentions correctors, which The Oxford English Dictionary cites as the first attestation of this printing-house term in English (s.v. corrector). Scattered though these references are, they suggest an ongoing process of linguistic focusing in printing-house practices.

\subsection{Growing impact in the 16 th century}

London became the capital of the English book trade with some $98 \%$ of the books published in England between 1500 and 1700 being printed there. However, the impact of printing and the spelling standards it promoted, or failed to promote, was not immediate as the volume of early printed books was relatively modest. Caxton published about one hundred printed books in his lifetime (Blake 2004). The number of titles published in England for the decade 1520-1529, for instance, was 550, rising to 1040 for the period 1550-1559. During the last two decades of the reign of 
Queen Elizabeth I, between 1580 and 1603, as many as 4,370 titles appeared (Bennett 1989, I: 194, II: 269-270).

A large proportion of the books printed in England in the late 15th and 16th centuries, some $40 \%$, were religious and devotional texts of various kinds; literary works accounted for about one quarter, and the rest consisted of political tracts and the law, history, geography, travel and news, medical and scientific writings, books on commerce, economics, education, guides to conduct, etc. (Bennett 1989, II: 269-270). ${ }^{8}$

Following the English Reformation under Henry VIII in the 1530s, there was an upsurge of vernacular Bibles: by 155730 editions of the whole Bible and 50 of the New Testament had appeared (Bennett 1989, I: 26). However, because of the religious turmoils of the age, many of these 16thcentury translations were produced abroad. As presented in the Appendix, it is generally held that they were not uniform enough to have played a leading role in the fixing of English spelling (Scragg 1974: 73). In the middle of the 16th century, the spelling reformer John Hart in fact argues that the irregularity of English orthography is an obstacle to literacy, for instance, to reading the Bible (Salmon 2004).

However, the textbooks, grammars and dictionaries of Latin and French may have had a role to play in raising general awareness of spelling standardization quite early on. Horobin (2001: 257) suggests that Pynson's publication of translations of classics in parallel-text editions for the use of English classrooms, and translations in general, may have prompted the printer's interest in developing a more fixed spelling system in the early decades of the 16 th century.

In the 16th and 17th centuries, literacy skills were finely graded: being able to read a printed text was a skill that was acquired by a larger section of the population than reading different kinds of hand-writing, while learning how to write was a separate skill to be acquired, if at all, only after reading had been mastered (Thomas 1985). As the 16th century wore on, printed teaching manuals and spelling books began to play a more decisive role in the codification of English lexis and spelling conventions. The process will be discussed below in sections 6.3. and 6.4. 


\section{16th-century controversies}

\subsection{Basic issues}

With a few well-known exceptions, English spelling came to be fixed in print in its present form by about 1650 . The process was remarkably rapid if we consider that a fair amount of variability can be found in printed texts around 1600 . This widening acceptance of the emerging spelling standard, however, also met with active opposition in the 16th century. These proposals for a spelling reform were countered by the first systematic attempts to codify the increasingly fixed standard and to regulate the variability that remained, such as word-final $<\mathrm{e}\rangle$. The process included the elaboration of the standard in the form of loan-word accommodation and etymological spellings.

In the 16th century, even the basic principles of the emerging spelling system were questioned by orthoepists and grammarians. They raised the issue whether English spelling should be phonemic, reflecting pronunciation as closely as possible, or logographic, distinguishing words, notably homophones, by spelling them differently. In practice, the issue had largely been settled: although the phonemic principle was approximated in short words such as and, man and not, the practices adopted in the course of the 15 th and 16th centuries were increasingly biased in favour of the nonphonemic principle. The free adoption of French orthographic norms had already resulted in multiple conventions in Late Middle English. At the same time, the gradual acceptance of "Chancery Standard" had effectively eliminated local spellings, which could reflect regional pronunciations (cf. ond, mon, nat). Finally, the masses of learned Latinate loan words that came into English in the 16th and 17th centuries were adapted, but not anglicized in terms of spelling (Brengelman 1980: 353).

As spelling systems tend to be conservative, they often record earlier stages of the language. In the Caxton passage in (5), for example, there are a number of words ending in $<\mathrm{e}>$ reminiscent of the stage when English had inflectional endings, first reduced to a schwa (represented by $<\mathrm{e}>$ ) and later on to zero (cf. wolde, toke, olde, boke). Historically disyllabic words such as these had thus become monosyllabic. When the vowel in them was long, the final silent $<\mathrm{e}>$ was commonly reinterpreted to mark its length. Although this convention reflected pronunciation, it did not do it on the phoneme level but logographically, on the level of the word. 


\subsection{Proposals for reform}

In the 16th century, a more phonemic spelling system was advocated by many scholars and educationalists, notably, Sir John Cheke (1514-1557), Sir Thomas Smith (1513-1577), John Hart (1501-1574) and William Bullokar (1531-1609), the author of the first English grammar published in English. Cheke and Smith were classical scholars, who had developed an interest in their mother tongue, whereas Hart and Bullokar both had practical teaching applications in mind. This desire to reform English spelling that all four of them shared has been seen as an indication of the developing sense of English national consciousness (Archer 2004).

All four called for a closer correspondence between pronunciation and spelling. The solutions they suggested varied, but typically included some changes to the Latin alphabet. Sir Thomas Smith published his De recta \& emendata Linguae anglicae scriptione, dialogus ('Dialogue concerning the correct and emended writing of the English language') in Paris in 1568. He proposed the retention of the letter equivalents of eth (ðe) and thorn (be), for instance, and the use of diacritics to mark a distinction between short and long vowels. But his proposal is a moderate one in that it is fundamentally based on the Latin alphabet and includes, for instance, the letter $\langle\mathrm{q}\rangle$ in words such as quit and quil ('feather').

The most far-reaching proposals for a reform were put forward by John Hart, an accomplished phonetician. He first presented his reformed spelling in The Opening of the Unreasonable Writing of Our Inglish Toung (1551), and refined it for print in An Orthographie (1569) and A Methode (1570). $\mathrm{He}$ criticized the many spelling practices current in the printed word that did not reflect contemporary pronunciation. One was the use of silent letters, such as the word-final $<\mathrm{e}>$ to indicate a long preceding vowel in words like spake, take and before, while in words spelled with double consonants (sunne, sonne) this final $<\mathrm{e}>$ created an extra syllable. He also commented on silent letters in individual words such as $<\mathrm{b}>$ in doubt, $<\mathrm{g}>$ in eight and $<_{0}>$ in people. Another major "corruption" of English spelling was the use of one letter to represent two different sounds, for instance, $<\mathrm{g}>$ representing /g/ in geve ('give') but / $\mathrm{d} 3$ / in gentle (Hart 1955 [1551]: 122-123).

The remedy Hart proposed was a reformed alphabet in which each sound was represented by one letter, and vice versa. He started from the sound system, and devised new characters for sounds that did not have one. In Hart (1569) he replaced the digraphs $<\mathrm{ch}>,<\mathrm{sh}>$ and $<$ th $>$ with phonemic symbols (in the case of $<$ th $>$, with two). Phonemic correspondences based on voicing were extended to $<\mathrm{k}>$ and $<\mathrm{g}>$ (kan 'can', gud 'good') and $<\mathrm{s}>$ and $<\mathrm{z}>$ (serten 'certain', hiz 'his'); $<\mathrm{q}>$ was abolished. Hart dif- 
ferentiated vowel quality and quantity by means of diacritics, and marked diphthongs by digraphs (leik 'like', oun 'own'). In his description of the individual sounds, he even notes some subphonemic distinctions, such as aspiration in initial plosives (pheip 'pipe'). In the application of his system, Hart omits silent vowels, writing, for instance oftn 'often', sevn 'seven', spokn 'spoken' and writn 'written'. He does not recognize the schwa, but does record certain features characteristic of continuous speech, such as assimilations and elisions ( $t$ 'iuz 'to use') (Hart 1569, Barber 1997: 82-85, Salmon 2004). Significantly, Hart does not contest the reference dialect of his revised orthography, but bases his spelling on the pronunciation of "the Court and London, where the flower of the English tongue is vsed" (Hart 1570: IIIb).

William Bullokar, a schoolteacher himself, was concerned about the difficulties that the English spelling system created for teachers of reading and writing. In his Booke at Large (1580), he complains about letters such as $<\mathrm{h}>,<\mathrm{y}>$ and $<\mathrm{w}>$, the names of which have no connection with the sounds they represent. Even more problematic he finds letters that could represent more than one sound. Here Bullokar shares the concerns of Smith and Hart, but not their solution of adding new characters to the existing set. He argues against this practice on the grounds that children would have to master both old and new spelling systems in order to be able to read what was already available in print. The proposal he presents in Booke at Large and, in a more concise form, in A Short Introduction or Guiding to Print, Write, and Reade Inglish Speech, also first published in 1580, makes more phonemic use of the Latin alphabet but also introduces some diacritics, for instance, to mark vowel length, and others to show the etymology of the word. Bullokar's spelling system was intended to become part of his literacy programme, complete with a grammar and a dictionary, but it was never completed (Barber 1997: 79-80, Salmon 1999: 16, 2004a).

Radical proposals such as Hart's had little impact on printers and few followers among the general public. Only five texts that loosely followed Hart's reformed spelling were printed. The musician and composer Thomas Whythorne applied it more systematically in his manuscript autobiography in the 1570s (Palmer 1969). However, as he separated the functions of $<\mathrm{i}>$ and $<j>$, and $<\mathrm{u}>$ and $\langle\mathrm{v}>$, reserving $<\mathrm{i}>$ and $<\mathrm{u}>$ for vowels, and $<\mathrm{j}>$ and $\langle\mathrm{v}\rangle$ for consonants, Hart (1569) anticipated the practice to be implemented in print in the early 17 th century. Overall, spelling reformers raised public awareness of the deficiencies of English spelling, and increased the popularity of spelling books from the last decade of the 16th century onwards (Scragg 1974: 73). In this way, paradoxically, they contributed to the fixing of the established non-phonemic practices. 


\subsection{The codifiers of "custom"}

The mere idea of a spelling reform based on the spoken language met with opposition from the teaching profession towards the end of the 16th century. It was explicitly denounced by Richard Mulcaster (1530-1611), an influential London schoolmaster, in his didactic manual, The First Part of the Elementarie (1582). He argued that there was too much variation in speech, especially in regional dialects, to recommend pronunciation as a basis for orthography. Instead, Mulcaster relied on established practices to provide the basic guidelines for spelling: "[ $[\mathrm{t}] \mathrm{he}$ vse \& custom of our cuntrie, hath allredie chosen a kinde of penning, wherein she hath set down hir relligion, hir lawes, hir priuat and publik dealings" (1582: 98).

Mulcaster based his principles of spelling on the traditional alphabet and suggested that the use of each letter of the alphabet should be governed by general orthographical rules. Like spelling reformers, he, too, rejected the use of "superfluous" letters and so, for example, the doubling of consonants to indicate a short preceding vowel in words like putt, grubb, ledd for put, grub and led. But unlike the reformers, he preferred the use of final $<\mathrm{e}>$ to mark vowel length in words like seme 'seem' and sene 'seen'. Following the logographic principle, he used the final $<\mathrm{e}\rangle$ to distinguish word pairs such as made and mad and stripe and strip, although he did not extend the principle to established homophones such as light (Mulcaster 1582: 111, 118).

Mulcaster also wanted to codify the established usage and called for a monolingual English dictionary to supply the "right writing" of words. This is a significant move towards fixity and prescription in the course of spelling standardization. Mulcaster appended to his book an alphabetical spelling list of some 8,500 common English words. Barber (1997: 86) reports that well over half of them are identical with modern standard spelling, and that the proportion grows even higher if we discard the variation between $<\mathrm{i}>$ and $<\mathrm{j}>$ and $<\mathrm{u}>$ and $<\mathrm{v}>$ current in the 16th century.

Teaching manuals and spelling books had a direct impact on how English orthography was taught and learned. One in particular, The English Schoole-maister (1596) written by Edmund Coote (c. 1562-1610), became a bestseller and went through some fifty editions in the 17th century. Besides spelling rules (syllable and word lists), it contains a short catechism, quotes from the Bible, psalms, prayers, some elementary arithmetic, as well as a 1,400-word dictionary, including "hard words" borrowed from Latin and French with their glosses. Coote's popularity may be partly explained by his practicality: by selecting for each word that spelling which appeared 
most frequently in print, he ensured his pupils' ability not only to spell but also to recognize words as quickly as possible, and thus to read the printed word more efficiently (Scragg 1974: 78-80). Coote's intended audience was clearly wider than the professional teachers of Mulcaster's, and his authority therefore became the printed word. It is, however, noticeable that Coote and Mulcaster do not agree on all the spellings they list.

\subsection{Towards fixity in print}

From the 1570s onwards, English printing-house practices show increased focusing. Printers made attempts to systematize irregular features such as vowel length and, in some cases, vowel quality, using the Latin alphabet. Vowels could be doubled to mark length, and digraphs used to indicate quality: <ee $>$ was used for $/ \mathrm{e}: /,<\mathrm{oo}>$ for $/ \mathrm{o} / /$ and $<$ ea $>$ for $/ \varepsilon$ : /, for example, as in seen, soon, and sea. The final $<\mathrm{e}>$ could similarly indicate the length of the preceding vowel (made, side, tune), and consonant doubling a short vowel (hill). An effort went into keeping homophones apart, and spelling words like all and awl and made and maid differently (Salmon 1999: 2728).

Moreover, at this time of intense lexical borrowing from Latin, the printed word is also characterized by an etymologizing movement. It caught the critical attention of Hart and other proponents of the phonemic spelling principle. Salmon (1999: 28) notes that respellings such as debt ( $<\mathrm{ME}$ dette; L débitum), doubt ( $<\mathrm{ME}$ doute(n); L dubitāre), and victuals $(<$ ME vitailes; L victuālia) must have represented standardization for those who knew Latin. Much of this regularization of Latinate loan words took place in the 17th century, and was codified in hard-word dictionaries. The way Mulcaster (1582) spells many of these words still reflects their current pronunciation and thus in part their French spelling. He omits, for instance, the $<\mathrm{b}>$ in debt and doubt, the $<\mathrm{c}>$ in indict, verdict and victual, $<\mathrm{d}>$ in advance, advantage and adventure, and $<\mathrm{h}>$ in rhyme (Brengelman 1980: 351-352). However, Mulcaster also gives variant forms such as blasfeam and blaspheme, perfit and perfect, ream and realm, showing that the etymologizing process was already well under way.

The gradual process of standardization of printing-house practices is manifest in the successive editions of best-selling titles such as Coote's The English Schoole-maister. Howard-Hill (2006: 16) examined the number of non-modern spelling elements in 242 words in Coote's word list, and found a steady decrease in the course of the 17th century: from well over a third 
of the total (93) in the first edition to $8 \%(21)$ in the 1696 edition. Similarly, Sönmez (2001) studied the consistency of 490 lemmas shared by the nine earliest monolingual English word lists and hard-word dictionaries published between 1582 and 1626. She compared these lemmas with their modern standard forms only excluding $\langle\mathrm{i}\rangle \mid\langle\mathrm{j}\rangle$ and $\langle\mathrm{u}\rangle \mid\langle\mathrm{v}\rangle$ alternation, which was regular. She found a very high degree of consistency within and between these texts, over $98 \%$, and a clear trend towards forms that are now standard in the 17th century: from $67 \%$ in Mulcaster and $63 \%$ in Coote up to $74 \%$ in the second edition of Henry Cockeram's The English Dictionarie (1626).

The fixing of English spelling continued to be a multi-party affair in the late 16th and 17th centuries. At least from the last decade of the 16th century on, spelling-book rules are assumed to have affected the work of compositors (Salmon 1999: 32). There is evidence to show that authors also participated in the proof-reading of their publications, and that their intentions were followed (Brengelman 1980: 341-342). Printers' norms were applied when the manuscript showed a lot of variation even in the late 16th century, but they did not become the rule until the late 17th and 18th centuries (Scragg 1974: 70-71). By that time, a fixed spelling system had become an area of technical specialization in the printing trade.

\section{Conclusion}

Returning to Auer's models of standardization (2005), we may conclude that, historically speaking, focusing appears to be a two-way street. It not only proceeds from diglossia to diaglossia, but also from native diaglossia towards increased diglossia, as in English, where the number of variant spellings was reduced and regional distinctions were obliterated in the incipient standards in the course of the 15th century.

The advent of the printing press in the late 15 th century did not impose spelling norms on the vernacular overnight, but the process became a fitful and protracted one. In the mid-16th century there was a reaction to the widening acceptance of the emerging standard and several proposals were made for a spelling reform. These proposals were countered by the first systematic efforts of codification of the increasingly focused norms in word lists and proto-dictionaries at the end of the 16th century. These tools, compiled to aid the teaching of basic literacy, were influenced by the printed word, but also came to modify it. They also elaborated the standard by way of loan-word accommodation and the promotion of etymological 
spellings. Grafting these Latinate elements onto the vernacular resulted in practical diglossia: the command of their correct spelling was stratified on the basis on the writer's education. This lexical stratum and its non-native spelling systems are reminiscent of the medieval exoglossic standard.

Finally, it is worth pointing out that in a polycentric language such as English there are also signs of diglossia tending towards diaglossia again. The American English spelling conventions codified by Noah Webster in the 19th century are here a case in point.

\section{Appendix: The impact of the Bible}

The influence of the Bible on the standardization of English spelling is of long standing but indirect. One of the incipient standards in the 14th century, Samuels's Type I, was associated with the Wycliffite Bible and the underground Lollard movement, which partly accounts for its decline. The Constitutions of Oxford, passed in 1408, made it illegal to publish the Bible in the vernacular (McGrath 2001: 26).

For fear of the influence of the German Reformation, the English Church vigorously enforced this ban in the early decades of the 16th century. William Tyndale (1494-1536), the first English translator of the New Testament from the Greek original, had his work printed at Worms, Germany, in 1526. During his exile, Miles Coverdale (1488-1569) translated the first complete English Bible, which was printed in Antwerp in 1535. The Great Bible, published in London in 1539, became the first authorized Bible in English; it combined Tyndale's and Coverdale's translations. After the period of Catholicism under Queen Mary (1516-1558), Protestantism was restored under Queen Elizabeth (1533-1603) at the end of the 1550s. The new Bible published in Geneva in 1560 proved highly popular, although the officially approved version was the Bishop's Bible printed in London 1568 (see further, McGrath 2001).

The most influential English Bible ever is no doubt the Authorized Version published in London in 1611, also known as the King James Bible, after James I of England (and VI of Scotland; 1566-1624). However, even this Bible did not serve as a model for contemporary London printers: its spelling is no more uniform than that in the First Folio of Shakespeare's plays, published in 1623, and its spelling continued to be regulated in the subsequent editions in the 17th century (Scragg 1984: 73). Some scholars, however, grant that, because of their wide distribution, the English Bibles 
as well as certain school books "may possibly have had an impact on the ultimate preference for certain spellings" (Brengelman 1980: 354).

Although the vernacular Bible did not have a marked impact on the standardization of English spelling, religious treatises and the Protestant Bibles, notably the Geneva Bible and the Authorized Version, served as models for the anglicization of Older Scots in print in the 16th and 17th centuries. Devitt (1989: 19) shows how <quh>, for example, gave way to $<w h>$ in relative pronouns after 1600 . The anglicization process was completed remarkably rapidly, and first in religious treatises. Before 1580, the vast majority of the books printed in Edinburgh were in Older Scots but in a few decades literary Scots merged in with written southern English (Görlach 1991: 18-23, Smith 1996: 77-78, Dossena 2003: 389).

\section{Notes}

1. The research for this paper was funded by the Academy of Finland and University of Helsinki Centre of Excellence funding for the Research Unit for the Study of Variation, Contacts and Change in English (2006-2011).

2. Haugen's model is applied to standardization processes in English at the different linguistic levels from spelling to pronunciation both in Nevalainen (2003) and in Nevalainen and Tieken-Boon van Ostade (2006). For the term reference variety, see Nevalainen (2003: 132).

3. In the Middle Ages, the rise of Older Scots was closely associated with the Northumbrian dialect. However, Modern Standard Scottish English (and its spelling) is usually not taken to be a direct descendant of older forms of Scots, but rather the result of its contact with southern English from the 16th century onwards (Devitt 1989, Dossena 2003: 383-384).

4. For the terms marker and stereotype, see, e.g., Labov (2001: 196-197). Samuels (1981: 43-44) suggests that these colourless usages served as a new lingua franca, a vernacular replacement for Anglo-Norman French. They were not uniform. As Benskin (1992: 85) points out, "what counts as colourless depends on the background: colourless Norfolk language is not the same as the neutralized language of Bristol or Nottingham".

5. The information in this section is largely based on the collection of texts in Fisher, Richardson and Fisher (1986). It is the only extensive edition available, and contains a selection of documents, including a number of Henry V's Signet letters, produced by the different Westminster writing offices in English before 1470. Although the editing unfortunately leaves much to be desired in terms of philological accuracy (Benskin 2004: 5-11), editorial inaccuracies should not, however, distort the overall picture. 
6. They were NOT (no forms with $<\mathrm{a}>$ ), AND, HAND, MAN (no forms with $<_{0}>$ ), FATHER, FURTHER. HITHER, TOGETHER (no forms with medial $<$ d $>$ ), MIGHT (no forms with $<_{0}>$ ), YET (no $<$ yit $>$ ), and WHICH (only variation between $<\mathrm{i} / \mathrm{y}>$ and $<\mathrm{wh} / \mathrm{w}>$ ).

7. Interestingly, <awne $>$ is also the form used by Henry VIII in his private letters, not included in this analysis (Nevalainen 2002b: 174).

8. As formal education was a male prerogative in the 16th century, women's writings are much rarer than men's. Less than $2 \%$ of all texts published in England between 1500 and 1700 were written by women (Bell and Crawford 1985: 266, Nevalainen 2002a). The spelling norms that were transmitted through the print medium were therefore largely shaped by men. There were, however, some women printers, either printers' widows or daughters. Joan Orwin, the widow of the printer Thomas Orwin, printed Edmund Coote's The English Schoolemaister (1596), discussed in 6.3.

\section{References}

\section{Primary sources}

Bullokar, William

1580 Bullokars Booke at Large, for the Amendment of Orthographie for English Speech. London: Henrie Denham.

Bullokar, William

1580 A Short Introduction or Guiding to Print, Write, and Reade Inglish Speech. London: Henrie Denham.

Caxton, William

1890 Caxton's Eneydos, 1490, Englisht from the French Liure des Eneydes, 1483. M.T. Culley and F.J. Furnivall (eds.). London/Oxford.

Cockeram, Henry

1970 The English Dictionarie or An Interpreter of Hard English Words. Hildesheim/New York: Olms. Original edition, London 1626.

Coote, Edmund

1596 The English Schoole-maister. London: Printed by the Widow Orwin for Ralph Iackson and Robert Dexter.

Hart, John

1569 An Orthographie. London: William Seres.

Hart, John

1570 A Methode or Comfortable Beginning for All Vnlearned. London: Henrie Denham.

Hart, John

1955 The opening of the unreasonable writing of our Inglish toung (1551). In John Hart's Works on English Orthography and Pronunciation, 
Bror Danielsson (ed.), part 1. (Stockholm Studies in English 5.) Stockholm: Almqvist and Wiksell.

Mulcaster, Richard

1582 The First Part of the Elementarie which Entreateth Chefelie of the Right Writing of our English Tung. London: Thomas Vautroullier.

Palsgrave, John

1530 Lesclarcissement de la Langue Françoyse. London: J. Haukyns. (Critical edition and French translation with a facsimile by Susan Baddeley. Paris: Honoré Champion, 2003.)

Smith, Thomas

1568 De Recta \& Emendata Linguae Anglicae Scriptione, Dialogus. Lutetiae: Ex officina Roberti Stephani.

\section{Secondary sources}

Archer, Ian W.

2004 Smith, Sir Thomas (1513-1577). In Oxford Dictionary of National Biography. H. C. G. Matthew, and Brian Harrison (eds.). Oxford: Oxford University Press. http://www.oxforddnb.com/view/article/ 25906 (accessed 2 March 2011).

Aronoff, Mark

1980 The orthographic system of an early English printer: Wynkyn de Worde. Folia Linguistica Historica 8: 65-97.

Auer, Peter

2005 Europe's sociolinguistic unity, or: A typology of European dialect/ standard constellations. In Perspectives on Variation, Nicole Delbecque, Johan van der Auwera, and Dirk Geeraerts (eds.), 7-42. Barber, Charles

(Trends in Linguistics 163.) Berlin: Mouton de Gruyter.

1997 Early Modern English. Edinburgh: Edinburgh University Press.

Bell, Richard, and Patricia Crawford

1985 Appendix 2: Statistical analysis of women's printed writings 16001700. In Women in English Society 1500-1800, Mary Prior (ed.), 265-274. London/New York: Methuen.

Bennett, Henry S.

1989 English Books and Readers. I: 1475-1557, II: 1558-1603. 2nd ed. Cambridge: Cambridge University Press.

Benskin, Michael

1992 Some new perspectives on the origins of standard written English. In Dialect and Standard Language in the English, Dutch, German and Norwegian Language Areas, J.A. van Leuvensteijn, and J.B. Berns (eds.), 71-105. Amsterdam: North Holland. 
Benskin, Michael

2004 Chancery Standard. In New Perspectives on English Historical Linguistics, Christian Kay, Carole Hough, and Irené Wotherspoon (eds.), 1-40. Amsterdam/Philadelphia: John Benjamins.

Blake, Norman F.

1997a Chancery English and the Wife of Bath's prologue. In To Explain the

Present: Studies in the Changing English Language in Honour of

Matti Rissanen, Terttu Nevalainen, and Leena Kahlas-Tarkka (eds.),

3-24. (Mémoires de la Société Néophilologique de Helsinki 52.)

Helsinki: Société Néophilologique.

Blake, Norman F.

1997b Review of The emergence of Standard English by John H. Fisher,

The Review of English Studies, N.S., 48 (192): 512-513.

Blake, Norman F.

2004 Caxton, William (1415 24-1492). In Oxford Dictionary of National

Biography, H. C. G. Matthew, and Brian Harrison (eds.), Oxford:

Oxford University Press. http://www.oxforddnb.com/view/article/

Brengelman, Fred H.

4963 (accessed 2 March 2011).

1980 Orthoepists, printers, and the rationalization of English spelling.

Journal of English and Germanic Philology 79: 332-354.

Britton, Derek

2000 Henry Machyn, Axel Wijk and the case of the wrong riding: the

South-West Yorkshire character of the language of Machyn's diary.

Neuphilologische Mitteilungen 101 (4): 571-596.

Conde-Silvestre, Juan Camilo, and Juan Manuel Hernández-Campoy

2004 A sociolinguistic approach to the diffusion of Chancery written practices in late fifteenth-century private correspondence. Neuphilolo-

Corrie, Marilyn gische Mitteilungen 105 (2): 135-152.

2006 Middle English - dialects and diversity. In The Oxford History of English, Lynda Mugglestone (ed.), 86-119. Oxford: Oxford University Press.

Davis, Norman

1983 The language of two brothers in the fifteenth century. In Five Hundred Years of Words and Sounds: A Festschrift for Eric Dobson, Eric G. Stanley, and Douglas Gray (eds.), 23-28. Cambridge: Brewer.

Devitt, Amy

1989 Standardizing Written English: Diffusion in the Case of Scotland 1520-1659. Cambridge: Cambridge University Press.

Dossena, Marina

2003 Scots. In Germanic Standardizations: Past to Present, Ana Deumert, and Wim Vandenbussche (eds.), 383-404. Amsterdam/Philadelphia: John Benjamins. 
Faltenbacher, Hans

1907 Die Romanischen, Speciell Französischen und Lateinischen (bzw. Latinisierten) Lehnwörter bei Caxton (1422?-1491). Diss. Munich: Mössl.

Fisher, John H.

1996 The Emergence of Standard English. Lexington: The University of Kentucky Press.

Fisher, John H., Malcolm Richardson, and Jane L. Fisher

1984 An Anthology of Chancery English. Knoxville: The University of Tennessee Press.

Gómez-Soliño, José

1981 Thomas Wolsey, Thomas More y la lengua inglesa estándar de su época. Revista Canaria de Estudios Ingleses 3: 74-84.

Görlach, Manfred

1991 Introduction to Early Modern English. Cambridge: Cambridge University Press.

Haugen, Einar

1997 Language standardization. In Sociolinguistics, Nicolas Coupland, and Adam Jaworski (eds), 341-352. London: Macmillan. Original edition 1966.

Heikkonen, Kirsi

1996 Regional variation in standardization: A case study of Henry V's Signet Office. In Sociolinguistics and Language History, Studies Based on the Corpus of Early English Correspondence, Terttu Nevalainen, and Helena Raumolin-Brunberg (eds.), 111-127. Amsterdam/Atlanta: Rodopi.

Hernández-Campoy, Juan Manuel, and Juan Camilo Conde-Silvestre

2005 Sociolinguistic and geolinguistic approaches to the historical diffusion of linguistic innovations: incipient standardisation in Late Middle English. International Journal of English Studies 5 (1): 101-134.

Horobin, Simon C. P.

2001 The language of the fifteenth-century printed editions of The Canterbury Tales. Anglia 119: 249-258.

Howard-Hill, Trevor H.

2006 Early modern printers and the standardization of English spelling. The Modern Language Review 101: 16-29.

Hudson, Anne, and Anthony Kenny

2004 Wyclif, John (d. 1384). In Oxford Dictionary of National Biography, H. C. G. Matthew, and Brian Harrison (eds.), Oxford: Oxford University Press. http://www.oxforddnb.com/view/article/30122 (accessed 2 March 2011).

Keene, Derek

2000 Metropolitan values: migration, mobility and cultural norms, London 1100-1700. In The Development of Standard English 1300-1800, 
Theories, Descriptions, Conflicts, Laura Wright (ed.), 93-114. CamKytö, Merja (comp.) bridge: Cambridge University Press.

1996 Manual to the Diachronic Part of the Helsinki Corpus of English Texts, 3rd ed. Helsinki: Department of English, University of Helsinki.

Labov, William

2001 Principles of Linguistic Change: Social Factors. Cambridge, MA: Blackwell.

McGrath, Alister

2001 In the Beginning: The Story of the King James Bible. London: Hodder and Stoughton.

McIntosh, Angus, Michael L. Samuels and Michael Benskin, with Margaret Laing and Keith Williamson

1986 A Linguistic Atlas of Late Mediaeval English. Aberdeen: Aberdeen University Press.

Milroy, James, and Lesley Milroy

1999 Authority in Language: Investigating Standard English. 3rd ed. London/New York: Routledge.

Nevalainen, Terttu

1999 Early Modern English lexis and semantics. In The Cambridge History of the English Language, Roger Lass (ed.), Vol. III: 1476-1776, 332-458. Cambridge: Cambridge University Press.

Nevalainen, Terttu

2002a Women's writings as evidence for linguistic continuity and change in Early Modern English. In Alternative Histories of English, Richard Watts, and Peter Trudgill (eds.), 191-209. London: Routledge/ Taylor and Francis.

Nevalainen, Terttu

$2002 \mathrm{~b}$ What's in a royal letter? Linguistic variation in the correspondence of Henry VIII. In Of Dyuersitie \& Chaunge of Langage; Essays Presented to Manfred Görlach on the Occasion of his 65th Birthday,

Nevalainen, Terttu Katja Lentz, and Ruth Möhlig (eds.), 169-179. Heidelberg: Winter.

2003 English. In Germanic Standardizations: Past to Present, Ana Deumert, and Wim Vandenbussche (eds.), 127-156. Amsterdam/Philadelphia: John Benjamins.

Nevalainen, Terttu, and Helena Raumolin-Brunberg

1993 Early Modern British English. In Early English in the Computer Age, Explorations through the Helsinki Corpus, Matti Rissanen, Merja Kytö, and Minna Palander-Collin (eds.), 53-73. Berlin/New York: Mouton de Gruyter. 
Nevalainen, Terttu, and Helena Raumolin-Brunberg

2003 Historical Sociolinguistics: Language Change in Tudor and Stuart England. (Longman Linguistics Library). London: Pearson Education.

Nevalainen, Terttu, and Ingrid Tieken-Boon van Ostade

2006 Standardisation. In A History of the English Language, Richard Hogg, and David Denison (eds.), 271-311. Cambridge. Cambridge University Press.

Osselton, Noel

1984 Informal spelling systems in Early Modern English: 1500-1800. In English Historical Linguistics: Studies in Development, N.F. Blake, and Charles Jones (eds.), 123-137. Sheffield: CECTAL.

The Oxford English Dictionary.

1989 Simpson, J. A., and E. S. C. Weiner (eds.). 2nd ed. Additions 19937, ed. J. Simpson, E. Weiner and M. Proffitt. 3rd ed. Mar. 2000-, ed. J. Simpson. OED Online. Oxford University Press. $<$ http://oed.com> Palmer, Rupert E. Jr.

1969 Thomas Whythorne's Speech. (Anglistica, 16). Copenhagen: Rosenkilde and Bagger.

Raumolin-Brunberg, Helena, and Terttu Nevalainen

1990 Dialectal features in a corpus of Early Modern Standard English? In Proceedings from the Fourth Nordic Conference for English Studies, Graham Caie, Kirsten Haastrup, Arnt Lykke Jakobsen, Jørgen Erik Nielsen, Jørgen Sevaldsen, Henrik Specht, and Arne Zettersten (eds.), Vol. I, 119-131. Copenhagen: Department of English, Uni-

Richardson, Malcolm versity of Copenhagen.

1980 Henry V, the English Chancery, and Chancery English. Speculum 55 (4): 726-750.

Salmon, Vivian

1999 Orthography and punctuation. In The Cambridge History of the English Language, Roger Lass (ed.), Vol. III: 1476-1776, 13-55. Cambridge: Cambridge University Press.

Salmon, Vivian

2004 Hart, John (c. 1501-1574). In Oxford Dictionary of National Biography. H. C. G. Matthew, and Brian Harrison (eds.), Oxford University Press. http://www.oxforddnb.com/view/article/12482 (accessed 2 March 2011).

Samuels, Michael L.

1963 Some applications of Middle English dialectology. English Studies 44: 81-94.

Samuels, Michael L.

1981 Spelling and dialect in the late and post-middle English periods. In So Meny People, Longages and Tonges: Philological Essays in Scots 
Scragg, Donald G.

and Mediaeval English Presented to Angus McIntosh, Michael Benskin, and M.L. Samuels (eds.), 43-54. Edinburgh: Middle English Dialect Project.

1974 A History of English Spelling, Manchester: Manchester University Press.

Smith, Jeremy

1996 An Historical Study of English. London: Routledge.

Sönmez, Margaret

2001 The influence of early monolingual dictionaries and word lists on the standardisation of English spelling. Anglia 119: 207-231.

Taavitsainen, Irma

2000 Scientific language and spelling standardisation 1375-1550. In The Development of Standard English 1300-1800; Theories, Descriptions, Conflicts, Laura Wright (ed.), 131-154. Cambridge: Cambridge University Press.

Taavitsainen, Irma

2004 Scriptorial 'house-styles' and discourse communities. In: Medical and Scientific Writing in Late Medieval English, Irma Taavitsainen, and Päivi Pahta (eds.), 209-240. Cambridge: Cambridge University Press.

Thomas, Keith

1985 The meaning of literacy in Early Modern England. In The Written Word; Literacy in Transition, Gerd Baumann (ed.), 97-131. Oxford: Clarendon Press.

Toon, Thomas E.

1992 Old English dialects. In The Cambridge History of the English Language, Richard Hogg (ed.), Vol. I: The Beginnings to 1066, 409451. Cambridge: Cambridge University Press.

Trudgill, Peter

1986 Dialects in Contact. Oxford: Blackwell. 



\title{
German \\ The emergence of suprasegmental spellings in German
}

\author{
Anja Voeste
}

\section{Introduction}

In recent years, the vehement discussions on the German spelling reform have emphasized, amongst other things, the fact that etymological links between so-called cognates may be indicated by a congruent spelling: Stengel 'stalk' derives from Stange 'stick' and is now written with $<\ddot{a}>$, whereas Wächte 'cornice' - a word that has nothing to do with Wacht 'guard' but derives from wehen 'to waft' - lost its $<\ddot{a}>$ and is now written Wechte. The spelling committee decided to intervene in favour of a principle that obviously had been in need of improvement, since it did not reflect the etymological interrelations in a satisfactory way. In words like Stengel, Eltern 'parents' (cf. alt 'old'), Geselle 'journeyman' (cf. Saal 'hall') or Henne 'hen' (cf. Hahn 'cock'), the etymological relations are not reflected by a congruent spelling with a-Umlaut. Cases like Wächte, in contrast, show an unsatisfactory application of the above-mentioned etymological principle: readers might surmise a semantic interrelation with Wacht that does not exist.

The fact that previous, historically-evolved spelling regulations did not indicate cognates in a consistent way leads to the conclusion that the etymological principle was not planned on a drawing board. The implementation of spelling regulations, which took place in Early Modern times, was not brought about by administrative acts and by language planning. Instead, economic considerations and technological advances in the 16th century set in motion a process of development that dealt a fatal blow to the preeminence of phonography and led to the invention of suprasegmental spellings such as the labelling of cognates by congruent spelling. The driving force behind this development was the impetus given by professionalization, which, by modernizing printing processes, quickly impacted the typesetting trade as well. The spelling regularities that resulted from this were, 
in my opinion, not devised by grammarians; they stemmed directly from the labour process. In the following, I will discuss how the segmentation and transformation of written words may have put in place conditions favourable for an analysis that contributed to the establishment of new principles for spelling words. The new spelling regulations bear witness to the general process of turning away from the segmental-phonographic practice that had prevailed prior to that time. They reveal a fundamental change in how the written word was perceived.

\section{Patterns of spelling up to the 16th century}

\subsection{Phonography under the influence of Latin}

The scriptualization of the German language, or rather of German dialects, is inextricably linked to Latin scribal traditions. The scribes, who had authored German texts since the 8th century, applied their Latin literacy skills to their German vernacular. They were heavily influenced by their first written language: they analyzed German sounds with Latin ears, and used Latin graphemes to encode them into written units. This procedure led to Latin interpretations of the actual phonemes, written down in a linear sequence. The aim was phonography: written units corresponded to spoken units, or to their interpretations respectively. Moreover, there was a second correspondence between written and spoken forms: up until the Middle Ages, the segments of Latin script were written in a continuous, linear succession with no breaks. This continuous script (called scriptio continua) reflected the oral current of sounds and shows quite plainly the phonographic character of the Latin writing system.

However, from the 8th century onwards, non-phonographic tendencies increased and perturbed the parallel order of oral and written units. The first step to this change was made by Celtic and Germanic scribes, for whom Latin was a language of the written and not of the spoken word. They began to break up the scriptio continua of Latin manuscripts, which was hard to decode, and separated word-units with blanks. This change was initially meant to help separate semantic units for translation, but it was to constitute an essential step forward to a grammatical view of writing (cf. Parkes 1992: 23).

In late medieval times, a second important development took place which helped readers to visualise semantic word units as graphical word bodies: the invention of the Gothic cursive. Until then, letters had never 
been systematically linked together by ligatures. Only if it was convenient for the scribe in the writing process, ligatures from left to right were used. However, in late medieval times, the extension of administration, the increasing importance of writing in the legal profession, in the universities and in trade led to the emergence of a new type of script. This Gothic cursive differed in one important way from older cursive scripts: not only did it bind single segments together for pragmatic reasons or for the sake of economy of movement, but it welded together all the word-segments into a firmly fixed group (cf. Rück 1988). The isolated segments were combined into a linked word-body. Furthermore, the scribes tended to begin words with a capital or at least with a special letter form, a so-called littera notabilior; or else the first and the last letters of a word were written with a special descending stroke to its minim (cf. Derolez 2003: 127-128, and see figure 1). These developments were a side-effect of the new Gothic script, but in German they eventually led to the use of capitals as markers of syntactic functions.

\section{$n \eta$}

Figure 1. Approach and end strokes due to rapid writing in Gothic script

There is evidence that the word-bodies of the cursive script were perceived as graphic units, and that the scribes wrote and copied manuscripts without reading aloud (cf. Saenger 1997 and 1999): only by operating with graphic units can one construct a perfectly laid out mise en page. This kind of layout is not consistent with taking texts under dictation.

Under these conditions, the segmental phonography, on which every alphabetic script is based, lost ground. The segment of a linear chain did not remain the one and only basic unit of script. Alongside it there existed a larger graphic unit that allowed for further grammatical processing: the written word-form. Therefore, on the one hand, written segments continued to correspond to the phonemic level; but, on the other hand, they began to be visualizations of semantic units, since written word-forms refer to the semantic level. This can be described as a mixture of existing phonographic and new logographic traits. We here encounter the two levels that dominated spelling up until the 16th century: segmental phonography and wordbound logography. They represent the smallest and the largest units of written words. 


\subsection{Variability}

However, we need more than the knowledge that written words were perceived as units: we need to know why it was possible to invent completely new spellings on the basis of word segmentation. Besides the developments in the perception of written words, there is an important characteristic of orthography that I consider to have been a prerequisite for the invention of new spellings. German texts in the late medieval and the Early Modern periods had a specific feature in common: their orthographic schemes showed extensive variation even though the scribes of the day had a good command of Latin, which showed virtually no variation. At the close of the previous Middle High German period, the poets had tried to avoid regional differences, and there is evidence of their efforts towards a more uniform spelling, as has been ascertained for example by Gärtner (2003) for the manuscripts of the commentaries of the Song of Solomon. This changed in the late 13th century. Within the same text and even within the same line we can find graphic variants of the same word. Figure 2 shows an example: three different variants of the word unzeitig 'untimely' in two lines (vnzeittig, vntzeittig, vnntzeittig).

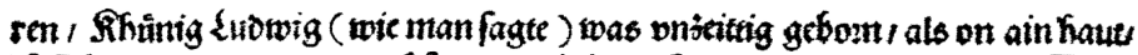

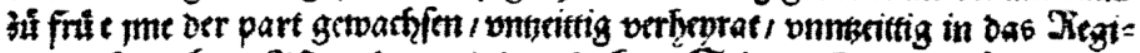

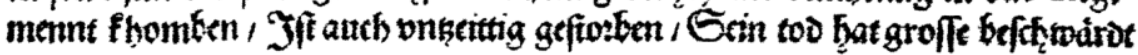

Figure 2. Graphic variants in a chronicle printed in Vienna (Herberstain 1557: E v)

The functional explanations usually given to explain such variations rely on diaphasic, diastratic, diasituational, diachronic and diatopic differences. Diaphasic variants refer to different phases in a scribe's life. During their lifetime, scribes or typesetters did not always stick to the same spellings. Spelling differences between different generations of scribes and typesetters are also diaphasic: the spellings of a scribe with decades of experience in a chancery may differ from those of a younger novice. Diastratic variants focus on social differences. The social background of a person, and, as a result, the level of schooling can be the cause of spelling variants. Diasituational variability may reflect different intentions related to different genres. Documenting, legitimizing, informing or entertaining the reader may result in different linguistic forms. Variants are called diachronic when old, established forms and modern ones appear at the same time. Here, traditional variants are mixed with modern ones in order to increase or to 
guarantee comprehensibility. This is the case when scribes put, for example, Middle High German mânôt and the more recent form monat 'month' side by side and write manot adder monat. Comprehensibility is also the object of diatopic variants, for example, if nowadays I refer to a lift or elevator or an aubergine or eggplant. Diatopic variability refers to different regional conventions or pronunciations which are reflected in the written forms. Specific regional characteristics can be chosen as a courtesy to the addressee. In this case, regional features do not show the characteristics of the sender's language, but those of the (supposed) language of the addressee (cf. Möller 1998).

In spite of this apparent wealth of possibilities for explanation, there are two findings that do not fit with common arguments: first, frequently-used words were written in different ways (cf. the prepositions bej, bey 'at, by' or in , inn, jn, jnn 'in'), although it would have been easy to use a uniform spelling. Secondly, these variant forms were sometimes used by the same typesetter on the same page or even within a single line. In light of these facts, doubts arise that the common diasystemic arguments can explain the existence of several of these spelling variants alongside each other. I believe that the variants were chosen deliberately, due to an imperative to vary. The scribes and typesetters were exhorted to pursue stylistic diversification that was supported by rhetoricians like Erasmus. As is shown by Erasmus' work De duplici copia verborum ac rerum (1512), which was diffused in 150 editions throughout Europe, variation was held to be the summum of stylistic eloquence:

It not infrequently happens that we have to say the same thing several times, in which case, if destitute of copia, we will either be at a loss, or, like the cuckoo, croak out the same words repeatedly, and be unable to give different shape or form to the thought. And thus betraying our want of eloquence we will appear ridiculous ourselves and utterly exhaust our wretched audience with weariness. ${ }^{1}$

The scribes and typesetters followed suggestions such as these on the lexical level, on the morphological and the syntactic level - and, according to my hypothesis, they also did it on the graphematic level. This striving for diversification functioned as a license or even a pressure to coin and try out new variants. Without this stylistic imperative, the bricolage of inventing new spellings would not have been possible. Therefore, in my opinion, variability in 16th-century texts is not a sign of insecurity in encoding spoken language. The question was no longer how to put down the spoken 
word in writing. Instead, variability brought into focus the process of decoding. How, the scribes and typesetters may have asked themselves, can one change the spelling of a given written word without making it undecodable? The transition from spoken input forms to written input forms mirrors the shift from encoding to decoding. It is part of the transition from an orally to a literally-determined culture.

\section{Changes in the 16th century}

\subsection{The preference for balanced variants}

Scribes and typesetters made an effort during this period to coin new spelling variants. In Voeste (2008) I tried to show that the process of coining did not lead to the stochastic aligning of segments, but to tagmatically regulated variants. Out of a number of possible variants, only a comparatively small number was in fact coined. Although the typesetters of my study strove for variation, they took account of the graphotactic structure of words. Such a graphotactic or tagmatic segmentation means analyzing the interplay of the word's elements: Which letters can be joined together, and how does this influence the shape or weight of the whole word?

I found approaches in which word-forms were revamped in accordance with aesthetic criteria in such a way as to create a balance between a word's beginning and its end. There is a tendency to add segments to a word's end in two cases: first, if the beginning of the word is "naked" or contains an $\langle 1\rangle$, which is the thinnest letter in the letter-case. Here, visual emphasis or weight is added to the whole word by increasing the number of elements (end $>$ endt, land $>$ lanndt). In the second case, in word-forms with two or more segments at the beginning, an equilibrium is created between the beginning and the end by adding segments (pferd 'horse'> pferdt, fchuld 'guilt'> fchuldt). Both tendencies can be observed, even though variability remains vital throughout the century - and even though there are regional differences.

An analysis of 2,189 words with $l, r, m, n+d t$ such as $\int c h u l d t$, herdt 'flock', hemdt 'shirt', landt 'land' in my corpus of 30 chronicles has shown that words without a left margin like _endt were written with <-dt> four times as often as those with only one segment in the left margin like handt (not counting the records with $<1>$ or the many variants of $v n d t$ ' and').

Under the appearance of stochastic variation - and this is my conclusion - the typesetters in fact developed graphotactic word patterns. Using 
the segments of the letter-case to set words, they considered and changed the width of the consonantal word margins. Irrespective of the stylistic imperative, regulated variants emerged, corresponding to aesthetic patterns. We therefore have to take into consideration the fact that aesthetic principles are not only responsible for the imperative to create variation, but they also played an important role in the emergence of regulated, aestheticallyshaped spelling variants. Some of those aesthetic patterns were to become an integral part of today's orthography: we do not extend the right margin of a word if the left one already shows a cluster of three or four consonants, cf. *Schwahn (Schwan), *Strohm (Strom), *Schahl (Schal).

\subsection{The demands of good craftsmanship}

Typographic alignment of text in an equably-set column that is evenmargined on the left and right demands the skills of a good craftsman: it is not easy to avoid so-called "loose" lines (with extended spaces) or "tight" lines (with compressed spaces). As long as printing was closely related to the scriptorial graphic traditions, abbreviations and titled letters were an integral part of printed texts. They were the typesetters' best friends, enabling them to avoid loose and tight lines (cf. figure 3).

\section{Dörem geet ex in fai fun ber c30g Ottè $\delta$ pfallits

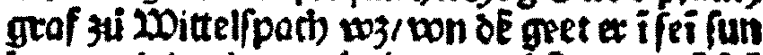 bercsog lubwig won bairn . won dé gett ex i fei}

Figure 3. Abbreviations $\left(d^{s}, w z\right)$ and titled letters $(\bar{o}, \bar{l}, \bar{e})$ in a chronicle printed in Munich (Ebran von Wildenberg 1501: aiiij r)

From about 1500 onwards, the use of abbreviations decreased significantly (cf. Ruge 2004: ch. V and Voeste 2008: ch. 3.4.), while other methods such as the doubling of consonants remained in force. This can be proved by comparing the different variants of vnd 'and'. The use of the short form with titled letter, $v \bar{n}$, decreased in the course of the century, while the extended form, vnnd, shows no downward trend. The following two scatter diagrams (figures 4 and 5) show the distribution of both forms throughout the century. The diagrams are based on my above-mentioned corpus of 30 printed chronicles. 


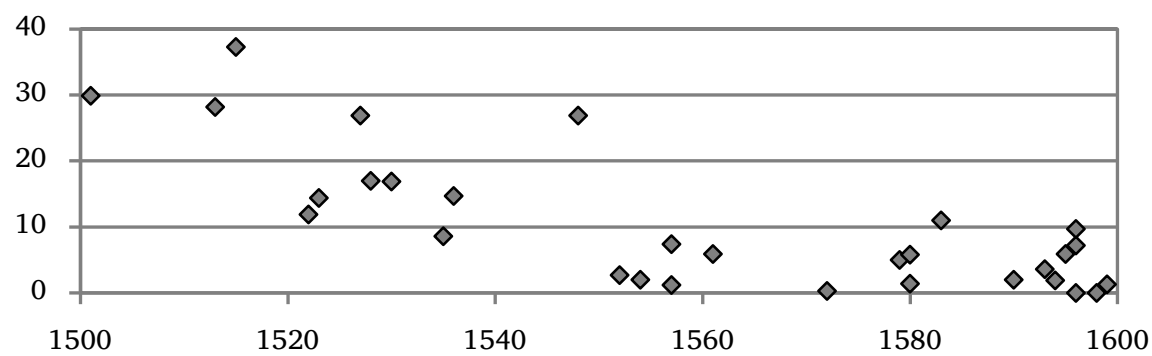

Figure 4. Percentage distribution of $<\mathrm{v} \bar{n}>$ in printed texts

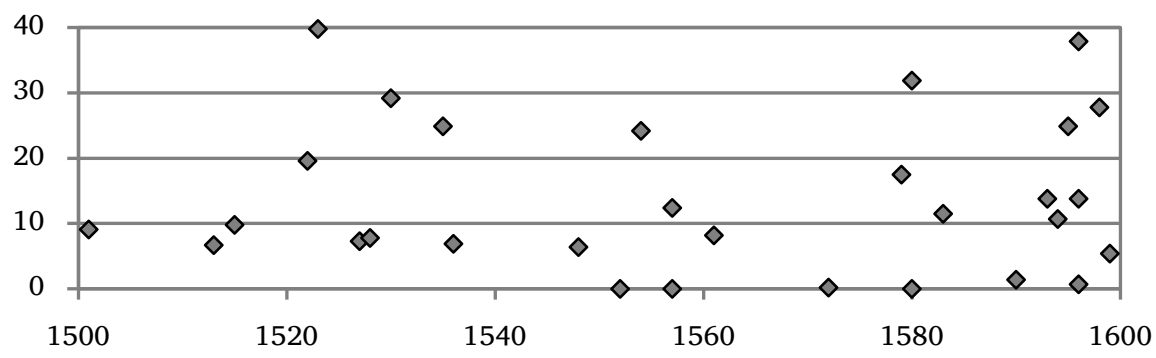

Figure 5. Percentage distribution of $<\mathrm{vnnd}>$ in printed texts

One can assume that essential changes in the printing shops led to printers gradually turning away from older calligraphic customs (as was already observed by Catach 1968: 14). Beginning in the late 15th century, technical and economic factors that had an impact on letterpress printing led to professionalization of the production processes as well as of the crafts and trades involved in printing. Technical innovations increased the efficiency of the printing presses just as finer wire-mesh sieves improved paper quality and cut down on misprints (cf. von Stromer 1993: 1-6). As a result, the printers' daily output rose considerably. The increased workload that a printer could handle in a day had an effect not only on production costs, but also on the price of the end product, both of which fell significantly (cf. Wittmann 1991: 29). The mode of remuneration of printers also changed in accordance with the pressures exerted by modernization: 16th-century printers no longer received time-based wages, but were paid according to their output (cf. Reith 1999: 216-225). The situation of the typesetters, 
however, was totally different: they were not paid by the number of characters they set, but rather according to the kind of printing form, the publication format, the typefaces used for the text and the languages that were used. Nevertheless, the professionalization of the printing crafts and trades put the typesetters under pressure, too. When they failed to deliver a printing form on time, the printers' pay was docked accordingly. For this reason, printing guild regulations from the mid-century onwards contained the stipulation that the typesetters had to make their printing forms available on time (cf. Reith 1999: 219). They assumed responsibility for the printing process not being delayed as well as for the proofreader having sufficient time to check the text prior to it going to press. As a result, the typesetters speeded up the typesetting process by "cleaning up" their letter-cases. Oldfashioned letter variants, ligatures and abbreviations adopted from the manuscript tradition were eliminated. The only ligatures retained were those that prevented the breakage of very thin individual letters and reduced the high cost of casting type. Now, with a streamlined letter case, the typesetters could find what they needed faster and work more efficiently (cf. Stetter 1997: 66). In the course of the 16th century, the modernized methods of typesetters entailed discrediting the earlier "unprofessional" methods. At the close of the 17th century the British printer Joseph Moxon described those old practices as a sign of bungling:

If the Compositor is not firmly resolv'd to keep himself strictly to the Rules of good Workmanship, he is now tempted to make Botches; viz. Pidgeonholes [i.e., "holes" in the line], Thin-Spaces, no Space before a Capital, Short \&s, Abbreviations or Titled Letters, Abbreviate Words, \&c. ${ }^{2}$

The efforts to standardize the letter-case also had an impact on orthography. Previously, the existence of several different spelling variants for the same word had been possible. This was a far cry from uniformity (cf. the possible variants of kinder 'children' and kind 'child' in figure 6).

\section{hinder thind biur bio bind bint bindt bio bit biot}

Figure 6. Spelling variants of kinder 'children' and kind 'child' 
Once numerous characters had been purged from the letter-case in order to speed up the typesetting process, the newly-reduced repertoire dictated the typographical possibilities available, and many variants became technically unfeasible. This process of maximizing efficiency thus generally led to greater consistency of form.

\section{The emergence of etymological spellings}

\subsection{Separating morphemes}

The decrease of possible variants and the increase of more consistent forms also had an impact on the spelling of cognates and of corresponding morphemes in word paradigms. A consistent graphical unit could be used as a basis for etymological spellings: it was utilized to denote that words belonged to the same morphological paradigm. From this point, it was only a small step to establishing and maintaining invariant forms in singular and plural $(<$ kind/kinder $>$ ).

Over the course of the 16th century, morphemes were increasingly segmented as parts of written words. This key step towards an etymological principle can be proved by the change of Latin-style spellings of $\langle\mathrm{v}>$ and $<\mathrm{u}>$ according to their position in the word. Until then, $\langle\mathrm{v}>$ had been placed at the beginning of words, and $<\mathrm{u}>$ within the word or in final position, e.g., vnter 'under' (with $<\mathrm{v}>$ for [v]), vater 'father' (with $<\mathrm{v}>$ for [f]), but herunter 'down', großuater 'grandfather', within the word. Now, during the 16th century, compounds were segmented into their morphemes, i.e., her + vnter or gro $\beta+$ vater, and written with the $<\mathrm{v}>$ marking the initial position of a word even within compounds. Therefore, one can discover a $<\mathrm{v}>$ within written words for the first time. This change in spelling habits happened slowly and subtly; it was never a point of interest in scholarly discourse. This situation differed from that of French. Baddeley (1996: 292) shows that the variant spelling of initial segments after apostrophes (qu'un/qu'vn, d'un/d'vn) was noticed and mentioned by the grammarians, but otherwise very little internal segmentation of morphemes took place. In German, the principle of word internal constant spellings of lexemes also applied to compounds that contained a morpheme ending in $\langle\beta$, such as bifher 'until now' or auffage 'testimony'. Those compounds were now written with final $<\mathrm{s}>$ : bisher, ausfage according to the spelling of bis 'until' and aus 'out'. This segmentation of written word-forms set the foundations for etymological spelling regulations. 
Further proof of the segmentation of morphemes can be found in hyphenation. It was explicitly underlined by the grammarians of the day that hyphenation should go hand in hand with a morphological analysis. In the 1520 s, Valentin Ickelsamer, the author of the first German grammar, gave the example of the word Buchftabe 'letter', lit. 'rod of beech' which should

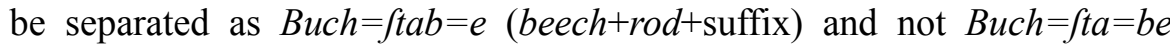
because otherwise nobody would know what $\int t a$ meant (cf. C8v). He obviously focussed on the semantic process of decoding by the reader. But alongside the theory we also encounter similar examples of word separation in practice. Examples such as jar=en 'years', zung=en 'tongues', Büch=er 'books', befitz=ung 'possession', her=aus 'out of' show that, in particular, plural morphemes, suffixes or prepositions in adverbs were separated morphologically in the 16th century.

\subsection{Umlaut spellings}

Although morphological segmentation increased significantly during the 16th century, etymological spellings existed only "in principle". As a spelling regulation, etymological spellings did not come under a more general rule until the 18th and 19th centuries. This fact is of great importance, since it shows that this historical development ran counter to the general application of a rule which was formulated, recommended, sanctioned and executed by administrative acts.

The change from $<\mathrm{e}>$ to $<\mathrm{e}>$ in words that had cognates containing an $<\mathrm{a}>$ (e.g., kelte $>$ kalte 'coldness' to align it with kalt 'cold') was based on a necessary preliminary: the re-analysis of the a-umlaut as a morphological spelling. This was not so easy to begin with. In the Upper German written dialects, a tradition of phonographic spellings of the more open e-variants by $<\mathfrak{a}>$ already existed. In the course of the 16 th century, this innovation spread out from the South to other German regions (cf. von Bahder 1890: 104-153, Moser 1929: §70, Hatz 1986, Ruge 2004: 57-104). The West Central German area was the gateway allowing the progression of the umlaut spelling into Central and Northern German regions. Only there was the spelling re-analyzed as a morphological spelling. It is a highly plausible presumption that the innovation was spread via trade or by journeyman typesetters. ${ }^{3}$ Their trails were in a sense channelled, and thus not only proceeded along the beaten paths of the trade routes. They also followed other affinities, such as religious ones. It was by no means coincidental that such innovations diffused from the Catholic South to Catholic Cologne (cf. 
Hoffmann 2003 and 2004). We do not know whether the $<\grave{a}>$ therefore initially had a rather unsavoury reputation as the "orthography of the Counter-Reformation" in the eyes of Protestants. However, this may be an important point in explaining resistance to the innovation: the area that was most resistant to this change was the one that is usually considered the most innovative, influential and trend-setting German region: Upper Saxony, the domain of Luther. So, the surprising reluctance to utilize the new letter might be explained by the fact that the $<\mathfrak{a}>$ was seen as a "Catholic" variant and thus one that was to be avoided as far as possible by Protestants.

Besides this possible reluctance on the part of Protestants in the East Central German area, there is another striking observation. The umlaut spellings spread both geographically and also to an increasingly greater number of words in the lexicon. However, it was done in an irregular and disorderly way. Old and new spellings coexisted side by side, at least in the hitherto-studied printed texts (cf. Ruge 2004 and Voeste 2007). The typesetters who were responsible for this mixing of variants did not seem to be disturbed by it at all. They set words with an umlaut and without one side by side, thus applying and ignoring the morphological principle in the same expression (cf. the variants Frâwlein and Frewlein 'young noble lady', derived from Fraw 'lady' in figure 7). The change in favour of an etymological spelling took place over time, but it was not a planned innovation. On the other hand, for a long time, spellings with umlaut might have been an additional help to coin new variants. For this reason, the spellings were not predictable: a form such as <nàchte > 'nights' did not necessarily bring about <måchte $>$ 'powers': the typesetters in the 16th century preferred $<$ mechte $>$ despite $<$ macht $>$. Similarly, they set $<$ tåglich $>$ 'daily' alongside $<$ nemlich $>$ 'namely' and disliked $<$ nămlich $>$ in spite of $<$ name $>$.

\section{Der $\mathfrak{j e r k z o g i n ~ j u ~ G o t t o r f i ~} 2$. Fräwlein.

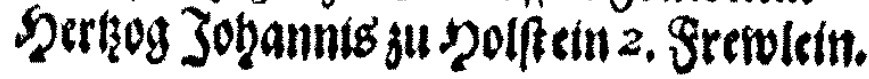

Figure 7. Variants of Fräwlein in a list from Rostock (Kurtze Jedoch Gruendliche und Warhafftige Relation 1596: C r)

Obviously, we have to consider that there has never been one single event that affected all possible cases under examination. The data argues against the general application of a rule. Nevertheless, language historians have proposed to attribute the role of spelling watchdog to the grammarians and their metalinguistic scholarly discourse. It is true that the grammarians put 
the etymological principle into words at an early stage, first and foremost Fabian Frangk in his chancery book (Ein Cantzley vnd Titel büchlin, printed in 1531 in Wittenberg, Upper Saxony). Unfortunately, it was the Upper Saxons who resisted the new spellings until the $1580 \mathrm{~s}$ - that is, 50 to 60 years after Frangk's remarks. ${ }^{4}$

\subsection{The transfer of geminate consonants}

In German, word forms that contain written geminate consonants can pass them on to their cognates. It nowadays is a general rule that the consonants are written double even when followed by another consonant (cf. the examples of stellen 'to put' and its cognates in table 1). However, the initial steps to this rule only developed during the 16th century. At the beginning of the century, we only find geminates in words that go back to an equivalent Middle High German counterpart, where the geminates were actually pronounced. The Early New High German writers still doubled letters as in mitte 'middle', halle 'hall', fonne 'sun', even though the consonants were no longer pronounced this way. The writers maintained the pattern, but they changed the ends: geminates indicated a preceding short vowel, as well as a following neutral vowel, schwa. But in Early New High German, other Middle High German words without geminates were also "infected" with this historical spelling. In the course of the 16th century, scribes and typesetters started to generalize this pattern. As a result, they even applied it to cognate forms without the necessary structural preconditions $(<$ blat $>$ 'leaf' $><$ blatt $>$ according to $<$ bletter $>/<$ blattter $>$, $<$ blattes $>$ ).

Table 1. Examples from the paradigm of stellen 'to put'

\begin{tabular}{lll}
\hline inflection & derivation & composition \\
\hline stellen & Stelle & Stellordnung \\
ich stelle & Vorstellung & Stellenpool \\
du stellst & Angestellter & Stellwerk \\
er stellt & bestellbar & Bestellschein \\
\hline
\end{tabular}

Again, etymological spellings prove to be indications of a logographic pattern formation, of the development of conventions in written language. While segmental-phonographic writing rules are based on phonological structures, etymological spellings can be regarded as grapho-phonological 
hermaphrodites. Their input form is a graphic form and not a phonological one. Or, to be more precise, their defining characteristic is an explicit (Eisenberg 1988) or supporting phonological form (Maas 1989) - usually the plural or the genitive form - whose graphic reproduction serves as a basis for the etymological spelling (cf. table 2).

Table 2. The derivation of the etymological spelling $<$ blatt $>$ 'leaf' (cf. Eisenberg 1993: 87ff.)

Stages in the derivation of $<$ blatt $>$

phonological structure

segmental-phonographic form

explicit or supporting form

graphic reproduction

etymological spelling [blat]

$<$ blat $>$

[blete], [blatəs] 'leaves', 'of the leaf'

$<$ bletter $>$ / $<$ blătter $>$, $<$ blattes $>$

$<$ blatt $>$

An examination of texts from the 16th century reveals a somewhat surprising inconsistency in this regard: some consonants, such as $\langle\mathrm{t}\rangle,\langle\mathrm{l}\rangle$ or $\langle\mathrm{f}\rangle$ are easily doubled, independently of their vocalic or consonantal context. We often find them succeeding a long vowel or a diphthong as in $<$ verratten $>,<$ bietten $>,<$ heuttig $>$. But on the other hand there are letters such as $<\mathrm{m}>$ that are rarely doubled, and then only after a preceding short vowel. That is why one cannot speak of an increasing trend towards transferring geminate consonants to their cognates. During the 16th century, we have to consider the graphetic form of the letter. Is it a "Giacomettic" letter, like $<\mathrm{t}\rangle,<\mathrm{l}>,<\mathrm{f}>$, or a "Rubenesque" one, like $<\mathrm{m}>$ ? Giacomettic letters are doubled in every given context, presumably for aesthetic reasons, whereas Rubenesque letters are only doubled for syllabic - and for etymological reasons.

\section{The emergence of syllabic spellings}

Syllabic spellings refer to specific features of the syllable structure in the correlating spoken word. The graphic segments that mark these peculiarities have no corresponding phonic correlates on their own. This applies, for example, to the so-called Dehnungs- $h$ 'lengthening $h$ ' (e.g., $<$ fohn $>$ [zo:n] 'son', <nehmen $>$ [ne:mən] 'to take'), to the gemination of vowels (e.g., $<$ eere $>$ [e:Rə] 'honour', <meer> [me:en] 'sea') or to the above-mentioned 
gemination of consonants that are followed by an unstressed syllable (e.g., $<$ mutter $>$ [mote] 'mother', <kommen> [komən] 'to come'). Many syllabic spellings can be explained historically as cases of re-analysis of former segmental-phonographic spellings. I have already mentioned one example, the gemination of consonants: double consonants originated in Middle High German, where these geminates were indeed realized phonetically.

In my corpus, a large number of spellings were found that were based on a syllabic segmentation. The syllable came to assume an ever-increasing importance for the typesetters. It was in particular the increase of double vowels and, above all, of the so-called "lengthening" with $<\mathrm{h}>$ that became "the latest trend". We find early spellings with double $<\mathrm{e}>$ such as $<$ ee $>$ 'before', $<$ Eer $>$ 'honour', <meer $>$ 'more' that correlate with a long vowel as nucleus. These spellings brought about others such as $<$ Heer $>$ 'army', $<$ Meer $>$ 'ocean', $<$ See $>$ 'sea', but they themselves were replaced by spellings with $<$ h $>(<$ ehe $>,<$ Ehr $>$, $<$ mehr $>$ ).

The $<\mathrm{h}>$ played an important role in the 16 th century. There were early spellings with initial $<\mathrm{h}>$ such as $<$ Fhane $>$ 'flag', $<$ jhar $>$ 'year', $<$ Nhame $>$ 'name', $<$ Whal $>$ 'election'. They were also used to note the long vowel of the corresponding syllable, but they had an additional special feature: they added visual emphasis or weight to the beginning of word-forms (cf. table 3). However, in the course of the 16th century those spellings were gradually eliminated, and the $<\mathrm{h}>$ was placed after the vowel. This can be illustrated by the change from the cluster $<\mathrm{rh}>$ to the use of the Dehnungs- $h$ in the word ruhm 'glory' and its derivations (cf. figure 8). The chronicles in my corpus that date back to the second half of the 16th century show that the older variant with $<\mathrm{rh}>$ was favoured until the 1580 s, when it was replaced by the form with Dehnungs- $h$.

Figure 8. "Weight gain" at the beginning of word-forms
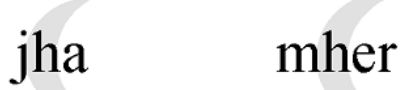

khein

The new word-forms with $<\mathrm{h}>$ after the vowel gained importance as model spellings. They also limited the productivity of the older double vowels and caused their general reduction. We even find spellings such as $<$ Schnehe $>$ (Schnee) 'snow' or $<$ Sehe $>$ (See) 'sea' in competition with the older variants. Obviously, the spellings with $<\mathrm{h}>$ succeeded in replacing most of the 
Table 3. The replacement of spellings with initial $h$ during the 16 th century

\begin{tabular}{|c|c|c|}
\hline$<r h>$ & place of printing & Dehnungs- $h$ \\
\hline \multirow{9}{*}{$\begin{array}{c}\text { rhum } \\
\text { gerhumet } \\
\text { rhum } \\
\text { berhümeften, } \\
\text { berhümbt } \\
\text { rhüenen } \\
\text { berhumbftem, } \\
\text { gerhüet, } \\
\text { rhümen } \\
\text { rhum }\end{array}$} & NUREMBERG 1554 & \multirow{7}{*}{$\begin{array}{c}\text { berühmbten, ruhm, } \\
\text { berühmete/r }\end{array}$} \\
\hline & LEIPZIG 1557 & \\
\hline & FRANKFURT/ODER 1561 & \\
\hline & EISLEBEN 1572 & \\
\hline & MAGDEBURG 1579 & \\
\hline & WITTENBERG 1580 & \\
\hline & COLOGNE 1583 & \\
\hline & DRESDEN 1590 & $\begin{array}{l}\text { gerühmet, } \\
\text { ruhmlichen, } \\
\text { rühmen }\end{array}$ \\
\hline & HAMBURG 1593 & $\begin{array}{c}\text { berühmbften, } \\
\text { berühmbt, } \\
\text { ruhmen, ruhmet, } \\
\text { verrühmpten }\end{array}$ \\
\hline \multirow[t]{3}{*}{ gerhümet } & $\begin{array}{c}\text { FRANKFURT/MAIN } 1595 \\
\text { PRAGUE } 1596\end{array}$ & $\begin{array}{l}\text { gerühmet, berühmbt } \\
\text { berühmbte, rühmen, } \\
\text { rühmlich, Ruhm }\end{array}$ \\
\hline & HALLE 1598 & gerühmbt, rühmlich \\
\hline & LUBECK 1599 & rühmeten \\
\hline
\end{tabular}

more traditional variants, because they had two advantages: on the one hand, they could be combined with all vowels, cf. $<$ Ruhm $>,<$ Nähe $>$, $<\mathrm{Vhr}>$ in contrast to the problem cases $*<$ Ruum $>$ 'glory', $*<$ Nääe $>$ 'proximity', $*<$ Vur $>$ 'clock', where the vowels are not to be doubled. On the other hand, the new spellings with $<\mathrm{h}>$ could carry out other roles too. They helped to disambiguate personal pronouns and prepositions, cf. $<\mathrm{jhm}$, jhn $>$ 'him' vs. $<$ jm, jn $>$ 'in', or served to highlight syllable onsets or codas in polysyllabic words, cf. $<$ blü.hen $>$ vs. $<$ blü.en $>$ or $<$ rüh.men $>$ vs. $<$ rü.men $>$ ). They were, first and foremost, reader-friendly variants (cf. Saito 2009).

Syllabic spellings were the great issue of the 16th century. German scholars recently argued that German underwent a change from a syllablecentered language to a word-centered language in Middle High German times (cf. Nübling, Dammel, Duke and Szczepaniak 2006: 21-22, Szczepaniak 2007). I am quite unsure what to think about this hypothesis when 
looking at 16th- and 17th-century spellings. Especially in the 17th century, a syllabic analysis became so all-powerful that it could override a morphological one. For example, the typesetters of the 16th century began to set loan-words in a different type of script. In the 17th century they even started to switch script in loan-words in order to mark the different morphological parts: they chose one script for the foreign and one for the German part. This was meant to be a morphological analysis, but if one takes a closer look, one can find a lot of examples showing a syllabic analysis that goes against the morphological one (cf. table 4).

Table 4. Syllabic and morphological segmentation of loan-words

\begin{tabular}{cc}
\hline syllabic segmentation & correct morphological segmentation \\
\hline Ornamen|ten & Ornament $\mid$ en \\
foli|den & folid $\mid$ en \\
Porta|len & Portal $\mid$ en \\
patrio|tifch & patriot $\mid$ ifch \\
\hline
\end{tabular}

\section{German standardization in a European perspective}

The spelling changes of the 16th century occurred at a time in which standardization, linguistic norms and the norm-consciousness that goes along with it were not yet set. The transition to rule-driven changes by administrative acts had not yet taken place, but the initial contours were already apparent. Variatio non delectat became the new, successful motto that led to codification and standardization.

As is so vividly illustrated by cases in point in many European languages, standardization is a process that is embedded within a particular scenario. In what follows, I will discuss four crucial factors that played a decisive role in the standardization of German - as well as in the development of other European languages.

First, we have to take into account that the Early Modern state used language as an instrument of power. Building up a modern state, attaining centralization and efficiency, meant not integrating but rather transforming different vernaculars or dialects into a unitary form that was easier to handle. By means of a kind of language-specific policy of "surrender and regrant"- a term used to describe the Anglicization policy towards the Welsh, Scottish and Irish nobility - centrally organized states granted privileges to 
those who conformed. We have to consider the correlation between language and politics in Early Modern state-building. This correlation encompassed three essential components: administration, law and religion. Uniform language became the medium of the new, privileged functional elites of the state machinery; it became the language of prestige, the language of power. Therefore, it is no wonder that a new, modern concept arose that only one of several variants should be considered correct and socially accepted. German language history is one of fragmented territories where there is no centralized power or dominant region whose dialect could have been chosen as the standard variety. There were new functional bourgeois elites in the territories, but no overall state structure. An important role was of course played by religion, more precisely by the Reformation, in the 16th century. The regional centre of the Reformation, East Central Germany, gained prestige and its dialect became a role model even for the Catholic South during the 18th-century Enlightenment.

Secondly, we have to consider historical situations of bi- or multilingualism. It was essential that the vernaculars did not simply become a medium of identification in nation-building. They were in competition with other, more dominant languages. We mainly think of Latin as the language of religion, politics and culture in Early Modern Europe, but we should also consider cases such as that of Bulgaria. Bulgarian served as the vernacular, Greek was the language of the Orthodox Church as well as the lingua franca of commerce, while Turkish was the language of administration. Languages like Bulgarian had, for political reasons, a different starting point for standardization and were usually standardized comparatively later, during the 19th century. The multilingual situation in Germany was a functional division between Latin, French and German. Latin was the language of the Catholic South and remained the means of communication among scholars until the 18th century. French was the language of the nobility, and German was the language of administration, law and the new elites - the enlightened bourgeoisie. Even though the common parlance was not standardized until the end of the 19th century, there is proof that even famous writers like Schiller were laughed at in the 18th century because they did not hide their dialect features. Listeners even said their pronunciation sounded like they were "choking on their words".

Thirdly, the vernaculars became a topic for scholarly discourse. I am not sure whether this is a side effect of political processes or due to cultural changes, or both. And one often cannot decide to what extent theory and practice differed. In many cases, we know that they differed to a great extent, for instance in the monarchy of Habsburg Spain. The Castilian gram- 
mar of Nebrija (1492) is one of the earliest codifications of a vernacular. It shows a cultural sense of superiority and stylizes the Castilian vernacular as a "handmaid" of power, taking Rome as a shining model of active language policy. Nevertheless, those theories did not infiltrate politics. The practice in Iberia remained a pragmatic one; it accepted the coexistence of a multitude of vernaculars, even though Castilian was a condition for anyone wanting to pursue a career in government service. We also discover a gap between theory and practice when we look at the effects of the metalinguistic discourse on grammar and orthography. The development of many linguistic patterns seems to be independent of or even contradictory to these linguistic efforts.

Furthermore, standardization did not evolve in a straightforward fashion. That is revealed, for example, by the work of Osselton $(1963 ; 1984)$ and Tieken Boon van Ostade (1998) for the history of English spelling. These authors raise the intriguing hypothesis that there were periods of double standards: an epistolary type of spelling used by "gentlemen" and a scholarly type of spelling that was also used in printing (for German cf. Voeste 2010).

German became a subject of scholarly discourse in the 16th century, when grammarians criticized the use of too many consonants and when schoolmasters wrote the first extensive primers, an indication of the growing demand for such texts in conjunction with the Reformation. In the 17th century, the first language academies were founded, but they never gained as much influence as their counterparts in Italy, France or the Netherlands. Grammar writing or dictionary work remained the job of individuals. The 17 th century was also the starting point for the criticism of "bad" language (cf. Davies and Langer 2006).

The first publications on language had proved that language was more than just a means of communication for everybody: it also existed in a three-dimensional form as a reference book, outside of its speakers. This meant, as Knoop (1987) puts it, that deviant oral and written forms became for the first time discriminable in both senses of the word: one could distinguish (recognize) them, and one could separate (reject) them. "The dialect became specifically perceptible, namely as the form of speech which, although existent, ought not to be used" (Knoop 1987: 29; my translation). Therefore, we find labels like "incorrect", "patched up", "offending the ear", "absurd" side by side with "lower Saxon", "from the March" or "Silesian". The grammarians made use of traditional evaluation criteria, the origins of which lie in the Latin rhetorical tradition. The typical arguments refer to common use and the auctoritas: the language as used by estab- 
lished writers. In most cases, patterns of argumentation suggest an evaluation a posteriori, which leads to the assumption that the grammarians did not trigger the standardization themselves (cf. Voeste 1999).

Finally, there are the effects of an increased use of the written language in general. Here, we must consider the new technical and economic demands resulting from the rising professionalism of scribes, printers, typesetters and proofreaders from the 16th century onwards. A lot of those effects, such as the increasing consciousness of word structures, of the interplay of letter segments, of (written) syllables and of morphemes, seem to have happened slowly and subtly. The Reformation was a lucky coincidence for German printing shops. The craft of printing was going downhill when Luther aroused the interest of the public and launched the first big "media event". I believe that we witness an important change due to the increased use of the written language during the 16th century. Indeed, scribes, and especially typesetters, left us proof that the perception of written words changed during the century.

\section{Conclusion}

Alphabetic spelling systems such as German are interpreted as going beyond the phonographic level. In this article, my aim has been to argue, with detailed examples, that the modern mixture of phonographic, graphotactic, etymological and syllabic parts is a historical product. The 16th century was an important period of time when professionalism in writing and printing led to new spellings and to new spelling principles. Scribes and typesetters developed the self-consciousness and the expert's eye to create aesthetically and grammatically-shaped word-forms. Variation is the driving force behind these innovations. It functioned as a license permitting new spellings.

It is true that the development of spelling was roughly reflected by the grammarians of the day. However, spelling changes were neither planned nor controlled by institutions. Only ex post is a self-organized path revealed to the onlooker. We know that the path also leads to modern orthographic times. However, we have to bear in mind that it did not take the shortest way. Today's spelling is the result of a meandering path of old variants and new variants, of bricolage and alteration, strongly influenced by historical, political, and societal changes. 


\section{Notes}

1. Erasmus (2005: 16).

2. Moxon (1683/84: 237).

3. For Late Medieval England, the spread via trade routes is convincingly illustrated by Bergs (2006).

4. For an overview of 16th-century discussions cf. Nerius (2000), Moulin (2004), and Moulin-Fankhänel (1994).

\section{References}

\section{Primary sources}

Ebran von Wildenberg, Johann

1901 Chronik und Stamm der Pfalzgrafen bei Rhein und Herzoge in Bayern. Georg Leidinger (ed.), Facsimile, Straßburg: Heitz \& Mündel. (Drucke und Holzschnitte des XV. und XVI. Jahrhunderts in getreuer Nachbildung 7.) Original edition, Munich: Hans Schobser, 1501 (VD 16: I 110). (URN: nbn:de:bvb:12-bsb00003570-2)

(URL: http://openlibrary.org/books/OL23286832M)

Erasmus of Rotterdam

2005 On Copia of Words and Ideas. Donald B. King, and H. David Rix (eds.). Translation of the 2nd edition 1514. Milwaukee, Wisconsin. Cf. also Biblioteca de la Universidad de Sevilla, A Res. 19/6/07. (URL: http://fama.us.es/record=b1554409 S5*spi)

Frangk, Fabian

1979 Ein Cantzley und Titel Buechlin. Reprint from the edition of 1531 (Wittenberg). (Documenta linguistica 4.) Hildesheim: Olms.

Herberstain, Siegmund Freiherr zu

1557 Moscouia der Hauptstat in Reissen. Sambt des Moscouiter Gepiet/ vnd seiner Anrainer Beschreibung vnd Anzaigung ... Vienna: Zimmermann. (URL: http://resolver.sub.uni-goettingen.de/purl? PPN339971460)

Ickelsamer, Valentin

[s.a.] Teutsche Grammatica Darauß Ainer von jm selbs Mag Lesen Lernen/ mit allem dem/ so zum Teütchen Lesen vnnd desselben Orthographian Mangel vī Überfluß/ auch Anderm Vil Mehr/ zů Wissen Gehört. [s.1.]. Universitätsbibliothek München (LMU), Cim. 37. (URN: nbn:de:bvb:19-epub-12188-8) 
Kurtze Jedoch Gruendliche und Warhafftige Relation

1596 ... der Fuernembsten Geschichten und Spectacul so Newlich zu Koppenhagen die Gantze Zeit der Kroenung des Durchleuchtigsten Großmechtigen Fuersten und Herrn Herrn Christiani Quarti Koenigs in Dennemarck etc. ... Sind Vorgelauffen. Rostock: Ferber. Staatsbibliothek Preußischer Kulturbesitz Berlin, Ua 200-3. (URL:

Moxon, Joseph http://resolver.staatsbibliothek-berlin.de/SBB000066D100000000)

1683/84 Mechanick Exercises on the Whole Art of Printing. Facsimile http://books.google.com. Reprint, Herbert Davis, and Harry Carter Nebrija, Antonio de (eds.). New York: Dover, 1962.

1492 Grammatica de la Lengua Castellana. Salamanca.

\section{Secondary sources}

Baddeley, Susan

1996 Tentatives de standardisation orthographique chez les imprimeurs français au XVIe siècle. In Proceedings of the International Colloquium "Italia ed Europa nella Linguistica del Rinascimento" (Ferrara, Italy, March 1991), Mirko Tavoni (ed.), vol. I, 287-300. Ferrara: Franco Cosimo Panini.

Bahder, Karl von

1890 Grundlagen des Neuhochdeutschen Lautsystems. Beiträge zur Geschichte der Deutschen Schriftsprache im 15. und 16. Jahrhundert.

Bergs, Alexander Straßburg: Trübner.

2006 Spreading the word. Patterns of diffusion in historical dialectology. In Topics in Dialectal Variation. Selection of Papers from the Eleventh International Conference on Methods in Dialectology. Markku Filppula, Juhani Klemola, Marjatta Palander and Esa Penttilä (eds.), 5-30. (Studies in Languages 40.) Joensuu: University Press.

Catach, Nina

1968 L'Orthographe Française à l'Epoque de la Renaissance (Auteurs Imprimeurs - Ateliers d'Imprimerie). Geneva: Droz.

Davies, Winifred V., and Nils Langer

2006 The Making of Bad Language. Lay Linguistic Stigmatisations in German: Past and Present. Frankfurt a.M.: Lang.

Derolez, Albert

2003 The Palaeography of Gothic Manuscript Books from the Twelfth to the Early Sixteenth Century. Cambridge: Cambridge University Press. 
Eisenberg, Peter

1988 Die Grapheme des Deutschen und ihre Beziehung zu den Phonemen. Germanistische Linguistik 93/94: 139-154.

Eisenberg, Peter

1993 Linguistische Fundierung orthographischer Regeln. Umrisse einer Wortgraphematik des Deutschen. In Homo Scribens. Perspektiven der Schriftlichkeitsforschung, Jürgen Baurmann, Hartmut Günther and Ulrich Knoop (eds.), 67-92. Tübingen: Niemeyer.

Gärtner, Kurt

2003 Variation im Mittelhochdeutschen am Beispiel der Handschriften des Hoheliedkommentars Williram von Ebersberg († 1085). In The Dawn of the Written Vernacular in Western Europe, Michèle Goyens, and Werner Verbeke (eds.), 415-426. Leuven: University Press.

Hatz, Erich Rolf Rüdiger

1986 Die Durchführung des „Etymologischen Prinzips“ bei der Graphie der Umlaute von 'a' und 'au'Untersucht an Drucken der Lutherbibel des 16. bis 18. Jahrhunderts. Bonn: Universitätsverlag.

Hoffmann, Walter

2003 Entregionalisierung im Kölner Buchdruck in den ersten Jahrzehnten des 16. Jahrhunderts? In Die deutsche Schriftsprache und die Regionen. Entstehungsgeschichtliche Fragen in Neuer Sicht, Raphael Berthele, Helen Christen, Sibylle Germann, and Ingrid Hove (eds.), 231-251. Berlin/New York: de Gruyter.

Hoffmann, Walter

2004 Zur Frage nach der sprachlichen 'Progressivität' des Buchdrucks im frühen 16. Jh.: Untersuchungen zum Fall Köln. In Sprachwandel und Gesellschaftswandel - Wurzeln des Heutigen Deutsch, Klaus J. Mattheier, and Haruo Nitta (eds.), 131-160. München: iudicium.

Knoop, Ulrich

1987 Beschreibungsprinzipien der neueren Sprachgeschichte. Eine kritische Sichtung der sprachwissenschaftlichen, soziologischen, sozialhistorischen und geschichtswissenschaftlichen Begrifflichkeit. Germanistische Linguistik 91/92: 11-41.

Maas, Utz

1989 Dehnung und Schärfung in der deutschen Orthographie. In Schriftsystem und Orthographie, Peter Eisenberg, and Hartmut Günther (eds.), 229-249. Tübingen: Niemeyer.

Möller, Robert

1998 Regionale Schreibsprachen im Überregionalen Schriftverkehr. Empfängerorientierung in den Briefen des Kölner Rates im 15. Jahrhundert. Köln/Weimar/Wien: Böhlau.

Moser, Virgil

1929 Frühneuhochdeutsche Grammatik. Band I: Lautlehre, 1. Hälfte: Orthographie, Betonung, Stammsilbenvokale. Heidelberg: Winter. 
Moulin, Claudine

2004 Das morphematische Prinzip bei den Grammatikern des 16. und 17. Jahrhunderts. Sprachwissenschaft 29: 33-73.

Moulin-Fankhänel, Claudine

1994 Bibliographie der Deutschen Grammatiken und Orthographielehren. Von den Anfängen der Überlieferung bis zum Beginn des 16. Jahr-

Nerius, Dieter (ed.) hunderts. Heidelberg: Winter.

2007 Deutsche Orthographie. 4th edition. Hildesheim/Zurich/New York: Olms.

Nübling, Damaris, Antje Dammel, Janet Duke, and Renata Szczepaniak

2006 Historische Sprachwissenschaft des Deutschen. Eine Einführung in die Prinzipien des Sprachwandels. Tübingen: Narr.

Osselton, N. E.

1963 Formal and informal spelling in the 18th century. Errour, honor, and

Osselton, N. E. related words. English Studies 44 (4): 267-275.

1984 Informal spelling systems in Early Modern English: 1500-1800. In English Historical Linguistics. Studies in Development, N. F. Blake, and Charles Jones (eds.), 123-137. Sheffield: CECTAL.

Parkes, Malcolm B.

1992 Pause and Effect. An Introduction to the History of Punctuation in the West. Aldershot: Scolar Press.

Reith, Reinhold

1999 Lohn und Leistung. Lohnformen im Gewerbe 1450-1900. Stuttgart: Steiner.

Rück, Peter

1988 Ligatur und Isolierung: Bemerkungen zum kursiven Schreiben im Mittelalter. Germanistische Linguistik 93/94: 111-138.

Ruge, Nikolaus

2004 Aufkommen und Durchsetzung Morphembezogener Schreibungen im Deutschen 1500-1770. Heidelberg: Winter.

Saenger, Paul

1997 Space Between Words. The Origins of Silent Reading. Stanford:

Saenger, Paul

Stanford University Press.

1999 Lesen im Spätmittelalter. In Die Welt des Lesens. Von der Schriftrolle zum Bildschirm, Roger Chartier, and Guglielmo Cavallo (eds.), 181217. Frankfurt/New York: Campus.

Saito, Kazushi

2009 Drucker- oder Leserinteressen? Eine Predigt von 1598 und ihre Nachdrucke auf dem graphematischen Prüfstand. In Historische Stadtsprachenforschung: Vielfalt und Flexibilität, Libuše Spáčilová, and Andrea Moshövel (eds.), 115-140. Wien: Praesens-Verlag. 
Stetter, Christian

1997 Schrift und Sprache. Frankfurt a.M.: Suhrkamp.

Stromer, Wolfgang von

1993 Große Innovationen der Papierfabrikation in Spätmittelalter und Frühneuzeit. Technikgeschichte 60: 1-6.

Szczepaniak, Renata

2007 Der Phonologisch-Typologische Wandel des Deutschen von einer Silben- zu einer Wortsprache. Berlin/New York: de Gruyter.

Tieken-Boon van Ostade, Ingrid

1998 Standardisation of English spelling: the eighteenth-century printers' contribution. In English Historical Linguistics 1996, J. Fisiak, and M. Krygier (eds.), 457-470. Berlin/New York: Mouton de Gruyter.

Voeste, Anja

1999 Varianz und Vertikalisierung. Zur Normierung der Adjektivdeklination in der Ersten Hälfte des 18. Jahrhunderts. Amsterdam/Atlanta: Rodopi.

Voeste, Anja

2007 Traveling through the lexicon. "Self-organized" spelling changes. Written Language and Literacy 10 (2): 215-227

Voeste, Anja

2008 Orthographie und Innovation. Die Segmentierung des Wortes im 16. Jahrhundert. Hildesheim/Zurich/New York: Olms.

Voeste, Anja

2010 Die Norm neben der Norm. Zum Zusammenhang von Graphienwahl und Überlieferungsform. In Fest-Platte für Gerd Fritz. Iris Bons, Dennis Kaltwasser, and Thomas Gloning (eds.). Gießen 24.05.2010.

(URL: http://www.festschrift-gerd-fritz.de/files/voeste_2010_normneben-der-norm.pdf)

Wittmann, Reinhard

1991 Geschichte des Deutschen Buchhandels. München: Beck. 



\title{
Swedish
}

\section{Variable norms in 16th-century Swedish orthography}

\author{
Alexander Zheltukhin
}

\section{Introduction}

The traditional view of 16th-century Swedish orthography recalls that expressed in Dickens' Pickwick Papers by Mr. Pickwick's servant Sam. "Do you spell it with $a\langle v\rangle$ or $a<w>$ ?" inquired the Judge. "That depends upon the fancy of the speller, My Lord". The opinion that the orthography of that period varied at random, with scribes spelling at whim, prevailed until recently. Indeed, the diversity in orthography, especially when seen from the point of view of modern normalization, is striking.

Since the earlier studies of 16th-century Swedish orthography, a clear distinction has been made between the secular and the religious literature on the one hand, and between the manuscripts and the printed matter on the other. Orthographic variation was mostly typical of manuscripts influenced by the Chancery language, which Wessén characterized as härskande regellöshet 'prevailing irregularity' (1927: 255). An essential degree of orthographic consistency was achieved in religious literature and in printed works, where there was less opportunity for local and idiosyncratic variation to manifest itself (Wessén 1992a: 115). Searching for patterns using sets of orthographic variables proved to be a rewarding method in the analysis of irregular orthography. Lindqvist (1918: 95) used a whole set of variables, which he called graphic variants, such as $\langle\mathrm{c} / \mathrm{ch}\rangle,\langle\mathrm{ct} / \mathrm{kt}\rangle$, $<-\mathrm{dt} / \mathrm{t}>\mathrm{to}$ describe the orthographic pattern of the famous Swedish reformer Laurentius Andreæ. He concluded that a person's orthography could be consistent over a long period of time and that it was thus possible to speak of individual orthographic strategies. In 1947, Palmér identified 21 distinctive orthographic features typical of the scribe Jon from the Chancery of Laurentius Andreæ. Focusing on the selected variables, Palmér examined changes in the original orthographic pattern of Olaus Petri in a copy penned by the scribe Jon. He concluded that a copyist could freely exchange elements of the original orthographic pattern for his own. Palmér 
also observed that a scribe's orthography could be characterized by a relative consistency (1947: 107).

In Zheltukhin (1996), I analyzed 16th-century orthographic material with the methodology used in sociolinguistic investigations of speech habits in a given community (e.g., Labov 1972, Thelander 1979, Thelander 1990, and Milroy 1992). These studies demonstrated that diffuseness in the speech of a community does not necessarily imply that this community's speech is unstructured. Variation itself can be structured, and the task is to find out how, by showing what the patterns of the community are like.

The sociolinguistic concept of norm holds that norms are social in the sense that they depend on consensus among speakers within the community (Sapir 1921: 148-152, Milroy 1992: 6, McIntosh 1956: 49). In other words, different social groups incorporate within themselves sets of recurrent and distinctive norms, also referred to as community norms, through which they can be characterized. In addition there may be prescriptive and/or codified norms (standard), to which the community norms are subordinate (cf. Milroy 1992: 82). The main difference between a standard and a community norm is that the former is stable and uniform, while the latter is unstable and variable. Community norms are dynamic entities. Due to the reciprocal influence between community norms each could be altered over the period that a standard was valid. Standard is thus a relatively static concept compared to the variable community norms. Under the conditions of permanent change the norms vary not only from one social group to another, but also from one period to the next. A periodic norm is a set of features characteristic of a specific time-period spanning multiple communities. A community norm preserves its distinctive character relative to the other communities even in transitions from one periodic norm to the next.

The variable-based method of describing variation is very effective in the study of variable norms and individual orthographic patterns (Zheltukhin 1996). A linguistic variable is present when it is possible to express the same thing in different ways. For example, the 16th-century Swedish verb hava 'to have' appeared in at least four different forms: <haffua>, $<$ hafua $>$, $<$ haffwa $>$, and $<$ hafwa $>$. Freely-occurring variants $<$-ffu- $>$, $<$-fu- $>$, $<$-ffw->, and <-fw-> together represent an orthographic variable. In Zheltukhin (1996: 36), I used twelve variables, each of them represented by at least two interchangeable variants throughout the period considered (see table 1). 
Table 1. Representations of orthographic variables

Representations of variables

1) th-/dh-/d-

2) $\mathrm{sk}-/ \mathrm{sch}-/ \mathrm{sc}-$

3) - ffu-/-ffw-/-fu-/fw-

4) $-\mathrm{V}-/-\mathrm{VV}-/-\mathrm{Vh}-/-\mathrm{hV}-$

5) $-\mathrm{ck}-/-\mathrm{k}-/-\mathrm{ch}-$

6) $-\mathrm{e}-/-\mathrm{ä}-;-$-o-/-å-

7) $-\mathrm{nC}-/-\mathrm{nnC}-$

8) $-\mathrm{Cn}-/-\mathrm{Cnn}-$

9) $-\mathrm{n} / \mathrm{-nn}$

10) $-\mathrm{t} /$-tt/-th/-tth/-dt/-dtt

11) endings of participles

12) endings of the supine

The choice of the variables was determined by the frequency of occurrences and based on the earlier work by Lindqvist (1918) as well as the observation that these variables tend to be represented by only one variant in the context of one document. There are more consonant-based variables, because consonants are generally more stable and they tend to be exchanged less often than vowels (Utterström 1968: 62, Lindblad 1954, Westlund 1974).

An orthographic code is a combination of dominant representations (variants) of the 12 variables in a single document. Table 2 on the next page offers the orthographic code of the Gustavus Vasa Bible (1541). The following edition of the Bible - the Gustavus Adolphus Bible (1617-18) - is characterized by the same orthographic code.

The analysis of 600 documents demonstrated that the orthography within each document was consistent enough to be described with the 12part code (Zheltukhin 1996: 36). Using similarities in the orthographic codes, I attributed 167 documents to 37 scribes and confirmed the results with paleographic and historical data (Zheltukhin 1996: 78).

In the following, the code-based analysis will be used to describe the most prominent community norms of the 16th century and to highlight several global developments in Swedish orthography that influenced changes in these community norms. 
Table 2. Orthographic code of the Gustavus Vasa Bible (1541) ${ }^{1}$

Code of the Gustavus Vasa Bible (1541)

1) th-

2) sk- [sc(h)rif-], [schola](n)

3) -ffu-

4) $-(\mathrm{V}) \mathrm{V}-$

5) -(c)k- [acht-], [-cht-], [macht], [frucht-]

6) e:o

7) $-\mathrm{nC}-$

8) $-\mathrm{Cn}-$

9) $-n$

10) $-\mathrm{t}$

11) $\mathrm{t}, \mathrm{d}-\mathrm{d}-\mathrm{t}-\mathrm{dt}$

12) $t-d t-t(t)$

\section{The sources}

The documents available for the period came from two major sources, the Royal printing house and the Royal Chancery. The first Royal printing house was established in 1526, and Georg Richolff, a burgher from Lubeck, was put in charge of it. In the summer of 1526 the printing house produced around 2000 copies of the New Testament. It was also Richolff who in 1540-41 printed the most eminent work of the 16th century - the abovementioned Gustavus Vasa Bible (Lindroth 1975: 229-232). Amund Laurentsson held the office of Royal printer between 1543 and 1576, much longer than anybody else in the 16th century. He published the two editions of the New Testament (1549) and (1550), Olaus Petri's Tobie Comedia (1550), a homily of Laurentius Petri (1555) and Gustavus I gensvar på Danska Krönikan 'Gustavus I's answer to the Danish Chronicle' (1558). Torbjörn Tidemansson and Anders Torstensson shared responsibility for the operation of the Royal printing house from 1576 to 1582 (Zheltukhin 1996: 25). They published John III's Liturgia eller den svenska mässoordningen 'Liturgy or the Swedish Mass Rules' and En nyttig och christelig bönbok 'A Useful and Christian Prayer Book' by Magnus Olaii Helsingii, Benedicti Olai's Läkare bok 'The Book on Medicine' in 1578 and a number of schoolbooks in Latin, for example, Prima Grammatices Rudimenta (1579), written by Johannes Billius, a teacher at John III's 
Catholic college in Stockholm (Klemming and Nordin 1883: 153). Andreas Gutterwitz, a former printer in Copenhagen and Rostock, came to Stockholm by John III's invitation in 1582 and remained in the office until his death in 1610. He published the new editions of John III's Liturgia (1588), En nyttig och christelig bönbok by Magnus Olaii Helsingii (1591) and a large number of official documents issued by the Royal Chancery. Anund Olofsson Helsing worked side by side with Andreas Gutterwitz from 1594 until 1603, when he was allowed to open his own print shop. Starting in the 1610 s, several print shops were chartered in Sweden, all by appointment to the Royal court.

The major producer of the 16th-century manuscripts was the Royal Chancery of Gustavus Vasa, his sons Erik XIV and John III, and the son of the latter, Sigismund. The other two major contributors of manuscripts were the Chancery of Duke Charles and the Chancery of King Sigismund established in Warsaw. The daily routines of the Royal Chancery are fairly well documented (Svalenius 1991). The Chancery was managed by secretaries who distributed and coordinated the work among the scribes. The sphere of a scribe's duties was strictly delineated. The specializations included open letters, communications with bailiffs, donations, and foreign affairs. This allocation of assignments was valid for periods ranging from several months to several years. It was common for the Royal secretaries to begin their careers as ordinary scribes (Svalenius 1991: 21). The person who commissioned the document was called the relator. The names of relators can be found after the formula "Mandatum a..." in the official registers. The king's orders were normally conveyed by the secretaries, by other court personnel or even by people from outside. Sometimes it happened that the king gave direct orders himself, reflected in the registers as ad proprium domini regis mandatum or Rex proprium (Svalenius 1991: 4142). Documents were written by ordinary scribes or, when it came to more important subjects, by secretaries. The relator had the opportunity to review and make corrections in the draft, and the letter was rewritten if necessary. In many instances a letter was the result of a combined effort, thus offering more than one orthographic strategy.

\section{16th-century community norms}

Figures 1-9 display the results of the computational analysis of the distribution of variables in documents produced by different social groups over the course of the 16th century. The comparative analysis of the orthographic 
tendencies contrasts printed documents with manuscripts, and religious literature with secular letters and charters. The social groups considered in the comparative analysis are the clergy, scribes and secretaries of the Royal Chancery, and employees of the Chancery of Duke Charles. The analysis focuses on several major changes in periodic orthographic norms and the rise of the $<\mathrm{CVh}>$ and $<\mathrm{ChV}>$ patterns.

Three major tendencies in the Swedish orthography of the period - the $<$ th-/dh- $>$ transition, the elimination of initial $<$ sch- $>$ in favour of $<$ sk- $>$, and the reduction of medial $<$-ffu- $>$ and $<$-ffw- $>$ to $<$-fu- $>$ and $<$-fw- $>-$ affected all community norms across the board.

The $<$ th-/dh- $>$ transition was a delayed reflection of the earlier sound change $/ \delta />/ d /$. The transition spanned the entire century, peaking in the late 1580s. Although the Ducal Chancery introduced the $<$ dh- $>$ forms later, the transition affected both the Royal and the Ducal Chancery at a similar rate (figure 1). The printed charters of the Royal Chancery also revealed the transition; however, the change was less pronounced than in the manuscripts, and religious printed literature remained unaffected by the change (figure 2).

The origin of the $<$ sk- $>/<$ sch- $>$ transition is not clear. Towards the 1590 s, use of the initial $<$ sch- $>$ declined significantly in all the social groups considered. This variant remained only in the form $<$ schola $>$ 'school'. Overall, the $<$ sch- $>$ was more common in the manuscripts of the Royal Chancery (figure 3). In the Ducal Chancery, its use was consistently low even before the 1580 s. After 1588 , the variant completely disappeared from the printed secular documents. The observed abruptness of this change, at least in the printed documents of the Royal Chancery, suggests a formal act of linguistic planning. It may have been associated with King John's puristic campaign formalized in his 1584 Charter to Bishop of Skara and in the Kalmar Statutes of 1588 . The $<$ sch- $>$ never appeared in religious printed literature, with the exception of $<$ schola $>$ (figure 4 ). 


\section{Royal Chancery (1521-88)}

Royal Chancery (1588-99)

Duke Charles (1571-88)

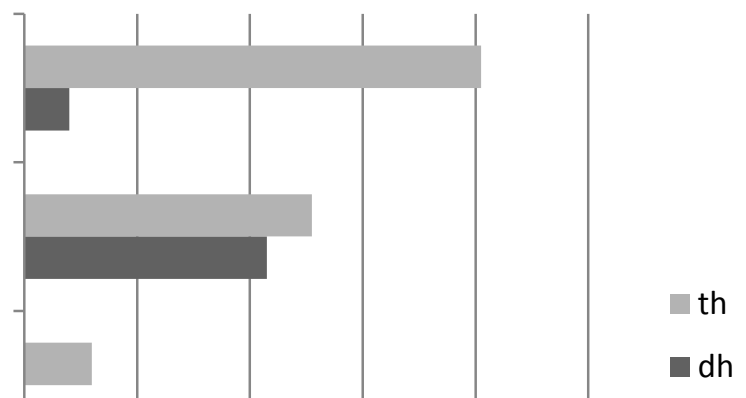

Duke Charles (1588-99)

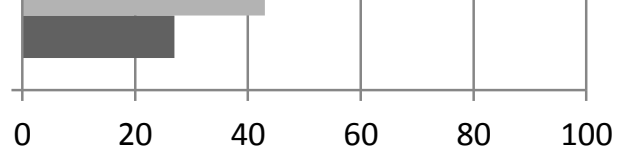

Figure 1. Transition from the initial $<$ th- $>$ to $<$ dh- $>$ in manuscripts from the Chanceries

Religious (1541-88)

Religious (1588-99)

Secular (1541-88)
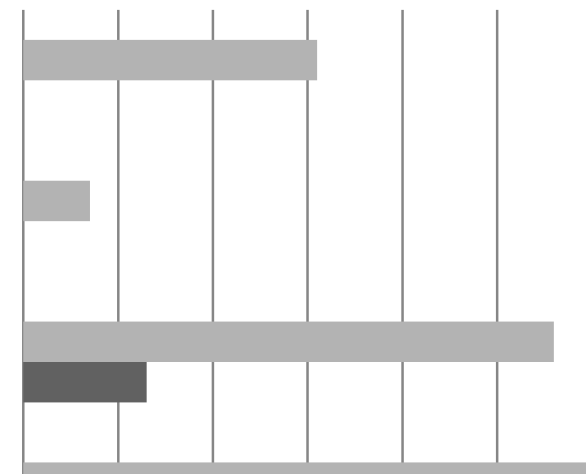

th

$\square \mathrm{dh}$

Secular (1588-99)

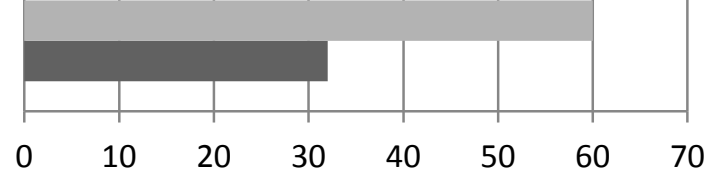

Figure 2. Transition from the initial $<$ th $->$ to $<$ dh- $>$ in printed literature 
Royal Chancery (1521-88)

Royal Chancery (1588-99)

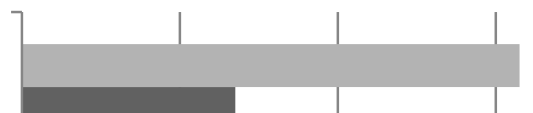

Duke Charles (1571-88)

Duke Charles (1588-99)

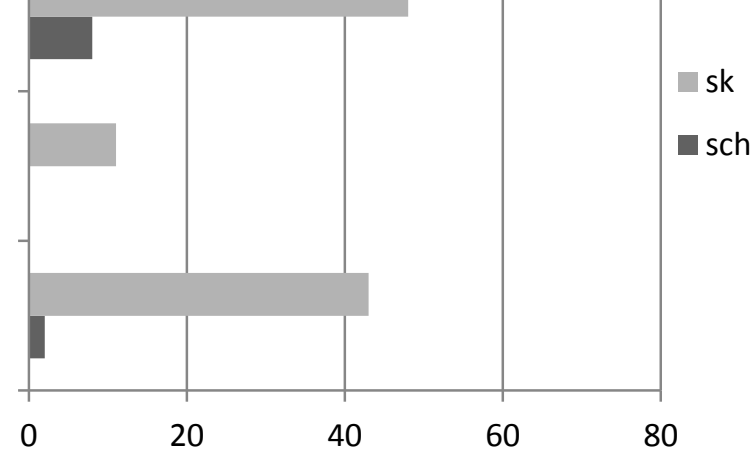

Figure 3. Decline of $<$ sch- $>$ in favour of $<$ sk- $>$ in manuscripts of the Chanceries

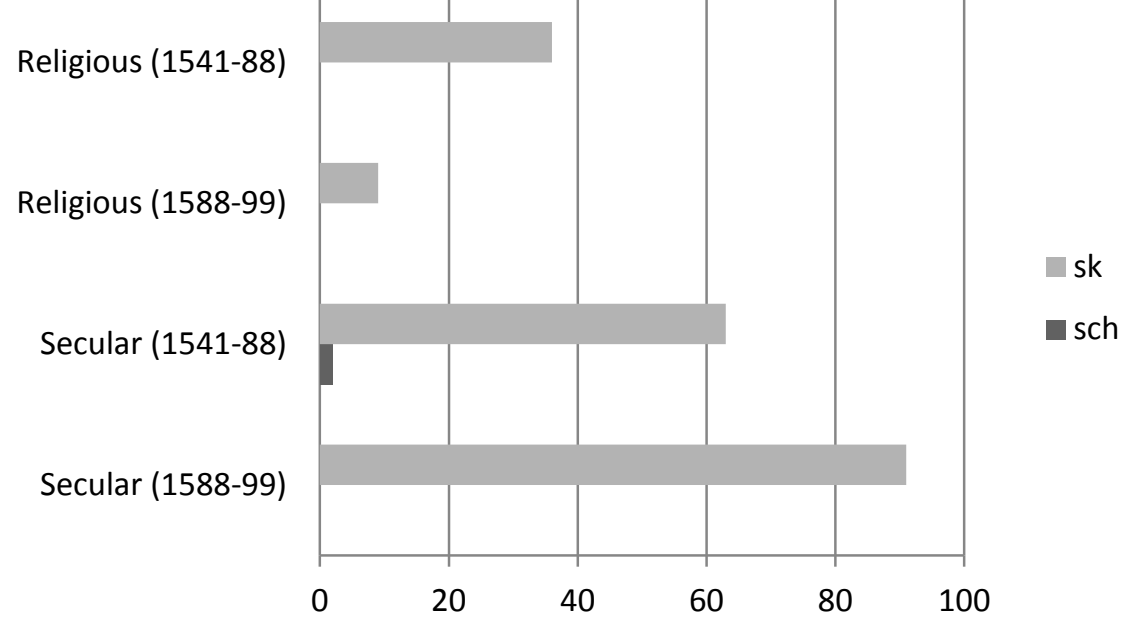

Figure 4. Decline of $<\mathrm{sch}->$ in favour of $<$ sk- $>$ in printed literature 


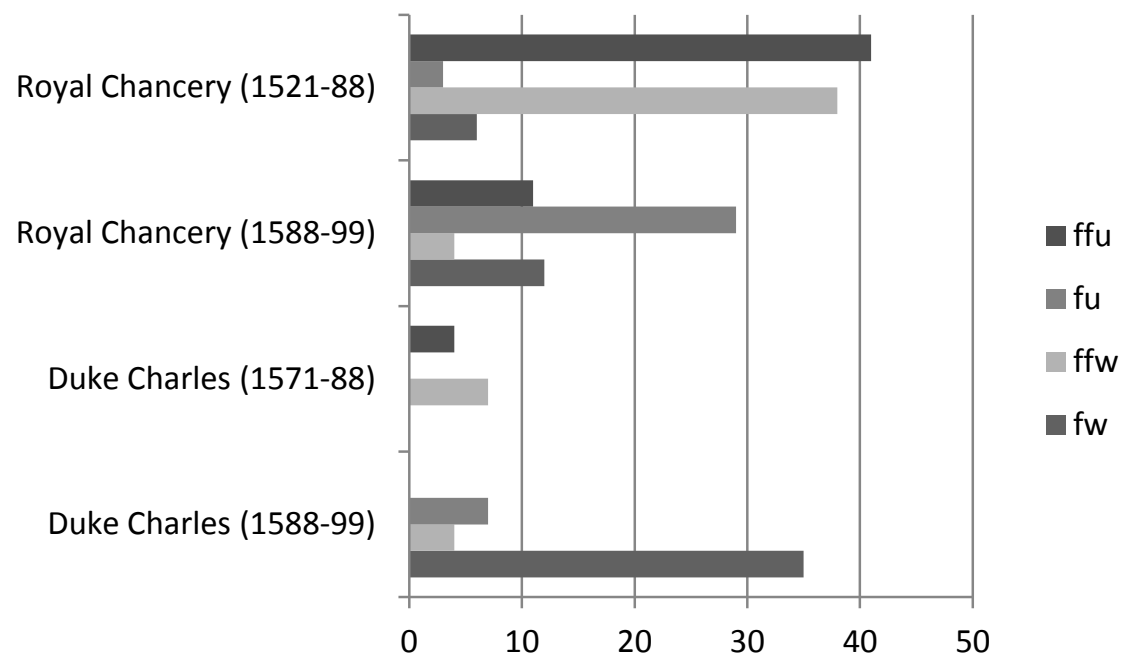

Figure 5. $<$-ffu- $>/<$-fu- $>$ and $<$-ffw- $>/<$-fw- $>$ reduction in manuscripts of the Chanceries

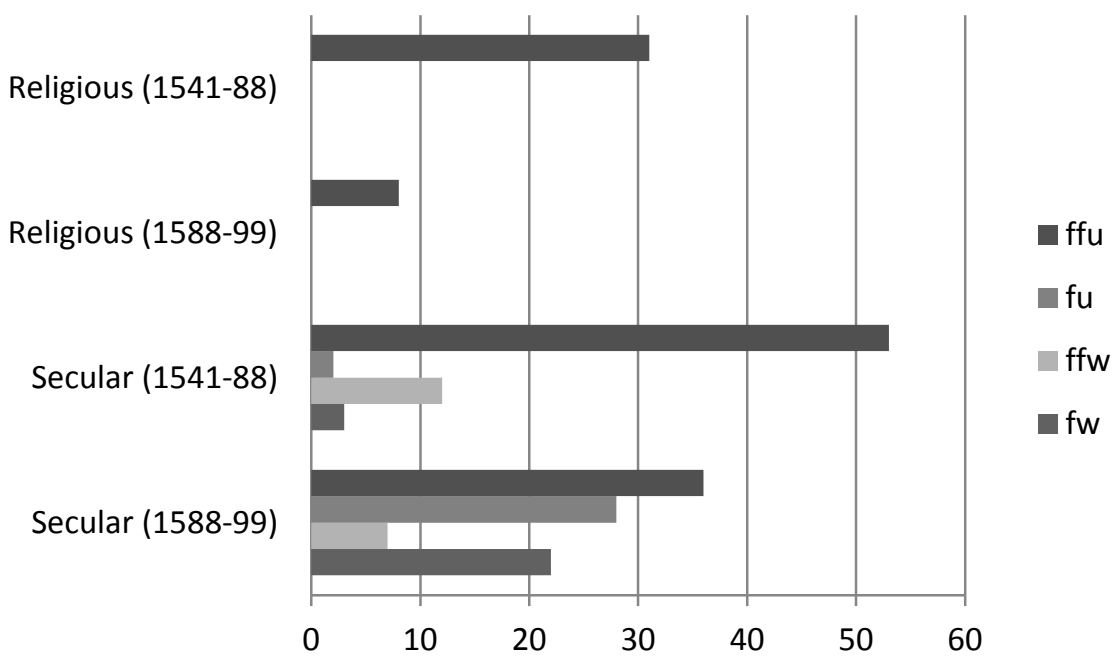

Figure 6. $<$-ffu- $>/<$-fu- $>$ and $<-$ ffw- $>/<-$ fw- $>$ reduction in print 
The <-ffu-/-fu-> and <-ffw-/-fw-> reduction is inherent to the sphere of written language, not being associated with any phonetic change. The second $<\mathrm{f}>$ must have been dropped simply for reasons of economy. The manuscripts reveal that the transition peaked in the late $1580 \mathrm{~s}$, as did the $<$ sch-/sk-> shift. By 1588, both social groups had switched to the short variants. The Royal Chancery favoured the <-ffu- $>$ variant, while the $<$-ffw-> variant was prevalent in the Ducal Chancery. After the peak of the transition, this difference became even more pronounced (figure 5). In print, the tendency is less straightforward (figure 6). Religious works in print remained unaffected by the reduction and consistently used the $<$-ffu-> variant. This variant also dominated in the secular printed works, but the other three variants were also represented. It is worth noting that, after the peak of the reduction in 1588 , the change manifested itself only in the $<$-ffw-/-fw- $>$ pair. The $<$-ffu- $>$ variant remained dominant even though the occurrences of the shorter $<$-fu- $>$ increased significantly in number compared to the earlier period. The dominance of the $<$-ffu- $>$ and its resistance to the reduction could have been caused by the influence of the widespread religious literature. The older variants $<$-ffw- $>$ and $<$-ffu- $>$ were still in use long after the peak of the transition throughout the entire 17th century (Santesson 1987).

Besides these universal changes, the analysis of manuscripts also revealed a number of distinct orthographic patterns characteristic of shorter periods and various social groups. The 1530 s were characterized by the combination of $<$ th- $>$, $<$ sk- $>$, <-ffu- $>$, and $<$ th- $>,<$ sk- $>,<$-ffw- $>$ prevailed in the late 1540s. The dominant pattern of the 1560s was the combination of $<$ sch- $>$ and $<$-ffw- $>$. The Royal Chancery under King Erik favoured $<$ sch- $>$ and $<$-dt $>$ in contrast to other Chanceries. The homogeneous pattern of the Ducal Chancery can be conveyed as $<$ sk- $>$, <-ffw- $>,<-\mathrm{V}(\mathrm{V})->$, $<-\mathrm{nC}->,<-\mathrm{Cn}->,<-\mathrm{n}->$ and $<-\mathrm{t}>$. The characteristic features of the Chancery of King Sigismund are the dominant $<$-fu- $>$ and the $<$-ä- $>$ and $<-a ̊$ variants. The forms $<$ huilchen $>$ 'which' and <elscheligh $>$ 'amiable' seem to have been favoured by the Chanceries of King Charles and King Gustavus Adolphus.

Changes in the variable orthographic norms were in some cases dictated by certain social, cultural or political events. The very first $<$ sch-/sk- $>$ shift in 1542 must have been connected to the publication of the Gustavus Vasa Bible, in which $<$ sk- $>$ is the dominant orthographic variant. The shift from the original form $<$ Johan $>$ to the Polish $<$ Jahan $>$, for example, was implemented over a very short period. The transition started in 1577 . Already by 1578 the new form $<$ Jahan $>$ had acquired dominance, which was to last 
until the end of King John's rule. The instantaneous nature of this change is indicative of linguistic planning. The change was implemented immediately after two important religious events: the publication of King John's Liturgia and the opening of the Catholic College in Stockholm (both in 1576). Given that the new wave of Catholicism in Sweden was introduced via Poland, the $<$ Johan/Jahan $>$ change can be linked to the Catholic endeavours of the king.

Changes in Royal power, also followed by changes of personnel within Chanceries, were clearly marked by strong orthographic variation. The last years of King John's reign (1588-92) and the 1596-98 civil war between King Sigismund and Duke Charles serve as good examples. Earlier, around 1560, when King Erik inherited the throne, $<$ sch-> replaced $<$ sk->, which had been dominant since the 1540s. The reversal of this change $(<$ sch- $/$ sk- $>$ ) followed in 1568, when King John came to power. Another example is the $<$-ffu-/-ffw-> shift, around the turn of the 1530-40s. Throughout the 1520 s and the $1530 \mathrm{~s}$, when the Royal Chancery was primarily manned by clerics (Loman 1956: 111), the <-ffu-> variant dominated in the manuscripts. The alternative <-ffw-> came into continuous use in the late 1530s, when the older secretaries were replaced by the Germans Georg Norman and Conrad von Pyhy. Historical changes can also explain the varying orthographic pattern in the Chancery of Duke Charles during the years 1570 to 1572. After the fall of King Erik, King John shared the burden of rule with his brother Charles. They together presided over the meetings of the Parliament (Riksdag) and the State Council, and both signed important political documents. The resulting contacts between the Chanceries caused the charters of the Ducal scribes to be interspersed with features typical of the Royal Chancery (e.g., <sk->, <-ffu->, <-nnC-> and <-nn>). In December 1572, when their co-operation collapsed, the period of marked variation ended. The break in relations led to prolonged isolation between the Chanceries (Söderqvist 1898: 200-201), during which the orthographic pattern of the Ducal Chancery remained distinct and invariable. In the early 1580s, with the thaw in relations between the brothers (Söderqvist 1898: 239), the relatively homogeneous pattern of the Ducal Chancery suffered an intrusion of orthographic features typical of the Royal Chancery (e.g., <-ch-> and $<-a ̈->$ forms). A similar trend is noticeable in the late 1590 s, when many Royal scribes were joining the Ducal Chancery. 


\section{Language contact}

One of the major factors contributing to the changes in 16th-century Swedish orthography was a strong influence of German and Dutch. Foreign studies became one of the characteristic features of the time. During the reign of the Vasa family, it was taken for granted that priests of higher ranks and schoolmasters had to study abroad, primarily in Lutheran universities of Wittenberg (founded in 1502), Rostock (1419) and Greifswald (1456). The first three students with letters of recommendation, signed personally by Gustavus Vasa, departed for Wittenberg in the 1520s. Among them was the first Swedish Protestant Archbishop, Laurentius Petri. Until 1536 only 28 Swedish students had studied in Wittenberg (less than one student a year). The number of guest-students from Sweden increased in the second half of the century, when on average 11 Swedish students visited these three German universities each year (cf. Wilner 1904). The greater interest in foreign studies during these decades was stimulated by the Skolordningen, the 'School Ordinance' of 1571 . To satisfy the demand for educated schoolmasters, the Ordinance proposed that every parish should send a number of students abroad to improve their command of different disciplines. The increase in the number of Swedish guest-students in Germany around 1580 was also due to the fact that wealthy middle class families had begun to send their sons to Germany. For many of the Royal secretaries - one of the most powerful and educated group in Swedish society - foreign studies were quite a common element of their educational background (Zheltukhin 1996: 212). Some ordinary scribes from the Chancery were also trained abroad during that period. Ivar Klementsson Oliverblad became a student in Leipzig in 1574, and then continued his education in Wittenberg (1575). Per Eriksson Utter entered Greifswald, together with the four young Oxenstiernas, to whom he acted as tutor (Svalenius 1991). A number of Chancellors, particularly under Gustavus Vasa, were of German origin. The most famous were Georg Norman, the author of an early version of the Swedish school ordinance, and Conrad von Pyhy, the trusted counsellor of the king.

John III, often referred to as "the builder-king", impressed by Renaissance architectural solutions and by their implementation in Holland and Northern Germany, employed architects and craftsmen from these countries. The German Philip Kern, the Dutch Pahr brothers, and their countryman Willem Boÿ were among the most famous architects of the period (Zheltukhin 1996: 213).

The frequent foreign studies undertaken by Swedes, and the visits of foreign experts to Sweden, resulted in a vast range of language contact 
phenomena, from occasional borrowings to long-term interference. Language contact in Swedish orthography produced new orthographic variants. A great number of recent lexical borrowings - such as certain newlyintroduced architectural terms - preserved the original orthography, e.g., the form $<$ Awstranch $>$ 'planed boards' appeared with the final $<\mathrm{ch}>$ as in Dutch. ${ }^{2}$ Certain borrowings which had long been taken over and still had their correspondences in the relevant foreign language regained their original spelling (cf. Söderberg 1985). The Latin loan word <skola $>$ 'school' appeared more often with the original $<$ sch- $>$, even in the religious literature. This noun also influenced the homographic verb $<$ skola $>$ 'to have to', frequently spelled $<$ schola $>$, and many other similar words, where $<$ sk- $>$ was exchanged for $<$ sch- $>$. The abundance of $<$ sch- $>$ forms in the first half of the 16th century was stimulated by German influence. The $<$ sk-/sch- $>$ fluctuation is apparent in German names and place names, for example, $<$ Pleskow/Pleschow $>$ and $<$ beskeed/bescheed $>$ 'errand'. $<$ Schamplun $>$ 'pattern' may serve as an additional example. Originally borrowed from Middle Low German, the word regained its foreign identity under the new wave of German influence and appeared in two forms, $<$ Skamplun $>$ and $<$ Schamplun>.

Certain originally Swedish words acquired foreign orthographic variants under the influence of foreign synonyms with similar graphic features. For example, the variants $<$ hwilcken/hwilchen $>$ were stimulated by the German welche 'which'. The $<\mathrm{li}(\mathrm{c}) \mathrm{knelse} / \mathrm{lichnelse}>$ pair belongs to the same category.

The contact with German orthographic systems also facilitated the $<$ th- $>$ / $<\mathrm{dh}->$ transition. The $<\mathrm{d}(\mathrm{h})->$ variant was introduced gradually into different words over long intervals of up to 50 years. The form $<$ dhå $>$ already existed in the $1530 \mathrm{~s},<$ der $>$ appeared in the mid-1550s, and $<\operatorname{det} / \mathrm{ded}>$ emerged only in the 1580 s. Table 3 shows the dynamics of this transition, listing the $<\mathrm{d}->$ forms in the order in which they were first introduced.

The words in italics here are orthographically similar to the frequent German conjunction $<$ da $>$ and the articles $<$ der $>,<$ den $>,<$ dem $>^{3}$. The relatively early transition in these particular words could have been paradigmatically stimulated by corresponding German forms, first in the letters of scribes who had contact with German texts. Over time these forms grew in number under the paradigmatic influence of German and the external influence of the scribes who had already adopted the new variants. ${ }^{4}$ 
Table 3. The progression of the <th-/dh->-transition from 1542 to 1586

\begin{tabular}{|c|c|c|c|c|c|c|c|c|}
\hline $15 \ldots$ & 42 & 47 & 61 & 68 & 76 & 77 & 83 & 86 \\
\hline 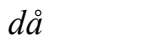 & $\mathrm{x}$ & $\mathrm{x}$ & $\mathrm{x}$ & $\mathrm{x}$ & $\mathrm{x}$ & $\mathrm{x}$ & $\mathrm{x}$ & $\mathrm{x}$ \\
\hline därföre & & $\mathrm{x}$ & $\mathrm{x}$ & $\mathrm{x}$ & $\mathrm{x}$ & $\mathrm{x}$ & $\mathrm{x}$ & $\mathrm{x}$ \\
\hline$d \ddot{a r} r$ & & & $\mathrm{x}$ & $\mathrm{x}$ & $\mathrm{x}$ & $\mathrm{x}$ & $\mathrm{x}$ & $\mathrm{x}$ \\
\hline dess & & & & $\mathrm{x}$ & $\mathrm{x}$ & $\mathrm{x}$ & $\mathrm{x}$ & $\mathrm{x}$ \\
\hline den & & & & & $\mathrm{x}$ & $\mathrm{x}$ & $\mathrm{x}$ & $\mathrm{x}$ \\
\hline de & & & & & $\mathrm{x}$ & $\mathrm{x}$ & $\mathrm{x}$ & $\mathrm{x}$ \\
\hline dem & & & & & & $\mathrm{x}$ & $\mathrm{x}$ & $\mathrm{x}$ \\
\hline det, deris & & & & & & & $\mathrm{x}$ & $\mathrm{x}$ \\
\hline dette & & & & & & & & $\mathrm{x}$ \\
\hline denne & & & & & & & & $\mathrm{x}$ \\
\hline
\end{tabular}

The forms $<$ den $>$ and $<$ de $>$ deserve special comment, because they had been adopted by many scribes long before the $<$ th-/dh- $>$ transition appeared. The $<$ den $>$ form was frequently used in one phrase, usually appearing in the address (protocol) and/or in the initial part of the main text of charters. The form $<\mathrm{d}(\mathrm{h}) \mathrm{en}>$ replaced the otherwise more common $<$ then $>$ before the name and the title of the addressee or the person mentioned in the text. This $<$ den $>$ - and $<$ de $>$ - phrase, often including adjectives like $<$ Ädle $>$, <welborne $>$, and $<\mathrm{e}(\mathrm{h})$ rlig $>$ 'noble', was originally a German formula, borrowed at the beginning of the 16th century. The $\langle\mathrm{d}(\mathrm{h}) \mathrm{e}\rangle$ form became affected by the transition in similar contexts by analogy with $<$ den $>$. One interpretation of the early $<$ th $->/<$ dh- $>$ transition in this context can be the paradigmatic influence of German (i.e., $<$ den $>$ and $<$ de $>$ were simply "imported" along with the whole phrase). Alternatively, it could be one of the numerous examples of the orthographic code-switching.

Orthographic code-switching is a juxtaposition of elements from different orthographic systems within one word, resulting in an orthographic hybrid (cf. Gumperz 1982). Code-switching is present when an element from a foreign orthographic system is selected instead of a commonly used Swedish variant, as if they were interchangeable orthographic variants of the same system. The selection of the foreign variant is governed by subconscious processes. It can be triggered by the context, the subject of the document, the name, origin and social position of the receiver, etc. One of the prerequisites of code-switching is a close-knit network characterized by 
the shared understanding and shared knowledge of the correspondents. It means that orthographic code-switching could be practised within a group (or groups) in which consensus on norms and conventions had been achieved, and the scribes were connected by strong social ties. Each case of code-switching could, along with other considerations, signal the identity of the scribe and his affiliation to a certain group. At the same time it gives the receiver an opportunity to assign the scribe to a social category and to assess a shared social background (cf. Gumperz 1982: 69).

In the early stages of 16th-century language contact, the code-switching group comprised people who had had the opportunity to study abroad and/or had frequent contact with foreigners at home: that is, the nobility, including Royal Chancellors, the clergy and a relatively large group of Royal secretaries. Later on, code-switching proliferated as a result of recurring language contact situations and the maintenance of group identity (cf. Gumperz 1982: 64). This tendency resulted in a growing number of contexts in which the scribes code-switched. What initially was a sporadic paradigmatic deviation from the scribe's individual orthographic code gradually became a part of the scribe's orthographic strategy. Scribes who practiced code-switching played the role of mediators of language contact among monolinguals. Due to the lack of shared knowledge and weak social ties, however, scribes from other social groups were not always able to interpret the instances of code-switching correctly. While in some cases orthographic hybrids were literally conveyed by the monolingual scribes, in other cases new "erroneous" forms were produced. These new forms, originally the results of other people's code-switching, gradually became a new norm within the "monolingual" group, for the same reasons of identity and group affiliation (Zheltukhin 1996: 219). The acceptance of the orthographic hybrids first by individuals and then at the community level led to orthographic interference, which manifested itself in a number of graphotactical changes. ${ }^{5}$

One of the most striking examples of orthographic interference in 16thcentury Swedish is the propagation of the $\langle\mathrm{Vh}\rangle$ and the new $\langle\mathrm{Ch}>$ sequences. The conventional $<\mathrm{h}>$, which traditionally appeared only in a small set of clusters $(<$ th- $>,<$ dh- $>,<$-dh- $>,<$-dh $>,<$-gh- $>,<$-gh $>$ ), started to emerge in a great number of sequences that had never been found at the earlier historical stages. According to Wessén (1992b: 154) "har väl $h$ brukats sporadiskt, efter tyskt mönster, ${ }^{6}$ för att i sluten stavelse beteckna vokalens längd" [ $h$ must have been used occasionally to denote the length of the vowel in the end of the syllable according to the German pattern]. In some cases "har väl ordskillnadsprincipen gjort sig gällande" [it was used 
to distinguish homographs] (Wessén 1992b: 153). Indeed, the $<\mathrm{Vh}>$-sequence often replaced the Swedish $\langle\mathrm{V}(\mathrm{V})\rangle$, where it corresponded to a long vowel in present-day Swedish (e.g., $<$ swahr $>$ instead of $<$ swa(a)r, $<$ fahra $>$ instead of $<\mathrm{fa}(\mathrm{a}) \mathrm{ra}>$, etc.). The assumption that the $<\mathrm{Vh}>$ variant identified long root vowels is also supported by Samuel Columbus, one of the first known Swedish grammarians from the 17th century. In his famous En Swensk Ordeskötsel 'The Swedish Language Handbook', he advised getting rid of the old habit of doubling vowel signs in favour of either a single $<\mathrm{V}>$ sign or a $<\mathrm{Vh}>$-sequence: "skrijf mån eller mohn, ... Fahr, Fader" (Columbus 1963: 66). Supporting evidence can also be found in Allén (1965), who observed an increase in $\langle\mathrm{Vh}\rangle$ sequences in the letters of Ekeblad, written in Holstein 1654-55. During the Holstein period the conjunction $<$ mähn $>$, for example, clearly outnumbered the alternative form $<$ men>: 76 to 1. For 1649, when Ekeblad stayed at Queen Christina's court, the ratio was exactly the opposite: $71<$ men $>$ to $3<$ mähn> (Allén 1965: 137). For the same period the form $<$ flehre $>$ was also recorded instead of the more common $<$ fle(e)re> (Allén 1965: 139).

Another innovation in the Swedish orthographic system of that time is the $<\mathrm{ChV}>,<\mathrm{ChVV}>$, and $<\mathrm{CVVh}>$ clusters, which emerged alongside the $<\mathrm{CVh}>$ forms. These clusters were freely exchanged with $<\mathrm{CVh}>$ in the same contexts (e.g., <lähn $>$ and $<$ lhän $>$, <mehra $>$ and $<$ mhera $>$, $<$ nähr $>$ and $<$ nhär $>$, $<$ fahra $>$ and $<$ fhara $>$ ), which indicates that they were variants of the same orthographic variable. The $\langle\mathrm{ChV}>$ forms are considered to be secondary to the borrowed $<\mathrm{CVh}>$ pattern. The $<\mathrm{CVh}>/<\mathrm{ChV}>$ variation was caused by the influence of the old Swedish $<\mathrm{C}+\mathrm{h}>$ graphotactical rule, according to which the conventional $<\mathrm{h}>$ could only follow consonants (Zheltukhin 1996: 225). Under the force of the rule, the $<\mathrm{h}>$ gravitated to the consonant, causing the $<-\mathrm{Vh}->/<-\mathrm{hV}->$ transposition. There are numerous examples of $<\mathrm{CVh} / \mathrm{ChV}>$ variation in letters of scribes who clearly preferred $\langle\mathrm{CVh}>$, and even in documents written by Swedish scribes in German. For example, in an undated letter of Nils Rask, there are forms like $<$ mher $>$, $<$ Wassermhiile $>$ and $<$ Jhar $>$. The form $<$ Jhar $>$, along with $<$ Jahr $>$, also appeared in a printed charter signed by Duke Charles. A document of May 20th 1581, penned by an unknown scribe, contains the German translation, which along with the form <nehmen $>$ also offers the distorted variant $<$ nhemen $>$. When there was no preceding consonant, the $<\mathrm{C}+\mathrm{h}>$ rule caused the $<\mathrm{h}>$ sign to be placed after the consonant that immediately followed the long vowel (e.g., $<$ ahnten/anhten $>$, $<$ ahnwenda/ anhwenda $>,<$ ahnseedt/anhseedt $>,<$ mehre/merhe $>$, <wohre/worhe $>$ ). The transition to these $<\mathrm{VCh}>$ forms could also be facilitated by the external 
influence of the growing number of the new $<\mathrm{Ch}>$ forms which emerged as the result of the $<\mathrm{CVh} / \mathrm{ChV}>$ variation (e.g., $<\mathrm{fh}>,<\mathrm{mh}>,<\mathrm{lh}>,<\mathrm{rh}>$, $<$ wh $>,<$ nh $>$ ). For many scribes, these clusters were conceptually independent from the original $<\mathrm{CVh}>$ forms and the $<\mathrm{h}>$ sign in them was no longer perceived as a vowel-length sign, as indicated by the numerous $<\mathrm{ChVV}>$ forms.

Overall, the $<\mathrm{ChV}>$ forms outnumber the $<\mathrm{CVh}>$ forms by $60 \%$ to $40 \%$. Half of the $<\mathrm{ChV}>$ forms, however, are represented by words starting with $<$ mh- $>$ and $<$ fh- $>$, in particular, the high-frequency verbs $<$ mhå $>$ and $<$ fhå $>$. Ironically, these verbs never appeared as *måh and *fåh. The $<\mathrm{h}>$ was immediately attracted by the consonant and could have persisted for a merely decorative reason, by making the originally "short" words longer.

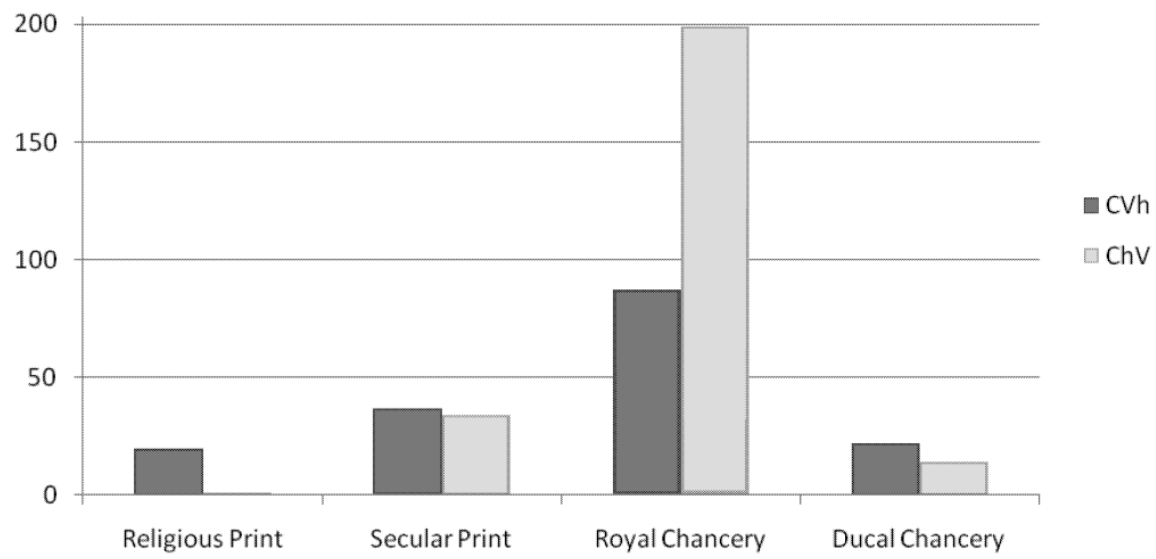

Figure 7. Distribution of $<\mathrm{CVh}>$ forms and $<\mathrm{ChV}>$ forms

Each social group displayed a unique pattern of distribution of the $<\mathrm{CVh}>$ and $\mathrm{ChV}>$ forms (figure 7). The Royal Chanceries of Erik and John were the greatest producers of the $<\mathrm{h}>$ forms, significantly contributing to the spread of $<\mathrm{ChV}>$ forms. The scribes of Duke Charles, in contrast, used $<\mathrm{h}>$ forms sparingly and were more strongly affected by orthographic interference (the $<\mathrm{CVh}>$ forms exceeded the $\langle\mathrm{ChV}>$ forms). It is noteworthy that the majority of the $<\mathrm{h}>$ forms in the documents of Duke Charles come from the periods of 1570-1572, 1580-82 and 1591-99, when diplomatic ties between his Chancery and the Royal Chancery were maintained. In religious printed works only $<\mathrm{CVh}>$ forms are found, and they are relatively 
few. In some cases they appear to have been used to distinguish homographs, e.g., noun <ähra $>$ 'honor' vs. verb <äre $>$ 'are', noun $<$ fahra $>$ 'danger' vs. verb $<$ fara $>$ 'to travel'. Some Royal scribes also utilized $<\mathrm{h}>$ in this function, e.g., noun <wår $>$ 'spring' vs. pronoun <wåhr $>$ 'our'. Printed secular documents offer a very different distribution of $\langle\mathrm{CVh}\rangle$ and $\langle\mathrm{ChV}\rangle$ forms compared to the manuscripts. The $<\mathrm{h}>$ forms are significantly fewer in print and the effect of the orthographic interference is more pronounced due to the slightly higher number of $\langle\mathrm{CVh}>$ instances.

One of the prerequisites of the interference is "preexisting similarity in patterns" (Weinreich (1953: 44). The similarity between German and Swedish clearly facilitated the orthographic interference. It must have been relatively easy to switch from $<\mathrm{fa}(\mathrm{a}) \mathrm{ra}>$ to $<$ fahra $>$ under the influence of German $<$ fahren $>$, and from $<$ me(e)ra $>$ to $<$ mehra $>$ under influence of German $<$ mehr $>$ (cf. $<$ hwilcken/welche $>$ ).

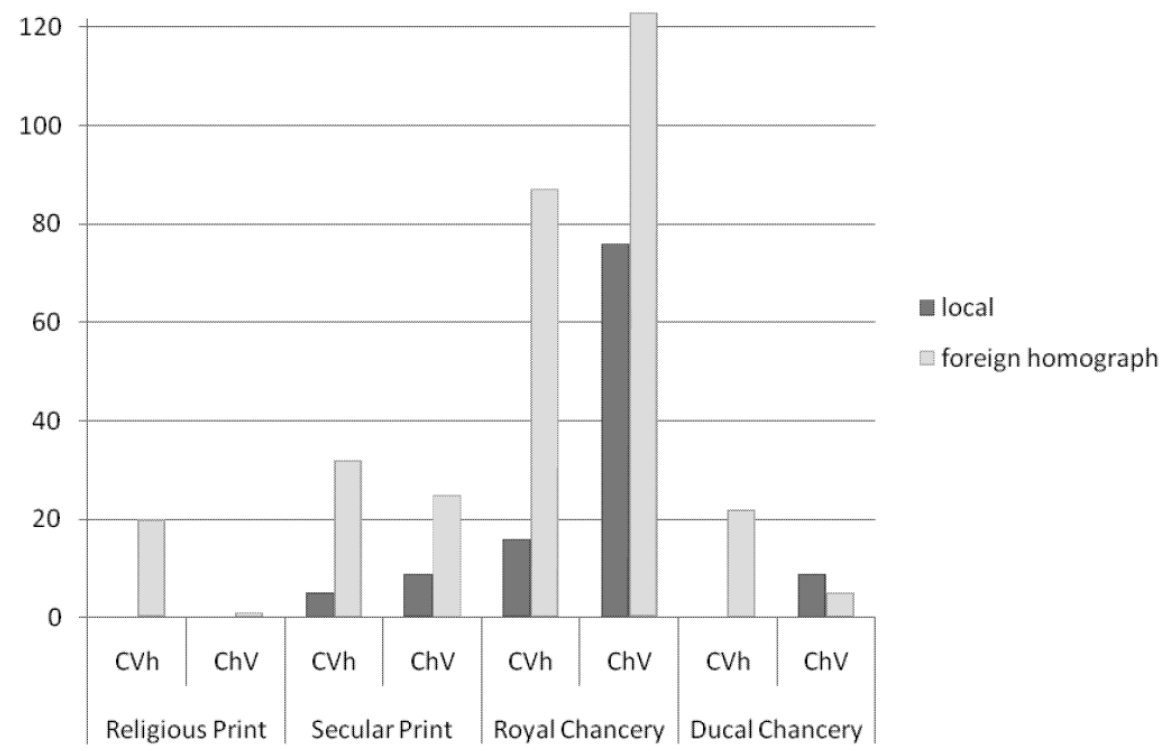

Figure 8 . Patterns of the $<\mathrm{Vh}>$ interference based on similarity with German

Figure 8 summarizes the distribution of $\langle\mathrm{CVh}\rangle$ and $\langle\mathrm{ChV}\rangle$ forms in words for which there was a corresponding homograph in German, and in words with no corresponding homographs. Words with corresponding foreign homographs were significantly more numerous than local words associated with both $<\mathrm{CVh}>$ and $<\mathrm{ChV}>$ forms. The $<\mathrm{CVh}>$ forms tended to occur far 
more frequently in words with corresponding foreign homographs than in local words. The same tendency applied to $\langle\mathrm{ChV}\rangle$, but the difference in frequency between the word-types was less pronounced. In the case of the Ducal Chancery the $\langle\mathrm{ChV}\rangle$ forms were more frequently used in words with no corresponding foreign homographs, indicating that $\langle\mathrm{ChV}\rangle$ was already perceived as a local construct. From a sociolinguistic perspective, these two patterns can be considered as elements of two social norms, which served as identity markers of two unequal, heterogeneous, yet distinct social groups. Individual scribes, with few exceptions, never mixed the two patterns, i.e., they consistently used either $\langle\mathrm{CVh}\rangle$ or $\langle\mathrm{ChV}\rangle$ forms. The $<\mathrm{CVh}>$ pattern was the identity marker of the so-called bilinguals (Zheltukhin 1996: 225-226). Most of the identified $<\mathrm{CVh}>$ users were highlyeducated Royal secretaries and eminent representatives of the clergy with many years of studies at German universities. At the same time, none of the identified systematic $\langle\mathrm{ChV}\rangle$ users, including secretaries and ordinary scribes, had studied abroad or was exposed to language contact to the same extent as the known $<\mathrm{CVh}>$ users. The quick penetration of the new orthographic patterns was conditioned in both practical and social terms. Originally, the $<\mathrm{CVh}>$ pattern was imported from German probably to serve as a separator of homographs. Under the stable and strong influence of German, yet more words acquired the conventional $<\mathrm{h}>$ after long vowels for both functional and decorative reasons. The sociolinguistic model of linguistic change and norm-shifts can explain the quick rise of the $<\mathrm{ChV}>$ pattern.

The reader can never be certain what is convention and what depends on strategy, because different people never have exactly identical norm systems. ... Consequently, the reader can erroneously interpret context-bound, communicative solutions as the scribe's conventions (on condition that they are not part of his own norm). This may be a prerequisite of linguistic change. $^{7}$

Under favourable conditions, the error of the reader, which at that moment was a deviation from his norm, could become widespread and even legalized (Milroy 1992). Prestige could be the common factor that fuelled the usage of both $\langle\mathrm{CVh}>$ and $\langle\mathrm{ChV}>$ forms. For the $\langle\mathrm{CVh}>$ users, the conventional $<\mathrm{h}>$ embodied the prestige of the German language that mediated the Reformation and public learning. The $\langle\mathrm{ChV}\rangle$ group might have attached prestige to the conventional $<\mathrm{h}>$ because it was used by the bilingual community: in other words, people of a higher social rank. The presence of $<\mathrm{h}>$ might also have been viewed by the $\langle\mathrm{ChV}>$ group as fashionable and appropriate. 


\section{The 16th-century orthographic standard}

All the major changes in 16th-century Swedish orthography: the $<$ th $->$ / $<$ dh- $>$ transition, the $<$ sch- $>/<$ sk- $>$ shift, the $<$-ff- $/$-f- $>$ reductions, and the introduction of the $\langle\mathrm{CVh}\rangle$ and $\langle\mathrm{ChV}\rangle$ forms, did not affect the religious literature in print. In fact, printed religious works of that time displayed a stable and consistent orthographic pattern that can be described with the orthographic code in figure 1. This code, taken from the Gustavus Vasa Bible (1541), is referred to as the "Standard Orthographic Code" (Zheltukhin 1996: 38), because it describes the only invariable orthographic norm of the 16 th century.

Standardization usually takes place together with the development of a written language, or after different written varieties of a language have been developed, and printed techniques have been invented in order to achieve a widespread distribution of literary works (Bartsch 1987: 250). Standards can evolve naturally in the course of history, or can be imposed by language-planning initiatives. The factors that contribute both to the emergence of a standard and to the successful implementation of a proposed standard are: 1) where the variety is spoken by a prestigious group, whereby prestige is defined in terms of political or economic power and education; 2) where the variety has a history of literacy, especially literature written by 'great authors'; and 3) where the variety is located in an area in which several varieties of language come into contact and therefore borrow from each other and assimilate (Bartsch 1987: 251). Thus, a social norm characteristic of a prestigious group gives rise to the standard. At some point in time, owing to its variable nature, the norm diverges from the static standard and the differences between the two increase over time. Eventually, the gap becomes too wide for the old standard to remain practical, and it collapses. A new standard, brought about by the same mechanism, takes its place.

The Standard Orthographic Code (SOC) is first recorded in the publication of the New Testament (1526). With its roots in the language of the 15th-century Vadstena monastery, the SOC was followed by prominent members of the clergy in the first half of the 16th century. The individual orthographic codes of Laurentius Andreæ, Olaus Petri, Laurentius Petri and many others were identical to the SOC. During the period when Laurentius Andreæ was in charge of the Royal Chancery, the SOC influenced the norm of the Chancery (cf. Loman 1956: 110-111). Individual orthographic strategies of several Royal secretaries (e.g., Rasmus Ludvigssons, Sarffue, Claes) were also very close to the SOC (Zheltukhin 1996: 103-113). Given 
that none of these secretaries belonged to the clergy, it appears that the SOC was also the norm agreed upon by a group of well-educated laity. Being used by the upper social strata, the SOC, as a prestigious orthographic pattern, was elevated to the level of the standard. The SOC became the codified standard of the 16th century to a considerable extent with the support of the Swedish educational system. Already in 1530, the Riksdag at its meeting in Västerås had already determined that the Gospels should be read in all schools. The Gospels were first read in Latin, but subsequently, with the translation of the Gustavus Vasa Bible, the Swedish text became more widespread. Pupils had to read selected parts of the Bible and the catechism for an hour each day (Lindroth 1975: 214). The Bible and other works of religious literature were also the prime educational tools in the writing classes. On a regular basis, pupils had to copy and memorize selected passages.

The SOC was not just the orthographic pattern that had to be followed in schools and in print shops when printing religious literature. It also appears to have been a guideline for printing any kind of secular literature, including Royal charters. Although characteristic features of respective social norms and individual features surface in secular printed literature, these idiosyncrasies are considerably fewer than in the manuscripts (figures $1-6,8,9)$. The orthography in secular printed works was apparently normalized to bring it into line with the SOC. There is no historical evidence however that secular works were proofread prior to printing. It is known that there was an office of the Royal corrector and it was associated with Swedish book-printing in the 16th century (Zheltukhin 1996: 25-26). However, the archives have preserved only few prescriptions to correctors, in which their duties were formulated in very general terms. Nothing was explicitly mentioned about proofreading and orthography. ${ }^{8}$ It is only known that correctors were specially employed to supervise the printing of the catechism and the Bible (Schück 1923: 68). Given that all the known correctors were clerics (Zheltukhin 1996: 26), it is reasonable to assume that one of their supervising duties was to ensure that at least the religious literature in print conformed to the SOC.

The SOC remained the orthographic standard for almost 100 years, until the 1646 edition of the Bible. Then, following the major orthographic changes of the previous century, a new standard emerged. The characteristic features of the new standard were the $<\mathrm{CVh}>$ forms (e.g., $<$ åhr $>$ ) and the short $<$-fw- $>$, which replaced the old $<$-ffu- $>$ variant. ${ }^{9}$

From a sociolinguistic perspective, prestige "can be subjectively attached by speakers to forms ... which are very distant from, and in conflict 
with, the codified norms of the standard" (Milroy 1992: 129). Such a conflict that ultimately led to the collapse of the SOC started in the early second half of the 16th century, when the $\langle\mathrm{CVh}>$ forms were introduced and the <-ffu-/-fu->, <-ffw-/-fw-> reductions began. The appeals of the most faithful adherents of the SOC to the clergy to use correct language were the first signs of the rift between the standard and the orthographic norm of the clergy. Although the tendency to code-switch was suppressed by constraints of linguistic purity in the clergy, various $<\mathrm{CVh}>$ appeared even in manuscripts written by clerics who strictly followed the SOC (Zheltukhin 1996: 229-244). Under the increasing German influence, the $<\mathrm{CVh}>$ pattern gained an even greater importance in the 17th century and became a part of the new standard orthographic code. In some proper names, it has been preserved up to the present time.

\section{Notes}

1. Forms with alternative representation of the variable are enclosed in square brackets. Variables 11 and 12 are represented by subvariables. Variable 11 (endings of participles) has four subvariables: post-vocalic position (utrum) post-consonantal position (utrum) - post-vocalic position (neutrum) - postconsonantal position (neutrum). Variable 12 (supine endings) has three subvariables: supine of first conjugation verbs (and some fourth conjugation verbs with similar features) - supine of third conjugation verbs (and some second conjugation verbs with preceding $\langle\mathrm{r}\rangle$ or $<\mathrm{l}>$ ) - all other second and fourth conjugation verbs.

2. This form is taken from a letter of April 10th 1572, written by a scribe with a clear $<$-ck $>$ preference. It is interesting that $<\mathrm{ch}>$ forms appeared also in two more letters: in March 27th $1572<$ löffvärch>, <panelvärch> and also $<$ trävärch $>$; in July 13th 1572 it spread over to $<$ folch $>$, <ämbetsfolch $>$. The increasing $<$-ck/-ch $>$ variation indicates the $<$-ch $>$ interference.

3. The Swedish $<$ dess $>$ which has a graphic equivalent in German (the article des) also emerged relatively early, in 1568, but then never reappeared until 1586 .

4. This theory is consistent with the empirical findings in the speech of immigrants who had difficulty in maintaining discourse in their native Swedish, due in part to a lack of practice (Hasselmo 1961: 61). Hasselmo found their conversation rich in examples of switching, and often lacking phonological borders, which childhood bilinguals were more likely to master. Having virtually only a single Swedish sound system, the subjects were prone to create replicas of English function words that were indistinguishable from corresponding colloquial Swedish ones (an>en, them/dem). 
5. Weinreich (1953: 69) proposed the criteria which might permit a linguist to say that a new norm (hybrid language) had come into existence as the result of interference. To assert that a new orthographic norm came about as the result of orthographic interference, it would be sufficient to determine that two or more scribes code-switched, and that the code-switching on an individual level exhibited a certain degree of consistency.

6. According to Bach (1965: 228) "nachdem - $h$ - zwischen Vokalen verstummt war (in Fällen wie mhd. Stahel $>$ nhd. Stahl, gemahel $>$ Gemahl) wurde es in der Schrift seit dem Ende des 15. Jh.'s häufiger zur Bezeichnung der Vokallänge verwandt, ja schließlich auch gesprochen" [After - $h$ - between vowels had become mute (in cases such as MHG stahel > NHG Stahl 'steel', gemahel $>$ Gemahl 'spouse') it was, from the end of the 15 th century, often used in writing in order to designate vowel length, and even ended up by being pronounced]. The Luther Bible may serve as an example of frequent usage of $<\mathrm{Vh}>$ sequences.

7. Teleman (1985: 70).

8. In general, little is known about the language policies of the 16 th century and speakers' attitudes towards them. There is only a small number of official documents from the second half of the 16th century that touched on linguistic matters, but in a rather superficial manner. Among those are Laurentius Petri's admonition to the clergy to use correct language (1571), the Kyrkoordningen 'Church Rules' (1571), the first known document prescribing a course of learning for schools, and The Church Council in Uppsala (1573), which proposed to prohibit the use of foreign words. The Nya Kyrkoordningen 'The New Church Rules' or Nova Ordinantia (1575) appealed to keep the Swedish language pure from the influence of foreign churches and schools. In the 1584 charter to the Bishop of Skara, John III admonished the Bishop to use correct Swedish in the pulpit. Finally, the Kalmarstadgar 'The Kalmar Statutes' (1587) declared a new drive for linguistic purity. It is noteworthy that this activity on the language normalization front immediately precedes the peak of the $<$ sch-/sk- $>$ change and the $<$-ffw- $>/<$-fw- $><$-ffu- $>/<$-fu- $>$ reductions.

9. The $<-$ fw- $>$ dominated until the end of the 19th century. According to Santesson (1987: 406), the <-ffu-/-fu-/-fw-> change was influenced by secular printed works, in which for example $<\mathrm{fw}>$ already dominated by 1606 . The data accord with the orthographic analysis of two printed theological works by King Charles, in which the $<-$ fw- $>$ was exclusively used. 


\section{References}

Allén, Sture

1965 Grafematisk Analys som Grundval för Textedering med Särskild Hänsyn till Johan Ekeblads Brev till Brodern Claes Ekeblad 16391655 [Text editing on the basis of a graphemic analysis with respect to letters by Johan Ekeblad to his brother Claes Ekeblad 1639-1655].

Bach, Adolf Stockholm: Almqvist \& Wiksell.

1965 Geschichte der deutschen Sprache [History of the German language]. 8th revised ed. Heidelberg: Quelle \& Meyer.

Bartsch, Renate

1987 Norms of Language. Theoretical and Practical Aspects. London/ New York: Longman.

Columbus, Samuel

[1963] En Swensk Ordeskötsel [The Swedish language handbook], Sylvia Boström (ed.). Stockholm.

Gumperz, John J.

1982 Discourse Strategies. (Studies in Interactional Sociolinguistics 1.) Cambridge: Cambridge University Press.

Hasselmo, Nils

1961 American Swedish. A Study of Bilingualism. Cambridge, Mass.: Harvard University Library.

Klemming, Gustaf Edvard, and Johan Gabriel Nordin

1883 Svensk Boktryckeri-Historia 1483-1883 [The history of Swedish book printing 1483-1883]. Stockholm: Mannerheim \& Mannerheim.

Labov, William

1972 Language in the Inner City. Philadelphia: University of Pennsylvania.

Lindblad, Gustaf

1954 Studier $i$ Codex Regius av Äldre Eddan I-III [Studies in Codex Regius of the Old Edda I-III]. (Lundastudier i nordisk språkveten-

Lindroth, Sten skap A 10.) Lund: Gleerup.

1975 Svensk Lärdomshistoria. Medeltiden, Reformationstiden [The Swedish history of ideas. Middle Ages, Reformation]. Stockholm: Norstedt.

Lindqvist, Natan

1918 Språket i Nya Testamentet 1526 i Belysning av de Svenska Reformatorernas Språk [Language of the 1526 New Testament highlighted by the language of the Swedish reformers]. Uppsala: Hæggström.

Loman, Bengt

1956 Försvenskning av latinska substantiv i reformations-tidens skriftspråk II [The Swedisizing of Latin nouns in the written language during the Reformation]. Nysvenska Studier 36: 74-121. 
McIntosh, Angus

1956 The analysis of written Modern English. Transactions of the Philological Society: 26-55.

Milroy, James

1992 Linguistic Variation and Change. (Language and society 19.) Oxford: Blackwell.

Palmér, Johan

1947 Den okända handen i reformationsskrifterna från år 1526 [The unknown hand in the Reformation manuscripts of 1526]. Arkiv för Nordisk Filologi 62: 104-119.

Santesson, Lillemor

1987 Några förändringar i svensk ortografi under 1600-talet [On some changes in 16th-century Swedish orthography]. In Svenskans Beskrivning 16. Förhandlingar vid Sammankomst för att Dryfta Frågor Rörande Svenskans Beskrivning $i$ Linköping den 22-23 Oktober 1987, P. Linell et al. (eds.), vol. 2, 401-414. Linköping.

Sapir, Edward

1921 Language. An Introduction to the Study of Speech. New York: HarSchück, Henrik court, Brace, and Company.

1923 Den Svenska Förlagsbokhandelns Historia. Festskrift Författad På uppdraget av P. A. Norstedt \& Söner i Anledning av dess 100 Arsjubileum Nittonhundratjugotre [Swedish publishing history. Festschrift commissioned by the P. A. Norstedt \& sons publishing house on occasion of its 100th anniversary in 1923], vols. 1-2. Stockholm: Norstedt.

Söderberg, Barbro

1985 Engelskan $i$ Sverige I-II [The English language in Sweden]. Unpublished.

Söderqvist, Olof

1898 Johan III och Hertig Karl 1568-1575 [John III and Duke Charles]. Uppsala: Almqvist \& Wiksell.

Svalenius, Ivan

1991 Rikskansliet $i$ Sverige 1560-1592 [The Royal Chancery in Sweden 1560-1592]. (Skrifter utgivna av Svenska Riksarkivet 7.) Stockholm: Kommentus.

Teleman, Ulf

1985. Historien och språkhistorien. [History and the history of language]. In Svenskans Beskrivning 15. Förhandlingar vid Sammankomsten för att Dryfta Frågor Rörande Svenskans Beskrivning. Göteborg den 11-12 Oktober 1985, Sture Allén et al. (eds.), 64-91. Gothenburg.

Thelander, Mats

1979 Språkliga Variationsmodeller Tillämpade på Nutida Burträsktal [Models of language variation applied to the modern dialect of Burträsk]. Uppsala: Almqvist \& Wiksell. 
Thelander, Mats

1990 Språkdrag och språkarter [Language features and language types]. Kungl. Humanistiska Vetenskapssamfundet $i$ Uppsala. Arsbok: 6591.

Utterström, Gudrun

1968 Fem skrivare. Metta Ivarsdotters Brev till Svante Nilsson. Studier $i$ Senmedeltida Svenskt Brevspråk [Five scribes. Letters by Metta Ivarsdotter to Svante Nilsson. Studies in the Late Medieval epistoWalde, Otto lary language]. Stockholm: Almqvist \& Wiksell.

1921 En svensk boksamlare från Vasatiden. Hogenskild Bielke och hans bibliotek [A Swedish book collector from the time of the Vasas. Hogenskild Bielke and his library]. Uppsala Universitetsbibliotekets

Weinreich, Uriel Minnesskrift: 193-267

1953 Languages in Contact. Findings and Problems. The Hague: Mouton. Wessén, Elias

1927 Studier över språket i Gustav Vasas Bibel. [Studies on the language in the Gustavus Vasa Bible]. Nysvenska Studier 7: 251-263.

Wessén, Elias

[1992a] De Nordiska Språken [The Scandinavian languages]. (Nytryck i Wessén, Elias nordiska språk 9.) Edsbruk: Akademitryck.

[1992b] Svensk Språkhistoria I. Ljudlära och Ordböjningslära [The history of Swedish. Phonetics and morphology]. Nytryck i nordiska språk. Edsbruk: Akademitryck

Westlund, Börje

1974 Skrivarproblemet $i$ Isländska Homilieboken [The problem with the scribe of the Icelandic book of homilies]. Stockholm: Almqvist \& Wiksell.

Wilner, Per O.

1904 Förteckning öfver svenskar inskrifna vid tyska universitet under 1500talets senare hälft [Register of the Swedes enrolled at German universities during the second half of the 16th century]. Samlaren 25.

Zheltukhin, Alexander

1996 Orthographic Codes and Code-Switching. A Study in 16th-Century Swedish Orthography. Stockholm: Almqvist \& Wiksell. 


\title{
Polish \\ The standardization of Polish orthography in the 16th century
}

\author{
Daniel Bunčić
}

\section{Introduction}

The history of Polish spelling is quite well-documented; this holds especially true for the 16th century, which is generally regarded as a watershed in the development not only of Polish orthography but also of the Polish language as a whole: in all relevant Polish language histories of the last fifty years (Klemensiewicz, Lehr-Spławiński, and Urbańczyk 1964, Rospond 1973, Klemensiewicz 1974, Kuraszkiewicz 1972 and 1981, Mazur 1993, Długosz-Kurczabowa and Dubisz 1998: 54-56, Walczak 1999), the beginning of the 16th century marks the transition from the Old Polish period (doba staropolska) to the Middle Polish period (doba średniopolska, until the middle or the end of the 18th century) and the inception of the Polish "literary" (i.e. standard) language (język literacki). ${ }^{1}$

Apart from such language histories, the source texts relevant to the history of Polish spelling are also readily available. There are several anthologies of 16th-century texts in their original spelling (e.g., Taszycki 1955 [texts from 1520 to 1760], Borawski and Furdal 1980 [1136-1974], Wydra and Rzepka 1984 [1136-1543]), the five orthographic treatises which appeared during the 16th century have all been reprinted in a handy volume with an informative foreword (Urbańczyk 1983), and the enormously valuable Stownik polszczyzny XVI wieku [Dictionary of 16th-century Polish] (1966-) includes exhaustive data about spelling variants (e.g., the frequency of each variant in the corpus and even data about individual texts). There is also a monograph on the history of Polish orthography, which dedicates a separate chapter to the 16th century (Jodłowski 1979: 29-40). Therefore the main lines of development of Polish orthography have been so well-established in Polish linguistics that the present article can do little more than extract these main lines from the existing literature, test them 
against the extant empirical data, make them understandable for non-Slavicists and occasionally offer a new interpretation of a minor phenomenon relevant to the present volume.

\section{Patterns of spelling variation around $\mathbf{1 5 0 0}$}

\subsection{Prehistory: Polish Orthography before 1500}

The development of Polish orthography before the 16th century is generally divided into two periods: the period of non-complex spelling (grafia nieztożona, 1136-14th c.) and the period of complex spelling (grafia złożona, since the end of the 14th c.; cf. Walczak 1999: 73-79). This terminology makes allowance for the fact that in the first of these periods the letters of the Latin alphabet were used indifferently for Latin and non-Latin phonemes alike, (e.g., both $<\mathrm{s}>$ and $<\mathrm{z}>$ were used to represent $/ \mathrm{s} /, / \mathrm{z} /, / \mathrm{c} /, / \mathrm{z} /$, $/ \mathrm{J} /$, and $/ 3 /$ ), whereas in the second period digraphs and trigraphs were used to make some, albeit still not all necessary, distinctions (for example, $<\Upsilon_{\mathrm{z}}>$ was created to represent $/ \delta /$ and $/ 3 /$ ).

\subsection{The task: Polish phonology in the 16th century}

At the beginning of the 16th century there was, therefore, no consistent system to represent the 35 consonant and 10 vowel phonemes of Early Middle Polish. Figure 1 is an attempt to outline a phoneme inventory for the whole 16th century (with IPA symbols indicating the approximate pronunciation of the main allophone of each phoneme rather than the "orthographic" transcription usually employed in Polish language histories). ${ }^{2}$

The consonant system, which is already very similar to that of contemporary Polish, is typically Slavonic in that it is deeply affected by palatality oppositions. The most striking characteristic of Polish is the existence of three-member chains of dental, postalveolar, and palatal affricates and sibilants (/ts : t $:$ tc/, /d $\left.: \mathrm{d} s: \mathrm{d} /, / \mathrm{s}: \int: 6 /, / \mathrm{z}: 3: \mathrm{z} /\right)$. The status of voiced /h/ is dubious, since it occurred only in loanwords and some interjections (e.g., historia 'history', handel 'trade', hatas 'noise', hej 'hey!, ho!') and is likely to have been spoken (as [6], [h], or [४]) only by most speakers from the East-Slavic territories of Poland and Lithuania (Perlin 2004: 13-14) and some educated people under their influence (cf. Stieber 1973: 145, § 123). Although others always pronounced $<\mathrm{h}>$ as $/ \mathrm{x} /$ (just like $<\mathrm{ch}>$ ), which is 
the only possible pronunciation nowadays, the grapheme is still preserved in orthography. The phoneme $/ \mathrm{r}^{3} /$, which resulted from $/ \mathrm{r}$ / $/$ and resembled the Modern Czech consonant represented by $<\breve{r}>$, then developed into $\left[{ }^{\mathrm{r}} 3\right]$ and eventually merged with /3/ (cf. Stieber 1973: 68-69 and 109-110, $\S \S 48$ and 82 ). The pronunciation of $/ \mathrm{t} / \mathrm{as}[\mathrm{w}]$, which has become general in the 20th century, is attested as early as the end of the 16th century (cf. Stieber 1973: 110-112 and 129, $\S \S 84$ and 101).

\begin{tabular}{|c|c|c|c|c|c|}
\hline p & $\mathrm{p}^{\mathrm{j}}$ & ts & $\mathbf{t}$ & $t_{6}$ & \\
\hline b & $b^{j}$ & c & d & $d \phi$ & \\
\hline $\mathbf{f}$ & $\mathrm{f}^{\mathrm{j}}$ & & $\mathbf{S}$ & 6 & \\
\hline $\mathrm{v}$ & $\mathrm{v}^{\mathrm{j}}$ & & $\mathrm{z}$ & z & \\
\hline $\mathbf{m}$ & $\mathrm{m}^{\mathrm{j}}$ & & $\mathbf{n}$ & $\mathrm{n}$ & \\
\hline & & & $\mathbf{r}$ & $\mathrm{r}^{3}$ & \\
\hline & & & 1 & 1 & \\
\hline i & (I) & & & & \\
\hline & $\mathrm{e}$ & & & & \\
\hline & & $\tilde{\mathcal{\varepsilon}}$ & & & \\
\hline
\end{tabular}

Figure 1. Phoneme inventory of 16th-century Polish ${ }^{3}$

The relatively rich vowel inventory of 16th-century Polish is mainly due to the loss of the quantitative oppositions of the Old Polish period and their change into qualitative ones. The result was the emergence of two nasal vowels $/ \tilde{\varepsilon} /$ and $/ \tilde{\mathrm{o}} /$ of different timbre from $/ \tilde{\mathrm{a}} /$ and $/ \tilde{\mathrm{a}}: /$, respectively, and of the so-called "narrowed vowels" (samogłoski ścieśnione) /a/ ${ }^{4}$, /e/, and /o/ (often called pochylone 'inclined' or podwyższone 'raised') from /a:/, /ع:/, and $/ \%: /$, respectively. In Modern Polish, these three vowel phonemes have now vanished, after merging back again with non-narrowed (or jasne 'clear') /a/ and / $\varepsilon$ :/ and in the case of /o/ with /u/, whereas the two nasal vowels and the remaining six oral vowels have remained unchanged up to the present. ${ }^{5}$

Word stress had been fixed on the first syllable since the 13th century and was now changing to the penultimate, but as it was not phonemic, it did not cause any problems for orthography. 
Confronted with these 44 phonemes of Polish, 16th-century spellers did not even have the 26 letters of the Latin alphabet we take for granted today: both $\left\langle\mathrm{j}>\right.$ and $\left\langle\mathrm{y}>\right.$ were just variants of $\left\langle\mathrm{i}>,{ }^{6}<\mathrm{u}>\right.$ and $\langle\mathrm{v}>$ were positional allographs, ${ }^{7}<\mathrm{x}>$ and $<\mathrm{qu}>$ were redundant, $<\mathrm{s}>$ and $<\mathrm{z}>$ often represented the same sound, $<\mathrm{h}>$ was often not pronounced at all, ${ }^{8}$ and $<\mathrm{c}>$ and $<\mathrm{g}>$ caused difficulties in that they represented $/ \mathrm{k} /$ and $/ \mathrm{g} /$ before back vowels, but $/ \mathrm{ts} /$ and $/ \mathrm{j} /$ before front vowels. The letters $\langle\mathrm{k}\rangle$ and $\langle\mathrm{w}\rangle$, which were very useful for printing Polish texts (the latter being originally nothing other than an allograph of $<\mathrm{uu}>^{9}$ ), were not needed for Latin texts, so that the Polish printer Jan Haller did not have them in his letter case and therefore had to make them up of combinations with $r$ rotunda $<_{2}>$ (see figure 2, $<$ dzÿewÿcza $>$ in line 1 and $<$ mathko $>$ in line 2; cf. Wydra and Rzepka 1984: 306). Therefore, the Latin alphabet as such provided only for about a third of the Polish phonemes.

\subsection{Free variation}

At the beginning of the 16th century, orthographic variation within one and the same text was immense. This is true even of the first Polish text printed in the Kingdom of Poland, the famous religious hymn Bogurodzica 'Mother of God (literally: God-Bearer)', which was included in a book written in Latin, the first Polish law codex compiled by the Great Chancellor of the Crown and archbishop of Gniezno Jan Laski, Commune Incliti Polonie Regni Privilegium Constitutionum ... [The Celebrated Kingdom of Poland's Privilege of Constitutions ...] (commonly called the Statuty Łaskiego 'Łaski's Statutes'), printed in 1506 by Jan Haller in Cracow. See for illustration some short excerpts ${ }^{10}$ (quoted from Woronczak 1962: 122 and plate 17, reproduced in figure 2) with an interlinear phonemic transcription:

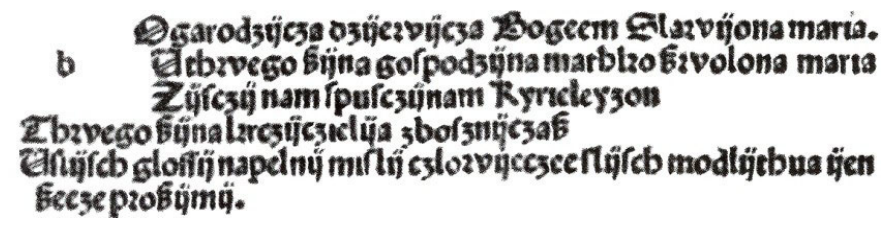

Figure 2. Beginning of the Bogurodzica $(1506)^{11}$ 
1. $b O \operatorname{Ogarodz} \ddot{y} c z a$
$d z \ddot{y e w y ̈ c z a}$ dezvitsa virgin,

Bogeem [sic]
bogem
God-INSTR

mathko
matks
mother

maria. marija/

Mary,

2. Uthwego fzüna gofpodzÿna mathko fzwolona maria /u tvego sina gospodzina matko zvolona marija/ by your son lord mother chosen Mary,

3. $Z \ddot{y} \int c z \ddot{y}$ /zIftI nam $\int p u \int c z y ̈ n a m$

Kyrieleyzon ... win-over

nam spuctci nam kurijelcjzon .../ we-DAT, have-mercy we-DAT, Kyrie eleison ...

4. Uflÿfch gloffÿ /ustis głosi

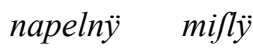
czlowyeczee ... hear-IMP voices-ACC napełni mIcli gfovicte ...l fill-IMP thoughts-ACC of-man-ACC ...

5. dä̈ na fwÿecze

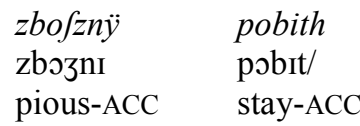
$\begin{array}{lllll}\text { /daj } & \text { na } & \text { cvictec } & \text { zboznI } & \text { pobit } \\ \text { give-IMP } & \text { on } & \text { world-LOC } & \text { pious-ACC } & \text { stay-ACC }\end{array}$

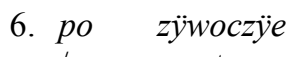
/po zivotce $R a \ddot{j} / k i$ rajski przebÿth after life-LOC paradisiac-ACC residence-ACC $\mathrm{pr}^{3} \varepsilon b i t$ Kyrieleyzon. ... kirijelejzon .../ Kyrie eleison ...

7. Ny fzrzebrem ny fzlothem nafz dyablv odkupyl /ni rr $^{3} \mathrm{ebrem}$ ni złotem nas djablu otkupjit/ neither silver-INSTR nor gold-INSTR us-ACC devil-DAT redeemed-3SG

8. Jzwa /svõ his-INSTR mocza

mots̃

power-INSTR

$$
\begin{aligned}
& \text { zastapyl } \\
& \text { zastõpiił/ } \\
& \text { defended-3SG }
\end{aligned}
$$

9. czyebye dla czlowyecze dal bog przeklocz fzobye

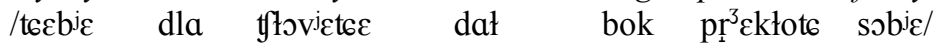
you for man-VOC gave-3SG god to pierce himself-DAT

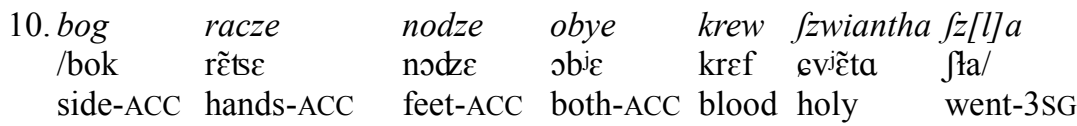

$\begin{array}{cll}\text { 11. Jboku } & \text { nafbawyenye } & \text { thobye } \\ \text { /z boku } & \text { na zbavigne } & \text { tob bi } / \\ \text { from the side } & \text { for salvation } & \text { you-DAT }\end{array}$


Even in this short passage we can see the lack of coherence in the spellings used by the printer: $\langle\mathrm{cz}>$ can represent $/ \mathrm{ts} /, / \mathrm{t} /$, or $/ \mathrm{tc} / ;<\mathrm{fz}>$ represents $/ \mathrm{s} /, / \mathrm{z} /, / 3 /$, or $/ \mathrm{c} / ;<\mathrm{y}>$ indicates $/ \mathrm{i} /, / \mathrm{I} /, / \mathrm{j} /$, or the palatality of the preceding consonant. Conversely, a phoneme combination such as /tce/ is written $<$ cze $>$, $<$ czie $>$, or $<$ czye $>$, the same morpheme /bit/ is spelled $<$ bith $>$ and $<$ bÿth $>$ in adjacent lines, and both $/ \mathrm{z} /$ and $/ 3 /$ are spelled either $<\mathrm{z}>$ or $<$ [z $>$. Of course, it would have been easy to find examples of even more variation in the rest of this text.

\subsection{Diatopic variation}

Against this background it might seem irrelevant to examine diatopic variation, since one or two variants more or less would not really change the picture seen in this short text passage. However, Jan Haller at least had a homogeneous native dialect, which cannot be said of writers and printers from different parts of Poland.

While of course there was variation on all linguistic levels, the variables most closely tied to orthography are phonological. One such variable is made up by the oppositions $/ \mathrm{s}: \mathrm{J} /, / \mathrm{z}: \mathrm{z} /, / \mathrm{ts}: \mathrm{f} /, / \mathrm{dz}: \mathrm{d} /$, which are neutralized in a number of dialects. This phenomenon is commonly called mazurzenie (in English Mazovianism, cf. Stieber 1973: 60, § 45, though the literal translation would be 'Mazurizing'), and Rospond (1957) devoted an entire monograph to its reflection in the spelling of texts from the 12th-16th centuries. Another phonological variable is the reflex of Proto-Slavic *r (IPA: $/ \mathrm{r} /$ ), which can include either an epenthetic $/ \mathrm{i} /$ or $/ \varepsilon /$. This variation in 16 thcentury prints is the subject of Borecki's (1974) monograph.

This article cannot describe all the phonological and morphological variation that results in differences in spelling but must be restricted to orthography in the narrower sense. However, the two variables mentioned above will be analyzed where appropriate because of their importance for the history of Polish spelling.

\subsection{Printed versus handwritten texts}

When in the 16th century the orthography of Polish printed texts diverged from the established tradition, this did not immediately affect the spelling of manuscripts: 
Ciekawy jest także fakt dwoistości systemu ortograficznego w tym okresie [tzn. w XVI wieku - D. B.] ..., bo kiedy w drukach ustaliły się już główne normy, w rękopisach długi jeszcze czas panuje chaos i dawna tradycja, tak że Rej i Kochanowski piszą starym sposobem, mimo iż utwory ich drukowano według zasad nowych. (Kamińska 1953: 6)

[Another interesting fact is the duality of the orthographic system in that period (i.e., in the 16th century - D. B.) ..., because when the main norms had already been established in prints, manuscripts continued for a long time to be governed by chaos and ancient tradition, so that Rej and Kochanowski write the old way although their works are printed according to new principles.]

Throughout the 16th century this duality remained, and the first person who seems to have been bothered by it is Jan Januszowski, who complained about the "bad spelling" of handwritten texts in his Nowy karakter polski [New Polish Style] printed in 1594:

Rzecze kto: Wfzák mamy dawnè zwyczáie w pifániu fwoie: mamy Orthográphią Pollką, którą vżywamy. Ia niewiém. Otoli widzę nie Orthográphią, ále rychléy Tàutográphią. (D1늘) (Urbańczyk 1983: 170-171)

[Someone may say: After all we have our ancient traditions in writing, we have the Polish orthography we use. I do not know. What I see here is not orthography but rather tautography.]

However, this article will concentrate on the development of Polish spelling in printed texts only. On the one hand this restriction is necessary because the description of handwritten spellings would take another article of at least the same length. On the other hand the printed texts are much more important for the further development, so that modern Polish orthography is based exclusively on the printed tradition, whereas the traditional spellings in handwritten texts have subsequently been replaced by the spellings prescribed by the printers. 


\section{Changes in the 16th century}

\subsection{The emergence of letterpress printing in Poland}

The first Polish texts were printed in 1475 in Silesian Wrocław (Breslau) by Kasper Elyan: the Lord's Prayer, Ave Maria, and Credo within a Latin book of church statutes. The first printers in Poland proper (Silesia was part of the Bohemian kingdom and at that particular time governed by the Hungarian king) were two Germans in Cracow: Kasper Straube, who printed some Latin books in 1473-1477, and Szwajpolt Fiol (Sebald Veyl), who produced the first Cyrillic prints (in Church Slavonic) around 1491 (cf. Borecki 1974: 72-73).

This, however, was just a prelude. A continuous tradition of letterpress printing in Poland was initiated by Kasper Hochfeder and Jan Haller (cf. Seruga 1933, Kapełuś 1962), who in 1503 opened a print shop in Cracow. ${ }^{12}$ In 1511, Haller's monopoly was challenged by Florian Ungler (cf. Bułhak 1959, 1964, 1970) and in 1517 by Hieronymus Vietor ${ }^{13}$ (cf. Świerk 1976). Figure 3 provides a very schematic and simplified overview of the subsequent development (based, together with the following comments, mainly on information from Borecki 1974 and Treichel 1972). Interruptions of business and temporary joint ventures are omitted here. Of course, there were more printers than shown here both in the towns mentioned and in more than a dozen other towns (e.g., Gdańsk, Grodzisk Wielkopolski, Knyszyn, L'viv (Lwów), Poznań, or Zamość; cf. Mazur 1993: 206), among them the Helicz brothers' Hebrew print shop, which was established in 1534 at Kazimierz, a town near Cracow (now a district of Cracow; cf. Pirożyński and Ptak-Korbel 1976: 398, Treichel 1972: 324).

Where the names of printers are shown within a row, a printing site was handed down to successors. In most cases these were the printer's sons (including Jan Januszowski, who took a different surname but left the name of the print shop unchanged as Oficyna Lazarzowa), while Jerzy Osterberger was Jan Daubmann's son-in-law. Ungler's and Vietor's businesses were after their deaths continued by their wives (while Marek Scharffenberg's wife worked together with her sons). Ungler's wife Helena ran the business independently from 1536 to 1551 and from 1542 onwards subscribed her products as "vidua Floriani" [Florian's widow], "wdowa Unglerowa" [Ungler's widow], or "Helena Florianowa" (cf. Borecki 1974: 75, Treichel 1972: 927). Both Łazarz Andrysowic and Mateusz Siebeneicher were former employees who married their masters' widows. Marek and Maciej Scharffenberg ${ }^{14}$ (cf. Bułhak 1981) were relatives, and Marek, who was 
Vietor's cousin (Świerk 1976: 195), had been employed as a bookseller and publisher before opening his own print shop. Both Ungler and Vietor worked for some time as Haller's employees (cf. Urbańczyk 1983: 9 and 40, Kapełusz 1962: 9-10) and exchanged equipment with him (cf. Bułhak 1959: 6).

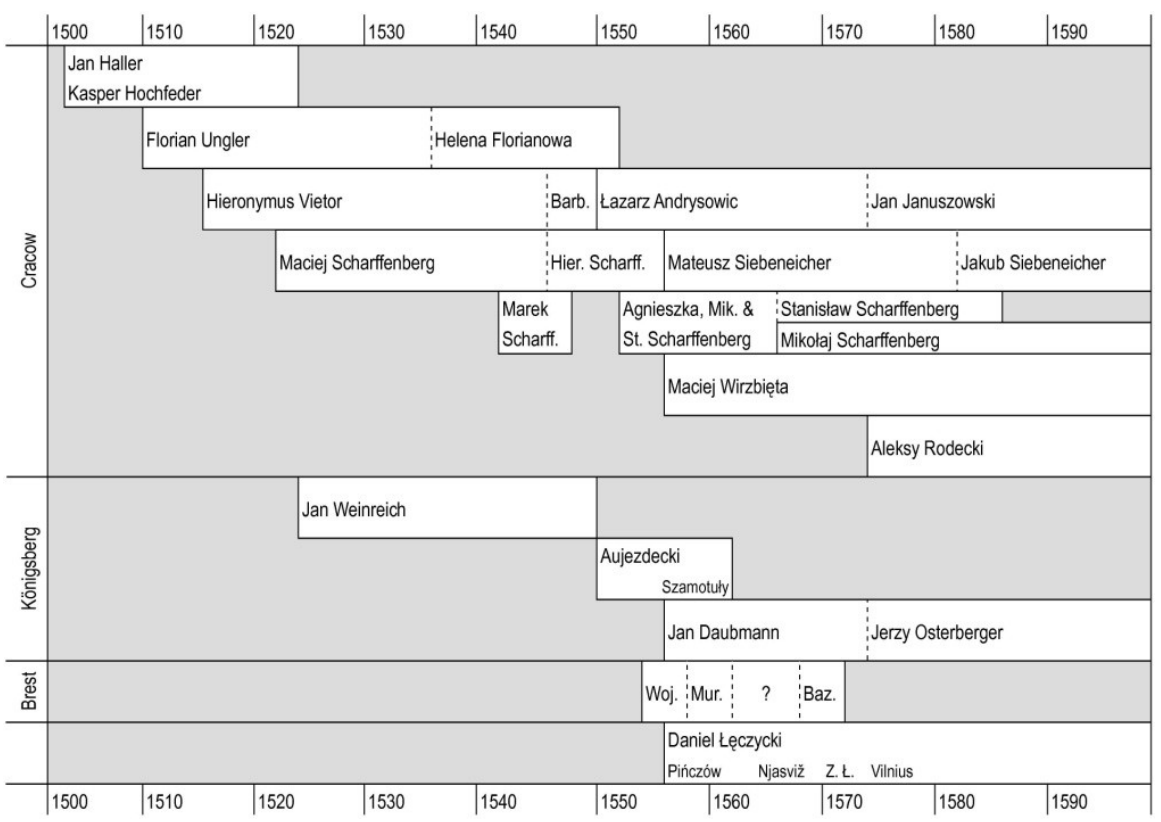

Figure 3. The most important printers in 16th-century Poland ${ }^{15}$

All of the printing sites established in the first half of the century were run by Germans or German-speaking Silesians (with the exception of Aleksander Aujezdecki, who was a Czech; cf. Buchwald-Pelcowa 1972); most of them married Polish women, with subsequent generations becoming more and more Polonized. Consequently, the first "real" Pole to run a print shop, "[p]ierwszym właścicielem drukarni w Krakowie narodowości polskiej" [the first owner of a Cracow print shop of Polish nationality] (Sowiński 1988: 37) was a woman: Florian Ungler's wife Helena Unglerowa (rather than Łazarz Andrysowic, as Sowiński claims).

Thus, especially for the first generation it is clear that orthography was influenced less by the printers themselves than by their Polish-speaking employees. However, in most cases we do not even know their names, so we have to keep to the owners of the print shops as labels for orthographic 
practices (cf. Borecki 1974: 92). A notable exception is the corrector Jan Sandecki-Malecki (Johannes Maletius from Sącz), who worked for several Cracow and Königsberg printers and whose prints are easily recognizable by their characteristic orthography (cf. Borecki 1974: 92-93, Rospond 1949: 92-108).

The Cracow printers were oriented towards Catholicism, with the exception of Maciej Wirzbięta (cf. Kawecka-Gryczowa 1974, 1975, 1981), who converted to Calvinism, and Aleksy Rodecki, who was an Anti-Trinitarian (cf. Pirożyński and Ptak-Korbel 1976: 400-402). The Königsberg ${ }^{16}$ print shops were Lutheran, those of Brest Calvinist, Sandecki-Malecki converted to Calvinism in 1536, and Daniel Łęczycki changed not only the place of his print shop but also the denomination he worked for several times between Catholics and Anti-Trinitarians (cf. Szabla 2006).

\subsection{An early orthographic theory: Jakub Parkosz (c. 1440)}

The first treatise on Polish orthography was written as early as around 1440 by Jakub Parkosz (or Parkoszowic; in the Latin text Jacobus Parcosii, cf. p. 5 of the treatise, reprinted in Kucała 1985). His suggestions are extraordinarily interesting. Obviously inspired by Jan Hus's influential insights (cf. Berger, this volume), Parkosz could not display the source of his inspiration because Hus had been burnt at the stake as a heretic in 1415 (cf. Urbańczyk 1983: 15). So instead of using diacritical marks to indicate palatalized consonants, he resorted to "round" letter forms, as can be seen in figure 4.

\section{6 gg 18 mm nn $p$ m 06

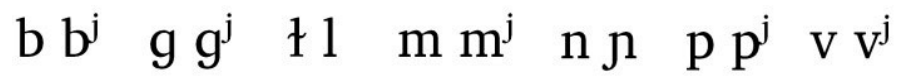

Figure 4. Some of Parkosz's "angular" and "round" letters

However, because this system was so inconvenient for quick writing, it seems never to have been used in practice. Even the only extant copy of Parkosz's treatise, written about thirty years later, does not apply it consistently to the words used as examples. 


\subsection{A better orthographic theory: Stanisław Zaborowski (1514)}

Apart from the practical problems, one of the reasons for the failure of Parkosz's proposals was probably the fact that they were circulated only in manuscript. The next orthographic treatise, Stanisław Zaborowski's Orthographia, already had the advantage of the printing press and was issued in Cracow in 1514. It turned out to be tremendously successful, being re-edited in $1518,1519,1529,1535,1539,1560$ and 1564 , thus becoming the most widely read spelling-book before 1918 (cf. Urbańczyk 1983: 26-27).

Zaborowski, who was acquainted with Parkosz's treatise and acknowledged the necessity of single representations, also had the further advantage of being able to use Jan Hus's orthographic ideas freely without any danger (the last Hussites had been burnt in 1442; cf. Urbańczyk 1983: 15). Therefore he could recommend dots above letters for non-Latin phonemes. However, Polish had more phonemes than Czech; e.g., where Czech had the two-member opposition $/ \mathrm{z} /: / 3 /$, for which Hus used $<\mathrm{z}>:<\dot{\mathrm{z}}>$, Polish had the three-member chain $|z /:| z /: / z /$, so that Zaborowski had to resort to double dots, e.g., $<\mathrm{Z}>:<\dot{\mathrm{Z}}>:<\ddot{\mathrm{Z}}>$. Apart from that, he introduced other diacritics like a dot below to represent narrowed /a/ as $<a>$ or a virgula to write $/ \mathrm{t} /$ as $\langle\mathrm{l}\rangle$. He even suggested the minute differentiation between semivirgula superior at the head of $\langle a>$ for $/ \tilde{\varepsilon} /$ and integra virgula at the lower end of $\left\langle\mathrm{a}>\right.$ for $/ \tilde{\mathrm{j}} /{ }^{17}$ All in all, this was quite a complex system which completely broke with tradition. As a result, the typesetter did not manage to follow this system consistently even in the sample texts given at the end of the treatise (see the facsimiles and transcript in Urbańczyk 1983: 70-72, 84-85, 97-99). Just for illustration, applied to the Bogurodzica text quoted above, it would look something like this: <Bogarodica deẅica bogem

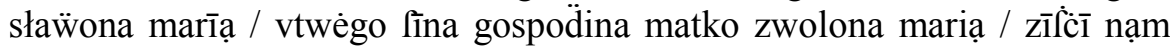
fpü̈̄inạm ...>.

However, Zaborowski did not prescribe the use of these diacritics strictly. On the one hand, he was very sympathetic to the printers and therefore offered alternatives for those spellings that might be difficult to find in a lettercase (e.g., $<l^{\prime}>$ as an alternative to $\langle\nmid>$; $<\dot{a}>$ instead of $\langle a>$ with semivirgula, for which he apparently allowed the typesetter to use an alpha $\langle\alpha\rangle$; a bar with a dot instead of two dots, i.e., $<\dot{\overline{\mathrm{c}}}>$ instead of $\langle\ddot{\mathrm{c}}>$ for $/ \mathrm{t} 6 /$; etc.), and he tried to use characters that printers would already have for Latin abbreviations (e.g., $<\ddot{\mathrm{p}}>/ \mathrm{p} /$, which was in use for $p r a$, as in $<$ fuppofito $>$ for supraposito, cf. Urbańczyk 1983: 16-17). On the other 
hand, he also describes traditional spellings without always condemning them. The following passage, which demonstrates the difference between $/ \mathrm{g} /$ and $/ \mathrm{ts} /$, is a good example:

$Z$ autem post $c$ non ponatur, nisi videatur sonare, vt in hoc polonico obiczaie id est mores, czop id est ducillus, czas id est tempus, czloüece id est o homo, et similibus, vbi $z$ post $c$ poni solet, verum in his vulgaribus $c$ aspere sonat, et est ibi $c$ durum, ideo more aliarum duarum litterarum potest signari puncto vnico superius posito, sic $\dot{c} o p$, $\dot{c} a s$, quod est regularius. In his vero vulgaribus clo id est teloneum, ö̈ca id est patrem, cebula id est cepe, cude id est alienum, et similibus $z$ post $c$ non debet poni, nec aliquo puncto signari, quia hic ponitur in sua propria significatione. (Zaborowski 1514: 4, quoted from the transcript in Urbańczyk 1983: 91; emphasis mine)

[However, one should not put $\langle\mathrm{Z}>$ after $\langle\mathrm{c}>$ unless it sounds like in Polish $<$ obiczaie $>$ 'customs', <czop $>$ 'peg', <czas $>$ 'time', <człoüece $>$ 'oh man!' and the like, where $\langle\mathrm{z}>$ is usually put after $\langle\mathrm{c}>$, but in these vulgar words $<\mathrm{c}>$ sounds rough, and there $\langle\mathrm{c}\rangle$ is hard, therefore in the fashion of the other letters it can be indicated by one dot placed above it, viz. $<\dot{\mathrm{c} o p}>$, $<$ cas $>$, which is more regular. However, in the vulgar words $<$ clo $>$ 'toll', $<$ oÿca $>$ 'father (acc.)', <cebula > 'onion', <cude $>$ 'foreign' and the like, $<\mathrm{c}>$ must not be followed by $<\mathrm{z}>$, nor must it be marked with any dot, for here it is used with its proper meaning.]

This is the main achievement of this treatise (which Zaborowski in fact inherited from Parkosz): it provided a thorough analysis of Polish phonology and demonstrated the principle of using graphemes to indicate phonemes in a consistent one-to-one relationship. This is why it was reprinted so many times, although only some of the diacritics proposed by Zaborowski finally entered orthographic usage.

The need for such a consistent orthography is not self-evident, and the conditions under which it was abel to win recognition will be analyzed in section 4. However, if a consistent spelling system was desired at all, then it is no wonder that it was Zaborowski's treatise that was used as a model. After all, it stands at the beginning of the printing of Polish books (Polish texts printed before had always been mere quotations within Latin books, cf. Urbańczyk 1983: 9), and it was printed by all the main pioneers of the letterpress: Florian Ungler (the first edition, about 1514), Jan Haller, and Hieronymus Vietor; in these three print shops the bulk of Polish-language books would be published during the next three decades. ${ }^{18}$ It was these printers themselves that apparently considered a systematic orthography useful and probably asked Zaborowski to work out such an orthography. 


\subsection{Orthographic practice: Hieronymus Vietor (1521/1543)}

Although Jan Haller had printed the first Polish text in Cracow (the Bogurodzica) and thereby started the continuous development of Polishlanguage printing, he subsequently concentrated on prints in Latin (of the 3,570 sheets he printed between 1505 and 1525, only a few pages are in Polish, cf. Borecki 1974: 73). The impetus for the further development of Polish orthography came from Hieronymus Vietor and Florian Ungler: "most Polish texts were printed at Ungler's press, but it was Vietor who most strongly campaigned for readership in Polish" ["najwięcej tekstów polskich wyszło spod pras Unglera, a najżywszą propagandę czytelnictwa w języku narodowym rozwinął Wietor”] (Borecki 1974: 73).

Although the first complete Polish-language book had already appeared in 1513 (Biernat of Lublin's Raj duszny 'Soul Paradise', printed at Ungler's press), in the following seven years only Polish passages from Latin books have survived. It was in 1521/22 that Polish-language printing seems to have exploded, with six books completely in Polish being issued in Cracow within these two years (five of them by Vietor and one by Ungler), and the practice that was established then was to be decisive for Polish spelling up to our time (cf. Lisowski 2001: 7-9).

For a detailed analysis of the spelling of these six prints the reader is referred to Lisowski's (2001) monograph dedicated entirely to this subject. ${ }^{19}$ Its author's main conclusion is that it was Vietor, rather than Ungler's corrector Jan Sandecki-Malecki, who worked out the more efficient orthographic system, the most accomplished form of which can be seen in Baltazar Opec's Żywot Pana Jezu Krysta [Life of the Lord Jesus Christ] from 1522 (cf. Lisowski 2001: 101; curiously enough, Vietor is not even mentioned in Polański 2004: 32). For a better comparison, however, this system is demonstrated here in another version of the Bogurodzica (in Mateusz z Kościana, Cohortatio Sarmaticarum ecclesiarum ad antiquae et avitae religionis observationem, fol. $\mathrm{B} 3-\mathrm{B}^{\mathrm{v}}$, quoted from the facsimile in Woronczak 1962: plates 27-30, see figure 5), which was printed by Vietor in 1543 in very much the same orthography that he had established in 1522: 


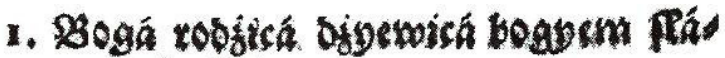 wovin 1 statua.

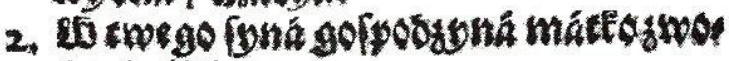 tQuál assáxya. \\ 3. 8uficts nam fpult witham Egtie steyson.

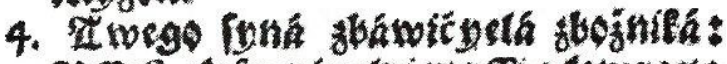

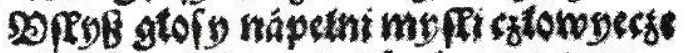

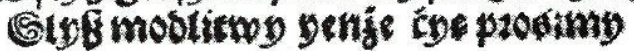

Figure 5. Beginning of the Bogurodzica (1543)

1. Bogá rodzicá dźyewicá, bogyem fáwyoná/ Márya.

2. U twego syná Golpodzyná, mátko zwoloná/ Márya.

3. Zyflczy nam fpuft winam Kyrie eleyzon. ...

4. Ułłyłz głofy, nápełni myfli człowyecze ...

5. day nam ná śwyećye zbożny pobyt/

6. po żywoćye ráyfki przebyt Kyrie eleyzon. ...

7. Ni śrebrem ni zlotem nas dyabłu odkupił

8. Iwą mocą záftąpił/

9. ćyebye dla człowyecze dał bog przekłoć fobye/

10. bok ręce nodze obye kreẃ śwyęta flłá

11. zboku ná zbáwyenye tobye.

\subsection{Main issues resolved in the first half of the century}

This text excerpt from 1543 shall now be taken as a starting point for a discussion of the main orthographic issues that were solved in the orthographic practice of the first half of the 16th century. As we will see, the overall face of Polish orthography was shaped at this time, leaving only a few issues open for the next centuries. Jodłowski (1979: 29) calls this 16thcentury spelling "the mature system of Polish orthography" ["dojrzały system ortografii polskiej"].

\subsubsection{Digraphs or diacritics?}

As can be seen in the excerpt above, the Hussite dot proposed by Zaborowski as such has only been preserved in $<\dot{\mathrm{Z}}>$ for $/ 3 /$, but the double dots for palatal consonants have been transformed into acute-like strokes (which 
makes them a lot easier to read and write), and an acute (Polish kreska 'stroke') instead of a dot also indicates the narrowed vowels.

In other cases, older digraphic spellings have survived, e.g., $<\mathrm{cz}>/ \mathfrak{f} /$, $<\mathrm{dz}>/ \mathrm{d} /,<\mathrm{rz}>/ \mathrm{r}^{3} /$, or $<\mathrm{fz}^{20}>/ \mathrm{J} /$. Palatal consonants occurring before vowels are indicated by a diacritical $<y>$, and some consonant letters are in these cases even redundantly marked with a stroke. However, the main conclusion is that all these spellings, whether diacritic or digraphic, are now used completely consistently, and even go so far as to represent a one-toone phoneme-grapheme correspondence.

Although Zaborowski's alphabet list of 1514 contains both $<\ddot{\mathbb{P}}>$ and $<\ddot{\mathrm{S}}>$, which should have been transformed into $\langle\dot{\hat{l}}>$ and $\langle\dot{\mathrm{S}}>$, diacritics above the ascender turned out to be a technical problem, so that the 1518 edition of the treatise already contained only $<\ddot{\mathrm{s}}>$. Consequently, it became common practice to write round $s$ with a stroke even in a position where long $s$ would have been required (cf. < prośimy $>$ in the quotation above). Where the palatality could be inferred because of assimilation, the typographically more correct long $\langle\beta>$ was used without any diacritic (e.g., $<$ mylli $>$ rather than $<$ myśli $>$ in the quoted text). The same problem existed for diacritics above capital letters, which were usually left out (just as in Modern French).

\subsubsection{The use of $<i>$ and $<y>$}

At first glance the case of $<\mathrm{i}>$ and $\langle\mathrm{y}\rangle$ is sightly more complicated, as the two letters were used to denote five phonological values $(/ \mathrm{i} /, / \mathrm{I} /, / \mathrm{j} /, / \mathrm{ji} /$, and the palatality of consonants). Most orthographic analyses, which view orthography as a set of "mappings from sounds to letters" rather than "from letter to sound" (Primus and Neef 2004: 133), treat these five sound values separately and thus arrive at fairly complicated representations (e.g., Kamińska 1953: 10-21, Gehrmann, Hentschel and Menzel 1999: 125). However, one has to remember that in the manuscript tradition of the 15th century $<\mathrm{i}>$ and $<\mathrm{y}>$ had usually functioned as free, positional, or lexicalized variants of the same grapheme. Consequently, it is advisable to group together all occurrences of these letters and their phonological values according to their positions, which for Vietor's Bogurodzica gives the picture presented in figure 6 . 


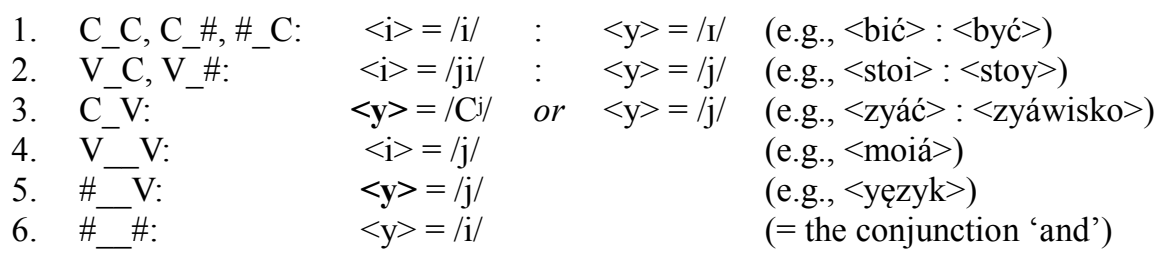

(In positions $4-6$ there is no possible contrast.)

Figure 6. Graphotactical and functional analysis of $<\mathrm{i}>$ and $<\mathrm{y}>$ (1)

As one can see, these two graphemes are in fact used quite efficiently for their five functions by taking into account phonotactic regularities. The only position with potential ambiguity is position 3 , where $<y>$ usually indicates the palatality of the preceding consonant (e.g., in <śwyećye $>$ /6victce/, <zbáwyenye > /zbav'cne/) but can also, after a morpheme boundary, represent /j/ (e.g., <odyął>/odjõł/, fol. B3v , <zyáwiło>/zjavjiło/, fol. $\mathrm{B}^{\mathrm{v}}$ of the text quoted above, not included in the excerpt). This ambiguity could on the one hand be overcome by an additional indication of the palatality of a consonant by a stroke, so that the pronunciation of $<$ zyáwiło> would immediately become clear because */zavjiło/ would have been written $*<$ źyáwiło $>$. On the other hand, Vietor replaced $<y>$ as a marker of palatality with $<\mathrm{i}>$, which also saved space. (This replacement had already taken place in the aforementioned prints from 1522 [cf. Lisowski 2001: 81-93], and was immediately accepted by the other printers [cf. Kamińska 1953: 18-19]; our Bogurodzica print is very conservative in this respect, probably because of the manuscript tradition of the text and because it had been published in a book printed mainly in Latin.) However, most printers of the 16th century, with the notable exception of Ungler and his widow, adhered to the practice of redundantly marking the palatality of /z/, /6/, /do/, and /t6/ before vowels with both a diacritical mark and a following diacritical letter, i.e., <źi >, <́si >, <dźi >, and <ći> (cf. Kamińska 1953: 17-18). Maybe the ambiguity of the older $<y>$ spellings offers a further explanation for this practice.

Another change affected word-initial /j-/ (position 5), which was written as $\langle\mathrm{i}\rangle$ instead of $\langle\mathrm{y}\rangle$ already in some of the prints from 1522 , and this spelling subsequently prevailed, although a text consistently spelling / $\mathrm{j}-/$ as $<y>$ can be found as late as 1574 (cf. Kamińska 1953: 10-11).

These two changes (indicated by bold type of the original $\langle y\rangle$ in figure 6) resulted in a fairly simple system, in which $<\mathrm{i}>$ was the "default" grapheme for $/ \mathrm{i} /, / \mathrm{j} /, / \mathrm{ji} /$, and palatality in all positions, whereas $<\mathrm{y}>$ indicated only the "marked" members of oppositions $(/ \mathrm{I} / \operatorname{instead}$ of $/ \mathrm{i} /, / \mathrm{j} / \mathrm{in}$ - 
stead of $/ \mathrm{ji} /$, or $/ \mathrm{j} /$ instead of the palatality of the preceding consonant). The only exception was the conjunction /i/ 'and', which continued to be spelled $<\mathrm{y}>$, probably because a simple one-minim $<\mathrm{i}>$ was regarded as too small to form a word on its own (note that in English the personal pronoun $I$ is written with a capital letter for similar reasons).

There are some other minor issues associated with $<\mathrm{i}>$ and $<\mathrm{y}>$, e.g., the question of how to write the sequence /ij/, and some additional solutions showing up in individual prints, e.g., $<\mathrm{ij}>$ representing initial $/ \mathrm{j}-/$ in a text from 1552 and /ji/ or /i/ in some other texts (cf. Kamińska 1953: 10-15), but the system outlined here is the one that prevailed throughout the Middle Polish period.

\subsubsection{The representation of nasal vowels}

From 1521 onwards the two nasal vowels are always consistently differentiated, using the virgula proposed by Zaborowski. However, in analogy to $<$ ą $>$ for $/ \tilde{\mathrm{J}} /$, which was kept unchanged, instead of reusing the same letter for $/ \tilde{\varepsilon} /$ with a slightly different diacritic (the semivirgula superior), Vietor preferred to reuse the same diacritic with a different letter, viz. <ę $>$, which was not only optically clearer but also corresponded better to the contemporary pronunciation of this phoneme. This practice was taken up by the other printers and applied consistently in all printed books from 1521 onwards (cf. Kamińska 1953: 21-22).

The fact that in a lot of texts a simple $<\mathrm{e}>$ appears instead of $<\mathrm{e}>$ (and also, though less frequently, $<\mathrm{a}>$ instead of $<\mathrm{a}>$ ) has nothing to do with spelling as such but is a reflection of the denasalization of the nasal vowels in Lesser Polish dialects (cf. Stieber 1973: 93-95, § 68). This especially affected the reflexive pronoun sie, which the majority of printers represent as $<$ fie $>$ rather than $<$ fię $>/ 6 \tilde{\varepsilon} /$. Eventually, however, the "etymologically correct" representation of the nasal vowels prevailed. ${ }^{21}$

Nowadays the nasal vowels are written with an ogonek 'little tail' rather than the virgula 'little stick' introduced by Zaborowski (see figure 7).

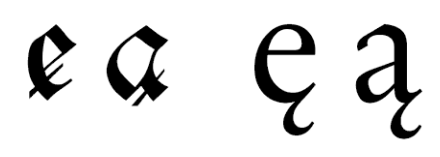

Figure 7. The nasal vowels with virgula and ogonek 
This purely typographic development is connected to the use of antiqua fonts instead of black letter. All the old texts printed in Polish were in black letter, but sometimes antiqua was used for emphasis, and then the special letters for Polish were often missing in the lettercase, so that for example in Murzynowski's translation of the Gospel of Matthew (Königsberg 1551) the title reads "Evangelia SVviETA ... Vedle Matthæufza Svietego" (quoted from the facsimile in Urbańczyk 1983: 123) rather than EVANGELIA SWIETTA ... wedle Matthceufza Swiętego [Holy Gospel ... according to Saint Matthew]. The first printer to cast special antiqua letters for Polish and to print a whole book almost entirely in antiqua was Jan Januszowski (Nowy karakter polski [The New Polish Style], Cracow 1594). He cast a special $<\mathrm{a}>$ with virgula, but for $/ \tilde{\varepsilon} /$ he used the e caudata 'tailed $e$ ' $<\mathrm{e}>$, which was very widespread in Latin prints as an allograph of $\langle\mathfrak{x}\rangle$. $^{22}$ Later, around the turn of the 18th century, when Polish antiqua prints had become more usual, the cauda 'tail' of $<\mathrm{e}>$ was placed under the back nasal, too, which resulted in modern $<\mathrm{a}>{ }^{23}$

\subsubsection{The narrowed vowels}

As we have seen, Zaborowski had recommended the use of diacritics in order to differentiate between narrowed $/ \mathrm{e} /, / \mathrm{o} /, / \mathrm{a} /$ on the one hand and non-narrowed $/ \varepsilon /, / \mathrm{o} /, / \mathrm{a} /$ on the other. In his treatise he had marked the three narrowed vowels as $<\dot{\mathrm{e}}>$ and $<\dot{\mathrm{o}}>$, but $<\mathrm{a}>$. The first to implement this idea was, as usual, Vietor in 1522: however, he marked only non-narrowed /a/ with an acute: $<$ á $>$. Eventually this would turn out to be the most widespread practice throughout the 16th (cf. Kamińska 1953: 22-23) and 17th centuries; in the prints edited by Jan Sandecki-Malecki, however, <á> represents narrowed /a/ (cf. Borecki 1974: 93). Already in 1522 Jan Haller had marked all three narrowed vowels with an acute, but this practice was not embraced generally. However, from 1565 onwards, Vietor's very active heirs Łazarz Andrysowic and Jan Januszowski noted narrowed /e/ and /o/ as $<$ é $>$ and $<$ ó $>$ while keeping $<$ á $>$ for non-narrowed /a/. Curiously enough, it was Vietor's system that persisted well into the 18th century, although on the one hand /a/ and /a/ had by that time merged again in Standard Polish, which resulted in "the complete confusion of $a$ and $a$ in eighteenth-century publications" (Stieber 1973: 98, § 73), and although on the other hand /o/, which gradually merged with /u/ (cf. Stieber 1973: 100-101, § 74), was thus mostly represented as $<_{0}>$ until the end of the 18th century. Only in 
the 19th century did the representation of $/ \mathrm{u} /$ derived from $/ 0 /$ as $<0$ $>$ become general (almost simultaneously with the final abolition of $<$ á $>$ and $<$ é $>$ ).

\subsubsection{Mazurzenie}

A large number of Old Polish manuscripts had not differentiated between dentals $(/ \mathrm{s}, \mathrm{z}, \mathrm{ts}, \mathrm{d} /)$ and postalveolars $\left(/ \int, 3, \mathfrak{t}, \mathrm{d} /\right)$ because their authors came from one of the parts of Poland where the neutralization of this opposition was a dialectal feature (Mazovia, Central Poland and parts of Lesser Poland and Silesia, cf. Stieber 1973: 60, § 45). The first half of the 16th century, however, made the indication of this opposition the norm:

Dla historii grafiki polskiej jest ważne to nasze stwierdzenie, że nasz nowopolski system znakowania $S-\check{S}-S$ jest z niewielkimi odchyleniami kontynuacją zwyczaju drukarni Wietora i jego współpracowników, redaktorów, thumaczy, korektorów, zecerów. (Rospond 1957: 467)

[What is important for the history of Polish spelling is our ascertainment that our Modern Polish system of indicating $S-\check{S}-\grave{S}$ is, with slight deviations, a continuation of the custom of Vietor's print shop and of his associates, editors, translators, correctors, and type-setters.]

2.6. Further developments during the second half of the century

\subsubsection{Orthographic theory}

Thus, the main parameters of Polish orthography had been set and were practised by the Polish printers. What was missing was a new orthographic treatise that would inform both readers and other printers of the rules of this new usage. The first such treatise was written by Jan Seklucjan and printed as a guide for the readers of the second edition of his catechism, which was printed in 1549 by Jan Weinreich in Königsberg (facsimile in Urbańczyk 1983: 117-121). This Krotka á profta náuká czytania y piffánia Jefyká polfkiego [Short and Simple Doctrine of Reading and Writing the Polish Language] is little more than a list of the letters of the Polish alphabet with two or three sample words each to illustrate the sounds associated with the letters. It is rather imperfect in many aspects (cf. Urbańczyk 1983: 29-32). One example of its flaws is that both dot and stroke above the letter are 
called punct 'point', so that in effect the author mentions only $<\dot{\mathrm{z}}>$ and forgets about $<$ Ź $>$.

Two other books issued by Jan Seklucjan in 1551 (a Gospel of Matthew and the beginning of a translation of the New Testament) contain a much better orthographic treatise, which was written by Stanisław Murzynowski (Urbańczyk 1983: 33). This is an accurate account of the orthographic practice of the time, but it also includes some new suggestions. One of these is the replacement of $\langle\dot{z}>$, which caused technical problems for Aujezdecki, the Königsberg printer who published the New Testament (Urbańczyk 1983: 35-36), and was indeed in many of the old prints hard to distinguish from $<\dot{z}>$, with a specially designed letter $\langle\mathrm{z}>$ (cf. the facsimile in Urbańczyk 1983: 129-135). Other proposals included the introduction of $<j>$ for $/ \mathrm{ji} /$, of $<\mathrm{ij}>$ for initial $/ \mathrm{j}-\mathrm{I}^{24}$ and of $<\ddot{\mathrm{u}}>$ or $<\dot{\mathrm{u}}>$ for postvocalic $/ \mathrm{u} /$ (in contrast to $<\mathrm{u}>$ for non-syllabic /u/ in Latin words such as Laurentius, cf. Urbańczyk 1983: 36). None of these suggestions affected the established usage.

A fairly accurate account of Polish orthographic usage (basically the Vietor model, with $<$ á $>$ for $/ \mathrm{a} /$ and no indication of narrowed /e/ and /o/) is contained in the first grammar of Polish, Polonicae Grammatices Institutio, which was written by Petrus Statorius (in Polish Piotr Stojeński, an immigrant whose native language was French) and printed by Maciej Wirzbięta in 1568 (Statorius 1980: A4-B3, 7-21). Little more than a short list of sample words for each letter, and entitled Orthographia Polfka/ Janá Kochánowfkiego [Polish orthography by Jan Kochanowski], it is included in Joannes Ursinus's Methodicae Grammaticae Libri Quatuor (printed in 1592 in L'viv; see the facsimile in Urbańczyk 1983: 137-141).

The last orthographic treatise of the 16th century was published in 1594 by the Cracow printer Jan Januszowski. This is a book exclusively dedicated to the problems of writing Polish, and it includes Januszowski's Wstępek do orthográphiiéy Polfkiéy, nowym kárákterem Polfkim vkośnym [Introduction to the Polish Orthography, in a New Polish Italic Font] and the previously unpublished orthographic treatises by Jan Kochanowski and Łukasz Górnicki, both of them with comments by Januszowski. These treatises offer a lot of suggestions as to how to improve Polish orthography, but most of them are repudiated by Januszowski. To mention just a few: Kochanowski suggests marking not just one but both "sorts" of $a$ and $e$ with a stroke: $<$ á $>/ \mathrm{a} /,<\mathrm{a}>/ \mathrm{a} /,<$ é $>/ \varepsilon /,<\mathrm{e}>/ \mathrm{e} /$, but Januszowski puts forward that in each case one of the strokes is superfluous (Urbańczyk 1983: 176-177, 182-183, comment: 43-44); Kochanowski suggests that /I/ can be spelled as $<i>$ after consonant letters that have no palatal counterpart and therefore cannot be followed by /i/, but Januszowski adheres to the more 
practical, traditional rule of writing /I/ as $<\mathrm{y}>$ in all positions (Urbańczyk 1983: 194-197, 45-46); Górnicki was much more radical, proposing to replace $\langle\mathrm{l}>,<\mathrm{cz}>,<$ [z $>,<\dot{\mathrm{z}}>,<\mathrm{d} \dot{\mathrm{z}}>$ with $<\mathrm{ll}>,<\mathrm{cc}>,<\mathbb{\mathrm { l }}>,<\mathrm{zZ}>,<\mathrm{d}>$ and to introduce the circumflex $\left\langle^{\wedge}\right\rangle$ instead of both the stroke $\left.<^{\prime}\right\rangle$ and $<$ i $>$ as a marker of palatality, which would have resulted in spellings like $<\hat{\text { ŝwecee }}>$ rather than <'świećie> (cf. Urbańczyk 1983: 198-205, 47-49); Januszowski himself makes a tentative suggestion that some of the traditional digraphs might also be replaced with alternative forms, e.g., $\langle\mathrm{cz}\rangle,\langle\mathrm{rz}\rangle,\langle$ [z $>$ with $<\dot{\mathrm{c}}>,<\dot{\mathrm{r}}>,<\dot{\mathrm{s}}>$ (the forms proposed by Zaborowski!), $<\dot{\mathrm{Z}}>$ with $<\mathrm{z}>$ (rec-

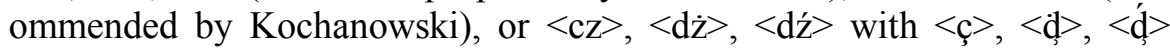
(Urbańczyk 1983: 206). However, except for $\langle z\rangle$, which is sometimes still used as a handwritten allograph of $<\dot{\mathrm{Z}}>$, none of these suggestions was ever used in practice.

Perhaps the most important effect of Januszowski's treatise was his introduction of (italic) antiqua, the "New Polish Style" mentioned in the title, which, as he writes, "I had long had the plan to cast for the Polish language, not without great cost, for the sake of my fatherland" ["gwóli oyczyznie fwéy dla ięzyká Pollkiégo nie bez kolztu wielkiégo dawno wydać był vmyślił"] (fol. D3, quoted from the facsimile in Urbańczyk 1983: 173). The 17 th and the first half of the 18th century would see a coexistence of black letter and antiqua, but during the second half of the 18th century the "German style" ["Niemiecki kárákter"] (fol. G1, Urbańczyk 1983: 193), as Januszowski called it, would finally fall out of use.

\subsubsection{Orthographic practice}

A phonologically conditioned orthographic problem was the spelling of words containing [ir] in some dialects and [er] in others (both from ProtoSlavic $\left.r_{o}^{\prime}\left[\mathrm{r}^{\mathrm{j}}\right]\right)$. After a period of mixed spellings, following a spread of [ir] in many dialects, around the middle of the century most printers had started to spell these words consistently with $<$ ir $>$. However, in the second half of the century an almost universal switch to <er $>$ occurred, and this spelling, which was adopted by Łazarz Andrysowic around 1554, eventually prevailed (cf. Borecki 1974: 151-154). The only printer who kept to <ir $>$ was Wirzbięta: 
Jedyny zgodny z szerzącą się wymową system ortograficzny Wirzbięty ... nie znalazł uznania i nie przyjął się powszechnie, bo w okresie kontrreformacji Wirzbięta, którego druki znalazły się na indeksie kościelnym, nie mógł być autorytetem. (Borecki 1974: 154)

[Wirzbięta's orthographic system, the only one according with the spreading pronunciation ... did not get any approval and was not commonly accepted because in the period of the Counter-Reformation Wirzbięta, whose prints were on the Index, could not be an authority.]

To be sure, there were other deviations from the usage described here. One of them was the Czech-inspired use of diacritics instead of the established digraphs by Bohemian-born Aujezdecki (e.g., $<\ddot{\mathrm{s}}>$ instead of $<$ sz $>$ for $/ \mathrm{J} /$; but note that the usual $<\dot{\mathbf{S}}>$ is used for $/ 6 /$, so that this solution differs from Zaborowski's recommendations; cf. Buchwald-Pelcowa 1972: passim). However, all these were overruled by the Catholic mainstream.

Thus, the state of orthographic practice at the very end of the 16th century, which differs very little from what had already been achieved in 1522, can be seen in another version of the Bogurodzica printed by Jan Januszowski in 1600 (in Statuta, prawa i konstytucje koronne..., p. ****4; quoted from the facsimile in Woronczak 1962: plate 55, see figure 8):

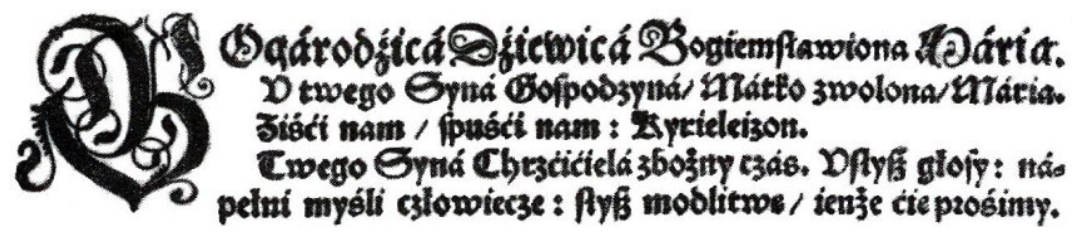

Figure 8. Beginning of the Bogurodzica (1600).

1. BOgárodźicá Dźiewicá Bogiemfławiona Mária.

2. V twego Syná Gofpodzyná/ Mátko zwolona/ Mária.

3. Ziśći nam/ Ipuśći nam: Kyrieleizon. ...

4. Vfłyfz głofy: nápełni myśli człowiecze ...

5. Day ná świećie zbożny pobyt/

6. po żywoćie Rayfki przebyt: Kyrieleyzon. ...

7. Ni Srebrem/ni Złotem/nas Dyabłu odkupił/

8. fwą mocą záftąpił:

9. ćiebie dla/Człowiecze/ dał Bóg przekłoć fobie/

10. bok/ ręce/ nodze obie: krew świętą fwą

11. z boku/ ná zbáwienié tobie. 


\section{From the 16 th to the 21 st century}

A modern transcription of this text in the orthography of the beginning of the 21 st century looks like this:

1. Bogarodzica Dziewica, Bogiem sławiona Maria,

2. u twego Syna Gospodzyna, Matko zwolona, Maria,

3. ziści nam, spuści nam. Kyrie eleison. ...

4. Usłysz głosy, napełń myśli człowiecze ...

5. Daj na świecie zbożny pobyt,

6. po żywocie rajski przebyt. Kyrie eleison. ...

7. Ni śrebrem ni złotem nas Diabłu odkupił,

8. swą mocą zastąpił.

9. Ciebie dla, człowiecze, dał Bóg przekłuć sobie

10. bók, ręce, nodze obie, krew świętą swą

11. $\mathrm{z}$ boku - na zbawienie tobie.

As one can see, the grapheme-phoneme correspondences have not changed much. The most noticeable changes are the purely typographic and essentially pan-European abolition of the allographs $<\mathrm{v}>$ and $<\beta>$ and their replacement by $<\mathrm{u}>$ and $<\mathrm{s}>$ respectively (and in this context the replacement of the ligature $<\beta>$ by $<$ sz $>$ ), as well as the considerable reduction of diacritics due to the loss of the narrowed vowel phonemes and because before $<\mathrm{i}>$ no (redundant) stroke of palatalization is used any more. Conversely, $/ \mathrm{u} /$ derived $/ \mathrm{o} /$ is now consistently represented as $<\dot{0}>$. There are essentially three Polish words in which Middle Polish orthography frequently used $<\mathrm{x}>$, namely $<$ xięga $>/<$ xiążka $>$ 'book', <xiążę > 'prince', and <xiądz $>$ 'priest', which are nowadays spelled $<$ księga $>/<$ książka $>$, $<$ książę $>$, and $<$ ksiądz $>$, the latter sometimes still being abbreviated as $<\mathrm{X}$. $>$ before a name (cf. English $<$ Rev. $>$ ).

The main orthographic innovation was the introduction in 1814 of $<j>$ as a separate grapheme for $/ \mathrm{j} /$ after almost three centuries of sometimes violent discussions (cf. Dąbrowska 1998: 150-155). Consequently, both $<j>$ and $<y>$ now directly correspond to one phoneme each, independently of position, and only $<\mathrm{i}>$ still has multiple functions (see figure 9).

Even the conjunction 'and' is now written $<\mathrm{i}>$ in accordance with these regularities.

A striking phenomenon is that the three graphemes $\langle\mathrm{rZ}>,<0$, and $<\mathrm{h}>$ have been preserved from the Middle Polish period although they do not represent any separate phoneme any more, since $/ \mathrm{r}^{3} /<\mathrm{rZ}>, / \mathrm{o} /<\mathrm{o}>$, and $/ \mathrm{h} /$ $<\mathrm{h}>$ have merged with $/ \mathrm{z} /<\dot{\mathrm{Z}}>, / \mathrm{u} /<\mathrm{u}>$, and $/ \mathrm{x} /<\mathrm{ch}>$, respectively. 


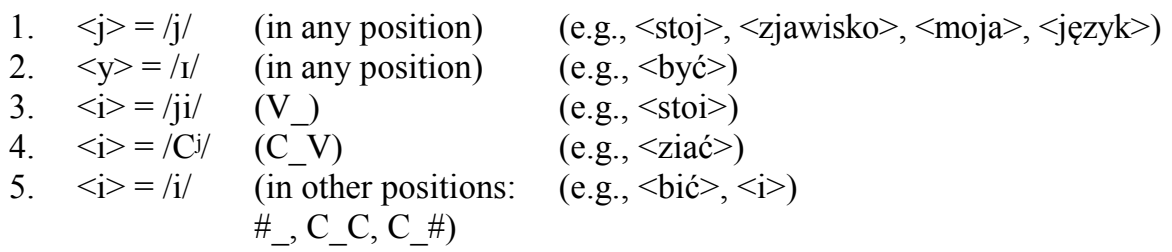

Figure 9. Graphotactical and functional analysis of $<\mathrm{i}>$ and $<\mathrm{y}>$ (2)

Several issues were not addressed at all by the meta-orthographic discourse of the 16th century (cf. Urbańczyk 1983: 5-6), although there were individuals who did care about them, especially Jan Sandecki-Malecki (cf. Rospond 1949: 92-108). One of these issues is word division. 16thcentury texts differ from modern ones in that combinations of preposition and noun were often written as one word then, and nie 'not' was also often written together with the following word. Sandecki-Malecki in these cases regularly inserted blanks in the texts he corrected (cf. Rospond 1949: 9697, 105).

Capitalization was far more widely used in the 16th century and is now restricted to certain names and proper nouns and to the first word of a sentence (as in English). This rule was already adhered to by SandeckiMalecki, who changed spellings like <proste Ludzi> 'simple people' to $<$ proste ludzi $>$ and < polácy> 'Poles' to < Polácy> (cf. Rospond 1949: 99, 107).

In the 16th century the virgula $<>>$ was used as the main punctuation mark (similar to a modern comma), interrogative sentences were often closed by a full stop or a colon, and in general the use of any punctuation mark at all was regarded as optional. Sandecki-Malecki was probably the first Pole to use a clearly differentiated system of full stop $<$. $>$, comma $<$, , , question mark $<$ ? $>$, colon $<:>$, and even semicolon $<;>$, but without the virgula (cf. Rospond 1949: 98-99, 106-107).

Other issues that are more closely connected to orthography in the narrower sense are the treatment of assimilation (including terminal devoicing) and of foreign words. In the 16th century both assimilations and foreign words were spelled according to etymology, so that on the one hand foreign graphemes like Greek $<\mathrm{ph}>/ \mathrm{f} /,<\mathrm{th}>/ \mathrm{t} /$, and $<\mathrm{y}>/ \mathrm{i} /$ or Latin $<\mathrm{c}>/ \mathrm{k} /$ and $<\mathfrak{x} /$ ę $>/ \varepsilon /$ were preserved in borrowings, e.g., $<$ Phęniciiéy $>$ for modern $<$ Fenicjej $>$ 'Phoenicia (gen. sg.)' (Urbańczyk 1983: 157), <Orthográphia $>$ for modern <ortografia > 'orthography' (Urbańczyk 1983: 198), < punct> for modern <punkt> 'dot, point' (Urbańczyk 1983: 78), <myth> for modern <mit> 'myth' (Dąbrowska 1998: 163). Foreign words inserted in texts 
printed in black letter were often printed in antiqua. On the other hand, alternations due to assimilation and terminal devoicing as in <odkupił> /otkupiil/, $<$ Bóg $>/$ buk/, $<$ krew $>/ \mathrm{krcf} /$ (from the quoted Bogurodzica passage) were usually neglected. Both tendencies were supported by SandeckiMalecki (cf. Rospond 1949: 96-98, 100, 105). While in the case of alternations modern orthography is virtually the same as in the 16th century, foreign words are nowadays mostly written phonetically (though overt Anglicisms are often spelled etymologically, e.g., <weekend $>$ rather than $<$ tikend $>$ ).

Of course a lot of other spellings have been changed since the 16th century, but these changes mostly concern individual words, forms, and endings, such as <przekłuć> 'to pierce' (line 9 of the Bogurodzica excerpts quoted above), which has since 1936 been spelled with $<\mathrm{u}>$ although the etymologically correct spelling would be <przekłóć> (cf. Dąbrowska 1998: 156). Concise accounts of Polish spelling history from the 17 th to the 20th century can be found in Jodłowski (1979: 41-162) and Polański (2004: 33-45).

\section{In lieu of a conclusion: Extralinguistic factors}

As we have seen, Modern Polish orthography is a continuation with only slight modifications of Middle Polish orthography, which was formed at the beginning of the 16th century and had more or less reached its definitive form by 1522. It was Hieronymus Vietor who had made the most important decisions: for the systematic use of both diacritics $(<\dot{\mathrm{c}}\rangle,\langle\mathrm{e}\rangle,\langle\mathfrak{l}\rangle,<\dot{\mathrm{z}}\rangle$ etc.) and digraphs $(<\mathrm{cz}>,<\mathrm{rz}>,<\mathrm{sz}>$ etc.), for the functional differentiation of $<\mathrm{i}>$ and $\langle\mathrm{y}\rangle$, for the modern spelling of the nasal vowels $(<\mathrm{a}\rangle,\langle\mathrm{e}>)$, and for the consistent representation of the three sets of sibilants $(<\mathrm{s}>:<\dot{\mathrm{S}}>$ : $<$ sZ $>$ etc.).

As traditional spellings continued to be used in handwritten texts throughout the 17th century, the decisive factor for the development of Polish orthography was clearly the introduction of letterpress printing. This was a result of its invention half a century earlier by Johannes Gutenberg and of its importation to the Polish capital by German printers such as Jan Haller, Florian Ungler or Hieronymus Vietor, who sought a new market to make profit. However, this would have had no effect whatsoever on Polish orthography had they not seen the necessity of printing some of their books in Polish. This, in turn, was due to the rising level of general education in Poland, which brought about a major increase of the number of people who 
could read and at the same time produced a considerable proportion of readers who did not understand Latin (cf. Urbańczyk 1983: 1). This is associated with the rise of the urban bourgeoisie, who needed public life to be in Polish in order to stand up to the patricians and the gentry, who could afford Latin education and translators. In the course of the 16th century the bourgeoisie obtained that more and more judicial and legal acts should be written in Polish (cf. Mazur 1993: 194-196).

An interesting fact is that in contrast to other countries, the Reformation did not play a major role in the history of orthography in Poland because, as we have seen, the main parameters of Polish orthography had already been set in 1522, just five years after Luther's Ninety-Five Theses. To be sure, in the further course of the 16th century there were Protestant printers and correctors (cf. section 2.1.), but they mainly used the orthography already established, and those changes they did introduce did not win general recognition - even if they accorded better with pronunciation, as in the case of Wirzbięta's <ir>-spelling. This, of course, is an effect of the extraordinary success of the Counter-Reformation in Poland. So if one looks for direct influences of religious movements in today's Polish orthography, one rather finds Jan Hus's orthographic ideas, which influenced 16th-century printers via Parkosz and Zaborowski. However, it should not be ignored that the Reformation, Counter-Reformation, and confessional polemics of the 16th and 17th centuries among Catholics, Protestants, and Orthodox further propagated the printing of texts in Polish rather than Latin. A good example of this is the Bible, which in the 16th century saw a Lutheran, a Calvinist, two Anti-Trinitarian, and two Catholic translations. Interestingly enough, the first complete printed translation of the Bible was accomplished in 1561 by Jan Leopolita for the Catholic Church - being preceded only by the Lutheran Stanisław Murzynowski's New Testament of 1551 and in 1599 Jakub Wujek produced another Catholic translation of the whole Bible, which is still in use today (cf. Mazur 1993: 199-200).

However, a spiritual movement that did have a considerable impact on the printing of texts in the vernacular was Humanism (cf. Mazur 1993: 206). As Świerk (1976: 198-199) points out, Vietor's motivation for propagating the use of the Polish language can hardly have been Polish patriotism, as he was a German-speaking Silesian who, incidentally, was also a committed and highly-appreciated printer of Hungarian texts (cf. Korompay, this volume, Pirożyński and Ptak-Korbel 1976: 397, Świerk 1976: 197). Nor did the Polish prints play a major financial role for him, as he made his money as the exclusive printer for the royal court and thus chiefly with Latin prints, which made up about $92 \%$ of his production (Świerk 
1976: 199). Consequently, Vietor's own assertions in several prefaces to his Polish books have to be taken seriously: thus, he printed Polish texts "in order that not only men but also women or girls learn to read texts in their own language, especially those that add to their advantage and also to their delight" ["aby nie tylko mężowie, ale też i panie lubo panny uczyły si(ę) czyść pisma języka swojego, nawięcej tego, co by im było ku pożytku i też ku pociesze"] (Vietor [1538] 1953: 20; quoted in German translation by Świerk 1976: 199). Such humanistic ideals must be assumed for the other printers and authors as well.

\section{Notes}

1. The exact date mentioned here varies between the turn of the century and 1543 , depending on the criteria used for periodization (cf. Mazur 1993: 3-9).

2. This chart has to be taken with a grain of salt, because of course the phonemic system of Polish kept changing during the 16th century and moreover was never homogeneous across Poland. Consequently, the chart tries to combine those features that are relevant to orthographic reform in the 16th century; e.g., on the one hand $/ \mathrm{r}^{3} /$ is still represented as an $r$-like consonant although at the turn of the century its development into $\left.{ }^{\mathrm{r}} 3\right]$ and later [3] was well under way, while on the other hand $/ \mathrm{J} /, / \mathrm{z} /, / \mathrm{ts} /, / \mathrm{d} /, / \mathrm{g} /$, and $/ \mathrm{d} / \mathrm{d} /$ are already treated as depalatalized although the depalatalization process had hardly started in 1500 .

3. In this chart, those phonemes that were treated as equivalents of Latin phonemes and could therefore be, and were, written with a simple Latin letter are indicated by bold type, whereas those phonemes for which "Polish" orthographic solutions had to be found are printed in normal type.

4. Although /a/ was in fact not narrower but "articulated farther back" than /a/ (cf. Stieber 1973: 78, § 55), the traditional collective designation narrowed vowels for all three phonemes is retained in this article.

5. For practical reasons both /I/ and the palatalized labials will be treated as phonemes in this article. The traditional approach (e.g., Stieber 1966) is to treat [I] as a positional allophone of $/ \mathrm{i} /$, because it appears only after non-palatal consonants. Modern phonologies of Polish (e.g., Wiśniewski 1997, Laskowski 1999) treat $/ \mathrm{i} /$ and $/ \mathrm{I} /$ as different phonemes and thus get rid of all the palatalized labials, which in Modern Polish appear only before /i/ and /j/ but in the 16th century were not yet neutralized in word-final position (cf. Derwojedowa, Karaś, and Kopcińska 2005: 129; in Modern Polish there are also some marginal borrowed - examples of [i] appearing after a non-palatalized consonant phoneme, e.g., sinus [sinus] 'sinus', tip-top [tiptop] 'tiptop'). Orthographies can, and did, go both ways, i.e., a minimal pair like [bitc] 'to be': [bitc] 'to hit' was interpreted either as /bitc/ : /bitc/ (spelled, e.g., <być $>$ : $<$ bić $>$ ) or as /bitc/ : 
/biite/ (spelled, e.g., <bić> : <bić>). Therefore it is worthwhile to keep both contrasts in mind simultaneously.

6. $<\mathrm{j}>$ was called "long i" (and is still called so in Swiss schools) and used especially as the last $<\mathrm{i}>$ in a series of two or more $<\mathrm{i}>$ (e.g., $<$ filij $>$ or roman numbers such as $<$ viij $>$ ), and the form $<\mathrm{J}>$ was often used as a capital $<\mathrm{i}>$ (cf. Juda 2001: 71 passim), whereas antiqua typefaces originally had only $<$ I $>$ and no $<\mathrm{J}>$ (cf. ibid. 161). As for $<\mathrm{y}>$, it was regarded as a "double i", often being written with two dots $<\ddot{y}>$ and thus resembling the combination $<\mathrm{ij}>$ (see fig. 2; cf. also Afrikaans $<\mathrm{y}>$ in the place of Dutch $<\mathrm{ij}>$ ). Jan Kochanowski and Jan Januszowski complained about this treatment of the letter as "dwoie i" [two i] or "tępe i" [dull i], demanding that $\langle\mathrm{y}\rangle$ be regarded as a separate letter ypsylon (cf. Januszowski, Nowy karakter polski, Cracow 1594, fol. F4" reprinted in Urbańczyk 1983: 192). Often $<y>$ was used instead of $<\mathrm{i}>$ just because it was much easier to read in the sea of minims that an Early Modern text constituted. The letter's French name $i$ grec, which is also in Polish usage as igrek (alongside ipsylon), also testifies to its status as a special form of $<\mathrm{i}>$.

7. Not all texts applied them completely consistently, but the overall norm was to write $\langle$ v $>$ only word-initially, e.g., usus as $\langle$ vfus $>$, vivus as $<$ viuus $>$, etc. This was fine for a lot of languages that had consonants and vowels in complementary distribution, but a problem for Polish, which had minimal pairs like /ubijatc/ ubijać 'stomp, pound' vs. /vbijate/ wbijać 'knock in'.

8. Therefore $<\mathrm{h}>$ was sometimes not even regarded as a letter, cf. Henrichmann ([1506] 1514: B1): "H afpirationis est fignum. Litera autem non eft" $[<\mathrm{h}>$ is a sign of aspiration, but it is not a letter]. This had already been observed by Quintilian (cf. Kramer 1996: 587).

9. The letter $<\mathrm{w}>$ was sometimes even used for $v u$ (e.g., in $<$ wlgari $>$ for vulgari, Woronczak 1962: plate 11), but Heinrich Bebel forbade this usage (cf. his Tübingen pupil Henrichmann 1514: B1, who was literally quoted by Zaborowski, see Urbańczyk 1983: 95).

10. I have left out those lines whose original form was so incomprehensible to the contemporaries that they were subject to constant change (cf. Ostrowska 1967: 7-8) and thus do not provide good parallels for comparison. After the third stanza I jump immediately to the eighth, which offers five instances of nasal vowels, which are not present in the verses quoted before.

11. Translation: [1] Oh Mother of God, Virgin Mary, glorified by God, [2] oh Mary, Mother chosen by your Son, our Lord, [3] win for us, send to us, Kyrie eleison! ... [4] Answer to the voices, fill the thoughts of Man .... [5] Give a pious stay on earth [6] and residence in paradise thereafter. Kyrie eleison! ... [7] Neither with silver nor with gold did He redeem us from the devil, [8] with His power He defended [us]. [9] For you, oh Man, God allowed His [10] side, both hands and feet to be pierced; His holy blood ran [11] away for your salvation.

12. Of these two, only Hochfeder was a trained printer, whose name appeared on the title pages until 1505 . From 1505 onwards, it was evidently Haller who ran the business and employed various specialists. 
13. Vietor is the Latinized form of the Silesian's original surname Büttner 'Cooper', and in modern Polish philology he is rendered as Hieronim Wietor (cf. Świerk 1976: 195, Borecki 1974: 78).

14. Their original German first names are Markus and Mathias, respectively (Świerk 1976: 195, 196); in some Polish studies (e.g., Bułhak 1981) their last name appears as Szarfenberg.

15. Abbreviations: Barb. $=$ Vietor's widow Barbara, Baz. $=$ Cyprian Bazylik, Hier. $=$ Hieronymus, Ł. $=$ Łosk, Mik. $=$ Mikołaj, Mur. $=$ Stanisław Murmeliusz, Scharff. $=$ Scharffenberg, St. $=$ Stanisław, Woj. $=$ Bernard Wojewódka, Z. = Zasław.

16. The traditional Polish name of modern Kaliningrad is Królewiec (from król 'king'), on the title pages of Polish books from the 16th century $<$ Krolewiec Prufki $>$. This article uses the German name because it is more common in English.

17. For technical reasons, the nasal vowel letters with virgula are here generally transcribed in their modern form; for an impression of the old shape see figure 7 . - The use of the letter $<\mathrm{a}>$ for both nasal vowels is of course a reflection of their earlier pronunciation as [ã] and [ã:], although Zaborowski already recognized some qualitative difference (cf. Urbańczyk 1983: 91).

18. For a chronological list of the 57 most important Polish works printed in the 16th century see Kamińska (1953: 25-28), for a rather exhaustive alphabetic list of 429 titles see Borecki (1974: 155-174), and for an almost complete (both chronological and alphabetical) list of 6,997 books printed in Poland in the 16th century regardless of their language see Estreicher's (1965) index volume (but cf. also Chojnacki 1966: XI-XII, who complains that $25 \%$ of the Protestant prints are not registered by Estreicher, and Estreicher 1965: XIII, who estimates the number of books actually printed to be some $40 \%$ higher than the number of titles included in his bibliography).

19. Lisowski uses the term grapheme in quite a particular sense, making it difficult to see any difference with the notion of phoneme, cf. "Grafem $\{a ̊\}$ realizowany jest 339 razy jako: - alograf prymarny 'á' ...; - homograf 'a' ...” [The grapheme $\{a ̊ a\}$ is realized 339 times as: - the primary allograph 'á' ...; - the homograph 'a' ...] (Lisowski 2001: 25). However, the statistic data he has collected about the spelling of these important early prints is nonetheless immensely valuable.

20. In ordinary black letter prints and in manuscripts, this grapheme was represented by a ligature of long $s$ and tailed $z,\langle\hat{\xi}>$, and just as in German it was evidently treated as a positional variant of $\langle\Pi\rangle$; in roman type, however, a ligature of long $s$ and round $s$ was used, $\langle\beta>$, which is still used in German, whereas in Polish $\left\langle{ }_{13}>\right.$ was later decomposed into modern $<$ sZ $>$. The positional allograph $<\llbracket>$ was first eliminated by Vietor in 1524 but had completely fallen into disuse no later than in the second half of the century (cf. Kamińska 1953: 18).

21 . The last decades even brought about a reintroduction of the previously denasalized (cf. Stieber 1973: 104, § 78) front nasal in terminal position because of 
spelling pronunciation; in my Polish lessons in the 1990s I was still taught the (conservative) pronunciation of <rękę> 'hand (acc. sg.)' as [røyke] rather than

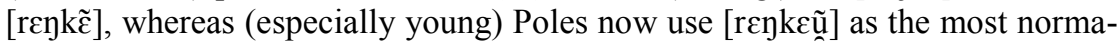
tive pronunciation.

22. For the development of $<$ ę $>$ from $<\mathfrak{x}>$ cf. Robert (1972). An antiqua $<\mathrm{e}>$ with virgula was later also sporadically used, cf. $<$ Swiętego $>$ with virgula next to $<$ náukę> with cauda in a print from c. 1621 (facsimile in Woronczak 1962: plate 63).

23. I cannot say exactly when this form was used first. In histories of Polish orthography this typographic aspect is not treated at all, and editions of old prints transcribe the virgula with the ogonek (which of course is completely sufficient for the purpose). However, among the facsimiles in Woronczak (1962), Klemensiewicz (1974), and Sowiński (1988) one finds <ą $>$ with cauda (or, rather, ogonek) for the first time in a print from 1698 (Klemensiewicz 1974: plate 62), and the virgula in antiqua appears for the last time around the middle of the 18th century (Klemensiewicz 1974: plate 65); in black letter, the virgula was retained for both nasal vowels (although long after black letter had ceased to be regularly used for Polish the ogonek was transfered to black letter prints as well, cf. Klemensiewicz 1974: plates 79 and 80 from the 1920s).

24. From a modern perspective this seems rather counterintuitive, but it would have been parallel to the use of double- $u<\mathrm{w}>$ for $/ \mathrm{v} /$ and single $<\mathrm{u}>$ for $/ \mathrm{u} /$ ).

\section{References}

\section{Primary sources}

Henrichmann, Jakob

1514 Gra[m]matice Inftitutiones Jacobi Henrichma[n]ni Sindelfingenfis, Caftigate Denuo atq[ue] Diligenter Elaborate. Exhortatio eiufde[m] ad Literaru[m] Studiofos vt Barbarie[m] Elimine[n]t [et] Eloq[ue]ntie Studeant. Ars Conde[n]dor[um] Carminu[m] Henrici Bebelij Juftingenfis Poete Laureati. Syllabaru[m] Qua[n]titates: Racematio[n]es [et] Exq[ui]fitiores Obferuatio[n]es eiufde[m]: cu[m] Additionibu[s] Multis. Centimetru[m] Mauri Seruij Honorati Gra[m]matici. Hagenau: Henricus Gran 1514. Original edition, Pforzheim: Thomas Anselm, 1506.

(URN: nbn:de:bvb:12-bsb00003233-2)

Statorius, Petrus (Piotr Stojeński)

1980 Polonicae Grammatices Institutio. Reinhold Olesch (ed.). Original edition, [1568]. Köln/Wien: Böhlau. 
Vietor, Hieronymus

1953 Foreword to the 1538 edition of the Żywot Pana Jezu Krysta (Life of Our Lord Jesus Christ). In Obrońcy Jezzyka Polskiego: Wiek XV$X V I I I$ [Defenders of the Polish language: 15th-18th centuries], Witold Taszycki, 19-21. Wrocław: Zakład im. Ossolińskich.

\section{Secondary Sources}

Borawski, Stanisław, and Antoni Furdal

1980 Wybór Tekstów do Historii Języka Polskiego [Selection of texts for the history of the Polish language]. Warszawa: Państwowe wydawnictwo naukowe.

Borecki, Marian

1974 Ksztattowanie się Normy Językowej w Drukach Polskich XVI Wieku (na Przykładzie Oboczności Typu Pirwszy ॥ Pierwszy) [The formation of a linguistic norm in Polish prints of the 16th century (with special reference to the alternations of the type pirwszy \| pierwszy)]. Wrocław/Warszawa/Kraków/Gdańsk: Zakład imienia Ossolińskich, Wydawnictwo Polskiej Akademii Nauk.

Buchwald-Pelcowa, Paulina

1972 Aleksander Augezdecki, Królewiec - Szamotuly 1549-1561 (?). (Polonia Typographica Saeculi Sedecimi 8.) Wrocław/Warszawa/ Kraków: Zakład narodowy imienia Ossolińskich.

Bułhak, Henryk

1959 Florian Ungler, Kraków. Pierwsza Drukarnia 1510-1516 [Florian Ungler, Cracow. The first print shop 1510-1516]. (Polonia Typographica Saeculi Sedecimi 3.) Wrocław/Warszawa/Kraków: Zakład narodowy imienia Ossolińskich.

Bułhak, Henryk

1964 Florian Ungler, Kraków. Druga Drukarnia 1521-1536 [Florian Ungler, Cracow. The second print shop 1521-1536]. (Polonia Typographica Saeculi Sedecimi 5.) Wrocław/Warszawa/Kraków: Zakład narodowy imienia Ossolińskich.

Bułhak, Henryk

1970 Florian Ungler, Kraków. Druga Drukarnia 1521-1536 [Florian Ungler, Cracow. The Second Print Shop 1521-1536]. (Polonia Typographica Saeculi Sedecimi 7.) Wrocław/Warszawa/Kraków: Zakład Bułhak, Henryk narodowy imienia Ossolińskich.

1981 Maciej Szarfenberg, Kraków 1527-1547. (Polonia Typographica Saeculi Sedecimi 12.) Wrocław/Warszawa/Kraków: Zakład narodowy imienia Ossolińskich. 
Chojnacki, Władysław

1966 Bibliografia Polskich Druków Ewangelickich Ziem Zachodnich $i$ Pólnocnych, 1530-1939 [Bibliography of the Polish Protestant prints from the western and northern regions, 1530-1939]. Warszawa: Zwiastun.

Dąbrowska, Anna

1998 Język Polski [The Polish Language]. Wrocław: Wydawnictwo Dolnośląskie.

Derwojedowa, Magdalena, Halina Karaś, and Dorota Kopcińska (eds.)

2005 Język Polski: Kompendium [The Polish language: A compendium]. Warszawa: Świat Książki.

Długosz-Kurczabowa, Krystyna, and Stanisław Dubisz

1998 Gramatyka Historyczna Języka Polskiego. Podręcznik dla Studentów Polonistyki [Historical grammar of Polish. A textbook for students of Polish studies]. Warszawa: Wydawnictwo Uniwersytetu Warszawskiego 1998.

Estreicher, Karol

1965 Bibliografia Polska XV.-XVI. Stólecia [Polish bibliography of the 15th-16th centuries]. Vol. 6, Supplement: Zestawienie Chronologiczne 7200 Druków w Ksztatcie Rejestru do Bibliografii, tudziéz Spis Abecadłowy tych Dziel, które Dochowały się w Bibliotekach Polskich [Chronological compilation of 7200 prints in the form of a register to the bibliography, with an alphabetical list of works preserved in Polish libraries]. New York/London 1965. Original edition, Kraków 1875.

Gehrmann, Maria, Gerd Hentschel, and Thomas Menzel

1999 Textlehrbuch zum Altpolnischen. Eine Exemplarische Einführung in das Altpolnische Schrifttum bis 1543 für die Universitäre Lehre. Oldenburg: Bibliotheks- und Informationssystem der Universität Oldenburg.

Jodłowski, Stanisław

1979 Losy Polskiej Ortografii [The fates of Polish orthography]. Warszawa: Państwowe Wydawnictwo Naukowe.

Juda, Maria

2001 Pismo Drukowane w Polsce XV-XVIII wieku [Printed fonts in 15th18th-century Poland]. Lublin: Wydawnictwo Uniwersytetu Marii Curie-Skłodowskiej.

Kamińska, Krystyna

1953 Pisownia druków polskich XVI wieku [The spelling of 16th-century Polish prints]. Prace Polonistyczne 11: 5-28.

Kapełuś, Helena

1962 Jan Haller, Kraków 1905-1925. (Polonia Typographica Saeculi Sedecimi 4.) Wrocław/Warszawa/Kraków: Zakład narodowy imienia Ossolińskich. 
Kawecka-Gryczowa, Alodia

1974 Maciej Wirzbięta, Kraków 1555/7-1605. (Polonia Typographica Saeculi Sedecimi 9.) Wrocław/Warszawa/Kraków: Zakład narodowy imienia Ossolińskich.

Kawecka-Gryczowa, Alodia

1975 Maciej Wirzbięta, Kraków 1555/7-1605. (Polonia Typographica Saeculi Sedecimi 10.) Wrocław/Warszawa/Kraków: Zakład narodowy imienia Ossolińskich.

Kawecka-Gryczowa, Alodia

1981 Maciej i Paweł Wirzbiętowie, Kraków 1555/7-1609. (Polonia Typographica Saeculi Sedecimi 11.) Wrocław/Warszawa/Kraków: Zakład narodowy imienia Ossolińskich.

Klemensiewicz, Zenon

1974 Historia Jezzyka Polskiego [History of the Polish language]. Warszawa: Państwowe wydawnictwo naukowe.

Klemensiewicz, Zenon, Teodor Lehr-Spławiński, and Stanisław Urbańczyk

1964 Gramatyka Historyczna Jezzyka Polskiego [Historical grammar of Polish]. Warszawa.

Kramer, Johannes

1996 Verschriftungsarten und -tendenzen in der Romania. In Lexikon der Romanistischen Linguistik, Günter Holtus, Michael Metzeltin, and Christian Schmitt (eds.), vol. II, 1, 584-597. Tübingen: Max Niemeyer.

Kucała, Marian

1985 Jakuba Parkosza Traktat o Ortografii Polskiej [Jakub Parkosz's treatise on Polish orthography]. Warszawa: Państwowe wydawnictwo naukowe.

Kuraszkiewicz, Władysław

1972 Gramatyka Historyczna Języka Polskiego: Podstawowe Wiadomości z Wyborem Tekstów Staropolskich do Ćwiczeń [Historical grammar of Polish: Elementary knowledge with a selection of Old Polish texts for exercises]. Warszawa: Państwowe zakłady wydawnictw szkolnych.

Kuraszkiewicz, Władysław

1981 Historische Grammatik der Polnischen Sprache. (Specimina Philologiae Slavicae 35.) München: Otto Sagner.

Laskowski, Roman

1999 System fonologiczny języka polskiego [The phonological system of Polish]. In Encyklopedia Języka Polskiego, Stanisław Urbańczyk (ed.), 344-347. 3rd edition. Warszawa: Zakład Narodowy im. Ossolińskich. Original edition, Wrocław 1978.

Lisowski, Tomasz

2001 Grafia Druków Polskich z 1521 i 1522 Roku. Problemy Wariantywności i Normalizacji [The spelling of the Polish prints from 1521 and 1522. Problems of variation and standardization]. Poznań: Wy- 
dawnictwo Naukowe Uniwersytetu im. Adama Mickiewicza w Poznaniu.

Mazur, Jan

1993 Geschichte der Polnischen Sprache. Frankfurt am Main etc.: Lang.

Perlin, Jacek

2004 Ile było w historii języka polskiego przypadków wpływu pisowni na ewolucję praw głosowych lub wymowę poszczególnych wyrazów? [How many cases of spelling influencing the evolution of sound laws or the pronunciation of individual words were there in the history of the Polish language?] In: Biuletyn Polskiego Towarzystwa Jezzkoznawczego/Bulletin de la Société Polonaise de Linguistique 40: 1115.

Pirożyński, Jan, and Wanda Ptak-Korbel

1976 A historical outline of Cracow printing in the 16th to the 18th cen-

Polański, Edward tury. Gutenberg-Jahrbuch: 392-412.

2004 Reformy ortografii polskiej - wczoraj, dziś, jutro [Reforms of Polish orthography - yesterday, today, tomorrow]. Biuletyn Polskiego Towarzystwa Językoznawczego/Bulletin de la Société Polonaise de Linguistique 40: 29-46.

Primus, Beatrice, and Martin Neef

2004 Introduction: From letter to sound. New perspectives on writing systems. In Written Language and Literacy 7 (2) (Special Issue: From Letter to Sound): 133-138.

Robert, Ulysse

1972 Note sur l'origine de l'e cédillé dans les manuscrits. In Mélanges Julien Havet. Recueil de Travaux d'Erudition Dédiés à la Mémoire de Julien Havet (1853-1893), 633-637. Genève: Slatkine. Original edition, Paris 1895.

Rospond, Stanisław

1949 Studia nad Językiem Polskim XVI Wieku [Studies on the Polish language of the 16th century] (Jan Seklucjan, Stanisław Murzynowski, Jan Sandecki-Malecki, Grzegorz Orszak). Wrocław: Nakładem Wro-

Rospond, Stanisław cławskiego Towarzystwa Naukowego.

1957 Dawność Mazurzenia w Swietle Grafiki Staropolskiej [The age of Mazovianism in the light of Old Polish spelling]. Wrocław: Zakład Narodowy imienia Ossolińskich.

Rospond, Stanisław

1973 Gramatyka Historyczna Języka Polskiego [Historical grammar of Polish]. Warszawa: Państwowe wydawnictwo naukowe.

Seruga, Józef

1933 Jan Haller, Wydawca i Drukarz Krakowski [Jan Haller, a Cracow publisher and printer]. Kraków: Towarzystwo miłośników historji i zabytków Krakowa. 
Słownik Polszczyzny XVI Wieku [Dictionary of 16th-century Polish]

1966- Maria Renata Mayenowa (ed.). Wrocław/Warszawa: Zakład Narodowy im. Ossolińskich (vol. 1-23)/Warszawa: Wydawnictwo Instytutu Badań Literackich (vol. 24 onwards).

Sowiński, Janusz

1988 Polskie Drukarstwo [Polish printing]. Wrocław etc.: Zakład Naro-

Stieber, Zdzisław dowy imienia Ossolińskich.

1966 Historyczna $i$ Wspótczesna Fonologia Języka Polskiego [Historical and contemporary phonology of Polish]. Warszawa: Państwowe Wydawnictwo Naukowe.

Stieber, Zdzisław

1973 A Historical Phonology of the Polish Language. Heidelberg: Winter.

Świerk, Alfred

1976 Hieronymus Vietor (Wietor) - ein Pionier des polnischen Buchdrucks im 16. Jahrhundert. Gutenberg-Jahrbuch: 194-199.

Szabla, Aleksandra

[2006] Drukarstwo Krakowskie XV i XVI Wieku [Cracow typography in the 15 th and 16th centuries]. [website based on the author's master thesis (praca licencjacka)] (last accessed 12 Oct 2007; still available at <http://web.archive.org/web/20071028203530/http://www.wzks. uj. edu.pl/epi/2004/lha23/Strony/mapa.htm>)

Taszycki, Witold

1955 Wybór Tekstów Staropolskich XVI-XVIII Wieku [A selection of Old Polish texts from the 16th-18th centuries]. Warszawa: Państwowe Treichel, Irena (ed.) wydawnictwo naukowe. Original edition, Lwów: Jakubowski, 1928.

1972 Słownik Pracowników Ksiązki Polskiej [Dictionary of workers of the Polish book]. Warszawa/Łódź: Państwowe Wydawnictwo Naukowe.

Urbańczyk, Stanisław (ed.)

1983 Die Altpolnischen Orthographien des 16. Jahrhunderts. Stanisław Zaborowski - Jan Seklucjan - Stanisław Murzynowski - Jan Januszowski. Köln/Wien: Böhlau.

Walczak, Bogdan

1999 Zarys Dziejów Języka Polskiego [An outline of the history of the Polish language]. Wrocław: Wydawnictwo Uniwersytetu Wrocławskiego.

Wiśniewski, Marek

1997 Zarys Fonetyki i Fonologii Współczesnego Języka Polskiego [An outline of the phonetics and phonology of Polish]. Torun: Wydawnictwo Uniwersytetu Mikołaja Kopernika.

Woronczak, Jerzy (ed.)

1962 Bogurodzica [Mother of God]. Wrocław/Warszawa/Kraków: Zakład Narodowy imienia Ossolińskich, Wydawnictwo Polskiej Akademii Nauk. 
Wydra, Wiesław, and Wojciech Ryszard Rzepka

1984 Chrestomatia Staropolska. Teksty do Roku 1543 [Old Polish chrestomathy. Texts until 1543]. Wrocław et al.: Zakład narodowy im. Ossolińskich. 


\title{
Czech
}

\section{Religion and diacritics: \\ The case of Czech orthography}

\author{
Tilman Berger
}

\section{Introduction}

Modern Czech orthography is characterized by an elaborate system of diacritics which has served as a model for several other Slavonic languages (Croatian, Slovenian, both Sorabian languages and, of course, Slovakian), for some non-Slavonic languages (such as Latvian and Lithuanian), and for the most common system of Cyrillic transliteration. Since this system of diacritics goes back to proposals attributed to the Czech religious reformer and reformer of orthography Jan Hus at the beginning of the 15th century, and became so influential afterwards, pre-existing orthographic systems have tended to be neglected in the linguistic literature, and the evolution of Czech orthography is usually described and presented in a teleological way, stressing the shortcomings of the older systems and praising the ingenious invention of Jan Hus (cf. Sedláček 1993; for a more neutral general overview cf. Pleskalová and Šefč́k 2007). In this article, I would like to show that the pathway to the modern orthographic system has been more complicated than most descriptions assume, and that alternative evolutions were at some points possible.

\section{The Czech phonological system}

To begin with, I would like to summarize the peculiarities of the Czech phonological system which posed a problem to anybody trying to write Czech names or words using the letters of the Latin alphabet. First of all, I should point out that several sibilants exist in the phonological system which are not accounted for in the Latin alphabet, i.e., [J], [3], [ [t]], and the 


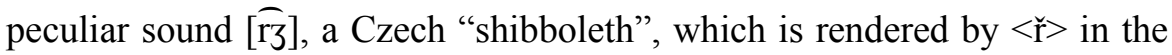
modern orthographical system. Secondly, there existed palatalized consonants, and thirdly, (distinctive) vowel length. These three main features are characteristic of Old Czech as well as Modern Czech. Other features which are relevant only for Old Czech will not be discussed here, such as the additional vowels [i] and $\left[i^{\mathrm{e}}\right]$ or the distinction between syllabic and non-syllabic $r$ between consonants.

\section{2. "Primitive orthography" (10th century)}

When efforts were first made in the 10th century to write Czech proper names with Latin letters, copyists simply used Latin letters that were close to the Czech sound and were not concerned about the possible ambiguity of such writing. Consider the following names from the chronicle of Cosmas of Prague, which was written in the 12th century, and their equivalents in modern orthography:

(1) Kladzco - Kladsko, Crocco - Krok, Bracizlau - Břecislav, Crinin -Černín, Satc - Žatec, Wissegrad - Vyšehrad (all examples from Bretholz 1955)

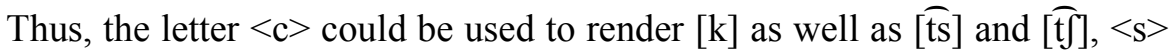
and $\langle\beta>$ were used to render [s] as well as [J], and $<\mathrm{z}>$ was used to render [z] as well as [3], and sometimes even [s]. Other distinctions, such as palatalization or vowel length, were simply ignored. This system, which is known as "primitive orthography" (primitivni pravopis) in Czech linguistics, continued to be used until the 13th century, and was applied in the first written Czech texts too. The following examples ( $n^{\circ} \mathrm{s} 2$ and 3 ) illustrate this primitive orthography (with its equivalent in modern orthography):

(2) Wlah dal geft dola zети bogu i fuiatemu fсерапи

Vlach dal jest Dolás zeńu bogu i sv́atému Ščepánu (Porák 1979a: 31)

'Vlach gave land in Dolany to God and to Saint Stephen'

(3) [Z]lovo do zveta tworene $v$ boftu zhowano

Slovo do světa stvořenie v božství schováno (Porák 1979a: 32)

'The word was till the creation of the world hidden in divinity'

Even in these early texts, some effort was made to write sounds that were characteristic of the Czech language in a more precise way. Palatalization 
was sometimes rendered by the vowel $<\mathrm{i}>$ (cf. fuiatemu), and digraphs like $<\mathbb{\Gamma}>$ or $<\mathrm{cz}>$ were used instead of sibilants (in this case, $\left[\int\right]$ and $[\widehat{[t}]$ ). However, this strategy was used in a rather unsystematic way.

\section{3. "Older Digraph Orthography" (14th century)}

The first systematic attempt to define a precise orthographic system for Czech appears in a group of verse legends written at the end of the 13th and at the beginning of the 14th century (cf. Havránek 1936: 22-23). We do not know who invented this system, nor do we know whether it was a single person or a group of authors. He (or they) introduced digraphs and even one trigraph to represent sibilants, consistently marked palatalization by $<\mathrm{i}>$, and sporadically even rendered vowel length by doubling the vowel letter or by adding a diacritical sign. This system was used in a number of manuscripts (mainly legends in verse), but was not successful in the long run. The failure of this "Older Digraph Orthography" (spřežkový pravopis staršiho typu) is not surprising if we take a closer look at the rather awkward system of digraphs which quite often uses simple letters for complex sounds and vice versa, consider the following equivalents (4) and a short example in (5) (cf. Cejnar 1964: 168-169):

$$
\begin{aligned}
& [\mathrm{s}]=<\mathrm{zZ}>,[\mathrm{z}]=<\mathrm{z}>,[\mathrm{d}]=<\mathrm{rl}>,[\mathrm{3}]=<\mathrm{s}>,[\widehat{\mathrm{ts}}]=<\mathrm{cz}>,[\widehat{\mathrm{t}}]]=<\mathrm{czh}>, \\
& {[\mathrm{r} \mathrm{r}]=<\mathrm{rs}>}
\end{aligned}
$$

\section{kak ho zzyn, kak wnuk na male zzie yzzž zzbȳli na zzem zzwietye} kak ho syn, kak vnuk na mále sě jsú sbyli na sem světě

'As well his son as his grandson shortly afterwards stayed behind in this world'

The artificial character of the "Older Digraph Orthography" may be explained by the fact that it was not the result of a gradual evolution, but was the conscious creation of an individual (or a group of individuals). This correlates with the fact that the first Czech texts were produced by a small intellectual elite linked to the royal court in Prague, whereas legal documents and administrative texts were still written in Latin. 


\section{4. "Newer Digraph Orthography"}

In the first half of the 14th century more and more Czech texts were produced, mainly literary texts, but from the middle of the century onwards, Czech also came to be used in administrative texts. Instead of the "Older Digraph Orthography" a new system was used which was much closer to the "primitive" system. It distinguished voiced and unvoiced sibilants and affricates, but did not take the distinction between alveolar and postalveolar sibilants into account. For example, the letter $\langle\mathrm{c}\rangle$ and the digraph $<\mathrm{cz}>$ were used for both $[\widetilde{\mathrm{ts}}]$ and $[\widetilde{\mathrm{t}}]$, occasionally the trigraph $<\mathrm{cz}\lceil>$ was used in the same function as well. Palatalization was marked regularly by $<\mathrm{i}>$ or $\langle\mathrm{y}\rangle$; vowel length was marked (although very rarely) by the doubling of vowels or by the use of digraphs such as $<\mathrm{ij}>$. Apparently, no satisfactory solution was found for the rendering of sibilants, which is not surprising if one bears in mind that the two other languages with a longer literary tradition in Bohemia, i.e., Latin and German, had a much simpler system of sibilants (for example, they lacked [3]). The "Newer Digraph Orthography" seems to have fulfilled the needs of language users quite well - this system was commonly used until the beginning of the 15th century. To illustrate this system, let us look at the first words of a famous old Czech love song called Závišová píseñ 'Song of Záviš', written at the end of the 14th century (Porák 1979a, 115):

Gyzt mne wffe radoft oftawa / gyz me wffe vtiechi Jtanu.

Jižt' mě všě radost ostává / již mě vše útěchy stánu.

'Already all pleasure has left me / already all my comfort has become...'

\section{The reform proposals of Jan Hus}

The most important and influential proposal to reform Czech orthography is contained in a Latin treatise from the early 15th century which František Palacký discovered in a library in Southern Bohemia in 1827. This treatise which is known under the name De orthographia bohemica proposes a system of diacritic signs which marked the length of vowels (e.g., <á $>$ vs. $<\mathrm{a}>$ ) and distinguished between consonants that did not exist in Latin and their Latin counterparts, e.g., the distinction of $\langle\breve{\mathrm{c}}\rangle,\langle\breve{\mathrm{r}}\rangle,\langle\breve{\mathrm{n}}\rangle$ vs. $\langle\mathrm{c}\rangle,<\mathrm{r}\rangle$, $<\mathrm{n}>$ (the author uses a diacritical dot, i.e., $\dot{c}, \dot{r}, \dot{n}$ ). The proposal was based on a detailed analysis of Old Czech pronunciation and the phonetic 
differences which were not taken into account in the contemporary system. The following quotation shows the way of argumentation of the treatise:

Ecce qui vis Bohemice scribere habes differencias literarum positas et noli ponere duplex zz cum vocalibus quia si centum z pones non facient plus in sono vel aliter quam z. Sed pone ż. (Schröpfer 1968: 86)

[Now, if you want to write in Czech, you will have marked differences of letters. And don't write double zz with vowels, since even if you write a hundred $\mathrm{z}$, they will not sound differently from z. Instead write ż.]

The treatise is traditionally attributed to the priest and religious reformer Jan Hus (born ca. 1370). He was a professor of Charles University in Prague from 1400 and one of the instigators of the Decree of Kutná Hora (1409) which gave the majority of votes at the university to the "Bohemian nation". As a result students and professors of other "nations" left Prague and founded the University of Leipzig. At the same time Hus became more and more critical of the official teachings of the Catholic Church, partly under the influence of Wycliffe. In 1410 he was excommunicated, but continued to preach at the Bethlehem Chapel in Prague. In 1412 he had to go into hiding and lived in South Bohemia under the protection of local gentry. In 1414 he returned to Prague and was summoned to the Council of Constance where he was imprisoned and sentenced to death for heresy. $\mathrm{He}$ was burned in Constance on 6th of July 1415.

Although his main theological works were written in Latin, Hus used to preach in Czech and also wrote some minor theological texts in this language. On several occasions he commented the language use of his contemporaries and condemned German influence on Czech. The attribution of the treatise to him relies mainly on the similarity of opinions of the author of the De orthographia bohemica and also on the fact that the author of the treatise evidently was a highly educated intellectual with good knowledge of ancient languages.

There has been a lot of discussion as to how far the author of De orthographia bohemica was influenced by other orthographical systems (cf. Schröpfer 1968: 23-30), and it has been pointed out that most elements of his system sporadically occur in older texts (e.g., the dot marking palatalization). Nevertheless the treatise is an ingenious original work which is far ahead of its time. Exaggerating slightly, Schröpfer (1968: 31) has called Hus's treatise "the first phonetic description of a Slavonic language". 
However, Hus's orthography was not accepted at once. It is not certain whether or not he used it himself in his few Czech writings, and there are only a few manuscripts from the first half of the 15th century that use the "diacritical orthography". We even cannot cite an example of his orthography which is longer than one word, since the preserved manuscripts use his system only inconsequently. For example, the beginning of the Lord's Prayer, an example given in Hus's orthographia, is written as follows (instead of the original dot in Hus's we use the modern diacritic $<^{v}>$ ):

(7a) Otče naš, gêz gfi naêbefieh ofwiet'lie gmie twé (Schröpfer 1968: 88),

although we would expect the following form:

(7b) Otče náš, gež gfi na nebefieh ofwiet' fie gmie twé.

Some elements were soon changed, since they proved to be rather impractical. Consequently, the use of a hook (háček) replaced the dot Hus had introduced, and the diacritical sign was moved from letters with ascenders such as $\langle\mathrm{d}\rangle$ and $\langle\mathrm{t}\rangle$ to the neighbouring vowel ( $<$ dě $\rangle,<$ tě $>$ instead of $\left.<\mathrm{d}^{\prime} \mathrm{e}\right\rangle,\left\langle\mathrm{t}^{\prime} \mathrm{e}\right\rangle$ ). The same was true for the use of the háček on the long $<\boldsymbol{\beta}$, so [S] continued to be written $<\llbracket \beta$.

All in all it is not possible to decide whether Hus as the author of De orthographia bohemica really planned to introduce a new orthography. His genuine interest for the vernacular goes hand in hand with the religious movement supporting sermons in Czech, but the treatise itself is more of an academic text, written for a small group of people. This would change with the introduction of printing about seventy years later.

\section{The introduction of printing}

The technology which was invented by Johannes Gutenberg in the middle of the 15th century soon found its way to neighbouring countries. According to traditional views, the first book which was printed in the Czech lands was the "Chronicle of Troy" (Kronika trojánská), issued in Plzeň. It is dated to 1468 by a handwritten notice, but could in fact have been written some years later. Other scholars assume that the first book was the "Statute of Arnošt z Pardubic" (Statuta Arnošta z Pardubic) from 1476, also issued in Plzeň. In both cases the name of the printer is not known, but we have to take into account the fact that Plzeň was a predominantly Czech 
(and Catholic) town with close relations to Germany. The next most important books were the New Testament, published in Prague in 1479, and the so-called Prague Bible from 1488.

The printers began to use diacritical signs right from the beginning, though at first in a rather unsystematic way. For example, the Spis o nových zemich [On the new lands and the new world] (a translation of Vespucci), printed in 1502/1503 by Mikuláš Bakalář in Plzeň, consistently uses $<\check{z}>$ and sometimes $<\breve{\mathrm{c}}>$ and $<\mathrm{e}>$, but vowel length is marked only rarely by digraphs such as $<\mathrm{ij}>$; [rz] is rendered by $<\mathrm{rz}>$; and $<\Gamma \beta$ is the main means to render $[S](<\check{\mathrm{s}}>$ was used only at the end of words). Cf. the title of the book (Porák 1979a, 241):
Spis o nowych zemiech a o nowem fwietie, o niemžto g/me prwe žadne znamofti neméli ani kdy czo flychali.
[Treatise about the new lands and the new world, about which we did not have any news earlier nor did we hear anything about it.]

In modern orthography this text would look as follows:

(8b) Spis o nových zemiech a o novém swětě, o němžto jsme prve žádné známosti neměli ani kdy co slýchali.

Similar systems can be found in other printed books dating from this time, but the whole of the 16th century was characterised by extensive variation of orthography in printed books. Two major types of variation can be distinguished: competing systems, and language change.

The digraph and the diacritical system compete, resulting in various mixed systems which have been described in detail by Porák (1979b). Cf. the following quotation from the book "Rules of Human Life" (Pravidla lidského života), written and edited by the humanist Mikuláš Konáč z Hodiškova in 1528:

Prawij, že byl gede[n] welikomocný král králúo w Indij gmene[m] Sedráš, kterýž měl kniježe některakee[h]o gmenem Beled. ... Měl g[ef]t také libú rzeč a krotkoft iazyku. (Porák 1979a, 250)

[They say that there was a mighty king of kings in India, called Sedráš, who had a certain knight called Beled. ... He also had a pleasant speech and a blandness of language.]

Here we see that vowel quantity is sometimes marked by diacritics (král, Sedráš, kterýż) and sometimes by digraphs (prawij, některakeeho); some- 
times it is not marked at all (gmenem instead of gménem). The diacritic is used regularly in $\langle\check{\mathrm{z}}\rangle$, sporadically in $\langle\breve{\mathrm{c}}>$ and $<\breve{\mathrm{r}}\rangle$.

In the second half of the 16th century the diacritical system achieved success, but several characteristics of Hus's proposal were lost. Only $<\check{z}>$, $<\breve{\mathrm{c}}>,<\breve{\mathrm{r}}>$ and $<\breve{\mathrm{n}}>$, and the long vowels $<$ á $>$ and $<$ é $>$ were used along the lines of the original proposal. Instead of $<\breve{s}>$, the digraph $<\mathbb{R}>$ dominates; digraphs were also used instead of diacritics on capital letters, except for $<\check{\mathrm{Z}}>; \check{C}$ and $\check{R}$ were rendered by $<\mathrm{C} \check{\mathrm{z}}>$ and $<\mathrm{R} \check{z}>$. The letters $<\check{\mathrm{n}}>,<\mathrm{d}^{\prime}>$ and $\left\langle\mathrm{t}^{\prime}\right\rangle$ were used only at the end of a syllable. The long vowel [i:] was not rendered by $<\hat{i}>$, but by $<j>-$ resulting from the older digraph $<\mathrm{ij}>$. The character $<\breve{e}>$, which was not part of Hus's proposal, was used to mark palatalization before $e$. Many printers also used the letter $<\nmid>$, today still in use in Polish orthography, to render a "hard" $l$. This phoneme was lost in the West in the 15th century, but continued to exist in Eastern dialects till modern times.

Another type of variation was caused by phonological changes which had occurred since the 15th century (cf. Lamprecht, Šlosar, and Bauer 1986: 107-111): in the first place, monophthongization of the diphthongs [ie] and [uo] (resulting in [i:] and [u:]), and the diphthongization of the long vowels [i:] and [u:] (resulting in [عI] and [ov]). While these vowel shifts began to take place in the western part and slowly migrated eastwards (though never reaching Slovakia or parts of Moravia), the result of this gradual development was not uniform, and different printers used different strategies to deal with it. In view of the fact that books from the West were also used in the East, the conservative position that one should continue to write as in former times tended to dominate. In the end, only in two of the four cases was orthography adapted to pronunciation $(<i>$ or $<j>$ instead of the older $<\mathrm{ie}>,<\mathrm{au}>\mid<$ ou $>$ instead of the older $<\dot{\mathrm{u}}>$ ). In one case, a special convention helped to maintain a visual reminder of the older state $(<\stackrel{\mathrm{u}}{>}$, i.e., $<\mathrm{u}>$ with a superscripted $<_{\mathrm{O}}>$, instead of the older graphy $<\mathrm{uo}_{\mathrm{o}}>$ ); and in one case the historical notation was preserved $(<\dot{y}>$ not $<\mathrm{ej}>)$. We may compare the following examples:

(monophthongization):

(diphthongization): miera 'measure' > mjra

buoh 'God'> buih

pýcha 'pride' > pejcha (written pýcha)

kut 'corner' > kout (written kaut) 


\section{Standardization of orthography}

From the 1530s onwards, a process of standardization of orthography took place. As opposed to what happened in other Slavonic countries (such as Poland and Russia), printers did not play the main role here. The first proposals for a unified orthography were made by three Protestant priests: Beneš Optát, Petr Gzel and Václav Filomates, who published the first Czech grammar in 1533, known as the "Grammar of Náměšt" (Náměšt'ská mluvnice), cf. Optát, Gzel and Philomates (1974). These priests had edited a new translation of the New Testament on the basis of Erasmus' Latin New Testament and stressed the necessity of a uniform and consistent orthography for their language. The authors advocated the use of diacritics with the modifications mentioned in section 6 , but they had rather conservative views on other linguistic questions: for example, they propagated synthetic verb forms, which had disappeared about a hundred years earlier. Therefore, the main critic of their grammar, Jan Blahoslav, who wrote a long text entitled "Czech grammar" (Gramatica česká), receives much more attention in modern linguistic literature, even though his text was published only in the 19th century, whereas the Grammar of Náměšt' was reprinted several times in the 16th and 17th centuries. Jan Blahoslav (15231571) was a bishop of the Czech Brethren and a member of a group of translators who decided to prepare a new translation of the Bible. This translation, the "Králice Bible" (Králická Bible), was printed in the small village of Králice close to Náměšt' between 1579 and 1593 and was widely distributed by the Czech Brethren. Because of his death at an early age, Blahoslav himself participated only in the translation of the New Testament; nevertheless, he was evidently one of the people who had advocated and realized the unified orthography found in the Bible translation. Cf. the following quotation from another of his texts, a book on music, published between 1558 and 1569:

Poněwadž o Muzyce napfati nětco vłožił fem, Neyprw ale Co by muzyka była necht' se powj. (Porák 1979a, 269)

[Since I decided to write something about music, yet first of all it should be explained what music is.]

The Králice Bible enjoyed a high esteem till the 20th century and is considered as the main text of the Golden period of the Czech language. The orthographic system which was consistently used in the Králice Bible is usually called "The Brethren's Orthography" (bratrský pravopis). It was 
to serve as a model for printed books throughout the 17th and 18th centuries, even after the expulsion of Protestants from the Czech lands in 1627 after the Catholic party had prevailed in the first phases of the Thirty Years' War.

It is very interesting that Catholic authors explicitly mentioned the Bible in grammars and orthographic treatises, although it was forbidden to possess and read this Bible in the Czech lands. Cf. the following quote from the title page of the well-known treatise Žáček 'The Pupil', published by Matěj Václav Štejer in 1668 (and reprinted in 1730 and 1781):

An excellent way to write and print well in Czech, extracted from the Czech Bible, which is divided into several parts and is explained by comments in the margin and is in high esteem among non-Catholics. However, because of its heretical errors, it should not be read nor possessed by Catholics. Nevertheless, since it was above other Czech books, printed in a more proper, better and a more diligent way than other Czech books, its way of writing must be praised beyond all measure.

\section{Manuscript usage}

At the same time as this unified system of orthography came into use in most books, manuscripts continued to employ a much simpler system reminiscent of the "Newer Digraph Orthography". It borrowed only one letter from the diacritical system, namely the $<\check{\mathrm{z}}>$, and used it as the second element of digraphs not only in capital letters (as in the Brethren's orthography), but also in lower case letters: [ $[\widehat{t}]$ ] was rendered by $\langle\mathrm{cž}\rangle$ (as opposed to [ts] which was written by the digraph $<\mathrm{cz}>$ ); [ [r3] was rendered by $<$ rž $>$. Vowel length was not marked at all; palatalization was marked by $<\mathrm{i}>$ (in the same way as in the Newer Digraph Orthography).

This system, which Čejka (1999) calls "orthography pro foro interno", was used in virtually all personal writings and in manuscripts until the end of the 18th century. Although it neglected the important phonological opposition between short and long vowels, it proved to be very practical for the writer, and it was flexible, since it allowed the writer to note dialectal words as well. The fact that it was not so comfortable for the reader apparently was not a major problem: the distinction between an orthography for the writer and a different one for the reader was introduced by Sgall into the discussion on Czech orthography, and has been quantified in an interesting study by Karel Kučera in 1998. 
Both systems existed side by side for quite a long time. Grammars from the late 17 th and the early 18 th centuries simply mention their existence as a given fact. Cf. the following quotation from Rosa's Grammatica linguae Bohemicae (1672: 10):

Consonans $\mathrm{c} / \breve{c} / \check{r}$ in impressis libris, moderno tempora scribitur absq: additione literae $\mathrm{z}$, sed Scribae \& Cancellistae semper solent ad $\mathrm{c} / \mathrm{c} / \check{\mathrm{r}} /$ addere z/ in scriptis, sic cz/cž/rž.

[The consonants c, $\breve{c}$, $\check{\text { r }}$ are written (sic) without addition of the letter $\mathrm{z}$ in printed books in modern times, but scribes and clerks always use to add $\mathrm{z}$ to $\mathrm{c} / \check{c} / \breve{r}$ in handwritten texts, thus cz, čz, rž.]

At that time, orthographic treatises such as the Žáček were intended for printers, who had to learn the art of applying all the rules of orthography to any manuscript which had been given to them.

Unfortunately, the pro foro interno orthography has not been studied in detail, so far. This is due to the fact that Czech editors tend to transcribe books and manuscripts into modern orthography, and only in recent years has the awareness that one might possibly overlook phonological distinctions by doing so been growing. A thorough analysis of the pro foro interno orthography will probably show broad sociolinguistic variations and even the existence of additional orthographic systems, based on a mixture of both orthographies. One example is the orthography of the East Bohemian painter Josef Ceregetti (1722-1797), whose chronicle of the town of Chrudim I edited in 2005. Ceregetti used only the dot as diacritic and combined it with the vowels $a$ and $e$ and with the consonants $c, z, r, n$; contrary to contemporary use he also wrote ou instead of $a u$. See the title page of the chronicle (Berger and Malý 2005):

Hiftorya Chrudimska, w niž fe wipifuge počátek Mělta Chrudimě, gakož take fkáza, a zafe poznow wiftawenj, a wffelikych wěcy w něm zběhlych.

[History of Chrudim, in which the beginning of the town of Chrudim is described, as well as its corruption and its reconstruction and all things which happened in it.]

From the middle of the 18th century onwards, grammarians began to recommend that one should write in the same way as books are printed (cf. Schamschula 1973: 160; Berger 2008: 43-44); after 1800 the pro foro interno orthography became obsolete. Since then, only diacritical orthography has been used for writing and printing Czech. 


\section{Conclusion}

The diacritical orthography was - in all likelihood - designed by a religious reformer who used to preach in the vernacular and who supported the cultivation of the vernacular as a literary language. Though manuscripts used the Older Digraph Orthography till the end of the 18th century and printed books adopted the diacritical system rather slowly, translators of the Bible played a crucial role in propagating a uniform orthography based on Hus's proposals. And the first translation of the whole Bible by the Czech Brethren served as the main example of good Czech for several centuries, even among the Catholics.

\section{References}

\section{Primary sources}

Berger, Tilman, and Tomáš Malý

2005 Kronika Paméti 888-1789 k.w. Města Chrudimě. Historia Chrudimská. Přepis s Komentárem [Chronical of the Royal dowry town of Chrudim, commemorating the years 888-1789]. Chrudim.

Bretholz, Berthold (ed.)

1955 Die Chronik der Böhmen des Cosmas von Prag. (Monumenta Germaniae Historica, Scriptores rerum Germanicarum Nova series II). Berlin: Weidmannsche Buchhandlung.

Kralická Bible, Kralitzer Bibel

1995 Hans Rothe, and Friedrich Scholz (eds.). Paderborn: Schöningh. Original edition, 1579-1593.

Optát, Beneš, Petr Gzel, and Václav Philomates

1974 Grammatyka České Gerd Freidhof (ed.) (Specimina Philologiae Slavica 7,1.). München: Kubon \& Sagner. Original edition, Prague 1533.

Rosa, Wenceslaus Johannes

1672 Cžechořečnost Seu Grammatica Linguae Bohemicae. Micro-Pragae: Joannis Arnolti â Dobroslawina.

Štejer, Matěj Václav

2001 Žáček aneb Výborně Dobrý Zpusob, jak se Má Dobře po Česku Psáti neb Tisknouti [The little pupil or an especially good manner how to write or to print well in Czech]. Prague: Akropolis. Original edition, 1668 . 
Vespucci, Amerigo

1926 Spis o Nových Zemích a o Novém Světě [On the new lands and the new world]. Praha: [V. Svobada a A. Škoda]. Original edition, Plzeň, [1502/1503].

\section{Secondary sources}

Berger, Tilman

2008 Der Beitrag von Johann Wenzel Pohl zur Entwicklung der slavischen Sprachwissenschaft. In Deutsche Beiträge zum 14. Internationalen Slavistenkongress Ohrid 2008, S. Kempgen, K. Gutschmidt, U. Jekutsch, and Ludger Udolph (eds.), 39-52. Munich: Sagner.

Cejnar, Jiř́i

1964 Nejstarši České Veršované Legendy: Soubor Rukopisných Zlomků. [The oldest Czech rhymed legends: A collection of manuscript fragments]. Prague: Nakladatelství Československé Akademie Věd.

Čejka, Mirek

1999 Srovnání Devotyho opisu Loutny české Adama Michny z Otradovic s původním tiskem [A comparison of Devoty's copy of "Loutna česká" of Adam Michna z Otradovic with the original printed version]. In Das tschechische Barock. Sprache, Literatur, Kultur, Jiří Holý, and Gertraude Zand (eds.), 21-32. Frankfurt a.M. and Vienna.

Havránek, Bohuslav

1936 Vývoj spisovného jazyka českého [The evolution of Standard Czech]. Československá vlastivěda, řada II., Spisovný jazyk český a slovenský: 1-144.

Kučera, Karel

1998 Vývoj účinnosti a složitosti českého pravopisu od konce 13. do konce 20. století [Evolution of the efficiency and the complexity of Czech orthography from the end of the 13th to the end of the 20th century]. Slovo a slovesnost 59: 178-199.

Lamprecht, Arnošt, Dušan Šlosar, and Jaroslav Bauer

1986 Historická Mluvnice Češtiny [Historical grammar of Czech]. Prague:

Státní pedagogické nakl.

Pleskalová, Jana, and Ondřej Šefčík

2007 Pravopis [Orthography]. In Kapitoly z Dějin České Jazykovědné Bohemistiky [Chapters of the history of Czech linguistic Bohemistics], Jana Pleskalová (ed.), 499-539. Prague: Academia.

Porák, Jaroslav

1979a Chrestomatie k Vývoji Českého Jazyka [Chrestomathy of the evolution of the Czech language]. Prague: SPN. 
Porák, Jaroslav

1979b Humanistická Čeština. Hláskosloví a Pravopis. [Humanist Czech. Phonology and orthography]. Prague: Univerzita Karlova.

Schamschula, Walter

1973 Die Anfänge der Tschechischen Erneuerung und das Deutsche Geistesleben (1740-1800). Munich: Fink.

Schröpfer, Johann

1968 Hussens Traktat „Orthographia Bohemica“. Die Herkunft des Diakritischen Systems in der Schreibung Slavischer Sprachen und die Älteste Zusammenhängende Beschreibung Slavischer Laute. (Slavistische Studienbücher 4). Wiesbaden: Harrassowitz.

Sedláček, Miloslav

1993 K vývoji českého pravopisu I, II [On the evolution of Czech orthography]. Naše Řeč 76: 57-71; 126-137. 


\title{
Croatian \\ On the creation of Croatian: \\ The development of Croatian Latin orthography \\ in the 16th century*
}

\author{
Roland Marti
}

\section{Introduction}

In many respects it is difficult to fit Croatia into simple and clear-cut categories. Nowhere is this more valid than in the area of writing. This applies to all aspects of writing. First of all, it is evident with regard to the "material" of writing, i.e., the alphabet. To my knowledge, Croatian is the only language in Europe that has developed a written tradition in three different alphabets, alphabets which were for a considerable period of time used simultaneously. ${ }^{1}$ Secondly, a similar complexity obtains with regard to the way in which the language is rendered in writing in the Latin tradition. Influenced by neighbours adhering to different systems, Croatian experimented with many solutions before eventually settling for the orthography now in use. And it was, finally, the language itself that lacked uniformity. As a result of the historical, political, geographical and religious situation, several "dialect traditions" developed and were often perceived as being the representatives of different languages. This is also borne out by the fact that Croatian, historically, was a language of many names ("Illyrian", "Croatian", "Slavonian" [?], "Dalmatian", to name but those that were the most common). ${ }^{2}$ It was not until the 19 th century that one written tradition finally gained the upper hand and was generally accepted as the only standard for all Croats. All of these factors contribute to the fact that Croatian orthography is a most complex affair. At the same time, it is a highly typical example of the problems inherent in the creation and evolution of orthographies, since it demonstrates the extent of possible variation and the consequences of co-occurrence and competition of various systems. It thus deserves more attention than has been paid to it, be it in general linguistic discussions of orthographic systems, or in descriptions of the history of the Croatian language. ${ }^{3}$ The following overview does not aim at filling these 
gaps. Rather, it attempts to present this unusual case by giving a general outline and by indicating in what ways the Croatian situation can be useful to gain a better understanding of the functioning of orthography in general. ${ }^{4}$

\section{Extra-linguistic aspects}

The lack of unity in the history of Croatian orthography finds its parallel in history, and this history is, at least partly, influenced by geography. The traditional home of the people that came to be called "Croats" is the eastern coast of the Adriatic Sea, including the islands and the adjoining regions, i.e., the mountainous area behind the sea coast as well as the plains beyond it. The mountainous area acted to some extent as a divide, separating the coast from the plains, and, apart from a small area towards the North connecting the coastal area and the plains, the mountains were eventually settled by people who had different "ethnic", political and also partly religious affiliations: the Bosnians. This geographically-determined situation is still mirrored in the hourglass shape of the Republic of Croatia today. The Croats settled the area in the course of the migration of the Slavs that took place after the Germanic migration, i.e., from the 6th-7th centuries onwards. ${ }^{5}$

Politically, the area settled by the Croats was highly disputed, and often a bone of contention between regional powers. It had been part of the Roman Empire, and the dividing line separating the western and the eastern half of the Empire after 395 ran not very far from the southern border of later Croatian territory. After the downfall of the Western Roman Empire, the eastern part extended its hold towards the West but did not succeed in establishing a lasting domination over the area. In the late Middle Ages, the situation became more complicated. On the Adriatic coast, it was mainly Venice and the Byzantine Empire that competed for control over this part of the Mediterranean, the latter being eventually replaced by the Ottoman Empire. In the hinterland, it was the Hungarian state, the Sublime Porte, and later the Habsburg Empire that vied for influence. In this context, several states emerged that were predominantly Croatian. Firstly, it was a Croatian principality under Trpimir (second half of the 9th century) that was eventually elevated to kingdom (Tomislav, first half of the 10th century). It enjoyed only a short period of independence and was united with Hungary on the basis of the Pacta Conventa in 1102, granting Croatia considerable autonomy. The south-eastern part of the region was subsequently conquered by the Ottoman Empire, only to return to the Habsburg Empire 
in the course of the latter's expansion in South-Eastern Europe. Another political entity was to be more lasting: the Republic of Dubrovnik (Ragusa). Even though it was for longer periods of time under the tutelage of other powers, viz. the Byzantine Empire, Venice, and the Sublime Porte (the Ottoman Empire), it managed to retain some degree of internal autonomy: a fact which had no little importance for the blossoming of culture, especially as far as the use of language was concerned.

The Croats, like all the Slavs at the time of migration, adhered to pagan beliefs. Many of the areas they settled, however, had already been Christianized in Roman times. The Croats accepted the new faith quickly, especially on the coast and on the islands where the Church had managed to conserve its infrastructure. Here, too, there were several protagonists vying for influence. On the highest level, it was the Roman Catholic Church (as opposed to the [Ecumenical] Patriarchate of Constantinople). On a lower level within the Catholic Church, it was the Roman, the Aquileian, the Bavarian and the Hungarian clergy that competed against each other. They had to reckon with the power of the traditional sees that were well established, especially in Dalmatia. The bishops enjoyed a considerable degree of autonomy, albeit within the framework of the Roman Catholic Church, and they used it to keep local traditions alive, the most important being the use of the Church Slavonic language and the Glagolitic alphabet. Thus, the religious situation was also rather complex, and the overall picture was further complicated by the fact that political boundaries did not always coincide with religious ones, nor with those established by the respective church administrations. A further problem arose from the fact that immediate neighbours had different religious affiliations. The Serbs in the SouthEast belonged to the Eastern Orthodox world, first as part of the Patriarchate of Constantinople, later as an autocephalous patriarchate. ${ }^{6}$ In Bosnia and Herzegovina, also to the South-East, where large groups of the population were, from an early date, accused of heretical leanings (the "Bogomil heresy", a dualistic sect roughly comparable to the Cathars in Southern France), Islam spread under the protection and with the support of the Sublime Porte. In Slovenia, to the North, Protestantism gained a foothold in the 16 th century, before eventually succumbing to the Counter-Reformation. 


\section{Linguistic aspects}

\subsection{Evolution of the linguistic continuum}

Linguistically, the Croatian situation is equally complex. It has to be assumed that at the time of migration the Slavonic branch of Indo-European was still fairly homogeneous, and formed a linguistic or dialectal continuum within which neighbouring varieties were mutually comprehensible. Today, this situation still obtains to some degree for the South Slavonic branch as far as dialects are concerned. The western part of this branch, made up today of the Slovenian, Croatian, Bosnian and Serbian standard languages (the last three for the second half of the 19th and most of the 20 th century united under the name of Serbo-Croatian or Serbo-Croat), ${ }^{7}$ developed into three different areas generally referred to as Kajkavian, C̆akavian and Stokavian (on the basis of the interrogative pronoun for what $),{ }^{8}$ with a further subdivision into (I)jekavian, Ekavian and Ikavian, based on the different reflexes of Common Slavonic * to Indo-European ${ }^{*} \bar{e}$ or to old $i$-diphthongs). ${ }^{9}$ The northern part of the Kajkavian territory eventually evolved into Slovenian and will not be considered here. In the remaining area, the situation was originally quite regular, with Kajkavian reigning in the North, Cakavian in Istria, along the coast and the islands, and Štokavian in the rest of the territory. This relatively clear picture was altered considerably with the expansion of the Ottoman Empire in the 15th-17th centuries, which led to large-scale emigration from Štokavian territories. As a result, the Kajkavian and Čakavian areas were fragmented, and as a further consequence Ikavian gave way to (I)jekavian in some areas. This prepared the ground for the eventual victory of Stokavian (I)jekavian as the basis of the Serbo-Croatian standard language and of today's standard Croatian. Croatian was much more affected by these developments than Serbian, since it encompassed all the dialectal varieties; furthermore, a written tradition existed in all of them in the 16 th century.

\subsection{The sound system of Standard Croatian today}

It is a prerequisite for the analysis of the orthography of a phonographic writing system to provide a description of the phonemic inventory (and perhaps even of those instances of phonetic variation that might have consequences for writing the language). Given the dialectal variety of Croatian, 
it is difficult to present such a description: as a matter of fact, different inventories would be needed for each writing tradition, since they were based on different dialects. Furthermore, the evolution of the phonemic systems of the various dialects would have to be taken into consideration. As this is not feasible in the framework of this article, I shall instead present the phonemic structure of contemporary Standard Croatian, giving the IPA value for the phonemes together with the graphemes in today's orthography, which is highly phonemic.

Croatian has quite a simple vowel system, consisting of the five vowels /a/, /e/, /i/, /o/, /u/, rendered by the graphemes $<\mathrm{a}>,<\mathrm{e}>,<\mathrm{i}>,<_{0}>,<\mathrm{u}>.^{10}$ To these, the sonorant $/ \mathrm{r} /(<\mathrm{r}>)$ has to be added, since Croatian has a vocalic $/ \mathrm{r}$ / (cf. the toponym Krk, or the official name of Croatia, Republika Hrvat$s k a$ ). On the suprasegmental level, things become somewhat more complicated: vowel length (long/short) as well as pitch level (rising/falling) is phonemic, resulting in four accents: long rising, long falling, short rising, short falling. ${ }^{11}$ Except in dictionaries and linguistic treatises, the four accents are usually not indicated in writing. The system of consonants is, as in the case of Slavonic languages in general, marked by a considerable number of fricatives and affricates as well as by palatalization (albeit to a lesser degree than in other languages of this group). There are six stops: $/ \mathrm{p} /$, $/ \mathrm{b} /, / \mathrm{t} /, / \mathrm{d} /, / \mathrm{k} /, / \mathrm{g} /(<\mathrm{p}><\mathrm{b}><\mathrm{t}><\mathrm{d}><\mathrm{k}><\mathrm{g}>)$, the nasal stop $/ \mathrm{m} / \mathrm{l}$ and again $/ \mathrm{r} /$, this time as a consonant $(<\mathrm{m}>,<\mathrm{r}>)$.

None of these is likely to pose major problems in Latin orthography, since they were also part of the Latin phoneme system and of its alphabet. ${ }^{12}$ The situation is more difficult with regard to the fricatives $/ \mathrm{f} /, / \mathrm{v} /, / \mathrm{s} /,|\mathrm{z} /,| \chi \mid$ $(<\mathrm{f}>,<\mathrm{V}>,<\mathrm{s}>,<\mathrm{Z}>,<\mathrm{h}>)$ and especially the fricatives $/ \mathrm{J} /, / \mathrm{z} /(<\breve{\mathrm{S}}>,<\check{\mathrm{Z}}>)$ and affricates $/ \mathrm{ts} /, / \mathrm{t} c /, / \mathrm{d} /, / \mathrm{g} /, / \mathrm{d} / \mathrm{d} /(<\mathrm{c}>,<\dot{\mathrm{c}}>,<\mathrm{d}>,<\breve{\mathrm{c}}>,<\mathrm{d} \check{\mathrm{z}}>){ }^{13}$ To these a lateral and a dental nasal, each with a palatalized counterpart, viz. $/ 1 /, / K /$; $/ \mathrm{n} /, / \mathrm{n} /(<\mathrm{l}>,<\mathrm{j}>;<\mathrm{n}>,<\mathrm{nj}>),{ }^{14}$ and finally $/ \mathrm{j} /(<\mathrm{j}>)$ have to be added. All in all, there are 30 phonemes if the suprasegmental aspect and the double status of $/ \mathrm{r} /$ are disregarded.

\subsection{The alphabets}

As mentioned above, Croatian uses (or rather used) three different alphabets in writing: Glagolitic, Cyrillic and Latin. In the Croatian context, the earliest of the three is Glagolitic. The invention of the Glagolitic alphabet is attributed to Constantine-Cyril, a highly erudite Byzantine scholar, who devised it when he and his brother Methodius, a clergyman later to become 
archbishop, were sent as missionaries and diplomatic envoys to Moravia at the request of the Moravian prince Rastislav in 862-863. The alphabet was basically constructed so as to render the phonemes of Slavonic according to a "one phoneme - one grapheme" principle; structurally, it was patterned after the Greek alphabet (sequence of letters common to both alphabets, inclusion of some letters to render Greek phonemes, use of letters as numbers etc.). The Glagolitic alphabet came to be used in Moravia, Pannonia, Bulgaria and Croatia. From Moravia it spread to Pannonia and was transplanted to Bulgaria when the Byzantine mission was expelled from Moravia after the death of Methodius in 885. It is assumed that it spread to Croatia from Moravia and Pannonia. In most of these areas it disappeared fairly quickly, giving way to the Latin alphabet in Moravia as well as in Pannonia, and to Cyrillic in Bulgaria. Only in Croatia did it manage to survive for a long time, being used, albeit in a rather restricted area and mainly for the purposes of the Catholic Church, for example in printed breviaries and missals, until the 20th century. ${ }^{15}$ It was here that Glagolitic developed a distinct angular variety (in contradistinction to the more rounded original and the later Bulgarian tradition), probably influenced by Beneventan script. Glagolitic being an invented and not an adapted alphabet, it had a letter for each phoneme of the language variety it was devised for, viz. the South Slavonic dialect of Thessaloniki, ${ }^{16}$ the birthplace of ConstantineCyril and Methodius. It was thus almost ideally suited to render Croatian. Minor changes were necessary, but since Croatian had fewer phonemes than Old Church Slavonic (OCS), and since the changes did not contradict the phonemic principle, the overall picture was not altered. ${ }^{17}$ There is a rich manuscript and epigraphic tradition in Glagolitic. It was mainly used by the Church, but it also gained currency in everyday life to some extent. ${ }^{18}$ Glagolitic came to be used in printing as well, and this at quite an early date: the first Croatian (or rather Croatian Church Slavonic) incunabulum was printed in Glagolitic. With the increasing popularity of the Latin alphabet in the 16th and 17th centuries, Glagolitic came under pressure; it survived in the Church thanks to the glagoljaši, i.e., the priests celebrating the Mass not in Latin but in Croatian Church Slavonic. ${ }^{19}$ Their stronghold was the Dalmatian islands. The Glagolitic tradition, with its "one phoneme one grapheme" principle was a rather attractive alternative to the Latin alphabet, in which the limited number of graphemes caused problems. ${ }^{20}$

The "Cyrillic" alphabet is a misnomer, since it was not in fact created by Constantine-Cyril. Nevertheless, it retains the basic structural principles of Constantine-Cyril's invention. It is, essentially, a far-reaching adaptation of the Greek alphabet of the Middle Byzantine period (this is most evident in 
the capital letters), and could be described as Greek in form and Glagolitic in content. For phonemes absent in Greek but existing in Slavonic (and therefore represented by letters in Glagolitic), the Cyrillic alphabet developed separate letters as well. It thus corresponded to the "one phoneme one grapheme" principle in much the same way as Glagolitic. The adaptation most likely took place in the late 9th century in Bulgaria, where Cyrillic soon ousted its Glagolitic predecessor. In the course of time, "Cyrillic" came to be equated with "Orthodox", but until the Counter-Reformation the use of a particular alphabet was dictated more by expediency than by religious considerations, and it is therefore not surprising that Cyrillic was used for Croatian, too, and this right up until the 20th century (Nazor 2004). It was mainly at home in the southern part of the coastal area, where it developed a particular variety known as Bosančica, Bosanica or Bukvica. ${ }^{21}$ Its main proponents were the Franciscans.

The Latin alphabet was the last to arrive on the scene. It was first used to render Croatian onymic material in Latin texts (first in the famous Evangeliario di Cividale with Croatian autographs from the 8th century onwards; cf. Cronia 1953b) and then for interlinear glosses, again in Latin texts. $^{22}$ Finally, beginning in the 14th century, complete Croatian texts and eventually whole manuscripts came to be written using the Latin alphabet. ${ }^{23}$

\section{Book printing}

The advent of the printing press did not alter the distribution of the alphabets in Croatia at first: as a matter of fact, the first printed book appeared in Glagolitic (Missal of 1483; cf. Misal 1971 [1483]), ${ }^{24}$ preceding the first dated incunabulum in the Latin alphabet (the Lectionary of Bernardin of Split 1495; cf. Bratulić 1991) by a dozen years and the first printed book in Cyrillic (or, to be more precise, in Bosančica) by almost thirty years ( $D u$ brovnik Breviary of 1512; cf. Rešetar and Đaneli 1938: 1-109). ${ }^{25}$ In the 16th century, the Swabian Protestant printing presses at Urach used all three alphabets for religious propaganda: of the Croatian or Croatian Church Slavonic materials (books and leaflets) printed there between 1561 and 1564, there were 13 in Glagolitic, 8 in Cyrillic and 6 in Latin. ${ }^{26}$ Nevertheless, the Latin alphabet eventually gained the upper hand, mainly due to the proliferation of secular texts that were almost exclusively printed in the Latin alphabet. As for the scripts used in the Latin tradition, there was some variation in the beginning: manuscripts generally used Gothic ${ }^{27}$ script, and so did the first dated printed book, the Lectionary of 1495 as well as the 
second edition of Marko Marulić's Judita of $1522,{ }^{28}$ probably to stress the religious character of the books (Bratulić 2004: 63). This tradition was not to last, however: Roman type ousted Gothic completely at a very early stage, so that the distinction of scripts will not be relevant for our purposes. $^{29}$

\section{Using the Latin alphabet}

Even though there were general tendencies as to what alphabet was to be used in certain areas for certain texts and for certain purposes, the three alphabets were not completely segregated. There were "polygraphic" writers, scriptoria, and printers. It could therefore be expected that Glagolitic and, to a lesser extent, also Cyrillic, would exert some influence on the emerging Latin tradition. ${ }^{30}$ This is all the more likely since, in the history of the tradition of a text, the alphabet used could and did change. ${ }^{31}$ It is surprising, however, that this influence was not of a structural nature: the Latin alphabet was not adapted to Croatian by introducing new letters for Croatian phonemes. ${ }^{32}$ The only partial exception is the use of the "superfluous" letter $<x>$ to designate a non-Latin phoneme. Another "superfluous" letter, viz. $\langle q\rangle$, was not used in the same way. Instead, the writers, the scribes and later the printers had recourse to other means of filling the lacunae of the Latin alphabet: means which had already been developed for other languages using the same alphabet.

\subsection{Sound-letter correspondences}

Basically, there are four ways of adapting the Latin alphabet to render other languages in writing without creating new letters. The most elementary technique is the use of one letter to represent different phonemes that are usually in some ways similar: this will be called the "monographic" approach. Thus, $<\mathrm{s}>$ could be used for $/ \mathrm{s} /, / \mathrm{z} /, / \mathrm{S} /, / 3 /$ etc. The major shortcoming of "monographic" writing is its ambiguity: the qualitative correspondence "one letter - one phoneme" is violated. Often ambiguity cuts both ways: thus $/ \mathrm{z} /$ might be represented by $<_{\mathrm{S}}>$ or $\left\langle\mathrm{z}>\right.$, and conversely $\left.<_{\mathrm{s}}\right\rangle$ could stand for $/ \mathrm{s} /, / \mathrm{z} /$ etc. This is the "elementary" version of monographic writing. A more sophisticated variant, "advanced" monographic writing, tries to attain a one-to-one relationship between sound and letter, using superfluous letters (e.g., $<\mathrm{x}>$ ) or letter variants (e.g., $<\mathrm{u}>$ and $<\mathrm{v}>$ ). 
More advanced from a linguistic point of view is the use of letter combinations so that the sequence of two or more letters would represent a phoneme: this will be referred to as the "digraphic" method, even though it might sometimes be tri- or even tetragraphic. Following this approach $<$ rz $>$ could be used for $/ 3 /,<\mathrm{sz}>$ for $/ \mathrm{J} /$ (as in Polish) or for $/ \mathrm{s} /$ (as in Hungarian), $<$ sch $>$ for $/ \mathrm{f} /$ (as in German), etc. There were two drawbacks to this system. One was that the quantitative correspondence "one letter - one phoneme" did not hold any more. The other one was again ambiguity: $<\mathrm{rz}>$ could stand for the phoneme $/ z /$ as well as for the phoneme sequence $/ \mathrm{r} /+/ \mathrm{z} /$ (cf. in Polish marzec 'March' with / $/$ / but marznać 'freeze' with /r/ + /z//); similarly, $<\mathrm{sch}>$ might be read either $/ \mathrm{g} /$ or $/ \mathrm{s} /+/ \mathrm{c} /$ (cf. in German kreischen 'scream' with $/ \mathrm{J} /$, but Kreischen 'small circle' with $/ \mathrm{s} /+/ \mathrm{c} /$ ), etc.

The third approach is of a "combinatory" nature: the sound value of a letter depends on its surroundings, usually on the following letter (this letter having a sound value of its own). Thus, $<\mathrm{c}>$ would designate $/ \mathrm{k} /$ if followed by $<\mathrm{a}>,<_{0}>,<\mathrm{u}>$ or a consonant, but $/ \mathrm{t} J /$ before $<\mathrm{e}>,<\mathrm{i}>$ in Italian. The main drawback of this method is again the ambiguous nature of the letters involved, necessitating sometimes the use of digraphic means or of special marks (thus amico 'friend' but amichevole 'friendly' in Italian, both with /k/, ambigu 'ambiguous' (masc.) but ambigüe 'ambiguous' (fem.) in French, both with $/ y /)^{33}$

The fourth method is the use of existing letters with additional marks: this is called the "diacritic" approach. ${ }^{34}$ Thus, in addition to $<\mathrm{u}>$, the diacritically-enhanced letters $<\dot{\mathrm{u}}>$ and $<\stackrel{\mathrm{u}}{ }>$ (as in Czech) or $<\mathrm{z}>$ as well as $<\dot{\mathrm{Z}}>$ and $<\dot{\mathrm{z}}>$ (as in Polish) would be used. This is a very old technique: already, in Latin, $<\mathrm{G}>$ developed out of $<\mathrm{C}>$ by adding a vertical line. If orthography changes in the course of time, it generally develops from the first to the fourth type, the combinatory type usually resulting from phonetic changes that lead to new phonemes (such as palatalization in the examples from Romance languages above). ${ }^{35}$

\subsection{Levels of representation}

In order to understand the intricacies of rendering speech in writing, yet another facet has to be considered, viz. the linguistic level represented. ${ }^{36}$ For alphabetic writing systems, the basic unit is the phoneme, hence the instruction "write as you speak"; thus Croatian robovi [b] 'slaves' but ropstvo [p] 'slavery', with devoicing of /b/ in the latter example due to regressive assimilation. This will be called phonemic orthography. 
Since, however, writing and reading depend on vision rather than hearing, they are structurally different from speaking and listening. Furthermore, the written word endures, whereas the spoken word is volatile (at least up to the 20th century). It is therefore not surprising that other levels of representation influenced writing.

Most important among these is the morphemic level, with the instruction "write a morpheme (or a word) always the same way if possible"; hence Russian raby [b] and rabstvo [p], where devoicing takes place in speaking but is not expressed in writing. More complex forms of this way of rendering sounds make use of diacritics, cf. German älter 'older' because of alt 'old', but Eltern 'parents'; Polish stót $[\mathrm{u}]$ alongside stotu 'chair' (nom. and gen.) and the converse solution in Czech dim [u] alongside domu 'house' (nom. and gen.). ${ }^{37}$ This is referred to as morphemic orthography.

Another form of writing is based on a diachronic approach: "retain an established writing regardless of the development of pronunciation"; thus English write or French humain. Here, too, there are complex forms such as the circumflex accent in French often symbolising a "lost" $<\mathrm{s}>$ (bête, hôte). This is known as historical orthography. ${ }^{38}$

Orthographies generally combine several of these approaches, but one of them usually dominates. Thus, Serbian and Croatian are mainly phonemic, Belarusian is phonemic in rendering vowels and morphemic elsewhere, German, Polish and Russian are morphemic, English and French are historical.

\section{Early Croatian Latin orthography}

Turning now to the prehistory of Croatian orthography using the Latin alphabet in the 16th century, and thus to the 14 th-15th centuries, ${ }^{39}$ we must recall that Croatia could, at least in theory, rely on her own threefold writing traditions, make use of Italian or Hungarian (marginally perhaps even German) orthographies or turn to systems developed for other Slavonic languages using the Latin alphabet, most notably Polish, Czech and Slovenian. As mentioned above, her own Glagolitic and Cyrillic traditions did not influence the composition of the Latin alphabet by adding new letters, nor did the emerging Latin orthography (or rather orthographies) rely on the other Croatian traditions in a noticeable way. It seems, in fact, that the Latin alphabet was perceived as being quite independent from the other two: whereas Glagolitic and Cyrillic could, and did, alternate in manu- 
scripts (in printed books, a similar situation obtains between the printed Glagolitic text and handwritten Cyrillic marginalia), this is not usually the case for Latin in its relationship to either of the other two alphabets. The same can be said of the orthographies: Cyrillic and Glagolitic usage did not serve as a model for Latin. ${ }^{40}$

\subsection{Manuscripts}

The oldest continuous Croatian texts written in Latin letters begin to appear in the middle of the 14 th century: ${ }^{41}$ the Zadar Dominican statute written in 1345, the Šibenik prayer and the Korčula lectionary, all written in Dalmatia. Their orthography is in some ways reminiscent of the "Italian" tradition $^{42}$ insofar as Croatian and Italian had similar sounds in their phonemic inventory. ${ }^{43}$ The Šbenik prayer and the Cantilena pro sabatho (Milčetić and Milošević 1911, Hadrovics 1984) used a rather underspecified orthography with ambiguity in both directions: $/ \mathrm{t} f /$ was rendered by $\langle\mathrm{c}\rangle,\langle\mathrm{c}\rangle$, $<\mathrm{ch}>$; $/ \mathrm{k} /$ by $\langle\mathrm{c}\rangle,\langle\mathrm{ch}\rangle,\langle$ çh $>,\langle\mathrm{q}\rangle$; /v/ by $\langle\mathrm{u}\rangle,\langle\mathrm{v}\rangle,\langle\mathrm{w}\rangle,\langle\mathrm{f}\rangle$; on the other hand, $\angle \beta$ (transcribed in the edition as $s$ ) could stand for $/ \mathrm{s} /, / \mathrm{z} /, / \mathrm{z} /$; $<\mathrm{ch}>$ for $/ \mathrm{k} /, / \mathrm{t} / /, / \mathrm{ts} /, / \mathrm{t} 6 / ;<\mathrm{g}>$ for $/ \mathrm{g} /, / \mathrm{j} /, / \mathrm{t} 6 /$; etc. On the whole, the orthography uses all possible ways of writing: the monographic approach $(<\mathrm{c}>$ for $/ \mathrm{k} /, / \mathrm{t} \mathrm{J} /, / \mathrm{ts} /,<\mathrm{g}>$ as above), digraphs $(<\mathrm{ch}>,<\mathrm{çh}>,<\mathrm{gh}>,<\mathbb{\mathrm { l }}>,<\beta>$, $<$ ng $>,<$ ny $>,<\lg >,<$ ly $>$ ), combinatory writing $(<$ ge $>$ for $/$ tce $/$ but $<$ go $>$ for $/ \mathrm{go} /,<\mathrm{ci}>$ for $/ \mathrm{t} \mathrm{ji} /$ but $<\mathrm{co}>$ for $/ \mathrm{ko} /$ ), and finally one diacritically altered letter $(<c ̧>)$. The orthography is, to quote the editors, "neobično nedosljedan" [unusually inconsistent] (Milčetić and Milošević 1911: 578), but this is quite typical for the first attempts to render vernacular texts in the Latin alphabet. ${ }^{44}$ Nevertheless, it is surprising in the case of Croatian, since the language had already been reduced to writing successfully in the Glagolitic-Cyrillic tradition, and this tradition might well have been an example to be followed. But it was not to be, and the tradition using the Latin alphabet could not get rid of this kind of inconsistency for quite a long period of time, although there is a tendency towards a less erratic orthography. Thus, the Vatican Prayer Book ${ }^{45}$ of the 14th century, written in Dubrovnik, is somewhat more coherent, perhaps because the text is longer and the contents more repetitive. Still, there is considerable variation: while $/ 3 /$ is usually rendered by $\langle\mathrm{g}\rangle$, there are also rare instances of $\langle\beta>$ and $\langle x>$; on the other hand, $<\beta$ stands for $/ \mathrm{s} /, / \mathrm{z} /, / 3 /$, etc. The only consistent feature is the use of the digraphs $<\mathrm{gl}>$ and $<\mathrm{gn}>$ for $/ K /$ and $/ \mathrm{n} /$, most likely influenced by the Italian tradition. A similar orthography is characteristic of the 
Zagreb Psalter dated to the 16th century: differences are in the occasional use of $<\mathrm{g}>$ or $<\mathrm{gi}>$ (instead of $<\mathrm{ch}>$ ) for $/ \mathrm{t} /,{ }^{46}$ and of $<\mathrm{x}>$ not only for $/ \mathrm{z} /$ as in other sources, but also for $/ \mathrm{J} /{ }^{47}$

Unfortunately, there is no description of orthographic variation in the manuscript tradition as a whole. Such a description might explain many of the inconsistencies in the later printed tradition. It is, however, safe to assume that variation was considerable, taking into account the number of scriptoria, their geographic dispersion, the administrative divisions and, last but not least, the linguistic variation reigning in the area.

\subsection{Incunabula}

The arrival of the printing press changed many of the conditions influencing the further development of written language, and especially of orthography. ${ }^{48}$ Books became a commodity, and as such were subject to the laws of the market. Mass production fostered "standardization": in this case the standardization of orthography. But this was a slow process. ${ }^{49}$ Printers set type on the basis of manuscripts written according to established traditions, and these traditions were rather variegated. An inexperienced typesetter, who quite often did not even know the language, would just deliver a more or less faithful copy of the manuscript. Experienced typesetters familiar with the language might strive for the unification of orthography within a book, and in the course of time a printer might achieve some uniformity in the orthography of all the books he published in one language using one alphabet ("house orthography"). However, this did not mean the unification of Croatian orthography, especially as there were so many different traditions, and as there was no real cultural centre that dominated all others. Matters were complicated even further by the fact that much of the early printing did not take place on Croatian soil. The first books in Croatian using the Latin alphabet were printed outside of the linguistic territory (in Venice) and this "expatriate" printing tradition continued for quite some time (in addition to Venice, Croatian books were later also printed in Budapest, Florence, Ljubljana, Loreto, Padua, Rome, Urach, Vienna, etc.). On Croatian territory, printing presses using the Latin alphabet for Croatian books eventually appeared in Dubrovnik, Nedelišce and Zagreb. It is perhaps not surprising that Glagolitic books were printed earlier in Croatia (printing presses in Senj and Rijeka [Fiume]). Obviously, the experience of the Venetian printers gave them a competitive edge when the Latin alphabet 
was used; however, for Glagolitic books it was the Croatian printers who were at an advantage. ${ }^{50}$

The oldest dated printed book in Croatian using the Latin alphabet, the Lectionary of Bernardin of Split published in $1495,{ }^{51}$ retains the shortcomings of the orthography that reigned in the manuscript tradition. ${ }^{52}$ (This is not surprising since the script used was the same as in manuscripts, viz. Gothic.) Thus, /ts/ as well as $/ \mathrm{t} / /$ is rendered by $\langle\mathrm{c}\rangle,\langle\mathrm{c}\rangle$ and sometimes $<\mathrm{z}>$; /tc/ by $<\mathrm{ch}>,<$ chi $>,<$ chy $>$ and in a few cases by $<\mathrm{k}>$; $/ \mathrm{f} /$ is written as

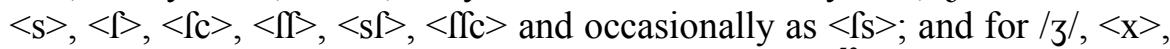
$<\mathrm{Z}>$, occasionally $<\boldsymbol{\beta}$ and (rarely) $<$ ç $>$ can be found. ${ }^{53}$ The palatalized lateral and nasal follow the Italian example; they are written as $\langle\mathrm{gl}>,<\mathrm{gli}>$ or $<$ gly $>$ on the one hand, and $<$ gn $>$ (rarely $<$ gni $>$ ), on the other. Double letters (for vowels and for consonants) are used to transport suprasegmental information (accent position, length of vowel), cf. otaac (genitive plural) 'father', tebbe 'to you'.

The oldest printed book using Roman characters, the Croatian printed prayer book, ${ }^{54}$ has a similar orthography. Here, $<\beta>$ can equally well stand for $/ \mathrm{s} /, / \mathrm{z} /, / \mathrm{J} /$ and $/ \mathrm{z} /$; and on the other hand $/ \mathrm{k} /$ is rendered by $\langle\mathrm{ch}>,<\mathrm{c}>$, $<\mathrm{k}>$. For $/ 3 /,<\mathrm{Cc}>$ is used ( $<\mathrm{x}>$ only from fol. $92 \mathrm{~b}$ onwards) alongside $<\beta$, but $<\mathrm{C} c>$ can equally well represent $/ \mathrm{J} /$. A most peculiar trait of the orthography is the use of $<$ th $>$ for $/ \mathrm{t} 6 /$ in the main body of the book (up to fol. $92 \mathrm{~b}){ }^{55}$ only in the last part is the more traditional $<\mathrm{ch}>$ found. This obviously indicates that more than one manuscript was used in setting the text, each source adhering to a different orthography. ${ }^{56}$

\section{Croatian Latin orthography in the 16th century}

Croatian Latin orthography in the 16 th century $^{57}$ seems to strive towards regularity. This tendency is countered by the fact that there were still no real centres of printing that might have contributed towards unification (as was the case in Poland with Cracow). Furthermore, it seems that the authors of the books printed in this century adhered to various local writing traditions according to their linguistic background and/or allegiance. ${ }^{58}$ These traditions prevailed upon the orthography and were not always influenced by the printers. On the whole, orthography in the 16th century was an area not of theoretical treatises, but rather of practical application and slow improvement ("learning by doing", as it were). The first treatises appeared in the 17th century and they essentially remained a dead letter, since the proposals for an improved orthography were as a rule not accepted. ${ }^{59}$ 
Orthographic "rules" can therefore only be deduced from the practice of the printers, as evident from the books that appeared in the 16th century. Since these books are not easily accessible, research in this area usually relies on Maretić (1889) ${ }^{60}$ In his History of Croatian Orthography he included data on a dozen books from the 16th century, and this data will form the basis of my description. Unfortunately, Maretić did not always choose the most instructive examples, ${ }^{61}$ and he completely ignored the Protestant books printed in Urach and Regensburg. ${ }^{62}$ Of necessity, then, the following overview must remain incomplete.

\subsection{Orthographic traditions}

In the 16th century, four orthographic traditions may be distinguished. ${ }^{63}$ Three of them are representatives of traditions that are loosely connected with a certain region; the fourth represents a denominational group. On the basis of the letter they use to render/ts/, the first three will be referred to as the $C$, the $Z$ and the $C Z$ groups, respectively. Regionally, they might be called the "Dalmatian", the "Dubrovnik" and the "inland" group. The first roughly corresponds to Čakavian, the third to Kajkavian dialects. The fourth is the Protestant tradition. They are easily distinguished by the way in which they render specific Croatian sounds for which there are no readymade solutions in the Latin alphabet. It must be borne in mind, however, that variation is still quite widespread in the 16th century, so that the shibboleths enumerated here represent a simplification of the actual situation found in the books analyzed.

The $C$ or Dalmatian (Čakavian) group has a 15 th-century predecessor in the Lectionary of Bernardin of Split. It already uses most of the typical letters and letter combinations of this group, but in a less consistent way. In the 16th century, the following authors belong to this group: Marko Marulić (Iftoria Sfete udouice Iudit, Venice 1521; cf. Marulić 1950), Petar Hektorović (RIBANYE I RIBARSCHO PRIGOVARANYE, Venice 1568), ${ }^{64}$ Petar Zoranić (PLANINE CHE ZDARXE usebi Pifni pete po Paftirich, Pripouifti, i Prituori Iunachou i Dechliç, i Mnoge oftale stuari, Venice 1569, cf. Zoranich 1952 [1569]); and Šimun Budinić (ISPRAVNIICH ZA EREI ISPOVIDNIICI, Rome 1582). ${ }^{65}$

The $Z$ or Dubrovnik group is, in an embryonic state, also represented by an incunabulum, viz. the Croatian printed prayer book, even though the 16th-century tradition of this group deviates more from its predecessor than the $C$ group does from Bernardin's Lectionary. Members of this group are 
Dinko Ranjina (PIESNI RASLIKE, Florence 1563), Basil Gradić (LIBARZE OD DIEVSTVA I DIEVICKOGA BITYA and LIBARZE VELLE DVHOVNO I BOGOGLIVBNO OD MOLITVE, both Venice 1567), Arkanđeo Gučetić (ROSARIO S'DRVXBOM PRISLAUNOGA IMENA IESVSA SPASSITEGLIA NASCEGA, Rome 1597) and Dominko Zlatarić (ELEKTRA TRAGEDIA, Venice 1597). ${ }^{66}$

The $C Z$ or inland (Kajkavian) group in our sample consists of Ivan Pergošić (DECRETVM KOTEROGA IE VERBEWCZI ISTVAN DIACHKI POPISZAL, Nedelišće 1574; cf. Kadlec 1909: XLVII-LXXXII), and Antun Vramec (Kronika, Ljubljana 1578; cf. Junković 1972: 25-41). They founded a tradition that remained unusually stable right up to the 19th century. ${ }^{67}$ Related to this group is Faust Vrančić (Faustus Verantius) (DICTIONARIVM QVINQVE NOBILISSIMARVM EVROPAE LINGVARVM, Venice 1595), even though he hails from Šibenik and should therefore belong to the first group. ${ }^{68}$ It is evident from his dictionary, however, that he adapted his orthography to Kajkavian practice.

The Protestant group is the most homogeneous one, since the books were essentially published by one printer in Urach (Swabia) within a short time span (1561-1565 [1568]). The responsibility for the books printed was shared by two printers, Antun Dalmatin and Stjepan (Konzul) Istranin. ${ }^{69}$ In spite of their participation in contemporary activities in the same region aimed at a Slovene readership, there was little or no mutual influence in the area of orthography. ${ }^{70}$ ing: ${ }^{72}$

The essential differences ${ }^{71}$ between the four traditions are the follow-

Table 1. The four orthographic traditions of 16th-century Croatian

\begin{tabular}{|c|c|c|c|c|}
\hline \multirow{2}{*}{$\begin{array}{l}\text { Phonemel } \\
\text { letter }(s)\end{array}$} & \multicolumn{4}{|c|}{ orthographic groups } \\
\hline & $C$ & $Z$ & $C Z$ & Protestant \\
\hline$/ \mathrm{ts} /<\mathrm{c}>$ & $<\mathrm{c}><\mathrm{c}>$ & $<\mathrm{z}>$ & $<\mathrm{cz}>$ & $<\underline{\mathrm{cz}}>$ \\
\hline$|\mathfrak{y}|<\check{\mathrm{c}}>$ & $<\mathrm{c}><\mathrm{c}>$ & $<\mathrm{c}>$ & $<\operatorname{ch}>(<\operatorname{cs}>)$ & $<\underline{\mathrm{ts}}>$ \\
\hline$/ \mathrm{k} /<\mathrm{k}>$ & $<\operatorname{ch}>$ & $<\mathrm{k}>$ & $<\mathrm{k}>$ & $<\overline{\mathrm{k}}>$ \\
\hline $\mid K /<\mathrm{lj}>$ & $<\mathrm{gl}>$ & $<\mathrm{gl}>$ & $<\mathrm{li}>(<\mathrm{ly}>)$ & $<\mathrm{ly}>$ \\
\hline$/ \mathrm{n} /<\mathrm{nj}>$ & $<$ gn $>$ & $<$ gn $>$ & $<$ ni $>(<$ ny $>)$ & $<\tilde{\mathrm{n}}>(<\mathrm{ni}>,<\mathrm{ny}>)$ \\
\hline$/ \mathrm{s} /<\mathrm{s}>$ & $<\boldsymbol{\Gamma}><\mathrm{s}>$ & $<\beta><s>$ & $<\beta>$ & $<\underline{\beta}>(<\underline{\mathrm{s}}>)$ \\
\hline$/ \int /<\breve{\mathrm{S}}>$ & $<\int \mathrm{c}>$ & $<\mathrm{fc}><\mathrm{sc}>$ & $<\Pi>$ & $<\underline{\Pi}>$ \\
\hline$|\mathrm{z}|<\mathrm{z}>$ & $<\mathrm{z}>$ & $<\beta$ & $<\mathrm{z}>$ & $<\underline{\mathrm{Z}}><\mathrm{S}>$ \\
\hline$|z|<\check{Z}>$ & $<\mathrm{X}>(<\mathrm{Z}>)^{73}$ & $<\mathrm{x}>$ & $<\boldsymbol{\beta}><_{\mathrm{S}}>(<\mathrm{X}>)$ & $<\underline{\mathbf{s}}>$ \\
\hline
\end{tabular}


It is evident from the comparison of the traditions that there are considerable differences between them, and that this could lead to confusion. On the whole, the "littoral" orthographies $C$ and $Z$ (Čakavian and Dubrovnik) exhibit certain similarities, and so do the $C Z$ (Kajkavian) and Protestant orthographies. The former are closer to Italian orthographic traditions; the latter have some affinity to Hungarian.

Some problems of the 16th-century orthographies are not included in the comparison above, since they deserve special consideration. The first is the use of diacritics. The only diacritic sign generally accepted in the 16th century was the cedilla on the $<$ ç>, and it had already been in use in the 15th century (see above). It posed no particular difficulties for the printers, since it was widespread in Italian books as well. ${ }^{74}$ In the 16 th century, the first writer in our sample to introduce new diacritic signs was Ivan Pergošić: he used $<\mathrm{e}>$ and $\langle\dot{\mathrm{g}}\rangle$. The function of the former is not quite clear. Maretić (1889: 29) assumes that it is in some way connected to the Glagolitic and Cyrillic letter for the OCS anterior nasal vowel, but there are many examples in which this is not the case. The latter stands for $/ \mathrm{d} / /,{ }^{75}$ and thus corresponds exactly to the use of the same letter in the strictly monographic Croatian orthography developed in the 19th century. In the Protestant books, $<\tilde{\mathrm{n}}>$ was used to render /n/ (Fancev 1916: 161). Finally, in the third volume of his Suma nauka kristianskoga of 1583, Šimun Budinić used three signs that are generally considered to be examples of diacritically enhanced letters: $\langle\mathrm{c}\rangle,<\dot{\mathrm{c}}>$ and a letter consisting of $\langle 3\rangle$ with a hook added on top. They stood for $/ \mathrm{ts} /, / \mathrm{t} /$ and $/ \mathrm{z} /$, respectively. ${ }^{76}$ Except for the already traditional $<c ̧>$, none of these innovations caught on, so that diacritics continued to play a marginal role in the development of Croatian orthography right up to the 19th century.

A particular instance of diacritics is the use of accents. Here, too, Italian printing set the example. However, the accentual patterns of Croatian were much more complicated, and ideally accents should not only indicate position, but also quality (long, short, rising, falling). It seems, however, that such an ideal system was not developed. Some authors use only one accent (e.g., Gradić), some two (e.g., Ranjina), or even three (Pergošić). The early Protestant books did not use any accents; those printed in Regensburg used three (Fancev 1916: 162-164). In some cases they are only used to indicate vowel length (i.e., short vowels do not get an accent); in others they correspond rather to Italian practice, accents being mainly used for short words. Finally, accents might be used in cases of homography only. Some books lack accents altogether. On the whole, the use of accents seems to have 
been a highly individualized practice, and none of the groups mentioned above is homogeneous in this respect.

Another interesting aspect of 16th century orthography, and one that is closely related to the preceding practice, is the use of double letters. As mentioned above, double letters were already used in incunabula orthography to express suprasegmental features. It was most likely prompted by the Italian practice, which was, however, restricted to consonants (Italian has phonemic quantity in consonants but not in vowels). ${ }^{77}$ Since in Croatian the situation was exactly the reverse (Croatian has phonemic quantity in vowels but not in consonants), it might be expected that, here, double letters might be used for long vowels only. This was actually the case, but in addition letters for consonants could also be doubled. Again, there is no clearly discernible pattern: there are books that use double letters sparingly, either with consonants (Zoranić) or with vowels (Vramec); some use them frequently, again with either consonants (Gučetić) or vowels (Vrančić) or both (Gradić). Sometimes doubling can be restricted to certain letters (e.g., $<\mathrm{i}>$, $<\mathrm{l}>$ and $<\mathrm{s}>$ in Zlatarić). Once more, the choice for or against doubling seems to be very individual and cuts across the different groups.

Finally, we should pay attention to another aspect of orthography already considered by Maretić (1889), but often neglected in analyses of orthography, viz. the linguistic level represented in writing. ${ }^{78}$ All of the books in the sample mix the different possibilities, so that morphemic (gospodstvo because of the basic morpheme gospod), phonemic (gospoctvo because of the pronunciation as [ts]) and blended orthographic solutions (gospotstvo because of morphemic analysis and phonemic writing) may coexist. It seems that the authors aimed at morphemic writing, but that their analysis of the morphemic structure of the words was insufficient. Again, this is a general tendency that cannot be attributed to any single one of the different groups.

The Protestant tradition occupies a position that distinguishes it from all the others in many respects. Linguistically, this is so for three reasons. First of all, the authors and printers used all three alphabets in their activities, and most of the books they published appeared in more than one, some even in three versions. ${ }^{79}$ Thus, they were daily confronted with the problems of transliteration (or rather transcription), and were in a privileged position to realize the advantages and shortcomings of the different alphabets and orthographies. Secondly, Protestant propaganda was aimed at a maximally large audience (this was the main reason for publishing multiple versions of books), and was therefore interested in finding a "compromise" language that would be understood by most readers in the western part of 
the South Slavonic continuum (ideally including even part of the Slovene reading public); cf. Vince (1976: 789-790). And, finally, they also had to find a compromise regarding the Latin orthography, a compromise that would be acceptable to all readers regardless of the orthographic tradition(s) they were accustomed to. It is interesting to note that in this context the Latin alphabet came last (cf. the publishing dates), and that it was considered to be the least known of the three, whereas Glagolitic was seen as the standard alphabet for Croatian. This is evident from the fact that the books printed in the Latin alphabet contained a reading instruction with the indication of some Glagolitic letters and their Latin equivalents, thus establishing an "official" transliteration. ${ }^{80}$

In spite of the considerable efforts put into proselytising Croatian Christians on the part of the Swabian Protestants, the Reformation did not gain a lasting foothold in Croatia. As a consequence of this, the Latin orthography used in the Urach publications did not survive, and it could not influence the subsequent development of Croatian Latin orthography.

\section{2. "Theoretical" treatises}

In the early years of the use of the Latin alphabet for Croatian, there was little theoretical reflection on orthographic problems; practical issues were more important. Theory did not enter the picture until the very end of the 16th century, ${ }^{81}$ and this development was motivated by several considerations. One was the desire to devise a systematic orthography which would render the phonemes of Croatian in an unequivocal way. Another aimed at the unification of the existing traditions. A possible third consideration, viz. the compatibility with the orthography of neighbouring languages (essentially Italian and Hungarian), would appear to have been relatively unimportant to reformers. Such compatibility had determined the beginnings and thus influenced the emergence of regional traditions. If the aim was unification, then compatibility with one or the other or even both of the neighbouring orthographies would have to be sacrificed. ${ }^{82}$ Equally unimportant was the compatibility with the other two alphabets still used in writing Croatian. Obviously, the future dominance of the Latin alphabet could already be perceived at the end of the 16th century, so there was no need to turn to the other alphabets as an alternative or as a structural model.

An eternal problem for theoreticians of orthography is the difficulty of introducing changes into established orthographies. Although they might be deficient, they are still preferred to new proposals, even if the latter are 
better: a "linguistically efficient orthography" is not necessarily "socially acceptable" (Tauli 1977: 27). This has to do with the social function of orthography and the symbolic weight it carries.

The first to consider orthography from a "theoretical" point of view were the publishers of Protestant books (see above), and they would have been uniquely qualified to put their expertise in Glagolitic and Cyrillic to good use. Instead, they stuck to the tradition of equivocal monographic and of digraphic and combinatory writing, even though Glagolitic and Cyrillic offered other and better solutions in most cases.

The next person to consider orthography theoretically was Faust Vrančić. In the preface to his dictionary of five languages, he explained some sound-letter correspondences in German, Croatian and Hungarian (Latin and Italian obviously needed no explanation). In the case of Croatian, he exemplified the difficulties by referring to the (Latin) letter $\langle\mathrm{c}>$ which, according to him, could be pronounced in four different ways in Croatian. In order to solve this problem, he proposed to use the digraphs $\langle\mathrm{cz}\rangle,<\mathrm{cs}\rangle$ and $<\mathrm{ch}>$ plus the letter $<\mathrm{k}>$. The digraphs should be pronounced as one phoneme and not separately. In a similar vein, the sound values of $\langle\beta>$ (or $<\left[\mathrm{Z}>\right.$ ) and $<\left\lceil\uparrow\right.$ were distinguished. ${ }^{83}$ Obviously, Vrančić saw the problem inherent in the use of digraphs, but he could not deviate from the Latin (and Italian) tradition. On the other hand, he tried to disambiguate in some cases, proposing to distinguish vowels (by using $<\mathrm{i}>$ and $<\mathrm{u}>$ ) from consonants (rendered by $<\mathrm{y}>$ and $<\mathrm{v}>$ ). Furthermore, he indicated length by doubling letters indicating vowels. ${ }^{84}$ Already equivocal in theory (cf. the variants $<\beta>/<[\mathrm{Z}>$ ), he was even less consistent in practice (cf. the use of $<\mathrm{g}>$ for $/ \mathrm{j} /$, of $<\mathrm{s}>$ and $<\mathrm{x}>$ for $/ \mathrm{z} /$, of $<\mathrm{th}>$ and $<\mathrm{gh}>$, etc.). An interesting aspect of his orthography is the fact (already mentioned above) that he, although originally from the "littoral" tradition of Croatian, assimilated spellings of the inland (Kajkavian) orthographic tradition (Vončina 1979: 31-35). His orthography can thus be seen as the first attempt, albeit unsuccessful, to arrive at a common solution to replace the local traditions. In general, he adhered to morphemic writing, but he did not consider the problem from a theoretical point of view.

Vrančić's dictionary (1595), the first large-scale lexicographic publication in which Croatian played an important role, was followed by three manuscript dictionaries. In the first of these, the so-called Perugia manuscript ${ }^{85}$ the Latin, Italian and Croatian columns were extracted from Vrančić's dictionary, reversed and arranged according to the alphabetical order of Croatian. There are furthermore two bilingual (Croatian - Italian) dictionaries that survived in the so-called Oxford and Dubrovnik manu- 
scripts, ${ }^{86}$ respectively. It is possible that all three manuscripts represent some kind of "missing links" between Vrančić and Bartol Kašić (Bartholomaeus Cassius), and that the latter himself might have been the author of all of them (von Erdmann-Pandžić 1990). This hypothesis is supported by orthographic considerations, since the orthography evolves from the Perugia manuscript (with Vrančić's orthography) to the Oxford and then to the Dubrovnik manuscript, which is already very close to the orthography of the first printed grammar of Croatian that appeared in print in 1604 and whose author was Bartol Kašić.

The Institutionum linguce illyrica libri duo (Cassius 1977 [1604]) treats orthographic problems in the first part of the first book. In developing an orthography for Croatian, Kašić is guided by two considerations: to use such letters "quæ \& neceffariæ ad pronunciationem funt, \& quam pauciflimæ a Latinis litteris forma, fonoque differant" [that are both necessary for (correct) pronunciation and deviate as little as possible from Latin letters in form and pronunciation] (Cassius 1977: 8). He uses only one diacritically enhanced letter, viz. $<$ ç $>$. Letters for vowels are doubled to indicate length; ${ }^{87}$ similarly, consonant letters may be doubled to indicate the quantity of the preceding vowel. As for the system of consonants, he distinguishes "monograph" from the rest, viz. di- and trigraphs. "Monograph" may be subdivided into letters that coincide with Latin, viz. $<$ b $>$,

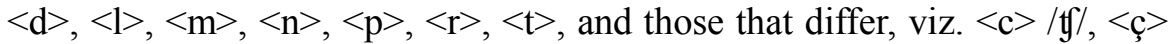
/ts/, $<\mathrm{f}>$ (having a slightly voiced pronunciation after $<\beta$ ) , $<\mathrm{g}>$ (usually /g/, but in conjunction with $<\mathrm{l}(\mathrm{i})>$ it is $/ K /$ ),${ }^{88}<\mathrm{h}>$ (usually $/ \chi /$, but also used in di- and trigraphs), $<\mathrm{k}>/ \mathrm{k} /$ (sometimes written as $<\mathrm{ch}>$, and this is obviously tolerated by Kašić), $<\mathrm{q}>$ (in conjunction with $<\mathrm{v}>$ to render $/ \mathrm{kv} /$ ), $<\mathrm{s}>$ $/ \mathrm{s} /,<\mathrm{v}>(/ \mathrm{v} /$, in other traditions rendered by $<\mathrm{f}>$ or $<\mathrm{u}>$ ), $<\mathrm{x}>/ \mathrm{z} /,<\mathrm{y}>$ (only for $/ \mathrm{j} /$ in educated usage, elsewhere also for $/ \mathrm{i} /$ ), $<\mathrm{z}>/ \mathrm{z} /$. As di- and trigraphs, he uses $<$ (c)ch(i) $>/ \mathrm{tc} /,<$ gn $>/ \mathrm{n} /$ (an additional $<\mathrm{i}>$ is unnecessary), $<$ cc $>/ \mathrm{f} /$ (in the letter sequence $<$ fct $>$ the first is sometimes omitted). In the chapter on accents (Cassius 1977: 15-16), he distinguishes theoretically a rising (acute, e.g., $<$ á $>$ ) and a falling (grave, e.g., $<\mathbf{a}>$ ) accent (referring to Greek practice) and a long (circumflex) accent that may be indicated either by doubling the vowel letter or by an accent (thus meed 'honey' is equivalent to $m \hat{e} d$ ).

It is clear from the description above that Kašić did not see himself as a normative linguist. Rather, he advocated certain spellings, but indicated variants as well. On the whole, his orthography stands in the tradition of the $C$ group, which, given his origins, is not surprising. 
He did not reflect on the linguistic levels to be rendered by his orthography, but essentially it seems to have been morphemic. Deviations are fairly frequent, but they may stem from insufficient insight into the morphemic structure of the language. Another reason, and perhaps a more important one, might be that this aspect of orthography was not seen as a problem requiring theoretical analysis and consistent solutions (cf. Bagarić-Gabrić 1984: 34-39).

As is the case in other languages as well, Kašić's theoretical orthography is not always correctly applied in the books he wrote. This has less to do with inconsistency on the part of the author than with the influence of typographical traditions ("house orthographies") varying from one printer to the next, personal preferences of the typesetter and perhaps even the proof-reader if he was not the author himself. The variation that can be observed in Kašić's books is considerable (cf. Bagarić-Gabrić 1984: 3133), but generally it remains within the traditions of the $C$ group.

The next (and last) text to be presented here is the first orthographic treatise in monographic form proposing a new (or at least partly new) orthography for Croatian written with the Latin alphabet. It was written by Rajmund Džamanjić, and appeared in print in Venice in $1639 .{ }^{89}$ Džamanjićs aim was to propose an unequivocal orthography to replace the existing "littoral" orthographies, ${ }^{90}$ and he does this by relying on monographic and digraphic solutions exclusively. As digraphs, he mentions $<\mathrm{ch}>(=/ \mathrm{t} 6 /)$, $<\mathrm{gh}>(=/ \mathrm{d} / \mathrm{d}),<\mathrm{gl}>(=/ \mathrm{K} /),<\mathrm{gn}>(=/ \mathrm{n} /),<\mathrm{fc}>(=/ \mathrm{J} /),</ \mathrm{c}>(=/ \mathrm{J} /) .{ }^{11}$ There is, however, one more digraph, which is used to render/dz/, viz. $<$ gi $>$ (cf. the spelling of his name as Giamagnich). ${ }^{92}$ The "monographs" consist of the traditional Latin (Italian) alphabet. Here again, he distinguishes $<\beta(=/ \mathrm{z} /)$ and $<\beta(=/ \mathrm{s} /)$, the latter having the traditional allograph $<\mathrm{s}>$. To this he adds the Gothic equivalent for $\langle\mathrm{z}>$, viz. 3 to render /dz/. In order to distinguish digraphs from sequences of two letters, he introduces the apostrophe as a separator: $<\mathrm{gn}>(=/ \mathrm{n} /) \neq<\mathrm{g}^{\prime} \mathrm{n}>(=/ \mathrm{g} / \mathrm{+} / \mathrm{n} /)$. Diacritics are used with vowel letters exclusively, viz. the grave accent on all vowel letters except $i j$ and the cedilla with $e: e$. They are used to indicate the length of the vowels or "diphthongal" pronunciation (when used in word-final position). On the other hand, double letters for consonants signal that the preceding vowel is short. Both diacritics and the doubling of letters are only to be used in case of equivocal words (i.e., words that would otherwise be homographs) or to indicate "diphthongal" pronunciation. ${ }^{93}$

The orthography proposed by Džamanjić does not seem to have met with the approval of his contemporaries. Today, this is generally blamed on the weakness of his system to mark quantity, whereas his proposals for 
consonants are valued highly. ${ }^{94}$ It seems to me, however, that this was not the main reason. More important was the typographical infelicity of using italicized and non-italicized variants of a letter as different characters. This ran counter to established usage, as it did not meet with writing (printing) and reading traditions (one wonders how the differences would have been expressed in handwriting). It also deprived authors and printers of one of the main means to mark emphasis in a text. And, finally, it could not satisfy aesthetically, as even the most superficial glance at any page of the reprint will show immediately. On the whole, Džamanjić's orthography remained a non-starter: apart from the treatise itself, which, however, teems with mistakes (cf. van den Berk 1959: 50-56), no other book seems to have been printed according to his rules. ${ }^{95}$

\subsection{General tendencies}

On the whole, Croatian Latin orthography in the 16th century presents a rather non-uniform picture. ${ }^{96}$ From the preceding two centuries it had inherited several local traditions that differed considerably. They were not unified because there was no real cultural centre which might have imposed its orthography. ${ }^{97}$ The advent of book printing did not contribute to unification either; it seems that (quite contrary to what is usually the case) the traditions diversified. This has to do with the lack of a typographic centre, which led to a situation in which Croatian books were generally printed outside of the Croatian language area. Printing furthermore facilitated the production of written materials so that more people than before could publish texts. Often they were less qualified than the scribes of manuscripts and did not pay particular attention to orthographic detail, thus actually adding to orthographic confusion. The Reformation could not promote a unified orthography due to the fact that it never gained a real foothold on Croatian territory. If unification occurred at all, this could only be within the established traditions (Šojat 1970: 265).

Theoretical considerations of the problem of orthography are conspicuously absent in the 16th century. Those that appear in the first half of the following century show that traditions were already so entrenched that there was no room for radical proposals, let alone their realization. Technically the orthographies of the 16th century applied monographic and digraphic solutions and remained to some extent equivocal. Diacritics were only used to a minimal extent. Even less thought, or so it seems, was given 
to the linguistic levels represented in orthography. It seems that the writers aspired to morphemic writing, but deviations were very frequent.

In many ways, the 16th century is a period of transition. It brought about the change from manuscripts to printed books (even though manuscripts were still copied afterwards, and there were even manuscript copies made of printed books). It ushered in the domination of the Latin alphabet and it already made clear that neither Glagolitic nor Cyrillic could aspire to become the alphabet to be used for a unified Croatian language. Furthermore, it enlarged the dialectal and orthographic basis of written Croatian by introducing Kajkavian and the $C Z$ orthography. This development in turn led to a new division of the area, opposing a North-Western tradition (Kajkavian and the northern part of Čakavian) to a South-Eastern group (Southern Čakavian and the Dubrovnik area). This eventually caused the demise of Čakavian as an independent tradition. At the end of the century, however, it was not quite clear which way Croatian would go.

\section{Later developments}

The development of Croatian after this transitional period has been interpreted and segmented differently by various scholars. Usually, four or five periods are distinguished: i) the 17th century (sometimes including the first half of the 18th century) as the period of the victory of Stokavian in the South-Eastern group; ii) the 18th century and the beginning of the 19th century with increased influence of Stokavian on the whole territory; iii) the remainder of the 19th century with the "Croatian renascence" and the final standardization in the context of Serbo-Croatian (sometimes seen as two periods), and finally iv) the 20th century up to the present with the various conceptions of Serbo-Croatian and its eventual demise (cf. Brozović 1973, 1978 and Moguš 1993). Since orthography is generally seen as the main aspect of standardization, it will suffice here to distinguish the period before standardization, standardization itself, the history of Serbo-Croatian and that of Croatian standardization, with the latter two being chronologically intertwined.

\subsection{Before standardization}

In the 17th and up to the 19th century, the variation in orthography that was characteristic of much of the 16th century slowly gave way to two main currents, representing the North-West and the South-East that rallied behind 
Kajkavian and Štokavian, respectively, Čakavian losing out in the process. ${ }^{98}$ On the other hand, a new centre developed in Slavonia, gravitating orthographically towards the South-East and thus giving its orthographic solutions and the Štokavian dialect an additional competitive edge. Another important development was the final victory of the Latin alphabet to the detriment of Glagolitic and Cyrillic as the alphabet to be used for a standardized language. As mentioned above, both Glagolitic and Cyrillic survived, but only in a clearly defined ecological niche, viz. writing relative to religious matters, mainly catering for a rural audience and not the urban elites. ${ }^{99}$ Finally, ambiguity in orthography could be overcome to a large extent due to an unequivocal relationship between sounds (phonemes) and letters, digraphs or letter combinations. It is interesting to note that the diacritic principle did not make much headway in this period; rather, preference was given to digraphic and, to a lesser extent, combinatory solutions. ${ }^{100}$

\subsection{Standardization}

The need for a unified orthography as the first step towards a Croatian standard language was obvious at the beginning of the 19th century, and a kind of compromise seemed to be the most likely solution. It was not to be, however, and the reason for a real change of direction in orthography was a powerful current that affected almost all the Slavs, and was variously referred to as the "Slav renascence", "Panslavism" or the movement of "Slav reciprocity". It advocated the rapprochement of the Slav peoples, and, given the political situation of restoration after 1815, concentrated on cultural matters. The cultural aspect was especially prominent among the Slavs in the Austro-Hungarian Empire, and an important aspect was orthography with its strong symbolic implications. Diacritics, first advocated for the Slavs by Jan Hus for Czech, were seen as one of those symbols, and were thus propagated by supporters of the movement.

Among the Southern Slavs, a particular variety of the movement developed that came to be known as "Illyrism". It called for the unification of all the Southern Slavs, and an important (if not the most important) part of the programme was a unified language, the "Illyrian" language. Initially, it was meant to serve all Southern Slavs, from the Slovenes to the Bulgarians ${ }^{101}$ but it soon became reduced to the central part, leaving Slovenian and Bulgarian to devise their own standard languages. The first step on the pathway towards "Illyrian" in this watered-down version (which in fact was 
already "Serbo-Croatian") was the unification of Croatian. This could be achieved in the area of orthography through the use of diacriticallyenhanced letters in all cases where formerly digraphic or combinatory writing had been customary, thus changing over to monographic writing. Such a principled monographic orthography using diacritics was first proposed for Croatian (or rather the Kajkavian variety of it) in 1830 by Ljudevit Gaj. ${ }^{102}$ As is customary for reform proposals, it remained a dead letter (Gaj's book was the only one ever to be printed in that orthography), but the principles underlying it would eventually win the day and be used for the new Croatian standard language that was Štokavian and (I)jekavian.

The next step had to clarify the relationship between Croatian and Serbian. It was helpful that, in Serbia, the Serbian variant of Church Slavonic had already been relinquished and replaced by slavenosrpski (SlavenoSerbian), a hybrid language allowing more vernacular words to enter the vocabulary, and that Vuk Stefanović Karadžić proposed a new Serbian standard language based on an (I)jekavian Štokavian dialect. The process was further facilitated by the fact that Karadžić devised a new orthography for Serbian. Serbian orthography had traditionally used Cyrillic, an alphabet generally unfavourable towards digraphic solutions, mainly relying on the monographic principle instead, while admitting combinatory writing in some cases. The new Serbian Cyrillic alphabet excluded combinatory writing as well, being exclusively monographic and having an exact one-to-one correspondence between phonemes and letters. ${ }^{103}$ This necessitated the creation of several new letters. There resulted an almost perfect fit between Croatian Latin diacritic and Serbian Cyrillic orthography. ${ }^{104}$ Two other aspects of Vuk's Serbian proved to be more challenging. One was his insistence on the "folk language" as the basis for the standard language, thus effectively excluding the literary tradition. This was due to the Romanticising underpinnings of his reform. The other was the introduction of a strictly phonemic orthography, marginalising morphematic writing. These two aspects were the real bones of contention.

It was up to the adherents of the linguistic ideas of Vuk Stefanović Karadžić, the Vukovci, to find a solution. There was considerable opposition from various "philological schools" in Croatia, and it took the Vukovci the remainder of the century to overcome these difficulties. ${ }^{105}$ In the end, the "folk language" tenet was modified so as to allow for the (Croatian) literary tradition to be considered as well. There was no compromise with regard to phonemic writing. The result was the Serbo-Croatian Standard language. ${ }^{106}$ 


\subsection{Serbo-Croatian}

Serbo-Croatian was, in some ways, more an abstract concept than a linguistic reality. Actual language use differed considerably in Croatia and Serbia. This, however, is not untypical for so-called "pluricentric" languages. Unusual is the see-saw between unification and diversification that characterizes much of the history of Serbo-Croatian. ${ }^{107}$ The language reached the peak of mutual acceptance early in the 20th century, just before and after the Kingdom of the Serbs, Croatians and Slovenes (SHS) was created. It seems that, for non-linguistic reasons, Croatian support for Serbo-Croatian was even stronger than on the Serbian side before independence. Growing Serbian domination of the state (renamed Jugoslavija in 1930) led to Croatian opposition and a weakening of the support for Serbo-Croatian. A similar development could be observed after the Second World War.

Interesting are the attempts to define the linguistic situation in official or semi-official documents (agreements, declarations). This curiously formal approach to linguistic problems started out with the Vienna Agreement of 1850 , declaring that one people should have one language. ${ }^{108}$ The constitution of the SHS Kingdom even spoke of a Serbo-Croatiano-Slovenian language. The various post-war constitutions of Yugoslavia and her constituent republics became ever more elaborate in verbal equilibristics, trying to reconcile centripetal and centrifugal tendencies. ${ }^{109}$ The last attempt on the unitarist side was the Agreement of Novi Sad signed in 1954, eventually to be renounced unilaterally by the Croatian side in 1971 as a consequence of the positions of the Deklaracija o nazivu i položaju hrvatskog književnog jezika [Declaration on the name and the situation (status) of the Croatian Standard language], published in 1967 and immediately answered by repressive measures from the hands of state and party institutions. There ensued an uneasy truce, lip service being paid to the concept of SerboCroatian while continuously watering it down on the Croatian side. As late as 1988, Serbo-Croatian could still officially be seen by Croatian and Serbian scholars as a language "united in diversity" (cf. Brozović and Ivić 1988).

The linguistic description of the situation deserves mentioning as well. It ranged from the demand for complete unification (with the Serbian side relinquishing the Cyrillic alphabet, the Croatian side accepting Ekavian) to increasingly artful models of the relationship of varieties, distinguishing at first two (Serbian and Croatian varieties with the respective centres Bel- 
grade and Zagreb), then three (adding the Bosnian "standard linguistic expression"), and finally four varieties (with a Montenegrin "(sub)variant"). ${ }^{110}$

The demise of Serbo-Croatian as a standard language was paralleled by the disintegration of Yugoslavia. ${ }^{111}$ The idea(1) of Serbo-Croatian continued for some time to be defended on the Serbian side (and it is still upheld by some scholars), but as a standard language it does not exist anymore, having been replaced by the Bosnian, Croatian, Montenegrin and Serbian Standard languages. ${ }^{112}$

\subsection{Croatian}

As mentioned above, the concept of Serbo-Croatian as the standard language for Serbs and Croats met with considerable opposition from traditional Croatian "philological schools" in the 19th century. The idea of an independent Croatian Standard language was revived in the short-lived puppet-state Nezavisna Država Hrvatska (Independent State of Croatia, NDH) during the Second World War (1941-1945). Some of the first acts of the government referred to linguistic matters, establishing the Croatian Standard language, forbidding the use of Cyrillic, fighting for the purity of the Croatian language and reverting to morphematic writing, the so-called korienski pravopis 'root orthography'; cf. Samardžija (2006: 20-21).

The linguistic policies established in the NDH were abolished immediately after the war, but for some time Croatian was treated as a standard language independent from Serbian in official terminology (Pranjković 2006: 29-30). There followed the period after the agreement of Novi Sad and renewed attempts at more independence (see above). In the early 1990 s, the Croatian standard language written with the Latin alphabet was declared the official language of independent Croatia (Cyrillic, however, was not forbidden). The purist tendencies that had a long tradition in Croatia were intensified, and a rigorous Ausbau took place, targeting in the first place loan-words and "Serbianisms" (which were now also considered loan-words). The discussion on the reintroduction of morphematic writing was also renewed, so far without much success. ${ }^{113}$ As far as orthography is concerned, then, the newly-won independence of the Croatian Standard language brought about no basic changes: the orthography of Serbian and Croatian is, aside from the different alphabets and some minor differences that had already been tolerated before, essentially still the same. 


\section{Tradition and innovation}

The history of Croatian orthography is unusually rich in profound changes, changes that affected many different areas. On the most basic level, it was the change of alphabets, from Glagolitic and partly Cyrillic to Latin. Within the Latin alphabet, it was a change from Gothic to Roman. Then the dialect basis changed (with obvious consequences for orthography) from Čakavian to Štokavian and Kajkavian, with Štokavian finally gaining the upper hand. Yet another turn in the development relinquished digraphic and combinatory writing in favour of diacritics and thus the monographic principle. At about the same time, the morphematic tradition that had dominated de facto gave way to a rather strict phonematic representation. To this has to be added the originally symbiotic, but increasingly dysfunctional relationship with Serbian. All of the changes influenced orthography to a greater or lesser degree.

Most of the changes occurred rather late in the history of Croatian. The 16 th century, so important in the history of the orthography of other languages (e.g., Polish), seems to be little more than a footnote in the case of Croatian. Still, it is relevant regarding two of the changes mentioned above. The first one is the eventual victory of the Latin alphabet. The 16th century marked the turning point in the struggle between the alphabets because Glagolitic could not extend the hold it had on religious writing to the increasingly important secular literature. The second is the demise of Cakavian as a possible basis for Standard Croatian. Here again, the 16th century saw a gradual move towards Štokavian, and that would eventually pave the way for the fateful rapprochement with Serbian.

It is worth noting that the most recent change, viz. the official divorce from Serbian (or the Serbo-Croatian concept), hardly influenced orthography at all in a way noticeable for the average user of the language. In spite of serious attempts to revive the idea of morphematic writing by some representatives of the linguistic establishment, it is not likely that such a change will be accepted, even though this would be the easiest way to join up with older traditions (and to mark the distance from Serbian). So, Croatian orthography has a tradition, the tradition of the 19th century, reaching in some cases back to the 16th century and this tradition is likely to remain. 


\section{Notes}

* I am indebted to M. Mihaljević and B. Kuzmić for helpful remarks and to P. Morris for linguistic advice.

1. This unique fact found an adequate expression in the exhibition "Drei Schriften - drei Sprachen" presented in Germany in 2004; see, for the catalogue, Lipovčan (2004). An earlier expression of the same idea is found in Hercigonja (1994), cf. also Žagar (2009). The three alphabets referred to are Glagolitic, Cyrillic and Latin; the languages are Latin, (Croatian) Church Slavonic and Croatian.

2. The examples are taken from the title pages of some of the earliest printed books using the Latin alphabet: "lingua yllirica" (Bernardin of Split, 1495), "haruacchi" [= hrvatski 'Croatian'] (Marko Marulić, 1521), "Szloujenßki iezik" (may be interpreted as 'Slovenian', 'Slavonian' or 'Slavonic'; none of them really fits here since they all have a different meaning today. Since 'Slavonian' is the one which is today least associated with language, it is chosen here). (Ivan Pergošić, 1574), "Dalmatic[a] [lingua]" (Faust Vrančić, 1595); cf. Maretić (1889: 1, 11, 29, 39).

3. To my knowledge, there is no general treatise on the topic taking into consideration the whole complexity of alphabets, orthographic traditions, and dialects. The Glagolitic and/or Cyrillic traditions have been studied rather in the area of palaeography, but usually in the context of the Glagolitic and/or Cyrillic manuscript traditions as a whole; cf., for example, Eckhardt (1989) on both traditions, Vajs (1932) on Glagolitic and Đorđić (1971) on Cyrillic. The Latin tradition is the only one in which orthography seems to have been more important than paleography; cf. Maretić (1889), Diels (1951) and Moguš and Vončina (1969). The most recent comprehensive publication on the history of the Croatian language, Bičanić (2009), is characterized by a complex approach, but the first volume covers only the Middle Ages.

4. Much has been written on the history leading to the establishment of the Croatian Standard language in the 19th century and most of the descriptions also treat questions of orthography and of the alphabets used, e.g., Brozović (1978), Franolić (1984), Moguš (1993), Vince (1976, 1990), Vončina (1988). Unfortunately, Franolić seems to be the only source available in English, and his treatment of these questions is rather superficial.

5. Cf., on the early history (prior and subsequent to the migration of the Slavs), Katičić (1999), devoted especially to cultural aspects.

6. The division between "East" and "West" within Christian religion and culture divides not only Europe but also the Slavs, thus establishing two areas: Slavia orthodoxa (sometimes called Slavia byzantina) and Slavia romana (also Slavia latina); cf. Picchio (1958) and the critical assessment by Dujčev (1981). The dichotomy is supported by differences in religion (Orthodox vs. Catholic/Protestant), cultural traditions (Byzantine Greek vs. Roman Latin), alphabet (Latin 
vs. Cyrillic) etc. The split is, however, not as clear-cut as it might seem, especially in transitional areas such as Croatia.

7. There are widely divergent interpretations of the linguistic situation that cannot be dealt with here. Even the glottonym and its orthography are a bone of contention, srpskohrvatski 'Serbocroatian' alternating with the hyphenated srpskohrvatski 'Serbo-Croatian', and both existing with the two elements in reverse order (hrvatskosrpski, hrvatsko-srpski). In addition, there is also hrvatski $i$ srpski 'Croatian and Serbian' and hrvatski ili srpski 'Croatian or Serbian', both in reverse order as well.

8. In dialectology, further groups are distinguished (e.g., Šćakavian), but for the evolution of the Standard language, and especially of Croatian, they were of minor importance and are generally subsumed under one of the main groups.

9. Cf., for example, toponyms with the adjective *běl- 'white': Bijelo Polje (Montenegro) [(I)jekavian], Beograd (Serbia) [Ekavian], Bila Gora (Croatia) [Ikavian]. On the linguistic history of the area, see Popović (1960).

10. Since Latin had letters for all of these vowels, problems were not likely to occur. The only difficulty was that, historically, the "division of labour" between $<\mathrm{u}>$ and $\langle\mathrm{v}>$ was not clear, since the two were considered variants of one and the same letter (allographs of one grapheme, as it were); in some cases it was even a question of majuscule vs. minuscule: upper case was $\langle\mathrm{V}\rangle$, lower case $<\mathrm{u}>$.

11. The dialect situation is particularly complex in this area as regards the number of accents, their quality and their position. Taking into consideration the diachronic dimension, the picture becomes even more complicated, since "old" and "new" accents have to be distinguished in some cases.

12. The main orthographic exceptions are $<\mathrm{k}>$ (Latin traditionally used $<\mathrm{c}>$ ) and $<\mathrm{g}>$ (often also used to render $/ \mathrm{j} /$ in various traditions of Latin). In Italian as well as in Latin as pronounced by Italians, both $\langle\mathrm{c}\rangle$ and $\langle\mathrm{g}>$ could be used to render the velar phonemes $/ \mathrm{k} /$ and $/ \mathrm{g} /$ and their palatal counterparts $/ \mathrm{t} /$ and $/ \mathrm{d} /$ (or similar corresponding sounds).

13. The letter $<\mathrm{d}>$ is sometimes replaced by $<\mathrm{dj}>$, even though $<\mathrm{dj}>$ represents the sequence $/ \mathrm{d} /+/ \mathrm{j} /$, thus making $<\mathrm{dj}>$ ambiguous. In addition to the orthography generally in use (which is the one used in this article), there is also a strictly monographic orthography on the basis of "one phoneme - one grapheme" in which $<\mathrm{d} \breve{z}>$ is rendered by $<\dot{\mathrm{g}}>$. The sequence $<\mathrm{d} \breve{z}>$ is ambiguous: it stands for $/ \mathrm{d} /$ in svjedodžba 'certificate' but for $/ \mathrm{d} /+/ 3 /$ at a morpheme boundary in nadživjeti 'survive'. The monographic orthography allows for a one-to-one Latin-Cyrillic transliteration. Its use is scholarly and essentially restricted to publications of the Croatian (formerly Yugoslav) Academy of Science and Arts (HAZU, formerly JAZU).

14. In strictly monographic orthography, $<\mathrm{lj}>$ and $<\mathrm{nj}>$ are written as $<\mathrm{l}>$ and $<n$, respectively. Here again, $<\mathrm{nj}>$ is ambiguous, since it may also occur at morpheme boundaries: <nj $>$ stands for $/ \mathrm{n} /$ in pisanje 'writing', but for $/ \mathrm{n} /+/ \mathrm{j} /$ in $i z$ vanjezični 'extralinguistic'. 
15. It has to be noted that Croatia was thus one of the few regions within the realm of the Roman Catholic Church where the liturgical language was not Latin but a language close to the vernacular: Church Slavonic had a basic vocabulary and a morphology similar to those of the Croatian dialects spoken in the area, and some of the phonemic developments in those dialects found their expression in writing as well, since Glagolitic was not favourable to a historical orthography. In the course of time, a distinct Croatian variant of Church Slavonic evolved: Croatian Church Slavonic. It was mainly the complex syntax and increasingly the different terminology that separated Croatian Church Slavonic from the Croatian vernacular. It is not surprising, therefore, that Croatian Church Slavonic was perceived by the Croatians as being a variety of their language (cf. Auty 1978: 31-32). Several attempts by the Roman Church to oust Croatian Church Slavonic (and by the same token also the Glagolitic alphabet) and to introduce Latin instead failed, so that the Roman Church finally accepted the status quo, preferring a textual Romanization to a linguistic one: thus, the readings that were originally based on translations from Greek (i.e., the Septuagint and the Greek New Testament) were gradually revised to conform to the Vulgate.

16. This oldest form of written Slavonic, conserved in a slightly altered form in manuscripts of the 10th and 11th centuries, is referred to as "Old Church Slavonic" (OCS).

17. The only major deviation from the "one phoneme - one grapheme" principle was the use of digraphs to render /n/ and / $/ /$; cf. Moguš (1982).

18. Glagolitic was generally seen as the Croatian alphabet. Thus H. Ungnad, financing the printing of Croatian Protestant books in the 16th century, generally uses "Croatian" in the sense of "Glagolitic": "Crabatische alphabet", "mit crabatischen Buechstaben", but "Crabatisch mit glagolischen und Lateinischen buechstaben" (Bučar 1916: 187-188).

19. It is interesting to note that the Catholic Church was opposed to the use of the Latin alphabet, at least for liturgical books and the Bible. This transpires from the position of the Congregatio Sancti Officii regarding the translation of the Bible into vernacular Croatian; cf. von Erdmann-Pandžić (2000) and Golub (2000) and, in the more global context of the Council of Trent and the CounterReformation, Thomson (2005: 151-212).

20. In spite of the restricted use of the Glagolitic alphabet, it probably exerted a highly important structural influence on its Latin counterpart. The most significant reform proposal for the Latin alphabet, i.e., the systematic use of the diacritic principle elaborated for the Czech language by Jan Hus (cf. Berger, this volume), was most likely inspired by Glagolitic, since Hus certainly knew the alphabet (Charles IV had revived the Glagolitic tradition in Bohemia in the 14th century and Croatian monks lived and worked in Prague while Hus was living there). Hus also refers to Glagolitic in his treaty Orthographia Bohemica 'Bohemian orthography'; cf. Schröpfer (1968: 58-61). The principle was gen- 
eralized in the 19th century, and is now universally applied when writing systems are devised for new languages.

21. Cf., on this variety of Cyrillic, Eckhardt (1978), Đorđić (1971: 145-188), and on the tradition in Dalmatia, Zelić-Bučan (2000).

22. Usually the Rado Bible of the 11th century is named as the oldest example, but the glosses in it are rather West Slavonic (Czech Church Slavonic); the Croatian influence is marginal if it exists at all; cf. Vintr (1986).

23. An overview of the texts, manuscripts and printed books which used the Latin alphabet from the 14th and 15th centuries is given in Fancev (1934: IV-XLV) and in Malić (2000a); on the history as a whole, cf. Bratulić (2004); the orthographic development is treated best in Moguš and Vončina (1969).

24. There is another incunabulum that might be even older but it is not dated: the Croatian printed prayer book; cf. the Giannelli edition (1934) and the description by the same author in Fancev (1934: XXX-XXXIV). The incunabulum is not to be confused with a manuscript from the Vatican library: the latter is here referred to as the Vatican Prayer Book (see 5.1.).

25. Cf. Nemirovskij (1997: 49-53, 96-100, 153-169). In some sources, it is claimed that the earliest Croatian book printed in Cyrillic appeared in 1493 (which would make it an incunabulum as well). The mistake is found in the authoritative index of incunabula by Hain (1948 [1826]: 530, $\mathrm{n}^{\circ} 3833$ ), but it is also repeated in Croatian sources (by authors who should know better); cf., for example, Franolić (1984: 145, $\mathrm{n}^{\circ}$ 9). As a matter of fact, the book referred to is the Glagolitic Baromic breviary, printed in Venice. Cf. on this also Nazor (1997).

26. Printing started out in Glagolitic and Cyrillic; Latin was not added until 1563. Furthermore, the press run was higher in Glagolitic and Cyrillic than in Latin. Thus, the Catechism was published in Glagolitic and Cyrillic, with a press run of 2000 copies each (1561), whereas the version in Latin characters appeared in only 400 copies (1563). The reduction may partly be explained by the dwindling funds of Baron $\mathrm{H}$. Ungnad, the sponsor of the whole enterprise. The addition of Latin may have been the result of a "market study" that showed a trend away from Glagolitic and Cyrillic; cf. Bratulić (1983). See, on printing activities, Bučar (1910: 238-246), Bučar (1916), Bučar and Fancev (1938), Vorndran (1977: 1, 10-13); a general Slavonic perspective is added by Klimaŭ (2004).

27. "Gothic script" is used here as a blanket term for all kinds of black letter and Fraktur. The same is true for "Roman script".

28. Cf. the title pages of the two editions in Badalić (1959: 38, 40). It is perhaps indicative of the diminished degree of popularity of the Gothic script today that it was the edition in Roman script that was chosen for publication in facsimile; cf. Marulić (1950 [1521]).

29. If the Croatian printed prayer book dated to the 1490's (rather than the Lectionary of 1495) was the first printed book in Croatian using the Latin alphabet, then not only the final victory but even the primacy would rest with the Roman script. 
30. Cf., however, Maretić's position: he sees a clear segregation between Glagolitic and Latin, and accuses the Dalmatian and Čakavian writers of acting "kao da glagolice nije nigda na svijetu bilo" [as if the Glagolitic alphabet had never existed] (1889: XII). For a critical assessment of this position, cf. section 6.

31. Thus, one of the oldest Croatian texts using the Latin alphabet, the Sibenska molitva, goes back to a Cyrillic antigraph. (On the other hand the Lectionary of Bernardin of Split was copied twice in Cyrillic; cf. Fancev 1934: XXIX.). Glagolitic antigraphs, however, are more frequent; cf. Fancev (1934: XLVXII). The "alphabet cross-over" in the textual tradition is evident from scribal mistakes that can only be explained if the antigraph had been written in a different alphabet; cf. on this in general Malić (2000b) and (2004).

32. The only additional letter used from the very beginning, viz. $<\mathrm{C}>$, was not a Croatian invention, but a loan from Italian scribal practice. In contradistinction to this, the Cyrillic alphabet was adapted: the Bosančica introduced a new letter $<\mathrm{h}>$ to render the phoneme $/ \mathrm{t}$ / that was absent from OCS. It was also used for the voiced counterpart $/ \mathrm{d} /$. Furthermore, it was used in digraphs to render $/ \mathrm{n} /$ and $/ \Lambda /$ (see above, 3.3).

33. A further complication may arise from the fact that the same sequence of letters may be digraphic or combinatory: the sequence $<\mathrm{ci}>$ is digraphic in the case of Italian cieco (since $<\mathrm{i}>$ does not represent the phoneme $/ \mathrm{i} /$, just as $<\mathrm{z}>$ in Hungarian $<$ sz $>$ does not represent the phoneme $/ \mathrm{z} /$ ), but combinatory in cima (here $<\mathrm{i}>$ stands for the phoneme $/ \mathrm{i} /$ but at the same time it indicates that $\langle\mathrm{c}>$ is to be pronounced as $/ \mathrm{t} \mathrm{f} /$ ).

34. The use of diacritics is a special case of modification. The latter is considered to be "the most profitable source of new letters" (Abercrombie 1981: 211). The major advantage of diacritics is that they leave the basic letter untouched. Furthermore, the letter relationship may be used to indicate phonetic relationship; cf. Klima (1972: 63). Examples from Croatian are $<\mathrm{c}>-<\breve{\mathrm{c}}>,<\mathrm{Z}>-<\breve{\mathrm{Z}}>,<_{\mathrm{s}}>-$ $<\breve{\mathrm{S}}>$.

35. It is interesting to note that recently the most advanced type, viz. diacritic writing, has given way to the most archaic in electronic communication: in Czech, Slovak, Croatian etc. (but also French) e-mails, diacritic signs were (and in many cases still are) often omitted altogether, since in the old 8-bit ASCII code the combination "letter + diacritic sign" was not codified in a uniform way and could thus appear in completely garbled form on the screen of the recipient. In a similar vein, Russian and Bulgarian e-mails use quite ingenious transcription systems, generally based on the digraphic principle, thus again avoiding the diacritic signs typical of scholarly transliteration.

36. This is often referred to as "principles of orthography"; cf. Nerius (1986), Glück (1987: 98-105).

37. In the case of Polish, there is a historical explanation for the <ó $>$ in stót, since the pronunciation of the vowel rose from [o] to $[\mathrm{u}]$ in the development of the language. When Polish orthography was first established, the sound rendered by $<$ ó $>$ was still distinctive, and had not yet merged with $/ \mathrm{u} /$. From the point of 
view of contemporary Polish, however, it is a clear case of the complex type of morphemic orthography. In Czech dim, the circle above the $<\mathbf{u}>$ symbolises, as it were, the "underlying" $<_{0}>$.

38. Under the influence of generative linguistics, the two basic types, viz. phonemic and morphemic, are sometimes referred to as "shallow" and "deep" orthography; cf. Lukatela, Popadić, Ognjenović and Turvey (1980). Historical orthography, however, may also claim to be "deep" (or even "deeper" than morphemic orthography).

39. This is the first period according to Brozović (1973: 129); cf. also Moguš (1993: 13-50).

40. Sometimes the opposite position is taken; cf. Moguš and Vončina (1969) and especially Moguš (1984). Convincing proof, however, is still lacking, especially as far as the influence of the Glagolitic (and Cyrillic) monographic principle on Latin orthography is concerned.

41. According to the inventory of texts from the 14th and 15th century in Fancev (1934: IV-XLV), there are four texts datable to the 14th century and about ten that belong to the 15 th century (excluding the two incunabula, see further on). Furthermore, a will written in 1419 in Dubrovnik mentions a Slavonic lectionary in Latin letters ("uno evangelistario schiavo de letera latina", Fancev 1934: XXXIX), but this text has not come down to us.

42. To speak of an "Italian tradition" in the 14th and 15th centuries is an anachronism, since there was no such thing as a unified linguistic, let alone orthographic tradition in those days. Different regions had different written languages and wrote in different ways. As was the case with many other languages, the printing press promoted unification, and together with unification there occurred a change from a more historical (Latinizing) orthography to a more phonemic one; cf. Hartmann (1907). Still, regional traditions survived, and for Croatia it was mainly the Venetian usage that served as a model; cf. Diels $(1951: 11,15)$. On the whole, however, the principles of rendering phonemes in writing were essentially the same, so that for our purposes the anachronism is only a venial sin.

43. Italian orthography used diacritics sparingly, and basically only on vowels (accents) to indicate stress (Hartmann 1907: 255-263), the major exception being $\langle$ ç $>$ (or a similar letter) representing $/$ ts/. For the rest, Italian relied on combinatory (of the type $<$ ce $>/<$ ge $>$ vs. $<$ ca $>/<$ ga $>$ ) or digraphic rendering (of the type $<\mathrm{gl}>/<\mathrm{gn}>,<\mathrm{ch}>/<\mathrm{gh}>$ ) of phonemes.

44. The inconsistency is also borne out by the comparison of this early orthography (if it may be called that) with that of the mid 16th century used by Hektorović; cf. Moguš and Vončina (1969: 65).

45. Cod. Vat. Barb. 370 (olim 2396); cf. Fancev's edition (1934: 1-114).

46. This seems to be an older tradition mainly present in 14th-century manuscripts; cf. Fancev (1934: LVI-LVII); remnants may be found in other 16th-century manuscripts, viz. the Dubrovnik Missal fragments of 1552; cf. Giannelli in Rešetar and Đaneli (1938: 160). 
47.Zagreb NSK R 3261 (olim SM 32 B 4); cf. the description and edition by Fancev (1934: LIV-LVIII and 115-249). It is worth noting that the manuscript is not written in Gothic script; however, some of the mistakes made by the scribe presuppose a Gothic original from which the present manuscript was copied. This is, therefore, yet another example of the development from Gothic to Roman script.

48. It has even been proposed to treat written language and printed language as two different varieties; cf. Vachek (1948).

49. In most languages a truly standardized orthography was only devised in the 19th/20th century. Orthography has even been called the "Moloch of the 20th century" (Žitomirskij 1915).

50. It is true that the earliest Glagolitic incunabulum that can be localized was printed in Venice (Baromic Breviary, 1493), but the two previous incunabula of 1483 and 1491 might have been printed in Croatia (Kosinj?), and the second oldest dated Glagolitic incunabulum is definitely from Senj (1494).

51. Badalić (1959: 28-29, n. 7); cf. the reprint by Bratulić (1991).

52. To give but one example of inconsistency in a short phrase repeated several times: GOfpodine ffetij otçe ffemoguchij viçgnij boze - GOfpodine fuetij otçe ffemogij viçgnij boze - gofpodine fuetij. otçe ffemögij: vignij boxe [Oh Lord, holy Father, eternal God Almighty] (Bratulić 1991: 205-208).

53. Cf. Maretić (1889: 1-3) and Bratulić (1991: XIV). Maretić (1889: 1) explains the use of $\langle\mathrm{z}>$ by the fact that the typesetter often used a Gothic $<\mathrm{z}>$, i.e., $<3>$, turned upside down to stand for $\langle c ̧>$ : according to him, the scribe obviously forgot to turn the letter $<\mathrm{z}>$ in these cases.

54. Vat. Inc. VI. 33, olim Stamp. Barb. C I 20; cf. Badalić (1959: 32, n. 13) and the edition by Giannelli (1934).

55. The editor maintains that this is unique, obviously relying on Maretić (1889: 350-351). There is, however, a 15th-century manuscript dictionary in which /t6/ - /do/ is rendered by $<$ hy $>$, but also by $<$ th $>$; cf. Rešetar (1904: 365-366). Other examples from manuscripts (autographs of Marulić?) are adduced in Mladenović (1959: 122).

56. Cf., on this question, Giannelli in Fancev (1934: XXXIII). It seems that there is an intermediary part (fol. 92b-101b) where a mixture of the two orthographies can be observed. This can be explained in two ways: either this part goes back to a third source, or the typesetter realized the difference in orthography and tried to correct it at first, but then gave up. In that case, the second manuscript was used from fol. 92b onwards. A third possibility is that one part (starting with fol. 102) was set separately (there is the word "finis" on fol. 101b) and that the two parts were bound together later. This, however, would not explain the "mixed" orthography on fol. 92b-101b.

57. In the classification proposed by Brozovic (1974) this is the second period in the history of written Croatian; cf. also Moguš (1993: 51-77).

58. It is important to take into consideration the possibility that an author might change his linguistic allegiance. The most famous case of such a switch in the 
history of Croatian is Ljudevit Gaj, who started out as a Kajkavian writer, but then switched to Štokavian in order to facilitate the unification of the "Illyrian" language (later to be realized as Serbo-Croatian in the course of the 19th century).

59. This is often the fate of theoretical analyses and reform proposals based upon them in the area of orthography. Tradition seems to be paramount, whereas logical rules count for little. A parallel to Croatian can be seen in the fate of Polish treatises on orthography published in the 16th century; cf. Bunčić (this volume). Since such treatises are obviously a cul-de-sac in the development of orthography, they will be treated separately.

60. It is interesting to note that Maretic is usually criticized for his book (cf., for example, Jagić 1890, and Diels 1951, who is full of praise for the collection of data but highly critical regarding the methodology employed). Until now, however, no book has been published to replace his work, and so it remains the essential reference.

61. Thus he included Budinić, but only with an earlier book of 1582, and not with the edition of 1583, where new diacritic letters are used. This data will be added, as well as data from other sources.

62. Since they differ in several aspects from all the other books, they will be treated separately on the basis of Bučar (1910), Fancev (1916) and Bučar and Fancev (1938). Most of the books were printed in Urach: only the two parts of the Postila printed in Latin letters appeared in Regensburg in 1568. There is one book (RAZGOVARANGE MEGIU PApiftu, i gednim Luteran) allegedly printed in Padua in 1555, but it belongs to the Urach Protestant tradition as well; cf. also Lipovčan (2004: 125, 196).

63. This classification is not identical to that of Vončina (1988). He distinguishes three groups on the basis of the tripartite division of dialects, and adds a hybrid group in order to capture the development of the linguistic (not orthographic) basis of the standard language(s). There is also a secondary distinction between South(-East) and North(-West); cf., for example, Moguš (1993: 70-71); both are widely used in the literature. In many cases, linguistic and orthographic classifications coincide, but this is not always so. In order to avoid confusion, the names of the groups that are used here do not refer to dialects. Unrelated to any of these groups is the Italian-Croatian dictionary that appeared in Ancona in 1527 . It was compiled by an Italian, and renders the Croatian equivalents by using Italian orthographic devices; cf. the edition in Putanec (1979b: 116-126).

64. Cf. Hektorovich (1973 [1568]). Hektorović's orthography, cf. Mladenović (1968: 7-23, 1970), is quite consistent, at any rate more so than that of the others in this group; cf. Mladenović (1968: 13, 1970: 147). Orthographically Hektorović's system is almost completely taken over by Hanibal Lucić; cf. Vončina (1988: 45-46).

65. The manuscript tradition is described by Mladenović (1959).

66. On the orthography of Zlatarić and other writers from Dubrovnik, cf. Vaillant (1928: 73-111). 
67. Cf. Šojat (1970: 266-270). He also offers samples of the Kajkavian tradition from 1574 to 1842 , showing this consistency which was only (unsuccessfully) interrupted by Krajačević in 1640 (Šojat 1970: 276-282).

68. Cf. the reprint by Vrančić (1971 [1595]). His language is basically Čakavian with some Štokavian elements. His Dalmatian patriotism is also evident from the fact that he refers to his language as "dalmatica lingua". On his hybrid orthography, see also Vončina (1988: 67-68). Another case of hybridization seems to be Nikola Dešić whose Raj duše was published in Padua in 1560; cf. Vončina (1988: 196-198). Since the data on his orthography available to me is not complete, he is not included here.

69. Croatian printing was connected with similar activities in Slovenian directed by Primus Truber; in fact, Croatian translations were also made from Slovenian; cf. Bratulić (1983: 47).

70. This becomes evident from the Slovenian - Croatian word-lists that were appended to the Slovenian Pentateuch (published 1578) and the Bible (1584). For the Croatian equivalents, the author (Juraj Dalmatin) used the Slovenian orthography, thus $<\mathrm{sh}>$ for $/ \mathrm{f} /,<\mathrm{zh}>$ for $/ \mathrm{g} /$, etc. The material was included in Hieronimus Megiser's quadrilingual dictionary published in 1592, and partly also in his multilingual dictionary of 1602 . The interested readers therefore gained the erroneous impression that the Slovenian and the Croatian orthographies were essentially identical. Cf., on the tradition of these word-lists, Putanec (1979a).

71. The following list includes only some of the "difficult" phoneme-letter combinations, viz. those that are "typical". The letters and letter-combinations enumerated further on are abstractions. Most of the authors have more than one graphic representative for a given phoneme. Those that are rarely used are disregarded. Amongst those that were used regularly, only the one that was also regularly used by the others in the same group was considered. In a few cases (e.g., /s/), more than one representative is listed because there is no clear preference.

72. In the column "Phoneme/letter(s)", the sound value and the letter (combination) in today's Standard Croatian is indicated. In the column " $C Z$ " the deviant orthography found in Vrančić is indicated in brackets. Underlined letters and letter-combinations in the column "Protestant" are taken from the "official" transliteration table (see further on).

73. It seems that there is a chronological and regional differentiation: $\langle\mathrm{x}>$ is more recent and appears first in East Čakavian texts; cf. Mladenović (1959: 121).

74. It is often questioned whether $<c ̧>$ is actually a combination of a letter plus a diacritic sign. Genetically, this is indeed doubtful, since it is generally considered to have evolved out of Greek $<\zeta>$; cf. Moguš (1993: 71). Furthermore, it is close to Gothic $<\mathrm{z}>$, and a Gothic $<\mathrm{z}>$ turned upside down was sometimes used to replace $<c ̧>$ (see above). Structurally, however, it is a clear case of the use of diacritics. 
75. The letter is used in positions that have /da/ in Standard Croatian. In Pergošić's dialect, however, /ds/ and /do/ were not distinguished, and coalesced into /dz/.

76. Following Fran Kurelac's book of 1861 on Budinić [non vidi], it has often been claimed that the introduction of these signs was prompted by the Czech orthography developed by Jan Hus at the beginning of the 15th century, but this is rather doubtful; cf. Moguš and Vončina (1969: 68-70), and Vončina (1988: 111-115).

77. To some extent, the doubling of consonant letters also indicated the position of the accent (cf. Vaillant 1928: 87).

78. It must be said, however, that this aspect is often treated in analyses of Croatian orthography; cf., for example, Bagarić-Gabrić (1984) on B. Kašić, and Vaillant (1928) on Zlatarić. This peculiarity has obviously to do with the fact that this is still a hotly-debated issue in the discussions regarding the orthography of contemporary Standard Croatian.

79. This is true of the Catechism, published in Glagolitic and Cyrillic in 1561 and in Latin letters in 1563, and the Postila (a collection of gospel readings for Sundays and holidays) that appeared in Glagolitic in 1562, in Cyrillic in 1563; the version using the Latin alphabet was published in Regensburg in 1568. For some of the publications there is even an Italian version (a Catechism, different from those just mentioned, in 1562, but also the Beneficium Christi in 1565, the same year as the Croatian version in Latin letters, and two years after the Glagolitic version), targeting an educated public living in urban surroundings where Italian was the prestige language; cf. the description in Bučar and Fancev (1938).

80. It contained the following equivalents (instead of the Glagolitic letters, the respective phonemes are indicated): $\left./ \mathrm{v} /=\langle\mathrm{v}\rangle, / \mathrm{z} /=<_{\mathrm{s}}\right\rangle, \mid \mathrm{z} /=\langle\mathrm{z}\rangle, / \mathrm{j} /=\langle\mathrm{y}\rangle$,

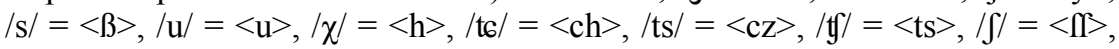
$/ \mathrm{ju} /=<\mathrm{yu}>$; cf. the respective text in Dalmatian and Istrian (1564), and in general Bučar and Fancev (1938: 64, 109). The Glagolitic equivalent of $<y>$ is the letter called đerv that originally represented / $/ 2 /$. This sound, however, had evolved into / $\mathrm{j} /$ in Kajkavian. Essentially the same information was contained in the Cyrillic Probzedl [= Probezettel, 'specimen'] on p. 2, containing four rows: 1. Latin equivalents (in the order of the Glagolitic alphabet [!]) in capital letters, 2. letter names as used in Glagolitic and Cyrillic, written in the Latin alphabet, 3. Glagolitic letters (in the order of the Glagolitic alphabet), 4. numerical value of the Glagolitic letters. On the same page, the Cyrillic alphabet in capital letters is added below. Cf. Bučar and Fancev (1938: 51-52) and Lipovčan (2004: 202), with a photograph of the specimen.

81. This is true of "linguistic" literature in general, i.e., grammars and dictionaries; cf. Vince (1976: 811-817).

82. On the other hand, the influence of the neighbouring languages remained an important factor for the reading public, since educated Croatians were as a rule multilingual. 
83. "In Dalmatica lingua littera C. uarijs modis \& à Latino ufu diuerfis effertur. Nunc enim acuto, nunc graui, nunc obtufo fono id facere oportet. Nos aliam rationem, qua id tibi innotefceret, faciliorem non habuimus, quàm ut alias eius fignificationis litteras, eidem adiungeremus, quæ tamen haud diuifo fed coniuncto fono pronuncientur, idque in hunc modum $\mathrm{Cz}, \mathrm{Cs}, \mathrm{Ch}$, quarto modo eodemque alijs uifitato $\mathrm{K}$, exprimitur. ... $\mathrm{S}$ acutum $\beta$, vel fic $\mathrm{z}$, graue sic: $\mathrm{I}$ pofuimus". [In the Dalmatian language, the letter $c$ is realized in various ways and differently from the Latin tradition. In some places it has to be an acute, in others a grave, elsewhere an obtuse sound. We found no easier way to inform you of this than to add other letters of the same meaning to it. They should, however, not be pronounced separately, but as one sound. This is then expressed in the following way: $c z, c s, c h$. The fourth way is $k$, often seen elsewhere.] (Vrančić 1971, unpaginated introduction).

84. "In utraque lingua ad differentiam uocalium, I confonantem fic: Y, y, notauimus: u uerò fic v. ... Vocales longas, ut cognofcantur, plerumque dupplicauimus ..." [In both languages (viz. Hungarian and Croatian, R.M.) we indicated the consonant $i$ by $y$ to distinguish it from the vowels, and similarly $u$ by $v$. Long vowels were usually doubled so that they might be recognized.] (Vrančić 1971, unpaginated introduction).

85. Biblioteca Augusta ms. 640 (I. 34); cf. the description and edition in Cronia (1953a) as well as the comparison with other sources in von Erdmann-Pandžić (1990).

86. Oxford ms.: Bodleian Library MS Selden Supra 95, fol. 10-42; cf. Pohl (1976); Dubrovnik ms.: Knjižnica Male braće 194; cf. Mitrović (1909: 533-539), Bagarić-Gabrić (1988), von Erdmann-Pandžić (1990: 16-18).

87. In the enumeration (p. 8), he speaks of seven "diphthongs" but then indicates only six: $<\mathrm{aa}>,<\mathrm{ee}>,<\mathrm{ii}>,<\mathrm{oo}>,<\mathrm{uu}>$ and $\langle\mathfrak{x}>$ (p. 8). In the explanation (p. 9), it becomes clear that they are not real diphthongs but rather long vowels. This is true of $<$ aa $>,<$ ee $>(<\mathfrak{x}>$ being only its allograph in word-final position), $<\mathrm{ij}>$ [sic, R.M.], $<\mathrm{oo}>,<\mathrm{uu}>$. The seventh "diphthong", $<\mathrm{ie}>$, is described as being the only real diphthong, consisting of the two "femiuocales", $<\mathrm{i}>$ and $<\mathrm{e}>$ [sic, R.M.].

88. In order to dissolve the conjunction, $<\mathrm{h}>$ is inserted between $<\mathrm{g}>$ and $<\mathrm{l}>$ so that $<\mathrm{ghl}>$ is pronounced $/ \mathrm{gl} /$. Thus, the letter $<\mathrm{h}>$ serves here as a separator. The same rule holds for $<\mathrm{gn}>$. The idea of using $<\mathrm{h}>$ as a separator is obviously borrowed from Italian. There, however, the separating function is not used in digraphs but rather in combinatory writing: $<\mathrm{ci}>\neq<\mathrm{chi}>,<$ gi $>\neq$ $<$ ghi $>$.

89. Džamanjić (1991 [1639]); cf. the detailed description and analysis in van den Berk (1959: 13-82), including the rendering of large portions of the booklet in French.

90. This is evident from the title of his treatise: "PIISATI DOBRO ... RIECI YE/IKA SLOVINSKOGA KOYIEMSE DVBROVCANI, I SVA DALMATIA Kakko vlasctitiem fvoyiem ye/ikom flu/cij" [to write properly the words of the 
Slavonic language that is used by the people of Dubrovnik and of all Dalmatia as their own language]. Furthermore, it transpires from the dedication to Bonaldi. It seems that he did not consider the inland tradition at all.

91. Džamanjić (1991: 14). Although in typographical practice, $<\beta$ is usually treated as the italicized correspondence of $\langle\beta$ and thus as the same letter, Džamanjić treats them as two different letters. The printer's letter-set, however, could not provide him with non-italic $<\beta$, and thus the text is a strange mixture of italicized and non-italicized letters. Some other letters add to this mixture: $\langle v\rangle$ and $\langle i j\rangle$ exist only in italicized form, and italics may extend to the following letter (in the case of the ligature $</ i>$ ). Typographically, this is a highly unsatisfactory approach. Yet, it seems to have been a practice that was not unknown, even in the 18th century; cf. the examples given in Jagić (1890: 607). Unfortunately, this problem is usually not treated in descriptions.

92. The use of this digraph causes an inconsistency, since <gi $>$ may stand for / d $/$ or for $/ \mathrm{g} /+/ \mathrm{i} /$. Incidentally, his name is spelled Giamagnik $[u]$ on the title page, thus using $<\mathrm{k}>$ instead of $<\mathrm{ch}>$ for $/ \mathrm{t} 6 /$. A Latinized form of his name is Zamagnius (van den Berk 1959: 15).

93. Cf., on the problem of the "diphthongs", van den Berk (1959: 37-38, 58-59, $80-82)$. It should be noted that the distinction of $\langle i j\rangle$ and $<\mathrm{ij}>$ (rendered as $<\ddot{y}>$ and $<\mathrm{ij}>$ by van den Berk) made by Džamanjić (1991: 33-36) is again one of italics vs. non-italics, and thus typographically hardly acceptable.

94. Cf. von Erdmann-Pandžić in Džamanjić (1991: X): "Hätte Džamanjić das Akzentproblem ausgeklammert, könnte man seine Rechtschreiblehre als uneingeschränkt gelungen betrachten". and similarly van den Berk (1959: 48): “On peut donc constater que le système de Giamagnich est plus parfait pour les consonnes que pour les voyelles”. Less impressed is Moguš (1993: 110) who, instead of simplicity, sees it as an incomprehensible and hardly acceptable system.

95. It has been claimed that one of Kašič's books (Pistule istomačene 1641) reflects Džamanjić's orthography (von Erdmann-Pandžić in Džamanjić 1991: XII, referring to Stojković, but cf. now von Erdmann-Pandžić 2000: 125, $\mathrm{n}^{\circ}$ 93). This is obviously not the case; cf. Bagarić-Gabrić (1984: 31-32).

96. This lack of uniformity was one of the reasons why the Catholic Church was very reticent regarding the use of the Latin alphabet, as can be seen from the opinion of an expert consulted by the Congregatio de Propaganda fide: "De characteribus vero latinis in linguae illyricae usu hoc tantum dicam: illyrice seu slavonice characteribus latinis scribere ridiculum est. Omnes enim nostrorum temporum scriptores Dalmatiae littoralis, qui materna illyrica lingua aliquid latinis characteribus typis mandarunt suo arbitratu et iuxta proprii capitis cerebrum (quoad orthographiam) scripserunt ita, ut alter alteri in orthographia adversetur et alter alterum bene intelligere non possit." [On the use of Latin letters for the Illyrian language let me say as much: it is ridiculous to write Illyrian or Slavonian with Latin letters. All the contemporary writers from the Dalmatian area who had anything printed in their native Illyrian tongue in Latin letters did 
it according to their own whim and (as far as orthography is concerned) wrote stubbornly, so that their orthographies contradicted each other and that they could not understand each other well.]; cf. von Erdmann-Pandžić (2000: 114).

97. There were also no academies that could have felt responsible for achieving some linguistic unification. The first academy on Croatian territory, the Academia Otiosorum Eruditorum (Accademia degli Oziosi Eruditi, Akademija Ispraznih), was founded around 1695 in Dubrovnik; cf. Deanović (1933).

98. One important fact was that the written language of Dubrovnik was eventually "Štokavized", a process setting in quite early. This meant that the most important centre along the coast was lost for Čakavian.

99. In the case of texts written in Glagolitic, a process of estrangement can be observed due to the peculiar development of the Croatian Church Slavonic language. Being already noticeably different from vernacular Croatian in the 16th century, this distance was artificially increased as a consequence of the activities of the Congregatio de Propaganda fide and its representative Rafal Levaković. In their publications, the language was subjected to a strong East Slavonic influence (often referred to as Russian Church Slavonic influence); cf. Babič (2000).

100. An exception was the orthographic commission that met in Zadar in 1820 and proposed an orthography that, aside from $\langle\mathrm{ch}\rangle,\langle\mathrm{nj}\rangle$ and $\langle\mathrm{lj}\rangle$, consisted only of monographic solutions and avoided at the same time the introduction of diacritics (with the exception of the traditional <ç>); cf. Vince (1990: 131-139). On the development in this period, cf. Brozović $(1974,1975)$ and Moguš (1993: 78-137).

101. The linguistic situation in Bulgaria was not very well known to the proponents of the movement, or else they might have realized rather early that such a unified language was not feasible: Bulgarian is structurally very different from the others and a language for all the Southern Slavs would have had to be a compromise between languages as different as, say, Latin and French.

102. The title page of his Kratka osnova horvatsko-slavenskoga pravopisan̆a has the motto "Non quia difficilia sunt, non audemus; sed quia non audemus difficilia sunt"; cf. Lipovčan (2004: 141, 217). Gaj proposed only the principle; the actual realization was quite different, introducing, for example, the (Czech) háček instead of the tilde used by Gaj.

103. This principled approach to alphabet reform has been highly praised: "Vuk hat das serbische zum modernsten Alphabet Europas gemacht" (Eckhardt 1967: 467). This has been questioned by others, e.g., Janakiev (1963: 57), who miss the indication of suprasegmentals, especially noting quantity.

104. As mentioned above (see notes 13 and 14), there is a strictly monographic variant of Croatian, but the one that is generally used today has three digraphs, viz. $<$ dž $>,<\mathrm{lj}>$ and $<$ nj $>$.

105. The history of this struggle is described in Vince (1990); cf. also Moguš (1993: 157-176). The Serbian perspective is summarized in Ivić (1991 [1981]). 
106. It is ironic that the Croatian side was more "Vukovian" than the Serbs, at least in one respect: whereas Vuk had proposed (I)jekavian as the basis for the standard language (a position readily accepted by the Croatians for obvious reasons), Serbia generally adopted Ekavian.

107. Equally unusual is the close connection between linguistic discussions and political crises in Yugoslavia: "Gotovo svakoj dubljoj društvenoj krizi ... prethodi (a i prati je) neki oblik 'jezičnopolitičke krize"” [Almost every deeper social crisis is preceded (and actually caused) by some kind of 'crisis of linguistic policy'] (Škiljan 1988: 135).

108. It has been interpreted variously by both sides: as some kind of birth certificate for Serbo-Croatian by the Serbian side, and as an informal gathering of individuals by Croatians.

109. An example is the language article in the constitution of the Croatian Socialist Republic of 1974, art. 139, 1 (originally an amendment to the previous constitution that was added in 1972): "U Socijalističkoj Republici Hrvatskoj u javnoj je upotrebi hrvatski književni jezik - standardni oblik narodnog jezika Hrvata i Srba u Hrvatskoj, koji se naziva hrvatski ili srpski" [In the Socialist Republic of Croatia the Croatian Standard language is used in public - the standard form of the people's language of the Croats and the Serbs in Croatia which is called Croatian or Serbian]; cf. Pranjković (2006: 43).

110. Brozović (1992: 358): he even splits the Serbian variant into two (Ekavian and Ijekavian), thus raising the number to five.

111. It has been claimed that Serbo-Croatian "never really was what is commonly understood by a 'unified language' and could therefore not be 'undone"" (Katičić 1997: 165). This, however, is more wishful thinking than reality, since in language politics, declarations matter just as much as linguistic facts. Furthermore the cohabitation of more than a hundred years could not but leave a noticeable imprint on both Croatian and Serbian.

112. Bosnian was first mentioned as an official language in the Dayton/Paris Agreement of 1996. A Montenegrin Standard language has been proposed; cf. Nikčević (1996), and it was declared to be the official language of Montenegro in the constitution of 2007. It is a moot point to discuss whether the differences between Bosnian, Croatian, Montenegrin and Serbian are linguistically so significant as to justify three standard languages. If standard languages are declared to be independent from other, closely related linguistic forms, this is usually accompanied by a kind of Ausbau that will maximise the differences so that Abstand will increase in the course of time.

113. Cf., on the development in the 20th century and on the most recent changes, the articles in Hekman (2006), especially Samardžija (2006), Pranjković (2006), Mamić (2006) and Badurina (2006); furthermore the articles in the two volumes of the series Najnowsze dzieje języków słowiańskich [Recent history of the Slavonic languages] devoted to Serbian and Croatian, respectively: Brboric (1996), Pešikan (1996), Brozović (1998), Badurina (1998). 


\section{References}

\section{Primary sources}

Bratulić, Josip (ed.)

1991 Lekcionar Bernardina Splićanina 1495. Pretisak. (Knjiga Mediterana 6.) Split: Književni krug.

Cassius, Bartholomaeus

1977 Institutiones Linguae Illyricae. R. Olesch (ed.). (Slavistische Forschungen 21.) Cologne/Vienna: Böhlau. Original edition 1604.

Džamanjić, Rajmund

1991 Nauk za Pisati Dobro. Elisabeth von Erdmann-Pandžić (ed.). (Quellen und Beiträge zur kroatischen Kulturgeschichte 5.) Bamberg:

Giannelli, Ciro Bayerische Verlagsanstalt. Original edition, 1639.

1934 Najstariji štampani hrvatski molitvenik. In Vatikanski Hrvatski Molitvenik $i$ Dubrovački Psaltir. Dva Latinicom Pisana Spomenika Hrvatske Proze 14 i 15 Vijeka. Franjo Fancev (ed.), 251-288. (Djela Jugoslavenske akademije znanosti i umjetnosti 31.) Zagreb: Nadbiskupska tiskara.

Hectorovich, Petre

1953 Ribanye $i$ Ribarscho Prigovaranye $i$ Razliche Stvari Ine. Zagreb: JAZU. Original edition, Venetia: Camotio, 1568.

Ispravniich za Erei Ispovidniici ...

$1582 \quad i$. e. Breve Direttorio, per Sacerdoti Confessori, e per Penitenti; Trad. da Lingua Latina nella Illirica. Roma.

[Marulić, Marko] (urn:nbn:de:bvb:12-bsb10187245-6)

1950 Libar Marca Marula Splichianina Vchomfe Ufdarfi Iftoria Sfete Udouice Iudit u Uerfih Haruacchi Slofena. Zagreb: JAZU. Original edition 1521.

Misal po Zakonu Rimskoga Dvora

1971 Zagreb: Mladost. Original edition, 1483.

Rešetar, Milan, and Ćiro Đaneli [Ciro Giannelli]

1938 Dva Dubrovačka Jezična Spomenika iz XVI Vijeka. (Posebna izdanja knj. 122, filosofski i filološki spisi 32.) Belgrade: Srpska kraljevska

Vrančić, Faust akademija.

1971 [DICTIONARIVM QVINQVE NOBILISSIMARUM EVROPAE LINGVARUM, Latince, Italica, Germanica, Dalmatice, \& Vngarica] Rječnik Pet Najuglednijih Evropskih Jezika. Zagreb: Liber. Original edition, Venetiae: Morettus, 1595. 
Zoranich, Petar

1952 Planine che Zdarxe Usebi Pifni Pete po Paftirich, Pripouifti, i Prituori Iunachou i Dechliç, i Mnoge Oftale Stuari. Zagreb: JAZU. Original edition, Venetia: Farri, 1569.

\section{Secondary Sources}

Abercrombie, David

1981 Extending the Roman alphabet: Some orthographic experiments of the past four centuries. In Towards a History of Phonetics, R. E. Asher, and J. A. Henderson (eds.), 207-224. Edinburgh: University Press.

Auty, Robert

1978 Pannonian parallels and divergences: Thoughts on the history of the

Babič, Vanda

Croatian and Hungarian literary languages. Filologija 8: 29-35.

2000 Vpliv Vzhodne Cerkvene Slovanščine na Hrvaške Glagolske Tekste v 17. in 18. Stoletju (Razprave Filozofske fakultete). Ljubljana:

Badalić, Josip Znanstveni inštitut Filozofske fakultete.

1959 Jugoslavica usque ad Annum MDC. Bibliographie der Südslavischen Frühdrucke. (Bibliotheca bibliographica aureliana 2.) Baden-Baden: Heitz.

Badurina, Lada

1998 Pravopis. In Hrvatski Jezik (Najnowsze dzieje języków słowiańskich), Mijo Lončarić (ed.), 65-73. Opole: Uniwersytet Opolski.

Badurina, Lada

2006 Hrvatska pravopisna norma u 20. stoljeću. In Hrvatski Jezik $u$ XX. Stoljeću, Jelena Hekman (ed.), 145-158. (Biblioteka XX. stoljeće.) Zagreb: Matica Hrvatska.

Bagarić-Gabrić, Darija

1984 Jezik Bartola Kašića. (Posebna izdanja 5) Sarajevo: Institut za jezik i književnost u Sarajevu. Institut za jezik.

Bagarić-Gabrić, Darija

1988 Jezična analiza anonimnog rukopisnog rječnika »Slovoslovje dalmatinsko-italijansko«. Čakavska Rič 2: 9-27.

Bičanić, Ante (ed.)

2009 Povijest Hrvatskoga Jezika. 1. Knjiga: Srednji Vijek. Zagreb: Croatica.

Bratulić, Josip

1983 Pogledi hrvatskih protestanata na književni jezik. Radovi Zavoda za Slavensku Filologiju 18: 43-49. 
Bratulić, Josip

2004 Lateinische Sprache und Schrift. In Drei Schriften - Drei Sprachen. Kroatische Schriftdenkmäler und Drucke durch Jahrhunderte, Srećko Lipovčan (ed.), 57-65. Zagreb: Nacionalna i sveučilisna knjižnica; Erasmus naklada.

Brborić, Branislav

1996 Predistorija i sociolingvistički aspekti. In Srpski Jezik, Milorad Radovanović (ed.), 17-35. (Najnowsze dzieje języków słowiańskich.) Opole: Uniwersytet Opolski.

Brozović, Dalibor

1973 O hrvatskom književnom jeziku šesnaestoga stoljeća. Zbornik Zagrebačke Slavističke Škole 1: 129-135.

Brozović, Dalibor

1974 O hrvatskom književnom jeziku sedamnaestoga stoljeća. Zbornik Zagrebačke Slavističke Škole 2: 51-57.

Brozović, Dalibor

1975 Hrvatski književni jezik u 18. stoljeću. Zbornik Zagrebačke Slavističke Škole 3: 75-85.

Brozović, Dalibor

1978 Hrvatski jezik, njegovo mjesto unutar južnoslavenskih i drugih slavenskih jezika, njegove povijesne mijene kao jezika hrvatske književnosti. In Hrvatska književnost u Evropskom Kontekstu, Aleksandar

Brozović, Dalibor Flaker, and Krunoslav Pranjić (ed.), 9-83. Zagreb: Liber.

1992 Serbo-Croatian as a pluricentric language. In Pluricentric Languages. Differing Norms in Different Nations, Michael Clyne (ed.), 347380. (Contributions to the Sociology of Language 62.) Berlin/New York: Mouton de Gruyter.

Brozović, Dalibor

1998 Povijesna podloga i jezičnopolitičke i socjolingvističke okolnosti. In Hrvatski Jezik, Mijo Loncarić, 3-34. (Najnowsze dzieje języków słowiańskich.) Opole: Uniwersytet Opolski.

Brozović, Dalibor, and Pavle Ivić

1988 Jezik Srpskohrvatski/Hrvatskosrpski, Hrvatski ili Srpski. Zagreb: Jugoslavenski Leksikografski Zavod "Miroslav Krleža".

Bučar, Franjo

1910 Povijest Hrvatske Protestantske Književnosti za Reformacije. (Crtice iz hrvatske književnosti 5.) Zagreb: Matica Hrvatska.

Bučar, Franjo

1916 Popis knjiga, koje su izašle u jugoslavenskoj protestantskoj tiskari u Urachu-Tübingenu u XVI. stoljeću. Carniola 7: 104-109; 178-188.

Bučar, Franjo, and Franjo Fancev

1938 Bibliografija hrvatske protestantske književnosti za reformacije. Starine 39: 49-128. 
Cronia, Arturo

1953a Contributo alla lessicografia serbo-croata. Un'inedita redazione trilingue del «Dictionarium quinque nobilissimarum Europae linguarum» di Fausto Veranzio. Ricerche Slavistiche 2: 117-130.

Cronia, Arturo

1953b Revisione dei nomi slavi nell'antico Codex Aquileiensis. In Studi Aquileiesi Offerti il 7 Ottobre 1953 a Giovanni Brusin nel suo 70. Compleanno, 357-371. Aquileia: Associazione nazionale per Aquileia.

Deanović, Mirko

1933 Odrazi talijanske akademije ,degli Arcadi“ preko Jadrana. Rad JAZU 248: 1-98.

Diels, Paul

1951 Aus der Geschichte der Lateinischen Schrift bei den Südslaven. (Sitzungsberichte der Bayerischen Akademie der Wissenschaften. Philosophisch-historische Klasse 1950, 10.) Munich: Beck.

Đorđić, Petar

1971 Istorija Srpske Ćirilice. Paleografsko-Filološki Prilozi. Belgrade: Zavod za izdavanje udžbenika SR Srbije.

Dujčev, Ivan

1981 Slavia orthodoxa als kulturhistorischer Begriff. In Colloquium Slavicum Basiliense. Gedenkschrift für Hildegard Schroeder, Heinrich Riggenbach (ed.), 87-94. (Slavica Helvetica 16.) Berne/Frankfurt a. M./Las Vegas: Lang.

Eckhardt, Thorvi

1967 Die slawischen Alphabete. Studium Generale 20 (8): 457-470.

Eckhardt, Thorvi

1978 Die Bosančica. Eine Sonderform der westlichen Kyrillica. Österreichische Osthefte 20: 183-192.

Eckhardt, Thorvi

1989 Azbuka. Versuch einer Einführung in das Studium der Slavischen Paläographie. (Wiener Archiv für Geschichte des Slawentums und Osteuropas 14.) Vienna/Cologne: Böhlau.

Fancev, Frańo

1916 Jezik hrvatskih protestantskih pisaca 16. vijeka. Prilog historičkoj gramatici jezika hrvatskoga ili srpskoga. Rad JAZU 212: 147-225; 214: 1-112.

Fancev, Franjo (ed.)

1934 Vatikanski Hrvatski Molitvenik i Dubrovački Psaltir. Dva Latinicom Pisana Spomenika Hrvatske Proze 14 i 15 Vijeka. (Djela Jugoslavenske akademije znanosti i umjetnosti 31.) Zagreb: Nadbiskupska tiskara. 
Franolić, Branko

1984 An Historical Survey of Literary Croatian. Paris: Nouvelles éditions latines.

Glück, Helmut

1987 Schrift und Schriftlichkeit. Eine Sprach- und Kulturwissenschaftliche Studie. Stuttgart: Metzler.

Golub, Ivan

2000 Quellen zur Bibel Kašićs im Archiv des Heiligen Offiziums. In Bib-

lia Sacra Versio Illyrica Selecta seu Declaratio Vulgatce Editionis

Latince. Bartholomoi Cassij Curictensis e Societate Iesu Professi, ac

Sacerdotis Theologi. Ex Mandato Sacra Congregationis de Propag:

Fide. Anno 1625, Hans Rothe, and Christian Hannick (eds.), 131-

196. (Biblia Slavica IV: Südslavische Bibeln 2,2.) Paderborn/Munich/Vienna/Zurich: Schöningh.

Hadrovics, László

1984 Cantilena pro sabatho (Starohrvatska pasionska pjesma iz 14. stoljeća.). Filologija 12: 7-25.

Hain, Ludwig

1948 Repertorium Bibliographicum I, 1. Milan: Görlich. Original edition, 1826.

Hartmann, Gottfried

1907 Zur Geschichte der italienischen Orthographie. Romanische Forschungen 20: 199-283.

Hekman, Jelena (ed.)

2006 Hrvatski Jezik u XX. Stoljeću. (Biblioteka XX. stoljeće) Zagreb: Matica Hrvatska.

Hercigonja, Eduard

1994 Tropismena i Trojezična Kultura Hrvatskoga Srednjovjekovlja. (Mala knjižnica Matice hrvatske; kolo 2, knjiga 8.) Zagreb: Matica hrvatska.

Ivić, Pavle

1991 Standardni jezik Srba i Hrvata u drugoj polovini devetnaestog veka. In Izabrani Ogledi II: Iz Istorije Srpskohrvatskog Jezika, Pavle Ivić, 277-299. Niš: Prosveta. Original edition, 1981.

Jagić, Vatroslav

1890 Review of Maretić, Tomo (1889), Istorija hrvatskoga pravopisa latinskijem slovima. (Djela Jugoslavenske akademije znjanosti i umjetnosti 9.) Zagreb: JAZU. Archiv für Slavische Philologie 12: 602609.

Janakiev, Miroslav

1963 Osnovy teorii orfografii. Voprosy Jazykoznanija 12 (5): 47-57.

Junković, Zvonimir

1972 Jezik Antuna Vramca i Podrijetlo Kajkavskoga Dijalekta. Dijahroniska Rasprava. (Rad JAZU 363.) Zagreb: JAZU. 
Kadlec, Karlo

1909 Stefana Verbecija Tripartitum. (Zbornik za istoriju, jezik i književnost srpskog naroda I. Spomenici na srpskom jeziku 5.) Belgrade: SKA.

Katičić, Radoslav

1997 Undoing a "unified language": Bosnian, Croatian, Serbian. In Undoing and Redoing Corpus Planning, Michael Clyne (ed.), 165-191. (Contributions to the Sociology of Language 78.) Berlin/New York: Mouton de Gruyter.

Katičić, Radoslav

1999 Literatur- und Geistesgeschichte des Kroatischen Frühmittelalters (Österreichische Akademie der Wissenschaften, phil.-hist. Klasse, Schriften der Balkan-Kommission, Philologische Abteilung 40.) Klima, Edward S. Vienna: ÖAW.

1972 How Alphabets Might Reflect Language. In Language by Ear and by Eye. The Relationships between Speech and Reading, James F. Kavanagh, and Ignatius G. Mattingly (eds.), 57-80. Cambridge/ London: MIT Press.

Klimaŭ, Ihar' Paŭlavič

2004 Réfarmacyja ŭ Historyi Litaraturnych moŭ Slavjan: Uklad Pol'skaBelaruskaha i Slavenska-Charvackaha Pratėstantyzmu 16 st. Minsk:

Lipovčan, Srećko (ed.) Belaruski dzjaržaŭny universitet kul'tury.

2004 Drei Schriften - Drei Sprachen. Kroatische Schriftdenkmäler und Drucke durch Jahrhunderte. Zagreb: Nacionalna i sveučilisna knjižnica; Erasmus naklada.

Lukatela, Georgije, Dragan Popadić, Predrag Ognjenović, and Michael T. Turvey

1980 Lexical decision in a phonologically shallow orthography. Memory and Cognition 8: 124-132.

Malić, Dragica

2000a Latinički tekstovi hrvatskoga srednjovjekovlja na narodnom jeziku. In Hrvatska i Europa. Kultura, Znanost i Umjetnost. Sv. II. Srednji Vijek $i$ Renesansa (XIII-XVI. Stoljeće), Eduard Hercigonja (ed.), 299-316. Zagreb: Školska knjiga.

Malić, Dragica

2000b Novija zapažanja o srednjovjekovnoj hrvatskoj latinici. Filologija 34: 97-128.

Malić, Dragica

2004 Skrivene veze hrvatske srednjovjekovne glagoljičke, ćiriličke i glagoljske slova. In Glagoljica i Hrvatski Glagolizam, Marija-Ana Dürrigl, Milan Mihaljević, and Franjo Velčić (eds.), 549-560. Zagreb/ Krk: Staroslavenski institut; Krčka biskupija. 
Mamić, Mile

2006 Hrvatsko jezično zakonodavstvo i jezična politika u 20. stoljeću. In Hrvatski Jezik u XX. Stoljeću, Jelena Hekman (ed.), 59-70. (Biblioteka XX. stoljeće) Zagreb: Matica Hrvatska.

Maretić, Tomo

1889 Istorija Hrvatskoga Pravopisa Latinskijem Slovima. (Djela Jugoslavenske akademije znjanosti i umjetnosti 9.) Zagreb: JAZU.

Milčetić, Ivan, and Joso Milošević

1911 Šibenska molitva (XIV. vijek). Starine 33: 572-592.

Mitrović, Pavo

1909 Četiri nepoznata dubrovačka rječnika. Nastavni Vjesnik 17: 522 539.

Mladenović, Aleksandar

1959 Grafija i jezik dalmatinskih čakavskih rukopisa u arhiva Jugoslavenske akademije. Godišnjak Filozofskog Fakulteta u Novom Sadu 4: 117-150.

Mladenović, Aleksandar

1968 Jezik Petra Hektorovića. Novi Sad: Matica Srpska.

Mladenović, Aleksandar

1970 O nekim osobinama jezika Petra Hektorovića. In Zbornik Radova o Petru Hektoroviću, Jakša Ravlić (ed.), 146-152. (Kritika 1970/6, posebno izdanje) Zagreb: Kritika.

Moguš, Milan

1982 O pisanju fonema /1̦/ i /ń/. Filologija 11: 93-98.

Moguš, Milan

1984 Glagoljica kao ortografiski uzorak u hrvatskoj književnosti. Slovo 34: $263-268$.

Moguš, Milan

1993 Povijest Hrvatskoga Književnoga Jezika. Zagreb: Globus.

Moguš, Milan, and Josip Vončina

1969 Latinica u Hrvata. Radovi Zavoda za Slavensku Filologiju Zagreb 11: 61-81.

Nazor, Anica

1997 Hrvatski glagoljski brevijar iz 1493. godine čitavo stoljeće opisivan kao ćirilski časoslov (Breviarium slavicum). Suvremena Lingvistika 43-44: 233-240.

Nazor, Anica

2004 Die kyrillische Schrift. In Drei Schriften - Drei Sprachen. Kroatische Schriftdenkmäler und Drucke durch Jahrhunderte, Srećko Lipovčan (ed.), 51-55. Zagreb: Nacionalna i sveučilisna knjižnica; Erasmus naklada.

Nemirovskij, Evgenij L.

1997 Gesamtkatalog der Frühdrucke in Kyrillischer Schrift II: Die Druckereien des Makarije in der Walachei und von Giorgio Rusconi in 
Venedig. (Bibliotheca bibliographica aureliana 152.) Baden-Baden: Valentin Koerner.

Nerius, Dieter

1986 Zur Bestimmung und Differenzierung der Prinzipien der Orthographie. In New Trends in Graphemics and Orthography, Gerhard Augst (ed.), 11-24. Berlin/New York: de Gruyter.

Nikčević, Vojislav

1996 Crnogorski Jezik. Cetinje: Dignitas.

Pešikan, Mitar

1996 Pravopisna norma. In: Srpski Jezik, Milorad Radovanović (ed.), 171179. (Najnowsze dzieje języków słowiańskich) Opole: Uniwersytet Opolski.

Picchio, Riccardo

1958 'Prerinascimento esteuropeo' e 'rinascita slava ortodossa'. Ricerche Pohl, Heinz Dieter Slavistiche 6: 185-199.

1976 Das Italienisch-Kroatische Glossar Ms Selden Supra 95. Edition des Textes und Linguistischer Kommentar. (Österreichische Akademie der Wissenschaften. Philosophisch-Historische Klasse. Schriften der Balkankommission. Linguistische Abteilung 24/1.) Vienna: Akademie.

Popović, Ivan

1960 Geschichte der Serbokroatischen Sprache. (Bibliotheca Slavica) Wiesbaden: Harrassowitz.

Pranjković, Ivo

2006 Hrvatski jezik od godine 1945. do 2000. In Hrvatski Jezik u XX. Stoljeću, Jelena Hekman (ed.), 29-58. (Biblioteka XX. stoljeće) Zagreb: Matica Hrvatska.

Putanec, Valentin

1979a Mali diferencijalni hrvatsko-slovenski rječnici iz 1578, 1584. i 1592. Rad JAZU 376: 159-215.

Putanec, Valentin

1979b Talijansko-hrvatski i hrvatsko-talijanski rječnik Petra Lupisa Valentiana (Ankona, 1527). Filologija 9: 101-138.

Rešetar, Milan

1904 Ein serbokroatisches Wörterverzeichniss aus der Mitte des XV. Jahrhunderts. Archiv für Slavische Philologie 26: 358-366.

Samardžija, Marko

2006 Hrvatski jezik od početka XX. stoljeća do godine 1945. In Hrvatski Jezik u XX. Stoljeću, Jelena Hekman (ed.), 9-28. (Biblioteka XX.

Schröpfer, Johann stoljeće) Zagreb: Matica Hrvatska.

1968 Hussens Traktat „,Orthographia bohemica“. Die Herkunft des Diakritischen Systems in der Schreibung Slavischer Sprachen und die 
Älteste Zusammenhängende Beschreibung Slavischer Laute. (SlavŠkiljan, Dubravko istische Studienbücher 4.) Wiesbaden: Otto Harrassowitz.

1988 Jezična Politika. Zagreb: Naprijed.

Šojat, Antun

1970 Pravopis stare kajkavske književnosti. Filologija 6: 265-282.

Tauli, Valter

1977 Speech and spelling. In Advances in the Creation and Revision of Spelling Systems, Joshua A. Fishman (ed.), 17-36. (Contributions to the Sociology of Language 8.) The Hague/Paris: Mouton.

Thomson, Francis J.

2005 The Legacy of SS. Cyril and Methodius in the Counter-Reformation. In Methodios und Kyrillos in ihrer Europäischen Dimension, Evangelos Konstantinou (ed.), 85-246. (Philhellenische Studien 10.) Frankfurt am Main et al.: Lang.

Vachek, Josef

1948 Written Language and Printed Language. Recueil Linguistique de Bratislava 1: 67-75.

Vaillant, André

1928 La Langue de Dominko Zlatarić, Poète Ragusain de la Fin du XVI Siècle. I. Phonétique. (Travaux publiés par l'Institut d'études slaves 5.1.) Paris: Imprimerie nationale.

Vajs, Josef

1932 Rukovět' Hlaholské Paleografie. Uvedení do Knižního Písma Hlaholského. (Rukověti Slovanského ústavu v Praze 2.) Prague: Orbis.

van den Berk, Christiaan A.

1959 Y a-t-il un Substrat Čakavien dans le Dialecte de Dubrovnik? Contribution à l'Histoire de la Langue Serbo-Croate (Slavistische drukken en herdrukken 16.) 's-Gravenhage: Mouton.

Vince, Zlatko

1976 Od Baščanske ploče do Kačića i Reljkovića. Forum 15: 781-838.

Vince, Zlatko

1990 Putovima Hrvatskoga Književnog Jezika. Lingvističko-Kulturnopovijesni Prikaz Filoloških Škol i Njihovih Izbora. Zagreb: Matica hrvatska.

Vintr, Josef

1986 Die tschechisch-kirchenslavischen Glossen des 12. Jahrhunderts in der Bibel Sign. 1190 der Nationalbibliothek in Wien (sog. JagićGlossen). Wiener Slavistisches Jahrbuch 32: 77-113.

Vončina, Josip

1979 Vrančićev rječnik. Filologija 9: 7-36. 
Vončina, Josip

1988 Jezična Baština. Lingvostilistička Hrestomatija Hrvatske Književnosti od Kraja 15. do Početka 19. Stoljeća. (Biblioteka znanstvenih djela 20.) Split: Književni krug.

von Erdmann-Pandžić, Elisabeth

1990 Drei Anonyme Wörterbücher der Kroatischen Sprache aus Dubrovnik, Perugia und Oxford. Zur Sammlung der 'Disiecta Membra' des Frühen Opus von Bartol Kašić. (Quellen und Beiträge zur kroatischen Kulturgeschichte 3.) Bamberg: Bayerische Verlagsanstalt.

von Erdmann-Pandžić, Elisabeth

2000 Der gescheiterte Drucklegungsversuch der Kašić-Bibel. In Biblia Sacra Versio Illyrica Selecta seu Declaratio Vulgatce Editionis Latince. Bartholomoi Cassij Curictensis e Societate Iesu Professi, ac Sacerdotis Theologi. Ex Mandato Sacrce Congregationis de Propag: Fide. Anno 1625, Hans Rothe, and Christian Hannick (eds.), 99-129. (Biblia Slavica IV: Südslavische Bibeln 2,2.) Paderborn/Munich/ Vienna/Zurich: Schöningh.

Vorndran, Rolf

1977 Südslawische Reformationsdrucke in der Universitätsbibliothek Tübingen. Eine Beschreibung der Vorhandenen Glagolitischen, Kyrillischen und anderen Drucke der »Uracher Bibelanstalt«. (ConŽagar, Mateo tubernium 24.) Tübingen: J.C.B.Mohr.

2009 Hrvatska pisma u srednjem vijeku. In: Povijest Hrvatskoga Jezika. 1. Knjiga: Srednji Vijek, Ante Bičanić (ed.), 107-219. Zagreb: Croatica. Zelić-Bućan, Benedikta

2000 Bosančica ili Hrvatska Ćirilica u Srednjoj Dalmaciji. Split: Državni arhiv.

Žitomirskij, Konstantin Grigor'evič

1915 Moloch XX Veka (Pravopisanie). Moscow. 


\title{
Hungarian
}

\section{6th-century Hungarian orthography}

\author{
Klára Korompay
}

\section{Introduction}

Before embarking on this overview of 16th-century Hungarian orthography, we shall first of all present briefly the essential features of this orthography, and then outline some of the major aspects of its development.

Hungarian has an alphabetic writing system, in which the relations between writing and sound are very regular: a grapheme corresponds to a single phoneme, and vice-versa, with very few exceptions. Although the phonemic principle is predominant, we should not, however, underestimate the importance of the morphological principle, since Hungarian, a member of the Finno-Ugrian family, is an agglutinative language.

The story of Hungarian orthography begins around the year 1000 AD, with the adoption of the Roman alphabet. As was the case in many other languages, difficulties soon arose due to the fact that the Latin alphabet (21 letters at first, then 23, before reaching the present number of 26) was inadequate to represent the phonological systems of the various vernaculars that it was called upon to transcribe. In the case of Old Hungarian, the number of phonemes stood at around 35, and this number was to increase over the centuries. Several special graphic devices therefore had to be introduced in order to create new signs: this was achieved either by creating digraphs, or by using diacritical signs (mainly different types of accents). During the Middle Ages, both of these devices were adopted, and this led to the creation of different models, whose parallel existence is significant in the 16th century. As Hungarian orthography was not fixed until quite a late date, its evolution during the period studied here underwent further modifications, and this led to variation. Some elements of the orthographical system were not to be fixed until the 19th century; others not even until the 20th. The changeability of Hungarian orthography is one of its essential features, and this no doubt accounts for the fact that the orthography has, over time, managed to adapt and to retain close links with pronunciation. 
Today, the Hungarian alphabet consists of 40 characters. They are presented below, with the phonemic value of each character given, so that the reader can gain a better understanding of the subject. These will provide the keys to the pronunciation of Hungarian, and also give us elements to allow us to understand some of the developments that took place between the 16 th century and the present day.

Of these 40 characters, 38 indisputably note phonemes: 24 consonants and 14 vowels ( 7 long and 7 short). The two remaining ones raise various questions: $<$ ly $>$ has been maintained out of respect for tradition, since, for a couple of centuries, $<\mathrm{ly}>$ and $<j>$ have represented the same phoneme for the vast majority of speakers. As for $\langle\mathrm{dz}>$, a very rarely-used element, there is some discussion at the moment as to its exact status (single phoneme or two-phoneme cluster?) We do not propose to enter into this discussion here. Table 1 shows the complete list of graphemes used to write present-day Hungarian, with their phonemic value:

Table 1. Graphemes and phonemes of present-day Hungarian

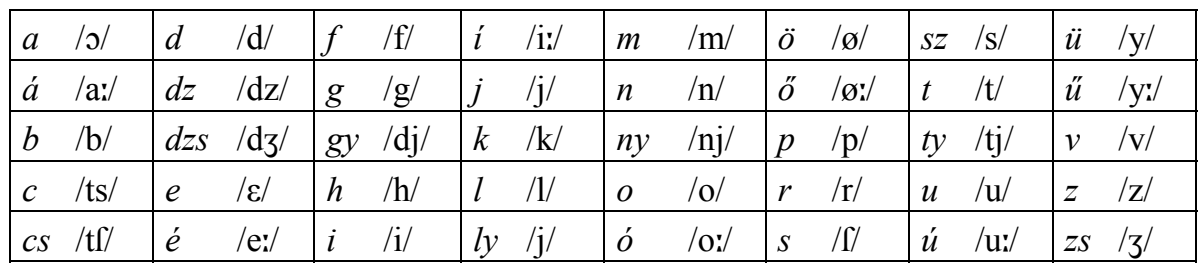

Two further remarks need to be made here: firstly, for the phonetic transcriptions, we have adopted the IPA system for Hungarian, with just one minor modification: to render the palatal consonants represented by the graphemes $<$ gy $>$, $<$ ny $>$ and $<$ ty $>$, we have chosen the simpler transcriptions $/ \mathrm{dj} /, / \mathrm{nj} /$ and $/ \mathrm{tj} /$. Secondly, in addition to the 40 characters described above, there are four further characters, $\langle\mathrm{q}\rangle,\langle\mathrm{x}\rangle,\langle\mathrm{y}\rangle$ and $\langle\mathrm{w}\rangle$, which are used in loan-words and in some proper nouns. They are relics of old spellings, but may also be considered as part of the alphabet. 


\section{The main types of orthography in the 16th century}

\subsection{The Chancery model}

The Chancery model is the oldest of all the models that existed in the 16th century: it originated in the 11th-12th centuries. 1181 is an important historical date, because in this year King Béla III founded a Royal Chancery, independent from the capella regia, on the lines of the one that existed in France, and made compulsory the recording of legal proceedings in writing. Legal acts written in Latin were produced in their thousands during the Middle Ages, and the Roman alphabet also gradually came to be used to write Hungarian, since these legal acts often contained proper nouns or words that had to be set down in their "vernacular" form. This eventually led to the elaboration of a whole set of sign-sound correspondences for the vernacular as a whole.

Chancery orthography, which remained very phonemic and occasionally developed new notations, evolved slowly over the centuries. This was the main model that authors copied when they had to compose texts in Hungarian. The first texts in Hungarian, composed from the second half of the 12th century onwards, were translated from Latin and were intended as supports for the teachings of the Church. However, they remained rare for quite some time.

This situation changed in the 15th century when, following a series of monastic reforms, an effort was made to reinforce discipline in the Franciscan and Dominican orders. A number of texts in Hungarian were produced for this particular purpose (cf. Horváth 2005 [1944]: 550-560). Extracts from the Scriptures, lives of saints, sermons and prayers were translated and set down in written form to provide spiritual nourishment for one group in particular: nuns in convents, who did not have access to Latin culture, and who were the main audience for these vernacular texts. Indeed, some of these nuns themselves were also copyists, such as the Dominican nun Lea Ráskay. There are around fifty manuscript books (codices) surviving from the 15th-16th centuries. As far as their orthography is concerned, many of them faithfully follow the Chancery tradition: this is especially true for manuscripts which were produced in Dominican scriptoria. It is, moreover, very likely that some of these texts were copied or adapted from older manuscripts, which have been lost.

What, then, are the structural characteristics of "Chancery orthography"? As the Roman alphabet was inadequate to note the phonemes of Hungarian, two types of adaptation had to be made. In some cases, two 
different phonemes were noted by a single grapheme: for instance, $<\mathrm{Z}>$ was used to note both $/ \mathrm{z} /$ and $/ \mathrm{s} /,<\mathrm{s}>$ was used to note both $/ \mathrm{g} /$ and $/ 3 /$, etc. The same notations could be used both for long vowels and for short vowels (in a few rare cases, the reduplication of graphemes was also used to mark long vowels). Another solution, a more elaborate one, consisted in using digraphs. Phonemes that had no equivalent in Latin (affricates, palatal consonants, rounded front vowels) were, most often, noted by combinations of letters $(<\mathrm{ch}>$ for $/ \mathrm{tg} /,<\mathrm{cz}>$ for $/ \mathrm{ts} / ;<\mathrm{ty}>,<\mathrm{gy}>,<\mathrm{ly}>,<$ ny $>$ for the palatal equivalents of $/ \mathrm{t} /, / \mathrm{d} /, / \mathrm{l} /$ and $/ \mathrm{n} /$; $<$ ew $>$ was used for $/ \varnothing: /)$. One of the most striking features of this early orthographical model is its wide range of digraphs (cf. Kniezsa 1952: 9-78, 1959: 5-9, Korompay 2003: 281-291).

Needless to say, this system spawned a large number of internal variants: the relations between phonemes and graphemes left a certain amount of room for manoeuvre, which was inevitable at the time. In some cases, variation was conditioned by more or less precise rules, often dictated by the pronunciation of Medieval Latin. For example, there were two ways of noting $/ \mathrm{k} /$ : either by $\langle\mathrm{c}>$ or by $<\mathrm{k}>$, the latter being preferred before $<\mathrm{e}>$ and $<i>$. Some letters could also stand either for a vowel or for a consonant: this was the case with $<\mathrm{i}>,<\mathrm{y}>$ and $<\mathrm{j}>$, which noted either $/ \mathrm{i} /$ or $/ \mathrm{j} /$. Similarly, $<\mathrm{u}>,<\mathrm{v}>$ and $<\mathrm{w}>$ could correspond either to $/ \mathrm{u} /, / \mathrm{y} /$ or $/ \mathrm{v} /$. This fluctuating use was of course a widespread phenomenon in European languages as a whole, during the Middle Ages.

Besides the Roman alphabet as such, other vernacular languages also made significant contributions to Hungarian orthography. During the foundation period of Hungarian orthography (11th-12th centuries), three European languages in particular seem to have played a part in the adoption of certain orthographical elements: German, Italian and French. According to language historians, the dual value of the graphemes $\langle\mathrm{z}>$ and $\langle\mathrm{s}\rangle$ which note, respectively, the two sibilants and the two palato-alveolar fricatives, is one of several features that can be attributed to the influence of the German language (cf. Kniezsa 1952: 69). As for Italian, this language no doubt played a part in the curious fact that the palatal consonant $/ \mathrm{dj} /$ is written as $<$ gy $>$ in Hungarian, as the pronunciation developed from a former /dź/, similar to the consonant noted by $g$ in Italian. Finally, the digraph $<\mathrm{ch}>$, pronounced $/ \mathrm{t} \mathrm{f} /$, was borrowed from Old French. The parallel which exists on this point between Old Hungarian and English is therefore no coincidence, for both languages borrowed the device from Old French at around the same time. 


\subsection{Hussite orthography}

A radically new system, created at the beginning of the 15th century, emerged as the second orthographical model, one which was to be adopted in a large number of manuscripts, even in the 16th century. It is seen for the first time in a set of three codices (the Vienna Codex, the Munich Codex and the Apor Codex) which were compiled after 1416 and have been preserved through 15 th-century exemplars. They contain the first translation (a partial, but systematic translation) of the Bible into Hungarian, commonly known as the "Hussite Bible", although its precise origins are still something of a matter for debate (we will return to this question later).

The new, innovative orthographical system used in these manuscripts is based on systematic use of diacritical signs. Accents and other marks were used to create new graphemes, which allowed certain sets of phonemes to be clearly distinguished. It should be pointed out, however, that the new system continued to draw heavily on the Chancery tradition, and in particular on its use of certain phoneme-grapheme correspondences which had been established for centuries. Two examples can be given here to illustrate the coherence of the new system: although the consonants $/ \mathrm{s} /$ and $/ \mathrm{z} / \mathrm{had}$ both been noted, until then, by $<\mathrm{z}>$, they would from now on be noted respectively by $<\dot{z}>$ and by $<\mathrm{z}>$; using the same device, the distinction between $/ \mathrm{g} /$ and $/ 3 /$ would henceforth be made with the traditional notation $s$, adapted to form two separate graphemes, $<\mathrm{s}>$ and $\langle$ s' $>$. The palatal consonants also received notations designed along similar lines: for example, the grapheme $<\mathrm{t}^{\prime}>$ replaced the grapheme $<\mathrm{ty}>$ of the Chancery model.

Diacritical signs were also used for vowels. In this particular case, accents enabled speakers to distinguish vowel quality, but not vowel length: because of the complexity of the system (composed of 8 short vowels and 8 long vowels), only one of these features could be noted. We should point out here the existence of two characters that look nothing like the traditional notations: the grapheme $<_{0}>$ (an $o$ with a hook) for $/ \varnothing /$; and, for $/ \mathrm{t} \mathrm{j} /$, the curious $<\mathrm{L}>$ whose form does however make sense when one considers it as a two-sided variant of $\langle\mathrm{c}>$.

Needless to say, this model, through its use of diacritics, eliminated all the digraphs, and therefore presented a much more coherent system in which the relations between grapheme and phoneme were almost ideal. When one thinks of the exceptional role played by Jan Hus both in attempting to establish equivalence between written signs and the signs of speech, and in setting down an orthography for Czech in which phonological oppositions were noted by diacritical signs (see Berger, this volume), one cannot 
but feel a sense of awe at how much 15th-century Hungarian orthography owes to him. His legacy can be seen not only in the details of the system (the new signs having been created by borrowing from both the Czech and Hungarian graphic traditions), but also in the very spirit of these two constructions, which are governed by the same principles and are structured in an entirely analogous manner (cf. Kniezsa 1952: 146-157, 1959: 11-13, Korompay 2003: 295-297).

As far as the Hungarian tradition is concerned, the emergence of this Hussite orthographical model is inseparable from the first translation of the Bible. It would therefore seem logical to suppose that they were both established by the same people, namely, former students of Jan Hus who, having returned to their native country, continued to spread their master's teaching in Hungary. There is no shortage of evidence to support such a hypothesis: presence of the Hussite "heresy" in Hungary as early as 1410-1420, and the evidence of a chronicle written by the Franciscans that contains information collected by the Inquisition, concerning in particular the activity of translation of the Bible into Hungarian. There are many striking convergences between the elements of the accusation and elements which can be found in the text of the Bible in question (cf. Kniezsa 1952: 172-179). Nevertheless, this debate is not yet closed (cf. Szabó 1989, Madas 1998: 50-51, Korompay 2006: 206-207), and the following point raises a certain number of questions: several decades later, the same Franciscan order was one of the first to adopt the orthography of the "heretics" in its manuscripts. Does this therefore mean that there may be some reason to doubt the "Hussite" origin of this orthography? Or might we suppose that the new orthography simply had so many advantages that scribes had every reason to adopt it?

Traditional orthography with digraphs or new orthography with accents: both of these existed as alternatives in scribal practice. When confronted with a manuscript to copy, scribes would adopt differing attitudes: while some would consider it their duty to remain faithful in all respects to the original, others would take more liberties, and would impose their own personal orthographical practices. The interference between the two systems would give rise to a number of mixed systems, which can be seen in the codices of the 16th century. Some elements, such as the notation of the consonant $/ \mathrm{t} \mathrm{f} /$, the vowel $/ \varnothing /$ and the palatal consonants were especially variable, and the choices made with regard to these elements were always significant. 


\subsection{The two parallel models of the grammarians Sylvester and Dévai}

With these two figures, we enter the realm of humanism, grammar, and the first printed books. They also take us into the cultural context of Cracow, and especially the circle of the printer Hieronymus Vietor (see below, and cf. Bunčić, this volume).

János Sylvester was a former student at Cracow University, and he worked as a corrector for Vietor, contributing also to the translation of trilingual editions for the printer in 1527 . He then returned to Hungary and by 1534 had started his own activity in Sárvár, in Western Hungary, in the circles of Tamás Nádasdy, future Count Palatine of Hungary (for his life and work see Horváth 2006 [1953]: 140-160, Balázs 1958, Bartók 2006, Varjas 1960). Sylvester persuaded Nádasdy to set up a printing press, which Sylvester would run himself. Sylvester had spent time in Wittenberg, and the personal influence of Melanchthon had pointed him towards the study of grammar and theology. His main project was to produce a Hungarian edition of the New Testament, and so he set to translating it, having studied beforehand the grammar of Hungarian. This activity gave rise to two works, the first forming the basis for the second: the Grammatica Hvngarolatina of 1539, and the New Testament of 1541. The latter is considered to be the first book ever written entirely in Hungarian and printed in Hungary. The choice of the typographical characters to be used (a technical question par excellence) naturally led to the question of what type of orthography to follow. This impelled Sylvester to take on a further activity, in addition to those of grammarian, Bible translator and printer: he was to establish an orthographical system which, drawing on several sources, would come to characterize his own printed production (cf. Balázs 1958: 424-426, Kniezsa 1959: 16-17, Varjas 1960: 18-24, J. Molnár 1963: 46-47, 293, Szathmári 1968: 122-127, Korompay 2003: 584-585).

We should first of all underline the innovative features of this system. Sylvester introduced several new characters, including $\langle\beta>$ to note $/ \mathrm{s} /$, and two composite characters: $<\stackrel{\mathrm{e}}{\mathrm{o}}>$ and $<\mathrm{\textrm {u }}>$, surmounted by an $e$, to note $/ \varnothing /$ and $/ y /$ respectively. Language historians consider that all three of these characters were of German origin. Sylvester's system is made up both of digraphs, such as $\langle\mathrm{cz}>$ to note $/ \mathrm{t} \mathrm{f} /$, and of characters with diacritics, such as $\langle\mathrm{t}\rangle$ for $/ \mathrm{tj} /$. In doing so, he borrowed simultaneously from the two previous traditions (it is also possible that printed use in Cracow inspired his use of diacritical signs). One of the most important innovations that he was responsible for was the use of accents, which he used to mark vowel length. The character $<\overline{\mathrm{a}}>$ was an early instance of this use. The precise values of 
the graphemes $\langle\hat{\mathrm{e}}>,<\overline{\mathrm{e}}>$ and $\langle\mathrm{e}>$ are more difficult to interpret (timbre and length may both be involved), but their presence is significant in view of subsequent developments, since, later on, accents would become the compulsory marker for all long vowels.

Dévai (whose full name was Mátyás Dévai Bíró) followed a path in many ways similar to that of his friend Sylvester. They both travelled to Cracow, Wittenberg and Sárvár (albeit at different times). Dévai was close to Luther and Melanchthon. He adhered to the ideas of the Reformation, and was himself a pioneer in the diffusion of Luther's teachings in Hungary.

The work which made him famous in the history of Hungarian spelling is entitled simply Orthographia Vngarica. It was published by Vietor in Cracow, first in 1538 (no copies remain of this edition), and again in 1549. It is a small book, printed in Hungarian, which was designed both for the teaching of writing and, because of the nature of the texts proposed, for religious education. It begins with a detailed description of the characters used, which in turn involves a number of remarks concerning pronunciation. This work, which was produced in parallel to that of Sylvester, probably benefited from the latter's experience, and was inspired by some of his inventions. The influence of the two men was, no doubt, mutual. We should also note that the Hungarian typographer Benedek Apáti, who was also trained by Vietor, played a crucial role in producing the printed works of these two authors. (For the spelling system of Dévai see Balázs 1958: 168174, Kniezsa 1959: 17, Varjas 1960: 20-24, J. Molnár 1963: 97, Szathmári 1968: 144-157, Korompay 2003: 585-587.)

Let us now turn to the innovations introduced by Dévai. To note long vowels, he systematically used various kinds of accents: the characters $<$ á $>$, $<\dot{\mathrm{e}}>,<\hat{\mathrm{i}}>,<\hat{\mathrm{o}}>$ and $<\hat{\mathrm{u}}>$ cover almost all of the long vowels. There are two graphemes which form an exception to this: the $<\stackrel{e}{\mathrm{e}}>$ and $<\stackrel{\mathrm{u}}{\mathrm{u}}>$, described earlier, whose already composite structure did not allow for an additional accent. Dévai is also known for his curious use of what he called "diphthongs", i. e. graphemes such as $<\stackrel{\mathrm{u}}{ }>$. According to specialists, these reflected dialectal varition, with $<\stackrel{\mathrm{u}}{>}$ interpreted either as /o:/, or as /u:/, depending on dialect (cf. Vértes O. 1958). Among the sources that influenced Dévai's thought, we may stress both that of the Pole Zaborowski and that of the German grammarians who succeeded him (cf. Balázs 1958: 166168, Szathmári 1968: 144, 148). 
1.4. Protestant orthography, Catholic orthography, and the historical reasons for a faith-based divide

The Reformation was adopted in Hungary at an early date, and in all its diversity. The Lutheran movement, the Calvinist reformation and the Antitrinitarian (or Unitarian) movement were all strongly embraced by 16thcentury Hungarian society (see M. Molnár 1996: 151-159). At first, all of these different movements existed in parallel, with the same people or the same communities passing from one orientation to another, without necessarily defining themselves as belonging to a particular new faith. The differences became more pronounced during the second half of the century, as a large number of debates on the subject of faith both reinforced and radicalized the different positions (cf. Horváth 2006: 249-251). Transylvania was a region which was especially open to all the new religious movements. The decision of the Diet of Torda, in 1568, to recognize the free observance and equality of rights of the four denominations (Catholicism, Lutheranism, Calvinism and Unitarianism, all four having received the status of receptae religiones) was a unique example of religious tolerance. By the end of the century, most of Hungary had adopted the Reformation. This situation was to be reversed later, with the influence of the CounterReformation (or Catholic Reformation), without however the relative importance of Protestantism ever being contested.

Confessional divisions developed in a country that was divided into three. After the Battle of Mohács (1526) and the defeat of the Hungarian army at the hands of the Turks, and the subsequent fall of the capital, Buda, in 1541, Hungarian unity would no longer exist for another 150 years. The kingdom, ruled over by the Habsburgs, was limited to the western and northern regions; the centre, which had been greatly devastated and depopulated, was annexed to the Ottoman Empire; while in the East, Transylvania became an autonomous principality whose independence was constantly under threat (cf. M. Molnár 1996: 125-163, V. Ecsedy 2000: 65-66).

One crucial fact emerged from this situation: during this period, there was no longer any central power. The royal court of Buda, which had been so strongly marked by 15 th-century Italian humanism, ceased to exist as the central political and cultural governing body. The main cultural centres, most of which had been destroyed, had to adapt to a completely different context, and moved outwards towards the border regions, which were better protected.

What became of orthographical developments under these conditions? First of all, since concepts such as "King's printer", "royal prestige" and so 
on were unthinkable under these circumstances, religious movements instead brought about the creation of new structures. Local centres emerged, in the courts of the most powerful nobles. Some of these became true patrons, gathering men of learning around them and financing the publication of their works (cf. V. Ecsedy 2000: 82-88).

Part of the programme of the Reformation was to allow every individual to have access to Bible reading in his or her own language. This entailed both a programme of translation and a programme of diffusion, the latter being largely linked to the resources of the printing press. The Protestant Church, conscious of the role of the national language, immediately recognized the importance of this technical means of diffusing its teaching. It is quite significant that the many printing houses that were founded in Hungary during the 16th century were all, with very few exceptions, linked to the activities of the Protestants.

The most important of these printing houses was no doubt that of Heltai, in Kolozsvár (Transylvania). It was founded in 1550 by Georg Hoffgreff, a printer of German origin, who soon took as an associate Gáspár Heltai, who was a Transylvanian Saxon, and therefore also a German native speaker. Heltai was an author and printer as well as a preacher, having passed successively from Catholicism to Unitarianism. Having taken over the running of the printing house in 1559 , he then produced, over a period of fifteen years, a large number of books in Hungarian, including many religious works (a series of volumes of translations covering most of the Bible), but also literary works aimed at a wider audience. The printer Heltai himself had a strong personality, and often intervened deliberately in the works of the authors he printed. By doing so, he was to have a considerable role in the unification of the spelling of the printed works he produced.

The emergence of a Protestant orthography is closely linked to his name (cf. Kniezsa 1959: 15-19, J. Molnár 1963: 122-126, 295-303, Szathmári 1968: 203-204, Korompay 2003: 587-588). In order to establish his model, he naturally borrowed from the orthographical traditions that were already in existence. Although he adopted several of the innovations that had been proposed by Sylvester and Dévai (in particular, the graph-

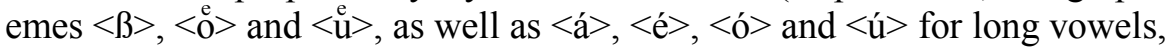
he also reverted (under the influence of Hungarian works printed in Cracow) to the orthographical habits of the Chancery, reintroducing the digraphs $<$ ty $>,<$ gy $>,<$ ny $>$ and $<$ ly $>$ for palatal consonants. He was followed in this by all subsequent printers, and the change was, this time, irreversible. 
Two books in particular made a major contribution to diffusing Protestant orthography: the first of these was the Vizsoly Bible, translated by Gáspár Károli and published in 1590. The importance of this first complete biblical translation lies above all in the exceptional role that it played in the formation of the literary language. For readers in the centuries to come, the style, the expressions and constructions characteristic of this text (which were soon to become archaic features) were synonymous with a prestigious "Biblical language", which continued to thrive even through subsequent reeditions. Its language can be found even in 20th-century poetry, and especially in the works of great poets such as Endre Ady and Mihály Babits, at the beginning of the modern era.

The second major book that diffused the Protestant orthographical model was the Psalterium Ungaricum, published by Albert Szenci Molnár in 1607. It is a verse translation of the Psalms, which was meant to be sung, and the translator and versifier was extremely careful to give a precise rendering of the words of Clément Marot and Théodore de Bèze. For more than four centuries, this Psalter has been a book of primary importance for the Hungarian Reformed Church.

The development of Catholic orthography followed a similar path, several decades later, once the importance of the national language had been fully recognized. The diffusion of this model, which was slightly different from the previous models, took place through the first Catholic translation of the Bible, established by György Káldi between 1605 and 1607, published in Vienna in 1626 (cf. Kniezsa 1959: 19-21, Korompay 2003: 588589).

What were, then, the main differences between the "Protestant" and the "Catholic" models of orthography? In fact, there were very few differences, and, if we disregard some of the initial hesitations to be found in both systems, the main differences concern the notation of affricates. From the range of spellings available, the Protestant model chose $<\mathrm{tz}>$ and $<\mathrm{ts}>$ to note respectively $/ \mathrm{ts} /$ and $/ \mathrm{t} \mathrm{f} /$, whereas the Catholic model preferred $\langle\mathrm{cz}\rangle$ and $<\mathrm{ch}>$. A slight modification occurred during the 17th century, at the initiative of Archbishop Péter Pázmány, a figurehead of the Catholic Reformation, who replaced $<\mathrm{ch}>$ by $<\mathrm{cs}>$. In printed practice and in handwritten texts, variants were, naturally, quite numerous. However, both models continued to exist until the beginning of the 19th century, a period when the unification of the national orthography became a pressing matter. A decision then had to be made, and it was the Catholic model that prevailed.

In addition to the difficult question of the affricates, variations linked to the use of $<\mathrm{i}>$ and $<\mathrm{j}>,<\mathrm{u}>$ and $<\mathrm{v}>$ should also be pointed out. Although 
the positional value of these letters prevailed over their phonetic value in 16th-century usage, the Catholic Bible of 1626 imposed modern usage and attributed a single value (vowel or consonant) to each of these letters. This Bible also eliminated the variation in usage between $<\mathrm{k}>$ and $<\mathrm{c}>$ to note $/ \mathrm{k} /$, and chose to use exclusively $<\mathrm{k}>$.

\section{External factors in orthographical change}

\subsection{A particular case of diglossia: The role of Latin}

If we are to understand the particular position occupied by Latin in Hungarian culture, we must go back in time to the meeting-point between the two languages.

When the Hungarians, who had come from Eastern Europe, settled in the Carpathian Basin around the year 900, the main problem that they were confronted with, as a semi-nomadic people, was how to integrate themselves into the structures of medieval Europe. A highly symbolic date is the year 1000, when the first King of Hungary, Saint Stephen, received the crown from Pope Sylvester II, an event which brought in its wake an alliance with Rome, and the adoption of the Roman alphabet. From then onwards, Latin was to be the language of the Church, of learning, and was the sole written language both for legal texts and for ecclesiastical literature or historiography (for an overview see Adamska 1999). (It should be pointed out that, in the 9th and 10th centuries, Hungarians had their own archaic writing system, made up of engraved marks and notches, similar to runic scripts. This writing system was probably originally borrowed from Turkish peoples who lived in the steppes, and its use all but died out once Roman letters had been adopted, see Korompay 2003: 102-105.) At first, very few members of the elite had a good command of Latin, and the key posts in the Church and in administration were held by men who had studied, from the 12th century onwards, at French universities. During the whole of the Middle Ages, the linguistic activities of learned people, who were becoming more and more numerous, took on two different orientations, according to whether they were using the oral or the written idiom: if they were writing a text, it would be in Latin; if they were addressing others orally, it would be in Hungarian. This led to the extraordinary role played by oral transmission: a genuine exercise in translation, which was carried out by the same members of the ecclesiastical elite, both in Church spheres and in practical matters. The language of this particular group, which de- 
veloped through exercise and is known today as the "secondary oral register" (see Tarnai 1981: 19-22, 1984: 229-239), left its mark on the structures, the vocabulary and the style of the first written texts.

This type of diglossia is quite characteristic of the spirit of medieval culture, in which "people spoke their vernacular and wrote in Latin" (Catach 2001: 26). However, there are some features that are proper to the Hungarian experience. First of all, unlike the situation of the Romance languages, in which Latin and French, for example, were felt to be one and the same language (Latin was read "as if it were French" and French was written "as if it were Latin", see Catach 2004: 9), as far as Hungarian (a FinnoUgrian language) was concerned, Latin was perceived as a completely alien language, absolutely incomprehensible to anyone who had not studied it, and, as far as those who used it were concerned, possessing structures that were quite different from the structures of their native language. Secondly, and quite paradoxically, Latin was to gain, in Hungary, the status of "father language" (to use an expression that prevailed during the 19th century), because of the extraordinary role as language of culture that it fulfilled for many centuries.

We can give two rather striking examples of this situation. The first one concerns the Hungarian word diák deák, which goes back ultimately to the

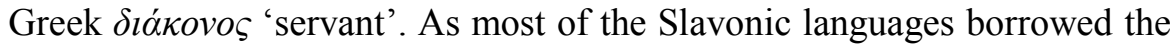
Greek word (in the senses of 'student', 'pupil', 'scribe', etc.), it was then passed on via them to Hungarian, and then a semantic shift occurred: the word came to mean not only a man of letters and of learning, but also the language through which this learning was acquired (cf. Horváth 2005: 487). This led subsequently to the emergence of a second meaning for the form deák, which came to mean 'Latin (language)'. This semantic shift, which took place only in Hungarian, speaks volumes about the importance of Latin, the language of learning at all levels.

Latin was also a vehicular language for intercommunication, as we can see from many travellers' tales. We may take the example of an Englishman, Edward Brown, who visited Hungary in 1668 and said that he had met coachmen, ferrymen and other ordinary people who could make themselves understood in Latin (see Tóth 1996: 148-149). We also have the reverse example, that of a Hungarian, Márton Szepsi Csombor, who on arriving in London was amazed to find, after passing through three whole streets full of merchants, furriers and tailors, that there was nobody who could speak to him in Latin (Europica Varietas, 1620). The importance of Latin, both as a written and as a spoken language, was to remain strong until the beginning of the 19th century, in many spheres of public life. 


\subsection{The emergence of a written national idiom}

During the Middle Ages, the vast majority of texts in Hungarian were texts that had been translated from Latin. There were relatively few texts in circulation until the 15th century. Whether this situation is due to texts having been lost or whether there was a very limited production is still a question which is open to debate. According to the medievalist László Mezey, the total number of lost manuscripts, for the whole of the medieval period, could represent as much as $98-99 \%$ (cf. Madas 1998: 50). Events such as the Mongol invasion of 1241 or the advance of the Ottoman army from 1526 onwards, were certainly responsible for the destruction of a large number of texts. Moreover, as learning and writing were so closely linked to use of the Latin language, the Church had an effective monopoly on written production for centuries, and there was in Hungary no real audience (and especially no lay audience) which would have encouraged the emergence of a readership in Hungarian.

Nevertheless, schools did exist: there were monastery schools and chapter schools in which future scholars were taught, but also parish schools which were created in towns and even in villages, especially during the 14 th and 15 th centuries. The use of the written word eventually got through to a lay audience, even though the process was slow and took time. A remark made by Dévai is significant in this respect: in the introduction to his Orthographia Vngarica of 1538 (1549), he insists on the acquisition of reading and writing skills as doubly important: first of all, they allow people to read the Scriptures, but they are also useful insofar as they allow people to communicate with each other, without having to resort to intermediaries for the slightest matter. This was a significant recognition of the importance of letters, in all senses of the word.

In the context of 16th-century Hungarian society, Protestantism was a driving force in favour of the spread of learning. The hundred and fifty "colleges" created during this period made an important contribution to teaching lay people, for whom the book was an essential means of access to culture. A readership began to emerge and private libraries grew up. It was during this time that the first great Hungarian lyrical poet, Bálint Balassi (1554-1594), arrived on the scene.

Private correspondence began to increase in significant proportions during this period, especially in noble families. Missives were regularly exchanged between spouses or between the master of the house and his righthand man, often separated because of wars or for business reasons. This correspondence was carried out with the help of scribes, who were indis- 
pensable figures in the functioning of noble courts. For the period before 1541, 244 missives are documented (see Hegedüs-Papp 1991), and this number increased greatly during the second half of the century, when a large part of the population took refuge in the northern and western regions. These migratory movements had important repercussions on cultural life and on the development of norms for the written language. The mixing of populations encouraged a similar mixing of dialectal forms, and the missives, set to paper by scribes, bear witness to their tendency to give priority to certain forms and to eliminate others. It is in their writings that we find the first signs of an emerging standardized written language. The evolution of this norm had a reconciliatory dynamics. No single dialect was standardized, although the north-eastern one had the highest prestige and the greatest influence. There is a paradox here that we should never lose sight of: it was at this time, in a country that was anything but unified, that the unification of the Hungarian language took place.

We should also note, from an orthographical point of view, that this specific written genre presents an infinite range of variation. All the models that were present throughout the 16th century are represented in scribal practice, and the scribes developed their own particular usage by experimenting freely with all the possibilities that presented themselves to them, in succession. Because of their particular status, they were indeed freer to experiment than were copyists or printers, and this freedom of choice led to a wide range of variation. For example, to note $/ \mathrm{t} f /$, a scribe had at his disposal several graphemes: $<\mathrm{ch}>,<\mathrm{cz}>,<\mathrm{ci}>,<\mathrm{cy}>,<\mathrm{chy}>,<\mathrm{c}>$ or $<\mathrm{ts}>$.

In Transylvania, the status of Hungarian underwent a special separate development. Hungarian had been in use as the legal language from as early as 1565 , which contrasts with other Hungarian regions. Similarly, legal texts written in Hungarian had become more and more common, the first of these dating back to the mid 15th century. Today, thanks to the extraordinary efforts of one particular scholar, Attila Szabó T., and his Historical Dictionary of the Hungarian Language in Transylvania to appear in fifteen volumes (1975-), we have at our disposal a wealth of information concerning all the cultural and linguistic aspects of this period, including orthography.

\subsection{Two key cultural institutions: Universities and printing houses}

In Hungary, several unsuccessful attempts were made by various kings to found a university, in particular in 1367, 1395, 1410 and 1467. Young Hungarians therefore went to study at the universities of Prague, Cracow 
and Vienna (founded in 1348, 1364 and 1365 respectively), which were the main three university centres in Central Europe from the 14th century onwards. Between 1455 and 1559, the universities of Vienna and Cracow took in five thousand Hungarian students. These two towns were also the most important printing centres of the time.

The city of Cracow played a central role, in many ways, in the teaching of Hungarian students from the beginning of the 16th century. The humanist spirit and the teachings of Erasmus were transmitted there by the English scholar Leonard Cox. Links were established between men of learning from different countries, different languages and different backgrounds, and we can see traces of these links in their numerous publications. Cracow was an important centre for the history of the printed book, but it was especially an important centre for Hungary: the first books in Hungarian were printed there by Hieronymus Vietor (cf. Varjas 1969, V. Ecsedy 2000; see also Bunčić, this volume).

The first books to be printed were two little books for schoolchildren in 1527 (written by Christoph Hegendorff and Sebald Heyden): they were books in Latin but with several passages translated into three vernacular languages: German, Polish and Hungarian. Sylvester also published his first translations here. The second book was the Lexicon of Joannes Murmellius, which was printed in Latin, German and Hungarian in 1533. This same year saw the printing of the translation of the Epistles of St Paul by Benedek Komjáti. This edition, which was printed entirely in Hungarian, had the characteristic feature of being printed in Roman type, which constituted a break with tradition, since Roman type had until then been reserved for printing in Latin. A total of thirty-one books, either totally or partially in Hungarian, were printed in Cracow during the 16th century.

A logical consequence of these particular links was that all the orthographical models introduced for Hungarian printed works at the time were strongly influenced by practices that were in use in Cracow. We do not intend to go into the question in much more detail here, but we may recall the importance of Cracow as a printing centre for Sylvester and for Dévai, and we may add that, indirectly, even Heltai had links with this tradition, as he adopted Roman type from a very early date. Seeing that the orthography of Jan Hus had a very strong influence on many Central European languages (Czech, Hungarian and Polish), it is very likely that the founder's role may go a long way to explain similarities and borrowings between these languages.

A historical study of printing houses in Hungary opens a much broader perspective. The first printing press was established in Buda as early as 
1473, by Andreas Hess, a German printer who had come from Rome. It was he who printed the first book ever printed in Hungary: a very fine edition, in Latin, of the Chronica Hungarorum. Hess, however, did not stay very long in Hungary, nor did his successor, and it was not until fifty years later that another printing house would be established in Hungary (for a detailed view see Varjas 1969: 80-99). The situation was rather different in Transylvania, and especially in the Saxon centres of Szeben (Hermannstadt in German, Sibiu in Romanian) and Brassó (Kronstadt or Braşov). Printing centres were established here in 1529 and in 1539. The latter was run by Joannes Honter, a key figure of the Reformation in this region. He printed a number of books in German, Latin and Greek. During the same period, Vienna also played an important part in the publication of books in Hungarian. It was in this city that the works of Gábor Pesti were published, by Johann Singriener, including his New Testament of 1536. Books printed in Hungarian in Vienna had the characteristic feature of following Chancery orthography faithfully, which was a major departure from the usage that prevailed elsewhere at that time. We should also point out a fact that is linked to the mobility of printing workers at the time: many printers and typographers were of foreign origin, usually German. Bálint Mantskovit, who published the Protestant Bible in 1590, was Polish. From the middle of the 16th century onwards, more and more printing centres were established in Hungarian towns. This was just one manifestation of a wider movement, "under the aegis of the Reformation" (to use an expression coined by the literary historian János Horváth [2006]), which encouraged various literary movements. In this context, the creation of a printing house entirely devoted to the publication of Catholic works, in Nagyszombat (Trnava in Slovakian) is something of an exception. This latter town played an important part in the history of higher education. It was in this town that a Jesuit school was founded by Archbishop Péter Pázmány in 1635: this institution was to give rise to the first university created on Hungarian soil, and which is now the Eötvös Loránd University of Budapest.

\subsection{Discovery of the Hungarian language by grammarians}

Do vernacular languages have a grammar that is peculiar to them? This is a question that was asked by a large number of scholars, all over Europe, when they started studying the various European vernaculars. The description of these languages is linked, indissociably, to that of Latin. Grammatical descriptions of these vernacular languages went through three stages 
from the 15th to the 16th century: first of all, "commentaries" on vernaculars in Latin grammars, then bilingual grammars (of the "hispano-latina", "latino-gallica" or "hungaro-latina" sort), and, finally, works written in the vernacular itself (see Balázs 1961).

Sylvester's Grammatica Hvngarolatina (1539) is the first known systematic description of the Hungarian language. It was one of the bilingual grammars that adopted, quite naturally, the theoretical framework that was in use for Latin at the time, and whose main representatives were Donatus and Priscian. This was all the more difficult in the case of Hungarian, as the two languages did not share a common origin and were quite different. Two other influences should be mentioned: that of Melanchthon, and that of Hebrew grammar. Sylvester had been a pupil of Melanchthon's in Wittenberg, and he referred to the latter as praeceptor noster. Melanchthon had, among other things, pointed out that the article, in Greek (which had no equivalent in Latin), could only really be understood by looking at German grammar. Sylvester, who was intrigued by this fact, realized that the article also existed in Hungarian, and that it was even an element which lent majesty and weight to speech (see Horváth 2006: 150-151). Through this experience (and others too), he was led to discover many of the specific features of his own language ("alia enim est ratio syntaxeos nostrae linguae, alia latinae"). Because of the existence of parallel features on the one hand, and of divergent features on the other hand, Hungarian appeared to him as a language that was worthy of studying, regulatissima just like the ancient Classical languages, and a source of hidden treasure to be uncovered.

This led on to a whole programme of reflexion about Hungarian as a national language, trying to define rules for it so that it could be taught, inspired by humanistic ideas, of which Sylvester was the first representative in Hungary.

The role of Hebrew should also be underlined, for several reasons. Brought to light by biblical studies, sacred language par excellence, Hebrew also imposed itself as a linguistic model, and as a model it was much more adequate for describing the structures of Hungarian than Latin was. It was through Hebrew that the Hungarian grammatical tradition discovered, after a great deal of time and effort, the existence of the morpheme, the central element in agglutinative languages. The same process took place for Finnish and Estonian, these three related languages having gone initially through the "Latin" school of analysis before finding, thanks to Hebrew, the key to their common features (cf. Constantinovitsné Vladár 2005: 6990). Sylvester, who was a professor of Hebrew and later of Greek, at the University of Vienna, towards 1544 , was the first person to realize the im- 
plications of this language for the study of Hungarian. Sylvester was also responsible for a major discovery in the field of prosody and versification. While he was correcting the proofs of his New Testament (1541), having got to the last few pages, he was surprised to notice the rhythm of certain sentences, which reflected different types of ancient meters (cf. Horváth 2004 [1943]). Like Latin and Greek, Hungarian was then also a language in which one could write hexameters, pentameters, distiches... This "hidden treasure" again filled him with admiration, and gave rise to a fine poem which he set at the beginning of his translation of the New Testament. This was the first instance of a poem in Hungarian written in ancient meters.

\section{The internal characteristics of change}

\subsection{Comparative study of 16th-century models: The nature of variation}

The orthographical models that emerged successively and existed in parallel during the 16th century have many features in common. First of all, they are all phonemic systems. Where significant divergences do exist, this is either because the various models are organized according to different principles (use of digraphs versus use of diacritics), or because specific choices have been made concerning the choice of graphemes to note the same phonemes.

First of all, a comparison must be made of the Chancery model and the Hussite model, both of which are to be found in 15th- and 16th-century codices. These two models, indeed, are quite different as far as the principles that govern them are concerned. As for their use, they also present several characteristics that deserve to be examined. Originally, the chronological gap between the two was considerable: the Chancery model had been in existence for several centuries, whereas the second, created all of a piece at one particular time, is a more recent construction. Moreover, the two models differ considerably when we look at history of the ways in which they were created. While the Chancery model was formed collectively, and was fashioned by anonymous scribes over the centuries, the Hussite model was an audacious invention, the work of a few individuals who were seeking to make a break with the previous tradition, by applying to Hungarian the principles of a system that had originally been designed for another language. Finally, the difference between the models is also linked to the different communities in which they were used: whereas the Dominicans remained faithful to the Chancery model, the Franciscans had a 
preference for the Hussite model. Neither of the models was ever dominant, and scribal practice shows that there was a lot of interference between the two: indeed, the Franciscans and Dominicans frequently copied each others' manuscripts.

The fact that, as far as orthography is concerned, there was no regional variation in these texts can be explained by the simple reason that the two scriptoria that produced the most codices were situated only a few hundred yards from each other, in what is today Budapest: on St Margaret's Island for the Dominican nuns, and in Óbuda for the nuns of the order of St Clare (whose manuscripts were written by the Franciscans). The date of the Battle of Mohács of 1526, which was a fateful date for Hungarian history in general, was also fateful for the scriptoria of these two orders: a flourishing written medium, that of codices, was to disappear together with the places that had given rise to it.

In a similar way, the systems of Sylvester and of Dévai also share a large number of common characteristics. Both of these systems are composite, using both digraphs and diacritics; both of them draw on the previous existing models and propose, at around the same time, innovations designed for similar purposes. The function given over to accents, which from now on were to note vowel length, was one of the most promising features to emerge from these systems. We should bear in mind at this point that, generally speaking, the printed medium, unlike the scribal tradition, encouraged the use of accents (Catach 2001: 126-133). The fact that Sylvester's works were published in Sárvár and Dévai's in Cracow did not give rise to any significant differences, since Sylvester himself had been trained in Cracow, at Vietor's printing house. Specialists of the subject consider that it is very likely that the significant role given over to accents originated in the Polish orthography of the time (cf. Kniezsa 1959: 16, V. Ecsedy 2000: 106).

With the Protestant and Catholic models, which were very similar in their structures and only differed in their choice of the use of certain digraphs, we enter into the heart of a difference that is, apparently at least, based on a faith divide. However, a closer analysis reveals that the crux of the matter is probably elsewhere. In a country which had been divided into three, any possible unification of orthography became difficult, if not impossible. And, at the time, since this was the time of Bible diffusion, the books that came out of the Protestant printing houses spread a particular type of orthographical model (in the absence of a fixed model that could have been adopted by everybody). In the same way, the Catholic version of the Bible diffused a slightly different model. In this perspective, the succes- 
sive emergence of two orthographical tendencies, which were each to remain in use in parallel, for two centuries, is the sign of a complex situation which reveals the importance of religious movements in cultural life, but also, reading between the lines, the difficulties of a particular period during which the absence of certain structures was harshly felt.

\subsection{The importance of the morphological principle}

As Hungarian is an agglutinative language, contact between stems and suffixes (derivational suffixes, inflections) often results in phonemic merging, and this inevitably leads to orthographical problems. It is a feature which occurs especially in verb and noun morphology. The following is a typical example: when the stem ends in $t, d, n$ or $l$ (or their palatal variants), and the suffix begins with $j$, this regularly gives rise to the geminate palatal consonants [tj:], [dj:] and so on. The writer, when faced with this phenomenon, has two choices: first, he can follow his ear, in which case he will note what is pronounced, and this will produce written forms such as $<$ tty $>$, $<$ ggy $>$ etc. This was the solution that was retained in Chancery orthography, and the solution that continues to be used in present-day Hungarian orthography. The second option is to take into account the original form of the two elements, to write $\langle\mathrm{tj}\rangle,\langle\mathrm{dj}\rangle$, and to accept that, in this case, writing does not mirror speech exactly. In the second case, the morphological principle prevails. Grammatical analysis often favours the second option, because it is the only one that can guarantee graphic stability in the paradigms. We may illustrate this by looking at a series of three verb forms constructed on the base tud 'to know': tudom 'I know it', tudod 'you know it', tudja 'he/she knows it'. If we apply the morphological principle, the third form fits in perfectly with the rest of the group - which would not be the case if it were written *tuggya, respecting the phonemic principle.

Without going into a detailed analysis of other cases, we may give just one more example: the very common cases in which $t, d$, ty or gy merge with sibilants or with palato-alveolar fricatives. This regularly gives rise to the affricates $/ \mathrm{ts} /$ and $/ \mathrm{t} \mathrm{J} /$. The question is, once more, whether to note this phenomenon phonemically, or whether it is better to keep the "unmerged" base forms. Of particular interest to this question is the fact that, among the numerous digraphs that were used to note affricates in the 16th century, we find, among others, the two graphemes $<\mathrm{tz}>$ and $<\mathrm{ts}\rangle$, characteristic of "Protestant" orthography, and which correspond to the prescriptions of the morphological principle. However, not all affricates resulted from phoneme 
merging: some are found, for example, in word-initial position. Thus, the graphemes $<\mathrm{tz}>$ and $<\mathrm{ts}>$ of this period often pose the delicate question of whether they should be interpreted as reflecting the morphological principle, or whether they are just simple digraphs.

Medieval scribes rarely had any regard for morphology. Most of the time, they wrote phonologically, and wrote merged consonants according to what they heard. However, the question of how to write merged consonants soon arose, thanks to the grammarians. This happened in the 17th century, when István Geleji Katona, scandalized by his printer's "ignorant" interventions in the spelling of his book of hymns, decided to set down a clear set of directives on the question. This was what he proposed in his Short Hungarian Grammar of 1645, and the rules that he set down then are exactly identical to the rules that prevail on the subject today (cf. Kniezsa 1959: 21-22, Szathmári 1968: 245-247, Korompay 2003: 589-592). However, even though a number of illustrious grammarians followed Geleji's precepts, it was not until the beginning of the 19th century, with a "battle" between those in favour of the $<j>$ forms and those in favour of the $<y>$ forms (the tudja/tuggya opposition seen earlier), that the phonemic versus morphological question was debated, and it was decided to give priority to respecting the morphological principle.

During the 16th century, another particular point led to a debate of a similar nature. The definite article $a z$, which was originally invariable, developed a variant which became quite common in the spoken language, in which the $z$ was dropped before an initial consonant. The opinions of the grammarians Sylvester and Dévai diverged on this point: Sylvester (whose interest in the article we have already seen) refused to drop the $z$ in the written form, on the grounds that speech could vary but orthography must remain stable. Following this logic, he proposed forms such as az barát 'the friend'. Dévai, on the other hand, favoured the phonemic principle, and therefore the form ab barát, with the geminate consonant corresponding, in this case, to a regional pronunciation. Later on, the Protestant Bible (1590) introduced an apostrophe to mark the disappearance of the $z, a^{\prime}$ barát, and this form was to subsist for several centuries. It was not until an orthographical reform in 1856 that the modern written form, a barát, was finally adopted.

This brief example is symptomatic of many things. It shows the different variations of a situation of compromise in which the simplest, most phonemic spellings have difficulty in becoming established when confronted with the constant effort to retain a link with the original base form, the latter being, of course, retained before an initial vowel (e.g., az inter- 
net). From another point of view, this case reminds us of similar variation concerning articles in other European languages (le, la, $l$ ' in French, a/an in English), in which the alternation of consonantal and vocalic forms is also a key question in the development of written forms.

\subsection{Punctuation}

The differences between printed and handwritten use are especially acute in the case of punctuation.

As far as codices are concerned, it is important to point out that, although the latter are often referred to as "manuscript books", they are not always genuine "books" in the modern sense of the word, being often a simple gathering together in book form of texts of different origins. Some of these collections have a certain internal coherence; others do not. Very often, there are no divisions within the text: a typical page is a page which is fully covered with writing, paragraphs are rare, and leaving blank spaces has been scrupulously avoided. The titles of chapters or incipit are often written in red ink. Punctuation is scarce, and very few marks are used: the full stop, the oblique stroke and the colon are the main ones, to which we may add the use of capitals, red letters, correction marks, etc. (cf. Keszler 1995: 30-56, Korompay 2003: 298-299). The question mark exists, but its use is unsystematic: sometimes it is used instead of an exclamation mark, as the latter did not exist in 16th-century Hungarian orthography. We can find very great differences in punctuation from one manuscript to another: there is a whole range of different usages, varying from (a few) manuscripts in which capital letters are practically the sole means of punctuation, to (a few) manuscripts in which several elements are used with quite distinct functions. It is often the combination of a single sign and the alternation between capitals and lower-case letters that allows us to distinguish between two essential functions: either closing, or some other function. Of particular interest is the variation that is linked to the particular uses of different communities. Generally speaking, the Dominicans used only a limited range of punctuation marks, and did not use the question mark. The Franciscans, on the other hand, used a wider range of elements, but not always in a coherent way. In the rare codices copied by Carthusian monks, question marks are written in such a particular way (as pipe-shaped marks) that this feature is considered as a characteristic of the manuscripts copied by monks of this order (cf. Keszler 2007: 8, 12). 
In printed works, the need for clear presentation gave rise to structuration of texts along more stringent lines. Title pages, division into chapters, blanks, are all used to show the major divisions of the text. The use of punctuation becomes both finer and more coherent. The main signs used are the full stop, the comma and the colon, to which we may add the semicolon (end of the 16th century) and the exclamation mark (beginning of the 17th century), cf. Keszler (1995: 47, 55, 68). The Nova Grammatica Ungarica (1610) of Albert Szenci Molnár is the first grammar to give a complete list of punctuation marks.

\section{The legacy of 16th-century orthography today}

Hungarian orthography never varied more at any time than it did in the 16th century. It was an important transitional period between the medieval tradition (with the production of codices continuing to flourish during the first quarter of the century) and new developments which associated the diffusion of texts through printing and the teachings of the Reformation, both of which brought about a major shift in mentalities. It was in this context that new orthographical models appeared on the scene in succession.

What have these models left to our present-day orthography? First of all, a whole set of graphemes that are still in use today were introduced at this time, together with the rules governing their use. There are several examples of this: the graphemes used to note the phoneme /s/, palatal consonants, rounded front vowels and long vowels. These were, generally speaking, the elements that had been the most problematic for the written language, ever since the Roman alphabet had been adopted to note the phonological system of Hungarian.

As far as /s/ is concerned, the modern notation was introduced by Sylvester. At the time, it had a variety of forms $\left(\beta, \delta, \beta_{3}, \beta_{3}\right)$, which are considered by specialists to be variants of $s z$. This innovation would be adopted by all the models that followed.

For palatal consonants, diacritical signs came into competition with the medieval tradition of digraphs $(<\mathrm{ty}>,<\mathrm{gy}>,<\mathrm{ny}\rangle,<\mathrm{ly}>$ ), and, although Sylvester and Dévai adopted the new signs, the printer Heltai restored the use of digraphs, and they came back into general use from the second half of the 16th century onwards.

Rounded vowels were noted, in printed works, by the characters $\stackrel{e}{o}$ and $\stackrel{e}{u}$, introduced by Sylvester and Dévai. They were adopted very quickly, but soon posed a small question, that of the evolution towards the present-day 
characters $\ddot{o}$ and $\ddot{u}$ (with the trema replacing the superscribed $e$ ). The early signs of this changeover were visible by the beginning of the 17th century. However, variants continued to exist side by side for some time. The use of variants often depended on the printing houses. In Szenci Molnár's Psalter of 1607, we find both sets of forms, while in a dictionary printed in 1708, the printer eliminated the archaic forms that were present in the author's manuscript, substituting the new forms.

As for long vowels, their systematic notation by means of accented characters was already adopted in the 16th century, and it was Sylvester and Dévai who introduced this innovation. Although most vowels could be noted in this way without any difficulty, with an accent similar to the acute accent used in French, this was not the case for $<_{0}^{e}>,<\stackrel{e}{\mathrm{u}}>,<\ddot{\mathrm{o}}>,<\ddot{\mathrm{u}}>$, which were already too complex to allow for notation by a further accent. It took a long time and a large amount of variation for the modern-day forms $<0 \%$, $<\ddot{u}>$ to come into general use, during the first half of the 19th century.

A synthetic view of the changes described here reveals that, for noting consonants, the preference went to digraphs, and that parallel spellings, based on the use of diacritical signs, would gradually be eliminated. As far as vowels were concerned, however, during the same period, we see the opposite trend: diacritical signs were favoured to note both the timbre of certain vowels, and to note their length, a notation which gradually became generalized.

Thus, one of the characteristic features of Hungarian orthography today, namely, its eminently composite nature, using digraphs for consonants and diacritics for vowels, originated in the period so strongly marked by variation that was the 16th century.

(The original French text was translated into English by Susan Baddeley) 


\section{References}

\section{Primary sources}

Bartók, István

2006 Sylvester János, Grammatica Hungarolatina (Bibliotheca Scriptorum Medii Recentisque Aevorum XV.), Budapest: Akadémiai Kiadó: Argumentum. Critical edition. Digital version: http://www.mek.oszk.hu/05700/05725/index.phtml (accessed 13 February 2012).

Dévai Bíró, Mátyás

1549 Orthographia Vngarica, Krakow. Digital version: http://www.mek.oszk.hu/02700/02712/index.phtml (accessed 13 February 2012).

Geleji Katona, István

1645 Magyar Grammatikatska [Hungarian grammar]. Gyulafehérvár.

Hegedüs, Attila, and Lajos Papp

1991 Középkori Leveleink (1541-ig) [Hungarian letters from the Middle Káldi, György Ages, before 1541]. Budapest: Tankönyvkiadó.

1626 Szent Biblia [The Holy Bible]. Vienna.

Károlyi Gáspár

1981 Károlyi Gáspár Vizsolyi Bibliája [The Vizsoly Bible], 1590, facsiPápai Páriz, Ferenc mile edition. Budapest: Magyar Helikon.

1708 Dictionarium Latino-Hungaricum, Dictionarium Hungarico-Latinum.

Leutchoviae (Lőcse).Varjas, Béla

1960 Sylvester János, Új Testamentum. Újsziget, 1541. Bibliotheca Hungarica Antiqua, I. Budapest: Akadémiai Kiadó. Facsimile edition of Sylvester's New Testament. Digital version: http://mek.oszk.hu/06900/06987/index.phtml (accessed 13 February 2012).

\section{Secondary sources}

Adamska, Anna

1999 The introduction of writing in Central Europe (Poland, Hungary and Bohemia). In New Approaches to Medieval Communication, Marco Mostert (ed.), 165-190. Turnhout: Brepols.

Balázs, János

1958 Sylvester János és Kora [János Sylvester and his time]. Budapest: Tankönyvkiadó. 
Balázs, János

1961 Nyelvtanirodalmunk előzményei és kezdetei [The background to and the beginnings of Hungarian grammatical literature]. In Nyelvtani Tanulmányok [Grammatical studies], Béla Sulán (ed.), 167-185. Budapest: Tankönyvkiadó.

Balázs, János

1989 A latin a Duna-tájon [Latin in the Danube region]. In Nyelvünk a Duna-Tájon [The Hungarian language in the Danube region], János Balázs (ed.), 95-136. Budapest: Tankönyvkiadó.

Catach, Nina

1968 L'Orthographe Française à l'Epoque de la Renaissance (Auteurs Imprimeurs - Ateliers d'imprimerie). Genève: Droz.

Catach, Nina

1994 La Ponctuation (Histoire et Système). (Que sais-je?) Paris: Presses Universitaires de France.

Catach, Nina

2001 Histoire de l'Orthographe Française. Paris: Honoré Champion.

Catach, Nina

2004 L'Orthographe. 9th edition. (Que sais-je?) Paris: Presses Universitaires de France.

Constantinovitsné Vladár, Zsuzsa

2005 A Latin Nyelvü Magyar Nyelvészeti Irodalom Terminusai [Hungarian grammatical terms taken from Latin]. Philosophiae Doctores. Budapest: Akadémiai Kiadó.

Horváth, János

2004 "Próféták által szólt rígen..." ["Through the mouths of the prophets...”]. In Horváth János Verstani Munkái [Works by János Horváth on versification], János Korompay H., and Klára Korompay Horváth János (eds.), 329-341. Budapest: Osiris Kiadó. Original edition, 1943.

2005 A magyar irodalmi müveltség kezdetei [The beginnings of Hungarian literary culture]. In Horváth János Irodalomtörténeti Munkái [Works by János Horváth on literary history], János Korompay H., and Klára Korompay (eds.), I, 477-705. Budapest: Osiris Kiadó. Original edition, 1944.

Horváth, János

2006 A reformáció jegyében [Under the sign of the reform]. In Horváth János Irodalomtörténeti Munkái [Works by János Horváth on literary history], János Korompay, and Klára Korompay (eds.), II, 7-507. Budapest: Osiris Kiadó. Original edition, 1953.

Keszler, Borbála

1995 A Magyar Írásjelhasználat Története a XVII. Század Közepéig [History of Hungarian punctuation until the middle of the 17 th century]. Budapest: Akadémiai Kiadó. 
Keszler, Borbála

2002 Zur Geschichte des Ausrufezeichens. Annales Universitatis Scientiarium Budapestinensis de Rolando Eötvös Nominatae, Sectio Linguistica 25: 99-110.

Keszler, Borbála

2004 Írásjeltan. Az Írásjelhasználat Szabályai, Problémái és Története [Punctuation. Rules for use, problems, history]. Budapest: Nemzeti Tankönyvkiadó.

Keszler, Borbála

2007 Írásjeltan és interdiszciplinaritás [Punctuation and interdisciplinarity]. Magyar Nyelv 103: 1-16.

Kniezsa, István

1952 Helyesírásunk Története a Könyvnyomtatás Koráig [History of HunKniezsa, István garian orthography before printing]. Budapest: Akadémiai Kiadó.

1959 A Magyar Helyesírás Története [History of Hungarian orthography]. 2nd edition. Budapest: Tankönyvkiadó.

Korompay, Klára

2003 Helyesírás-történet [History of orthography]. In Magyar Nyelvtörténet [History of the Hungarian language], Jenö Kiss, and Ferenc Pusztai (eds.), 101-105, 281-300, 579-595, 697-709, 781-788. Bu-

Korompay, Klára dapest: Osiris Kiadó.

2004 Grammaire et orthographe, au carrefour d'influences linguistiques et culturelles (domaine hongrois, parallélismes français). In La Circulation des Hommes, des Euvres et des Idées entre la France, l'Italie et la Hongrie (XV $V^{e}-X V I I^{e}$ siècles). Actes du Colloque International, Paris, 21 et 22 Janvier 2000 Université de la Sorbonne NouvelleParis III, Amadeo Di Francesco, and Adelin Charles Fiorato (eds.), Korompay, Klára 121-135. Naples: M. D’Auria.

2006 Helyesírás-történet, müvelődéstörténet: két tudományág dialógusa, különös tekintettel a huszita helyesírásra [History of orthography, history of civilisation: dialogue between two fields, with special ref-

Madas, Edit erence to Hussite orthography]. Magyar Nyelv 102: 204-209.

1998 Középkori bibliafordításainkról [Hungarian translations of the Bible Molnár, József in the Middle Ages]. Iskolakultúra 98 (1): 48-54.

1963 A Könyvnyomtatás Hatása a Magyar Irodalmi Nyelv Kialakulására 1527-1576 között [The influence of printing on the formation of the Hungarian literary language from 1527 to 1576]. Budapest: Akadémiai Kiadó. 
Molnár, Miklós

1996 Histoire de la Hongrie. Paris: Hatier.

Szabó, Flóris

1989 Huszita-e a Huszita Biblia? Bírálat és útkeresés [Is the Hussite Bible Hussite? Critical views, research perspectives]. Irodalomtörténeti Közlemények 93: 118-126.

Szabó T., Attila

1975- Erdélyi Magyar Szótörténeti Tár [Historical Dictionary of the Hungarian vocabulary of Transylvania], I. Bucarest: Kriterion.

Szathmári, István

1968 Régi Nyelvtanaink és Egységesülö Irodalmi Nyelvünk [The oldest grammars of the Hungarian language and the unification of the liter-

Tarnai, Andor ary language]. Budapest: Akadémiai Kiadó.

1981 Szóbeliség - latinság - írásbeliség [L’oral, le latin et l'écrit]. In $A$ Magyar Kritika Évszázadai I. Rendszerek a Kezdetektöl a Romantikáig [Hungarian literary criticism throughout the centuries. I. Systems developed from the beginnings until the Romantic period]. István Sötér (ed.), 11-26. Budapest: Szépirodalmi Könyvkiadó.

Tarnai, Andor

1984 “A Magyar Nyelvet Írni Kezdik”. Irodalmi Gondolkodás a Középkori Magyarországon ["Starting to write in Hungarian". Literary reflection in medieval times]. Budapest: Akadémiai Kiadó.

Tóth, István György

1996 Mivelhogy magad Írást nem Tudsz... [As you don’t know how to write...]. Budapest: MTA Történettudományi Intézete.

Varjas, Béla

1969 A magyar könyviadás kezdetei és a krakkói magyar nyelvü kiadványok [The beginnings of the Hungarian book trade and the Hungarian-language publications of Cracow]. In Tanulmányok a Lengyel-Magyar Irodalmi Kapcsolatok Köréböl [Studies on Hungaro-Polish literary relations], István Csapláros, Lajos Hopp, Jan Reychman, and László Sziklay (eds.), 79-128. Budapest: Akadémiai Kiadó.

Vértes O., András

1958 Nyelvjárási változatok vagylagos jelölése Dévai Bíró helyesírásában [Characters with a dual value used by Dévai Bíró to note dialectal variants]. Magyar Nyelv 54: 22-32.

V. Ecsedy, Judit

2000 Die Rolle des Krakauer Druckwesens in der ungarischen Kultur des XVI. Jahrhunderts. In Rola Krakowskich Drukarzy w Kulturze węgierskiej-Die Rolle des Krakauer Druckwesens in der Ungarischen Kultur - A Krakkói Nyomdászat Szerepe a Magyar Müvelödésben, 61-118. Budapest: Balassi Kiadó. 



\title{
Finnish
}

\section{Standardization of Finnish orthography: From reformists to national awakeners}

\author{
Taru Nordlund
}

\section{Introduction}

This article examines the standardization of Finnish orthography, concentrating on the two periods of rapid development: the 16th and the 19th centuries. The first part discusses the role of the Western Church at the early stages of written Finnish: conversion to Christianity and especially the Lutheran Reformation in the 16th century set the foundations for the usage of Finnish as a literary language. To provide a background to the standardization of orthography in the 16th and the 19th centuries, the spelling system of Modern Finnish is introduced in section 2. The following sections 3-5 discuss the orthography of the earliest writings and provide some examples of the problems that the first writers were faced with. The second external trigger for the evolution of Standard Finnish was European nationalism, which had reached Finland by the beginning of the 19th century. This era was characterized by a strong desire for nation-building, which was linguistically reflected in the process of standardization with its often heated debates about the "authenticity" or "purity" of the language. In section 6, aspects of 19th-century spelling are discussed. In most respects, the orthography of 19th-century Finnish resembles that of Modern Finnish. However, there were some debates on orthography that clearly reveal the nationalistic aspirations of the time. At the end of the article, one of these debates is discussed in more detail. 


\section{The role of the Western Church in the early stages of literary Finnish}

\subsection{Traces of written Finnish in medieval Finland}

In the 12th century, the Catholic Church stretched its northernmost point of influence to Finland. However, the language used by the Church, Latin, had no tradition in Scandinavia. It is therefore difficult to estimate how much of the religious message of the Church was meant to be taught to the people, and more importantly, how much of this message was actually understood. Even though the language of the Church was Latin, it has been speculated that some Finnish must have been used in the Mass and in everyday parish life, even in Catholic times (Maliniemi 1955: 82-112).

Before the Reformation, no documents exist in written Finnish. However, the statutes of the Synods shed some light on the linguistic situation in medieval Finland. These statutes explicitly set down the most important doctrines and teachings that were to be explained for the people in their own language. The Synods of 1441 and 1492 are especially important in this respect. These Synods, including as their delegates the bishops of Turku, Maunu Tavast and Maunu Särkilahti, ordered that the basis of popular education should be established in the vernacular: particularly, the Pater Noster, the Credo, the Ave Maria and the Modus Confitendi should be translated into the vernacular (in linguam maternam), read aloud at church every Sunday, and written down to ensure that their wording remained stable enough to be learned by the people. ${ }^{1}$ It is also clear that the sacraments that involved some kind of interaction with the parishioners, for example communion, baptism and marriage, must have been partly in Finnish. Thus, even though no written documents in Finnish exist from the late Middle Ages, it is probable that these early ceremonies moulded the language for religious uses and later formed the basis for the literary use of Finnish (Maliniemi 1955: 82-112).

\subsection{The Reformation}

As stated above, the earliest printed texts in Finnish date from the first half of the 16th century. The history of the standard written language has its origins in translations of the Bible and other religious texts into vernacular Finnish, the language of the common people. The reformers set to work, with Latin, German and Swedish orthographies as their models. 
The first authority on Finnish orthography (often described as "the father of written Finnish") was Mikael Agricola, bishop of Turku and the best-known figure of the Finnish Reformation. In 1536, Agricola was sent to Wittenberg to study the doctrine of the Reformation under Luther and Melanchthon. No doubt, Agricola and other young students from Finland were sent to Germany with the intent of translating the Bible into Finnish. And indeed, Agricola lived up to these expectations and became a pioneer in the cultivation of Finnish in written form, by translating no less than 2500 pages, including an ABC-book (an early catechism), the New Testament and parts of the Old Testament, a book of sermons and several other books to be used by ministers. Agricola worked methodically, and he usually used several sources in Swedish, German, Latin and Greek to create a Finnish text that was adapted to the Finnish context. Agricola's texts can be understood by a modern speaker of Finnish, with a small amount of training in his spelling. Apart from those of Agricola, Finnish texts from the first part of the 16th century only exist as a few isolated manuscripts, and after Agricola, almost a hundred years' silence in written Finnish followed. This was probably due to the impoverishment of the Church, caused by royal policies. The first edition of the whole Bible appeared in Finnish in 1642 (Heininen 2007).

Sections 3 and 4 discuss features of Agricola's orthography. To provide some background information for this, basic features of Modern Finnish orthography are introduced in the next section.

\section{The orthography of Modern Finnish}

Modern Finnish has almost a one-to-one correspondence between phonemes and graphemes: each grapheme corresponds to one and the same phoneme, and each phoneme corresponds to one and the same grapheme. As a result, Finnish orthography uses almost as many graphemes as there are phonemes in the language. ${ }^{2}$

Table 1. Phonemes and graphemes of Modern Finnish

\begin{tabular}{ll}
\hline phonemes & corresponding graphemes \\
\hline$/ \mathrm{a} /, / \mathrm{e} /, / \mathrm{i} /, / \mathrm{d} /, / \mathrm{u} /, / \mathrm{y} /, / \mathrm{x} /, /\left.\mathrm{ø}\right|^{3}$ & $<\mathrm{a}>,<\mathrm{e}>,<\mathrm{i}>,<\mathrm{o}>,<\mathrm{u}>,<\mathrm{y}>,<\ddot{\mathrm{a}}>,<\ddot{\mathrm{o}}>$ \\
$/ \mathrm{d} /, / \mathrm{h} /, / \mathrm{j} /, / \mathrm{k} /, / \mathrm{l} /, / \mathrm{m} /$, & $<\mathrm{d}>,<\mathrm{h}>,<\mathrm{j}>,<\mathrm{k}>,<\mathrm{l}>,<\mathrm{m}>$, \\
$/ \mathrm{n} /, / \mathrm{h} /, / \mathrm{p} /, / \mathrm{r} /, / \mathrm{s} /, / \mathrm{t} /, / \mathrm{v} /$ & $<\mathrm{n}>,<\mathrm{p}>,<\mathrm{r}>,<\mathrm{s}>,<\mathrm{t}>,<\mathrm{v}>$ \\
\hline
\end{tabular}


Phoneme length is an essential distinctive feature in Finnish: differences in length of the sounds very frequently serve to distinguish separate words. In writing, a long sound is always written with two letters, a short sound with a single letter (Karlsson 1983: 16-19, Laaksonen and Lieko 2003: 159, Sulkala and Karjalainen 1992: 365-374).

There are very few exceptions to the phoneme-grapheme correspondence. There is only one phoneme, the phoneme $/ \mathrm{y} /$, which does not have a grapheme of its own. ${ }^{4}$ And indeed, the phoneme $/ \mathrm{y} /$ is not a full phoneme, insofar as it only ever appears as a long sound, and always as a result of morpho-phonological alternation in inflectional forms, e.g.,

$\begin{array}{ll}\text { lanka } & \text { langa-t } \\ {[\text { lanka }]^{5}} & {[\text { langa-t] }} \\ \text { 'thread, wire or string' } & \text { 'thread, wire or string' + PL }\end{array}$

Another feature of spoken Finnish that is not represented in orthography is so-called consonantal reduplication. After certain morphological categories, the initial consonant of the following word is lengthened: that is, in the written form, a word ends in a vowel, even though a word-final consonant is pronounced. If followed by a vowel, a glottal stop is pronounced:

Table 2. Comparison of written and pronounced forms

\begin{tabular}{ll}
\hline writing & pronunciation \\
\hline $\begin{array}{l}\text { tule_tänne } \\
\text { 'come-IMP. 2.S. here' }\end{array}$ & [tulet tænne] \\
lapsille_leluja & [lapsillel leluja] \\
children-ALLAT. toys-PART. & \\
'toys for the children' & [mennæ $^{\text {? }}$ elokuviin ${ }^{6}$ \\
mennä_elokuviin & \\
go-INF. movies-PL.+ILLAT. & \\
'to go to the movies' & \\
\hline
\end{tabular}

Consonantal reduplication has its explanation in phonological history. At an earlier stage, the consonants $/ \mathrm{k} /$ and $/ \mathrm{h} /$ were used in word-final position in several morphological groups (e.g., *tulek tännek 'come here'). In the spoken language, the final $/ \mathrm{k} /$ or $/ \mathrm{h} /$ was assimilated with the first sound of the following word. The final $/ \mathrm{k} /$ and $/ \mathrm{h} /$ were lost in most dialects, but as a relic from older days, the consonant is even today realized either as a gemination of the following consonant, or as a glottal stop (see examples above; 
Hakulinen 2000 [1978]: 51-52). Consonantal reduplication has no counterpart in the writing system. At the end of this article, 19th-century attempts to standardize the notation of this phenomenon in Finnish orthography will be examined.

\section{The orthography of the earliest writings in Finnish}

\subsection{Foreign models}

As there were no manuscripts written in Finnish before the 16th century, the closest models for writing were Swedish, Latin and German texts. Until 1809, Finland was part of Sweden, and in addition to Latin, Swedish was used in writing. Typologically, Finnish differs from most European languages, and thus the earliest writers faced some serious problems in the standardization of its orthography.

Table 3. Agricola's discrimination of vowels in different positions

\begin{tabular}{lll}
\hline initial syllable & final syllables & Modern Finnish: all syllables \\
\hline $\begin{array}{l}\text { caatua } \\
\text { 'to fall' }\end{array}$ & $\begin{array}{l}\text { loppun } \\
\text { 'till the end' }\end{array}$ & kaatua, loppuun \\
\hline
\end{tabular}

Firstly, there were phonological distinctions that should have been made in orthography, but were not, as there were no suitable models for them in other languages. An example of this is the marking of long vowels. For lack of a model (at least, a systematic one) in other languages, the marking of long vowels was at first very sporadic. In Agricola's works there was, however, a difference between the initial syllable and the final syllables of the word. Originally, Finnish used to have long vowels in the first syllable only, and thus all the long vowels in the final syllables are secondary. They arose as a result of contraction (e.g., *talohon > taloon 'into the house'). In the initial syllable, Agricola often used two letters to mark long vowels, even though marking with only one letter was also possible. In the final syllables, Agricola usually used one letter only (Häkkinen 1994: 174, Lehikoinen and Kiuru 2001: 62-63, Rapola 1965: 54-55).

As we shall see in section 4.1., Agricola's tendency to use just one letter in final syllables may have been influenced by the phonological system of 
the south-western dialects of Finnish where all long vowels in final syllables are shortened.

The second feature of orthography probably influenced by the source languages is the tendency to create hypercorrect distinctions, that is, the earliest orthography sometimes represented phonological features of the model languages, features that Finnish did not necessarily share. An example of this is the variation in the marking of the phoneme $/ \mathrm{k} /$, which in Finnish is a palatal or velar stop. In early written texts, the notation of $/ \mathrm{k} /$ often followed the models of Latin and Swedish. When $/ \mathrm{k} /$ preceded a front vowel, the grapheme $<\mathrm{k}>$ was used, and the grapheme $<\mathrm{c}>$ often (but not always) preceded a back vowel. The orthography thus reflected the pronunciation of Medieval Latin (and Modern Italian). When preceding the vowel $/ \mathrm{u} /$, the grapheme $<\mathrm{q}>$ was sometimes used for $/ \mathrm{k} /$, which was also a Latin tradition. And when $/ \mathrm{k} /$ preceded the vowels $/ \mathrm{e} /, / \mathfrak{m} /$ or $/ ø /$, the grapheme $<\mathrm{ki}>$ could sometimes be used, which in turn reflected Swedish pronunciation (cf. Modern Swedish känna [çenna] 'to know, to feel') (Lehikoinen and Kiuru 2001: 65). However, it is important to remember that Agricola's writings (and those of his contemporaries) always show a great amount of (so far unexplained) variation in all these cases.

Table 4. Unexplained variation in Agricola's works

\begin{tabular}{ll}
\hline Agricola & Modern Finnish \\
\hline $\begin{array}{l}\text { lukea } \\
\text { read-INF. }\end{array}$ & lukea \\
'to read' & \\
$\quad$ caunis \\
'beautiful' \\
$\begin{array}{l}\text { kieula } \\
\text { 'bow (of a ship), } \\
\text { quin } \\
\text { (conj.) 'as, like, that' }\end{array}$ \\
\hline
\end{tabular}

\subsection{The phoneme /d/ - an orthographic loan}

The phoneme /d/ is not part of the phonemic system of any Finnish dialect. It was introduced into Standard Finnish in the 19th century as an orthographic loan from Swedish. In Agricola's orthography, the graphemes $<\mathrm{d}>$ or $\langle\mathrm{dh}>$ were used for the voiced dental spirant [ð]. The model for the or- 
thography came from Swedish, which used a similar orthographical convention for a similar type of spirant sound (see Zheltukhin, this volume). In Swedish, / $/$ / developed into /d/ in the 17 th century, and the orthography changed accordingly. Consequently, the orthographic variant $<\mathrm{dh}>$ disappeared from Finnish texts, and, in the 1642 Bible, only the grapheme $<\mathrm{d}>$ was used to note [ð]. The spirant sound then started to disappear from spoken Finnish as well, and as the spirant gradually fell out of use, the pronunciation of $<\mathrm{d}>$ as [d] (as an apico-alveolar voiced stop) spread. Thus, a new phoneme was added to the phoneme system of Finnish, mainly after the written model (Lehikoinen and Kiuru 2001: 74-75).

Until 1809 Finland belonged to the Kingdom of Sweden, and all authorities, officials, priests, and teachers either came from Sweden or were educated in Swedish. It is therefore understandable that the pronunciation of /d/ did not cause any trouble for the Swedish-speaking intelligentsia (who had the same sound in their own language), but it proved to be extremely difficult for the Finnish-speaking people. Thus, it is no surprise that this "newcomer" was the source of a heated debate in the nationalistic language reform in the 19th century, as will be shown in more detail in section 6 .

\section{Some traditional and less-traditional explanations for the variation in the earliest texts}

\subsection{Diatopic variation: Features of south-western dialects in 16th-century writings}

Since the city of Turku ( $\AA$ bo) on the southwest coast of Finland was the capital city until 1812, Standard Finnish developed primarily out of southwestern dialects. South-western features are particularly clearly seen in the texts of the earliest writers. As mentioned above, even the marking of long phonemes in final syllables with single vowels in Agricola's writings could have been a feature from the south-western dialects. In these dialects, all long vowels in final syllables are shortened (cf., e.g., Rapola 1965: 70):

$$
\begin{array}{lll}
\text { ehtoo } & > & \text { ehto } \\
\text { 'evening (a dialectal word)' } & & \\
\text { [monta] kertaa } & \text { [mont] kertta }{ }^{7} \\
\text { [many-PART] time-PART. } & & \\
\text { 'many times' }
\end{array}
$$


As stated above, apart from Agricola, only a few short and isolated manuscripts exist from the first half of the 16th century. One of these is The Gospel Book of Upsala, a manuscript that consists of 31 pages of texts from the Gospels and the Epistles. This manuscript has a lot of variation in the marking of long vowels, but it does not display the discrepancy between the marking of the initial and the final syllables as seen in Agricola's texts (Penttilä 1932: 41-43).

Another feature in Agricola's orthography that probably reveals diatopic variation is the marking of geminate nasals and liquid consonants. As stated in section 2, double consonants have a phonemic status in Finnish, and in Modern Finnish spelling they are always written with two letters. In the earliest writings, the marking of geminates shows a lot of variation.

However, even though the spelling of geminates was unstable, Agricola's tendency to write, in particular, double nasals ( $\mathrm{mm}$ and $\mathrm{nn}$ ) and liquids ( $l l$ and $r r$ ) with only one letter seems to suggest that this is not pure coincidence. This tendency can be observed in the Gospel Book of Upsala as well. Indeed, the spelling of geminate nasals and liquids is especially complicated because of a regional south-western feature: in these dialects, these geminate nasals and liquids were shortened after a long vowel or a diphthong, or when preceded by a syllable that did not have main stress:

$\begin{array}{lll}\begin{array}{l}\text { aallot } \\ \text { wave-PL } \\ \text { 'waves' } \\ \begin{array}{l}\text { annamme } \\ \text { give-IND.1.PL }\end{array}\end{array} & \begin{array}{l}\text { aalot } \text { [geminate } l \text { shortened when preceded } \\ \text { by a long vowel] }\end{array} \\ \text { 'we give' } & >\quad \begin{array}{l}\text { anname } \text { [geminate } m \text { shortened when } \\ \text { preceded by a syllable with no main stress] }\end{array}\end{array}$

In Agricola's texts, the spelling is systematic enough to suggest that the words written with one letter would have been pronounced as short, and therefore the variation seen in the spelling of geminate nasals and liquids can partly be explained as diatopic. In addition, some cases seem to be lexically governed, so that there are morphological categories or words where spelling with one letter is much more usual than in others (Lehikoinen and Kiuru 2001: 82-83, Penttilä 1932: 80-81).

Of course, we cannot know for certain exactly what served as a model for Agricola in his marking of long vowels in final syllables or of geminate nasals and liquids. In all probability, the spelling was guided both by foreign models and the influence of south-western dialects. And of course, we do not know the intentions of the early writers themselves: was it their in- 
tention to reflect spoken language, to indicate that the vowels in the final syllables were really pronounced as short, and geminate consonants as single consonants? Or did they want to follow models from other languages? If so, then why did they sometimes use long vowels instead of short ones? There was no written standard for 16th-century Finnish, a standard that would have led to the emergence of a non-variant form. As to some variables, we will probably just have to come to terms with the idea that there is no ultimate solution in understanding the variation, and no one single way of interpreting the texts.

\subsection{Are there other explanations for variation?}

Apart from diatopic variation, Agricola's spelling shows diachronic variation. One example of this is the spelling of the spirant sound $[\gamma]$ that was used as a weak grade variant of [k]. It has been stated that the spirant $/ \gamma /$ was disappearing from Finnish in the 16th century, and the varying pronunciation is probably revealed by the variation in spelling (see e.g., Häkkinen 2007: 70):

Table 5. Agricola's spelling variants for $[\gamma]$

\begin{tabular}{lll}
\hline$<g h>$ & $<g>$ & $\varnothing$ \\
\hline roghan & algusta & luØen \\
food-GEN & beginning-ELAT & read-IND.1P \\
'food's/of the food' & 'from the beginning' & 'I read' \\
\hline
\end{tabular}

Several studies have pointed out the variation to be found in Agricola's different works, for example, the translations of the New Testament from earlier and later stages of his career. Surprisingly enough, no systematic research on Agricola's works has yet been carried out. A morphosyntactically coded database of Agricola's works is being prepared at the moment, and the first critical edition of Agricola's works, an edition of the $A B C$-book, his first printed text, was published in 2007 (see Häkkinen 2007). Along with the database, new insights on diaphasic variation in Agricola's works will hopefully appear in the future.

Recently, a suggestion has been made concerning the role of printers, typesetters and typography in general on Agricola's spelling (see Perälä 2007: 10-40). Agricola's works were printed in Stockholm, since the first 
printing house in Finland was opened only in 1642. However, Agricola had a personal representative in Stockholm, who supervised the printing, and he himself also often visited the printing house. Therefore, it has been assumed that the correctors of the printing house - who probably did not know Finnish at all - did not play a significant role in his spelling (Heininen 2007: 158-163, Perälä 2007: 29). Perälä (2007: 20) has pointed out that the typography in Agricola's works closely resembles the works of the printing houses in Northern and Central Germany, and especially the books of Luther printed in Saxony.

Some variation in the early spelling could be explained by the general practices of the printing houses (Perälä 2007: 29). To cut down expenses, 16th-century works were printed in a dense and compact form. The printing surface was ideally very homogeneous and the margins straight. The printers did not want to use wide spaces between words to attain this. Rather, it is possible that the lines were made straight at the expense of orthography: a large number of sounds in several words could be written with either one or two letters, for example hedelmä / hedhelme 'fruit', perkele / perchele 'Satan'. In addition, abbreviations and typographic ligatures (e.g., æ) were also used. It is noteworthy that the variation between short and long sounds could also have provided printers with options to treat the layout of the page. A typographical approach of this kind is certainly in resonance with current views on the variation in vernacular texts from the late Middle Ages and the Early Modern period elsewhere in Europe (see for example Voeste 2008).

\section{The development of orthography in the successive editions of the Bible}

Quite a lot of the orthographical variation seen in the texts of Agricola and his contemporaries was regularized in the first translation of the Bible into Finnish in 1642. From this time onwards, the standardizers apparently aimed at a one-to-one correspondence between graphemes and phonemes. In Agricola's writings, there were still many cases where a single grapheme had several functions. In the first edition of the Bible, the graphemes $<\mathrm{q}>$ and $<\mathrm{ki}>$ disappeared for the notation of $/ \mathrm{k} /$. However, the distinction between $/ \mathrm{k} /$ preceding a front vowel (noted with $<\mathrm{k}>$ ) and that preceding a back vowel (noted with $<\mathrm{c}>$ ) subsisted until the end of the 18th century. The spelling of long vowels in final syllables remained unstable until the 
19th century (Häkkinen 1994: 179, Lehikoinen and Kiuru 2001: 72, Rapola 1965: 73-76).

Until the 19th century, successive editions of the Bible served as an authority for the standardization of orthography. Each committee or editor appointed to this work made slight improvements in the orthography. In practice, variation decreased and phoneme-grapheme correspondence became the norm. Towards the turn of the 19th century, opposition to "foreign" letters increased, for example $<\mathrm{g}>$ used for [k] after nasal or liquid consonants as in hengi (today henki) 'spirit', $<\mathrm{c}>$ or $<\mathrm{x}>$ used for [ks] as in caxi (today kaksi) 'two'. This anticipated the beginning of the nationalistic aspirations, and led to lively debates on Finnish orthography in the first decades of the 19th century.

Towards the end of the 18th century, and especially along with the Bible translation of 1776 (the so-called Old Church Bible), orthographical innovations were usually to be found in profane literature. Religious writings fell behind, and the Bible, which in the early stages of standardization used to function as a precursor for all innovations, now became archaic, too "sacred" to be manipulated at all. However, this applied to syntax and vocabulary more than to orthography, phonology or morphology. This was the situation up until 1992, which saw the latest translation of the Bible into Modern Finnish. This change in attitudes also reflects a change in translation strategies, as the strategy of faithful translation gave way to more functional approaches.

\section{The 19th century: Nation-building reflected in the standardization of orthography}

\subsection{Introduction to 19th-century Finland}

As mentioned above, literary Finnish was at first mainly based on the western dialects. However, along with the political and ideological climate of the 19th century, the dialectal basis of Standard Finnish became wider and more democratic, as eastern dialects started to have their impact as well. In the 19th century, the official status of Finnish changed; in 1863 Finnish was decreed to have equal status with Swedish, and towards the turn of the century - slowly but gradually - it became a fully-fledged cultural language that was used, for example, in education, administration, culture, science and literature. 
The nationalist movement had a variety of linguistic effects. Old (Standard) Finnish ${ }^{8}$ was greatly influenced by Swedish, and 19th-century scholars tried to purify Finnish by ridding it of Swedish loanwords and grammatical structures borrowed from Swedish. On the orthographical level, the phoneme /d/ was attacked on the same basis. In the 1810 s to $1820 \mathrm{~s}$, there was heated debate on the phoneme /d/ and its orthography (see, for example, Mielikäinen 1996). The most radical writers wanted to abandon /d/ altogether and replace it with its dialect variants. In original Finnish words, /d/ only appears in word-medial position, as a weak grade form of $/ \mathrm{t} /$ in consonant gradation. In dialects, /d/ is not used, ${ }^{9}$ and there are several variants of the weak grade form:

Table 6. Diatopic weak-grade forms of $/ \mathrm{t} /$

\begin{tabular}{ll}
\hline strong grade & weak grade \\
\hline & padan (Standard Finnish) 'pot-GEN' \\
paran/palan (western dialects) 'pot-GEN' \\
paØan (eastern dialects) 'pot-GEN'
\end{tabular}

Despite the debate at the beginning of the 19th century, the phoneme /d/, as well as the grapheme $<\mathrm{d}>$, remained in Standard Finnish. What were the reasons for this?

Firstly, abandoning the grapheme $<\mathrm{d}>$ and using its dialect variants would have caused variation in the writing, as there were several different variants in different dialects. At the same time, the dialect basis of Standard Finnish was under discussion: some writers wanted to increase the eastern elements in the standard. Therefore, there was no consensus on which dialect form would be chosen - in fact, in this debate, nobody even suggested that only one dialect variant could be chosen for the standard.

Secondly, and more importantly, $<\mathrm{d}>$ remained in the orthography, as it had already become a marker of "civilized speech". As mentioned before, Swedish had been the language of the educated classes and the intelligentsia, and only towards the end of the century did Finnish gradually become the official cultural language. During the standardization process, many Swedish-speaking people chose to speak Finnish, and it also became possible to have a higher education in Finnish. Even though the nationalromantic ideology of the time highly valued Finnish dialects and rural living, the language of the Finnish-speaking peasantry as such could not have served as a model for the language of the educated classes. Thus, the dialect 
variants of $<\mathrm{d}>$ were not accepted by the educated classes, being too "provincial". And as there originally was no standard educated spoken Finnish - the language being only spoken by the common people - even the ideal of the proper way to speak came to be very close to written Finnish. In a way, spoken Standard Finnish was carefully constructed and artificial, not based on the dialect of a politically and culturally influential region, as is the case for the spoken standard in many other European languages (e.g., London English or Parisian French). This has affected - and promoted strictly normative attitudes on both written and spoken Finnish up to the present day (Mäntynen 2003: 32-39, Paunonen 2006: 44-47).

\subsection{9th-century attempts to standardize consonant reduplication:}

An example of etymological spelling

I will next look at attempts to standardize the notation of the so called consonant reduplication (see section 2) into Finnish orthography: that is, attempts to create a system that would represent this phenomenon in writing. This is an example of an attempt to create etymological spelling: the explicit marking of consonant reduplication in writing was thought to reveal an older and more original stage of the language.

As explained in section 2 , word-final $/ \mathrm{k} /$ or $/ \mathrm{h} /$ was earlier used in many morphological categories. In final position, before a pause, it was lost (*veneh > vene 'a boat'). In the western dialects, the final consonant was lost earlier than in the eastern dialects, probably before the 14th century, well before Agricola's texts. In some eastern dialects, the final $/ \mathrm{k} /$ or $/ \mathrm{h} / \mathrm{is}$ still heard in final position. In the word-boundary position, between two words, the final $/ \mathrm{k} /$ or $/ \mathrm{h} /$ was assimilated with the following consonant, and before a vowel, it was pronounced as a glottal stop (cf. table 7).

In the earliest known texts, the morphological categories that ended with $\mathrm{a} / \mathrm{k} /$ or $/ \mathrm{h} /$ normally end in a vowel. There are sporadic occurrences of consonants in some words (e.g., pereh 'family', mod. Finnish perhe) and for example in the allative case (talollen ${ }^{10}$ talo-ALLAT, 'to the house'). The assimilated form only appeared in writing before clitic particles:

$$
\begin{array}{lll}
\text { pojallekkin } & & \\
\text { pojalle } & + & \text { kin } \\
\text { boy-ALLAT } & + & \text { a clitic particle } \\
\text { 'to a/the boy as well' } & &
\end{array}
$$


Table 7. Word-final $/ \mathrm{k} /$ and $/ \mathrm{h} /$ in different phonological environments

\begin{tabular}{|c|c|c|}
\hline example & position & $\begin{array}{l}\text { result of } \\
\text { sound change }\end{array}$ \\
\hline $\begin{array}{l}\text { tuleeko veneØ] } \\
\text { come-IND.PRES.3.S.-QUES. boat } \\
\text { 'Does the boat come?' } \\
\text { [venet tulee }] \\
\text { boat come-IND.PRES. 3.S. } \\
\text { 'a/the boat comes' } \\
\text { [venev_vaja] } \\
\text { 'boat shed' } \\
\text { [vene? 'ehtii] } \\
\text { boat arrive in time-IND.PRES.3.S. } \\
\text { 'a/the boat arrives in time' }\end{array}$ & $\begin{array}{l}\text { before a consonant } \\
\text { (between two words) } \\
\text { before a consonant } \\
\text { (in compound words) } \\
\text { before a vowel }\end{array}$ & $\begin{array}{l}\text { assimilation } \\
\text { assimilation } \\
\text { glottal stop }\end{array}$ \\
\hline
\end{tabular}

Thus, in the earliest texts, consonant reduplication is only occasionally marked. If marked, it only appears within a single word, that is, assimilation is never taken into account in writing if it appears between two separate words (Karemo 1971: 10-67).

The earliest grammars ${ }^{11}$ did not mention consonant reduplication at all. It was not until the 19th century that this phenomenon started to arouse interest on the whole. During the first half of the 19th century, several different proposals were made to create a notation for consonant reduplication in Finnish orthography: for example, the letters $\langle\mathrm{h}\rangle$ and $\langle\mathrm{c}\rangle$, as well as different types of diacritics were suggested for this purpose (Karemo 1971: 68-119):

Table 8. Suggestions for the notation of consonant reduplication

\begin{tabular}{ll}
\hline suggested form & author \\
\hline sanoh & Renvall (1826) \\
sanoc & Lönnrot (1841) \\
sanok & Gottlund, e.g., (1829) \\
sano' & von Becker (1824) \\
sano' & Varelius (1845) \\
say-IMP.2.S. & \\
'Say!' & \\
\hline
\end{tabular}


In the mid-1840s, a debate about consonant reduplication and its orthography flared up. In his textbook on natural sciences, Enon opetuksia luonnon asioista [The uncle's teachings about matters of nature] (1845), Antero Varelius used the sign $\langle>>$ after a word to indicate consonant reduplication. As the following page of his book shows, consonant reduplication was - and still is - a frequent phenomenon in Finnish:

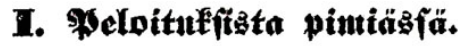

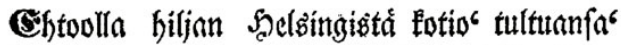

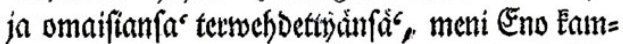

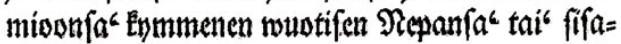

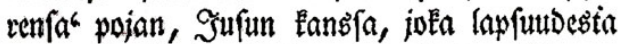

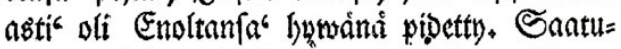

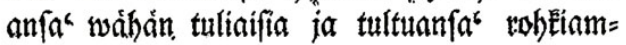
maffi Enfyi Jufu Enoltanfát

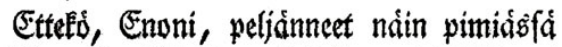
EulEeisfanne? Nina en fuinenan tobtisi' myt

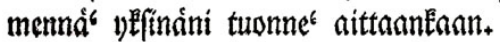

Eno.

Mitásbán minun tartwitfe peljátít? Et:

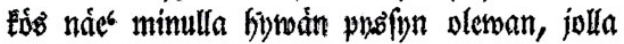

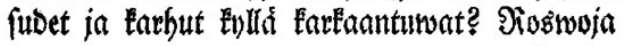

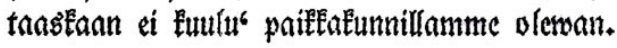
$\Im \mathfrak{u} \mathfrak{i} u$.

Mutta Aaweet ja Menninkífet? $\mathfrak{R e}$ ci

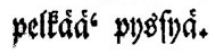

Figure 1. A page of Varelius's book Enon opetuksia luonnon asioista (1845: 5)

Varelius used his notation very systematically, both in final position (before a pause) and between separate lexemes. As was to be expected, Varelius's text provoked criticism from other writers, which resulted in heated discussion in newspapers. Varelius used the notation in his own works until 1851. He also received some support from the newspaper Suometar, a proFinnish newspaper founded by Varelius and some of his friends in 1847. However, Varelius's proposition did not catch on, and he finally gave it up himself (Kaasalainen 1988, Karemo 1971: 120-126). 
Why was the notation suggested by Varelius not accepted? Firstly, there was (and still is) a lot of variation in the distribution of consonant reduplication in different dialects. Some dialect speakers recognized the system, but for others, consonant reduplication might have been less of a recognized phenomenon. Even today, consonant reduplication is stronger in some morphological categories and phonological environments, and weaker in others. There is regional variation and even idiolectal variation. It is easy to see that the notation would have been difficult and complicated for many speakers of Finnish, especially people with no linguistic training to help to identify the relevant categories. Indeed, some opponents pleaded the ignorance of the "peasantry": it would be unnecessary to complicate texts that were mainly directed at uneducated people, as Varelius's textbook was.

Secondly, from the early texts on, the final consonant may have appeared sporadically in writing in certain words, in the allative, and before the clitic particles, that is, within a single word. However, no sign of the marking of the geminate between two separate words can be seen (Karemo 1971). ${ }^{12}$ Even those 19 th-century writers who had no formal education and who were minimally exposed to written language do not have a trace of this phenomenon in their manuscripts. Some self-educated eastern writers do have single lexemes that end in $-/ \mathrm{k} /$ or $-/ \mathrm{h} /$, or words with clitic particles written with a geminate, but there is no sign of the geminate between two separate words. Most speakers of Finnish today probably do not recognize consonant reduplication in their speech. It is subconscious. Either it did not receive a notation in orthography because it is subconscious, or, it is subconscious because it is not represented in writing. Whatever the explanation, the independence of the single word, at least in writing, was too strong for a phenomenon that appears between two words to become a part of standard orthography (Nordlund 2007).

Last, but not least, it was pointed out that the notation Varelius suggested would be "messy" and difficult for printing houses. Printing would be slow and prone to misprints. Suitable printing letters did not always exist. For example, as can be seen in figure 1, the sign that came to be used in Varelius's own book bore more of a resemblance to the number $6<6>$ than to the apostrophe $<'>$ that it was meant to be.

The final point to make is that, despite the obvious difficulties, why was it so important for some 19th-century writers to design notations for consonant reduplication? The answer probably lies in the attitude towards the Finnish language in general. The norms of Standard Finnish were consciously built in the 19th century, and the national-romanticists readily saw Finnish as a genuine, pure, original, and a beautifully symmetrical lan- 
guage. The marking of the final $/ \mathrm{k} /$ and $/ \mathrm{h} /$ would in a way represent the older and fuller form of the language. The older stage of the language would be systematically reconstructed if the elements that had been lost were represented by a specific sign in the writing. This was a scientific attitude towards language, and it reflected the growing interest in the study of Finnish. More than orthography, however, 19th-century debates were usually concerned with morphology. There were debates such as: which ending should be chosen for the inessive case in Standard Finnish? Is the Finnish negation verb a real verb with full inflection, or a particle that is not conjugated (see Laitinen 2004)? Thus, for Varelius and others who suggested notations for consonant reduplication, it was probably less important to have a one-to-one correspondence between pronunciation and writing than to preserve a morpho-phonological feature of older times (Laitinen 2004, Nordlund 2004, Nordlund 2006).

\section{Conclusion}

The role of the Western Church was essential in the initial stages of the development of literary Finnish. Some traces of religious uses of Finnish can be seen in Catholic times but it was the Reformation that started the history of written Finnish properly, with the idea that everyone should have a chance to familiarize himself or herself with the religious message in his or her own language. The earliest writings in Finnish show a lot of variation in spelling. This is partly explained by the foreign models of writing that did not always do justice to the phonological system of Finnish. Diatopic variation is also usual, and due to the political and cultural situation in late medieval Finland, especially features of south-western dialects appear. Very rarely-used south-western features were removed from the spelling along with the first edition of the whole Bible in 1642, and during the 19th century, the dialect basis of Standard Finnish became broader as several eastern features were accepted for the standard.

An electronic morpho-syntactic database of Mikael Agricola's works has just been prepared, and in 2007, the first critical edition of his works was published (Häkkinen 2007). These projects will hopefully lead to thorough research on the variation seen in Agricola's spelling, especially the diaphasic variation in his own works that is for the most part unexplained. ${ }^{13}$ No doubt, the morpho-syntactic database will also open several new vantage points on variation, for example, the role of typography and printing on the spelling and the process of writing in late medieval Finland. 


\section{Notes}

1. An early variant of the Pater Noster in Finnish is found in the Cosmography of Sebastian Münster, printed in 1544. This variant includes features of eastern and Bothnian dialects, and supposedly dates from the Catholic period (Häkkinen 1994: 80).

2. A conventional view is that there are 21 phonemes in Finnish: 8 vowels and 13 consonants. In Standard Finnish, all the vowels and most of the consonants have long variants, that is, double vowels or double consonants, geminates. The sounds [b], [f], [g] and [f] do not appear in original Finnish words, but only in loan-words.

3. The phoneme $/ \mathfrak{x} /$ is an open front unrounded vowel (as in the English word hat) and the phoneme $/ \varnothing /$ a close-mid front rounded vowel (as in the French word deux 'two').

4. The following notation is used: the notation $/ \mathrm{k} /$ refers to the phonemic level, $[\mathrm{k}]$ reflects pronunciation, the phonetic level, and the notation $<\mathrm{k}>$ is used to indicate the graphemic level.

5. As shown in this example, the phoneme $/ \mathrm{n} /$ is always pronounced homorganically with the following velar or bilabial stop. In this case, $/ \mathrm{y} /$ does not have a status as an independent phoneme, but it only functions as a phonetic variant of $/ \mathrm{n} /$ in certain environments.

6. The $<$ ? $>$ is the sign of a glottal stop.

7. In addition to the shortening of the vowel, there are other phonological changes in this phrase as well. These are also typical for south-western dialects.

8. The conventional way to periodize the history of Standard Finnish is as follows:

- before 1540 Early Finnish

- 1540-1810/1820 Old Finnish

- 1810/1820-1870/1880 Early Modern Finnish and

- from 1870/1880 onwards Modern Finnish.

9. Apart from a small area on the south-western coast where it is considered to be a language-contact feature from Swedish.

10. The allative case ended either in a phoneme $/ \mathrm{k} /$ or a phoneme $/ \mathrm{n} /$. The allative with the ending -llen was used in Finnish texts until the 20th century, however, always along with the allative that ended in a vowel, which is the present day norm.

11. The earliest grammars of Finnish date from the 17th century. At first, grammars were mainly directed towards the Swedish-speaking authorities and officials in Finland. Descriptive grammars and grammar books for the instruction of Finnish as a mother tongue only appeared in the 19th century.

12. There are at least two obvious exceptions to this. The 18th-century lexicographer, folklorist and writer, Christfrid Ganander, used the final $-k$ in his collections of folklore, as well as the 19th-century scholar and writer Carl Axel Gottlund, who aimed to use some kind of eastern Finnish dialect in his writings. 
13. Suggestions have been made that the variation could partly be explained by the fact that there were several authors working on the translation of the Bible, along with Agricola. However, no systematic study has been made of this so far.

\section{References}

\section{Primary sources}

Becker, Reinhold von

1642 Biblia, Se on: Coco Pyhä Raamattu, Suomexi 1642. [Biblia, i.e. the complete Holy Scriptures in Finnish 1642.] Facsimile. Porvoo: WSOY 1986.

Biblia

1776 Biblia, se on: koko Pyhä Raamattu, suomexi alku-raamattuin hebrean ja grekan jälkeen wastauudesta ojettu: esipuhetten, lukuin sisällepitoin, yhtäpitäwäisten Raamatun paikkain osotuxen, ja lisättyin registerein kanssa 1776. [Biblia, i.e. the complete Holy Scriptures, translated into Finnish from the Hebrew and Greek original versions of the Bible. With a foreword, marginalia, concordance and index 1776]. Turku: Frenckell.

Gottlund, Carl Axel

1829 Otava eli suomalaisia huvituksia, osa 1 [Ursa Major or Finnish diversions, part 1]. Tukholma [Stockholm]: Norstedt.

Häkkinen, Kaisa (ed.)

2007 Mikael Agricola. Abckiria. Kriittinen editio. [Mikael Agricola's ABC-book, a critical edition]. Helsinki: Suomalaisen Kirjallisuuden Seura.

Lönnrot, Elias

1841 Bidrag till Finska Språkets Grammatik. Suomi 1 (4): 11-39. Helsinki: Suomalaisen Kirjallisuuden Seura.

Münster, Sebastian

1544 Cosmographia. Beschreibung aller Lender. Basel: Heinrich Petri.

URN of the edition (1545): nbn:de:hbz:061:1-4685

Renvall, Gustaf

Decription of Finland: http://s1.doria.fi/helmi/bk/rv/fem970026/)

1826 Suomalainen sana-kirja = Lexicon linguae Finnicae, cum interpretatione duplici, copiosiore Latina, breviore Germanica. Åbo: Frenckell. 
Varelius, Antero

1845 Enon opetuksia luonnon asioista [The uncle's teachings about matters of nature]. Helsinki: J. Simelüksen perillisten tykönä. (http://ia700404.us.archive.org/13/items/wrlennp/wrlennp.pdf)

\section{Secondary sources}

Hakulinen, Lauri

2000 Suomen kielen rakenne ja kehitys. [The structure and evolution of the Finnish language.] Helsinki: Helsingin yliopiston suomen kielen lai-

Heininen, Simo tos. Original edition 1978.

2007 Mikael Agricola. Elämä ja teokset. [Mikael Agricola: Life and writings.] Helsinki: Edita.

Häkkinen, Kaisa

1994 Agricolasta nykykieleen. Suomen kirjakielen historia. [From Agricola to Modern Finnish. The history of written Finnish.] Helsinki: WSOY.

Kaasalainen, Erkki

1988 Antero Varelius. Kirjailija - Pappi - Suomalaisuusmies. [Antero Varelius, writer, minister and a fennoman.] Vammala: Tyrvään sanomat.

Karemo, Kaarina

1971 Suomen kielen aspiraatio- eli loppukahdennusilmiön säännöttäminen ja ortografiset ilmenemismuodot Agricolasta nykyaikaan. [Consonantal reduplication from Agricola to Modern Finnish.] Unprinted

Karlsson, Fred thesis, Department of Finnish, University of Helsinki.

1983 Finnish Grammar. Helsinki: WSOY.

Laaksonen, Kaino, and Anneli Lieko

2003 Suomen kielen äänne-ja muoto-oppi. [Finnish phonology and morphology.] Helsinki: Finnlectura.

Laitinen, Lea

2004 Kieltosana ja kieletär. Yhden kielikiistan kulku ja ideologiat. [Negation verb: A case study on language debates and language ideologies.] In Yhteistä kieltä tekemässä. Näkökulmia suomen kirjakielen kehitykseen 1800-luvulla, Katja Huumo, Lea Laitinen, and Outi Paloposki (eds.), 177-222. Helsinki: Suomalaisen Kirjallisuuden Seura.

Lehikoinen, Laila, and Silva Kiuru

2001 Kirjasuomen kehitys. [Evolution of written Finnish.] Uudistettu laitos. Helsinki: Helsingin yliopiston suomen kielen laitos. 
Maliniemi, Aarno

1955 Kansankieli Suomen keskiajan kirkossa. [The vernacular in the Finnish church in medieval times.] Novella Plantatio: 82-112. Suomen Kirkkohistoriallisen Seuran toimituksia 56. Forssa: Forssan kirjapaino.

Mäntynen, Anne

2003 Miten kielestä kerrotaan. Kielijuttujen retoriikkaa. [Talking about language. The rhetoric of language columns.] Helsinki: Suomalaisen Kirjallisuuden Seura.

Mielikäinen, Aila

1996 Reinhold von Becker ja murteiden taistelu. [Reinhold von Becker and the debate on dialects.] In Kuuskymppinen, Seppo Pekkola (ed.), 126-156. Jyväskylä: Jyväskylän yliopiston suomen kielen laitos.

Nordlund, Taru

2004 Arat taimet ja ankarat puutarhurit - 1800-luvun lopun kielikeskustelun metaforat ja kieli-ideologiat. [Metaphors and ideologies of language debates in the latter part of the 19th century.] In Yhteistä kieltä tekemässä. Näkökulmia suomen kirjakielen kehitykseen 1800-luvulla, Katja Huumo, Lea Laitinen, and Outi Paloposki (eds.), 286-322. Helsinki: Suomalaisen Kirjallisuuden Seura.

Nordlund, Taru

2006 Kielioppia rakentamassa: otta- ja oitta-verbien normittamisen historiaa. [Building the grammar: history of standardization of o(i)ttaverbs.] In Kielioppi koulussa. Äidinkielen opettajain liiton vuosikirja $X L X$, Minna Harmanen, and Mari Siiroinen (eds.), 55-69. Helsinki: Äidinkielen opettajain liitto.

Nordlund, Taru

2007 Double diglossia - lower class writing in 19th-century Finland. Multilingua 26 (2/3): 229-246.

Paunonen, Heikki

2006 Vähemmistökielestä varioivaksi valtakieleksi. [From a minority language to a varied dominant language.] Helsinki: Helsingin yliopiston suomen kielen ja kotimaisen kirjallisuuden laitos.

Penttilä, Aarni

1932 Upsalan suomenkielisen (1500-luvulta polveutuvan) evankeliumikirjan fragmentin kielestä. [On The language of Upsala Gospel Book from the 16th century.] Suomi 5 (13), 1-138.

Perälä, Anna

2007 Mikael Agricolan teosten painoasu ja kuvitus. [Typography and illustration in Mikael Agricola's works.] In Mikael Agricola Abckiria. Kriittinen editio, Kaisa Häkkinen (ed.), 10-40. Helsinki: Suomalaisen Kirjallisuuden Seura. 
Rapola, Martti

1965 Suomen kirjakielen historia pääpiirteittäin. I Vanhan kirjasuomen kirjoitus- ja äänneasun kehitys. [History of Old Biblical Finnish, Orthography and phonology.] Helsinki: Suomalaisen Kirjallisuuden Seura.

Sulkala, Helena, and Merja Karjalainen

1992 Finnish. (Descriptive Grammars) London/New York: Routledge.

Voeste, Anja

2008 Orthographie und Innovation. Die Segmentierung des Wortes im 16. Jahrhundert. Hildesheim/Zurich/New York: Olms. 


\section{Index Rerum}

abbreviation, 5, 12, 31, 34, 71-73, 76, 98-99, 102, 112, 116, 138, $173,175,229,241,247,360$ accent, 57, 75, 80, 90, 97, 102-105,

$107,113,118,120,122,124$, 273, 278, 281, 284, 288-289, $302,306,321,325-328,340,345$ acute, 103-105, 232-233, 236, $288,307,345$

circumflex, 104-105, 118, 239, 278, 288

grave, 105, 118, 120, 288-289, 307

agglutinative language, 321, 338, 341

allograph, 132, 222, 236, 239, 241, 247, 289, 298, 307

alphabet

Cyrillic, 11, 226, 255, 273-276, 278-279, 284, 287, 291-298, 300-302, 306

Glagolitic, 10, 271, 273-276, 278-281, 284, 286-287, 291-292, 296-297, 299-303, 306-307, 309, 312, 316-317, 320

Greek, 274

Latin, 2-3, 8, 11, 22-23, 100, 152-153, 155, 220, 222, 255, 274-276, 278-282, 285-286, 289, 291-292, 295-297, 299-301, 306, 308, 312, 321, 323-324, 332, 344

ampersand (\&), 99, 175

apocope, 104

apostrophe, 73, 75, 80, 90, 103-105, $176,289,342,366$
Arabic, 4, 24, 30-31, 129

ash (æ), 10, 132

assibilation, 45

assimilation, 12, 89, 153, 233, 242-243, 277, 354, 363-364 auxiliary sign, 102-105, 107, 113

bi-univocity, 107, 119

Bible, 3-5, 9, 11, 27, 39, 52, 113, $115,120,122,134,150,154$, 157-158, 163, 195-196, 202, 212-213, 215, 218, 244, 261, 263-264, 266, 299-300, 305, 323, 325-327, 330-332, 334, 337, 340, 342, 346, 348-349, 352-353, 357, 360-361, 367, 369

black letter, 236, 239, 243, 247-248, 300

blank, 168, 242, 342, 344

borrowing, 10, 132, 155, 205, 242, 326,336

calligraphy, 4 cedilla, 104, 284, 289

Chancery orthography, 30, 32-33, $35,72,83,128,130,134$, 136-137, 139-141, 145, 148-149, 151, 161-162, 164, 193, 198-203, 211-212, 323, $325,330,337,339,341$

Church

Greek-Orthodox, 184

Reformed (Protestant), 120, 157, 215, 330-331

Roman Catholic, 2-3, 12, 130, 215, 244, 259, 271, 274, 299, 308, $323,332,334,351-353,367$ 
code-switching, 139, 206-207, 215 codification, 3, 29-30, 32, 58-59,

64, 89, 96, 103, 128, 131,

149-151, 154-157, 183, 185,

194, 213-214, 301

cognates, 167, 176-177, 179-180

colon, 242, 343-344

comma, 75, 242, 344

common usage, 49, 83, 185, 206

conservatism, 15, 21, 42, 47, 53, 83, $109,137,151,234,262-263$

consonant

affricate, 2, 64-65, 220, 258, 273, $324,331,341$

alveolar, 258, 324, 341, 357

dental, 31, 44, 220, 237, 273, 356

final, 115, 354, 363, 366

fricative, 2, 22, 64, 90, 137, 273, 324,341

geminate, 8, 66, 179-181, 341-342, 358-359, 366, 368 glottal stop, 354, 363-364, 368

lateral palatal, 31, 273, 281

liquid, 358, 361

mute, 3, 80-81, 99-100

nasal, 99, 273, 281, 358, 361

palatal, 2, 8, 22, 100, 119-220, 232-233, 298, 322, 324-326, 330, 341, 344, 356

palatal fricative, 22

palatal lateral, 2, 31, 110, 119, 273,281

palatal nasal, 23, 31, 110, 119

palato-alveolar, 324, 341

post-alveolar, 220, 237, 258

sibilant, 2, 31, 44, 220, 243, 255, 257-258, 324, 341

sonorant, 10, 273

spirant, 356-357, 359

unvoiced, 31, 63, 65-66, 258

voiced, 31, 63-66, 152, 220, 258, 288, 301, 356-357

contraction, 146,355 copia, 171, 187

correction mark, 343

Counter-Reformation, 1, 9, 46, 113, 178, 240, 244, 271, 275, 299, 319,329

cryptographic writing, 21

cultismo, 43, 47

cursive handwriting, 34, 53, 72, 99, 168-169

decoding, 8, 107, 168, 172, 177

devoicing, 242-243, 277-278

diacritic sign, 6, 9, 11, 53, 66, 97, $103,152-153,228-230$, 232-236, 240-241, 243, 255, 257-258, 260-266, 277-279, 284, 288-290, 292-293, 296, 299, 301-302, 304-306, 309, $321,325,327,339-340$, 344-345, 364

diaglossia, 130-132, 156-157

dialect, 6, 24-25, 32, 45, 64-65, 68-69, 84, 89-90, 129-131, 133, 135, 139-140, 146, 153-154, 158, 160-161, 164-165, 168, 177, 183-185, 217, 224-225, 239, 262, 269, 272-274, 282, 292-293, 296-299, 304, 306, $328,335,354,356-358$, 361-363, 366-368, 371

dialectal form, 33, 45-46, 48, 53-54, 129, 140, 144, 149, 164, 237, 264, 272, 328, 335, 349, 357,361

diglossia, 131-132, 156-157, 332-333, 371

digraph, 51, 74, 80, 86, 90, 100, 111 , 132-133, 137, 152-153, 155, 220, 232-233, 239-240, 243, 257-258, 261-262, 264, 266, 277, 279, 287, 289-290, 292-293, 296, 299, 301-302, 307-309, 321, 324-327, 330, 339-342, 344-345 
diphthong, 3, 85, 153, 180, 262, 272, $307-308,328,358$

disyllabic words, 151

elision, 103, 153

enclitic particles, 104

eth (ð), 3, 10, 132, 152

etymology, 16-17, 34, 51, 90, 98, $100,108,153,242$

exclamation mark, 343-344

feminine $e, 103$

focusing, 127-130, 133, 137, 139, $144,149,155-156,193$

full stop, 75, 242, 343-344

glottal stop see consonant

Gothic script, 33, 116, 168-169, 189, 275-276, 281, 289, 296, 300, 303,305

Great Vowel Shift, 10

Greek, 3, 71, 79-80, 86, 90-91, 100, $109,113,116,119,157,184$, 242, 274-275, 288, 297, 299, $305,333,337-339,353,396$

Greek character, 3, 79-80, 90, 274

Hebrew, 3, 113, 226, 338, 369

heterograph, 19

heterophone, 19

homograph, 208, 210-211, 247, 284, 289

homophone, 108, 115, 151, 154-155 hybrid form, 23, 206-207, 215, 293, 304-305

hypercorrect form, 21, 34, 356

hyphen, 6, 77-78, 177, 298

koinè, 32, 79

language change, 41, 164, 261

language contact, $2,133,204-205$, 207, 211, 341, 368

language planning, 167, 212 language policy, 40, 135-136, 183, 185,310

Latin, 2-4, 7-13, 18-25, 27, 30-32, 36-40, 43-44, 47, 49-50, 52-53, $56,62,64-65,68-69,71-73,75$, 80-81, 84, 86-91, 98-100, 102-103, 106-107, 109-112, 116-119, 125, 127, 129-130, $132,134,140,150,152-155$, $168,170,176,184-185,196$, 205, 213, 216, 220, 222, 226, 228-231, 234, 236, 238, 242, 244-245, 255-259, 269, 273-282, 286-293, 295-302, 304-309, 321, 323-324, 332-334, 336-339, 347, 349, 352-353, 355-356

Latinism, 31

Latinization, 16, 21, 64-65, 70, 73-74, 90, 106, 110, 162, 247 , 302,308

learned word, 41, 43, 47, 151

legibility, 33-34, 53, 99

letter capital, $6,12,71,74,81,86,116$, $144,169,175,233,235,242$, $246,262,275,306,343$

double, 110-111, 155, 179-180, $182,188,285,289,307$

red, 343

rounded, 33, 274

silent, 3, 11-12, 42, 51, 151-153

titled, 173, 175

levelling, 135, 141, 146

lexical diffusion, 146

ligature, 6, 76, 169, 175, 190, 241, $247,308,360$

line ending, 6

lingua franca, 11, 130, 158, 184

linguistic interference, 19, 68, 98, 205

literacy, 4, 6, 9-10, 12-13, 99, 106, $114,150,153,156,168,212,334$ littera notabilior, 169 
loan word, 119, 133, 137, 149, 151, 155-156, 183, 220, 295, 322, 362,368

logographic principle, $8,11-12,21$, $34,131,151,154,169,179$ long $s(f), 233,247,260$

morphological principle, $8-12,28$, $63,98-99,108,115,171$, 177-178, 183, 321, 341-342, $354,363,366$

multilingualism, 129, 184, 307 mute consonant, see consonant

nasality, 23

norm, 3, 23, 44-45, 47, 49, 63, 127-133, 135-136, 139-142, $156,159,163,183,193-195$, 197, 207, 211, 213, 225, 335, 366 community, 194-195, 197-198 orthographic, 131, 151, 198, 202

oblique stroke, 104, 343

orthoepia, 129

orthographic interference, 207, 209-210, 214-215, 326, 340

palaeographic constraints, 32-34, 53 palatality, 31, 220, 224, 233-234, 239

palatalization, 2, 228, 241, 245, 256-259, 262, 264, 273, 277, 281

phonemic merging, 221, 341-342 phonetic syntax, 42, 234

phoneticism, 15-16, 32-37, 51, 146, 167-169

phonographic writing system, 2-3, $6-8,10-12,63,66,68,70,98$, 167-169, 177, 179, 181, 186, 272 pitch, 273

printing, 1, 3-6, 35-36, 68, 70, 75, $80,100-105,112-115,117-118$, $120,128-129,147-149$, 155-156, 167, 173-174,
185-186, 196, 222, 225-227, 229-231, 243-244, 260, 265, 274-275, 280-281, 284, 290, 299-300, 302, 305, 327, 330, 335-336, 340, 344-345, 348, $360,366-367$

punctuation, $6,12,63,68-69,73,75$, $80-81,90,122,142,164,242$, 343-344, 347

question mark, 242, 343

reduplication

of consonants, $34,149,154-155$, $173,285,289,306,354$, 363-366, 370

of vowels, 133, 208, 257-258, $285,287,324$

Reformation, 1, 3-5, 9-11, 39, 107, $110,112-113,120,136,150$, 157, 184-186, 211, 244, 286, 290, 328-330, 337, 344,

351-353, 367

repetitio, 27

rhyme, 26, 28

scriptio continua, 168

segmentation, 168, 170, 172,

176-177, 181, 183

semi-colon, 344

semiographic writing system, 2 ,

$8-12$

silent reading, 9

spelling

etymological, 7, 10, 12, 15-16, $34,44,51,53,63-64,69,74$, 81, 85-86, 89-90, 98-100, $102,106,112,114,116,151$, $156,167,176-180,186,235$, 243,363

historical, 10, 12, 99, 106, 151, $179,181,262,278,299$, 301-302 
paradigmatic, 8-9, 11-12, 176, 205-207, 341

syllabic, 180,182

standard endoglossic, 127-132, 139 exoglossic, 127, 129-130, 132, 157

standard language, 29-30, 64, 272, 292-295, 297-298, 304, 310 standard variety, 127, 184, 194, 212-214, 219, 236, 269

standardization, 5-6, 15-16, 29-30, $32-33,35,37,41,47,68,70,82$, $84,127-129,133,135,139-140$, $142,146,148,150,154-158$, 183-186, 219, 263, 280, 291, $351,355,361-362,371$ stress, $69,80,221,302,358$ suprasegmental notation, 167, 273, 281,285

synalephe, 104 syncope, 104

thorn (b), 3, 10, 132, 138, 152

tilde, 99, 309

timbre, 41, 117, 153, 155, 221, 325, 328,345

trema ("), 103-104, 345

trigraph, 220, 257-258, 288

umlaut, 8, 167, 177-178, 278

variance, $20,26-27$

variatio, 26-27, 53, 60

variation

calligraphic, 100, 174

diachronic, 18-20, 41, 54, 163, $170,278,298,359$ diaphasic, 19-20, 170, 359, 367

diasituational, 19-20, 170

diastratic, 20, 170

diatopic, 24, 32, 34, 44, 64, 79, 170-171, 224, 357-358, 359, 362,367

lexical, 26, 46, 73, 233, 358

vowel

closed, 2, 63, 66, 79-80, 83, 90, 103

long, $105,117,132-133,152$, 180-181, 208, 211, 262, 264, 273, 284-285, 288, 307, 322, 324-325, 328, 330, 344-345, 354-361, 368

narrowed (in Polish), 221, 229, $233,236,241,245$

nasal, 221, 235-236, 243, 246-248, 284

open, 2, 63, 66, 80, 90, 103, 118, 177,368

rounded, 324, 344-345, 368

short, 117, 133, 152, 154-155, 179-180, 264, 273, 284, 289, 324-325, 359-360

unstressed, 41, 133, 137, 181

vowel aperture, 103

vowel contraction, 181, 355

vowel length, 100, 153-158, 261, $273,284,325,327,340$

Vulgar Latin, 20-24

word separation, $6,77,177$

$\operatorname{yogh}(3), 132$ 



\section{Index Nominum}

Ady, Endre, 331

Agricola, Mikael, 353, 355-360, 363, 367, 369-371

Alberti, Leon Battista, 66-67, 90, 92

Alphonse X, King of Castile, 24, 29-30, 32-33

Andreæ, Laurentius, 193, 212

Andrysowic, Łazarz, 226-227, 236, 239

Angelini, Evangelista, 68, 92

Apáti, Benedek, 328

Augereau, Antoine, 104, 112, 118, 122-123, 125

Aujezdecki, Aleksander, 227, 238, 240, 249

Auron, Jean d', 109

Babits, Mihály, 331

Baïf, Jean-Antoine de, 111

Bakaláŕ, Mikuláš, 261

Bartoli, Daniello, 84, 93

Béla III, King of Hungary, 323

Bello, Andrés, 17, 61

Bellot, Jacques, 117, 121

Bembo, Bernardo, 72

Bembo, Pietro, 6, 40, 54, 70-75, 78-79, 82, 84, 89-90, 93, 95

Berceo, Gonzalo de, 28

Bernardin of Split, 275, 281-282, 297, 301, 311

Bèze, Théodore de, 53, 109-110, $115,119,121,331$

Biernat of Lublin, 231

Billius, Johannes, 196

Blahoslav, Jan, 263

Boccaccio, Giovanni, 68, 72, 74-75, 83-84, 87-89, 93
Boscán, Juan, 38

Bossuet, Jean-Bénigne, 53, 111, 114

Boÿ, Willem, 204

Budinić, Šimun, 282, 284, 304, 306

Bullokar, William, 152-153, 159

Buommattei, Benedetto, 87-89, 93

Calvin, John, 108-110

Castiglione, Baldassare, 38, 40

Caxton, William, 128, 147-149, 151, $159,161-162$

Ceregetti, Josef, 265

Chalcocondylis, Demetrios, 79

Charles IV, Holy Roman Emperor, 299

Charles V, Holy Roman Emperor, 37

Charles the Bald, 98

Charles IX, King of Sweden and Poland, former Duke of Södermanland, 197-203, 208-209, 215, 217

Chaucer, Geoffrey, 130, 134-136, 140,148

Cheke, John, 152

Christina, Queen of Sweden, 208

Cicero, Marcus Tullius, 40, 68, 75, 93

Cieza de Leon, Pedro, 45, 61

Cockeram, Henry, 156, 159

Colines, Simon de, 112, 122

Colonna, Francesco, 71, 77, 93

Columbus, Samuel, 208, 216

Coote, Edmund, 154-156, 159

Correas, Gonzalo de, 38, 55

Cosmas of Prague, 256, 266

Coverdale, Miles, 157

Cox, Leonard, 336 
Dalmatin, Antun, 283

Dalmatin, Juraj, 305

Dante Alighieri, 6, 68-70, 72, 77, 87-89, 92-93

Daubmann, Jan, 226

Des Autels, Guillaume, 108

Dešić, Nikola, 305

Dévai Bíró, Mátyás 327-328, 330, 334, 336, 340, 342, 344-346, 349

Dickens, Charles, 193

Dolet, Etienne, 5, 105, 113, 118, 122

Donatus, Aelius, 338

Du Bellay, Joachim, 40, 119

Dubois, Jacques, 7, 103, 106-107, $110,118,122-123$

Džamanjić, Rajmund, 289-290, 307-308, 311

Elizabeth I, Queen of England 150, 157

Elsevier (family), 114

Elyan, Kasper, 226

Erasmus, Desiderius, 3, 39-40, 54, $56-57,61,171,187,263,336$

Erik XIV, King of Sweden, 197, 202-203, 209

Estienne, Robert, 37, 103, 106, 108, 112, 117-118, 122

Ferdinand III, King of Castile, 30, 32-33

Filomates, see Philomates, Václav

Fiol, Szwajpolt, 226

Firenzuola, Agnolo, 80, 91, 94, 96

Francis I, King of France, 104, 107, 118

Frangk, Fabian, 179, 187

Gaj, Ljudevit, 293, 304, 309

Geleji Katona, István, 342, 348

Gelli, Giambattista, 76, 94

Gerard, Jean, 113, 122

Gianicolo, Tolomeo, 80, 95

Górnicki, Łukasz, 238-239
Gradić, Basil, 283-285

Gučetić, Arkanđeo, 283, 285

Gustavus Adolphus, King of Sweden, 202

Gustavus Vasa, King of Sweden, 196-197, 204

Gutenberg, Johannes, 68, 243, 260

Gutterwitz, Andreas, 197

Gzel, Petr, 263, 266

Haller, Jan, 222, 224, 226-227, 230-231, 236, 243, 246, 250, 252

Hart, John, 6, 150, 152-153, 155, 159,164

Hegendorff, Christoph, 336

Hektorović, Petar, 282, 302, 304, 317

Helicz (brothers), 226

Helsing, Anund Olofsson, 197

Helsingii, Magnus Olaii, 196-197

Heltai, Gáspár, 330, 336, 344

Henry V, King of England, 135-136, $158,162,164$

Henry VI, King of England, 138

Henry VII, King of England, 148

Henry VIII, King of England, 141-142, 150, 159, 163

Hess, Andreas, 337

Heyden, Sebald, 336

Hoccleve, Thomas, 134

Hochfeder, Kasper, 226, 246

Hoffgreff, Georg, 330

Honter, Joannes, 337

Hus, Jan, 228-229, 244, 255, 258-260, 262, 266, 292, 299, $306,318,325-326,336$

Ickelsamer, Valentin, 6, 177, 187

Isabella, Queen of Castile and Léon 6

Istranin, Stjepan, 283

James I, King of England, 157 
Januszowski, Jan, 225-226, 236, 238-240, 246, 253

John III, King of Sweden, 196-198, 203-204, 209, 215, 217

Káldi, György, 331, 346

Karadžić, Vuk Stefanović, 293, 309-310

Károli, Gáspár, 331

Kašić, Bartol, 288-289, 306, 308, $312,315,320$

Kern, Philip, 204

Kochanowski, Jan, 225, 238-239, 246

Komjáti, Benedek, 336

Konáč, Mikuláš, 261

La Ramée, Pierre de, 5-6, 110-111, $115,119,122-123$

Landino, Cristoforo, 72-73, 92

Łaski, Jan, 222

Laurentsson, Amund, 196

Le Fèvre, Raoul, 147

Łęczycki, Daniel, 228

Lefèvre d'Etaples, Jacques, 112, 117, 123

Lipsius, Justus, 101

Lope de Vega, Félix, 36

Louis XIII, King of France, 50

Louis XIV, King of France, 14

Louis the German, King of East Francia, 98

Ludvigssons, Rasmus, 212

Luis de León, 47-48, 54, 58

Luther, Martin, 4, 9, 120, 178, 186, $244,328,353,360$

Machyn, Henry, 146, 161

Mantskovit, Bálint, 337

Manutius, Aldus, 5-6, 37, 70-72, 74-75, 77-78, 80, 82, 89-90, 93-94

Marguerite of Navarre, 104-105, $112,122-123$
Marot, Clément, 104, 112, 119, 331

Martelli, Lodovico, 80, 94

Marulić, Marko, 276, 282, 297, 300, 303, 311

Mary I, Queen of England 157

Mateusz z Kościana, 231

Megiser, Hieronimus, 305

Meigret, Aimé, 118

Meigret, Louis, 6, 63, 94, 107-111, 113, 118-119, 122,

Melanchthon, Philip, 327-328, 338, 353

More, Thomas, 141, 146, 162

Moxon, Joseph, 175, 187-188

Mulcaster, Richard, 154-156, 160

Murmeliusz, Stanisław, 247

Murmellius, Joannes, 336

Murzynowski, Stanisław, 236, 238, 244, 252-253

Nádasdy, Tamás, 327

Nebrija, Antonio de, 3, 6-7, 37-38, $46,49,53,55-56,58-59,185$, 188

Norman, Georg, 203-204

Numeister, Johannes, 68, 92

Olai, Benedict, 196

Oliverblad, Ivar Klementsson, 204

Olivétan, Pierre Robert, 113, 123

Opec, Baltazar, 231

Optát, Beneš, 263, 266

Osterberger, Jerzy, 226

Pahr (brothers), 204

Palsgrave, John, 117-118, 123, 149, 160

Pannartz, Arnold, 68, 93

Parcosii, Jacobus, see Parkosz, Jakub

Parkosz, Jakub, 228-230, 244, 251

Pasquier, Estienne, 111, 120, 123

Paston (brothers), 140

Paul II, Pope, 37

Pázmány, Péter, 331, 337 
Peletier du Mans, Jacques, 63, 94, 108-109, 113, 115, 119, 123

Pergošić, Ivan, 283-284, 297, 306

Pesti, Gábor, 337

Petrarch, Francesco, 68-69, 72, 75-76, 82-83, 87-89, 94

Petri, Laurentius, 196, 204, 212, 215

Petri, Olaus, 193, 196, 212

Philip II, King of Spain, 50, 54-55

Philomates, Václav, 263, 266

Plantin, Christopher, 101, 113, 118

Priscian (Priscianus Caesariensis), 3 , 107, 119, 338

Pucci, Benedetto, 83, 94

Pulci, Luigi, 68, 94

Pyhy, Conrad von, 203-204

Pynson, Richard, 148, 150

Quintilian (Marcus Fabius

Quintilianus), 3, 38, 246

Ramus, see La Ramée, Pierre de

Ranjina, Dinko, 283-284

Raphelengius, Franciscus, 101

Rask, Nils, 208

Ráskay, Lea, 323

Rastell, John, 149

Rastislav, Prince of Moravia, 274

Régnier-Desmarais, François-

Séraphin, 114

Richolff, Georg, 196

Rodecki, Aleksy, 228

Ronsard, Pierre de, 108, 119

Rosa, Wenceslaus Johannes, 265-266

Saint Teresa of Ávila, 35, 42, 46-49, $54,58,60$

Salvador, Gregorio, 16-17, 61

Salviati, Leonardo, 84-85, 93-94

Sanctius, Franciscus, 6

Sandecki-Malecki, Jan, 228, 231, 236, 242-243, 252
Sansovino, Francesco, 75-76, 78, 82, 91, 95

Sarmiento, Domingo Faustino, 17

Sauvage, Denis, 109

Scaliger, Joseph, 6

Scharffenberg, Maciej, 226

Scharffenberg, Marek, 226, 247

Seklucjan, Jan, 237-238, 252-253

Shakespeare, Wiliam, 157

Siebeneicher, Mateusz, 226

Sigismund III, King of Poland and

King of Sweden, 197, 202-203

Singriener, Johann, 337

Skrope, Katherine, 143

Smith, John, 153

Smith, Thomas, 3, 152, 160

Statorius, Petrus, 238, 248

Štejer, Matěj Václav, 264, 266

Stojeński, Piotr, see Statorius, Petrus

Straube, Kasper, 226

Sweynheym, Conrad, 6, 8, 93

Sylvester II, Pope, 332

Sylvester, János, 327-328, 330, 336, 338-340, 342-346

Sylvius, Jacobus, see Dubois, Jacques

Szenci Molnár, Albert, 331, 344-345

Tidemansson, Torbjörn, 196

Tolomei, Claudio, 82, 95

Torstensson, Anders, 196

Tory, Geofroy, 5, 37, 103-104, 112, 117-119, 123

Tournes, Jean de, 113

Trissino, Giangiorgio, 3, 6, 63, 79-81, 90, 94-96

Tyndale, William, 157

Ungler, Florian, 226-227, 230-231, 234, 243, 249

Unglerowa, Helena, 226-227, 243

Ursinus, Joannes, 238

Utter, Per Eriksson, 204 
Valdés, Juan de, 7, 37, 39-44, 49, 54-56, 58-59

Varelius, Antero, 364-367, 370

Vespucci, Amerigo, 261, 267

Veyl, Sebald, see Fiol, Szwajpolt

Vietor, Barbara, 247

Vietor, Hieronymus, 5, 226-227, 230-231, 233-238, 243-245, $247,249,253,324,327-328$, 336,340

Virgil (Publius Vergilius Maro), 75, 147

Vramec, Antun, 283, 285

Vrančić, Faust, 283, 285, 287-288, 297, 305, 307, 311

Waesberghe (family), 114

Webster, Noah, 157

Wechel, André, 111, 119, 122
Wechel, Chrestien, 64, 108, 111

Weinreich, Jan, 237

Whythorne, Thomas, 153, 164

Wirzbięta, Maciej, 228, 238-240, 244, 251

Wolsey, Thomas, 141, 162

Worde, Wynkyn de, 149, 160

Wycliffe, John, 133, 162, 259

Zaborowski, Stanisław, 229-230, 232-236, 239-240, 244, 246-247, 253, 328

Zlatarić, Dominko, 283, 285, 304, 306, 319

Zoranić, Petar, 282, 285, 312 


